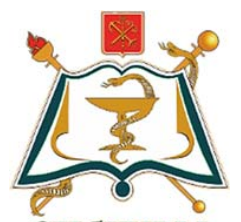

СПбГУВМ

МИНИСТЕРСТВО СЕЛЬСКОГО ХОЗЯЙСТВА РОССИЙСКОЙ ФЕДЕРАЦИИ

ДЕПАРТАМЕНТ ОБРАЗОВАНИЯ, НАУЧНОТЕХНОЛОГИЧЕСКОЙ ПОЛИТИКИ И РЫБОХОЗЯЙСТВЕННОГО КОМПЛЕКСА

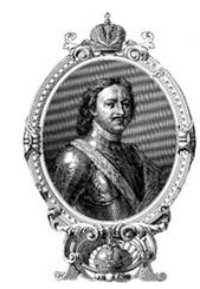

ФЕДЕРАЛЬНОЕ ГОСУДАРСТВЕННОЕ БЮДЖЕТНОЕ ОБРАЗОВАТЕЛЬНОЕ УЧРЕЖДЕНИЕ ВЫСШЕГО ОБРАЗОВАНИЯ «САНКТ-ПЕТЕРБУРГСКИЙ ГОСУДАРСТВЕННЫЙ УНИВЕРСИТЕТ ВЕТЕРИНАРНОЙ МЕДИЦИНЫ»

МЕЖРЕГИОНАЛЬНАЯ ОБЩЕСТВЕННАЯ ОРГАНИЗАЦИЯ «ПЕТРОВСКАЯ АКАДЕМИЯ НАУК И ИСКУССТВ»

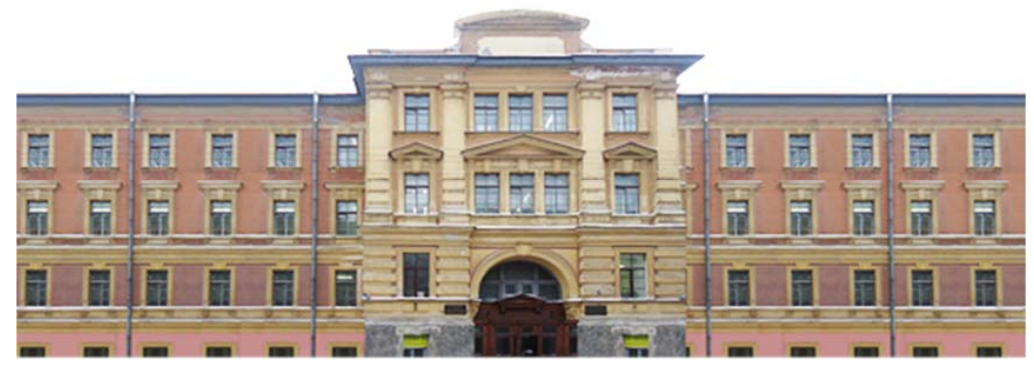

МАТЕРИАЛЫ

Международной научно-практической конференции «ТЕОРИЯ И ПРАКТИКА ВЕТЕРИНАРНОЙ ФАРМАЦИИ, ЭКОЛОГИИ И ТОКСИКОЛОГИИ В АПК»,

посвященной 100-летию кафедры фармакологии и токсикологии СПбГУВМ 19-21 мая 2021 года
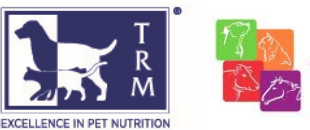

\title{
VETAPTEKA.RU WormStop
}

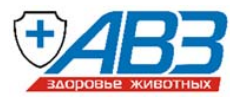

HAEMOBALANS injection

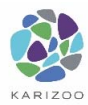

Уристоп

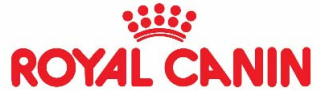

САНКТ-ПЕТЕРБУРГ 


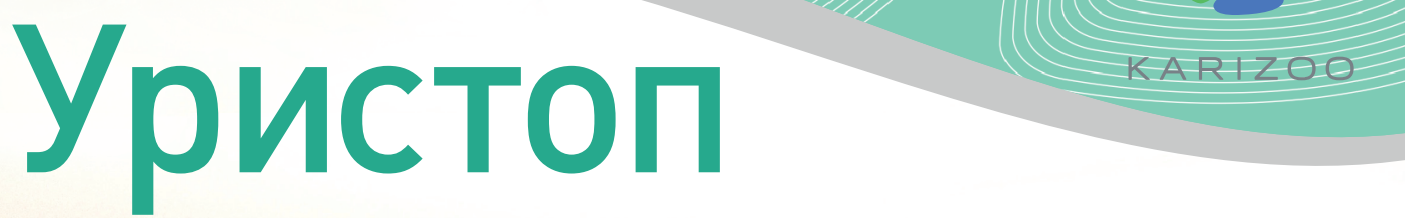

\section{0 мг/мл фенилпропаноламина}

\section{Сироп для перорального применения}

В 1 мл содержится $40,28 \mathrm{Mr}$

фенилпропаноламина

(50 мг фенилпропаноламина гидрохлорида).

Показания: уристоп назначают стерилизованным (после овариоэктомии / овариогистерэктомии) сукам при недержании мочи, связанном с функциональной недостаточностью сфинктера уретры.

Способ применения: перорально ежедневно, в дозе 0,1 мл препарата на 5 кг массы тела животного 3 раза в сутки С кормом (эквивалентно суточной дозе 0,06 мл на 1 кг массы тела животного).

Форма выпуска: 50 мл и 100 мл.

Производитель: Laboratorios Karizoo, S.A., Испания

Официальный эксклюзивный дистрибьютор в странах ЕАЭС: ГК HEBA-BET, тел. (812) 596-39-62,e-mail: shop@vetapteka.ru 
МИНИСТЕРСТВО СЕЛЬСКОГО ХОЗЯЙСТВА РОССИЙСКОЙ ФЕДЕРАЦИИ

ДЕПАРТАМЕНТ ОБРАЗОВАНИЯ, НАУЧНО-ТЕХНОЛОГИЧЕСКОЙ ПОЛИТИКИ И РЫБОХОЗЯЙСТВЕННОГО КОМПЛЕКСА

ФЕДЕРАЛЬНОЕ ГОСУДАРСТВЕННОЕ БЮДЖЕТНОЕ ОБРАЗОВАТЕЛЬНОЕ УЧРЕЖДЕНИЕ ВЫСШЕГО ОБРАЗОВАНИЯ «САНКТ-ПЕТЕРБУРГСКИЙ ГОСУДАРСТВЕННЫЙ УНИВЕРСИТЕТ ВЕТЕРИНАРНОЙ МЕДИЦИНЫ»

МЕЖРЕГИОНАЛЬНАЯ ОБЩЕСТВЕННАЯ ОРГАНИЗАЦИЯ «ПЕТРОВСКАЯ АКАДЕМИЯ НАУК И ИСКУССТВ»

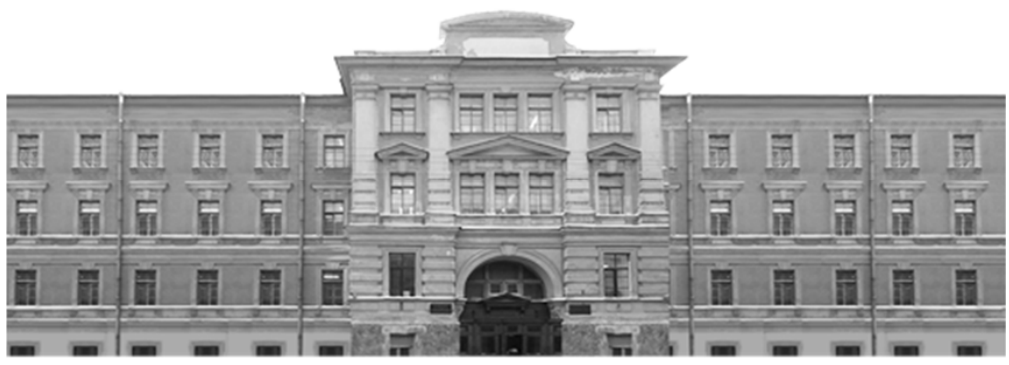

МАТЕРИАЛЫ

Международной научно-практической конференции «ТЕОРИЯ И ПРАКТИКА ВЕТЕРИНАРНОЙ ФАРМАЦИИ, ЭКОЛОГИИ И ТОКСИКОЛОГИИ В АПК»,

посвященной 100-летию кафедры фармакологии и токсикологии СПбГУВМ 
Материалы Международной научно-практической конференции «Теория и практика ветеринарной фармации, экологии и токсикологии в АПК», посвященной 100 -летию кафедры фармакологии и токсикологии СПбГУВМ - Санкт-Петербург, 2021. - 261 с.

В материалах Международной научно-практической конференции «Теория и практика ветеринарной фармации, экологии и токсикологии в АПК», посвященной 100 -летию кафедры фармакологии и токсикологии СПбГУВМ представлены сведения по изучению и использованию в ветеринарии иммуномодуляторов, антимикробных, ранозаживляющих препаратов, гепатопротекторов и других групп лекарственных средств, токсикологические и общебиологические проблемы при использовании лекарственных средств и кормовых добавок, а также методические вопросы преподавания дисциплин по ветеринарной фармакологии, токсикологии, экологии и фармации.

\section{Организационный комитет}

Председатель: Померанцев Дмитрий Александрович - врио ректора ФГБОУ ВО СПбГУВМ, доктор ветеринарных наук

Члены оргкомитета: Андреева Надежда Лукояновна - профессор кафедры фармакологии и токсикологии ФГБОУ ВО СПбГУВМ, доктор биологических наук, профессор, почетный работник высшего образования РФ, академик Петровской академии науки и искусств

Лунегов Александр Михайлович - зав. кафедрой фармакологии и токсикологии ФГБОУ ВО СПбГУВМ, кандидат ветеринарных наук, доцент, член-корреспондент Петровской академии науки и искусств

Мкртчян Маня Эдуардовна - проректор по науке и международным связям ФГБОУ ВО СПбГУВМ, доктор ветеринарных наук, профессор

Карпенко Лариса Юрьевна - зав. кафедрой биохимии и физиологии ФГБОУ ВО СПбГУВМ, доктор биологических наук, профессор, председатель отделения ветеринарной медицины Петровской академии наук и искусств, академик Петровской академии науки и искусств

Ноздрин Григорий Антонович - доктор ветеринарных наук, профессор, профессор кафедры фармакологии и общей патологии Новосибирского государственного аграрного университета, заслуженный работник высшей школы РФ, почетный работник высшего профессионального образования РФ, почётный доктор Санкт-Петербургской академии ветеринарной медицины, академик экологической академии, заслуженный деятель науки Новосибирской области

Великанов Валериан Иванович - доктор биологических наук, профессор, профессор кафедры анатомии, хирургии и внутренних незаразных болезней Нижегородской государственной сельскохозяйственной академии, заслуженный работник высшей школы РФ, почётный доктор Санкт-Петербургской академии ветеринарной медицины

Секретариат: Попов О.С. ответственный секретарь.

Секретари научных направлений и круглых столов: Барышев В.А., Зенков К.Ф., Каурина О.Н., Крюкова В.В., Кузнецова Н.В., Сабирзянова Л.И., Понамарев B.C.

ISBN 978-5-00105-621-8 


\section{0 ЛЕТ КАФЕДРЕ ФАРМАКОЛОГИИ И ТОКСИКОЛОГИИ САНКТ- ПЕТЕРБУРГСКОГО ГОСУДАРСТВЕННОГО УНИВЕРСИТЕТА ВЕТЕРИНАРНОЙ МЕДИЦИНЫ (ИСТОРИЧЕСКИЙ ОЧЕРК)}

Лунегов А.М. доц., к.вет.н., Андреева Н.Л. проф., д.биол.н. (ФГБОУ ВО СПбГУВМ, Россия)

Кафедра фармакологии и токсикологии была основана в Ленинградском ветеринарном институте 16 июля 1921 года, в 1924 году была введена фармация, а в 1937 году курс токсикологии с защитой курсовых работ на пятом курсе.

Первым заведующим кафедрой был ученик И.П. Павлова -

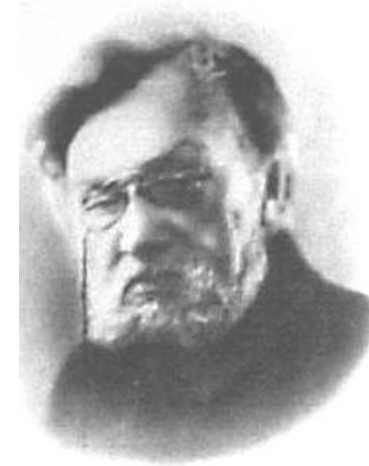
профессор Савич Владимир Васильевич (1874 -1936), который руководил кафедрой с 1921 по 1936 г. Известный советский физиолог и фармаколог, был признанным «старшиной» Павловской школы. Будучи студентом Военно-медицинской академии, увлекся исследованиями И.П. Павлова в области пищеварения и по окончании академии стал работать по этой проблеме в лаборатории своего учителя, связав с ним всю свою жизнь. С 1907 по 1912 гг. работал на кафедре физиологии Военно-медицинской академии в должности ассистента. В 1912 г. В.В. Савич был представлен И.П. Павловым на должность старшего физиолога института физиологии Академии наук, затем он работал в должности прозектора кафедры физиологии Ленинградского женского медицинского института. После переезда ветеринарного института в отдельное здание по адресу ул. Черниговская, д.5 были организованы многие кафедры. 16 июля 1921 года В.В. Савич организовал и до последних дней жизни (5 июля 1936 г.) возглавлял кафедру фармакологии Ленинградского ветеринарного института (ЛВИ).

До 1924 года кафедра не имела ни одного ассистента, и почти всё преподавание вёл В.В. Савич. В связи с этим, а также ввиду отсутствия надлежащей материально-технической базы, в первые годы организации кафедры, преподавание проводилось чисто теоретически; однако, как и в других ветеринарных и медицинских вузах, фармакологии была придана фармацевтическая пропедевтика (технология лекарственных форм и общая рецептура). Несмотря на то, что В.В. Савич по образованию был медиком, с первых же лет существования кафедры, лекции приняли специфический для ветеринарной медицины характер. Приближение ветеринарной фармакологии к запросам ветеринарии удалось достичь В.В. Савичу и его школе благодаря постоянному интересу к ветеринарной литературе и к вопросам клиники, актуальным в тот или иной период. Отражением связи преподавания фармакологии в ЛВИ с ветеринарной практикой являются два факта: 1) профессор В.В. Савич подготовил к изданию руководство по фармакологии для ветеринарных вузов, добился издания и выпустил в свет переведенное руководство Кешни (1930-1931 годы) в двух томах, которое дополнил необходимой информацией для ветеринарной практики; 2) профессором В.В. Савичем отредактировано издание «Основ фармакологии» Н.П. Кравкова, где он сумел сохранить стиль автора, и дополнил труд накопившимися фактами.

В.В. Савичем было опубликовано около 100 научных работ. В.В. Савич много внимания уделял эндокринологии, исследованиям секреторной деятельности желудка, кишечника, поджелудочной железы, а также влияние фармакологических веществ на вегетативную нервную систему. Владимир Васильевич создал крупную школу советских фармакологов. Учениками В.В. Савича были А.И. Кузнецов, М.М. Николаева, А.П. Локк, Е.Н. Сперанская-Степанова, Н.П. Говоров, Г.И. Цобкалло, В.С. Золотов, В.М. Чернов, Д.Р. Джафаров, И.А. Сторожев, Ф.Т. Дубинин, С.И. Ордынский и др. 


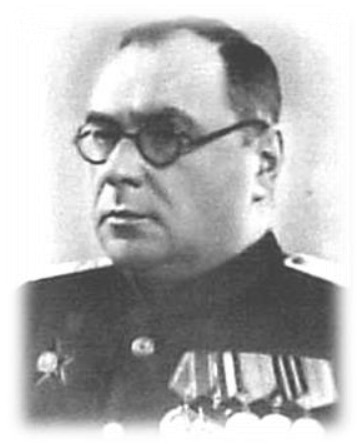

Вторым заведующим в 1936 году стал ученик В.В. Савича профессор Кузнецов Анатолий Иванович (1897 - 1951). Свою научную деятельность начал слушателем Военно-медицинской академии в 1922 г. в лаборатории Н.П. Кравкова. После окончания академии был оставлен в адъюнктуре при кафедре фармакологии с рецептурой и прошел путь от адъюнкта до начальника кафедры. Докторскую диссертацию на тему «Фармакологическое исследование советской синтетической камфоры» защитил в 1934 году. По совместительству А.И. Кузнецов работал в Институте физиологии АН СССР и в институте экспериментальной медицины АМН СССР. С 1936 по 1940 гг. и с 1945 по 1951 гг. заведовал кафедрой фармакологии в ЛВИ. Он проводил исследования по многим научным направлениям: физиология и фармакология эндокринных желез, фармакология вегетативной нервной системы, фармакология и токсикология ТЭС (тетраэтилсвинец), фармакология сердечно-сосудистой системы, в том числе и сосудистых рефлексогенных зон, проблемы наркоза и многие другие. Он является автором более 100 научных трудов. А.И. Кузнецов подготовил 8 кандидатов ветеринарных наук (П.Г. Меньшаков, Д.М. Геловани, М.А. Некрасова, П.Д. Евдокимов, Н.С. Сафронов, Т.М. Кучеренко, В.П. Гумилевский, В.Л. Узюмов) и 4 доктора ветеринарных наук (А.П. Локк, П.Г. Меньшаков, Д.М. Геловани, П.Д. Евдокимов).

В период 1940-1941 г. кафедру возглавлял Локк Альберт Петрович (1897-1958). А.П. Локк был одним из первых учеников В.В. Савича по ветеринарному институту. С 1931 г. обучался в аспирантуре, с 1933 г. работал ассистентом, с 1937 г. доцентом, с 1940-1941 г. зав кафедрой фармакологии. В 1935 г. кандидат ветеринарных наук, в дальнейшем защитил докторскую диссертацию.

После ВОВ А.П. Локк заведовал кафедрой фармакологии Эстонской СХА, а позднее Воронежского СХИ. А.П. Локк провел большое исследование по фармакологии сердечно-сосудистой и вегетативной нервной системы, он был первым автором учебника по фармакологии для техникумов. А.П. Локк был прекрасным педагогом, научным работником, пользовался большим авторитетом среди студентов и сотрудников.

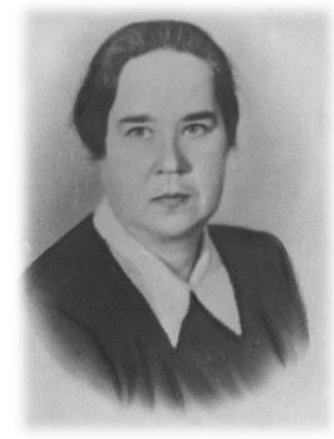

С 1952 по 1953 годы заведующей была ученица И.П. Павлова доктор медицинских наук Сперанская Екатерина Николаевна (18991979). Ею было опубликовано 170 научных работ, в т.ч. 5 монографий, таких как: «Методика операций на пищеварительном тракте» (1952); «Методика операций на собаках и проведение хронических опытов в физиологии» (1953); «Руководство по оперативной методике в физиологическом эксперименте» (1948). Большая часть опубликованных ею работ посвящены, главным образом, экспериментам по эндокринологии и физиологии вегетативной нервной системы. Разработала оперативный метод изучения нарушений функции печени.

Установила, что удаление гипофиза или нарушение функции щитовидной железы ведет к снижению синтетической и дезинтоксикационной способности печени. Проблемы эндокринологии и гормонотерапии стали ее основным научным направлением.

А с 1954 по 1960 год кафедру возглавлял профессор Ордынский Сергей Илларионович. В 1924 г. он окончил ВМедА им. С.М. Кирова. В области фармакологии начал работать еще в студенческие годы в фармакологической лаборатории ВМедА, под руководством академика Н.П. Кравкова, где работал в течение 19231924 гг. С 1928 по 1929 гг. работал ассистентом биологического

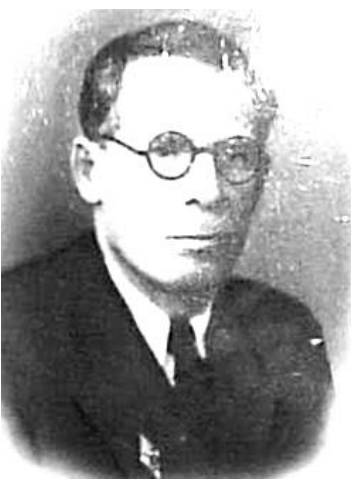


отделения фармако - химической и медицинской исследовательской лаборатории г. Ленинграда. С 1932 г. - научный сотрудник фармакологического отдела Государственного института экспериментальной медицины, где работал под руководством профессора В.В. Савича. С 1933 г. ассистент кафедры фармакологии 2-го Ленинградского медицинского института, с1939 г. - доцент кафедры фармакологии 1-го Киевского медицинского института. С 1943 г. был профессором кафедры фармакологии Казахского медицинского института в г. Алма-Ата. С 1944 г. - начальник фармакологического отдела Ленинградского научноисследовательского химико-фармацевтического института. С 1949 г. работал заведующим кафедрой ЛИУВВ, с 1954 г. заведовал кафедрой фармакологии ЛВИ. Основным направлением его исследований было изучение действия фармакологических средств при патологии сердечно-сосудистой системы. Является автором 80 научных работ. Под руководством Сергея Илларионовича подготовлено 10 кандидатских диссертаций. С.И. Ордынский пользовался уважением среди профессорско - преподавательского состава института, он был внимательным, отзывчивым и доброжелательным человеком.

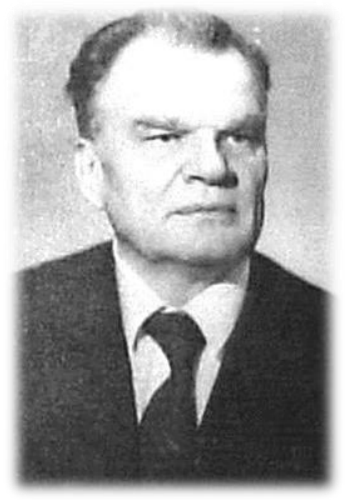

С 1960 по 1986 год заведующим был ученик А.И. Кузнецова профессор Евдокимов Петр Дмитриевич (1916-1986), научный кругозор которого охватывал многие научные направления фармакологии и токсикологии, в частности, изучение антимикробных и химиотерапевтических свойств химиопрепаратов при различных заболеваниях животных. В 1938 году с отличием окончил ЛВИ и был оставлен аспирантом кафедры фармакологии. С 1939 по 1946 гг. служил в Советской армии сначала в должности ветеринарного врача артиллерийского полка, а затем начальника инфекционного отделения армейского лазарета и ветеринарной лаборатории. Участвовал в освобождении Венгрии, Чехословакии, Австрии. Награжден орденами: «Красная Звезда», «Знак Почета», медалями: «За боевые заслуги, «За победу над Германией», «За трудовое отличие» (в связи со 100-летием со дня рождения В.И. Ленина,20-,30- и 50-летия Советской Армии, 250-летия Ленинграда). Петр Дмитриевич участвовал в боевых операциях в финскую кампанию 1939 - 1940 гг. на Ребольском направлении, а во время ВОВ он воевал вначале на Карельском фронте в составе 7-й Отдельной Армии (1941 - 1944 гг.), был начальником инфекционного отдела армейского ветеринарного лазарета, а с 1944 по 1945 г. был начальником полевой ветеринарной лаборатории в составе 9-й Гвар-дейской Армии 2-го Украинского Фронта.

Приобретенный опыт лечебной работы в период ВОВ, интерес к фармакологии и токсикологии позволили ему в 1951 г. успешно закончить аспирантуру и защитить кандидатскую диссертацию. А в 1955 году П.Д. Евдокимов успешно защитил докторскую диссертацию. Обе диссертации были посвящены применению наркотических препаратов и особенностям сочетанного и потенцированного наркоза у разных видов животных. Большую роль в формировании его как ученого и преподавателя оказал его научный руководитель генерал-майор медицинской службы проф. А.И. Кузнецов.

В 1957 г. он был утвержден в ученом звании профессора и с 1960 г. руководил кафедрой фармакологии и токсикологии ЛВИ. Во время работы в институте профессор П.Д. Евдокимов был известен как крупный ученый, высоко эрудированный педагог, прекрасный лектор.

В последние годы профессор П.Д. Евдокимов с сотрудниками кафедры успешно вел научно-исследовательские работы, направленные на изучение влияния нейролептиков, сульфаниламидных и других препаратов на процессы регуляции электролитного баланса у животных, на полостное и мембранное пищеварение у птиц.

П.Д. Евдокимов опубликовал около 250 статей, книг, справочных и методических пособий. За годы своей научной жизни воспитал более 50 учеников, защитившие кандидатские и докторские диссертации.

Именно он сумел с наибольшей отдачей соединить теоретические и практические изыскания в научные разработки и их внедрение в производство. 
П.Д. Евдокимов создал крупную школу ветеринарных фармакологов, подготовил 42 кандидата наук. Среди них: Жентелетите Л.А. (1955), Мирча, Зеленский В.П., Зеленская Н.П., Фолина Л., Антонов В.Я., Беспалько И.Г., Закардонец В.С.(1966), Зайцев А.В. (1969), Зюбан В.И. (1965), Карамышев В.А., Сотников В.В., Артемьев В.И. (1968) Погребняк Л.Л. (1963), Федорова 3.П. (1964), Буянова М.П. (1964), Сидоров Е.М., Кленова А.А. (1969), Соколов В.Д. (1967), Соколова Г.А., Придыбайло Н.Д.(1971), Мотрич Т.А., Попова В.Д., Бабаева М.А., Никитин Г.И. (1969), Хабаров Г.Н., Семенченко Н.А., (1965), Клочкова Ю.Ф.,(1970), Иванова Г.Ф., Нифантова В.П., (1972), Арсеньев Ю.И., Никитина Н.В., Селезнев Н.И., (1973), Степанова Г.А. (1973), Тушашвили Ц.Г., Бобашвили Л.Г., Павлова П.А. (1978), Рыбаков Ю.Н. (1975), Викторенко В.В., Мосин, Бакина Т.А. (1983), Милованова Т.А., Горшкова Е.Г., Кассин, Тивилев П.Г., Шафран Р.С., Сергеева Н.И., Рыжова Н.В., Святковский А.В., (1984), Бацанов В.П. (1986), Виноходов В.О. (1986). И 5 докторов наук: Некрасова М.А., Юриссон Э.Э. (1968), Мухамедшин В.А., (1964), Королев В.В., Соколов В.Д. (1975).

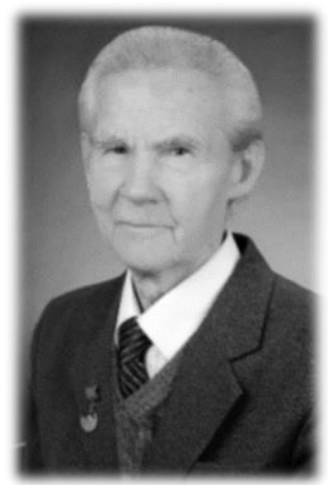

С 1986 по 2006 заведующим кафедрой был ученик П.Д. Евдокимова Соколов Владимир Дмитриевич (1932-2016). В 1947 - 1950 гг. он учился в Наумовском зоотехникуме, работал ветфельдшером Земцовского зооучастка, затем служил в рядах Советской Армии. В 1954 году поступил и в 1959 году с отличием окончил Ленинградский ветеринарный институт. Работал до 1965 года главным ветврачом района, зам. Председателя райисполкома и зам. начальника районного управления сельского хозяйства Новгородской области. В 1965 году поступил в аспирантуру Всесоюзного НИВИ птицеводства, которую успешно окончил и в 1968 году защитил кандидатскую диссертацию. В 1975 году защитил докторскую диссертацию на тему: «Химиопрофилактические свойства аэрозолей антимикробных препаратов при некоторых бактериальных инфекциях птиц». В 1981 году ему присвоили ученое звание профессора по специальности ветеринарная фармакология с токсикологией.

За широкие научные исследования, их внедрение в практику, постоянную связь с производством В.Д. Соколов стал лауреатом премии Совета Министров СССР, ему присвоено звание заслуженного деятеля науки РФ, а в 1995 году он избран академиком международной академии аграрного образования.

В.Д. Соколов был основоположником научного направления - ингаляционная химиотерапия животных. Им были разработаны теоретические и практические аспекты ветеринарной иммунофармакологии, стрессофармакологии, психофармакологии, энзимофармакологии, гомеопатии и реабилитационной фармакокоррекции.

Все свои знания, опыт и умение В.Д. Соколов направлял на дальнейшее развитие фармакологической науки и укрепление ее связи с практической ветеринарией, на пропаганду научных и педагогических знаний. Только благодаря его настойчивости и целеустремленности с 1989 проводились ежегодные Международные межвузовские научнопрактические конференции «Новые фармакологические средства в ветеринарии» с изданием материалов, а с 2008 конференции перешли в статус конгрессов. Так с 2008 года по 2019 год пять Международных конгрессов ветеринарных фармакологов и токсикологов «Эффективные и безопасные лекарственные средства в ветеринарии».

Благодаря его непосредственным усилиям, начиная с 2004 года по настоящее время выпускается журнал «Международный вестник ветеринарии», учрежденный двумя ветеринарными академиями: Санкт-Петербургской и Витебской. Ежегодно формируется и выпускаются 4 номера журнала, который входит в ядро РИНЦ, в Russian Science Citation Index (RSCI) на платформе Web of Science и заключено соглашение c CrossRef на регистрацию DOI.

Кроме того, В.Д. Соколов уделял много времени выпуску газеты «Ветеринарное обозрение», дающей информацию о деятельности всех ветеринарных организаций города, области и вуза. 
Большую работу В.Д. Соколов вел по подготовке научных кадров. Под его руководством подготовили и защитили диссертации 7 докторов наук и 40 кандидатов наук. Им опубликовано более 400 научных работ и монографий, в их числе несколько справочников и под его редакцией изданы учебники «Фармакология», «Клиническая фармакология» и «Ветеринарная фармация».

С 2006 по 2018 гг. в должности заведующего кафедрой фармакологии и токсикологии была Андреева Надежда Лукояновна, доктор биологических наук, профессор, Почётный работник высшего профессионального образования Российской Федерации. В 1972 году окончила биологический факультет Горьковского государственного университета имени Н.И. Лобачевского. С 1972 по 1974 годы работала в научно-исследовательском институте генетики и разведения животных (г. Пушкин), с 1976 по 1986 гг. научным сотрудником во Всесоюзном научно-исследовательском ветеринарном институте птицеводства. С 1986 году в ЛВИ, а затем в СПбГАВМ прошла все ступени должности педагога:

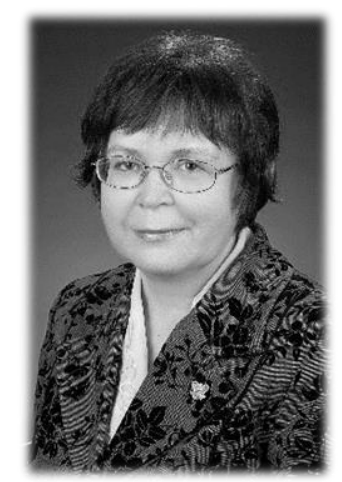
ассистента, доцента, профессора.

Как вдумчивый, целенаправленный, крупный ученый, профессор Н.Л. Андреева разработала, продолжает совершенствовать и развивать одно из важнейших научных направлений фармакологии и токсикологии - использование биологически активных веществ в ветеринарии для повышения устойчивости животных к различным неблагоприятным воздействиям внешней среды и увеличения их продуктивности. Это её научное направление прослеживается ещё в кандидатской диссертации, которое успешно было продолжено при выполнении докторской диссертации, благодаря этим работам кафедра не только теоретически обобщила материалы, но и внедрила в практику ряд уникальных иммуностимуляторов, адаптогенов и других препаратов.

Андреева Н.Л. является соавтором трех учебников «Фармакология», «Клиническая фармакология» и «Ветеринарная фармация» и учебных программ по этим дисциплинам. Ведет методическую и научную работу на кафедре. В большинстве учебных и методических пособиях, изданных на кафедре, она является соавтором. Имеет более 400 печатных работ и учебно-методических пособий, под её руководством защищено 7 докторских и 15 кандидатских диссертаций.

Основные научные направления профессора Андреевой Н.Л.: иммунофармакология, стрессофармакология, стимуляция продуктивности животных, повышение эффективности лекарственных средств, а также изучение побочного действия лекарственных препаратов и снижение их негативного действия на организм. По этим направлениям работают и её ученики.

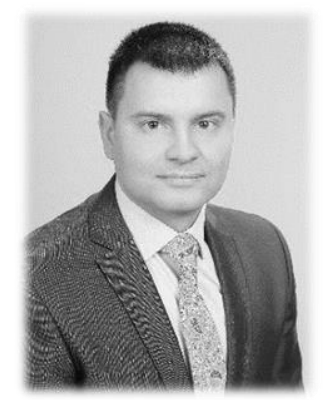

С 2018 года и по настоящее время заведует кафедрой фармакологии и токсикологии ученик Андреевой Н.Л. Лунегов Александр Михайлович. После окончания, в 2002 году, Санкт-Петербургской государственной академии ветеринарной медицины и службы в вооруженных силах РФ, обучался в аспирантуре при кафедре фармакологии и токсикологии СПбГАВМ. Защитил диссертацию на соискание ученой степени кандидата ветеринарных наук. С 2006 г. работал на кафедре фармакологии и токсикологии ассистентом, а с 2010 по 2018 гг. - доцентом кафедры. В 2010 году в СПбГАВМ открывают новое подразделение - факультет биоэкологии, и с 2010 года по 2015 год Лунегов А.М. занимает должность декана факультета биоэкологии, с 2012 г. дополнительно исполняет обязанности декана факультета водных биоресурсов аквакультуры, а с 2014 по 2015 гг. дополнительно исполняет обязанности декана факультета ветеринарно-санитарной экспертизы. Благодаря новым факультетам Лунегов А.М. внедряет в учебный процесс новую дисциплину и новое направление - фармакологию в аквакульутре, под которое было издано первое учебное пособие в России «Фармакология в аквакультуре». С появлением на кафедре студентов 
факультета биоэкологии, которым читается учебная дисциплина «Экологическая токсикология», Лунеговым А.М. было организовано обучение студентов факультета биоэкологии в качестве экологических волонтеров по ликвидации нефтеразливов в акватории Санкт-Петербурга и Финского залива совместно с Комитетом по природопользованию, охраны окружающей среды и обеспечению экологической безопасности.

Лунегов А.М. читает лекции и ведет лабораторно-практические занятия со студентами 3 и 5 курсов на высоком методическом уровне. Принимает активное участие в учебнометодической и научной работе кафедры. Лунеговым А.М. опубликовано свыше 140 научных трудов, среди которых два учебника и 13 патентов.

Кафедра по праву считается центром ветеринарной фармакологии России. Единственная кафедра, которая с 1989 года и по сегодняшний день объединяет ветеринарных фармакологов и токсикологов России в стенах Санкт-Петербургского государственного университета ветеринарной медицины проводя научные форумы, которые начал Соколов В.Д. и Андреева Н.Л.

Лунегов А.М. с сотрудниками кафедры продолжает начатое дело своих учителей и в 2019 году организовал 30-й по счету форум - V конгресс ветеринарных фармакологов и токсикологов «Эффективные и безопасные лекарственные средства в ветеринарии».

На кафедре с 2005 года используются гуманные альтернативные формы, обучения студентов с применением адаптированных компьютерных программ, целью которых является отказ от вивисекции - опытов на животных, приводящих нередко к их гибели, можно назвать это прорывом в методологии обучения студентов. Использование компьютерных программ позволило более глубоко и детально изучать нейротропные средства, многие из которых в силу особых причин, резко регламентированы. Благодаря внедренному методу обучения, университет вошел в список первых вузов России, внедривших этот прогрессивный метод обучения, и был премирован на международном уровне и получил приз «самому гуманному вузу России» - бронзовую скульптуру «Лягушка», которую вручил автор благотворительной работы скульптор Александр Цигаль. А также кафедра выиграла грант и получила муляж собаки Джерри для изучения работы сердечно-сосудистой и дыхательной систем на практических занятиях по дисциплине «Клиническая фармакология».

На сегодняшний день на кафедре обучаются студенты по специальности «Ветеринария» и бакалавры по направлениям подготовки «Ветеринарно-санитарная экспертиза», «Водные биоресурсы и аквакультура» и «Биоэкология». Сотрудники кафедры читают лекции и ведут практические занятия по следующим дисциплинам: «Ветеринарная фармакология», «Токсикология», «Клиническая фармакология», «Фармакология в аквакультуре», «Ихтиотоксикология», «Фармацевтическая технология», «Фармацевтическая химия», «Фармакогнозия», «Токсикологическая химия», «Управление и экономика фармации», «Современные проблемы науки и производства в ветеринарной фармации», а также ведут курсы повышения квалификации специалистов в области ветеринарии «Правовые аспекты фармацевтической деятельности, осуществляемой организациями в сфере обращения лекарственных средств, предназначенных для животных».

Коллектив кафедры постоянно совершенствует методы преподавания дисциплин, активизирует пропаганду ветеринарных знаний и старается поднять приоритет Санкт-Петербургского государственного университета ветеринарной медицины в области подготовки ветеринарных врачей высокой квалификации.

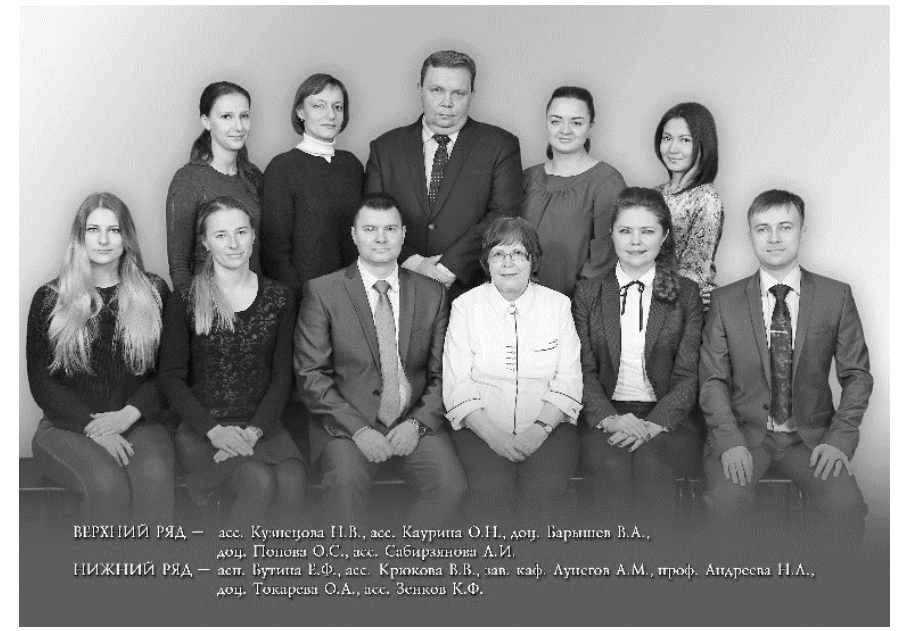




\title{
ВЫРАЩИВАНИЕ ГИДРОПОННОГО КОРМА С ЗАДАННЫМИ СВОЙСТВАМИ ДЛЯ ФУНКЦИОНАЛЬНОГО КОРМЛЕНИЯ КРС
}

Агафонова Л.А. студ 3 к. ФГБОУ ВО СПБГУВМ

Научный руководитель: к.в.н., доц. Попова О.С.

\begin{abstract}
Аннотация. Гидропоника - технология выращивания растений при помощи водяного питательного раствора, без применения земли и почвы. Данная технология в 5 раз эффективнее классического культивирования растений на грунте. В статье мы рассмотрим различные виды бизнеса, основанного на данной технологии.
\end{abstract}

Ключевые слова: гидропоника, кормление, скотоводство.

Зональными почвами Северо-Западного региона, то есть наиболее характерными для данной местности, являются почвы подзолистого и болотного типа, а также их подтипы. [6] Эндемической формой микроэлементоза, характерного для данных типов почв, является гипокобальтоз. [2]. Следовательно, скот, выращиваемый в Северо-Западном регионе, находится в зоне повышенного риска развития данной патологии. Таким образом встает вопрос об эффективной и дешевой профилактике данного заболевания. Такой профилактикой может стать дача гидропонного корма, выращенного с заданными свойствами.

Почвы Ленинградской области относят к зонам рискованного земледелия [7]. Это обусловлено физико-химическими параметрами почв, а также климатическими условиями данной области. Подзолистые и болотные почвы данного региона характеризуются повышенной кислотностью, обедненностью азотом и зольными элементами, такими как кобальт, фосфор, молибден, йод, медь селен [6]. В большинстве почв Карелии, которые по физико-химическим свойствам относятся к тому же типу, что и почвы Ленинградской области, зарегистрировано содержание подвижной формы кобальта 0,06-0,5 мг/кг [1], тогда как ПДК составляет 5 мг/кг [4]. При этом почвы содержат значительное количество подвижного марганца до 3500 мг/кг [1], при ПДК до 1500 мг/кг [4]. В связи с перечисленными свойствами использование данных почв в сельско-хозяйственных целях проблематично, требуются известкование и внесение больших доз минеральных удобрений [6].

Растения испытывают недостаток в кобальте при его концентрации в почве менее 2,02,5 мг/кг [2]. Следовательно, растения, выращиваемые на территориях Северо-Западного региона без внесения минеральных удобрений, являются обедненными кобальтом. Гипокобальтоз - это патологическое состояние, этиологическим фактором которого является алиментарная недостаточность кобальта и/или избыток в рационе антагонистов кобальта марганца, бора и стронция. Он характеризуется хроническим течением и не имеет патогномоничных признаков. Могут наблюдаться такие симптомы как анорексия, парарексия, выпадение шерсти, истощение и снижение продуктивности [2]. Главным источником кобальта для крупного рогатого скота является растительная пища. Однако, как было указано, территории Ленинградской области обеднены кобальтом и содержат большое количество его антагонистов - марганца и стронция. При этом, несмотря на данные условия, около 164 тыс. га Ленинградской области занято выращиванием кормовых культур для крупного рогатого скота, что соответствует 24,9 ц кормовых единиц грубых и сочных кормов на 1 условную голову крупного рогатого скота [7].

Для выращивания таких объемов кормов в почву вносится огромное количество удобрений. Однако регулярное внесение большого количества удобрений ухудшает качество почвы. Изменяются ее физико-химические характеристики, естественные для данной местности, такие как кислотность, соотношение катионов, снижается количество гумуса. Все это приводит к изменению видового состава бактерий, накоплению неестественных для среды соединений и дальнейшему загрязнению грунтовых вод. Помимо перечисленных факторов, часто внесение удобрений не контролируется, в результате чего в растениях накапливается больше минералов, чем должно быть, и они становятся токсичными для животных [3]. 
Поэтому в целях профилактики алиментарной недостаточности микроэлементов, в частности, таких как кобальт, а также для обеспечения экологичного сельского хозяйства, можно использовать добавки гидропонного зеленого корма. Гидропонный корм представляет собой зелень сочных кормов, таких как ячмень, овес, вика, рожь, кукуруза, соя, горох и другие виды злаковых или бобовых культур, выращенных гидропонным способом [5].

Преимуществами гидропонного корма являются повышение концентрации питательных веществ, а также их переход в легко усвояемые формы. При этом увеличивается количество минеральных веществ и витаминов. Так, например, если смотреть по усредненным данным кормовых таблиц, в 1 кг сухого вещества зерна ячменя содержится 0,3 мг кобальта, тогда как в том же количестве гидропонного корма, выращенного из этого зерна, содержится уже 2,33 мг кобальта [5]. Также питание растений находится под постоянным контролем, параметры можно изменять при необходимости. Сокращаются трудовые и пространственные затраты. Повышается качество урожая, за счет сокращения использования пестицидов и отсутствия гербицидов [5].

Однако у гидропонного метода выращивания корма есть и недостатки. Прежде всего это дороговизна оборудования, а также затраты на электричество [5]. Однако при наличии квалифицированных сотрудников и при оптимальном использовании оборудования данные затраты полностью себя окупают. К тому же, гидропонный корм не используется как полная замена почвенным зеленым кормам, а лишь как добавка. По данным опытов полная замена корма на гидропонный приводит к увеличению количества азота в рубце, сильному закислению мочи, а также поедаемость такого корма до конца не изучена [5].

Для таких регионов, как Северо-Западный, использование гидропонного корма в качестве минеральной подкормки может быть более эффективно и экологично. Проведенные исследования сообщают о том, что добавление гидропонного корма способствует повышению удоя высокопродуктивных коров на $6 \%$, при этом в молоке МДЖ повышается на $0,4 \%$, а МДБ на $0,35 \%$. Другие исследователи отмечают, что скармливание вместо $30 \%$ концентратов гидропонного ячменного корма по питательности было экономически выгоднее. Так, суточный удой коров в опытном варианте был выше на 24,2\% в сравнении с контролем [5]. Помимо перечисленного положительного влияния гидропонного корма на продуктивность животных, также обеспечивается профилактика гипокобальтоза, так как подобный корм будет содержать необходимое количество кобальта и марганца. Исходя из вышесказанного представляется возможным выращивание гидропонного корма с заданными свойствами для профилактики различных микроэлементозов, а также в целях повышения продуктивности животных.

Выводы. Применение добавок гидропонного корма с заданными свойствами в условиях Северо-Западного региона представляется экономически выгодным. Во-первых, снижается негативное влияние большого количества минеральных удобрений на почвы, и повышается экологичность производства. Во-вторых, за счет подбора специальных растворов крупный рогатый скот может получать все необходимые микроэлементы и витамины из зеленого корма, которыми беден данный регион. В-третьих, обеспечивается профилактика труднодиагностируемых эндемичных микроэлементозов, в частности гипокобальтоза.

Литература 1. Завгородняя, Р. Е. Микроэлементный состав некоторых торфяных почв Карелии разных сроков освоения / Р. Е. Завгородняя. - Текст: непосредственный // Ученые записки Петрозаводского государственного университета. - 2015. - № 8. - С. 111-114. 2. Красочко, П. А. Болезни сельскохозяйственных животных / П. А. Красочко, М. В. Якубовский, А. И. Ятусевич [и др.] - Минск: Бизнесофсет, 2005. - 798 с. - Текст: непосредственный. 3. Нилов, Н. Минеральные удобрения: польза и вред / Н. Нилов. — Текст: электронный // Союз органического земледелия : [сайт]. — URL: https://soz.bio/mineralnye-udobreniya-polza-i-vred/ (дата обращения: 27.04.2021). 4. О санитарно-эпидемиологическом благополучии населения: Федеральный закон № 52-Ф3 от 30 марта 1999 г.: принят Государственной Думой 1 апр. 2006 г. // Собрание законодательства Российской Федерации 5. Попов, В. В. Гидропонный корм: достоинства и недостатки, качество и эффективность/В.В.Попов. - Текст: 
непосредственный//Адаптивное кормопроизводство. - 2019. - № 3. - С. 86-101. 6. Почвы Ленинградской области / Под ред. канд. с.-х. наук В. К. Пестрякова. - Ленинград: Лениздат, 1973. - 344 с 7. Растениеводство Ленинградской области. - Текст: электронный // Агровестник: [сайт]. — URL: https://agrovesti.net/lib/regionals/region-47/rastenievodstvo.html (дата обращения: 27.04.2021).

\title{
CULTIVATION OF HYDROPONIC FEED WITH TARGETED PROPERTIES FOR FUNCTIONAL FEEDING OF CATS
}

Agafonova L.A. student 3 c. FSBEI HE St.Peterburg SUVM

Scientific adviser: Ph.D., docent Popova O.S.

Summary. Hydroponics is a technology of growing plants using an aqueous nutrient solution, without the use of land and soil. This technology is 5 times more effective than classical cultivation of plants on the ground. In this article, we will look at various types of businesses based on this technology.

Key words: hydroponics, feeding, cattle breeding.

УДК 619:614.48:631.22

\section{ОЦЕНКА КАЧЕСТВА АКТИВНОСТИ ДЕЗИНФИЦИРУЮЩЕГО СРЕДСТВА «ПАРАСОД» НА ПРЕДПРИЯТИИ ПО ВЫРАЩИВАНИЮ ИНДЕЙКИ.}

Ажикина О.Ю., студент, ФГБОУ ВО СПбГУВМ, Россия

Научный руководитель: к.в.н., доц. Зенков К.Ф.

\begin{abstract}
Аннотация. Ввиду ускоренного метаболизма индейки, особенности ее содержания и ухода за ней, при возникновении вспышки инфекции, болезнь распространяется молниеносно и течение ее нередко бывает острым, что вызывает высокий процент падежа. По этой причине, основным методом борьбы с заболеваниями разнообразной этиологии на птицефабриках является их профилактика, важным звеном которой является дезинфекция. В данной статье рассматривается эффективность препарата «Параформ» при обработке птицеводческих помещений, а также его влияние на организм индейки.
\end{abstract}

Ключевые слова: Парасод, индейка, дезинфекция.

С 2005 года российский рынок индейки демонстрирует динамичный рост увеличения числа тонн реализуемой продукции, вместе с тем происходит закономерное сокращение доли импортируемого мяса индейки. Так в 2010 году доля импорта составляла 32,5\%, в 2016 - лишь $1,8 \%$. Ввиду быстрого темпа развития и ежегодного увеличения количества голов птицы, крупные сельскохозяйственные комплексы столкнулись с рядом проблем, касающихся профилактики и борьбы с инфекционными заболеваниями. Поскольку домашняя индейка является самостоятельным видом, имеющим определенные физиологические особенности, полное перенятие проведения зоогигиенических профилактических мероприятий проводимых на птицеводческих предприятиях по разведению курицы не всегда возможно. По этой причине, в настоящий момент, ведутся различные исследования, направленные на оценку уже имеющихся дезинфектантов и разработку новых средств [1], применяемых в работе с индейкой.

Целью данного исследования являлось оценить качества дезинфектанта «Парасод», одновременно с этим произвести оценку физиологического состояния индейки, перемещенной в птичник, где ранее производилась обработка «Парасод». Исследование проводилось в Тульской области, на территории одного из филиалов птицефабрики «Краснобор» в 2020 году.

Препарат парасод содержит 50\% параформа и 50\% карбоната натрия. По внешнему виду он представляет собой порошок белого цвета, хорошо растворимые в горячей воде (50$\left.60^{\circ} \mathrm{C}\right)$, устойчивый при хранении. Широко распространен в качестве дезинфицирующего 
средства в животноводческих помещениях [2]. Преимуществами данного препарата являются его широкий спектр действия, распространяющийся на микроорганизмы, грибки, и ряд простейших. Кроме того, преимуществом парасода является так же и возможность применение препарата в виде аэрозолей и водных растворов. В основе механизма действия лежит термическая реакция деполимеризации параформа до формальдегида, либо до раствора формальдегида в присутствии воды. Полученное вещество обладает антимикробной активностью за счет отнятия кислорода от белковых соединений [3] и коагуляции белка клетки бактерии. Для исследования использовался 40\%-й растворов из расчета 20 мл на 1 м $^{3}$ в форме аэрозольной дезинфекции. Препарат применялся в 5 помещениях, после удаления птицы и последующей механической обработки и мойкиптичников.

Для оценки бактериальной активности по завершению обработки парасодом, через 24 часа герметизации и последующего проветривания до исчезновения запаха, проводилось бактериологическое исследование посредством смывов с объектов окружающей среды (поилки, кормушки, стены, ограждающие конструкции, пол) [4].

Взятие проб производилось с помощью стерильных ватных тампонов в пробирки с 3-5 мл. физиологического раствора. Для обнаружения тех или иных микроорганизмов делали последовательные разведения. Посев производился на соответствующие агаризированные питательные среды в чашках Петри в объеме 0.1 мл суспензии пробы различных разведений. Бактериологический контроль качества проводился по подсчету клеток санитарнопоказательных микроорганизмов, относящихся к 1-ой и 2-ой группам устойчивости к дезинфицирующим средствам (кишечная палочка и стафилококки).

По окончании бактериологического исследования было установлено отсутствие $e$. coli в смывах, полученных из пяти птицеводческих помещений. В $87 \%$ от общего числа смывов, взятых после проведения дезинфекции, рост стафилококков не отмечено, а в остальных - рост единичных культур.

По окончании проведения дезинфицирующих работ и завершения проветривания до исчезновения характерного для средства запаха, была произведена транспортировка птицы в возрасте 30 дней. При оценке состояния поголовья на предмет наличия аллергических реакции, на 1-й, 5-й и на 10-й день, не показали каких-либо результатов. Поведение птицы не изменялось, угнетение не наблюдалось.

Таким образом, дезинфецирующее средство «Парасод» в ходе исследования показало высокую активность и безопасность в использовании по отношению к санитарнопоказательным микроорганизмам. Кроме того, преимуществом дезинфектанта является его слабо выраженное раздражающие действие на организм индейки. Исходя из этого препарат «Парасод» может-быть рекомендован для проведения профилактической и вынужденной дезинфекции птичников, при содержании индейки.

Литература 1. Антимикробные и противопаразитарные средства : учебно-методическое пособие по ветеринарной фармакологии / сост.: Н. Л. Андреева, А. М. Лунегов, О. С. Попова, В. А. Барышев. - Санкт-Петербург : Санкт-Петербургская государственная академия ветеринарной медицины, 2017. - 57 с., 2. Изучение эффективности дезинфицирующих средств в производственных условиях / О. П. Пугач, Н. Л. Андреева, А. М. Лунегов, В. А. Барышев // Инновационные исследования как локомотив развития современной науки: от теоретических парадигм к практике : сборник научных статей по материалам XVI Международной научнопрактической конференции, Москва, 15 декабря 2019 года. - Москва: ООО "Научный инновационный центр Международный институт стратегических исследований", 2019. - С. 461-466., 3. Санитарно-гигиеническое обоснование применения Монклавита-1 для обработки вымени у коров / А. Ф. Кузнецов, Г. С. Никитин, К. Ф. Зенков [и др.] // The Scientific Method. - 2017. - Т. 1. - № 10. - С. 16-19., 4. Понамарев, В. С. Полимеразная цепная реакция с электрофоретической детекцией продуктов амплификации / В. С. Понамарев, С. А. Макавчик // Молодежный научный форум: естественные и медицинские науки. - 2016. - № 10(38). - С. 148-152. 


\section{EVALUATION OF THE QUALITY OF THE ACTIVITY OF THE DISINFECTANT "PARASOD" AT THE ENTERPRISE FOR GROWING TURKEYS}

Azhikina O.Yu., student, FSBEI HE St.Peterburg SUVM, Russia

Scientific adviser: Ph.D., docent Zenkov K.F.

Summary: Due to the accelerated metabolism of the turkey, the peculiarities of its keeping and caring for it, when an outbreak of infection occurs, the disease spreads with lightning speed and its course is often acute, which causes a high mortality rate. For this reason, the main method of combating diseases of various etiologies in poultry farms is their prevention, an important link in which is disinfection. This article examines the effectiveness of the drug "Paraform" in the treatment of poultry buildings, as well as its effect on the body of a turkey.

Key words: Parasod, turkey, disinfection.

УДК 37.091.3;68.4;619.615.9

\section{К ВОПРОСУ СОВЕРШЕНСТВОВАНИЯ ПРЕПОДАВАНИЯ ДИСЦИПЛИНЫ «ВЕТЕРИНАРНАЯ ФАРМАКОЛОГИЯ»}

Акчурин С.В., доц., к.в.н., Акчурина И.В., доц., к.в.н., Вершинина М.А., студент 3 курса специальности «Ветеринария» (ФГБОУ ВО РГАУ-МСХА имени К.А. Тимирязева, Россия)

Аннотация. Подготовка ветеринарных врачей, а, следовательно, и качество оказываемых ими ветеринарных услуг, во многом зависит от качества реализуемой образовательной программы. Одной из ключевых дисциплин образовательной программы

Ветеринария является «Ветеринарная фармакология». На основании проведенного анализа был выявлен ряд тем, вызывающих наибольшее затруднение у студентов. Предложены меры по повышению доступности учебного материала с использованием видеоформата его представления.

Ключевые слова: ветеринария, фармакология, образование.

Глубокое понимание основ фармакологии важно для способности выпускника ветеринарного факультета позволяет правильно и безопасно решить, какое лекарство использовать в каждом отдельном случае.

В соответствии с рабочей программой дисциплины ветеринарная фармакология преподается для студентов специальности 36.05.01 Ветеринария очной формы обучения ФГБОУ ВО РГАУ-МСХА имени К.А. Тимирязева в рамках дисциплины «Ветеринарная фармакология. Токсикология» в 5 семестре. Учебный процесс по дисциплине реализуется в форме лекций и практических занятий. На третьем курсе обучается три академические группы.

При проведении лекций применяется объяснительно-иллюстративный метод, который предусматривает получение студентами новой информации, ее осмысление, обобщение и систематизация. 100 \% лекций сопровождается материалом в мультимедийной форме.

Практические занятия проводятся с использованием информационно-рецептивного и репродуктивного, частично-поискового методов обучения с использованием ситуационных задач. В процессе обучения проводятся текущий, рубежный и итоговый формы контроля.

Для выявления тем, вызвавших наибольшее затруднение, было проведено анкетирование студентов. Анкета была разработана с помощью интернет-сервиса Google Forms. Студентам было предложено обозначить не более трех таких тем. Ссылка на анкету была разослана через личные кабинеты студентов на портале университета.

В анкетировании приняли участие 70,4 \% студентов, освоивших курс «Фармакология».

По результатам анкетирования установлено, что наиболее сложными темами по ветеринарной фармакологии стали:

- Действие лекарства и фармакодинамика - 65 \% опрошенных; 
- $\quad$ Фармакокинетика - $60 \%$;

- $\quad$ Виды действия лекарственных веществ - $60 \%$.

Для повышения доступности учебного материала предпочтение было отдано решению по включению видеоформата представления информации в лекционный материал. Выбор в пользу видеоформата обусловлен наличием у него ряда преимуществ:

- $\quad$ привлекает и удерживает внимание, вовлекает;

- $\quad$ способствует облегчению восприятия новой и сложной информации;

- $\quad$ служит способом для демонстрации явлений, ситуаций и событий реального мира, которые нет возможности немедленно продемонстрировать вживую [1].

Аналитический отчет Harvard Business Publishing Education [2] свидетельствует об эффективности видеоформата в сравнении с другими формами подачи материала, в том числе текстом.

Для поиска видеоматериалов по темам «Фармакодинамика», «Фармакокинетика»,

«Действие лекарственных веществ» была использована поисковая система «Яндекс». Поиск осуществлялся в разделе «Видео».

Для отбора видеофайлов были применены следующие критерии:

«Фармакокинетика»,
«Действие лекарственных веществ»;

- $\quad$ наличие информации, применимой для ветеринарного образования;

- $\quad$ четкий хронометраж времени (информация представлена кратко, «без воды»);

- $\quad$ наличие анимации;

- $\quad$ способность вызывать эмоции.

Анализ размещенных в сети Интернет видеоматериалов, посвященных указанной тематике, позволил установить, что в наибольшей степени указанным критериям соответствуют видеоролики канале Vetmedacademy на видеохостинге YouTube:

- $\quad$ Визуализация фармакокинетики (продолжительность 16 мин.) [3];

- $\quad$ Фармакодинамика: лекарственные агонисты (14 мин) [4];

- $\quad$ Лекарственные антагонисты (13 мин.) [5].

Указаны видеоролики были озвучены диктором с использованием английского языка.

Видеоролики были переведены на русский язык, озвучены с синхронизацией текста и видеоряда.

Переведенные на русский язык видеоролики были представлены студентам специальности «Ветеринария», освоившим курс «Ветеринарная фармакология». 82 \% студентов, посмотревших указанные видеоролики, отметили преимущество данной формы представления учебной информации в сравнении с традиционной лекцией, содержащей мудьтимедийную презентацию.

Таким образом, при изложении учебного материала, представляющего наибольшую сложность в понимании студентов, целесообразно, наряду с использованием мультимедийных презентаций, демонстрировать видеролики.

Литература. 1. Видео в обучении: создаем и вовлекаем. EduTech. - 2021. - № 1 (39). - 3 с. URL:https://sberbank-university.ru/upload/iblock/eb3/EduTech_39_web.pdf (дата обращения 21.04.2021). Online learning report covid-19 pulse survey. 2020. - 19 c. URL: https://s3.amazonaws.com/he-product-images/docs/Higher_Education_Online_Learning_Report_ Aug2020.pdf?cid=email\% 7Celoqua\% 7C8-26-20-back-to-school-online-teaching-resources-projectace-webinar-reg-and-edu\%7C617648\%7Cthemed-broadcast\%7Ceducator\%7Cvarious\%7Caug 20202001\&acctID (дата обращения 21.04.2021). 2. Pharmacokinetics Visualized. URL: https://youtu.be/0-fERRXiOzo (дата обращения 21.04.2021). 3. Pharmacodynamics: Drug Agonists: Full and Partial. URL: https://youtu.be/y0QKdF-1ocE.(дата обращения 21.04.2021). 4. Drug Antagonists, Agonist/Antagonists and Inverse Agonists. URL: https://youtu.be/GTZCKeqnpLo. (дата обращения 21.04.2021). 


\section{TO THE PROPOSAL FOR STREAMLINING THE TEACHING OF THE «VETERINARY PHARMACOLOGY»}

S. Akchurin, Associate Professor, Candidate of Veterinary Sciences, I. Akchurina, Associate Professor, Candidate of Veterinary Sciences, M. Vershinina, a third-year student of speciality "Veterinary".

Russian State Agrarian University - Moscow Timiryazev Agricultural Academy, Russia

Summary. Training for the veterinarian specialists and therefore the quality of veterinary services depend on the capacity of current education program. One of the key disciplines of the educational program 36.05.01 Veterinary Medicine is «Veterinary Pharmacology». Based on the analysis, there were a number of topics cause the greatest difficulties in students. The article refers to measures to increase the accessibility of educational material using the video format of its representation.

Key words: veterinary medicine, pharmacology, education.

УДК: 578.8:612.017.12

\section{СОВЕРШЕНСТВОВАНИЕ ТЕХНОЛОГИИ ИЗГОТОВЛЕНИЯ АССОЦИИРОВАННОЙ ВАКЦИНЫ ПРОТИВ ЧУМЫ МЕЛКИХ ЖВАЧНЫХЖИВОТНЫХ И ОСПЫ ОВЕЦ}

Аманова Ж. Т., н.с, Баракбаев К. Б., к.в.н., Булатов Е. А., к.б.н., Абдураимов Е. О., д.в.н., Закарья К.Д., д.б.н.

(Научно-исследовательский институт проблем биологической безопасности, Казахстан)

Аннотация. Чума мелких жвачных животных (ЧМЖЖ) и оспа овец (ОО) являются высококонтагиозными заболеваниями мелкого рогатого скота, которые в случае вспышки наносят значительный экономический ущерб сельскому хозяйству. В данной работе отражены результаты исследования по совершенствованию существующей в РК технологии изготовления ассоциированной вакцины против ЧМЖЖ и ОО. В результате усовершенствованной технологии была получена ассоциированная вакцина против ЧМЖЖ и ОО с высокой биологической активностью.

Ключевые слова: ассоциированная вакцина, чума мелких жвачных животных, оспа овец.

Введение. Современное животноводство характеризуется широким внедрением интенсивных форм производства. Специфика современной технологии содержания и кормления животных существенно изменила их среду обитания. Большая концентрация животных на ограниченных площадях, поступающих из разных эпизоотических регионов, широкий обмен животными внутри страны и ввоз из-за рубежа их высокопродуктивных племенных пород, трудности организации непрерывного производства, полноценного кормления и обеспечения оптимального микроклимата создают благоприятные условия для возникновения массовых инфекционных заболеваний [1]. К таким опасным инфекционным заболеваниям животных относятся чума мелких жвачных животных (ЧМЖЖ) и оспа овец (ОО), которые могут проявляться и протекать одновременно или последовательно, чередуясь друг с другом. Для территории Республики Казахстан (РК) и стран Центральной Азии эти два заболевания всегда представляют серьезную биологическую угрозу.

Следует отметить, что в 2019 г в сельском округе Кызыл Озен, Тупкарагайского района, Мангистауской области, а также в селе Суюндук, Курмангазинского района Атырауской области было зарегистрировано ОО и оспа коз (ОК) [2]. Благодаря экстренным мерам, принятым ветеринарными службами РК, удалось локализовать инфекцию.

В связи сэпизоотической ситуацией по ЧМЖЖ и ОО ветеринарная служба РК, с целью недопущения их проникновения из сопредельных или отдаленных стран, ежегодно проводит плановую профилактическую иммунизацию овец зон риска моновалентными вакцинами против данных инфекций. 
Использование указанных двух моновалентных вакцин требует от ветеринарных специалистов и животноводов проведения двукратной компании вакцинопрофилактики, что требует отдельных временных, трудовых и финансовых затрат. Кроме того, каждое ветеринарное вмешательство оказывает стрессовое воздействие на организм животных. Для исключения этих и других негативных явлений, возникающих при применении моновалентных вакцин и других ветеринарных вмешательств, в последние годы большое значение придается разработке ассоциированных вакцин против ЧМЖЖ и ОО, так как данный тип вакцины при ее применении способствует одновременному развитию иммунитета против этих заболеваний, при этом по иммунологической и эпизоотологической эффективности не уступает моновалентным вакцинам против этих инфекций[3].

В связи с этим, для одновременной профилактики ЧМЖЖ и ОО в Казахстане в лице НИИПББ была разработана ассоциированная вакцина. По разработанной технологии ассоциированную вакцину против ЧМЖЖ и ООизготавливали путем совместногокультивированиявакцинных штаммов данных вирусов в первичнотрипсинизированной культуре клеток почки ягненка (ПЯ) стационарным методом с последующим смешиванием полученнойассоциированной суспензии с лактоза-пептонным стабилизатором [4].

Учитывая строгие требования к технологии производства вакцин, возникает необходимость внедрения усовершенствованного варианта ассоциированной вакцины против ЧМЖЖ и ОО. В связи с этим авторами данной статьи проведены исследования по совершенствованию существующей в РК технологии изготовления ассоциированной вакцины против ЧМЖЖ и ОО.

Целью данной работы является совершенствование технологии изготовления ассоциированной вакцины против ЧМЖЖ и ОО.

Материалы и методы. Вирусную биомассу ЧМЖЖ и ОО получали согласно методике [5] и [6] соответственно смодификацией некоторых параметров культивирования данных вирусов. При этом, культуру клеток Vегоинфицировали вирусом ЧМЖЖ и ОО в дозах 0,01 и 0,1 ТЦД50/кл соответственно. Сосуды, с инфицированными культурами клеток устанавливали в роллерный аппарат на 30 мин, для контакта монослоя клеток с вирусом ЧМЖЖ и ОО. В качестве поддерживающей среды использовалиDMEM, содержащий 2 \% инактивированную сыворотку КРС и 1 \% глутамина. Вирусы культивировали без смены среды в роллерном аппарате, где они вращались со скоростью от 10 до 12 об/чпри температуре $(37,0 \pm 0,5){ }^{\circ} \mathrm{C}$ в течение $4-5$ сут. По достижении цитопатического действия в монослое культуры клеток Veroна 70-80 \% сосуды замораживали при (-20) ${ }^{\circ} \mathrm{C}$ в течение 10-12 ч. После все сосуды подвергали двум циклам замораживания и оттаивания при комнатной температуре с последующим сбором размороженных вируссодержащих суспензий (BCC) ЧМЖЖ и ООв чистые емкости и отбором их проб в асептических условиях.

Балк-продукт получали путем объединение суспензий вирусов ЧМЖЖ и ОО 1:1с последующим добавлением в полученную ассоциированную суспензию защитную среду, охлажденную до $(4 \pm 1){ }^{\circ} \mathrm{C}$, в соотношении $1: 1$, пенициллин 500000 ЕД и стрептомицин 0,5 г или гентамицина 200000 мкг на 1 дм3 смеси. После контакта с антибиотиками в течении 12 ч при плюс $4{ }^{\circ} \mathrm{C}$ балк-продукт разливали в ампулы по 1,0 см3 и лиофилизировали в сублимационной установке согласно методике [7].

Активность наработанной суспензий вирусов ЧМЖЖ и ОО и высушенной вакцины определяли в культуре клеток Vero согласно методике $[8,9]$ соответственно, при этом титр высушенной вакцины определяли с использованием специфических сывороток к указанным вирусам. Расчет титра вируса производили по методу ReedI.J. и MuenchH.А и указывали в $1 \mathrm{~g}$ ТЦД50/см3[10].

Стерильность полученной суспензий вирусов ЧМЖЖ и ОО, а также лиофилизированной ассоциированной вакцины определяли согласно методике [11].

Статистическая обработка экспериментальных данных. Математическую достоверность результатов исследований устанавливали с использованием программы 
GraphPadPrism 8.0.1. Для всех данных была применена описательная статистика: подсчитаны средняя значения (M), стандартное отклонение (SD) и стандартные ошибки среднего (SEM). Порогом статистической значимости считали $\mathrm{P} \square 0.05$.

Результаты исследований. $\mathrm{B}$ результате проведенных исследований по совершенствованию технологии получения ВСС ЧМЖЖ и ОО путем раздельного культивирования вакцинных штаммов Nigeria-75/1 вируса ЧМЖЖ и штамма НИСХИ вируса ОО в перевиваемой линии клеток Vero роллерным методом, наработаны стерильные ВСС ЧМЖЖ и ОО с биологической активностью 6,66lgТЦД50/см3 и $6,41 \lg$ ТЦД50/см3 соответственно, тогда как биологические активности ВСС ЧМЖЖ и ОО, полученные по существующей технологии изготовления ассоциированной вакцины против ЧМЖЖ и ОО [4], составляли5,16 lg ТЦД50/см3 и 5,83 lg ТЦД50/см3 соответственно (рис. 1).Разница между биологическими активностями ВСС ЧМЖЖ, полученных двумя разными технологиями, составила 1,501g ТЦД50/см3,при этом между активностями ВСС ЧМЖЖ отмечен достоверное различие $(\mathrm{P}<0,01)$, тогда как различие между активностями ВСС ОО составила 0,501g ТЦД50/см3 соответственно $(\mathrm{P}<0,05)$.

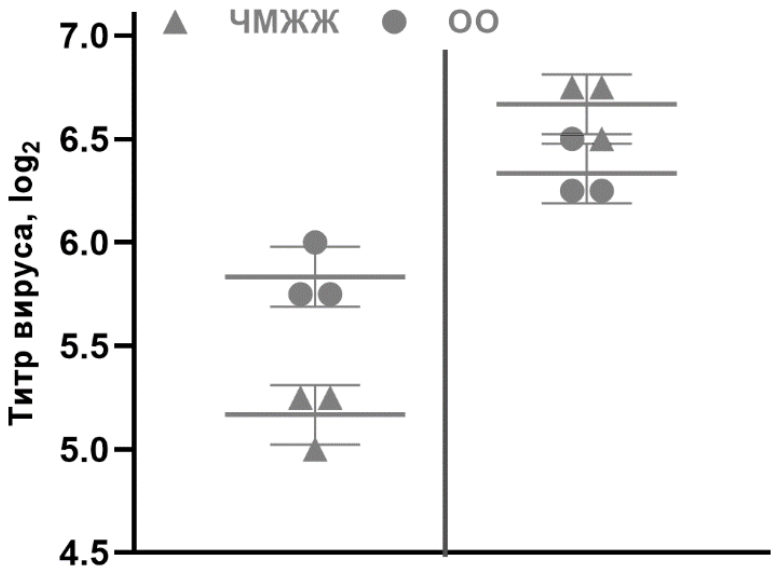

A

Б
Рисунок 1 - Биологическая активность вирусов ЧМЖЖ и ОО.

А.Ассоциированная биомасса ЧМЖЖ и ОО, полученная по ранее разработанной технологии изготовления ассоциированной вакцины;

Б.Вирусные биомассы ЧМЖЖ и ОО, полученные по усовершенствованной технологии изготовления ассоциированной вакцины.

Следует отметить, что существенное различие между биологическими активностями ВСС ЧМЖЖ, полученных по разным технологиям, обусловлена не только с модификацией технологии получения ВСС, но и выбором штамма Nigeria-75/1 вируса ЧМЖЖ в качестве одного из основных агентов для совершенствования технологии изготовления ассоциированной вакцины против ЧМЖЖ и ОО.

Балк-продукт готовили путем объединение полученных ВСС ЧМЖЖ и ОО в соотношении 1:1 с добавлением защитной среды (5 \% пептона-3 \% сахарозы) и антибиотиков в готовую ассоциированную суспензию. Готовый балк-продукт разливали в ампулы и лиофилизировали. Результаты физико-биологических свойств приготовленной ассоциированной вакцины представлены в таблице 1.

Таблица 1 - Биологические и физические параметры экспериментально-лабораторной серии ассоциированной вакцины против ЧМЖЖ и ОО

\begin{tabular}{|c|c|c|c|c|}
\hline $\begin{array}{l}\text { № } \\
\text { серии /* }\end{array}$ & $\begin{array}{l}\text { Состав защитной } \\
\text { среды в вакцине } \\
(\%) / * *\end{array}$ & 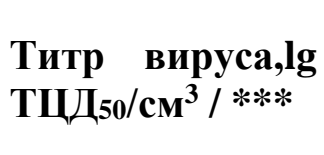 & Стерильность & $\begin{array}{l}\text { Физические } \\
\text { показатели } \\
\text { вакцин/ *** }\end{array}$ \\
\hline $1 / 2500$ & $\begin{array}{l}\text { Пептон - } 5 \\
\text { Сахароза - } 3\end{array}$ & $\begin{array}{l}6,33 \pm 0,08 / \\
5,92 \pm 0,08\end{array}$ & Стерильно & $\begin{array}{l}\text { Однородная } \\
\text { таблетка } \\
\text { светло- } \\
\text { коричневого } \\
\text { цвета }\end{array}$ \\
\hline
\end{tabular}


Примечания:

Числитель - активность вируса ЧМЖЖ;

Знаменатель - активность вируса ОО;

* - серия состоит из 2500 доз;

**-конечное концентрация защиттной среды,

*** - после лиофилизации вакицны.

Из данных таблицы следует, что в результате проведенных исследований приготовлена 1 серия стерильной ассоциированной вакцины с биологической активностью вирусов ЧМЖЖ и ОО 6,33 lg ТЦД50/см3 и 5,92 lg ТЦД50/см3 соответственно.

Таким образом, на основе анализа проведенных исследований было установлено, что с использованием усовершенствованной нами технологии можно приготовить ассоциированную вакцину против ЧМЖЖ и ОО с высокой биологической активностью.

Обсуждение результатов. Основной трудностью при разработке комбинированных вакцинных препаратов является подбор иммуногенов (штаммов), входящих в состав препарата, которые обеспечивают полноценный иммунный ответ у животных после вакцинации.

Разработанная нами комбинированная вакцина против ЧМЖЖ и ОО была основана на высокоиммуногенных штаммах: Nigeria-75/1 вируса ЧМЖЖ (адаптированный на культуру клеток Vero при 75 пассаже) и НИСХИ (адаптированный на культуру клеток Vero при 5-м пассаже) вируса ОО. Следует отметить, что вакцинный штамм НИСХИ был аттенуирован из низкопатогенного полевого штамма вируса ОО путем проведения 30 последовательных пассажей на культуре клеток почки ягненка (ПЯ) [12]. Указанный штамм НИСХИ, используемый в составе ассоциированной вакцины, был адаптирован к культуре клеток Vero при 5-м пассаже. Адаптация штамма НИСХИк культуре клеток Vero была определена с помощью цитопатогенного эффекта (ЦПЭ), специфичной к вирусу ОО и путем обнаружения вирусной нуклеиновой кислоты с использованием ПЦР тест-системы. Следовательно, адаптированный к культуре клеток Vero штамм НИСХИ был проверен на безвредность путем вакцинации овец в дозе в 100 раз превышающую иммунизирующую дозу (5,0 см3), где вакцинированные овцы оставались, здоровыми без каких-либо признаков заболевания (ОО) в течение 30 сут. Выбор вакцинных штаммов Nigeria-75/1 вируса ЧМЖЖ и НИСХИ вируса ОО для усовершенствование существующей технологии изготовления ассоциированной вакцины обусловлен тем, что полученные с их помощью моновалентные вакцины против ЧМЖЖ и ОО характеризуются полной безопасностью и надежной эффективностью при использовании для профилактической иммунизации овец и коз в угрожаемых ЧМЖЖ и ОО зонах РК и других неблагополучных по данным инфекциям странах.

Целью данной работы является совершенствование технологии изготовления ассоциированной вакцины против ЧМЖЖ и ОО.

Процесс достижения поставленной цели начался с наработки ВСС ЧМЖЖ и ОО, путем раздельного культивирования данных вирусов в перевиваемой культуре клеток Vero роллерным методом. В результате проведенных работ были получены ВСС ЧМЖЖ и ОО с высокой биологической активностью и стерильностью. В дальнейших исследованиях из полученных ВСС ЧМЖЖ и ОО была изготовлена ассоциированная вакцина против ЧМЖЖ и ОО. Приготовленная ассоциированная вакцина по биологическим показателям превосходит существующий в РК аналог данной вакцины [4].

Следовательно, исходя из анализа полученных результатов исследований было установлено, что применение усовершенствованной технологии изготовления ассоциированной вакцины против ЧМЖЖ и ОО позволяет получить высокоактивную ассоциированную вакцину.

Заключение. В результате проведенных исследований была усовершенствована технология изготовления ассоциированной вакцины против ЧМЖЖ и ОО. Установлено, что применение усовершенствованной технологии позволит получить ассоциированную вакцину 
против ЧМЖЖ и ОО с высокой биологической активностью, которая в будущем обеспечит надежную защиту от данных инфекций.

Литература. 1. Аманова Ж.Т., Таранов Д.С., Жугунисов К.Д., Кондибаева Ж.Б., Баракбаев К.Б., Булатов Е.А. Безопасность и реактогенность ассоциированной вакцины против чумы мелких жвачных животных и оспы овец // Наука и образования. - 2019. - №1(54). - С. 234-240. 2. Эпизоотическая ситуация в мире по данным МЭБ [Электронный ресурс]. - 2020. - URL: https://www.fsvps.ru/fsvps/iac/foreign.html(дата обращения: 10.09.2020). 3.Аманова Ж.Т., Жугунисов К.Д., Булатов Е.А., Жунушов А.Т., Саметова Ж.Ж., Шаяхметов Е.А., Баракбаев К.Б., Абдураимов Е.О. Оценка эффективности стабилизирующих сред при лиофилизации и хранении ассоциированной вакцины противчумы мелких жвачных животных и оспы овец // Известия НАН КР. - 2020. - № 2. - С. 25-34. 4. Taranov D, Yershebulov Z, AmanovaZh, Bulatov Ye, Barakbayev K, Abduraimov Ye, KondibaevaZh, Znugunissov K, Sansyzbai A. Study of Cultural Characteristics and Interference of PesteDes Petites Ruminants Virus and Sheep Pox Virus in CoCulture. LifeSciJ 2014;11(9):227-231 5. Таранов Д.С., Абдураимов Е.О., Ершебулов 3.Д., Кулманбетов К.Д., Кошеметов Ж.К. Культивирование вируса чумы мелких жвачных животных в культурах клеток животных // Биотехнология в Казахстане: Проблемы и перспективы инновационного развития: Матер. Междунар. науч.-практ. конф., посв. 50-летию НИИПББ НЦБ МОН РК - Алматы, 2008.- С. 150-154 6.Кукушкина М.С. Иммунобиологические характеристика вакцинных и вирулентных штаммов вирусов оспы овец и оспы коз: Дисс. на соиск. учен. степ. канд. наук. - г. Владимир - 2008 г. 7. Аманова Ж.Т., Жугунисов К.Д., Булатов Е.А., Жунушов А.Т., Саметова Ж.Ж., Шаяхметов Е.А., Баракбаев К.Б., Абдураимов Е.О. Оценка эффективности стабилизирующих сред при лиофилизации и хранении ассоциированной вакцины против чумы мелких жвачных животных и оспы овец // Известия НАН КР. - 2020. - № 2. - С. 25-34. 8. OIE, 2019. Testerial manual,Chapter 3.7.9. Peste des petits ruminants (infection with peste des petits ruminant's virus) $P$. 1-16. 9. OIE, 2018. Testerial manual, Chapter 3.7.12. Sheep pox and goat pox $\square$ P. 1513-1524. 10. Reed I.J., Muench H.A. A simple method of estimating fifty per cent endpoints // Am. J. Hyd. - 1938. - 27. - Р.493 - 497 11. ГОСТ 28085-2013 Средства лекарственные биологические для ветеринарного применения. Метод бактериологического контроля стерильности. 12. ZhugunissovK., BulatovYe., OrynbayevM., KutumbetovL., AbduraimovYe., ShaiyakhmetovYe., TaranovD., AmanovaZh., MambetalievM., AbsatovaZh., AzanbekovaM., KhairullinB., ZakaryaK., TuppurainenE., (2020). Goatpox virus (G20-LKV) vaccine strain elicits a protective response in cattle against lumpy skin disease at challenge with lumpy skin disease virulent field strain in a comparative study. Vet. Microbiol. 245. https://doi.org/10.1016/j.vetmic.2020.108695

\title{
IMPROVEMENT OF THE TECHNOLOGY OF MANUFACTURING OF AN ASSOCIATED VACCINE AGAINST PESTE DES PETITS RUMINANTS AND SHEEPPOX
}

\author{
Zh. T.Amanova,s.r., K. B. Barakbayev,c.v.s., Ye. A. Bulatov, c.b.s., \\ Ye. O.Abduraimov,ass. prof., K. D. Zakarya, d.b.s. \\ (Research Institute for Biological Safety Problems, Kazakhstan)
}

Annotation. Peste des petits ruminants (PPR) and sheeppox (SP) are highly contagious diseases of small ruminants that, in the event of an outbreak, cause significant economic damage to agriculture. This paper reflects the results of a study to improve the existing technology in the Republic of Kazakhstan for the production of acombined vaccine against PPR and SP. As a result of the improved technology, acombined vaccine against PPR and SP with high biological activity was obtained.

Key words: combined vaccine, peste des petits ruminants, sheeppox. 


\title{
ВЛИЯНИЕ ФИТОСОРБЦИОННОГО КОМПЛЕКСА НА СОДЕРЖАНИЕ ТЯЖЕЛЫХ МЕТАЛЛОВ В МОЛОКЕ
}

\author{
Барышев В.А., доц., к.в.н., Попова О.С., доц., к.в.н. \\ (ФГБОУ ВО СПбГУВМ, Россия)
}

\begin{abstract}
Аннотация.Проблема загрязнения окружающей природной среды тяжелыми металлами, в частности такими опасными, как кадмий и свинец, обостряется во многих странах СНГ. В странах Европейского Союза загрязнение данными поллютантами связано преимущественно с выбросами автотранспорта, но государственная экологическая политика направлена на решение и этой проблемы в целом.
\end{abstract}

Ключевые слова: тяжелые металлы, сорбенты, продукция.

Тяжелые металлы - одна из проблем, получивших широкое внимание во всем мире. Важность токсического действия этих минералов заключается в том, что они не поддаются биологическому разложению, и они обнаруживаются в низких концентрациях. Ограниченное количество финансовых ресурсов не позволяет в ближайшее время осуществить быструю модернизацию производства. Поэтому актуальными являются вопросы изучения миграции тяжелых металлов в системе «почва $\rightarrow$ растение $\rightarrow$ организм животного $\rightarrow$ продукция животноводства $\rightarrow$ организм человека». Это путь к некоторым нежелательным элементам, таким как свинец, кадмий, затем эти элементы, достигают других тканей и органов животного и человека, таких как печень, почки и молоко. И одно из самых опасных свойств, это то, что данные вещества могут передаваться с молоком молодняку.

Ученые разных направлений изыскивают способы изменить экологическую ситуацию в лучшую сторону. Одним из таких вариантов получения «зеленой» продукции является применение энтерособции в кормлении сельскохозяйственных животных. Создание таких комплексов, которые максимально бы сорбировали на себя и выводили бы из организма животных токсиканты, является актуальной задачей на сегодняшний день.

Целью наших исследований было изучить влияние фитосорбционного комплекса на основе перлита, вермикулита и полифепана, и растительных компонентов, на содержание тяжелых металлов в молочной продукции. Были отобраны 40 телок с одинаковыми параметрами продуктивности и разделены на 2 группы по 20 голов в каждой. Одна группа животных служила контролем, второй группе дополнительно к рациону добавляли фитосорбционный комплекс в дозе4\% от основного рациона. Длительность эксперимента составила 15 дней. В начале эксперимента и в конце отбирали пробы молока и определяли наличие тяжелых металлов. В пробах молока наличие тяжелых металлов определяли периодатным методом и методом атомно-адсорбционным спектрометрии. Результаты исследований представлены в таблице.

Таблица. Влияние фитосорбционного комплекса на содержание тяжелых металлов в молочной продукции

\begin{tabular}{|c|c|c|c|c|}
\hline \multirow[t]{2}{*}{ Показатель } & \multicolumn{2}{|c|}{ Контрольная группа } & \multicolumn{2}{|c|}{ Подопытная группа } \\
\hline & 0 сут. & 15 сут & 0 сут & 15 сут. \\
\hline $\mathrm{Cd}$, мг/л & $0,004 \pm 0,03$ & $0,0046 \pm 0,06$ & $0,006 \pm 0,01$ & $0,003 \pm 0,04$ \\
\hline $\mathrm{Pb}$, мг/л & $0,0175 \pm 0,04$ & $0,0206 \pm 0,03$ & $0,034 \pm 0,03^{*}$ & $0,0113 \pm 0,02$ \\
\hline $\mathrm{Hg}$, мг/л & - & - & - & - \\
\hline
\end{tabular}

На начало исследований наличие тяжелых металлов в опытной и контрольной группах было значительно ниже предельно допустимых значений. Ртуть не была обнаружена ни в одном из образцов. Количество кадмия в контрольной группе к концу эксперимента увеличилось на 15\%, свинца на 17\%. В подопытной группе, где применялся фитосорбционный комплекс мы наблюдали обратную динамику, количество кадмия уменьшилось на 50\%, 
свинца на 66\%. Однако стоит отметить, что уровень тяжелых металлов в молоке как в подопытной, так и в контрольной группах к концу эксперимента оставался в пределах допустимых значений.

Проведенный эксперимент показал перспективность изучения и внедрения в рационы сельскохозяйственных животных сорбционных комплексов, для получения экологически чистой продукции.

Литература. 1. Биологическая оценка применения диоксида кремния на организм лабораторных крыс / А. Ф. Кузнецов, В. В. Ачилов, К. Ф. Зенков, Г. С. Никитин // Международный вестник ветеринарии. - 2013. - № 2. - С. 50-54. 2. Кузнецов, А. Ф. Влияние некоторых энтеросорбентов на рост и развитие крыс / А. Ф. Кузнецов, К. Ф. Зенков // Материалы международной научной конференции профессорско-преподавательского состава, научных сотрудников и аспирантов СПбГАВМ, Санкт-Петербург, 23-26 января 2012 года. - Санкт-Петербург: Санкт-Петербургская государственная академия ветеринарной медицины, 2012. - С. 38-39. 3. Лобков, В. Ю. Оценка показателей безопасности молока коров в хозяйствах Ярославской области / В. Ю. Лобков, Н. Г. Ярлыков, А. Н. Еремеева // Вестник АПК Верхневолжья. - 2017. - № 2(38). - С. 27-32. 4. Мартынов, А.К. Структурнофункциональная организация реализации лечебных свойств энтеросорбентов / А.К. Мартынов // Эферентная терапия. - 2006. - №2. -С.11-17.

\title{
INFLUENCE OF THE PHYTOSORPTION COMPLEX ON THE CONTENT OF HEAVY METALS IN MILK
}

Baryshev V.A., Associate Professor, Ph.D., Popova O.S., Associate Professor, Ph.D. (FSBEI HE St.Peterburg SUVM, Russia)

Summary. The problem of pollution of the natural environment with heavy metals, in particular such dangerous ones as cadmium and lead, is aggravated in many CIS countries. In the countries of the European Union, pollution with these pollutants is mainly associated with vehicle emissions, but the state environmental policy is aimed at solving this problem as a whole.

Key words: heavy metals, sorbents, products

УДК615.331:619

\section{ПЕРСПЕКТИВЫ И ПРОБЛЕМЫ ИСПОЛЬЗОВАНИЯ АНТИМИКРОБНЫХ ПЕПТИДОВ В ВЕТЕРИНАРНОЙ МЕДИЦИНЕ}

Бахта А.А., доц., к.б.н., Махнин И.А., студент

(ФГБОУ ВО СПБГУВМ)

\begin{abstract}
Аннотация. Антибиотикорезистентность стала остро стоящей проблемой науки XXI века. Распространение множественной лекарственной устойчивости вынуждает научное сообщество вести поиск антибиотических субстанций эффективных в отношении резистентных штаммов и препятствующих развитию устойчивости к препаратам. Данным требованиям в полной мере соответствуют антимикробные пептиды (АМП).

Ключевые слова: Антимикробные пептиды, антибиотикорезистентность, лекарственные препараты

Антибиотикорезистентность стала остро стоящей проблемой науки XXI века. Для поддержки ФАО (Продовольственная и сельскохозяйственная организация ООН) по борьбе с высокорезистентными (MDR, XDR, PDR) инфекциями РФ выделила3,3 млн.\$[1]. Распространение множественной лекарственной устойчивости вынуждает научное сообщество вести поиск антибиотических субстанций эффективных в отношении резистентных штаммов (Klebsiellaspp., P.Aeruginosa и др.) и препятствующих развитию
\end{abstract}


устойчивости к препаратам. Данным требованиям в полной мере соответствуют природные, модифицированные и синтетические антимикробные пептиды (АМП). В связи, с чем определена цель работы: определить перспективы и проблемы использования антимикробных пептидов в ветеринарной практике.

История изучения эндогенных антимикробных соединения насчитывает уже более ста лет, однако систематический интерес к ним возник в последние десятилетия, когда появилась проблема устойчивости микроорганизмов к конвенциональным антибиотикам ( $\beta$-лактамы и др.) [2]. На сегодняшний день уже определена первичная структура более 900 АМП, принадлежащих к разным гомологическим семействам [3]. Важно понимать, что в отличие от классических антибиотиков, являющихся вторичными метаболитами продуцентов, аминокислотная (АКТ) последовательность АМП детерминирована геномом и включает в себя протеиногенные АКТ.По месту синтеза АМП подразделяются на рибосомные и нерибосомные - синтез осуществляется на различных биологических поверхностях, преимущественно на многообразных мегаферментах. За одну полипептидную последовательность отвечает один или несколько мегаферментов. Гены, отвечающие за эти синтетазы обычно оформлены в один оперон (у бактерий) или в кластеры (у эукариот).

АМП широко распространены в природе, база данных GenBank содержит информацию о более чем 100 тыс. АМП закодированных в геномах различных организмов. Единой, интернациональной классификации АМП, как лекарственных средств, на сегодняшний день не предложено [4].

Изучение и понимание механизма действия АМП в условиях invitro и invivoявляется фундаментальной частью при разработке новых препаратов. На сегодняшний день изучены два основных механизма действия АМП:

1. Прямое литическое действие. Молекулы АМП с помощью первичных взаимодействий (электростатическое сближение, наличие молекул адгезии) связываются с поверхностью мембраны; встраивают в нее гидрофобные участки; в клетке формируются поры; гибель клетки наступает из-за осмотического шока.

2. Действие на ферменты синтеза РНК, белков, клеточной стенки, белков теплового шока, ферменты репарации ДНК

Часто активность АМП опосредована сразу же несколькими механизмами действия на клетку.

Рассмотренные механизмы действия АМП, ведут к ряду следствий:

А) Пептиды со смешанным механизмом являются наиболее желательными при разработке препаратов, так как снижается вероятность развития лекарственной устойчивости [4]. Однако следует учитывать, вероятность разбития биохимической резистентности. Решением проблемы может стать поиск новых соединений, к которым резистентность формируется длительное время; разработка гайдлайнов (guideline) и системы мониторинга за оборотом АМП.

Б) Недостаточная селективность молекул АМП становится причиной выбраковки препаратов с высокой антимикробной активностью и широким спектром действия. В ряде экспериментов было показано цитопатическое действие АМП на эукариотические клетки. Одним из возможных подходов к повышению селективности, стала замена L-аминокислот на D-аминокислоты.

Широкий спектр пациентов ветеринарного врача, наталкивает на ряд препятствий при внедрении АМП в повседневную практику:

1. Обеспечение безопасности (отсутствие эмбриотоксического действия, тератогенного и т.д.) при использовании на разных видах и породах животных.

2. Защита вводимого препарата от действия протеаз (калликреины и др.) организма.

3. Экономическая целесообразность применения препарата на продуктивных животных. 
Весомый фактор, тормозящий широкий выход АМП на рынок гуманной и ветеринарной медицины - финансовые издержки. Например, производство 1 г. субстанции АМП может составлять 50-400 \$, в то время как 1 г. традиционного антибиотика оценивается менее 1 \$. Итоговый продукт будет не рентабелен для использования в лечении сельскохозяйственных животных. Возможным рынком сбыта может стать только рынок медицины непродуктивных животных. В тоже время производство нерибосомального АМП ванкомицина составляет менее $2 \$$, а конечная цена на российском рынке колеблется от 185 P до 300 Р, что делает препарат доступным для среднестатистического российского потребителя. В настоящий момент ряд компаний (NovozymesInc и др.) предлагают получать АМП с помощью технологии рекомбинантной ДНК. Например, АМП плектазин можно получить с помощью генетически модифицированного продуцента - $\mathrm{P}$. nigrella, себестоимость продукта снижается в 50 раз.

Животные активно используются для выделения АМП. Например, из клеток костного мозга обезьян (Macacamulatta) выделеныRTD-2 bRTD-3; из клеток желудка жабы (Bufogargarizans) выделены буфоринI и II типа; от королевской кобры (Ophiophagushannah) полученкателицидин ОН-САТН; из гранул нейтрофилов КРС (Bostaurus) выделен индолицидин[2]. Кроме того предполагается наличие АМП (апидаецины, абаецины) в меде [5].

В настоящий момент среди АМП в ежедневной ветеринарной практике применяются следующие препараты: Peptivet (AMP2041) для лечения наружных отитов собак и кошек; Ванкомицин для лечения тяжелых инфекционных процессов; Полимиксин В для лечения колибактериозов у птиц, актиномикоза у крупного рогатого скота, гнойных заболеваний, некротических язв и заболеваний желудочно-кишечного тракта у поросят, ягнят и телят.

Таким образом, использование антимикробных пептидов в ветеринарной медицине является перспективным направлением для борьбы с высокорезистентнымиинфекциями.

Литература. 1.Любоведская, А.А. Вред антибиотиков, применяемых в сельском хозяйстве / А.А. Любоведская // Сельскохозяйственный вестник. - 2018. - № 4. - С. 23-27. 2. Алешина, Г.М. Антимикробные катионные пептиды и белки врожденного иммунитета как эффекторные и регуляторные молекулы защитных функций организма/ Г.М. Алешина. - Санкт-Петербург: ФГБНУ "ИЭМ", 2019. - 283 с. 3. Скопичев, В. Г. Физиолого-биохимические основы резистентности животных: учебное пособие / В. Г. Скопичев, Н. Н. Максимюк. - СанктПетербург: Лань, 2021. - 352 с. 4. Иванов, О.С. Антибактериальные пептиды как альтернативное будущее терапии бактериальных инфекций / О.С. Иванов // наука и инновации. - 2018. - Т. 7, № 185. - С. 73-78. 5. Клыченков, С.В. Антимикробные пептиды меда, перспективы их получения и использования / С.В. Клыченков // Вестник Пензенского государственного университета. - 2017. - № 4. - С. 60-66.

\section{PROSPECTS AND PROBLEMS OF USING ANTIMICROBIAL PEPTIDES IN VETERINARY MEDICINE}

Bahta A.A. associateprofessor, Ph.D.,Makhnin I.A.,student (FSBEI HE St.Peterburg SUVM, Russia)

Summary. Antibiotic resistance has become an acute problem of science of the XXI century. The spread of multidrug resistance forces the scientific community to search for antibiotic substances that are effective against resistant strains and prevent the development of drug resistance. Antimicrobial peptides (AMP) fully meet these requirements.

Key words: Antimicrobial peptides, antibiotic resistance, drugs 


\title{
КОРРЕКЦИЯ ТЕХНОЛОГИЧЕСКОГО СТРЕССА НИЗКОИНТЕНСИВНЫМ
} ЛАЗЕРНЫМ ИЗЛУЧЕНИЕМ

\author{
Белов А.А., ассистент ${ }^{1}$ Дерюгина А.В., д.б.н., доцент ${ }^{2}$, Иващенко М.Н., к.б.н., доцент ${ }^{1}$ \\ $\left({ }^{1}\right.$ ФГБОУ ВО «Нижегородская государственная сельскохозяйственная академия»; \\ ${ }^{2}$ ФГАОУ ВО «Национальный исследовательский Нижегородский государственный \\ университет им. Н.И. Лобачевского»)
}

\begin{abstract}
Аннотация. Интенсивные промышленные технологии в животноводстве приводят к увеличению случаев развития стресса и нарушения обмена, что влияет на качество молочной и мясной продукции. Актуальным является повышение резистентности животных к факторам внешней среды немедикаментозными методами. Целью работы - изучение действия технологического стресса и низкоинтенсивного лазерного излучения на уровне клеток.
\end{abstract}

Ключевые слова: технологический стресс, крупный рогатый скот, эритроциты, низкоинтенсивное лазерное излучение.

Технологии промышленного производства крупного рогатого скота приводят к увеличению случаев развития стрессовой реакции и возникновению нарушения обмена, что влияет на качество молочной и мясной продукции. Необходим поиск эффективных методов коррекции стресса. Профилактика стресса лекарственными средствами не всегда эффективна. Современные лекарства стали не только более эффективными, но и более агрессивными. Даже в странах с развитой фарминдустрией проблема безопасности лекарственных средств выходит на одно из первых мест [1].

Актуальным является повышение резистентности животных к факторам внешней среды немедикаментозными методами доступными, недорогими, возможными в использовании любыми хозяйствами.

Методы лечения лазерной терапии способны снизить потребность, а иногда и полностью заменить медикаментозную терапию. С каждым годом, все шире в современной медицине и ветеринарии используется низкоинтенсивное лазерное излучение (НИЛИ). Это обусловлено, полученными данными, свидетельствующими о высокой терапевтической эффективности низкоинтенсивного лазерного излучения (НИЛИ) при различных заболеваниях.

Развитие стрессовой реакции сопровождается молекулярными изменениями плазматических мембран эритроцитов, являющихся, как любая клетка, непосредственной мишенью и конечным звеном стрессового воздействия, так и вовлеченными в развитие и исход стрессовой реакции в связи с выполняемой функцией. Нарушение структуры мембраны эритроцитов приводит к ухудшению деформации эритроцитов и снижению процессов газообмена, что в конечном итоге, влияет на весь метаболизм организма.

При этом механизмы действия НИЛИ на эритроциты и эффективность воздействия НИЛИ в ходе нивелирования стрессовой реакции у крупного рогатого скота изучены недостаточно [2].

В связи с вышеизложенным цель работы - установление изменений белкового спектра мембран эритроцитов, морфологии и концентрации малонового диальдегида в эритроцитах в условиях технологического стресса и коррекции низкоинтенсивным лазерным излучением.

Исследование проведено на высокопродуктивных коровах черно-пестрой породы. Методом аналогов было сформировано 6 групп коров по восемь голов в каждой. Первая группа животных являлась интактной, 2, 3, 4, 5, 6 группы подвергались действию технологического стресса, затем 3, 4, 5, 6 группы облучали НИЛИ ежедневно однократно в течение 7 дней. Время экспозиции - 5 или 15 минут в область уха или холки. Для лазеротерапии применяли автономный лазерный душ «МарсИК» (НПО "Петролазер", СанктПетербург) с длиной волны 830 нм. Кровь для исследований брали из яремной вены через сутки, неделю, месяц после начала опыта. 
Разделение белков мембраны эритроцитов проводили методом электрофореза в полиариламидном геле в присутствии додецилсульфата натрия по методу Laemmli U.K. [3].

Определение концентрации малонового диальдегида проводили в отмытых эритроцитах по цветной реакции с тиобарбитуровой кислотой по методу Владимирова Ю.А. и Арчакова А.И. [4]. Морфологию эритроцитов изучали на лазерном интерференционном микроскопе МИМ-340 (Екатеринбург).

Полученные данные были обработаны статистически с помощью пакетов прикладных программ BIOSTAT и Microsoft Excel.

Проведенные экспериментальные исследования показали, что после стресса наблюдается изменение белкового состава эритроцитарных мембран, связанное с уменьшением спектрина, белка полосы 3 с постепенным увеличением гликофорина. Значительно увеличивается количество эхиноцитов и сфероцитов к 7 суткам после стресса. При этом эхиноциты так же имеют значительную сферичность. К 14 суткам увеличивается количество дегенеративно-изменённых форм. Известно, что при прогрессировании ПОЛ увеличивающееся количество ненасыщенных фосфолипидов, способствует уменьшению жидкостности мембраны и подвижности пептидных цепей белков. Модификация белков эритроцитарных мембран, изменение морфологии эритроцитов, может быть опосредовано увеличением процессов липопероксидации в мембранах эритроцитов.

Использование НИЛИ вызывало восстановление белковых фракций эритроцитарных мембран, что сочеталось с нормализацией процессов ПОЛ и морфологией клеток. При этом действие НИЛИ 5 мин в области уха не вызывало улучшения исследуемых параметров в течение 14 суток после начала опыта. Тогда как действие НИЛИ в течение 15 мин в область уха, определило заметное восстановление исследуемых параметров к 7 суткам опыта. Наибольшей эффективностью обладало воздействие НИЛИ в области холки в течение 5 мин.

Обсуждая полученные эффекты можно предположить действие лазерного излучения на порфирины и метаболические процессы в эритроцитах. Вероятно, действие НИЛИ определяется не только на уровне первичных реакций, но и на основе вторичных клеточных сигнальных каскадов, которые будут вызывать множественные эффекты на уровне организма, что может проявляется улучшением продуктивности.

Литература. 1. Абдуллина Р.И. Терапевтические эффекты воздействия электромагнитного излучения на организм человека // Аллея науки - 2017. — №16. - C. 330-333. 2. Deryugina AV, Ivashchenko MN, Samodelkin AG, Ignatiev PS, Balalaeva IV. Low-level laser therapy as a modifier of erythrocytes morphokinetic parameters in hyperadrenalinemia. Lasers in Medical Science. 2019; 34 (8): 1603-1612. doi: 10.1007/s10103-019-02755-y. 3. Laemmli U.K. Cleavage of structural proteins during the assembly of the head of bacteriophage T4. Nature. 1970; 227(259): 680-685. 4. Владимиров Ю.А., Арчаков А.И. Перекисное окисление в биологических системах. М., Наука. - 1972. - 251 с.

«Исследование выполнено при финансовой поддержке РФФИ в рамках научного проекта №19-316-90066».

CORRECTION OF TECHNOLOGICAL STRESS BY LOW-INTENSITY LASER RADIATION

\author{
Belov A. A., Assistant ${ }^{1}$
}

Deryugina A.V., Doctor of Biological Sciences, Associate Professor ${ }^{2}$,

Ivashchenko M.N., Candidate of Biological Sciences, Associate Professor ${ }^{1}$ ( ${ }^{1}$ FSBEI HE «Nizhny Novgorod State Agricultural Academy»)

${ }^{2}$ FGAOU VO «Lobachevsky National Research Nizhny Novgorod State University»;

Annotation. Intensive industrial technologies in animal husbandry lead to an increase in cases of stress and metabolic disorders, which affects the quality of dairy and meat products. It is important to increase the resistance of animals to environmental factors by non-drug methods. The aim of the work is to study the effect of technological stress and low-intensity laser radiation at the cell level.

Keywords: technological stress, cattle, red blood cells, low-intensity laser radiation. 


\title{
ВЛИЯНИЕ ИНКОРПОРИРОВАННОГО ОБЛУЧЕНИЯ НА ОРГАНИЗМ ПРОДУКТИВНЫХ ЖИВОТНЫХ
}

А.Е. Белопольский, д.в.н., доцент

ФГБОУ ВО «Санкт-Петербургский государственный университет ветеринарной медицины»

\begin{abstract}
Аннотация: Загрязнение радионуклидами (которые являются ксенобиотиками для животных) культивируемых растений для производства кормов может происходить через атмосферные осадки, почву и воду. Поглощение долгоживущих радионуклидов микроорганизмами содержащихся в почве ведёт к изменению их химической формы, что приводит к усилению подвижности и повышенной усвояемости этих изотопов в корнях кормовых растений. Расположение долгоживущих радионуклидов в верхних слоях пахотных земель и обуславливает проникновение этих элементов в растения за счёт процессов адсорбции и диффузии.
\end{abstract}

Ключевые слова: радионуклиды, смертность, заболеваемость, продуктивные животные

Загрязнение радионуклидами (которые являются ксенобиотиками для животных) [1] культивируемых растений для производства кормов может происходить через атмосферные осадки, почву и воду. Поглощение долгоживущих радионуклидов микроорганизмами содержащихся в почве ведёт к изменению их химической формы, что приводит к усилению подвижности и повышенной усвояемости этих изотопов в корнях кормовых растений. Расположение долгоживущих радионуклидов в верхних слоях пахотных земель и обуславливает проникновение этих элементов в растения за счёт процессов адсорбции и диффузии. Не менее важную роль в загрязнении растений играет вода естественных водоёмов, где радионуклиды накапливаются в непроточных замкнутых лагунах и затонах с малой скоростью движения воды. Оседая долгие годы в речных донных отложениях, радионуклиды затем интенсивно вымываются и передвигаются по руслу рек, попадая на различные земли сельскохозяйственного назначения. И поскольку очень часто основными источниками грубых и сочных кормов в хозяйствах являются естественные луговые угодья, расположенные в поймах рек, уровень загрязнения радионуклидами кормов растительного происхождения полученных с таких естественных кормовых площадей получается очень высокий. Из грубых и сочных кормов высокой способностью аккумулировать $137 \mathrm{Cs}$ и $90 \mathrm{Sr}$ отличаются бобовые и многолетние травы естественных сенокосов и пастбищ. А в пересчёте на единицу сухого вещества самый высокий уровень накопления радионуклидов наблюдается у злаково-бобовых смесей, клевера и многолетних злаковых трав. Высокий уровень содержания долгоживущих радионуклидов в окружающей среде и скармливание загрязнённых кормов сельскохозяйственным животным приводит к падению иммунной защиты организма, повышению роста заболеваемости и падежу животных. Реакция продуктивных животных на ионизирующее излучение многообразна и определяется параметрами излучения, механизмами развития и особенностями самого организма[2]. При инкорпорированном облучении механизмы поражения гораздо сложнее, чем при внешнем облучении. Так, радионуклиды в первую очередь интенсивно воздействуют на органы дыхания и кожный покров животных. На коже животных всегда находится разнообразная микрофлора и при лучевом воздействии её количество быстро увеличивается, что и вызывает различные поражения кожного покрова (дерматиты, абсцессы и др.). Распределение долгоживущих радионуклидов по органам и тканям животного при инкорпорированном облучении имеет особое значение. Так, например, в первое время после поступления радионуклидов этот патологический процесс очень похож на острое течение лучевой болезни. В дальнейшем, даже после поступления сравнительно небольших доз таких радионуклидов, начинается атрофия лимфоидной ткани, в том числе селезенки и угнетение функции щитовидной железы [3]. Долгоживущие радионуклиды, выделяемые вместе с желчью, всасываются в кишечнике и неоднократно контактируют со слизистой оболочкой тонкого кишечника, вызывая различные 
заболевания, попутно стимулируя развитие циррозов и опухолей печени[4]. Выраженные повреждения желудочно - кишечного тракта и органов дыхания, развиваются на фоне нарушений кроветворной функции организма[5]. Эти повреждения желудочно - кишечного тракта влекут за собой угнетение синтеза структурных белков лимфоидных органов и торможение образования антител. При продолжающем инкорпорированном облучении организма развивается атрофия иммунокомпетентных органов и тканей. Вызванные инкорпорированным облучением патологические процессы происходящие в тимусе, селезёнке, лимфоидной ткани пищеварительного тракта вызывают уменьшение количества Ти В - лимфоцитов, ведёт к снижению производства цитокинов, антител и др. Количество костномозговых клеток в крови животных довольно быстро убывает, снижается число лимфоцитов, моноцитов и нейтрофилов. Снижение количества Т-лимфоцитов и невозможность поражённых инкорпорированным облучением В-лимфоцитов синтезировать глобулины и антитела, ведёт к резкому подъёму числа различного рода заболеваний и смертности у животных. Хроническое алиментарное поступление долгоживущих радионуклидов в организм продуктивных животных вызывает поражение различных органов и систем, вызванных контактным бета - облучением. Такие поражения в основном несут ярко выраженный очаговый характер, особенно при поступлении радионуклидов, которые длительно задерживаются в криптах ЖКТ, лимфатических узлах и лимфоидных тканях, в результате чего формируются высокие местные дозы. Поражения органов и систем при инкорпорированном облучении вызывает нарушение обмена веществ, падение активности некоторых ферментов и накопление токсичных продуктов жизнедеятельности. Восстановлению организма продуктивных животных после инкорпорированного облучения мешают изменения в гормональной системе, обусловленные поражением желез внутренней секреции. Проникновение в организм долгоживущих радионуклидов вызывает глубокие структурно - метаболические изменения, приводит к обострению хронических заболеваний и как следствие к гибели животных.

Литература 1. Понамарев, В. С. Исследование острой токсичности гепатопротектора "ГЕПАТОН" на грызунах / В. С. Понамарев, Н. Л. Андреева, М. С. Голодяева // Международный вестник ветеринарии. - 2019. - № 4. - С. 81-85., 2. Изучение детоксикационных свойств минерального сорбента при отравлении хлоридом ртути / К. Ф. Зенков, А. Ф. Кузнецов, И. В. Иванова [и др.] // Эффективные и безопасные лекарственные средства в ветеринарии : Материалы V-го Международного конгресса ветеринарных фармакологов и токсикологов, Санкт-Петербург, 22-24 мая 2019 года. - Санкт-Петербург: Санкт-Петербургская государственная академия ветеринарной медицины, 2019. - С. 75-76., 3. Белопольский, А. Е. Влияние изотопов цезия на щитовидную железу свиней / А. Е. Белопольский, К. Ф. Зенков // Эффективные и безопасные лекарственные средства в ветеринарии : Материалы V-го Международного конгресса ветеринарных фармакологов и токсикологов, Санкт-Петербург, 22-24 мая 2019 года. - Санкт-Петербург: СанктПетербургская государственная академия ветеринарной медицины, 2019. - С. 12-13., 4. Кострова, А. В. Некоторые аспекты проверки безопасности гепатопротектора на растительной основе / А. В. Кострова, В. С. Понамарев // XXII Всероссийская научно-практическая конференция Нижневартовского государственного университета : Материалы конференции, Нижневартовск, 06-07 апреля 2020 года / Научный редактор: Д.А. Погонышев. Нижневартовск: Нижневартовский государственный университет, 2020. - С. 25-28., 5. Понамарев, В. С. Влияние препарата с гепатопротекторной активностью "Гепатон" на показатели периферической крови лабораторных животных / В. С. Понамарев // Международный вестник ветеринарии. - 2020. - № 2. - С. 116-121. - DOI 10.17238/issn20722419.2020.2.116. 


\title{
EFFECT OF INCORPORATED RADIATION ON THE BODY OF PRODUCTIVE ANIMALS
}

A.E. Belopolsky, D.Sc., Associate Professor

FSBEI HE "St. Petersburg State University of Veterinary Medicine"

Summary: Contamination of cultivated plants for feed production with radionuclides (which are xenobiotics for animals) can occur through precipitation, soil and water. The absorption of long-lived radionuclides by micro-organisms contained in the soil leads to a change in their chemical form, which leads to an increase in the mobility and increased assimilation of these isotopes in the roots of fodder plants. The location of long-lived radionuclides in the upper layers of arable land determines the penetration of these elements into plants due to the processes of adsorption and diffusion.

Key words: radionuclides, death rate, disease, productive animals

УДК: 619:618.177-089.888.11

DOI:10.52419/3006-2021-2-28-30

\section{АКТУАЛЬНОСТЬ ПРИМЕНЕНИЯ ФСГ ДЛЯ СУПЕРОВУЛЯЦИИ КОРОВ- ДОНОРОВ И ПУТИ ПОВЫШЕНИЯ ЕГО ЭФФЕКТИВНОСТИ}

Бригида А.В., зам. директора, к.в.н., Скачкова О.А., науч. сотр. (ИИБЖ — филиал ФГБНУ ФНЦ ВИЖ им. Л.К.Эрнста, Россия)

\begin{abstract}
Аннотация. В технологии трансплантации эмбрионов крупного рогатого скота применяют классический протокол суперовуляции коров-доноров эмбрионов, основанный на 8-10кратном введении фолликулостимулирующего гормона (ФСГ) каждые 12 часов в течение 4-5 дней. В течение многих десятков лет использования этой технологии выход качественных эмбрионов варьирует в пределах 4-6 шт. Необходимо повышение эффективности действия ФСГ для увеличения числа эмбрионов. Мы провели исследование эффективности фармакологической композиции, состоящей из ФСГ сочетано с полиэтиленгликолем (ПЭГ) с молекулярной массой 6000 Да, которая повышает выход количества получаемых эмбрионов, пригодных для пересадки реципиентам, или их криоконсервации.
\end{abstract}

Ключевые слова: коровы-доноры, суперовуляция, фолликулостимулирующий гормон, полиэтиленгликоль.

На сегодняшний день в скотоводстве Российской Федерации наблюдается высокий интерес к применению биотехнологических методов ускоренного воспроизводства крупного рогатого скота. Наряду с искусственным осеменением, внедренным в большинстве фермерских хозяйств, разводящих молочный и мясной скот, технология трансплантации (ТТЭ) эмбрионов вновь начинает внедряться в практику многих ведущих сельхозпредприятий для селекции и ремонта стада.

Однако применение классического протокола суперовуляции у коров-доноров эмбрионов, который широко распространен в современной ветеринарной практике и основан на многократном введении фолликулостимулирующего гормона (ФСГ) (8-10-кратное введение каждые 12 часов в течение 4-5 дней) [1,2], характеризуется получением таких негативных показателей, как отсутствие полиовуляции (примерно у 30\% обработанных животных) [3] или её низкий результат с числом овуляций $1-3$ ещё у $30 \%$ животных [4, 5]. При этом, только у 40\% обработанных животных регистрируют положительную суперовуляторную реакцию. В связи с нестабильностью этих результатов, не удовлетворяющих потребностям хозяйств, стоит задача повышения у коров-доноров уровня суперовуляторной реакции яичников, и, как следствие, увеличения числа качественных эмбрионов, приводящих после пересадки реципиентам к рождению телят-трансплантантов. Поиск путей повышения эффективности ФСГ во всем мире продолжается. Одним из 
направлений является поиск веществ, пролонгирующих действие ФСГ при однократном его введении в организм животного.

В связи с этим, нами были проведены сравнительные исследования по эффективности применения полиэтиленгликоля (ПЭГ) в качестве вещества, пролонгирующего действие ФСГ, в процессе вызывания суперовуляции у коров-доноров эмбрионов. Исследования проводились в ряде фермерских хозяйств и сельхозпредприятий в Кировской, Брянской, Оренбургской областях. Было отобрано 183 коров-доноров эмбрионов, которые были разделены на две группы. В группе I $(\mathrm{n}=96)$ у доноров на 9 - 12 день полового цикла применяли классический протокол, основанный на восьмикратном внутримышечном введении препарата «Плюсет» (Испания) с интервалом 12 ч (утро-вечер) в убывающих дозах (50 AE, $3 ; 3 ; 2,5 ; 2,5 ; 2 ; 2 ; 1,5 ; 1,5$ мл/гол.). В группе II $(\mathrm{n}=87)$ донорам на десятый день полового цикла вводили однократно, подкожно в область лопатки смесь, состоящую из «Плюсет» (ФСГ в полном объеме - 50 АЕ) и пролонгатора ПЭГ с молекулярной массой 6000 Да из расчета 3 грамма на голову и растворителя, в качестве которого использовали физиологический раствор (0,9 \% водный раствор хлорида натрия) в объеме 10 мл. Осеменение доноров проводили во время прихода животного в половую охоту трехкратно с интервалом 12 ч с использованием пяти доз семени, при этом применяли ректо-цервикальный метод введения спермы.

В процессе исследования, в среднем, из расчета на одного донора установлено следующее. В группе II отмечена наиболее высокая суперовуляторная реакция яичников $(15,0 \pm 0,80$ шт.) в сравнении с группой I $(10,5 \pm 0,62$ шт.). В группе II в сравнении с группой I отмечен более высокий выход качественных эмбрионов $(9,1 \pm 0,59$ против 4,6 $\pm 0,35)$, что в процентном выражении составляет 70,5\% против 54,5\%. Также в группе II в сравнении с группой I зарегистрирован более низкий выход дегенерированных эмбрионов (12,0\% против $27,0 \%)$. Кроме того, в группе II в сравнении с группой I получено высокое количество эмбрионов отличного и хорошего качества $(89,9 \%$ против $76,3 \%)$, являющихся пригодными как для пересадки в свежеполученном виде реципиентам, так и для криоконсервации.

На основании полученных результатов можно сделать вывод, что использование фармакологической композиции (ФСГ сочетано с ПЭГ с молекулярной массой 6000 Да) повышает эффективность технологии трансплантации эмбрионов и может быть применимо в животноводческих хозяйствах, разводящих крупный рогатый скот.

Работа выполнена в рамках Государственного задания № 0445-2021-0016.

Литература 1. Ochea, M. The effect of epidural administration of FSH in bovine superovulation protocol / M. Ochea, M. Pascal, A. Sonea, et all. // Scientific papers-series d-animal science, 2015. Vol. 58. - P. 217-220. 2. Silva, F. The effects of injectable trace mineral supplements in donor cows at the initiation of a superovulation protocol in embryo outcomes and pregnancy rates in recipient females / F. da Silva, N. Negrin-Pereira, B. Funnell, et all. // Journal of animal science, 2018. - Vol. 96. - P. 346-346. 3. Wohlres-Viana, S., Arashiro, E.K.N., Minare, T.P., Fernandes, C.A.C., Grazia, J.G.V., Siqueira, L.G.B., Machado, M.A., Viana, J.H.M., 2019. Differential expression of LHCGR and its isoforms is associated to the variability in superovulation responses of Gir cattle. Theriogenology. 26, 68-74. DOI: 10.1016/j.theriogenology.2018.12.004 4. Bekele, T., Mekuriaw, E., Walelegn B., 2016. Bovine Embryo Transfer and Its Application: Arwiew. Journal of Health, Medicine and Nursing. 26, 48-60. 5. Brigida, A., Skachkova, O., Bykova, O., Sorokin. V., 2019. Comparative evaluation of the efficiency of poliovulation induction in donor cows using "FSHsuper" drug with various injection schemes. Atlantis Press. 167, 491-497. DOI: 10.2991/ispc19.2019.110

\section{THE RELEVANCE OF THE APPLICATION OF FSH FOR SUPEROVULATION OF DONOR COWS AND WAYS OF INCREASING ITS EFFICIENCY}

Brigida A.V. Deputy Director, PhD Vet. Sci., Skachkova O.A., researcher

Summary. In the technology of cattle embryo transplantation, the classic protocol for superovulation of embryo donor cows is used, based on 8-10-fold administration of follicle-stimulating hormone (FSH) every 12 hours for 4-5 days. For many decades of using this technology, the yield of high- 
quality embryos varies within 4-6 pcs. It is necessary to increase the effectiveness of FSH to increase the number of embryos. We conducted a study of the effectiveness of a pharmacological composition consisting of FSH combined with polyethylene glycol (PEG) with a molecular weight of $6000 \mathrm{Da}$, which increases the yield of the number of embryos obtained, suitable for transplantation into recipients, or their cryopreservation.

Key words: cows-donors, superovulation, follicle-stimulating hormone, polyethylene glycol.

УДК: 636.2.034

\title{
РАСТИТЕЛЬНЫЕ БИОАКТИВНЫЕ СОЕДИНЕНИЯ ДЛЯ СТИМУЛЯЦИИ РЕПРОДУКТИВНОГО И МОЛОЧНОГО ПОТЕНЦИАЛА КРУПНОГО РОГАТОГО CKOTA
}

\author{
Бурсаков С.А. к.б.н., с.н.с., Бригида А.В., к.в.н., зам. Дир.
} (ИИБЖ — филиал ФГБНУ ФИЦ ВИЖ им. Л.К. Эрнста, Россия)

\begin{abstract}
Аннотация. В связи с широким распространением синтетических химических веществ, используемых в животноводстве, возрастают потенциальные риски для окружающей среды и здоровья людей, связанные с их использованием. Вынужденное сокращение использования химических веществ в сельском хозяйстве одновременно увеличивает интерес к натуральным средствам, способных их заменить. Поэтому целью данной работы является выделение наиболее перспективных подходов для открытия биоактивных соединений и их применения в виде возможных исследовательских стратегий.
\end{abstract}

Ключевые слова: растительные биологически активные вещества, молочная продуктивность, репродукция

Растения, используемые в качестве корма для животных, являются важным источником биологически активных веществ, производя поразительное количество органических химических соединений с огромным структурным разнообразием, включая сапонины, эфирные масла, дубильные вещества, лигнаны, белки и пептиды, алкалоиды, проантоцианы, терпены и флавонолы, необходимые для их роста и развития [1].

Взаимодействие между растениями и крупным рогатым скотом (КРС) очень сложное, поскольку влияние питания носит комплексный характер и воздействие может оказываться на разнообразные рецепторы одновременно. В настоящее время все больший интерес проявляется к нутрицевтикам, которые представляют собой пищевые растения, фармацевтическая ценность которых превышает их питательную ценность. Согласно достаточно большим сложностям в их изучении и апробации, очень мало внимания уделяется систематическому описанию и изучению традиционных лекарственных трав, для повышения молочной продуктивности, контроля и лечения различных репродуктивных нарушений у сельскохозяйственных животных [2]. Для того, чтобы доказать ценность и эффективность средств на растительной основе при лечении репродуктивных расстройств требуется большое внимание и систематическая работа. Однако указанные натуральные препараты, действительно имеющие значительную лечебную ценность, имеют огромный потенциал для будущего и нуждаются в самом широком использовании для улучшения различных репродуктивных расстройств у животных с особым акцентом на молочных коров.

Флора России - это неиспользованный ресурс, который может дать экологически разумное и ответственное решение в отношении здоровья животных. Стратегические области исследования биоактивных веществ растений важных для здоровья КРС, включают в себя такие активные направления как потребление корма и его усвояемость, репродуктивные функции и поддержание высокой молочной продуктивности (состав, удой) у КРС и др.

В течение последних десятилетий генетический отбор и улучшение управления стадами резко увеличили производство молока молочными коровами, в то же время снизилась фертильность [3]. Поэтому в случае молочной коровы лактация становится приоритетом в 
ущерб репродуктивным функциям. Выбор программы питания, которые предотвращают дефицит питательных веществ или чрезмерное потребление энергии, могут улучшить репродуктивную функцию. В последние годы наблюдается рост заинтересованности в улучшении репродуктивной функции путем кормления молочных коров пищевыми добавками. Добавки, например, антиоксидантов и иммуномодуляторов в переходный период, приводит к раннему началу послеродовой течки и улучшение показателей беременности у КРC [4].

Биоактивные вещества растений все еще остаются малоизученной областью исследований и во многих случаях, несмотря на наблюдаемую биологическую активность, натуральное действующее вещество выявлено не было. Идентификация биологически активного агента требует систематического фракционирования и биологических испытаний растительных экстрактов. Также необходимо выяснение того, чтобы растительный материал содержит постоянные уровни биоактивных соединений или их модификаций в процессе хранения или переработки.

Существует множество исследовательских стратегий, которые могут быть использованы для решения поставленных задач. Определение представляющих интерес растений включает предварительную оценку эффективности различных систем доставки, и наличия местных растений, присутствующих в интересующих регионах России. Определение и сбор какие-либо химических знаний, связанных с этими растениями. Разработка и создание эффективного, соответствующего цели биоанализа и библиотеки растений, являются ключевыми шагами в выполнении этих проектов. Приготовление экстрактов для скрининга. Оценка активности, устранение повторов (т. е. присутствие одних и те же соединений с одинаковой активностью в разных экстрактах растений). Оценка природы биологически активного вещества по уровням активности in vitro и эффективности in vivo.

В идеале необходимо провести дальнейшие исследования в этой области в полностью интегрированной среде, где имелся опыт в области разработки биопроб, химии природных продуктов, животноводства и систем земледелия. Интегрированный подход определяет преимущества с точки зрения времени, стоимости и более тесного взаимодействия, которое может происходить между исследователями с разным опытом. Литературный анализ показывает, что существуют убедительные доказательства того, что вторичные метаболиты растений могут влиять на повышение молочной продуктивности, воспроизводство и в целом для улучшения здоровья КРС. Многообразие уникальной растительной флоры России и возможности потенциала разнообразия сельскохозяйственного производства, предлагают потенциальные преимущества для исследований, с разнообразными растительными источниками для исследования. Разумно привлечение к работе государственных гербариев и ботанических садов для получения коллекции образцов пригодных для экстракции биоактивных соединений. Необходимо иметь необходимый кадровый опыт и инфраструктуру для выделения и идентификации биоактивных натуральных продуктов. Библиотека растений может также включать сельскохозяйственные растения и растительные биоотходы. Предлагаемые исследовательские стратегии направлены на преобразование этого фитохимического потенциала в экономическую выгоду для российских производителей.

Анализ литературных данных, показывает существование почти всех мыслимых растительных соединений различных химических классов с определенной биологической активностью, но с относительно малым количеством исследований, проведенных, например, для жвачных животных. Исследования были качественными, а не количественными с точки зрения химии растений, где химическая природа и количество в растительном материале редко учитывались. Поскольку небольшие изменения химической структуры могут привести к большим изменениям в активности, и эти эффекты нелегко предсказать, то такие источники могут быть лишь косвенными свидетелями наличия нужного эффекта. Оценка большей части доступной литературы свидетельствует об отсутствии химического анализа кормов, несмотря на свидетельства взаимосвязи их структуры и биологической активности. Многие исследования основываются на анализе in vitro, что недостаточно для понимания того, что 
растения действительно могут быть полезными для здоровья животных. Поэтому возникает необходимость для контролируемых исследований in vivo для подтверждения биологической активности растений.

Существует несколько подходов к открытию биоактивных веществ, и нет единственного правильного способа. Возможно, одним из самых фундаментальных из них является определение полной химической структуры, которая может указывать на биологическую активность. Однако, этого недостаточно, поскольку нет учета трехмерной структуры соединения, и как она влияет на молочную и репродуктивную функцию. Лучший метод зависит от объема проекта. Так, если нужно исследовать несколько очень многообещающих растений, тогда может быть применена модельная система животного. Если необходимо исследовать большое количество растений, тогда следует использовать фармацевтическую модель. Для сосредоточения внимания на использовании на месте может оказаться целесообразным раннее сочетание моделей. Растения должны быть проверены на активность и токсичность in vivo, а затем реакция животных с точки зрения приемлемости и вкусовых качеств корма. В то же время биологически активные вещества могут быть изолированы и определена их структура. Создание полевых испытаний по потреблению сразу же позволит оценить уровни соединений в различных растениях в реальной окружающей среде и реакцию растений на стресс от выпаса. Способность предсказать положительный или отрицательный эффект кормов, содержащих биологически активное соединение, будет зависеть от междисциплинарных исследований, проводимых специалистами по питанию животных и химиками-растений.

\section{Благодарности}

Работа выполнена в рамках Государственного задания № 075-01250-20-00.

Литература. 1. Breilmann H.L., Setzer W.N., Kaufman P.B., Kirakosyan A., and Cseke "Phytochemicals: the chemical components of plants" in Natural Products from Plants, 2nd ed, CRC Press, Boca Raton, Florida, USA. 2006. 2. Perumal P., Veeraselvam M., Nahak A.K. Herbal Treatment in Animal Reproduction. International Journal of Bioresource and Stress Management. 2013. 4(3). 460-467. 3. Butler W. Energy balance relationships with follicular development, ovulation and fertility in postpartum dairy cows. Livestock Production Science. 2003. 83. 211-218. 4. Khan H.M. Prepartum and postpartum managemental interventions for improving reproductive performance in murrah buffaloes. Ph.D thesis submitted to NDRI (Deemed University), Karnal, Haryana, India, 2008. 5. Rochfort S., Dunshea F. and Parker T. (in cons. with Panozzo J. and Premier R.) "Natural bioactive compounds for livestock health and production - Knowledge and Opportunity Audit", , Victoria. 2006. 58p.

\section{PLANT BIOACTIVE COMPOUNDS FOR STIMULATION REPRODUCTIVE AND DAIRY POTENTIAL OF CATTLE}

Bursakov S.A. research scientist, Ph.D., Brigida A.V. Vice-Dir., Ph.D. (IIBZH - a branch of the FSBSI FRC AH named after L.K. Ernst, Russia)

Summary. With the widespread availability of synthetic chemicals used in animal husbandry, the potential risks to the environment and human health associated with their use are increasing. The forced reduction in the use of chemicals in agriculture is simultaneously rise interest in natural remedies that can replace them. Therefore, the aim of this work is to highlight the most promising approaches for the discovery of bioactive compounds for their use in the form of possible research strategies.

Key words: plant biologically active substances, milk productivity, reproduction 


\title{
ФОРМИРОВАНИЕ ПРОФЕССИОНАЛЬНЫХ КОМПЕТЕНЦИЙ У СТУДЕНТОВ ПО ВЕТЕРИНАРНОЙ ФАРМАКОЛОГИИ И ТОКСИКОЛОГИИ С УЧЕТОМ ФГОС З++
}

Бурцева Т.В., доц., к.П.н., Курочкина Н.Г., доц., к.в.н. (ФГБОУ ВО Уральский ГАУ, Россия)

\begin{abstract}
Аннотация. В статье рассматривается формирование профессиональных компетенций у студентов по ветеринарной фармакологии и токсикологии на основе трудовых функций, отраженных в профессиональном стандарте «Ветеринарный врач». Трудовые функции и трудовые действия включены в новую рабочую программу дисциплины «Ветеринарная фармакология. Токсикология» в соответствии с требованиями ФГОС $3++$. Новый образовательный стандарт открывает перспективы дальнейшего совершенствования
\end{abstract} методологических основ учебного процесса.

Ключевые слова: профессиональные компетенции, ветеринарная фармакология и токсикология, профессиональный стандарт, трудовые функции, ФГОС 3++.

Одной из основных доктрин модернизированного федерального государственного образовательного стандарта третьего поколения высшего образования - ФГОС $3++$ является применение требований к вновь введенной образовательной организацией основной образовательной программе ВО в соответствии с профильными профессиональными стандартами [1,2]. Такой подход позволит сформировать у будущего специалиста профессиональные компетенции, востребованные в его дальнейшей профессиональной деятельности.

В настоящее время при разработке образовательной программы часть профессиональных компетенций образовательная организация учреждает самостоятельно на примере профильных профессиональных стандартов и с учетом требований партнеров работодателей. В профессиональном стандарте «Ветеринарный врач», вышедшем в 2018 году, представлен новый подход к формированию профессиональных компетенций на основе трудовых функций, то есть, определены сначала обобщенные трудовые функции, затем трудовые функции, а также трудовые действия и соответствующие им требования к необходимым знаниям и умениям будущего ветеринарного врача [2,3]. Кардинально новым, с учетом требований работодателей, является решение разработки индикаторов достижения компетенций, позволяющее это сделать посредством разложения задач деятельности на отдельные действия [4]. Но этот путь непростой, часто способствующий включению в состав обязательную часть образовательной программы множества дисциплин, ведь каждое действие в некоторых случаях требует изучения отдельно дисциплины, с которой не всегда может быть согласен эксперт, проверяющий качество основной профессиональной образовательной программы вуза. Легче индикаторы представлять в виде привычных знаний, умений и навыков.

В образовательной программе высшего образования - программы специалитета по специальности 36.05.01 «Ветеринария» выпускники в ФГБОУ ВО Уральского ГАУ в соответствии с п. 1.12 ФГОС ВО готовятся к решению задач профессиональной деятельности врачебного типа. Процесс изучения дисциплины «Ветеринарная фармакология. Токсикология» направлен на формирование следующей компетенции: ПК-2 - способности проводить мероприятия по лечению больных животных, определенной на основе профессионального стандарта «Ветеринарный врач». Обучающийся должен получить знания и навыки по дисциплине для успешного освоения трудовых функций и выполнения трудовых действий. Для дисциплины «Ветеринарная фармакология. Токсикология» обобщенной трудовой функцией является оказание ветеринарной помощи животным всех видов, это 7 уровень квалификации - код $\mathrm{B}$, трудовой функцией - проведение мероприятий по лечению больных животных, а трудовыми действиями - осуществление выбора необходимых лекарственных препаратов химической и биологической природы для лечения животных с 
учетом их совокупного фармакологического действия на организм. Для этого необходимо уметь рассчитывать количество медикаментов для лечения животных и профилактики заболеваний с составлением рецептов на определенный период, определять способ и дозы введения лекарственных препаратов в организм животных, вводить лекарственные препараты в организм животных различными способами, а также знать государственный реестр лекарственных средств для ветеринарного применения, фармакологические и токсикологические характеристики лекарственного сырья, лекарственных препаратов химической и биологической природы, биологически-активных добавок для профилактики и лечения болезней животных различной этиологии, технику введения лекарственных веществ в организм животного энтеральными и парентеральными способами. Дисциплина «Ветеринарная фармакология. Токсикология» формирует у обучающегося необходимые знания теоретических основ и практических приемов эффективного и экономически оправданного использования лекарственных средств для лечения и профилактики сельскохозяйственных и промысловых животных при инфекционных, инвазионных и незаразных болезнях, защите животных от насекомых, клещей и грызунов, методов диагностики и профилактики отравлений животных, в том числе птиц, рыб и пчел, лекарственными и ядовитыми веществами, нормирования содержания остатков пестицидов, токсичных элементов и других опасных загрязнителей в кормах, предупреждения загрязнения их остатками продуктов животноводства. Терапия лекарственными препаратами имеет огромное значение в комплексе лечебных манипуляций при любых заболеваниях животных, поэтому изучение ветеринарной фармакологии студентами факультета ветеринарной медицины и экспертизы в Уральском ГАУ проходит в 5 и 6 семестрах. В 5 семестре студенты начинают изучение ветеринарной фармакологии, а завершают в 6 семестре, одновременно в 6 семестре проходят занятия по токсикологии. Поэтому освоение этих дисциплин упрощает понимание и запоминание материала, так как прослеживаются закономерности действия лекарственных средств и ядов на организм животных. Постоянное сопряжение этих двух дисциплин позволяет выработать у обучающихся четкое представление о том, что лекарственные средства оказывают не только терапевтическое действие, но и обладают опасными свойствами и в конкретных клинических ситуациях необходимо сопоставлять пользу с возможными нежелательными эффектами.

Методология преподавания студентам ветеринарной фармакологии и токсикологии осуществляется в соответствии с разработанными учебными планами и рабочей программой дисциплины. Тема каждого лекционного и практического занятия включает препараты, собранные в одну группу по принципу преимущественного действия на определенную систему организма. Лекарственные средства, наиболее часто применяемые, обучающиеся выписывают в рецептах в качестве домашнего задания и на практических занятиях, письменно обосновывают их принадлежность к определенной группе лекарственных средств, указывают фармакологические эффекты, показания к применению и побочные действия. Лабораторные занятия по ветеринарной фармакологии проводятся с применением компьютерных программ-симуляций, в которых представлены требования к виртуальному опыту, указаны растворы и вещества, которые будут использованы обучающимися на занятии, описана и представлена установка для опыта, приведена методика проведения опыта и в режиме обучения, и в режиме проверки. Студенты могут вводить различные лекарственные средства и наблюдать эффекты, вводимые веществами. Полученные результаты студенты оформляют в виде таблицы наблюдений с использованием формы таблицы-образца и отчитываются в конце лабораторного занятия преподавателю, представляя собственное заключение [5]. По разделам дисциплины «Ветеринарная фармакология. Токсикология» на платформе Moodle для самостоятельного изучения студентам выставлены учебные и учебно-методические пособия, изданные преподавателями кафедры инфекционной и незаразной патологии, а также интерактивные лекции, что облегчает подготовку к занятиям и позволяет систематизировать знания при подготовке к зачету и экзамену. На этой же платформе выложены ссылки на вебинары, учебные фильмы и вопросы к тестам. 
Обучающиеся на платформе Moodle выполняют тестовые задания по каждому разделу дисциплины, что дает возможность оценить уровень знаний у студентов.

Внедрение образовательных стандартов 3++ требует дальнейшего совершенствования методологических основ учебного процесса. Определенная профессиональная компетенция может обеспечивать готовность выпускника к выполнению целого ряда трудовых функций. Большинство работодателей стремятся найти себе компетентных специалистов в сфере ветеринарии, готовых осуществлять разнообразные трудовые функции. Перечень профессиональных компетенций не регламентирован четко образовательным стандартом, а формируется на основе профессиональных стандартов, а также основывается на анализе требований к профессиональным компетенциям, предъявляемых к выпускникам на рынке труда, обобщения отечественного и зарубежного опыта и обеспечивает возможность беспрепятственной актуализации профессиональных компетенций выпускника с учетом непрерывных изменений требований работодателей к квалификации работников.

Литература 1. Федеральный государственный образовательный стандарт высшего образования - специалитет по специальности 36.05.01 Ветеринария [Электронный ресурс]. Утвержден приказом Министерства образования и науки Российской Федерации от 22 сентября 2017 года № 974 - : http://fgosvo.ru/fgosvo/153/150/26/128 (дата обращения: 02.04.2021). 2. Профессиональный стандарт «Ветеринарный врач» [Электронный ресурс]. Утвержден приказом Министерства труда и социальной защиты Российской Федерации от 23 августа 2018 года № 547 н - URL: http://fgosvo.ru/uploadfiles/profstandart/ 13.012.pdf (дата обращения: 27.03.2021). 3. Аристова, Е.П. Формирование профессиональных компетенций на основе обобщенных трудовых функций / Е.П. Аристова, В.М. Аристов, А.О. Харитонов // Компетентность/Competency (Russia). - 2018. - № 1. - C. 4-7. — ISSN 1993-8780. - Текст: электронный // Лань: электронно-библиотечная система. - URL: https://e.lanbook.com/journal/issue/306663 (дата обращения: 27.03.2021). 4. Аристова, Е.П. Формирование индикаторов достижения профессиональных компетенций / Е.П. Аристова, B.M. Аристов, А.О. Харитонов // Компетентность/Competency (Russia). — 2019. — № 3. — C. 22-25. - ISSN 1993-8780. - Текст: электронный // Лань: электронно-библиотечная система. — URL: https://e.lanbook.com/journal/issue/310547 (дата обращения: 27.03.2021). 5. Бурцева Т.В., Курочкина Н.Г. Применение интерактивного метода обучения «Компьютерные симуляции» на лабораторных занятиях по ветеринарной фармакологии // Аграрное образование и наука. 2016. № 5. C. 67. - URL: http://aon.urgau.ru/ru/issues/19/articles/374 (дата обращения: 03.04.2021).

\section{FORMATION OF PROFESSIONAL COMPETENCIES IN STUDENTS IN VETERINARY PHARMACOLOGY AND TOXICOLOGY, TAKING INTO ACCOUNT FGOS 3 ++}

Burtseva T.V., associate professor, Ph.D., Kurochkina N.G., associate professor, Ph.D

(FSBEI HE Ural State Agrarian University, Russia)

Summary. The article discusses the formation of professional competencies among students in veterinary pharmacology and toxicology on the basis of labor functions, reflected in the professional standard "Veterinarian". Labor functions and labor actions are included in the new work program of the discipline "Veterinary Pharmacology. Toxicology "in accordance with the requirements of the Federal State Educational Standard $3++$. The new educational standard opens up prospects for further improving the methodological foundations of the educational process.

Key words: professional competence, veterinary pharmacology and toxicology, professional standard, labor functions, FSES $3++$. 


\title{
О ПЕРСПЕКТИВЕ ПРИМЕНЕНИЯ ЭТАМЗИЛАТА (ДИЦИНОНА) В КАЧЕСТВЕ АНГИОПРОТЕКТОРА ПРИ ЛЕЧЕНИИ ИНФЕКЦИОННОГО ПЕРИТОНИТА КОШЕК
}

\author{
Бушарова Ю.Б., студентка
}

Научный руководитель: ассистент Понамарев В.С.

(ФГБОУ ВО СПбГУВМ, Россия)

\begin{abstract}
Аннотация. Коронавирус кошек вызывает васкулит. Этамзилат перспективен в качестве антикоагулянта и ангиопротектора.
\end{abstract}

Ключевые слова: этамзилат (дицинон), ангиопротектор, коронавирус кошек, инфекционный перитонит кошек, васкулит.

Введение. Инфекционный перитонит кошек (ИПК) - наиболее часто встречаемое инфекционное заболевание кошек, индуцированное, предположительно, мутацией кошачьего коронавируса у конкретного представителя семейства кошачьих. Основой патогенеза является иммунопосредованный системный васкулит, проявляющийся изменением электрического потенциала сосудистой стенки с повышением её проницаемости. Происходит экстравазация сыворотки крови (при выпотной форме), в том числе фибриногена, который может выпадать в осадок, преобразуясь в нити фибрина на стенках внутренних органов (при сухой форме). Появляется воспаление серозных оболочек (перитонит, плеврит, вентрикулит, перикардит) с развитием водянок при выпотной форме ИПК (асцит, гидроторакс, гидроцефалия, гидроторакс) (по частоте встречаемости воспалений и водянок - убывание слева направо). При выпотной форме отмечается также гиповолемия [3].

На данный момент ИПК считается смертельным заболеванием и не имеет утвержденных протоколов лечения. [4]

Кудряшов А.А. также рассматривает ИПК как часто встречаемый при патологоанатомическом исследовании кошек. [2]

При применении этамзилата уменьшается образование в эндотелии сосудов простациклина, что ведет к повышенной адгезии и агрегации тромбоцитов. Под действием этамзилата увеличивается дифференциация тромбоцитов из мегакариоцитов, ускоряется выход тромбоцитов из депо крови. Усиливается образование тканевого тромбопластина. Все эти факторы направлены на ускорение тромбообразования и усилению ретракции тромба, т.е. являются основой гемостатического действия этамзилата. [5]

Применение этамзилата при коронавирусе кошек показано в статье Жавниса С.Э. и др.

В качестве ангиопротективного действия препарата отмечено усиление образования мукополисахаридов с большой молекулярной массой в стенке капилляров, что повышает резистентность сосудистой стенки, уменьшает её проницаемость и улучшает микроциркуляцию. [5]

На крысах показана противовоспалительная активность этамзилата (влияние на цикл арахидоновой кислоты) и антиоксидантное действие против гидроксильных радикалов в реакции Фентона (сопоставимое с антиоксидантным действием витамина Е, троксерутина и маннитола), однако против супероксидов и радикалов оксидов азота его антиоксидантное действие не выражено. [6] ИПК.

Цель исследования - исследовать перспективность применения этамзилата для лечения

Материалы и методы. Исследование проведено с учётом принципов биоэтики [7] на 20-ти кошках возрастом от 5-ти месяцев до 17-ти лет, которым по результатам данных клинического обследования и данных лабораторной диагностики [8] (ПЦР, ИХА и ИФА) был поставлен диагноз ИПК (выпотная форма, асцит). Этамзилат применялся в комплексной терапии, включающей в себя иммуномодулятор растительного происхождения [9] на основе 
омелы белой, антибиотик широкого спектра действия, противовоспалительный нестероидный препарат. Также проводилась инфузионная терапия.

При снижении проницаемости стенки кровеносного сосуда экстравазация также снижается вплоть до полного прекращения при восстановлении целостности стенок сосуда. При восстановлении целостности стенки кровеносного сосуда количество выпотной жидкости не увеличивается и при тенденции к выздоровлению начинает снижаться. Именно поэтому каждые три дня оценивалось общее состояние животного (аппетит, активность, ментальный статус, данные клинической диагностики - осмотр, пальпация, аускультация, термометрия), относительное количество выпота (с помощью УЗИ) и гематокрит для оценки состояния эндотелия капилляров.

Результаты исследования и обсуждение. Комплексная терапия оказалась эффективной для 13-ти кошек.

В ходе исследования погибло 7 кошек, у которых с самого начала присутствовала выраженная иктеричность кожи и слизистых оболочек и был повышен общий билирубин и трансаминазы в крови более чем в 5 раз, отмечалась гипоальбуминемия, а по данным УЗИ отмечалось большое количество свободной жидкости в брюшной полости и ультразвуковые признаки острого гепатита (понижение эхоструктуры печени с усилением интенсивности кровотока при проведении ангиодопплерографии).

У выживших 13-ти кошек после трехнедельной терапии свободная жидкость в брюшной полости не визуализировалась, гематокрит был восстановлен, общее состояние оценивалось как удовлетворительное или хорошее.

Поскольку в исследовании не участвовала контрольная группа животных, опытная группа была неоднородна по клиническим признакам и присутствовали другие препараты при лечении ИПК, достоверно оценить действие этамзилата невозможно, однако в связи с эффективностью данной схемы лечения представляется перспективным дальнейший вопрос изучения ангиопротекторных свойств этамзилата для лечения ИПК.

Литература. 1. Жавнис С.Э., Переслегина И.О., Санина А.А Комплексное лечение коронавирусного гастроэнтерита у котят: клинический случай // Известия ОГАУ. 2019. №5 (79). С. 205-207. 2. Кудряшов А.А., Балабанова В.И. Структура причин смерти кошек за 3,5 года (2012-2015) по секционным данным // Актуальные вопросы ветеринарной биологии. 2015. №2 (26). С. 54-61. 3. Куликов Е. В. Патологоанатомическая характеристика вирусного перитонита кошек / Е.В. Куликов, Ю.А. Ватников, Н.В. Сахно и др. // RJOAS. 2017. №4. С. 270-280. 4. Михайловская П.А. Новый подход в лечении вирусного перитонита кошек / П.А. Михайловская, К.М. Кондрашкина, Е.И. Симонова и др. // Бюллетень науки и практики. 2019. №5. С. 210-220. 5. Русин В.И. Непосредственные результаты лечения кровотечений из варикозных вен пищевода у пациентов с В-классом цирроза печени / В.И. Русин, К.Е. Румянцев, И.И. Кополовец и др. // Новости хирургии. 2013. №1. С. 36-45. 6. Hannaert Р. Vascular permeabilization by intravenous arachidonate in the rat peritoneal cavity: antagonism by ethamsylate / P. Hannaert, M. Alvarez-Guerra, H. Hider et. al. // Eur J Pharmacol. 2003. № 11. P. 207-212. 7. Анализ нормативных документов, регламентирующих требования к проведению доклинических исследований ветеринарных препаратов / С. В. Герасимов, В. С. Понамарев, Н. Л. Андреева [и др.] // Вопросы нормативно-правового регулирования в ветеринарии. - 2020. - № 3. - C. 27-29. - DOI 10.17238/issn2072-6023.2020.3.27. 8. Понамарев, В. С. Полимеразная цепная реакция с электрофоретической детекцией продуктов амплификации / В. С. Понамарев, С. А. Макавчик // Молодежный научный форум: естественные и медицинские науки. - 2016. - № 10(38). - С. 148-152. 9. Кострова, А. В. Некоторые аспекты проверки безопасности гепатопротектора на растительной основе / А. В. Кострова, В. С. Понамарев // XXII Всероссийская научно-практическая конференция Нижневартовского государственного университета : Материалы конференции, Нижневартовск, 06-07 апреля 2020 года / Научный редактор: Д.А. Погонышев. - Нижневартовск: Нижневартовский государственный университет, 2020. - С. 25-28. 


\title{
PROSPECTS OF ETHAMSYLATE (DICYNENE) APPLICATION AS AT ANGIOPROTECTOR IN CURE OF FELINE INFECTIOUS PERITONITIS
}

Busharova Y.B., student

Scientific adviser - assistant Ponamarev V.S.

(FSBEI HE St.Peterburg SUVM, Russia)

Summary. Feline coronavirus causes vasculitis. Ethamsylate is promising as an anticoagulant and angioprotector.

Key words: ethamsylate (Dicynene), angioprotector, feline coronavirus, feline infectious peritonitis, vasculitis.

УДК: 615.9-07:615.24:57.082.2

\section{ОСОБЕННОСТИ ИССЛЕДОВАНИЯ ОСТРОЙ ОРАЛЬНОЙ ТОКСИЧНОСТИ В СООТВЕТСТВИЕ С МЕТОДОМ «ВВЕРХ-И-ВНИЗ» (СОГЛАСНО ОЕСD/ОСDЕ 425)}

Великодная Е.К., студент

Научный руководитель Понамарёв В.С. асс. (ФГБОУ ВО СПбГУВМ, Россия)

\begin{abstract}
Аннотация. Острая токсичность соотносится с теми вредными последствиями, которые возникают после попадания пероральным путем или через кожу одной дозы вещества или нескольких доз в течение 24 часов или путем их вдыхания в течение 4 часов.
\end{abstract}

Ключевые слова: острая токсичность, пероральное введение, OECD/OCDE 425

Процедура «вверх-и-вниз» (согласно OECD/OCDE 425) используется для определения острой токсичности химических веществ. Принята ASTM в 1987 году с изменениями в 1999. Описанная процедура имеет значение для минимизации количества животных, необходимого для оценки острой пероральной токсичности химического вещества.

Сбор информации о химическом веществе перед исследованием полезен для определения актуальности теста для защиты здоровья человека и окружающей среды и в выборе подходящей начальной дозы[1]. Метод позволяет оценить ЛД50 с доверительным интервалом и классифицировать вещество, а так же более эффективно использовать животных и повышает точность прогнозирования значения LD50.

Метод эффективен, если вещество вызывает смерть за 1-2 дня. Вещества в дозах, вызывающих выраженную боль, не вводят. Умирающие или испытывающие боль животные умерщвляются согласно принципам биоэтики[2].

Тест на предельную дозу возможен для низкотоксичных веществ[3]. Предел-тест - это последовательный тест, в котором используют не более 5 животных. Тестовая доза - 2000 мг/кг, в исключительных случаях - 5000 мг/кг.

Первое животное получает дозу ниже уровня предполагаемой LD50. Если животное выживает/умирает, то доза для следующего животного увеличивается/уменьшается в 3,2 раза. Дозирование прекращают, когда удовлетворяется один из критериев остановки. Результаты основного испытания позволяют вычислить доверительный интервал.

Дозу желательно готовить незадолго до введения. Вводить желательно всегда один объём, меняя концентрацию. Нельзя превышать максимальный объём дозы для введения (для грызунов 1 мл/100 г массы тела; в случае водных растворов может быть 2 мл/100 г массы тела).

Если животное погибает при вводимой дозе - проводится основной тест. Если выживает - вводят дозу ещё 4 животным. Если 3 из них умирают/выживают, проводят основной тест/LD50 превышает 2000 мг/кг. Поздние смерти также учитываются.

Если умирают 3 из 5 животных, то LD50 меньше 2000 мг/кг. Проводится основной тест. Если выживают 3 из 5 животных, то LD50 больше 2000 мг/кг. Проводится предел-тест при дозе 5000 мг/кг. 
Литература. 1. Понамарев, В. С. Исследование острой токсичности гепатопротектора "ГЕПАТОН" на грызунах / В. С. Понамарев, Н. Л. Андреева, М. С. Голодяева // Международный вестник ветеринарии. - 2019. - № 4. - С. 81-85., 2. Анализ нормативных документов, регламентирующих требования к проведению доклинических исследований ветеринарных препаратов / С. В. Герасимов, В. С. Понамарев, Н. Л. Андреева [и др.] // Вопросы нормативно-правового регулирования в ветеринарии. -2020 . - № 3. - С. 27-29. DOI 10.17238/issn2072-6023.2020.3.27., 3. Понамарев, В. С. Изучение эмбриотоксического и тератогенного действия препарата «Гепатон» / В. С. Понамарев // Инновационные тенденции развития российской науки : Материалы XIII Международной научно-практической конференции молодых ученых, Красноярск, 08-09 апреля 2020 года. - Красноярск: Красноярский государственный аграрный университет, 2020. - С. 85-86.

\title{
FEATURES OF THE STUDY OF ACUTE ORAL TOXICITY IN ACCORDANCE WITH
} THE "UP-AND-DOWN" METHOD (ACCORDING TO OECD / OCDE 425)

\author{
Velikodnaya E.K., student
}

Scientific adviser V.S. Ponamarev ass. (FSBEI HE St.Peterburg SUVM, Russia)

Annotation. Acute toxicity refers to those harmful effects that occur after ingestion of a single dose of a substance or several doses through the skin within 24 hours or by inhalation within 4 hours.

Key words: acute toxicity, oral administration, OECD / OCDE 425

УДК: 615.9-07:615.24:57.082.2

\section{ОСОБЕННОСТИ ИССЛЕДОВАНИЯ СУБХРОНИЧЕСКОЙ КОЖНОЙ ТОКСИЧНОСТИ В СООТВЕТСТВИЕ С ОЕСD/ОСDЕ 413}

\author{
Великодная Е.К., студент
}

Научный руководитель Понамарёв В.С. асс. (ФГБОУ ВО СПбГУВМ, Россия)

\begin{abstract}
Аннотация. Указанный метод исследования предназначен для изучения субхронической кожной токсичности химических веществ в целях получения информации о воздействии на организм человека в результате повторного нанесения на кожу в течение 90 дней.
\end{abstract}

Ключевые слова. Субхроническая кожная токсичность, OECD/OCDE 413.

В основе тестирование лежит нанесение исследуемого вещества на кожу подопытных животных в течение 90 дней и их ежедневное обследование в течение всего срока. Погибших животных подвергают аутопсии. Выживших умерщвляют согласно принципам биоэтики [1] и так же подвергают аутопсии.

Перед началом исследований животных акклиматизируют к лабораторным условиям, разделяют на экспериментальную и контрольную группы, удаляют волосяной покров в области спины на 10\% поверхности тела[2,3]. Тестируемые твёрдые вещества увлажняют, жидкие обычно не разбавляют.

В качестве подопытных животных могут быть использованы: половозрелые крысы (200-300 г), кролики (2,0-3,0 кг) или морские свинки (350-450 г).

Используют примерно 20 животных (10 самок и 10 самцов) на исследование каждой дозы, 20 животных для вспомогательной группы и дополнительные животные, если планируется промежуточное умерщвление.

Для животных характерно: индивидуальное содержание. $22^{\circ} \mathrm{C}\left( \pm 3^{\circ}\right)$ для грызунов, $20^{\circ} \mathrm{C}\left( \pm 3^{\circ}\right)$ для кроликов. Относительная влажность 30-70\%, световой режим: 12 часов - свет, 12 часов - темнота; стандартная лабораторная диета с неограниченным количеством питьевой воды.

При исследовании используются три уровня доз. Самый высокий уровень дозы должен привести к токсическим эффектам. Средний уровень - к минимальным видимым токсическим эффектам. Самый низкий уровень - не должен вызвать никаких признаков интоксикации. 
Если уровень дозы более 1000 мг/кг, токсические эффекты не видимы, токсичность маловероятна, то три уровня доз не требуется.

Животных обрабатывают исследуемым веществом течение 90 дней. Исследуемое вещество фиксируют на обработанном участке тела. Нельзя допустить поглощение животным испытуемого вещества. Регистрируются признаки токсичности. Наблюдения за животными включают: изменения кожи, волосяного покрова, глаз и слизистых, органов дыхания, кровообращения, вегетативной и центральной нервной системы, соматотропной деятельности и модели поведения. Еженедельно животных взвешивают, и измеряют потребление пищи [4]. Умирающих животных удаляют из эксперимента и умерщвляют.

Все животные подвергаются офтальмологическому осмотру[5], гематологическим исследованиям[6], биохимическому анализу крови[7], анализ мочи только по показаниям.

Субхроническое кожное исследование даёт данные о последствиях повторной дермальной экспозиции вещества. Экстраполяция результатов на человека может дать информацию о кожной резорбции вещества, уровне, не оказывающем влияния, и допустимом уровне воздействия.

Литература. 1. Анализ нормативных документов, регламентирующих требования к проведению доклинических исследований ветеринарных препаратов / С. В. Герасимов, В. С. Понамарев, Н. Л. Андреева [и др.] // Вопросы нормативно-правового регулирования в ветеринарии. - 2020. - № 3. - С. 27-29. - DOI 10.17238/issn2072-6023.2020.3.27., 2. Кострова, А. В. Изучение аллергизирующих свойств препарата «Гепатон» / А. В. Кострова, В. С. Понамарев // Инновационные тенденции развития российской науки : Материалы ХIII Международной научно-практической конференции молодых ученых, Красноярск, 08-09 апреля 2020 года. - Красноярск: Красноярский государственный аграрный университет, 2020. - С. 75-76., 3. Кострова, А. В. Некоторые аспекты проверки безопасности гепатопротектора на растительной основе / А. В. Кострова, В. С. Понамарев // XXII Всероссийская научнопрактическая конференция Нижневартовского государственного университета : Материалы конференции, Нижневартовск, 06-07 апреля 2020 года / Научный редактор: Д.А. Погонышев. - Нижневартовск: Нижневартовский государственный университет, 2020. - С. 25-28., 4. Влияние препарата с гепатопротекторной активностью «Гепатон» на выживаемость, массу тела, потребление корма и воды у подопытных животных / В. С. Понамарев, Н. Л. Андреева, Е. С. Королева, А. В. Кострова // Современные проблемы естественных наук и медицины : Сборник статей Всероссийской научной конференции, Йошкар-Ола, 18-20 мая 2020 года. Йошкар-Ола: Марийский государственный университет, 2020. - С. 445-448., 5. Понамарев, В. С. Влияние препарата "Гепатон" на офтальмологические параметры крыс при длительном введении / В. С. Понамарев, К. Ф. Зенков // Материалы национальной научной конференции профессорско-преподавательского состава, научных сотрудников и аспирантов СПбГУВМ, Санкт-Петербург, 25-29 января 2021 года. - Санкт-Петербург: Санкт-Петербургский государственный университет ветеринарной медицины, 2021. - С. 76-78., 6. Понамарев, В. С. Влияние препарата с гепатопротекторной активностью "Гепатон" на показатели периферической крови лабораторных животных / В. С. Понамарев // Международный вестник ветеринарии. - 2020. - № 2. - C. 116-121. - DOI 10.17238/issn2072-2419.2020.2.116., 7. Биохимические показатели крови экспериментальных животных при лечении препаратом "Гепатон" и препаратами сравнения токсического поражения печени, вызванного дихлорэтаном / В. С. Понамарев, Н. Л. Андреева, Е. С. Королева, А. В. Кострова // Биотехнология: взгляд в будущее, Ставрополь, 16 апреля 2020 года. - Ставрополь: Ставропольский государственный медицинский университет, 2020. - C. 19-21.

\section{FEATURES OF THE STUDY OF SUBCHRONIC DERMAL TOXICITY IN ACCORDANCE WITH OECD / OCDE 413}

Velikodnaya E.K., student

Scientific adviser V.S. Ponamarev ass. (FSBEI HE St.Peterburg SUVM, Russia) 
Annotation. The specified research method is intended to study the subchronic skin toxicity of chemicals in order to obtain information on the effects on the human body as a result of repeated application to the skin within 90 days.

Keywords. Subchronic dermal toxicity, OECD / OCDE 413.

\title{
УДК 619:615.2
}

\section{СОЧЕТАННОЕ ДЕЙСТВИЕ ФИТОКОМПОЗИЦИИ И АГОНИСТОВ АЛЬФА2- АДРЕНОРЕЦЕПТОРОВ}

Веретенникова В.С., ветеринарный врач, Якоб Д.А., асп., Жарикова Е.А. асп., Бойко Т.В., д-р ветеринарныхнаук

(ФГБОУ ВО Омский ГАУ)

\begin{abstract}
Аннотация. С целью повышения безопасного применения лекарственных препаратов, в том числе совместно с фитопрепаратами для животных, необходимо повышать уровень информированности ветеринарных врачей о возможных взаимодействиях лекарственных средств и фитопрепаратов. Экспериментально установлено снижение седативной активности альфа2-агонистов адренорецепторов на фоне многократного введения спиртсодержащейфитокомпозицииУртикостим.
\end{abstract}

Ключевые слова: клиническая фармакология, взаимодействие лекарственных препаратов, фитопрепараты.

Введение. В клинической практике для лечения многих паталогических состоянийу животных врачи используюткомплекс лекарственных препаратов с разнымимеханизмами действия, при этом клинический эффект от их сочетанного применения зачастую непредсказуем, в связи с отсутствием сведений о фармакологическом взаимодействиимногих препаратов в организме разных видов животных.

В отличии от ветеринарной,в гуманитарной медицине накопилось много данных о возможности не только фармакодинамического, но и фармакокинетического взаимодействия между лекарственными средствами разных групп, в том числе и фитопрепаратами при их сочетанном применении [1]. Вместе с тем, для животных наряду с лекарственными препаратами синтетического происхождения, ведется активная разработкаи применение лекарственных средств на основе растительного сырья [2]. Важность изучения этого вопроса продиктована, прежде всего, поиском наиболее эффективного и безопасного подхода в лечении заболеваний животных и человека.

Доказано, что наибольшее клиническое значение имеет способность компонентов, входящих в состав фитопрепаратов, индуцировать или ингибировать изоферменты цитохрома P-450 и (или) гликопротеин Р. В связи с этимфитопрепараты способны как снизить эффективность совместно применяемых с ними ЛС, так и провоцировать возникновение нежелательных лекарственных реакций. В клинической ветеринарии для успокоения разных видов животных широкое применение имеют седативные препараты - агонисты альфа2адренорецептов. При этом данных об их сочетанном применении с фитопрепаратами в доступной литературе не обнаружено.

Цель исследования - изучить фармакологические эффекты агонистов альфа2адренорецепторов при их сочетанном действии спиртсодержащей полифункциональной фитокомпозиции Уртикостим.

Объекты, предмет и методы исследования. Объектами исследования явились коровы, белые беспородные крысы, фитокомпозиция и Ксиланит. Предметом исследования фармакологические эффекты, возникающие при совместном применении спиртсодержащей полифункциональной фитокомпозиции и агонистов альфа2-адренорецепторов. Методы исследования: клинические, аналитические, статистические. 
Результаты исследования. Изучая ранее терапевтическую эффективность биологически активного комплекса растительного происхождения Уртикостим при гинекологических заболеваниях послеродового периода у коров в монорежиме, нами не было обнаружено каких-либо особенностей в поведении животных кроме основных фармакологических эффектов фитокомпозиции[3]. ФитокомпозицияУртикостим представляет собой комплекс спиртоводных вытяжек чемерицы белой, тысячелистника лекарственного и крапивы двудомной [4]. Фитокомпозиция вызывает одновременное сокращение матки и преджелудков, стимулирует у коров аппетит, обладает противовоспалительным, иммуноактивным и кровеостанавливающим действием[5, 6]. В связи с действием на многие системы в организме фитокомпозицию рассматриваем как полифункциональную.

Клинические наблюдения.В схемы лечения ипрофилактики послеродовых заболеваний у молочных коров на некоторых предприятиях Омской области с целью успокоения животных перед парентеральным введениемнекоторых болезненныхантибактериальных препаратов, в частности цефалоспоринов, используют альфа2-агонистыадренорецепторов, такие какКсиланит ${ }^{\circledR}$ (д.вксилазина гидрохлорид).Согласно инструкции по применению препарата Ксиланит ${ }^{\circledR}$ относится к седативным лекарственным препаратам из группы производных тиазина.Ксилазина гидрохлоридявляется агонистом центральных $\alpha 2$-адренорецепторов, оказывает успокаивающее, миорелаксирующее и обезболивающее действие, стимулирует как центральные, так и периферические альфа2-адренорецепторы. При парентеральном введении вызывает быстрое наступление диссоциированной анестезии [7]. После внутримышечного или подкожного введения начало действия лекарственного препарата наступает через 5-20 минут. Продолжительность успокаивающего действия колеблется у крупного рогатого скота от 30 минут до 5 часов.Болеутоляющее действие сохраняется у крупного рогатого скота до 45 минут, миорелаксирующее действие у животных наступает через 20-50 минут в зависимости от дозы и индивидуальной чувствительности организма.Нежелательным фактом является то, что седативный и миорелаксирующий эффекты сохраняются не только до обедней, но и вечерней дойки, в связи с этим доярки не могут самостоятельно поднять животных для доения.Замечено, что на фоне введения альфа2-агонистов адренорецепторову коров снижается аппетит и суточный надой молока.

В ходе испытаний новой полифункциональной спиртсодержащей фитокомпозицииУртикостимбыло обнаружено значительное сокращение времени седации у коров опытной группы(более, чем в 2 раза по сравнению с животными, которым фитокомпозицию не вводили). Данный эффект наблюдали у всех коров, которым внутривенно была введена спиртосодержащаяфитокомпозиция. Моторика и секреция рубца у коров опытной группы восстанавливались быстрее, чем у коров, получавших антибактериальный препарат на фоне действия Ксиланита, что клинически проявлялось в повышении аппетита.

Лабораторные испытания. Для подтверждения предположения о влиянии фитокомпозиции на метаболизм альфа2-агонистов была проведена специальная серияэкспериментов на лабораторных животных, в ходе которых было сформировано 4 группы крыс, по три головы в каждой. Все животные были одного пола, одной возрастной группы и имели среднюю живую массу $300,0 \pm 1,3$. Группа $1-$ не получали фитокомпозицию и являлись контрольными животными. Группа 2 -фитокомпозициюинъецировали в дозе 0,15 мл внутримышечно. Группа 3 -инъецировалифитокомпозицию в дозе 0,3 мл внутримышечно. Группа 4 -инъецировали фитокомпозицию в дозе 0,6 внутримышечно. Продолжительность экспериментасоставила 10 дней. Внутримышечные инъекции фитокомпозиции проводили пятикратно через день. На 11 день всем экспериментальным животнымподкожно вводилиКсиланит в дозе 1 мл на голову с дальнейшим наблюдением за изменениями их общего состояния.

Оценка фармакологического действия альфа2-агонистов на фоне предварительного введения фитокомпозициипроходила путем оценивания седативного эффекта у крыс по 10 
бальной системе, где 0 -считали отсутствие седации, а 10 - седативный эффект выражен (сомнеленция, реакция на внешние раздражители отсутсвует).

Результатыисследований свидетельствуют о значительном (более, чем в 2 раза) сокращении времени седативного эффекта альфа2-агонистов на фоне многократного введения спиртосодержащегофитокомпозиции.Вызвать стадию сомнеленции у крыс, которым предварительно пятикратно был введен спиртсодержащаяфитокомпозиция, не удалось. Животные всех опытных групп сохраняли активность в течение всего периода наблюдений. При этом значительного дозозависимого эффекта установлено не было.

Снижение фармакодинамического (седативного) эффекта агонистов альфа2адренорецепторов возможно сопряжено со снижением егоконцентрации в плазме крови на фоне влияния фитокомпозиции на ферменты детоксикации в печени. Известно, что различные компоненты, содержащиеся в фитопрепаратах, могут влиять на ферменты биотрансформации (изоферменты цитохрома Р-450) и транспортеры ЛС (гликопротеин Р и др.), выступая в роли их индукторов (повышают активность) или ингибиторов (снижают активность). Следуя этой теории можно предположить, что спиртсодержащая фитокомпозиция Уртикостим индуцируя изоферменты цитохрома Р-450, катализирует реакции I фазы биотрансформации - окисление, в связи с чем концентрация альфа2-агонистов в организме снижается и основные фармакологические эффекты ксилазина ослабляются.

Заключение. Экспериментально подтверждено снижение седативной активности альфа2-агонистов адренорецепторов на фоне многократного введения спиртсодержащей фитокомпозиции Уртикостим. Для предупреждения развития нежелательных лекарственных реакций и предотвращения снижения эффективности лекарственных средств, которые являются следствием их взаимодействия, врач должен учитывать подобную информацию при проведении комбинированной фармакотерапии, в том числе с применением фитопрепаратов. Литература. 1. Сычёв Д.А. Механизмы фармакокинетического взаимодействия лекарственных средств и фитопрепаратов: взгляд клинического фармаколога / Д.А. Сычёв, Е.В. Ших, В.М. Булаев, Г.В. Раменская, В.Г. Кукес, С.В. Колхир // Биомедицина. - № 1. - 2005, c. 25-34. [Электронный ресурс]. - Точка доступа: file:///C:/Users/User/Downloads/mehanizmyfarmakokineticheskogo-vzaimodeystviya-lekarstvennyh-sredstv-i-fitopreparatov-vzglyad-

klinicheskogo-farmakologa.pdf(дата обращения 10.03.2021). 2. Попова О. С., Барышев В. А. Фитобиотики - перспективы использования / О.С. Попова. В.А. Барышев // Актуальные проблемы экологии и природопользования. - Матер. Нац. Науч.-практич.конф. студентов, аспирантов, молодых ученых и специалистов, посвященной 75-летию Победы в Великой Отечественной войне. Санкт-Петербург. - 2020. - С.68-68.3. Веретенникова В.С., Бойко Т.В., Варфоломеева К.В. Терапевтическая и профилактическая эффективность биологически активного комплекса растительного происхождения Уртикостим при гинекологических заболеваниях послеродового периода у коров / В.С. Веретенникова, Т.В. Бойко, К.В. Варфоломеева // Вестник Алтайского государственного аграрного университета. 2020. № 3 (185). С. 98-106.4. Бойко Т.В., Веретенникова В.С., Лукша Е.А. Средство для лечения и профилактики послеродовых заболеваний у коров / Бойко Т.В., Веретенникова В.С., Лукша Е.А. // Патент на изобретение RU 2719225 C1, 17.04.2020. Заявка № 2019119969 от 25.06.2019. 5. Веретенникова В.С., Бойко Т.В. Изучение противовоспалительной активности фитопрепаратаУртикостим методом подсчета лейкограммы / В.С. Веретенникова, Т.В. Бойко // В книге: Инновационные решения в аграрной науке - взгляд в будущее. Материалы XXIII международнойнаучно-производственнойконференции. 2019. С. 73-75. 5. The Urticostimphytocomposition'simpact on the hematological and immunological status of experimentalanimals. 6. Veretennikova V., Boyko T., Vlasenko V., Shitikov V. Всборнике: Advances in Social Science, Education and Humanities Research. Materials of the International scientific and practical conference. $2019 . \quad$ C. $17-20 . \quad 7$. Инструкцияпоприменениюлекарственногопрепаратаксиланит[Электронныйресурс].

Точкадоступа:https://www.nita-farm.ru/produktsiya/ksilanit/instruktsiya/ 


\section{COMBINED EFFECTS OF PHYTOCOMPOSITION AND ALPHA-ADRENORECEPTOR AGONISTS}

Veretennikova V.S., veterinarian, Yakob D.A., asp.,Zharikova E.A. asp., Boyko T.V., Doctor of Veterinary Sciences

(Federal State Budgetary Educational Institution of Higher Education Omsk State Agrarian University)

Annotation. In order to increase the safe use of drugs, including in conjunction with herbal remedies for animals, it is necessary to raise the level of awareness of veterinarians about possible interactions between drugs and phytopreparations. A decrease in the sedative activity of alpha2-adrenergic receptor agonists was experimentally established against the background of repeated administration of the alcohol-containing phytocompositionUrticostim.

Key words: clinical pharmacology, drug interactions, phytopreparations.

УДК:615.835.56:616.233-002-007.271:636.1

\section{ЭФФЕКТИВНОСТЬ ЛЕЧЕНИЯ ХРОНИЧЕСКОГО ОБСТРУКТИВНОГО БРОНХИТА ЛОШАДЕЙ С ПОМОЩЬЮ ИНГАЛЯЦИОННЫХ ПРЕПАРАТОВ}

Веселова Д.К., студ., Моисеева К.А., асп. напр. 06.02.02. (ФГБОУ ВО СПбГУВМ, Россия)

Аннотация. В современном мире конный спорт получает все большую популярность. Для лучшей продуктивности лошадей возникает необходимость в профилактике и лечении различных заболеваний. Была проведена оценка эффективности лечения хронического обструктивного бронхита лошадей с помощью такого ингаляционного препарата, как беродуал среди 5 голов лошадей.

Ключевые слова: обструктивный бронхит, беродуал, ингаляция.

Введение.Заболевание дыхательной системы распространено по всему миру, в связи со снижением резистентности организма лошадей. За последние годы в связи с ухудшением экологической обстановки в Саратовской области, снижением уровня содержания и кормления, в конюшнях участились случаи заболевания хроническим обструктивным бронхитом лошадей (ХОБЛ).При заболевании легких развивается гипоксия и вторичный иммунодефицит, что приводит к снижению работоспособности и возрастанию риска развития других патологий. Эффективность лечения в первую очередь зависит от правильности поставленного диагноза[3].

Этиологическими факторами развития бронхита могут служитьразвитие секундарной микрофлоры, неправильное применение синтетических кортикостероидов, и, главным образом, аллергические реакции на различные раздражители - пыль от подстилки, споры патогенных грибов, содержание в условия с повышенной влажностью и др.

Цель. Целью исследования являлось определение эффективности лечения хронического обструктивного бронхита лошадей с помощью ингаляционных препаратов.

Материал и методика исследования. Объектом исследования послужили разделенные 2 группы лошадей: опытная и контрольная, возрастом от 8 до 14 лет по 5 голов в каждой группе.

Для опытной и контрольной групп отбирались животные с комплексно установленным диагнозом «хронический обструктивный бронхит лошадей» на основании клинических исследований: у больных лошадей наблюдали быструю утомляемость при обычной работе, после прогонки в деннике животные принимали вынужденную позу - лошади опускали голову, горбили спину и редко ложились, отмечался редкий сухой кашель. При аускультации количество дыхательных движений было увеличено в 2-2,5 раза и составило в среднем 26 
вдохов в минуту без добавления физической нагрузки. На слизистой оболочке носовой полости наблюдались истечения серозно-катарального характера.

В ходе проведения эксперимента для опытной группы лошадей применялось ингаляционноелечение препаратом беродуал.

Результаты исследований. Для лечения опытной группы лошадей был назначен недельный курс беродуала по 30 капель на 15 мл физиологического раствора перед работой с утра.

Беродуал содержит два компонента, обладающих бронхолитической активностью: ипратропия бромид и фенотерола гидробромид. Ипратропия бромид является четвертичным производным аммония, обладающим антихолинергическими (парасимпатолитическими) свойствами, предотвращает увеличение внутриклеточной концентрации кальция, что происходит вследствие взаимодействия ацетилхолина с мускариновым рецептором, расположенным на гладких мышцах бронхов. Фенотерола гидробромид расслабляет гладкую мускулатуру бронхов и сосудов и противодействует развитию бронхоспастических реакций, обусловленных влиянием гистамина, метахолина, холодного воздуха и аллергенов (реакции гиперчувствительности немедленного типа)[6]. После введения фенотерол блокирует высвобождение медиаторов воспаления и бронхообструкции из тучных клеток.

Лошади опытной и контрольной группы получали одинаковую нагрузку. После применения ингаляций к вечеру первого дня у лошадей отмечался влажный кашель. На третий день эксперимента у лошадей опытной группы отмечалось улучшение состояния: они медленнее утомлялись, после прогонки не принимали вынужденную позу, а также снизилась частота кашля. После курса применения препарата, лошади смогли полностью восстановить работоспособность. При увеличении нагрузки у них не наблюдалось ухудшений в самочувствии. У контрольной группы лошадей по-прежнему наблюдались клинические признаки хронического обструктивного бронхита.

Вывод. При введении лекарственных препаратов с помощью ингаляций действующее вещество доставляется напрямую в бронхи, терапевтический эффект развивается быстро, самые высокие концентрации создаются в дыхательных путях, а системное действие сводится к минимуму. Из проведенного эксперимента можно сделать вывод, что ингаляционные препараты - самые эффективные средства для лечения ХОБЛ.

Литература. 1. Дорош М.В. Болезни лошадей. - М.: Вече, 2007. - 176 с. 2. Калашник И.А. Незаразные болезни лошадей. - М.: Агропромиздат, 1990. - 272 с. 3. Хоффман Э.М. Воспалительные заболевания дыхательных путей: определение и диагностика у спортивных верховых лошадей // Болезни лошадей. Современные методы лечения: пер. с англ. - М.: Аквариум-Принт, 2007. - 1007 с. 4. Ковач М. Колики лошади. Причины. Диагноз. Лечение. М.: Королевский изд-кий дом, 2010. - 234 с. 5. Корнеева А.В. Хронические обструктивные болезни бронхов у лошадей. // Вестник РУДН, серия Агрономия и животноводство - 2011 - № 1 - С. 45-49. 6. Романова О.В., Крячко О.В. Принципиальная схема лечения хронических обструктивных заболеваний легких у лошадей. // Практик - 2004 - № 1-2 - С.59-61. 7. Стекольников, А. А. Содержание, кормление и болезни лошадей / А. А. Стекольников, Г. Г. Щербаков, Г. М. Андреев [и др.]. - Санкт-Петербург: Лань, 2007. - 624 с.

\section{EFFICIENCY OF TREATMENT OF CHRONIC OBSTRUCTIVE BRONCHITIS IN HORSES WITH INHALATION PREPARATIONS}

Veselova D.K., student, Moiseeva K.A., Ph.D. for example. 06.02.02. (FSBEI HE St.Peterburg SUVM, Russia)

Summary.Equestrian sport is gaining popularity in the modern world. For the best performance of horses, there is a need for the prevention and treatment of various diseases. Evaluation of the effectiveness of the treatment of chronic obstructive bronchitis in horses using an inhaled drug such as berodual among 5 horses was carried out.

Key words: obstructive bronchitis, berodual, inhalation. 


\section{РЕТРОСПЕКТИВНЫЙ АНАЛИЗ РАСПРОСТРАНЁННОСТИ ҒСУ У КОШЕК В САНКТ-ПЕТЕРБУРГЕ}

Виноходов В.О. - к. вет. н., доцент каф. микробиологии, вирусологии и иммунологии, Фаттахов А.К. - студ. 5 курса ФВМ

(ФГБОУ ВО СПБГУВМ)

Аннотация: Оценивали титры антител к калицивирусу кошек (FCV) у 24 пациентов и поствакцинальные изменения у здоровых взрослых кошек-вирусоносителей. Кошкам старше 1 года, ранее не вакцинированным вводили инактивированную вакцину из штамма FCV 431. Антитела контролировали до вакцинации, на 7 и 28 день поствацинального периода иммуноферментным методом. Предвакцинальные антитела были обнаружены у 69 \% кошек. Более, чем 4-кратное увеличение титра после вакцинации наблюдалось у 33,7 \%. Таким образом, калицивироз у кошек в Санкт-Петербурге широко распространён.

Ключевые слова: калицивироз, Санкт-Петербург, ретроспективный анализ

Введение. Калицивироз (FCV) часто встречается у кошек и может периодически вызывать острые стоматиты, трахеиты и бронхиты. Высоко вирулентные штаммы FCV могут приводить к системным заболеваниям с высокой смертностью. Поэтому поголовная вакцинация настоятельно рекомендуется, особенно племенным животным у заводчиков. Однако вакцины против FCV не обеспечивают полной защиты от болезни из-за высокой генетической и антигенной изменчивости полевых вариантов вируса, реверсии вакцинных штаммов, приводящих к перекрестной реактивности с снижению специфичности иммунитета. Защита, обеспечиваемая вакцинами, ограничена определенным спектром полевых штаммов, и поэтому вакцинные штаммы в идеале должны быть адаптированы к полевым изолятам, которые в настоящее время циркулируют в местном регионе среде. Современные вакцины против FCV бывают моноспецифичными (штаммы F9 и 255), либо комбинированные из двух вакцинных штаммов (G1 и 431). Единичные вакцинные штаммы используются в течение нескольких десятилетий. Однако они считаются менее эффективными из-за высокой скорости мутации FCV. Вакцинация комбинацией G1 и 431 дала более высокие титры нейтрализующих антител, лучшую защиту и снижение выделения вируса во внешнюю среду после контрольного заражения. В настоящей статье предпринята попытка установить распространённость болезни среди иммунизированных и интактных кошек в СанктПетербурге.

Материалы и методы. Исследовали образцы сывороток крови от 24 кошек. Критериями выбора пациентов были: (1) результаты клинических исследований; (2) возраст кошек до 1 года; и (3) все кошки были первично вакцинированы менее против FCV менее 1 года назад. Каждая кошка получала однократную дозу инактивированной вакцины из штамма FCV 431.

Для обнаружения антител к FCV до и после вакцинации у кошек брали кровь, получали выворотку крови до вакцинации и на 7 и 28 дни после вакцинации. Образцы замораживали при $-20{ }^{\circ} \mathrm{C}$. Анализировали все сыворотки одновременно в ELISA-тесте.

Результаты исследований. Предвакцинальные антитела были обнаружены у 69 \% кошек. Более, чем 4-кратное увеличение титра специфических антител после вакцинации наблюдалось у 33,7 \%.

Все кошки, вакцинированные в течение 1 года, имели предвакцинальные антитела. У невакцинированных 16 особей предвакцинальных антител не обнаружено.

После вакцинации к 28 дню одна кошка не имела антител, другие 25 показали примерно 4-кратное увеличение титра антител после вакцинации по сравнению с результатами предыдущих исследований.

Обсуждение. Время, прошедшее после последней вакцинации, коррелировало с наличием антител у кошек, вакцинированные в течение 1 года. Шестнадцать из 24 кошек, 
которые никогда не были вакцинированы, были антителаположительными как в ELISA-тесте. За исключением одной, все эти кошки жили ранее в семьях с несколькими кошками на момент исследования и, поэтому, естественное заражение было наиболее вероятной причиной появления антител.

У кошек старше 2 лет вероятность наличия антител к калицивирусу до вакцинации выше, чем у более молодых особей. Пожилые кошки более подвержены воздействию вируса и, следовательно, чаще имеют антитела против FCV. У кошек моложе 2 лет взаимодействие с материнскими антителами при первой вакцинации является еще одной причиной неудачной вакцинации и отсутствия антител.

Выводы. Таким образом, калицивироз у кошек в Санкт-Петербурге широко распространён. Проведение массовой иммунизации кошек против калицивироза - актуальная задача ветеринарии.

Литература 1. Алексеева, И. Г. Инфекционные болезни мелких домашних животных : учебное пособие / И. Г. Алексеева, В. П. Дорофеева, М. В. Маркова. - Омск : Омский ГАУ, 2019. - 121 с. - ISBN 978-5-89764-841-2. 2. Алиев А.С., Данко Ю.Ю., Ещенко И.Д. [и др.] Эпизоотология с микробиологией : учебник для вузов; Под редакцией В. А. Кузьмина, А. В. Святковского. - 6-е, стер. - Санкт-Петербург : Лань, 2021. - 432 с. - ISBN 978-5-81147577-3. 3. Белоусова Р.В., Ярыгина Е. И., Третьякова И. В. [и др.] Вирусология и биотехнология: учебник. — 3-е изд., стер. - Санкт-Петербург : Лань, 2018. — 220 с. — ISBN 978-5-8114-2266-1. 4. Госманов, Р. Г. Ветеринарная вирусология : учебник для вузов / Р. Г. Госманов, Н. М. Колычев, В. И. Плешакова. - 7-е изд., стер. - Санкт-Петербург : Лань, 2021. - 500 с. - ISBN 978-5-8114-7251-2. 5. Масимов, Н. А. Инфекционные болезни собак и кошек : учебное пособие / Н. А. Масимов. - 2-е изд., стер. - Санкт-Петербург : Лань, 2021. - 128 c. - ISBN 978-5-8114-0938-9. 6. Brian W. J. Mahy, Marc H. V. van Regenmortel. Desk Encyclopedia of Animal and Bacterial Virology. ISBN: 978-0-12-375144-7

7. James N. MacLachlan, Edward J. Dubovi, Stephen W. Barthold, David E. Swayne, James R. Winton. Fenner's Veterinary Virology - 5-th ed. ISBN: 978-0-12-800946-8 8. Nicholas H. Acheson. Fundamentals of molecular virology - 2nd ed. p. ; cm. ISBN 978-0-470-90059-8

\section{A RETROSPECTIVE ANALYSIS OF FCV PREVALENCE IN CATS IN ST} PETERSBURG

Vinohodov V. O. - PhD, Department of Microbiology, Virology and Immunology, Fattakhov A.K. - 5th-year student of the FVM (FSBEI HE St.Peterburg SUVM, Russia)

Summary: The titers of antibodies to feline calicivirus (FCV) were evaluated in 24 patients and postvaccination changes in healthy adult virus-carrying cats. Cats over 1 year old, previously not vaccinated, were injected with an inactivated vaccine from the FCV 431 strain. Antibodies were controlled before vaccination, on days 7 and 28 of the postvacinal period by the enzyme immunoassay. Prevaccinal antibodies were found in $69 \%$ of cats. More than 4 -fold increase in titer after vaccination was observed in $33.7 \%$. Thus, calicivirus infection in cats in St. Petersburg is widespread.

Key words: calicivirus, St. Petersburg, retrospective analysis

УДК: 636.033

\section{ФУНКЦИОНАЛЬНЫЕ ПАРАМЕТРЫ ТРОМБОЦИТОВ У ТЕЛЯТ МОЛОЧНО- РАСТИТЕЛЬНОГО ПИТАНИЯ ЧЕРНО-ПЕСТРОЙ ПОРОДЫ \\ Воробьева Н.В., к.б.н. ${ }^{1}$, Медведев И.Н., д.б.н., профессор ${ }^{2}$ \\ ${ }^{1}$ ФГБОУ ВОЮго-Западный государственный университет, Россия \\ ${ }^{2}$ ФББОУ ВОРоссийский государственный социальный университет, Россия}

Аннотация. К возрасту 45 суток у телят происходит ускорение наступления агрегации тромбоцитов, исчезающее к концу фазы молочно-растительного питания. В основе развития 
этих изменений у наблюдавшихся телят, видимо, лежит кратковременное нарастание генерации тромбоксанапо причине усиления функции тромбоцитарныхциклооксигеназыи тромбоксансинтетазы. Кратковременное усиление активности тромбоцитов также было связано с непродолжительным повышением уровня в них аденозинфосфатов и ростом их секреции при повышении тромбоцитарных уровней актина и миозина.

Ключевые слова:телята,черно-пестрая порода, фаза молочно-растительного питания, тромбоциты.

Функциональные свойства первичного гемостаза сильно зависят от активности тромбоцитов[2]. В свою очередь она во многом определяет течение процессов микроциркуляции и метаболизма в тканях[1]. Доступные немногочисленные работы, посвященные физиологии тромбоцитам, не дают ясного представления по данному вопросу [4]. Это формирует острую потребность в дальнейших углубленных исследованиях по разным аспектам тромбоцитарной активности [3]. Ввиду наличия явных межпородных различий у крупного рогатого скота и большим влиянием тромбоцитов на микроциркуляцию, тесто связанную с уровнем продуктивности, представлялось важнымизучать функциональные особенности тромбоцитов у телят молочных пород в период их интенсивного роста.

Цель - проследить активность тромбоцитов у телят черно-пестрой породы на протяжении фазы молочно-растительного питания.

Материалыиметоды. В выполненное исследование взято 44 теленка, относящихся к черно-пестрой породе, полученных в результате 2-3 стельности от здоровых коров. Телята обследовались пятикратно: на 31, 45, 60, 75 и на 90 сутки жизни. У животных учитывали уровень генерациитромбоксана в тромбоцитах,активность, реализующих этот процесс, ферментовциклооксигеназы и тромбоксансинтетазы. Также в тромбоцитах у животных регистрировали количество аденозинтрифосфата и аденозиндифосфата.Выясняли способность тромбоцитов животных к секреции этих соединений. В тромбоцитах выясняли уровни актина и миозина в ответ на воздействие аденозиндифосфата.

Время наступления агрегации тромбоцитов (АТ)отслеживали визуальногомикрометодом. Внутрисосудистая активность тромбоцитов выяснялась при применении фазового контраста.Статистическая обработка данных велась с помощью программ«Статистика для Windowsv. 6.0».

Результаты исследований. Содержаниедискоидных тромбоцитов в крови обследованных телят в возрасте 45 суток уменьшалось на 13,6\%,нарастая к концу наблюдения довеличины $70,7 \pm 0,20 \%$. Общее количество активных тромбоцитов к возрасту 45 суток кратковременно возрастала на 29,2\%,затем быстро возвращаясь к исходу. В крови телят этого возраста число мелких и более крупных агрегатов тромбоцитов возрастало на 20,9\% и на $53,8 \%$, соответственно, затем снижаясь к концу наблюдения до изначальных величин.

У телят в возрасте 45 суток наступала короткая активация тромбоцитов. В этом возрасте у них ускорялась АТ под влиянием агониста коллагена на 24,1\%. Затем онатормозилась, достигая к 75 суткам жизни исходной величины. Некоторое ускорение развития АТ найдено было в отношенииаденозиндифосфатом(на 19,1\%) и в отношении ристомицина(на 21,9\%). Аналогичное быстро устранимое ускорение АТ имело место в ответ на тромбин и адреналин.Время развития АТ с нимисокращалось в возрасте 45 суток и достигало исходных значений к 75 суткам их жизни.

Одним из механизмов интенсификации агрегации у телят в возрасте 1,5 месяцев является короткое усиление синтеза тромбоксана. На это указывала интенсификация на 18,3\% агрегации тромбоцитов, отмечаемойв простой пробе переноса. Она обеспечивалась кратковременным повышением у телят в это время ферментативной активности тромбоцитарныхциклооксигеназы на 13,0\% и тромбоксансинтетазы на 19,1\%. Об этом также говорило быстро устраняющееся усиление агрегации тромбоцитов регистрируемой коллагенаспириновой пробе (до 96,3 $\pm 0,16 \%$ ) и агрегации тромбоцитов регистрируемой коллагенимидазольной пробе (до $53,6 \pm 0,19 \%$ ) с последующим ее ослаблением до исходного уровня к возрасту 75 суток. 
Небольшое в начале исследования содержание в тромбоцитах молодняка аденозинтрифосфата и аденозиндифосфатаувеличивалось к возрасту 1,5 месяцев на 13,0\% и на 17,2\% при активизации их секреции соответственно на 27,1\% и 17,2\%. Найденное повышение этих показателей сменялось их понижением к 75 суткам жизни до значений, характерных для исхода.

Содержание актина и миозина в дискоидных тромбоцитах у телят 45 суток возрастало на $21,9 \%$ и на $30,5 \%$, затемуменьшаясь к 75 суткам доисходных значений $(32,3 \pm 0,12 \%$ общего белка в тромбоците и $16,8 \pm 0,10 \%$ общего белка в тромбоците). В ходе агрегации в тромбоцитах у телят в возрасте 45 сутокбыло выявлено усилениесамосборки белка актина на 19,4\% и белка миозина на $31,7 \%$, нивелирующееся к 75 суткам онтогенеза.

Заключение. У телят, относящихся к черно-пестрой породе, в начале фазы молочнорастительного питания наступает непродолжительное усиление функций тромбоцитов. В основе этой активации, без сомнения, лежит кратковременное усилениефункциональных процессов, реализующих в тромбоцитах адгезию, агрегацию и секрецию. Быстро завершающееся в течение фазы молочно-растительного питания усиление активации тромбоцитов, видимо, являлось умолодняка черно-пестрой породы проявлением адаптационных процессов.

Литература. 1. Завалишина, С.Ю. Сосудистый гемостаз у телят в период молочнорастительного питания / С.Ю. Завалишина // Зоотехния. - 2012. - №2.- С.21. 2. Завалишина, С.Ю. Контроль сосудистой стенки над индуцированной агрегацией тромбоцитов у новорожденных телят в условиях дефицита железа / С.Ю. Завалишина, Т.И. Глаголева // Ветеринарная практика. - 2013.-№2.-C.40. 3. Skoryatina, I.A.Some aspects of treatment of patients having dyslipidemia on the background of hypertension / I.A. Skoryatina, S.Y. Zavalishina, O.N. Makurina, G.S. Mal, O.V. Gamolina //PrensaMedica Argentina. - 2017. - T.103, №3.- C.3. 4. Vorobyeva, N.V. Influence of physical exercise on the activity of brain processes / N.V. Vorobyeva, T.I. Glagoleva, G.S. Mal, S.Y. Zavalishina, I.I. Fayzullina //Research Journal of Pharmaceutical, Biological and Chemical Sciences.- 2018. T.9. № 6.- C.240-244.

\title{
FUNCTIONAL PARAMETERS OF PLATELETS IN THE CALVES OF THE MILK- VEGETABLE NUTRITION OF THE BLACK AND MOTLEY BREED
}

\author{
Vorobyeva N.V., Ph.D. ${ }^{1}$, Medvedev, I.N., D.S., professor $^{2}$ \\ ${ }^{1}$ FGBOU in Southwest State University, Russia \\ ${ }^{2}$ FGBOU to Russian State Social University, Russia
}

Summary. By age 45 days in calves, the occurrence of platelet aggregation occurs, disappearing by the end of the phase of milk-vegetable nutrition. At the heart of the development of these changes in observed calves, apparently, there is a short-term increase in the generation of thromboxane due to enhancing the functions of platelet cyclooxygenase and thromboxintetase. A short-term strengthening activity of platelets was also associated with a short increase in the level of adenosine phosphates and the growth of their secretion with increasing the thrombocyte levels of actin and myosein.

Keywords: calves, black and print breed, phase of milk and vegetable nutrition, platelets.

УДК:615.3:616.993.192.1:636.2-053

ПРИМЕНЕНИЕ ПРЕПАРАТА «АЗИФЛУМИН» ПРИ КРИПТОСПОРИДИОЗЕ ТЕЛЯТ Гаврилова Н.А. д.в.н, проф., Белова Л.М., д.биол.н., проф.,Щербина Ю.А., асп. (ФГБОУ ВО СПбГУВМ, Россия)

Аннотация.Применение препарата «Азифлумин», содержащего в 1,0 мл азитромицина100 мг и флуниксинамеглумина- 44 мг в дозе 1 мл на 20 кг массы животного ежедневно, однократно, курсом 5 дней недостаточно эффективно при криптоспоридиозе телят. 
Увеличение курса лечения до 7 дней приводит к повышению эффективности лечения, но не избавляет животных от криптоспоридий полностью.

Ключевые слова:криптоспоридиоз, телята, лечение, азифлумин.

Криптоспоридиоз телят остается актуальной проблемой для ветеринарии, так как во многих животноводческих хозяйствах имеет широкое распространение. Кроме того, важность изучения данной инвазии обусловлена ее зоонозным потенциалом [1]. Из млекопитающих наиболее чувствительными к возбудителютелята до 30-дневного возраста, имеющие иммунодефицит [2]. У таких животных криптоспоридиоз протекаетс выраженными симптомами диареи, дегидратации, истощения и нередко гибели. Комплексная терапия, включающая применение препаратов симптоматического и этиотропного действия, используемая в хозяйствах, в ряде случаев не достигает желаемого эффекта по причине формирования резистентных форм простейших.Для лечения животных, больных криптоспоридиозом, применяют препараты различных фармакологических групп. Кокцидиостатики, используемые в течение длительного времени, сталинедостаточно эффективными и в ряде случаев оказывают выраженное терапевтическое действие только при комплексной терапии, включающей применение пробиотиков [3, 4, 5]. При проведении сравнительной эффективности препаратов, содержащих альбендазол, метронидазол и парамомицинустановлено выраженное терапевтическое действие антибиотика (парамомицина) при криптоспоридиозе телят[6]. В последние годы все чаще стали использовать антибиотики в этиотропной терапии при криптоспоридиозе $[7,8]$.

Применение раствора для инъекций «Азифлумин», содержащего в 1,0 мл азитромицина (в форме дигидрата) - 100мг и флуниксинамеглумина- 44 мг, эффективно при бактериальных инфекциях крупного рогатого скота, но не изучено при кокцидиидозах. Целью нашего исследования стало изучение эффективности препарата «Азифлумин» при криптоспоридиозе телят.

На животноводческом комплексе в Лужском районе Ленинградской области проведено изучение терапевтической эффективности препарата «Азифлумин» при криптоспоридиозе телят.

У телят черно-пестрой породы 3-28-дневноговозраста с признаками диареи, дегидратации, истощения были отобраны пробы фекалий из прямой кишки при помощи инструмента, состоящего из ручки, соединенной с заборным элементом, выполненным из двух цилиндрических половин с округлыми концами [9]. Диагноз на криптоспоридиоз подтверждали в лаборатории по изучению паразитарных болезней при кафедре паразитологии им В.Л. Якимова ФГБОУ ВО «Санкт-Петербургский государственный университет ветеринарной медицины».Фекалии исследовали методом Дарлинга с использованием усовершенствованной флотационной жидкости и нативных мазков с последующим их окрашиванием по Цилю-Нильсену. Изучали препараты в микроскопе CarlZeissPrimoStar c визуализацией при увеличении $10 \times 100$.

Животным из группы № 1 внутримышечно вводили препарат «Азифлумин» в дозе 1 мл на 20 кг массы животного ежедневно, однократно, в течение 5 дней.

Телятам из группы № 2 препарат «Азифлумин» вводили внутримышечно в дозе 1 мл на 20кг массы животного ежедневно, однократно, в течение 7 дней.

Животным контрольной группы (№3) препарат «Азифлумин» не применяли, но проводили симптоматическое лечение.

За животными подопытных и контрольной группы вели наблюдение со дня введения препарата «Азифлумин» в течение 21 дня. Обращали внимание на активность животных, потребление ими корма, наличие изменений функции желудочно-кишечного тракта, состояние слизистых оболочек и шерстного покрова. Фиксировали физиологическое состояние животных до введения препарата в дальнейшем каждый день в течение 8 дней.

На 6 и 8 день провели окраску мазков из проб фекалий по Цилю-Нильсену с целью выявления ооцисткриптоспоридий у животных подопытных и контрольной групп. 
При микроскопии мазков, окрашенных по Цилю-Нильсену, на 6 день после применения препарата у 7 телят первой группы были обнаружены ооцисты рода Cryptosporidiumsp. У 3-х телят ооцисткриптоспоридий не обнаружили. Клиническое состояние животных было удовлетворительное, но фекальные массы имели разжиженную консистенцию.

У животных второй группы на 8 день после применения препарата у 5 телят обнаружены ооцисты рода Cryptosporidiumsp. Несмотря на наличие возбудителя, все животные были активные, аппетит у них был сохранен, слизистые оболочки имели бледно розовый цвет, но фекалии были кашицеобразной консистенции.

У телят из третьей группы диарея с примесью слизи, обезвоживание сохранялось в течение всего периода наблюдения. При микроскопии мазков фекалий, окрашенных по ЦилюНильсену были обнаружены до 5 ооцисткриптоспоридий в поле зрения микроскопа при ув. $10 \times 100$.

Было установлено, что применение препарата «Азифлумин» при криптоспоридиозе телят в дозе 1 мл на 20 кг массы животного ежедневно, однократно, курсом 5 дней недостаточно эффективно при криптоспоридиозе телят.Увеличение курса лечения до 7 дней приводит к повышению эффективности лечения, но не избавляет животных от криптоспоридий полностью.Применение препарата способствует стабилизации функции желудочно-кишечного тракта животных.

Следует отметить, что препарат «Азифлумин» был применен телятам в возрасте до 1 месяца, что по инструкции относится к ограничениям при назначении препарата. Введение препарата не вызывало аллергических, токсических и других побочных действий на организм телят.

Литература. 1.Кряжев, А.Л. Криптоспоридиоз телят в хозяйствах молочной специализации Северо-Запада России: монография /А. Л. Кряжев, П.А. Лемехов. - Вологда. - Молочное: ИЦ ВГМХА, 2010. - 111с. 2. Мусаева, М.Н. Криптоспоридиоз при иммунодефиците у новорожденных телят /М.Н. Мусаева, Н.Р. Будулов, С.Ш. Абдулмагомедов, З.Г. Мусаев // Российский паразитологический журнал. - 2013.- №3.- С. 64-66. 3. Краснова, О.П. Криптоспоридиоз телят и меры борьбы с ним: автореф. дис. ... канд. вет. наук: 03.00.19. / Краснова Оксана Петровна. - Саратов, 2000.-21 с. 5. 4. Андрушко, Е.А. Сравнительная эффективность препаратов «Ампробел Р» и «Толтарокс» / Е. А. Андрушко, С.В. Егоров. // Вестник КГУ им. Н.А. Некрасова. - Кострома, 2014. - № 7. - С.48 -49. 5. Петрович, Е.В. Эффективность пробиотиков и Байкокса при спонтанном криптоспоридиозе телят/ Е.В. Петрович //Ветеринария. -2010.-№ 9. - С.32.6.Masood, S. Anti-Cryptosporidium Activity of Albendazole, Metronidazole and Paromomycin in Experimentally Infected Cattle Pakistan / S. Masood, A. Maqbool, U. J. Khan [et al.] // J. Zool.-2013.- vol. 45(4) .- P. 935-940. 7. Новак, М.Д. Эффективность комплексного антибиотика азидокс при заболеваниях желудочнокишечного тракта и органов дыхания молодняка крупного рогатого скота /М.Д. Новак, С.В. Енгашев, Э.Х. Даугалиева //Теория и практика паразитарных болезней животных. -2014. №15. -С. 187-191. 8. Четвертнов, В.И. Терапия телят при криптоспоридиозе / В.И. Четвертнов, Е.А. Киц, О.Э. Грига // Международный вестник ветеринарии. - 2020, №4. - С.19-24. 9. Патент на изобретение. Инструмент для взятия проб фекалий из прямой кишки животных / Л.М. Белова, К.А. Рожков, Н.А. Гаврилова, Ю.Е. Кузнецов, М.С. Петрова, И.В. Лунегова, О.А. Логинова, Е.В. Ермакова // Патент № 179944, зарег. ВГос. реестреизобретенийРФ 29 мая 2018 г., Бюл. №27.

\section{THE USE OF THE DRUG "AZIFLUMIN" IN CRYPTOSPORIDIOSIS OF CALVES}

Gavrilova N.A, Dr. Habil. Veter. Scie, professor, Belova L. M., Dr. Habil. Biol. Sci., professor, ShcherbinaYu.A., graduate student.

(FSBEI HE St.Peterburg SUVM, Rossia)

Summary.An Aziphlumin injection solution containing in $1.0 \mathrm{ml}$ of azithromycin $-100 \mathrm{mg}$ and flujects of meglumum - $44 \mathrm{mg}$ in a dose of $1 \mathrm{ml}$ per $20 \mathrm{~kg}$ of the mass of the animal daily, one-time, a course of 5 days is not enough effective at cryptosporidiosis calves. An increase in treatment course 
up to 7 days leads to an increase in the effectiveness of treatment, but does not eliminate animals from cryptosporidycompletely.

Key words: cryptosporidiosis, calves, treatment,aziflumin.

УДК : $615.065: 619$

\section{К ВОПРОСУ ОБ ИНФОРМАТИВНОСТИ ИНСТРУКЦИЙ ПО ПРИМЕНЕНИЮ ИММУНОМОДУЛЯТОРОВ ВЕТЕРИНАРНОГО НАЗНАЧЕНИЯ}

${ }^{1}$ Герунов Т.В., доц., канд. биол. наук, ${ }^{1}$ Герунова Л.К., проф., д-р ветеринар. наук, ${ }^{1}$ Тарасенко А.А., асс., канд. ветеринар. наук, ${ }^{2}$ Чигринский Е.А., доц., канд. биол. наук

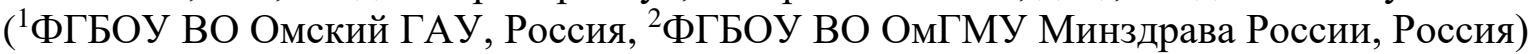

Аннотация. Сфера применения иммуномодуляторов ветеринарного назначения расширяется. При этом в большинстве случаев отсутствуют сведения о нежелательных эффектах препаратов данной группы. Необходимо расширить исследования в указанном направлении и повысить информативность инструкций по применению иммуномодуляторов для животных. Ключевые слова: иммуномодуляторы, побочные эффекты, анандин, гамавит, фоспренил, иммунофан, циклоферон

Современная ветеринарная медицина располагает большим количеством лекарственных средств для животных - в государственном реестре, включающем лекарственные препараты, зарегистрированные на территории РФ, их более двух тысяч. При этом к обороту на территории страны разрешено немало препаратов, обладающих иммунотропным действием. Преимущественно это вакцины, но несколько десятков из них иммуностимулирующие лекарственные средства $[1,2]$, основной целью применения которых является повышение иммунной реактивности животных $[3,4,5]$. Препараты данной группы используют при лечении заболеваний, сопровождающихся снижением иммунной защиты [6]. При этом следует учитывать наличие нежелательных эффектов в фармакодинамике любых препаратов $[7,8,9,10]$, в том числе иммуномодуляторов [11]. Снизить риск их развития при использовании препаратов - ответственная задача ветеринарного врача.

Как показало проведенное анкетирование врачей (194 человека), ветеринарные специалисты достаточно широко используют в своей работе иммуномодуляторы. При этом наибольшему количеству респондентов, практикующих в городе Омске и преимущественно работающих с мелкими домашними животными (животными-компаньонами), а также врачам из районов Омской области, производственная деятельность которых связана с сельскохозяйственными животными, наиболее известны такие препараты как Анандин 10\% раствор для инъекций, Гамавит, Иммунофан, Фоспренил и Циклоферон.

Мы проанализировали содержание инструкций по применению указанных препаратов на предмет наличия информации о побочном действии указанных иммуномодуляторов:

- Анандин 10\% раствор для инъекций. «При применении лекарственного препарата в соответствии с настоящей инструкцией побочных явлений и осложнений, как правило, не наблюдается. При повышенной индивидуальной чувствительности и появлении аллергических реакций использование препарата прекращают и при необходимости назначают животному антигистаминные препараты и средства симптоматической терапии».

Гамавит. «При применении препарата Гамавит в соответствии с настоящей инструкцией побочных явлений, нежелательных реакций и осложнений, как правило, не наблюдается. В случае появления аллергических реакций использование препарата прекращают и назначают антигистаминные средства или другое симптоматическое лечение».

- Иммунофан. «При применении препарата в соответствии с настоящей инструкцией побочных явлений и осложнений, как правило, не наблюдается». 
- Фоспренил. «При применении препарата Фоспренил в соответствии с настоящей инструкцией побочных явлений, нежелательных реакций и осложнений, как правило, не наблюдается. В случае появления аллергических реакций использование препарата прекращают и назначают антигистаминные средства или другое симптоматическое лечение».

- Циклоферон. Сведения о данном препарате в Государственном реестре лекарственных средств для ветеринарного применения отсутствуют, что, вероятно, свидетельствует об истечении срока действия его регистрационного удостоверения.

Как свидетельствуют приведенные примеры, разделы инструкций по применению указанных препаратов, описывающие нежелательные эффекты, малоинформативны. При этом содержание их практически идентично по всем указанным препаратам. Ознакомление с такой информацией не дает ориентиров для мониторирования безопасности используемых схем лечения и профилактики. Это затрудняет внедрение системы сбора сообщений о нежелательных реакциях при применении ветеринарных лекарственных средств, что является неотъемлемой частью мониторинга безопасности лекарственных препаратов для животных. При обобщении лишь спонтанных сообщений о возникновении побочных реакций на фоне фармакотерапии происходит потеря важной части клинической информации, необходимой для разработки более рациональных алгоритмов и схем применения лекарственных средств, что сопряжено с дополнительными финансовыми издержками при оказании лечебной помощи. Таким образом, сбор и систематизацию сведений о побочных нежелательных эффектах лекарственных препаратов (в том числе иммуномодуляторов) следует рассматривать как важный шаг по пути к совершенствованию инструкций по применению и обеспечению безопасности лекарственной терапии.

Литература. 1. Федоров Ю.Н., Клюкина В.И., Романенко М.Н., Богомолова О.А. Иммуномодуляторы и стратегия их применения // Ветеринария. 2015. № 7. С. 3-7. 2. Герунов Т.В., Герунова Л.К., Фёдоров Ю.Н. Классификация иммуномодуляторов, представленных в государственном реестре лекарственных средств для ветеринарного применения // Ветеринария. 2017. № 10. С. 3-10. 3. Гаврилова Н.А. Иммуномодуляторы в комплексной терапии при демодекозе собак // VetPharma. 2012. № 3. С. 60-63. 4. Федоров Ю.Н. Клиникоиммунологическая характеристика и иммунокоррекция иммунодефицитов животных // Ветеринария. 2013. № 2. С. 3-8. 5. Санин А., Наровлянский А., Пронин А. Иммуномодуляторы в сельском хозяйстве - дань моде или необходимость // Ветеринария сельскохозяйственных животных. 2014. № 11. С. 6-13. 6. Петрянкин Ф.П., Семенов В.Г., Иванов Н.Г. Иммуностимуляторы в практике ветеринарной медицины: монография. - Чебоксары: Новое время. - 2015. - 272 с. 7. Pirmohamed M., Breckenridge A.M., Kitteringham N.R., Park B.K. Adverse drug reactions. ВМJ. 1998; 316(7140): 1295-1298. 8. Дорожкин В.И., Герунова Л.К., Пьянова Л.Г., Лихолобов В.А., Герунов Т.В., Воронцова А.А., Шитиков В.В. Фармакокоррекция иммунотоксического действия пестицидов: монография. М.: НАУЧНАЯ БИБЛИОТЕКА, 2018. - 200 c. 9. Potlog Shchory M., Goldstein L.H., Arcavi L., Shihmanter R., Berkovitch M., Levy A. Increasing adverse drug reaction reporting-How can we do better? PLoS One. 2020; 15(8): е0235591. 10. Герунов Т.В., Дорожкин В.И., Тарасенко А.А., Герунова Л.К, Чигринский Е.А., Шантыз А.Х. Проблема резистентности членистоногих к инсектицидным и акарицидным препаратам // Российский журнал «Проблемы ветеринарной санитарии, гигиены и экологии». 2021. № 1(37). С. 91-98. 11. Иммунотерапия: руководство / Под ред. Р.М. Хаитова, Р.И. Атауллханова. - М.: ГЭОТАР-Медиа, 2012. - 672 с.

\section{TO THE QUESTION ABOUT THE INFORMATIVITY OF THE INSTRUCTIONS FOR} THE APPLICATION OF IMMUNOMODULATORS FOR VETERINARY PURPOSE

${ }^{1}$ Gerunov T.V., associate professor, Ph.D., ${ }^{1}$ Gerunova L.K., prof., D.Sc., ${ }^{1}$ Tarasenko A.A., ass., Ph.D., ${ }^{2}$ Chigrinski E.A., associate professor, Ph.D.

( ${ }^{1}$ FSBEI HE Omsk SAU, Russia, ${ }^{2}$ FSBEI HE Omsk SMU, Russia)

Annotation. The scope of application of veterinary immunomodulators is expanding. Moreover, in most cases, there is no information about the undesirable effects of drugs in this group. It is necessary 
to expand research in this direction and increase the information content of instructions for the use of immunomodulators for animals.

Key words: immunomodulators, side effects, anandin, gamavit, fosprenil, immunofan, cycloferon

УДК619:615.272.2:615.015.45

\section{РЕГИДРАТАЦИОННЫЕ СРЕДСТВА: МЕХАНИЗМ ДЕЙСТВИЯ И КЛИНИЧЕСКОЕ ЗНАЧЕНИЕ}

Герунова Л.К., проф., д.в.н., Шилков А.А., аспирант, Тарасенко А.А., асс., к.в.н. (ФГБОУ ВО Омский ГАУ, Россия)

Аннотация. Дегидратация организма отмечается при многих инфекционных и незаразных заболеваниях, интоксикациях и повышенном диурезе. Потеря 20-25\% жидкости опасна для организма. Эффективные электролитные растворы должны содержать достаточное количество натрия, калия, хлора с преобладанием сильных катионов. Глицин, ацетат и пропионат улучшают всасывание натрия.

Ключевыеслова: дегидратация, регидратационные средства, электролитные растворы

Дегидратация является одним из основных патогенетически значимых признаков заболеваний, сопровождающихся развитием диарейного синдрома. Она возникает вследствие потери значительного количества жидкости организмом и наблюдается при многих инфекционных и незаразных болезнях, различных интоксикациях, повышенном диурезе [13]. Потеря 20-25\% жидкости организмом вызывает выраженное нарушение кислотноосновного равновесия, электролитного баланса, препятствует передаче нервных импульсов, обусловливает гипоперфузию, ишемию жизненноважных органов. Взависимости от продолжительности и тяжести патологического процесса дегидратация может быть обратимой или необратимой. В связи с этим важная роль в комплексе лечебных мероприятий при диарейных заболеваниях молодняка сельскохозяйственных животных принадлежит регидратационным лекарственным средствам.

Препараты для регидратации подразделяются по способу введения в организм: регидратирующие средства для внутреннего применения (Регидрон®, Тригидросоль $\left.{ }^{\circledR}\right)$ и препараты для парентерального введения с регидратационными и детоксицирующими свойствами (растворы с различной комбинацией и содержанием солей натрия, калия, кальция, ацетатов и других компонентов)[4].

Регидратационные средства широко используют в ветеринарной медицине мелких домашних животных. Однако подходы к оценке степени тяжести состояния сельскохозяйственных животных, количественные и качественные критерии возможности оказания им быстрой и адекватной помощи при дегидратации требуют совершенствования.

При введении внутрь регидратационные средства эффективно устраняют обезвоживание организма, купируют метаболический ацидоз, снижают интоксикацию. При бактериальных и вирусных диареях необходимо применять изо- или гипоосмолярные солевые растворы, так как в основе патогенеза и пускового механизма диареи лежит нарушение всасывания воды из кишечника из-за гиперосмолярности химуса вследствие развития дисахаридазной недостаточности или накопления в просвете кишечника осмотическиактивных продуктов воспаления и нарушенного пищеварения[5].

Регидратационные препараты для парентерального применения корректируют кислотно-основное состояние, восполняют дефицит жидкости и электролитов, усиливают диурез, обладают антиагрегантными свойствами, уменьшают метаболический ацидоз, улучшают микроциркуляцию, оказывают дезинтоксикационное, противошоковое действие. Обезвоживание при острых кишечных инфекциях носит изотонический характер. Поэтому внутривенная регидратационная терапия должна осуществляться изотоническими полиионными кристаллоидными растворами. Задачей терапии является восстановление 
нарушенных параметров гомеостаза, в том числе водно-солевого и кислотно-основного, гемодинамики, микроциркуляциии гемостаза [6].

При разных патологических состояниях возможны три типа дегидратации: изоосмолярная, гипоосмолярная, гиперосмолярная.

Изоосмолярная дегидратация развивается при эквивалентной потере воды и электролитов, что наблюдается приполиурии, кишечном токсикозе, острой кровопотере, рвоте, диарее. При этом уменьшается в основном количество внеклеточной жидкости.

При гиперосмотической дегидратации преобладает потеря воды, повышается осмотическое давление крови и позакону изоосмолярности вода перемещается из клеток во внеклеточное пространство. В плазме увеличивается концентрация натрия.

Гипоосмолярная дегидратация характеризуется потерей электролитов, преобладающей над потерями воды, внутриклеточным отеком, тяжелой гиповолемией. При этом снижается артериальное давление, отмечается тахикардия. Жажда отсутствует, хроническая потеря электролитов из желудочно-кишечного тракта и гипоальдостеронизм усугубляют состояние [7].

Регидратационная терапия осуществляется в два этапа. На первом этапе происходит восстановление жидкостного и электролитного объема до стабилизации гемодинамических показателей, нормализации объема диуреза исокращения эпизодов диареи. Второй этап - это активная коррекция тех водно-электролитных нарушений, которые продолжают определяться у пациента. Обязателен контроль гидробаланса пациента с подсчетом всей потребляемой жидкости за сутки и объема диуреза. Параллельно с регидратационной терапией необходимо устранение причин, вызвавших обезвоживание.

В определенных клинических ситуациях применяют регидранты сложного состава. Одним из используемых компонентов является натрия фумарат-антигипоксант, способствующий адаптации клеток к недостатку кислорода. Его действие связано с участием в реакциях обратимого окисления и восстановления в цикле Кребса. В процессе этих реакций происходит синтез АТФ в количестве, необходимом для поддержания функций клеток организма при гипоксии[8,9].

Широко известен Мафусол, содержащий натрия фумарат. При метаболическом ацидозе он проявляет ощелачивающий эффект, его осмолярность составляет 400-410 мОсм/л, при гиповолемических состояниях данный раствор быстро восполняет объем циркулирующей крови, предотвращает дегидратацию тканей. Уменьшая вязкость крови и улучшая ее реологические свойства, повышает диурез, способствует активации дезинтоксикационных процессов; снижает концентрацию в крови промежуточных и конечных продуктов перекисного окисления липидов, то есть обладает антиоксидантными свойствами) [10].

Глюкоза, входящая в состав многих регидрантов, в первую очередь поступает во внутрисосудистое пространство с последующим перемещением в межклеточное пространство. В процессе гликолиза она превращается в пируват или лактат. Лактат частично участвует в реакциях цикла Кребса. Пируват полностью окисляется кислородом до углекислого газа и воды. Продукты окисления глюкозы выводятся легкими и почками.

Глюкоза, включенная в состав электролитных растворов, усиливает окислительновосстановительные процессы, служит источником энергии в организме. В норме глюкоза не элиминируется почками. При патологических состояниях с гипергликемией она появляется в моче. Гипергликемия, в зависимости от степени выраженности, может привести к осмотическому диурезу с последующим развитием гипертонической дегидратации гиперосмотическими нарушениями вплоть до гиперосмотической комы [10].

Эффективный электролитный раствор должен содержать достаточное количество натрия (оптимальная концентрация 90-130ммоль/л) для компенсации потерь жидкости и восстановления циркуляции крови. При этом в его составе необходимо наличие вспомогательных электролитов-калия (оптимальная концентрация 10-30 ммоль/л) и хлора (40-80 ммоль/л). Крайне важно преобладание сильных катионов (натрия, калия, кальция, магния) по сравнению с концентрацией сильных анионов (хлора, бикарбоната, D-лактата). 
Желательно присутствие нейтральных аминокислот/ жирных кислот - глицина, ацетата или пропионата, способствующих всасыванию натрия и жидкости в кишечнике. Для поддержания pH крови необходимо включение ощелачивающих агентов - ацетата или пропионата. Для восстановления уровня глюкозы в крови целесообразно использовать не молочные источники энергии. Оптимальная концентрация осмотически активных частиц в растворе составляет $600 \mathrm{MOcм} / л[11]$.

Дегидратация - угрожающий жизни симптомокомплекс, ему подвержены все виды животных, вособенности молодняк. Накапливающиеся токсичные метаболиты повышают нагрузку на сердце, увеличивают угрозу образования тромбов в крупных кровеносных сосудах. Изменение реологических свойств крови на фоне дегидратации сопровождается уменьшением объема крови (гиповолемией), дилатацией периферических кровеносных сосудов, возникновением ишемических явлений (местным малокровием).

Указанные изменения свидетельствуют о важной роли регидратационных средств в патогенетической терапии диарейных и других заболеваний животных, протекающих с выраженным обезвоживанием.

Литература.1. Бронская, Г.М. Тиазидные и тиазидоподобные диуретики, их место и роль в лечении артериальной гипертензии / БронскаяГ.М., Т.А.Коршак,Д.В. Казакевич // Проблемы здоровья и экологии. - 2009. - № 4(22). - С. 74-79. 2.Петрухин, М.А. Колибактериоз телят в верхнем Приамурье / М.А. Петрухин, Н.Н. Шульга // Дальневосточный аграрный вестник. 2010. - №2(14). - С. 12-16. 3. Герунова, Л.К. Профилактика микотоксикозов в животноводстве / Л.К. Герунова, В.И. Герунов, Д.В. Корнейчук // Вестник Омского государственного аграрного университета. - 2018. - №3 (31). - С. 36-43. 4.Молочный, В.П. Инфузионная терапия у детей : методические указания / В.П. Молочный. Н.Ю. Миропольская. - Хабаровск : МЗ ХК, 2018. - 16 с. 5. Новокшенов, А.А. Пероральная регидратационная терапия при кишечных инфекциях у детей-новые стандарты состава солевых растворов / А.А.Новокшенов,Н.В.Соколова // Детскиеинфекции. - 2010. - № 9(4). - С. 57-61. 6.Смирнова, О.О. Диабетический кетоацидоз. Подход к стабилизации «нестабильного» диабетика (часть 2) // Ветеринарный Петербург. - 2016. - № 2. - URL: https://www.spbvet.info/zhurnaly/22016/diabeticheskiy-ketoatsidoz-podkhod-k-stabilizatsii-nestabilnogo-diabet-2/(дата обращения 9.04.2021).7.Регидратационная терапия - основа лечения острых кишечных инфекций у детей / М.К.Бехтерева, И.В.Раздьяконова, С.Г.Семенова, Иванова В.В. // Медицинский совет. - 2017. - № 4. - С. 11-15.8.Эффективность препарата конфумин при инфузионно-трансфузионной терапии тяжелых гастродуоденальных кровотечений / В.Г. Вербицкий, А.К. Сухомлин, И.П. Ястребов [и др.] // Скорая медицинская помощь. - 2014. - № 2. - С. 69-75. 9.Вербицкая, В.Г. Возможности применения инфузионного антигипоксанта натрия фумаровокислого в терапии постгеморрагических нарушений гомеостаза при гастродуоденальных кровотечениях /В.Г. Вербицкий, А.К. Сухомлин, Слепнева Л.В. // Экстренная медицина. - 2015. - № 3(15). - С. $42-$ 50. 10.Сапожников, А.Ф. Применение регидратационной терапии при лечении телят, больных диспепсией / А.Ф. Сапожников,О.В.Суханова,М.Л.Лебедева // Известия ОГАУ . - 2004. - № 31. - С.140-141. 11. Эффективная регидратационная терапия / Молоко иферма. - 2018. № 1(44). - URL: http://magazine.milkua.info/indexrus.php?action=issue\&id=47 (дата обращения 10.04.2021).

\section{REHYDRATION AGENTS: MECHANISM OF ACTION AND CLINICAL SIGNIFICANCE}

Gerunova L.K., professor, Dr. of Vet. Sci., Shilkov A.A., post-graduate student, Tarasenko A.A., ass., Ph.DofVeterinary

(Omsk SAU, Russia)

Summary.Dehydration of the body is observed in many infectious and non-infectious diseases, intoxications and increased urine output. Loss of 20-25\% of fluid is dangerous for the body. Effective electrolyte solutions should contain a sufficient amount of sodium, potassium, chlorine with a predominance of strong cations. Glycine, acetateandpropionateimprovesodiumabsorption.

Key words:dehydration, rehydration agents, electrolyte solutions 


\title{
ТОКСИКОЛОГИЧЕСКАЯ БЕЗОПАСНОСТЬ НАНОСТРУКТУРНЫХ ВЕЩЕСТВ ПРИ ПАРЕНТЕРАЛЬНОМ СПОСОБЕ ВВЕДЕНИЯ ЖИВОТНЫМ
}

\author{
Гирфанов А.И., доцент, к.в.н., Бозова Г.Б., аспирант, Шах А.Д. студент,Ежова А.М., \\ профессор, д.биол.н. \\ (ФГБОУ ВО Казанская ГАВМ, Россия)
}

\begin{abstract}
Аннотация. Настоящее исследование посвящено изучению токсикологической безопасности применения комплексного препарата, состоящего из наноструктурного цеолита и аминокислоты. Материалом для исследования служили самки белых крыс породы Wistar $(\mathrm{n}=24)$ с живой массой 160-200 г. которые были разделены на 1 контрольную и 5 опытных групп. Установили, что комплексный препарат относится к веществам 5 класса токсичности, не классифицируется и соответственно безвреден для животных в указанных дозах.

Ключевые слова:наноструктурный цеолит, острая оральная токсичность.

Увеличение производства продуктов птицеводства тесно связанно с эффективностью использования кормов и профилактики болезней птиц. Для достижения этой цели необходима разработка технологий и адаптация методов ведения сельского хозяйства за счет использования природных и возобновляемых ресурсов, оказывающих положительное воздействие на окружающую среду, и обеспечивающие максимальный прирост живой массы птиц [1]. Особенно эффективным в сельском хозяйстве оказалось использование природных цеолитов.
\end{abstract}

Цеолит - природный, кристаллизованный минерал вулканической породы с высокой впитывающей и ионообменной способностью. Его добывают из земли. Цеолиты применяют длядетоксикации организмов животных и человека, улучшения пищевого статуса и иммунитета сельскохозяйственных животных, разделения различных биомолекул и клеток, создания биосенсоров и обнаружения биомаркеров различных заболеваний.

В последнее время повысился интерес к наноразмернымвеществам.На кафедре физиологии и патофизиологии Казанской государственной академии ветеринарной медицины имени Н.Э.Баумана разработан комплексный препарат, состоящий из наноструктурногоцеолита (размер наночастиц - 50-180 нм) с добавлением органического компонента, представленного аминокислотой - метионин, изучены потенциальные способы введения нановеществав организм лабораторных животных $[2,3]$. В связи с этим целью настоящего исследования является изучение острой оральной токсичности комплексного препарата на организм лабораторных животных.

Материалом для исследования послужили самки белых крыс породы Wistarc живой массой 160-200 г.

Исследование острой пероральной токсичности проводили согласно ГОСТ 32644-2014 «Методы испытания по воздействию химической продукции на организм человека. Острая пероральная токсичность - метод определения класса острой токсичности», в опытеиспользовали 24 крысы, которые были разделены на 1 контрольную и 5 опытных групп. За 12 часов перед началом эксперимента все животные были лишены корма, за 3 часа животных лишили свободного доступа к воде. Животные опытных групп получали комплексный препарат, состоящий из наноцеолита в различных дозах и метионина, который вводился внутрижелудочно в объеме 5 мл с помощью зонда размером 16G. Крысы 1 опытной группы получили наноцеолит в дозе 2000мг/кг, 2 группы - 2970 мг/кг, 3 группы - 4000 мг/кг и 5 группы - 5000 мг/кгживой массы,для крыс всех опытных групп доза метионина была неизменна 140 мг/кг живой массы. Крысам контрольной группы водили дистиллированную водув объёме 5 мл. После введения комплексного препарата животнымопытных групп и дистиллированной воды контрольным аналогам,крысам предоставили свободный доступ к корму и питьевой воде. 
По истечению 30 минут после введения комплексного препарата крысам, отклонения в их поведении по сравнению с крысами контрольной группы не отмечалось. Последующее наблюдение проводили спустя 4 часа после введения комплексного препарата, все подопытные животные вели себя активно, угнетенного состояния не отмечали, падеж отсутствовал. По истечению 24 часов после введения комплексного препарата, падежа среди животных не выявлено, животные активны, поедаемость корма на уровне животных контрольной группы. В дальнейшем, поведение животных, поедаемость корма, отсутствие симптомов поражения пищеварительной системы наблюдались в течение 13 суток. На 14 сутки после проведения эксперимента животные были подвергнуты патоморфологическому исследованию, которое включало в себя макроскопический осмотр органов пищеварительной системы, почек, селезенки, сердца, легких.Установили, что желудок - правильной формы, на слизистой оболочке видимых повреждений нет, гиперемия отсутствует, граница железистой и без железистой части выражена хорошо. Кишечник - слизистая без видимых повреждений, гиперемия отсутствует, количество содержимого умеренное. Почки эллипсовидной формы,поверхность гладкая, консистенция упругая, на разрезе корковая и мозговая зоны хорошо различимы. Селезенка, вишневого цвета, края острые, поверхности гладкие, консистенция упругая. Печень темно вишневого цвета, доли хорошо обозначены, поверхность гладкая, края острые, консистенция упругая. Сердце конусовидной формы, на разрезе консистенция миокарда упругая, кровоизлияния отсутствуют. Легкие - поверхность гладкая, края острые добавочная доля выражена хорошо.

По результатам патоморфологического исследования, установили отсутствие какихлибо выраженных морфологических изменений по сравнению с животными контрольной группы.

Учитывая полученные результаты, можно сказать, что комплексный препарат состоящий из наноструктурного цеолита и метионина, относится либо к веществам 5 класса токсичности, либо не классифицируется как токсичное вещество. В связи с этим комплексный препарат безвреден для животных в указанных выше дозах.

Литература.1. Кузнецов, А.Ф. Зоогигиеническая эффективность использования рыбной кормовой добавки при выращивании цыплят-бройлеров /Кузнецов А.Ф., Белорусская Е.М., Яковлев И.С.// Вопросы нормативно-правового регулирования в ветеринарии. 2018. № 3. С. 155-157. 2. Гирфанов, А.И. Морфологические изменения при парентеральном введении наноструктурного препарата /Гирфанов А.И., Шаламова Г.Г., Ежкова А.М. // Ученые записки Казанской государственной академии ветеринарной медицины им. Н.Э. Баумана. 2020. Т. 242. № 2. С. 47-50. 3. Гирфанов, А.И. Морфологические изменения при энтеральном и парэнтеральном введении наночастиц в организм животных /Гирфанов А.И., Ежкова А.М., Ежков В.О.// Ветеринарный врач. 2020. № 3. С. 11-15.

\section{TOXICOLOGICAL SAFETY OF NANOSTRUCTURED SUBSTANCES IN THE PARENTERAL METHOD OF ADMINISTRATION TO ANIMALS}

Girfanov A. I., Associate Professor, Candidate of Veterinary Sciences., Bozova G. B., postgraduate student, Shah,A.D. student, Ezhova A.M., Professor, Doctor of Biological Sciences.

(FSBEI HE Kazan GAVM, Russia)

Summary.This study is devoted to the study of the toxicological safety of the use of a complex drug consisting of a nanostructured zeolite and an amino acid. The material for the study was female white Wistar rats $(n=24)$ with a live weight of 160-200 g. They were divided into 1 control and 5 experimental groups. It was established that the complex preparation belongs to substances of the 5 th class of toxicity, is not classified and, accordingly, is harmless to animals in the specified doses.

Key words: nanostructured zeolite, acute oral toxicity. 


\section{ПРАКТИКА ВЕДЕНИЯ ПРЕДМЕТА «ЭКОЛОГИЯ» СТУДЕНТАМ ВЫСШЕЙ ШКОЛЫ (НА ПРИМЕРЕ РОССИЙСКОГО ГОСУДАРСТВЕННОГО АГРАРНОГО УНИВЕРСИТЕТА ИМЕНИ К.А. ТИМИРЯЗЕВА)}

${ }^{1}$ Глебов В.В., доцент, кандидат биологических наук, ${ }^{2}$ Соловьева Е.А., доцент, кандидат ветеринарных наук

('ФГБОУ ВО РГАУ - МСХА имени К.А. Тимирязева, Россия)

$\left({ }^{2}\right.$ ФБОУ ВО ЕГУ имени И. А. Бунина, Россия)

Аннотация. В работе представлены методические подходы, которые практикуются по курсу преподавание «Экология» для инженерных специальностей Российского государственного аграрного университета - МСХА имени К.А. Тимирязева. Даны результаты анализа статистики успешности освоение студентов данного предмета.

Ключевые слова: методические подходы, обучение, студенты высшей школы, экология

Введение. Важным аспектом устойчивого развития общества и воспитания человека в парадигме естественно-научного познания является обязательное экологическое образование и воспитание человека ().

В этой связи введенная в Федеральный государственный образовательный стандарт дисциплина «Экология» стала важной лептой в формирование экоцентрического мышления подрастающего поколения.

Курс лекций по дисциплине «Экология» читается студентам 3 курса инженерной специальности кафедрой экологической безопасности и природопользовании Российского государственного аграрного университета - МСХА имени К.А. Тимирязева.

Учебно-методические разработки по дисциплине «Экология» состоят из достаточно объемного материала, имеющий специфику и нацеленный на студентов строительного дела. Подача лекции сопровождается богатым иллюстрированным материалом, по которого введены различные ситуационные задачи, диаграммы, схемы, графики и таблицы.

На первом ознакомительном занятии студентам излагается структура курса, где подробно обсуждаются различные нюансы представленного курса По просьбе преподавателя курса, старосты групп предоставляют в табличной форме свои данные (мобильный телефон и электронной почты) для обратной связи или отправки индивидуальных заданий. Такая обратная связь также дает возможность вести консультации по тематике лекций.

Помимо этого на сайте, в созданном общем почтовом ящике для группы студентов, изучающие курс, старосты рассылали задания студентам своей группы для самостоятельной работы, либо размещения выполненных заданий. Такой вид связи давал возможность интенсифицировать работу в диаде «преподаватель-студент» давало дополнительные возможности гармонизации учебного процесса, в котором можно с успехом использовать очное и дистанционное обучение. Такой вид связи, кстати, очень пригодился, когда студенты, вследствие ковидной пандемии были массово переведены на дистантное образование.

Такой подход в преподавание курса экологии положительно отразился на освоении предмета «Экология» и итоговых оценках студентов.

Согласно программе ФГОС, дисциплина «Экология» включала в себя следующие разделы:

1. Социум и окружающая среда

2. Оценка загрязнение окружающей среды: виды и формы загрязнения.

3. Воздействие комплекса токсикантов окружающей среды на состояние здоровье населения.

4. Различные методические подходы в оценке экологического мониторинга и контроля окружающей среды

5. Методы защиты окружающей среды.

6. Рациональное использование природных ресурсов. 
7. Экологические и социальные проблемы отходов

8. Основы экологической экономики

9. Международное сотрудничество в области охраны окружающей среды

10. Экологическая ситуация на территории Москвы, Московской области и России

Каждая из представленных учебных разделов курса «Экология» включала большой объем информации и блок вопросов по самопроверке знаний студентов, которые создавали мотивацию студентов для изучения и усвоению новых комплексных знаний, так как не погружение в комплексную науку и проработки учебного материала по экологии, ответить на контрольные вопросы тестирования в интерактивном режиме и условиях ограничения времени не возможно сдать.

Анализ успеваемости студентов по курсу экология показала, что большая часть исследуемой выборки (86\%) студентов имели высокие оценки («хорошо» и «отлично») и только 14\% -«удовлетворительно».

Изучая половые различия по успеваемости исследуемой выборки студентов, было выявлено, что успеваемость девушек была выше, чем у юношей.

Заключение. Подводя итоги выше сказанному можно сказать, что методические подходы в преподавании курса «Экология» студентам Российского государственного аграрного университета - МСХА имени К.А. Тимирязева с применением современных интерактивных средств обработки и передачи информации является важной, особенно в свете увеличения доли дистантной подачи информации из-за вирусной пандемии. Она имеет большой практический интерес при организации учебного процесса и совершенно обоснованно может быть повсеместно рекомендовано к применению.

Литература. 1. Выявление состава компетенций выпускников вузов как необходимый этап проектирования ГОС ВПО нового поколения. Методическое пособие/Авт. -сост.: В.Г.Казанович, Л.В.Павлова. - М.: Исследовательский центр проблем качества подготовки специалистов, 2006. - 177c. 2. ДаначеваМ.Н., ГлебовВ.В. Various approaches to the competitiveness of universities in Europe // Всборнике: Образование: молодежь, конкурентоспособность. Сборник докладов Международной научно-практической конференции, приуроченной к 80- летнему юбилею академика Российской академии образования, доктора философских наук, профессора Г.Ф. Шафранова-Куцева. 2018. С. 153155. 3. Каба Ф., Глебов В.В. Адаптивно-ландшафтное обустройство территорий как важный аспект в экологии сельского хозяйства // В сборнике: Современные подходы и методы в защите растений Материалы Всероссийской научно-практической конференции с международным участием. 2018. С. 206-208. 4. МартышовА.В., ГлебовВ.В. The specifics of internationalization of higher education in Russia // Всборнике: Образование: молодежь, конкурентоспособность. Сборник докладов Международной научно-практической конференции, приуроченной к 80- летнему юбилею академика Российской академии образования, доктора философских наук, профессора Г.Ф. Шафранова-Куцева. 2018. С. $155-$ 158. 5. Савватеева О.А., Спиридонова А.Б., Лебедева Е.Г. Современное экологическое образование: российский и международный опыт // Современные проблемы науки и образования. - 2019. - № 5.URL: http://science-education.ru/ru/article/view7icH29188 (дата обращения: 17.04.2021). 6. Glebov V.V. Monitoring of the quality of higher education in the university competitiveness //Всборнике: Образование: молодежь, конкурентоспособность. Сборник докладов Международной научно-практической конференции, приуроченной к 80 летнему юбилею академика Российской академии образования, доктора философских наук, профессора Г.Ф. Шафранова-Куцева. 2018. С. 134-140.

\section{THE PRACTICE OF TEACHING THE SUBJECT "ECOLOGY" TO STUDENTS OF HIGHER EDUCATION (ON THE EXAMPLE OF THE RUSSIAN STATE AGRARIAN UNIVERSITY NAMED AFTER K. A. TIMIRYAZEV) \\ Glebov V. V., associate Professor, Candidate of Biological Sciences ${ }^{2}$ Solovyova E. A., associate Professor, Candidate of Veterinary Sciences \\ ('FSBEI HE RGAU - MSHA named after K. A. Timiryazev, Russia)}


$\left({ }^{2}\right.$ FSBEI HE Bunin State University, Russia)

Summary.The paper presents methodological approaches that are practiced in the course of teaching "Ecology" for engineering specialties of the Russian State Agrarian University-the Timiryazev Moscow Agricultural Academy. The results of the analysis of the statistics of the success of students' mastering this subject are given.

Key words: methodological approaches, teaching, higher school students, ecology

\title{
УДК 619:619.2
}

\section{ОЦЕНКА ЭФФЕКТИВНОСТИ ЛЕЧЕНИЯ КОРОВ С АТОНИЕЙ ПРЕДЖЕЛУДКОВ}

Глухова Э.Р., доц., к.б.н., Кичеева Т.Г., доц., к.в.н., Лебедева М.Б., доц., к.в.н., Пануев М.С., доц., к.в.н.

(ФГБОУ ВО ИГСХА, Россия)

\begin{abstract}
Аннотация. У крупного рогатого скота из функциональных расстройств желудочнокишечного тракта, острая атония преджелудков составляет более половины всех заболеваний. Однако, несмотря на большое количество предлагаемых руминаторных средств, возникает потребность в современных, безвредных и доступных средствах, для снижения себестоимости сельскохозяйственной продукции за счет уменьшения затрат на лечение животных [1]. Проведен поиск эффективных схем лечения коров с атонией преджелудков, процесс анализ результатов клинических и тамары лабораторных исследований,оценка затрат на помощью диагностику и третьей лечение животных.
\end{abstract}

Ключевые слова. Крупный рогатый скот, атония преджелудков, Тимпанол, Настойка чемерицы.

Исследования проводились на28 коровах голштино-фризской породы. Возраст животных, подвергшихся лечению составил от 2 до 5 лет. Все животные на момент исследования находились в одинаковых условиях кормления и поения, имели среднюю упитанность.

Диагноз ставился на основании общего клинического осмотра животных, пальпации, аускультации и перкуссии рубца, а также исследовании содержимого рубца и гематологического анализа животных.

После постановки диагноза,животных разделили на 2 группы по 14 голов в каждой.Предложено 2 схемы лечения, а также голодная или полуголодная диеты, массаж области рубца и прогулки. Лечение животных первой группы проводили по схеме: Тимпанол, Детокс, Активитон. Тимпанол давали внутрь по 100 мл в первые сутки, дважды. Лечение животных второй группы проводили по схеме: Настойка чемерицы, Детокс, Активитон.Настойку чемерицы давали внутрь по 12 мл, предварительно разводя в 500 мл воды, трижды в день с интервалом в 3 часа. Обеим группам Детокс вводили подкожно по 50 мл 1 раз в день в течении трех дней. Активитон вводили внутримышечно по 30 мл 1 раз в день в течении 5 дней.В ходе лечения проводился ежедневный осмотр, массаж, диета и прогулки животных.

В результате проведенного лечения было обнаружено, что пищевая возбудимость, жвачка и отрыжка в первой опытной группе появляется на 2-ой день, сокращения рубца восстанавливаются на 3-й. Во второй опытной группе пищевая возбудимость и отрыжка появлялись в среднем на 3-4 день, а сокращения рубца восстанавливались на 4-й день.Однако, во второй опытной группе, были отмечены осложнения. При использовании Настойкичемерицы у некоторых животных наступило стойкое возбуждение рвотного центра.

При морфологическом и биохимическом исследовании крови, до лечения, было выявлено уменьшение количества гемоглобина на 25\%, увеличение лейкоцитов на 6,5\%, 
количество общего кальция и неорганического фосфора находилось в пределах нижней границы нормы, количество общего белка уменьшено на 17\% и обнаружены следы каротина.

Проведенное лечениепоказало, что количество гемоглобина, лейкоцитов, количество общего кальция и неорганического фосфора, а также количество общего белка в первой группе практически полностью соответствовали норме. А во второй группе, количество гемоглобина оставалось сниженным на $11 \%$, количество общего белка - на $4 \%$. Количество общего кальция и неорганического фосфора, а также количество лейкоцитов также соответствовали физиологической норме.

Полученные данные свидетельствуют об эффективности обеих схем лечения, однако в первой схеме улучшения в состоянии животных наступали раньше (2-3 день), чем во второй (3-4 день), а также не было выявлено осложнений. Кроме того, были отмечены показатели крови, которые свидетельствовали о неполном восстановлении обменных процессов у животных, получающих лечение с применением Настойки Чемерицы.

При использовании Тимпанола происходит разрушение образовавшихся в кормовых массах пузырьков газа и быстрое удаление их во внешнюю среду. Препарат также усиливает секрецию и перистальтику пищеварительного тракта, расслабляет тонус сфинктеров преджелудков, что обеспечивает быстрое продвижение содержимого в кишечнике. В результате быстрее восстанавливаются пищевая возбудимость, жвачка, отрыжка, а также количество рубцовых сокращений.

При применении Настойки чемерицы, ее алкалоиды раздражают слизистую оболочку и рефлекторно усиливают моторику и секрецию рубца. Такое действие препарата может вызывать стойкое возбуждение рвотного центра.Таким образом, Тимпанол обладает более мягким действием на преджелудки и не влечет за собой побочного действия, в отличие от Настойки чемерицы.

При сравнении экономической эффективности двух способов лечения, суммарный индекс эффективности ветеринарных мероприятий из расчёта на одну голову составлял в первой группе 1, во второй - 1,1. Следовательно, лечение коровс применением Тимпанолабыло эффективнее, чем с Настойкой чемерицы и разница затрат на лечение между группами составила 141 рубль.

Литература. 1. Новое в лечении и профилактике болезней преджелудков жвачных животных/ Методические рекомендации/А. Ч. Ли, А. П. Чернявский, П. Н. Безбородов,- Белгород: Издво БелГСХА, 2007.-31с.2. Prasad J. A study on reticulo-ruminal movements and rumen pH in clinical indigestions in cattle and buffeloes// Indian Veter. J. 2019,-Vol. 56.-№ 6,- P. 474477.

\section{EVALUATION OF THE EFFECTIVENESS OF TREATMENT OF COWS WITH ATONY OF THE PRE-VENTRICLES}

Glukhova E. R., Associate Professor, Candidate of Biological Sciences, Kicheeva T. G., Associate Professor, Candidate of Biological Sciences, Lebedeva M. B., Associate Professor, Candidate of Biological Sciences, Panuev M. S., Associate Professor, Candidate of Biological Sciences (IGSHA, Russia

Summary. In cattle from functional disorders of the gastrointestinal tract, acute atony of the preventricles accounts for more than half of all diseases. However, despite the large number of proposed ruminatory agents, there is a need for modern, harmless and affordable means to reduce the cost of agricultural products by reducing the cost of animal treatment [1]. The search for effective treatment regimens for cows with atony of the pre-ventricles, the process analysis of the results of clinical and tamara.

Keywords. Cattle, atony of the pre-ventricles, Tympanol, Tincture of hellebore. 


\title{
КЛИНИЧЕСКИЙ СЛУЧАЙ ЛЕЧЕНИЯАЛЛОПЕЦИИ Х ХИМИЧЕСКОЙ КАСТРАЦИЕЙ
}

Горбунова А.С. студент

Научный руководитель Понамарёв В.С., асс.

(ФГБОУ ВО СПбГУВМ, Россия)

\begin{abstract}
Аннотация. Аллопеция - заболевание невоспалительной природы, которое характеризуется симметричным выпадением шерсти. Этиология и патогенез аллопеции $\mathrm{X}$ до конца не выявлены, при этом заболевание поддается лечению.
\end{abstract}

Ключевые слова: Аллопеция X, медикаментозная кастрация, дерматология.

Аллопеция $\mathrm{X}$ - заболевание невоспалительной природы, чаще всего встречающееся у собак. Характеризуется симметричным облысением, чаще всего в области тела и конечностей. Причины появления болезни не установлены. Считается, что аллопеция обусловлена генетическим фактором, так как проявляется у определенных пород (щпиц, маламут,чау-чау, миниатюрные пудели).[1] Ген, отвечающий за развитие болезни, не выявлен.

Так кобель померанского шпица, не кастрированный, возраст- 1,5 года, поступил с жалобой владельца «выпадает шерсть, не растет новая». Был проведен тщательный сбор анамнеза, осмотр, изучены результаты клинического[2] и биохимического[3] анализов крови, сделана трихоскопия. При трихоскопии косвенно можно установить аллопецию, если животное клинически здорово, а при анализе не обнаружен демодекоз или дерматофитоз. При данном исследовании можно обнаружить тотальную телогенезацию волосяных луковиц.

Аллопеция X больше проблема «косметическая». Владелец желает вернуть былую «пушистость» своему питомцу. Есть несколько способов решения данной проблемы. В данном случае была выбрана медикаментозная кастрация.

Деслорелин (Suprelorin ${ }^{\circledR} 4,7 \mathrm{mg}$, Virbac)используется для обратимой медикаментозной кастрации и лечения гормонозависимых болезней. Данный имплант вживляют в область холки. В течение 3 месяцев происходило обрастание шерсти. Спустя 6 месяцев после первого вживления, поставили второй имплант. У собаки полностью отросла шерсть. В течение 1,5 лет покров оставался неизменным.

При повторении лечения шерсть может отрастать с каждым разом все хуже. Следует применять и другие способы лечения(местная терапия, трилостан, мелатонин, деслорин, гормон роста, финастерид). При аллопеции Х очень все индивидуально и следует подбирать. Так, например, самки не реагируют ни на хирургическую кастрацию, ни на медикаментозную, могут развиваться фолликулярные кисты. [1]

В данном случае медикаментозная кастрация препаратом Деслорелин (Suprelorin ${ }^{\circledR}$ 4,7 mg, Virbac) помогла пациенту отрастить новый шерстный покров. Дополнительны были назначены препараты для улучшения состояния кожного покрова ( содержащие Омега $3,6,9$ ). Литература.1. https://vetpharma.org/articles/66/5365/(дата обращения 09.04.2020), 2. Понамарев, В. С. Влияние препарата с гепатопротекторной активностью "Гепатон" на показатели периферической крови лабораторных животных / В. С. Понамарев // Международный вестник ветеринарии. - 2020. - № 2. - C. 116-121. - DOI 10.17238/issn20722419.2020.2.116., 3. Биохимические показатели крови экспериментальных животных при лечении препаратом "Гепатон" и препаратами сравнения токсического поражения печени, вызванного дихлорэтаном / В. С. Понамарев, Н. Л. Андреева, Е. С. Королева, А. В. Кострова // Биотехнология: взгляд в будущее, Ставрополь, 16 апреля 2020 года. - Ставрополь: Ставропольский государственный медицинский университет, 2020. - С. 19-21.

\section{CHEMICAL CASTRATION TREATMENT FOR ALOPECIA $X$}

Gorbunova A.S. student

(FSBEI HE St.Peterburg SUVM, Russia) 
Summary.Alopecia is a non-inflammatory disease. Characterized by symmetrical hair loss. The etiology and pathogenesis of alopecia X are not fully identified. In this case, the disease is treatable. Key words: Alopecia X, medical castration, dermatology.

\section{УДК 615:628}

\section{ИЗУЧЕНИЕ ЭФФЕКТИВНОСТИ ТИЛМИКОЗИНА ПРИ ЭНТЕРИТАХ И ПЕРИТОНИТАХ У ПТИЦ}

Готовский Д. Г., проф., д.в.н., Петров В. В., доц., к.в.н., Кондакова В. В., асс., Романова Е. В., acc., м.в.н.

(УО ВГАВМ, Республика Беларусь)

Аннотация. Установлен высокий терапевтический эффект при использовании тилмикозина при энтеритах и перитонитах у цыплят и индюшат. В частности отмечено снижение заболеваемости, а в дальнейшем полное прекращение падежа цыплят при применении тилмикозина. Следовательно, препараты на основе тилмикозина могут быть рекомендованы в комплексном лечении птиц при болезнях сопровождающихся поражением желудочнокишечного тракта и перитонитами в качестве средства этиотропной терапии.

Ключевые слова: антибиотики, тилмикозин, энтерит, перитонит, птица.

В комплексном лечении животных при внутренних болезнях у в условиях промышленного животноводства большое значение имеет борьба с условно-патогенной и патогенной микрофлорой с преимущественным использованием химиотерапевтических средств (прежде всего, антибиотики и сульфаниламиды). Применение, которых позволяет существенно снизить заболеваемость, тяжесть течения и летальность, особенно в промышленном птицеводстве, где практикуется сосредоточение значительных поголовий [15]. Следовательно, лечение и профилактика болезней в условиях промышленного животноводства, а в частности птицеводства предусматривает широкое применение антимикробных средств $[2,3,4,5]$.

Следует отметить, что длительное применение одних и тех антимикробных средств в отдельном хозяйстве приводит к снижению эффективности химиотерапии при различных инфекционных и внутренних болезнях, что значительно увеличивает наносимый ими экономический ущерб. У резистентных к антимикробным средствам форм микроорганизмов сохраняется способность к размножению даже при поддержании терапевтической концентрации препаратов. При этом бактерицидный эффект достигается за счет повышения дозы лекарственных средств, являющихся токсичными для макроорганизма [6]. Одним из направлений повышения эффективности химиотерапии является создание новых антимикробных препаратов широкого антибактериального спектра, к которым не имеется резистентности со стороны патогенной и условно-патогенной микрофлоры. Таким образом, арсенал практического ветеринарного врача должен содержать антимикробные препараты из разных групп, так как это позволит выбрать препарат в зависимости от чувствительности возбудителя, локализации патологического процесса и др. $[4,5,6]$.

В последнее время, в условиях животноводческих предприятий Республики Беларусь в ветеринарной практике в качестве эффективных средств этиотропной терапии при внутренних патологиях, осложненных патогенной и условно-патогенной микрофлорой в стали применять полусинтетические антибиотики из группы макролидов, в частности тилмикозин. Препарат активен преимущественно в отношении грамположительных и некоторых грамотрицательных микроорганизмов (Actinobacillus pleuropneumoniae, Pasteurella multocida, Staphylococcus spp., Streptococcus spp., Ornithobacterium rhinotracheale, Clostridium spp., Corynebacterium spp., Brachyspira spp., Bordetella spp., Mannheimia haemolitica, Chlamydia spp., Spirocheta spp.), а также Mycoplasma spp. Механизм 
бактериостатического действия тилмикозина заключается в подавлении синтеза белка в бактериальной клетке на рибосомальном уровне. После перорального введения тилмикозин хорошо и быстро всасывается в желудочно-кишечном тракте и проникает в большинство органов и тканей организма, достигая максимального уровня в сыворотке крови через 2-3 часа. Терапевтические концентрации антибиотика сохраняются в организме в течение 24 часов. Выводится препарат из организма в основном в неизмененном виде, главным образом с фекалиями и частично почками.

Исходя из вышеизложенного, основная цель наших исследований - определение терапевтической эффективности двух ветеринарных препаратов на основе тилмикозина «Тилмикофорс-О» и «Тилфлотрим», производимых в Республике Беларусь в комплексной схеме лечения при энтеритах и перитонитах у птиц.

Исследования проводились в условиях двух птицефабрик Витебского района Витебской области на фоне принятых в хозяйстве технологий, условий кормления и содержания, а также схем ветеринарных мероприятий. В качестве препарата сравнения использовали ветеринарный препарат «Тилмикон» производства ООО «Рубикон» (Республика Беларусь), который в момент проведения производственных испытаний был задействован для лечебных мероприятий. Для определения комплексной лечебной эффективности «Тилмикофорс-О» выпаивали цыплятам с питьевой водой три дня подряд из расчета 300 мл на 1000 литров воды. Поголовье птиц во время эксперимента составило 93450 голов ремонтного молодняка кур 70-тидневного возраста. За птицей во время применения препаратов вели ежедневное клиническое наблюдение, учитывали степень проявления энтеритов. В частности у цыплят наблюдали угнетение, малую подвижность, отказ от корма, общую слабость и диарею.В результате проведенных исследований установили, что заболеваемость энтеритом цыплят в подопытных птичниках составляла 0,9-1,5\%. Цыплятам из контрольного птичника в качестве этиотропного средства применяли ветеринарный препарат «Тилмикон», в дозе 300 мл на 1000 литров воды три дня подряд. Курс лечения проводили в течение 3 дней подряд. Ежесуточно приготавливали раствор препарата. При применении ветеринарного препарата «Тилмикофорс-О» отмечалась положительная динамика выздоровления у большинства цыплят. Симптомы болезни исчезали уже через два дня.

При использовании ветеринарного препарата «Тилмикон» так же отмечалось положительная динамика. Уже через двое суток у цыплят отмечалось уменьшение клинического проявления симптомов энтерита, так на третьи-четвертые сутки у всех птиц с вышеуказанными клиническими признаками симптомы болезни исчезали. В частности наблюдали исчезновение основных клинических признаков энтерита - угнетение, малую подвижность, отказ от корма, общую слабость и диарею. Средняя длительность заболевания цыплят в опытной группе составила два дня, а в контрольной три с половиной дня.

Падеж в опытном птичнике перед использованием ветеринарного препарата «Тилмикофорс-О» составил пять голов ремонтного молодняка кур, затем на первые, вторые и третьи сутки выпаивания препарата пал всего один цыпленок. Также установлено, что при применении ветеринарных препаратов «Тилмикофорс-О» у опытных и «Тилмикон» у цыплят контрольной группы видимых побочных явлений не наблюдалось.

На втором этапе исследований изучали эффективность еще одного препарата на основе тилмикозина, ветеринарного препарата «Тилфлотрим» при перитонитах у индюшат в условиях другого птицеводческого предприятия специализирующегося на выращивании индюшат-бройлеров. Для определения комплексной лечебной эффективности препарат выпаивали цыплятам с питьевой водой пять дней подряд из расчета 2 л на 1000 литров воды. Поголовье птиц во время эксперимента составило 16000 индюшат двухдневного возраста.

За птицей во время применения ветеринарного препарата вели ежедневное клиническое наблюдение, учитывали степень проявления перитонита. В частности у индюшат наблюдали угнетение, малую подвижность, отказ от корма, общую слабость и диарею. В результате проведенных исследований установили, что заболеваемость 
перитонитом цыплят в подопытных птичниках составляла 0,4-0,9\%. Индюшатам из контрольного птичника в качестве этиотропного средства применяли ветеринарный препарат «Тилмикон» по вышеописанной схеме. Курс лечения проводили в течение пяти дней подряд. Ежесуточно приготавливали раствор препарата. При применении ветеринарного препарата «Тилфлотрим» отмечалась положительная динамика выздоровления у большинства индюшат. Симптомы болезни исчезали уже на второй-третий день.

При использовании ветеринарного препарата «Тилмикон» так же отмечалось положительная динамика. Уже через двое суток у индюшат отмечалось уменьшение клинического проявления симптомов перитонита, так на третьи-четвертые сутки у всех птиц с вышеуказанными клиническими признаками симптомы болезни исчезали. В частности наблюдали исчезновение основных клинических признаков перитонита - угнетение, малую подвижность, отказ от корма, общую слабость и диарею. Средняя длительность заболевания цыплят в опытной группе составила два с половиной дня, а в контрольной - три с половиной дня.

Падеж в опытном птичнике перед использованием ветеринарного препарата «Тилфлотрим» составил 380 индюшат, затем на первые, вторые и третьи сутки выпаивания препарата соответственно 143, 27 и 6 голов. На четвертый-пятый дни применения тилфлотрима падежа индюшат не отмечено. Также установлено, что при применении ветеринарных препаратов «Тилфлотрим» у опытных и «Тилмикон» у индюшат контрольной группы видимых побочных явлений не наблюдалось.

Таким образом, исходя из полученных данных, следует, что при использовании «Тилмикофорс-О», установлен высокий терапевтический эффект в комплексной терапии цыплят с признаками энтерита. Так, на первые-вторые сутки после применения препарат способствовал снижению заболеваемости и падежа цыплят, а на третьи сутки полному прекращению падежа ремонтного молодняка кур. Схожие данные получены при применении «Тилфлотрим», в частности при использовании антибиотика наблюдали высокий терапевтический эффект в комплексной терапии цыплят с признаками перитонита. Так, на вторые-третьи сутки после введения препарат способствовал снижению заболеваемости птиц в пять, три и 23 раза соответственно, а на четвертые-шестые сутки полному прекращению падежа индюшат.

Следовательно, изученные нами препараты на основе тилмикозина могут быть рекомендованы в комплексном лечении птиц при болезнях сопровождающихся поражением желудочно-кишечного тракта и перитонитами в качестве средства этиотропной терапии.

Литература. 1. Андросик, Н. Н. Справочник по болезням молодняка жвачных / Н. Н. Андросик, М. В. Якубовский, Е. А. Панковец. - Минск: Ураджай, 1995. - 256 с. 2. Болезни птиц: учебное пособие / Б. Ф. Бессарабов [и др.]. - СПб.: Издательство «Лань», 2007. - 448 с. 3. Болезни сельскохозяйственных птиц : справочник / сост. А. А. Лимаренко [и др.] - СанктПетербург : Лань, 2005. - 448 с. 4. Болезни домашних и сельскохозяйственных птиц : в 3-х ч. / под ред. Б. У. Кэлнека [и др.] ; пер. с англ. И. Григорьева. - 10-е изд. - Москва : Аквариум Принт, 2011. - Ч. 1. - 412 с. 5. Великанов, В. И. Лекартсвенные средства, применяемые в ветериарной медицине 6 учебное пособие для ВУЗов / В. И. великанов, Е. А. Елизарова. Санкт-Петербург : Лань, 2020. - 176 с. 6. Пламб Дональд К. Фармакологические препараты в ветеринарной медицине/ Пер. с англ. / В двух томах. Том 2. (О-Я) - М.: Издательство Аквариум, 2019. - 1040 с.

\section{STUDY OF THE EFFICIENCY OF TILMICOSIN IN ENTERITIS AND PERITONITIS IN BIRDS}

Gotovskiy D. G., professor, D.Sc., Petrov V. V., associate professor, Ph.D., Kondakova. V.V., ass., Romanova E.V., ass. M.Sc.

Vitebsk State Academy of Veterinary Medicine, Vitebsk, Republic of Belarus

Summary. A high therapeutic effect was established when using Tilmicosin for enteritis and peritonitis in chickens and turkey poults. In particular, a decrease in the incidence rate was noted, and in the future, a complete cessation of the mortality of chickens when using Tilmicosin. Therefore, 
preparations based on Tilmicosin can be recommended in the complex treatment of birds for diseases accompanied by lesions of the gastrointestinal tract and peritonitis as a means of etiotropic therapy. Key words: antibiotics, tilmicosin, enteritis, peritonitis, poultry.

УДК: 636.5

\title{
МОРФОЛОГИЧЕСКИЕ И БИОХИМИЧЕСКИЕ ПОКАЗАТЕЛИ КРОВИ У ГУСЕЙ, ПОТРЕБЛЯВШИХ ВИТАММИН
}

\author{
Гришин Е.А., асп. \\ (ФГБОУ ВО «Курганская ГСХА имени Т.С.Мальцева», Курган, Россия)
}

Аннотация. Использование добавки Витаммин для гусей способствовало более интенсивному обмену веществ, в сравнении со сверстниками из контроля. В опытных группах у гусят отмечено повышение уровня тканевого дыхания, что характерно при увеличении обменных процессов и как следствие, повышении продуктивности.

Ключевые слова:витамины, гуси, гематологические показатели

«Для обеспечения стабильного роста отрасли птицеводства необходимо увеличение продуктивности птицы, ее сохранности и качества получаемой продукции. Продуктивность птицы зависит от многих факторов - генетических, селекционной работы, условий кормления и содержания. Необходимо поддержание продуктивности птицы, определяемой ее генетическим потенциалом» [1].«Условия кормления и содержания накладывают отпечаток на состав крови и поэтому ее количественные и качественные показатели могут изменяться. В связи с этим, важное значение имеет изучение гематологических показателей, по которым судят о степени интенсивности обмена веществ, обуславливающей физиологическое состояние и продуктивность птицы» [2 -12]. «Основными биологически активными веществами, необходимыми для нормальной жизнедеятельности организма птицы являются витамины. Недостаток витаминов наносит существенный ущерб, приводя к нарушению биохимических процессов и морфологическим изменениям в органах и тканях птицы» [13].

Такими образом,использование кормой добавки Витаммин для молодняка гусей является актуальным и имеет практическое значение. Кормовая добавка ВитАмМин имеет сбалансированный состав витаминов, аминокислот и эссенциальных микроэлементов.

Целью работы являлось изучение морфологических и биохимических показателей крови у молодняка гусей при использовании в рационах кормовой добавки Витаммин.

Опыт был проведен на базе КФХ «Попов С.Н.» Шумихинского района, Курганской области. Для научно-хозяйственного опыта формировали группы птицы методом сбалансированных групп. Исследования проведены на 1500 гусятах, разделенных в 3 группы. Срок выращивания 60 суток. Молодняк гусей контрольной группы кормили основным рационом (ОР); 1 опытной дополнительно ввели добавку Витаммин в дозе 0,2 мл/л воды; а 2 опытной 0,5 мл/л воды. Условия содержания, плотность посадки, фронт кормления и поения, параметры микроклимата во всех группах были равные [14]. Полученный в опытах цифровой материал подвергли биометрической обработке с использованием программы MicrosoftExcel [15]. Разницу считали достоверной при $\mathrm{P} \leq 0,05$.

Для изучения морфологических и биохимических показателей крови у подопытного молодняка гусей, утром за час до кормления птицы была взята кровь из крыловой вены конце выращивания (в возрасте и 60 суток). Исследованиями установлено, что в контрольной группе количество эритроцитов было меньше, чем у гусят опытных групп на 4,42 и $12,39 \%(\mathrm{P}<0,05)$ соответственно. Гусята контрольной группы имели гемоглобина в среднем 124,48 г/л, что меньше по сравнению с опытными на 7,00 и 8,06 \% (P<0,05) соответственно. Это указывает на интенсивный рост молодняка опытных групп. Большее содержание гемоглобина $(134,51 г / л)$ отмечено у птицы 2 опытной группы, в сравнении с 1 опытной на $0,99 \%$. 
Количество лейкоцитов у гусят, получавших добавку Витаммин, больше по сравнению с контрольными. Так, в опытных группах лейкоцитов было на 2,15 и 9,19 \% соответственно больше, по сравнению с контрольной. Некоторое увеличение количества лейкоцитов у гусят, получавших добавку Витаммин, указывает на усиление деятельности аппарата кроветворения, что вероятно связано с более интенсивным ростом молодняка птицы.

Содержание кальция в сыворотке крови гусят было наибольшим у контрольной группы $-2,68$ ммоль/л, что на 1,49 \% больше, чем в 1 опытной и - на $6,34 \%$, в сравнении со 2 опытной. Содержание неорганического фосфора в сыворотке крови было максимальным у гусят контрольной группы - 2,69 ммоль, что на 12,64 \%больше, чем в 1 опытной, и на 16,36 \%, в сравнении со 2 опытной. Щелочной резерв у молодняка гусей в контрольной группе был меньше, чем в опытных на 1,49 и 8,21 \% $(\mathrm{P}<0,05)$ соответственно.

Содержание общего азота в контрольной группе составило 933,67 мг\% и было меньше, чем в опытных на 5,70 и $8,84(\mathrm{P}<0,05) \%$ соответственно. Общего белка у гусят контрольной группы было меньше, чем в опытных на 9,40 и 9,24 \%. Полученные данные указывают на активное протекании окислительно-восстановительных процессов в организме гусят опытных групп.

В контрольной группе у молодняка гусей на долю альбуминовой фракции приходилось на $5,63 \%$ и $6,96 \%(\mathrm{P}<0,05)$, меньше в сравнении с опытными соответственно. У птицы 1 опытной группы альбуминов было меньше, чем у 2 опытной на $1,33 \%$.Глобулинов у гусят контрольной группы было больше, чем у опытных на 5,63 \% и 6,96 \% (P<0,05) соответственно.

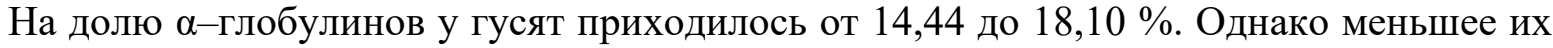
количество было у гусят контрольной группы, в сравнении с опытными на 4,66 и 0,06 \% соответственно. У птицы 1 опытной группы $\alpha-$-гобулинов было больше, чем у сверстников из контроля на 4,66 \%, из 2 опытной - на 4,60\%.及-глобулинов у гусят контрольной группы было больше, чем у молодняка из опытных на 1,12 и $1,63 \%$, а $\gamma$-глобулинов - на 7,98 и 0,78 $\%$ соответственно. $\beta$-глобулинов было больше у птицы 1 опытной группы на $0,51 \%$, чем во 2 опытной, а $\gamma$-глобулинов больше у 2 опытной, чем в 1 опытной на 7,20\%.

Альбумин-глобулиновый коэффициент был большим $(0,56)$ у молодняка гусей опытных групп на $24,44 \%(\mathrm{P}<0,05)$ в сравнении с контролем.

Следовательно, использование кормовой добавки Витаммин в рационах гусей способствовало более интенсивному обмену веществ, в сравнении со сверстниками из контроля. Полученные результаты подтверждают,что при увеличении дозировки кормовой добавки Витаммин у гусят отмечено повышение уровня тканевого дыхания, что характерно при увеличении обменных процессов и как следствие, повышении продуктивности.

Литература. 1. Астраханцев А.А., Казанцева Н.П., Санникова Н.А. Реализация потенциала продуктивности яичных и мясных кроссов кур в промышленном птицеводстве // Материалы Междунар. научно-практической конф. "Современному АПК - эффективные технологии". Ижевск: Ижевская государственная сельскохозяйственная академия, 2019. - С. 40 - 45. 2. Суханова С.Ф., Азаубаева Г.С., Кузнецов А.П., Махалов А.Г. Гематология сельскохозяйственной птицы. - Курган: Изд-во Курганская ГСХА, 2017. - 404 с. 3. Азаубаева, Г. С. Продуктивность гусынь родительского стада при использовании кормовой добавки Лив 52 вет / Г. С. Азаубаева, С. Ф. Суханова, В. К. Баскаев // Вестник Курганской ГСХА. - 2014. № 1(9). - С. 31-35. 4. Суханова, С. Ф. Морфологические и биохимические показатели крови цыплят-бройлеров / С. Ф. Суханова, С. В. Кожевников // Кормление сельскохозяйственных животных и кормопроизводство. - 2009. - № 1. - С. 46-50. 5. Суханова, С. Морфологические показатели крови у гусят, получавших бентонит / С. Суханова, Ю. Кармацкий // Птицеводство. - 2004. - № 6. - С. 16-17. 6. Суханова, С. Ф. Влияние пробиотических препаратов на биохимические показатели крови гусят-бройлеров / С. Ф. Суханова, С. В. Кожевников, С. В. Шульгин // Главный зоотехник. - 2012. - № 4. - С. 55-57. 7. Суханова, С. Ф. Авизим 1100 в составе кормосмесей для гусят-бройлеров / С. Ф. Суханова, А. Г. Махалов // Кормление сельскохозяйственных животных и кормопроизводство. - 2008. - № 4. - С. 3943. 8. Азаубаева, Г. Особенности естественной резистентности шадринских гусей / Г. 
Азаубаева, С. Суханова // Птицеводство. - 2007. - № 6. - С. 7. 9. Суханова, С. Ф. Влияние Лактобифадола на продуктивность молодняка гусей / С. Ф. Суханова // Современные научные тенденции в животноводстве, охотоведении и экологии : Сборник статей Международной научно-практической конференции, Киров, 12 декабря 2013 года. - Киров: Вятская государственная сельскохозяйственная академия, 2013. - С. 186-188. 10. Кожевников, С. В. Биологически активные вещества в кормах для цыплят-бройлеров / С. В. Кожевников, С. Ф. Суханова // Зоотехния. - 2010. - № 4. - С. 16-17. 11. Суханова, С. Ф. Влияние пробиотических препаратов на биохимические показатели крови гусят-бройлеров / С. Ф. Суханова, С. В. Кожевников, С. В. Шульгин // Главный зоотехник. - 2011. - № 4. - С. 22-24. 12. Суханова, С. Ф. Показатели естественной резистентности гусят-бройлеров, потреблявших Левисел $\mathrm{Sb}$ плюс / С. Ф. Суханова, И. Г. Корниенко // Вестник Алтайского государственного аграрного университета. - 2017. - № 5(151). - С. 103-108. 13. Суханова С.Ф., Махалов А.Г. Использование биологически активных веществ в гусеводстве: теория и практика. - Курган: изд-во ОАО ПК «Зауралье», 2006. - 232 с. 14. Суханова С.Ф., Азаубаева Г.С., Махалов А.Г. Планирование и организация эксперимента. - Курган: Изд-во Курганская ГСХА, 2015. - 210 с. 15. Суханова С.Ф., Азаубаева Г.С., Лещук Т.Л., Кощаев А.Г. Биометрические методы в животноводстве.- Краснодар: КубГАУ, 2017. - 162с.

\section{MORPHOLOGICAL AND BIOCHEMICAL PARAMETERS OF BLOOD IN GEESE WHO CONSUMED VITAMMIN}

Grishin E.A., graduate student

(FSBOU VO "Kurgan State Agricultural Academy named after T.S. Maltsev," Kurgan, Russia) Summary. The use of Vitammin min supplementation for geese contributed to more intensive metabolism, and as a consequence, better oxygen supply of organs and tissues, compared to peers out of control. In experimental groups, geese showed an increase in the level of tissue respiration, which is characteristic with an increase in metabolic processes and, as a result, an increase in productivity.

Key words: vitamins, geese, hematological indicators

\section{МИТОКСАНТРОН КАК ПРЕПАРАТ ВЫБОРА НА ОСНОВЕ КЛИНИЧЕСКИХ} СЛУЧАЕВ ПРИ ЛЕЧЕНИИ УРОТЕЛИАЛЬНОЙ КАРЦИНОМЫ У СОБАК

${ }^{1}$ Гурина Е.Р.- студент, ${ }^{1}$ Барышев В.А. - к.в.н., доцент каф. фармакологии и токсикологии,

${ }^{2}$ Каблуков А.Д. - к.в.н., ветеринарный врач хирург-онколог.

$\left({ }^{1}\right.$ ФГБОУ ВО «Санкт-Петербургский государственный университет ветеринарной медицины», ${ }^{2}$ ГВОЦ «Прайд»)

Аннотация: Карцинома мочевого пузыря составляет 2\% от всех клинических случаев проявления новообразований у собак. В этот процент наиболее часто входит переходноклеточная карцинома (ТCC), или уротелиальная карцинома. Переходно-клеточная карцинома является наиболее распространенным раком мочевого пузыря у собак, с преимущественным поражением самого органа, реже мочеиспускательного канала и предстательной железы.

Ключевые слова: Митоксантрон, уротелиальная карцинома, ТСС.

Введение. Карцинома мочевого пузыря составляет $2 \%$ от всех клинических случаев проявления новообразований у собак. В этот процент наиболее часто входит переходноклеточная карцинома (ТCC), или уротелиальная карцинома.[1] Переходно-клеточная карцинома является наиболее распространенным раком мочевого пузыря у собак, с преимущественным поражением самого органа, реже мочеиспускательного канала и предстательной железы. Метастазирование отмечается в 20\% случаях на момент постановки диагноза и у 50\% на момент смерти. [2] Данное заболевание несёт в себе риск, так как 
симптоматическое проявление в виде гематурии и странгурииявляется признаком инфекции мочевыводящих путей, и высока вероятность допущения врачебной ошибки в виденеправильной постановки диагноза, неполноценной диагностики и мониторинга патологии. $[3,4]$ При выявлении ТССцелью лечения является уменьшение объёма поражения, a также увеличение общей медианы выживаемости и более длительного периода качественной жизни. Стандартное лечение включает в себя прием НПВС и химиотерапию Митоксантроном или Карбоплатином в дозе 5 - 5,5 мг $/ \mathrm{m}^{2}$ и $300 \mathrm{Mг} / \mathrm{M}^{2}$ соответственно.[5] Также используются Доксорубицин, Цисплатин, Гемцитабин, Винбластин и др. Хирургическое лечение рака мочевого пузыря рекомендовано при возможности полного удаления опухолевого очага. Среднее время выживания (MST) составляет, по разным данным, от 247 до 350 дней. [6]

Материалы и методы. Проведено исследование эффективности схемы химиотерапии Митоксантроном (согласно принципам биоэтики) [7]в дозе $6 \mathrm{m \Gamma} / \mathrm{M}^{2}$ по сравнению с общерекомендуемой дозой $5,5 \mathrm{~m} / \mathrm{M}^{2} \mathrm{c}$ целью получения лучших результатов по общей выживаемости. Исследование проведено на базе ГВОЦ «Прайд», в нем участвовали собакикомпаньоны, проходившие лечение в клинике за период с 05.2016 по 12.2019. Всего участвовала 21 собака, которых разделили на 2 группы - группа №1 состояла из 11 собак и получали Митоксантрон в дозе 5,5 мг/м²; группа №2 состояла из 10 собак, получавших в дозе 6,0 мг/м², все собаки дополнительно принимали НПВС (Фирококсиб) в рекомендованных дозах. Препарат вводили в/в капельно каждый 21-й день с контролем гематологических нарушений [8]. Средний возраст составил 11,5 года (от 8 до 15 лет).

Результаты исследования. Общая выживаемость в группе №1 составила 265 дней, против 317 дней в группе №2. Клинические улучшения наблюдались в группе №1 у 8 собак (72,7\%), в группе №2 у 9собак (90\%). Гематологические нарушения наблюдалась в группе №1 у 4 собак (36,4\%), вгруппе №2 у 5 собак (50\%). Желудочно-кишечные нарушения наблюдались в группе №1 у 3 собак $(27,3 \%)$ и у 3 собак (30\%) в группе №2. У одного пациента из группы №2 прекращено лечение по причине желудочно-кишечных осложнений.

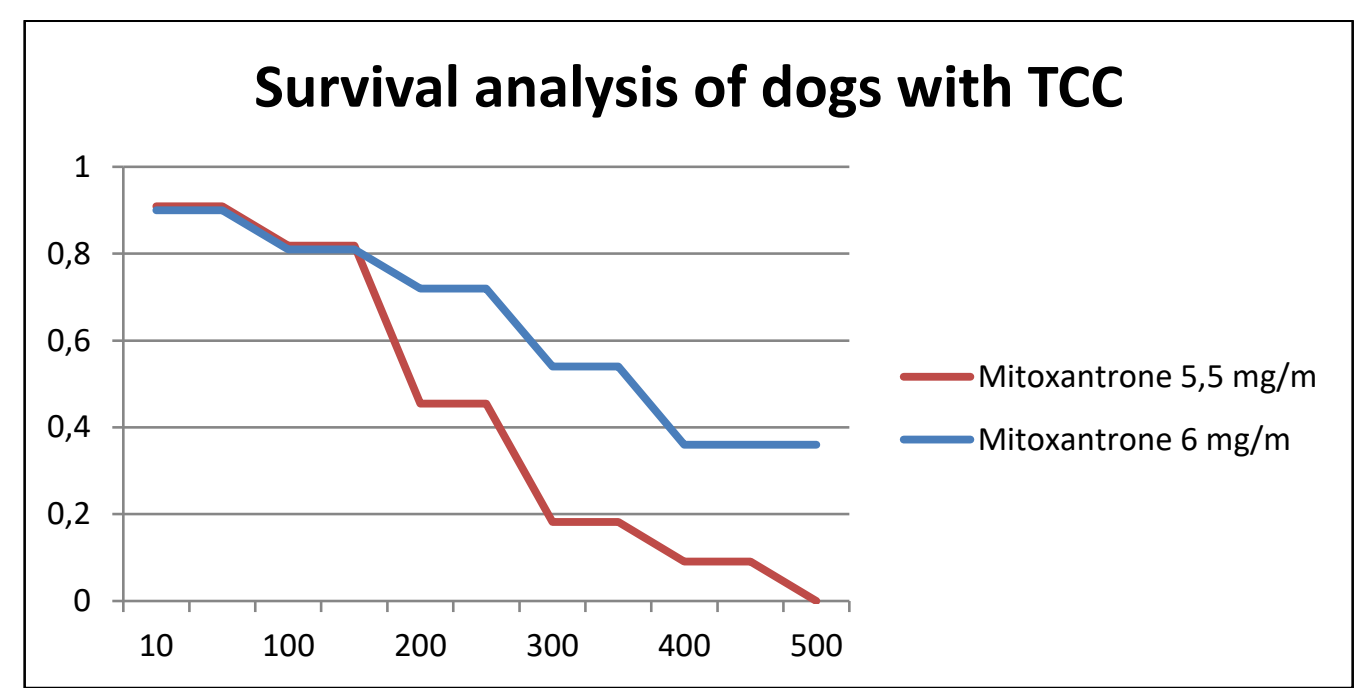




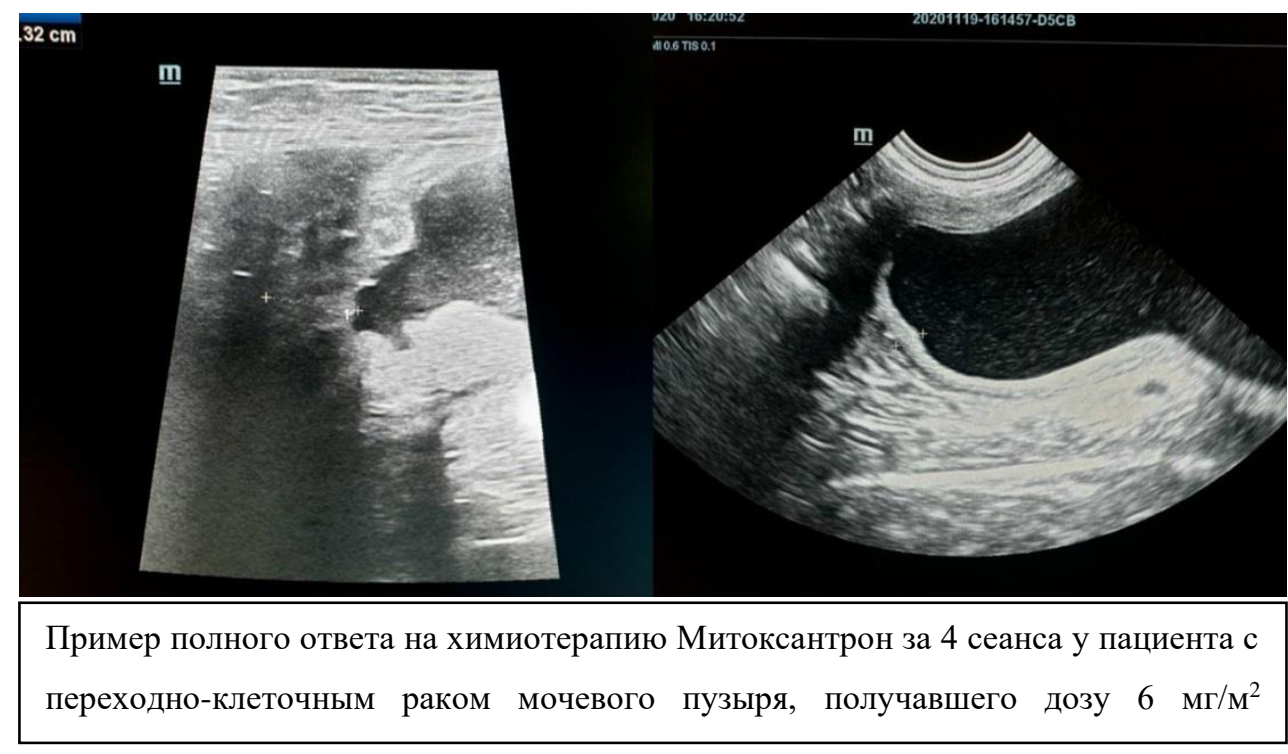

Выводы. На основании полученных данных можно сделать вывод о том, что использование Митоксантрона собакам при раке мочевого пузыря в дозе 6 мг/м² приводит к увеличению общей выживаемости на фоне удовлетворительной переносимости терапии. Следует провести дальнейшие исследования эффективности данного метода лечения.

Литература. 1. Allstadt S.D. et al. Randomized phase III trial of piroxicam in combination with mitoxantrone or carboplatine for first-line treatment of urogenital tract transitional call carcinoma. J Vet Intern Med 2015;29:261 - 267. 2. Santos M, Dias Pereira P, Montenegro L, Faustino AMR. Recurrent and metastatic canine urethral transitional cell carcinoma without bladder involvement. Vet Rec 2007;160:557-558. 3. Molnar T, Vajdovich P. Clinical factors determining the efficacy of urinary bladder tumour treatments in dogs: Surgery, chemotherapy or both? Acta Vet Hung 2012;60:55-68. 4. Robat C, Burton J, Thamm D, Vail D. Retrospective evaluation of doxorubicin-piroxicam combination for the treatment of transitional cell carcinoma in dogs. J Small Anim Pract 2013;54:67-74. 5. Nguyen SM, Thamm DH, Vail DM, London CA. Response evaluation criteria for solid tumours in dogs (v1.0): A Veterinary Cooperative Oncology Group (VCOG) consensus document. Vet Comp Oncol 2013. 6. Knapp DW, Henry CJ, Widmer WR, et al. Randomized trial of cisplatin versus firocoxib versus cisplatin/firocoxib in dogs with transitional cell carcinoma of the urinary bladder. J Vet Intern Med 2013;27:126-133. 7. Анализ нормативных документов, регламентирующих требования к проведению доклинических исследований ветеринарных препаратов / С. В. Герасимов, В. С. Понамарев, Н. Л. Андреева [и др.] // Вопросы нормативно-правового регулирования в ветеринарии. - 2020. - № 3. - С. 27 29. - DOI 10.17238/issn2072-6023.2020.3.27. 8. Понамарев, В. С. Влияние препарата с гепатопротекторной активностью "Гепатон" на показатели периферической крови лабораторных животных / В. С. Понамарев // Международный вестник ветеринарии. - 2020. № 2. - C. 116-121. - DOI 10.17238/issn2072-2419.2020.2.116.

\section{MITOXANTRONE AS A CASE-BASED DRUG OF CHOICE FOR THE TREATMENT OF CANINE UROTHELIAL CARCINOMA}

Gurina E.R.- student, Baryshev V.A.- Ph.D., associate professor of the department.pharmacology and toxicology, Kablukov A.D.- Ph.D., veterinarian surgeon-oncologist.

( ${ }^{1}$ FSBEI HE St. Petersburg SUVM", ${ }^{2}$ State Research and Exhibition Center "Pride")

Summary: Bladder carcinoma accounts for $2 \%$ of all clinical cases of neoplasms in dogs. This percentage most often includes transitional cell carcinoma (TCC), or urothelial carcinoma. Transitional cell carcinoma is the most common cancer of the bladder in dogs, with primary involvement of the organ itself, less commonly the urethra and prostate.

Key words: Mitoxantrone, urothelial carcinoma, TCC. 


\title{
ОПЫТ ПРИМЕНЕНИЯ ПРЕПАРАТА «АПОКВЕЛ» В ЛЕЧЕНИИ АТОПИЧЕСКОГО ДЕРМАТИТА У КОШЕК И СОБАК
}

\author{
Дроздова А.М., студент \\ Научный руководитель Сабирзянова Л.И., к.в.н., асс. \\ (ФГБОУ ВО СПбГУВМ, Россия)
}

\begin{abstract}
Аннотация. В настоящее время, с постоянно ухудшающейся экологической обстановкой, можно наблюдать большое количество относительно новых заболеваний у мелких домашних животных, в том числе и в области дерматологии. И, в связи с этим необходимы новые открытия и исследования в области фармакологии, которые бы могли помочь в лечении этих болезней. Мы рассмотрели применение препарата «Апоквел» при лечении такого сложнодиагностируемого заболевания как атопический дерматит.

Ключевые слова: атопический дерматит, ингибиторы JАК.

Введение.Аллергия, или гиперчувствительность - это патологическая, повышенная реакция иммунной системы животного на какие-либо вещества.Вещества, которые у обычных животныхпросто удаляются из организма, у аллергиков вызывают воспалительный процесс. Аллергии строго специфичны, то есть возникают только на определенные вещества и, как правило, слабо зависит от количества этого вещества, попавшего в организм.Большинство аллергийимеет наследственную предрасположенность.
\end{abstract}

Одним из самых распространенных видов является аллергия на вещества внешней среды, или атопический дерматит.

Атопический дерматит(атопия, атопическое заболевание) является генетическипредрасположенной тенденциейк появлению иммуноглобулинов $\mathrm{E}$ после контакта с окружающим аллергенами,что приводит характерную воспалительному, зудящему дерматозу.[1]

Обычно первое проявление аллергии возникают в возрасте от 10 месяцев до 3 лет.Вещества, вызывающие аллергическую реакцию, могут быть самыми разнообразными пыльца, домашняя пыль, плесень.Достаточно«микродозы»для возникновения реакции, поскольку невозможно изолировать животное от внешней среды, поэтому этот тип аллергии нуждается в пожизненном лечении.

Патогенез данного заболевания комплексный и выделяют несколько основных этиологических факторов возникновения:

- Иммунологический фактор.Считается, что контакт аллергенов с эпидермисом приводит к поглощению его клетками Лангерганса и последующему представлению аллергена на Т- лимфоциты. Нарушает соотношение между $\mathrm{T}_{1}$-хелперами(способствуют задержке гиперчувствительности) и $\mathrm{T}_{2}$-хелперами(стимулируют выработку иммуноглобулинов Е и А, способствуют появлению эозинофилов). Что приводит к воспалительными процессам и зуду.

- Н Наследуемость.Поскольку клинические наблюдения показывают, что данное заболевание часто встречается у определенных пород собак и в определённых линиях, что может говорить о генетической предрасположенность.

В настоящее время стоит также учитывать условия плохой экологии, в которых живут домашние животные, что только способствует появлению атопического дерматита у большего количества собак и кошек.

Материалы и методы. Исследование проводили на базе ветеринарной клиники Петроградского район города Санкт-Петербург. В наблюдении участвовали как кошки, так и собаки различных пород, всего 26животных.

Так, все животные, у которых во время первичного приёма регистрировался продолжительный зуд, поражения на коже, эритема между пальцами, отит, а также 
образование папул на коже под нижней губой, попадали в предварительный список для внесения в опытную группу.

Условиями отбора животных для исследования также были ежегодная вакцинация, промышленный тип кормления, своевременная обработка от эктопаразитов и дегельминтизация.

Ко всем животным наблюдаемой группы применялись цитологического исследование с пораженного участка кожи, а также внутрикожные аллерготесты, которые в свою очередь могли дифференцироватьтакие диагнозы как пищевая аллергия и аллергия на вещества внешней среды.

В ходе цитологии у всех животных были обнаружены нейтрофилы, кокки и повышенный рост грибов рода Malassezia. Что нам говорит о протекании воспалительного процесса, нарушении барьерной функции кожи, а также изменениях её свойств. А при проведении внутрикожных аллерготестовне у всех животных опытной группы подтвердилась аллергия на вещества внешней среды: у 2 собак и 1 кошки не было выявлено повышенной иммунной реакции,что может говорить о другом виде аллергии - пищевой, также у 2 собак наблюдалась повышенная реакция на все покрытосеменные растения (тимофеевка, трава садовая, береза, вяз, ива, крапива, полынь) у остальных кошек и собак было выявлено, что наиболее распространенными аллергенами являются мучной клещ (у 14 животных), зерновой клещ (у 9 животных), клещ домашней пыли (у 9 животных), кошачий эпителий (у 4 животных).

В качестве лечения был подобран препарат, который широко используется в клинической практике ветеринарных врачей-дерматологов, «Апоквел». «Апоквел» - это лекарственные средство для лечения дерматитов различной этиологии. Лицензирован он для собак, но используются в терапии атопического дерматита у кошек. Препарат обладает высокой эффективностью, побочных эффектов достаточно мало, эффект можно оценить уже в течение первых двух недель приёма, дешёвых аналогов пока на рынке нет.

«Апоквел» является ингибитором янус-киназы, то есть в терапевтических дозах он угнетает противовоспалительные, проаллергические и зудогенные функции цитокинов.

В инструкции к препарату указаны дозы только для собак. Для кошек же используются дозы в два раза выше $(0,8-1,2 \mathrm{мг} / к г)$.[2]

Поскольку у всех исследуемых кошек вес колебался в пределах 3,5-4,0 кг, то им был назначен «Апоквел» 3,6мг внутрь, по 1 таблетке, 2 раза в день, в течение 14 дней. Собакам препарат был прописан согласно инструкции по ветеринарному применению в соответствии массы животного и дозировке одной таблетки.

После назначения «Апоквел» у исследуемой группы животных средним уже через десять дней приёма наблюдалось уменьшение зуда и восстановление кожных покровов. Повторную цитологию проводили только у половины исследуемой группы, где уже не было обнаружено патологических изменений кожных покровов.

Побочные эффекты наблюдались только у одной собаки и проявились лишь единичной диареей в самом начале приёма лекарственного препарата.

Но при всех положительных результатах стоит помнить, что атопический дерматит требует пожизненного лечения и в дальнейшем следует вести наблюдение за частотой рецидивов.

Заключение. Атопический дерматит - это достаточно распространённое заболевание домашних животных на сегодняшний день. И в связи со сложностями его диагностирования, лечение часто назначают нецелесообразно, что в последующем не даёт желаемого результата. Не так давно на рынке ветеринарных лекарственных препаратов появился «Апоквел», который в настоящее время не имеет достойных и дешёвых аналогов. Отобрав животных в опытную группы и сделав необходимые лабораторные тесты для подтверждения диагноза, был использован для лечения данный препарат. 
Положительный ответ на лечение атопического дерматита «Апоквел» у всех опытных животных даёт возможно для развития новых исследований в этой области ветеринарной дерматологии.

Литература. 1.HnilicaK.A., Small Animal Dermatology/ K.A. Hnilica, A.P. Patterson //Elsevier.2016. - 652 p. 2.https://www.vidal.ru/veterinar/apoquel-28311 (дата обращения 13.04.2021).

\title{
EXPERIENCE WITH «APOQUEL» IN THE TREATMENT OF ATOPIC DERMATITIS
}

IN CATS AND DOGS

Drozdova A.M., student

Principal Investigator Sabirzyanova L.I.ass., Ph.D

(FSBEI HE St.Peterburg SUVM, Russia)

Summary. Currently, due to the constantly deteriorating environmental situation, a large number of relatively new diseases among small domestic animals can be observed, also in the area of dermatology. In this regard, there is a need in new discoveries and researches in the field of pharmacology, that could help in the treatment of these diseases. We considered the use of the drug "Apoquel" in the therapy of such difficult to diagnose diseases as atopic dermatitis.

Key words:atopic dermatitis, JAK inhibitors.

\section{ИЗУЧЕНИЕ ЭМБРИОТОКСИЧЕСКОГО И ТЕРАТОГЕННОГО ДЕЙСТВИЯ КОРМОВОЙ ДОБАВКИ АБИОПЕПТИД-ПЛЮС}

Еганян Е С., аспирант.

(ФГБНУ Краснодарский научный центр по зоотехнии и ветеринарии, Россия)

\begin{abstract}
Аннотация. Автором данной статьи было изучены эмбриотоксические и тератогенные свойства кормовой добавки Абиопептид-плюс на куриных эмбрионах. Установлено, что кормовая добавка не оказывает негативных последствий в развитии эмбрионов кур и способствует формированию здорового полноценного цыпленка.
\end{abstract}

Ключевые слова: эмбриотоксичность, тератогенность, куриные эмбрионы, Абиопептидплюс

Введение в рацион кур-несушек новых препаратов или кормовых добавок может спровоцировать появление тератогенеза, который проявляется в определенный период развития и оказывает токсическое действие или гибель эмбриона, но не оказывает заметного воздействия на организм кур [4,5]. Применение нетоксичных и эффективных кормовых добавок для повышения прироста, сохранности и резистентности животных и птицы является актуальной задачей $[1,2]$.Поэтому целью исследования было изучить влияние новой кормовой добавки на эмбриотоксичность и тератогеность.

Материалы и методы исследования. Экспериментальная часть работы была проведена в лаборатории НИЦ Ветфармбиоцентр, которая входит в состав ФГБОУ ВО «Кубанский государственный аграрный университет имени И. Т. Трубилина».

Кормовая добавка Абиопептид-плюс состоит из нескольких компонентов включающих гидролизат белка из сои и микроэлементы йод, селен.

Для проведения эксперимента были взяты 20 оплодотворенных 11 дневных яиц от курнесушек родительского стада бройлеров. Которые были помещены в инкубатор воздушной камерой вверх с температурой $37^{\circ} \mathrm{C}$ и влажностью $70 \%$.

Перед началом опыта была проведена овоскопия яиц, обозначена граница воздушной камеры и определено место нахождения зародыша [3].

Перед тем как ввести Абиопептид-плюс поверхность яйца была обработана раствором йода. 
Со стороны воздушного мешка острым скальпелем было сделано по одному отверстию, а потом в горизонтальном положении в боковой поверхности было введено вещество в желточный мешок однограммовым шприцом на глубину 3 см и на один эмбрион применяли дозу 0,2 мл [2].

После введения препарата через отверстие в скорлупе, далее оно было залито расплавленным парафином.

В контрольную группу в количестве 10 штук яиц был использован хлорид натрия.

Были учтены следующие параметры при проведении опыта:

-гибель эмбрионов в начале и в конце инкубации;

- рост и отклонения в развитии эмбрионов и цыплят;

- рождение цыплят и их физиологическое состояние;

- определение веса цыплят после вылупления и на 10 день.

Ежедневно проводилось овоскопирование с целью отбраковки и учета погибших эмбрионов. Инкубация проводилась в течение 14 дней [4].

Часть эмбрионов была заморожена на 19-е сутки, после чего проведен их осмотр, определяли массу и делали замер по конечностям.

Был проведен сравнительный анализ контрольной и опытной группы цыплят.

При замерах конечностей, костной системы и общего объема массы тела - видимых отклонений не наблюдалось.

Для дальнейшего изучения внутренних органов по методу Вильсона, 50\% эмбрионов была законсервирована в жидкости Буэна на 10 суток.

Результаты исследования. При исследовании внутренних органов контрольных эмбрионов и тем, кому вводили Абиопептид-плюс, наблюдалась следующая картина:

После вскрытия эмбрионов обеих групп видимых различий не было. Плодные оболочки имели гладкую поверхность, сосуды среднего кровенаполнения. Околоплодная жидкость чистая с включением хлопьев и пленок.

Исследуя плод, мы видим, что он опушенный, кожа розовая. Пуповина нормальных размеров, сосуды кровенаполнены, пупочное кольцо целостное. При осмотре головы было определено: пропорционально сформированные глазные яблоки. Закрытый клюв, который имел гладкое небо, язык продолговатой формы. Нормальное развитие мозга, сформированные полушария с гладкой поверхностью.

Анатомически правильно сформированная гортань трахея и пищевод по всей длине проходимы и эластичны, покрыты секретом. Органы грудобрюшного отдела без видимых изменений. Легочная ткань темно-вишневого цвета, упругая.

Конусовидное сердце со сформированными камерами и сосудами - заполнены кровью. Плотная прилегающая к желудку селезенка вишневого цвета. Упругая печень с ярко выраженными долями, края которых заострены. Почки бобовидные, вишневого цвета, упругие. Желудок делится на отделы, структурно сформированный. В кишечнике слизистое содержимое присутствует, слизистая оболочка гладкая.

Вылупились с 21 по 22 день, в контрольной группе -7 в опытной -8 птенцов. В обеих группах цыплята были хорошо развиты, подвижные, активно реагировали на внешние раздражители. Телосложение правильное. Кожа розового цвета слегка опушенная, эластичная и упругая.

Однодневные цыплята имели вес в контрольной группе $38,84 \pm 0,54$ г, в опытной группе вес составлял 39,52 $\pm 0,54$ г. На 10 день жизни цыплят был проведен замер веса, и существенных различий между группами не было установлено. Соответственно $249,7 \pm 11,03$ г. опыт и $248,08 \pm 15,4$ г. контроль.

При визуальном осмотре наблюдаем, что цыплята покрыты пухом желтого цвета. Живот подобранный и мягкий на ощупь. Клоака чистая розового цвета.

Глазные яблоки сформированы без отклонений, выделений вокруг глаз нет.

При патологоанатомическом вскрытии после убоя у цыплят в обеих группах в развитии внутренних органов различий не обнаружено. 
Ротовая полость и нос влажные, гладкие, покрыты небольшим количеством слизи. Язык упругий, хорошо выраженный и правильной формы. В зобе присутствуют кормовые массы, ферментированные с кисловатым запахом. Железы зоба правильно сформированы. Пищевод покрыт слизью его оболочка складчатая.

Органы грудобрюшной полости имеют нормальное расположение, серозные покровы гладкие бледно-розового цвета.

Желудок разделен на мышечный и слизистый отдел, присутствует небольшое количество слизи. Хорошо выражены железы, оболочка желудка складчатая и гладкая. Содержит полупереваренные кормовые массы.

Печень упругой консистенции нормального размера, вишневого цвета без признаков дистрофии. Наполненный желчью пузырь желто-зеленого цвета. Кишечник тонкий и толстый покрыт слизистым секретом и имеет проходимость по всей длине.

Трахея и бронхи имеют кольцевое строение, легкие красного цвета полностью раскрыты с пористой консистенцией.

Правильно сформированное сердце, розового цвета, конической формы. Миокард, эпикард и эндокард сформированы хорошо, блестящие и гладкие. Клапаны имеют створчатые и полулунные формы. Соотношение 1:3 имеют стенки левого и правого желудочка.

Почки нормальной величины в объеме, темно-красного цвета, капсула влажная. В мочеточниках содержимого не обнаружено.

Селезенка анатомически правильная, темно-красного цвета. Округлой формы, при разрезе края сходятся. Фабрицева сумка визуально определяется хорошо. Внутренняя часть выстлана цилиндрическим эпителием.

Заключение. Исходя из вышеизложенного установлено, что Абиопептид-плюс не вызывает негативных последствий в развитии эмбрионов кур и способствует формированию здорового полноценного цыпленка. Не нарушает нормального развития в структуре органов.

Кормовая добавка не оказывает тератогенного влияния и не обладает эмбриотоксическими свойствами. Не имеет ограничений в использовании как добавка для птицы и сельскохозяйственных животных.

Литература 1. Индюхова, Е.Н. Рост и развитие эмбрионов кур при тепловом стрессе в условиях дополнительного йодированного трансовариального питания / Е.Н. Индюхова, Т.О. Азарнова, В.И. Максимов // Вестник ИГЛУ. - 2015. - №. 1 (34). - С.69-74. 2. Константинов, В.А. Изучение эмбриотоксического и тератогенного влияния стимулятора продуктивности препарата «Полизон» / В.А. Константинов, П.А. Гуревич, В.А. Антипов, Т.Б. Пахомова, В.В. Зайцев, Б.П. Струнин, Л.Ф. Саттарова // Вестник Казанского технологического университета. - 2011.- № 5.-189-194 С. 3. Методические рекомендации по изучению репродуктивной токсичности лекарственных средств. / Руководство по проведению доклинических исследований лекарственных средств. Ч. 1. М.: Изд. «ФГБУ НЦЭСМП». - 2012. - С. 80-93. 4. Строганова, И.Я. Куриные эмбрионы и их использование в вирусологии: метод. указания к лабораторным занятиям / И Я. Строганова; Краснояр. гос. аграр. ун-т. - Красноярск, 2013. 19 с. 5. Щербатов, В.И. Ритм яйцекладки мясных кур при клеточном содержании / В. И. Щербатов // Птица и птицепродукты. - 2016. - № 3 - С.36-43.

\section{STUDY OF THE EMBRYOTOXIC AND TERATOGENIC EFFECTS OF THE FEED ADDITIVE ABIOPEPTIDE-PLUS}

Yeganyan E. S., Ph.D student.

(Krasnodar Scientific Center for Animal Science and Veterinary Medicine, Russia)

Summary: The author of this article studied the embryotoxic and teratogenic properties of the feed additive Abiopeptide-plus on chicken embryos. It was found that the feed additive does not have negative consequences in the development of chicken embryos and contributes to the formation of a healthy full-fledged chicken.

Key words: embryotoxicity, teratogenicity, chicken embryos, Abiopeptide-plus 


\title{
ИСПОЛЬЗОВАНИЕ БАКТЕРИЙ РОДА АZОТОВАСТЕR В ПЕРЕРАБОТКЕ ОТХОДОВ ПТИЦЕВОДСТВА
}

\author{
Елисютикова А. В., студ., Баженова Е. Д., студ., Милованов А. В., к.б.н., \\ Лунева А. В., доц., к.б.н \\ (ФГБОУ ВО Кубанский ГАУ, Россия)
}

\begin{abstract}
Аннотация. Проблема утилизации отходов является одной из наиболее актуальных в современном птицеводстве, поэтому внедрение новых способов их переработки и применения развивается с каждым годом. Для этих целей предлагается использовать бактерии рода Azotobacter и, соответственно, на их основе биопрепараты.
\end{abstract}

Ключевые слова: Azotobacter, птицеводство, биоудобрение, биологическая активность

Одной из основных и наиболее прибыльных отраслей сельского хозяйства является птицеводство, так как ее продукция имеет широкий спектр использования и применения. Птицеводство активно развивается сейчас, так что внедрение новых технологий и инноваций всегда будет одним из главных вопросов в сельском хозяйстве. Особое внимание уделяется проблеме утилизации и дальнейшего применения отходов, а также тому, как сделать процесс безопасным, быстрым и экономичным. Как известно, естественная утилизация помета птицы занимает долгое время, а его хранение предполагает собой занимание достаточной большой территории. Именно поэтому развитие новых способов переработки отходов птицеводства всегда является актуальным [1, 2, 3].

Бактерии рода Azotobacter широко используются в производстве биоудобрений, так как они значительно повышают плодородие почвы и стимулируют рост растений путем фиксации азота в полезных для сельскохозяйственных растений формах $[4,5]$. Следовательно, их можно применить и в переработке богатого азотом птичьего помета. Для достижения этой цели, необходимо решить следующие задачи: подобрать штаммы и среду, на которой они будут выращены, исследовать различные факторы на активность микроорганизмов, разработать биопрепараты на основе Азотобактера, оценить качество разработанного продукта. Исследование выполнено при финансовой поддержке Кубанского научного фонда и Организации в рамках научного проекта № МФИ-П-20.1/4

Для начала отобранные пробы необходимо протитровать методом Бертрана для изучения редуцирующих веществ (pB, \%). Затем они высеваются на плотную среду методом Коха для определения количества клеток (КОЕ, кл/мл). Далее методом спиртоосаждения оценивается количество полисахаридов в них, а потенциометрическим методом выявляется активная кислотность $\mathrm{pH}$. После исследований будут отобраны наиболее продуктивные формы штаммов, и на их основе будет произведен биопрепарат. Качество произведенного продукта будет оцениваться по показателю биологической активности. Принадлежность бактерий к родам и видам - по молекулярно-генетическому описанию с использованием $16 \mathrm{~S}$ rRNA.

В итоге, когда будут сняты все показатели, должен быть представлен продукт на основе микробной ассоциации для переработки отходов птицеводства и получения в дальнейшем органических биоудобрений для растениеводства. В первую очередь, предполагаемый биопрепарат должен воздействовать на следующие показатели: сроки выдерживания помета, эффективность дезодорирования, биобезопасность. Таким образом, с использованием разработанного продукта переработанные отходы птицеводства можно будет представить как ценное биоудобрение с высокой биологической активностью.

Литература. 1. Thyagarajan, D. Scope of poultry waste utilization / D. Thyagarajan [et al.] // IOSR J Agric Vet Sci. - 2013. - T. 6. - №. 5. - C. 29-35. 2. Limbashev, M. B. A new method of biological disposal of poultry droppings / M. B. Limbashev [et al.] // International Journal of Engineering and Advanced Technology. - 2019. - T. 9. - №. 1. - C. 4953-4956.3. Williams, C. M. Poultry waste management in developing countries / C. M. Williams // The role of poultry in human nutrition. - 
2013. - T. 46. 4. Jnawali, A. D. Role of Azotobacter in soil fertility and sustainability - A Review / A. D. Jnawali, R. B. Ojha, S. Marahatta // Adv. Plants Agric. Res. - 2015 - T. 2 - №. 6 - C. 1-5. 5. Mrkovacki, N. Use of Azotobacter chroococcum as potentially useful in agricultural application / N. Mrkovacki, V. Milic // Annuals of Microbiology. - 2001 - T. 51 - №. 2 - C. 145-158.

THE USE OF AZOTOBACTER IN THE PROCESSING OF POULTRY WASTE

Elisyutikova A. V., student, Bazhenova E. D., student, Milovanov A. V., PhD, Luneva A. V., associate professor, $\mathrm{PhD}$

(FSBEI HE KubSAU, Russia)

Summary. The problem of processing poultry waste is topical, so the introduction of new ways of processing and using it is developing every year. We suggested using Azotobacter for this purpose and producing a biological product based on them. As a result a product that will ensure the biosafety of waste disposal will be produced.

Key words: Azotobacter, poultry farming, biofertilizer, biological activity

УДК: 619:/087:632:582.28:633.1

ТОКСИЧЕСКОЕ ДЕЙСТВИЕ МИКОТОКСИНА МОНИЛИФОРМИНА

Ермолаева О.К., к.б.н., Танасева С.А., к.б.н., Тарасова Е.Ю., к.б.н., Садыкова А.Ш., аспирант (ФГБНУ «ФЦТРБ-ВНИВИ», Россия)

Аннотация. Монилиформин - метаболит, продуцируемый несколькими видами грибов рода Fusarium, поражающий зерновые культуры в различных климатических условиях. Наличие данного микотоксина в пищевых продуктах и кормах является основным фактором риска для здоровья животных и человека. Монилиформин очень токсичен для белых крыс, пороговое значение ЛД изменениям во всех внутренних органах, вызывая у животных кардиотоксикозы и повреждения сердечной мышцы.

Ключевые слова: микотоксины, монилиформин, гистоструктура

Микроскопические грибы рода Fusarium во всем мире поражают важные для сельского хозяйства растения и вызывают распространенные болезни, такие как корневая, стеблевая и початковая гниль кукурузы, а также фузариоз зерновых $[1,2,3]$. Кроме того, большинство грибов рода Fusarium продуцируют арсенал вторичных метаболитов, микотоксинов, которые вызывают широкий спектр неблагоприятных воздействий на здоровье животных и человека, включая нейротоксичность, иммунотоксичность, токсичность и канцерогенность [4, 5]. На сегодняшний день наибольший интерес представляет малоизученный микотоксин монилиформин, ведущий к развитию алиментарных токсикозов животных и человека. Монилиформин часто встречается в кукурузе (400 мг/кг) и мелкозерновых злаках (810 мкг/кг) $[6,7,8,9]$.

Монилиформин - высокополярная молекула, представляющая собой водорастворимую натриевую или калиевую соль. Кардиотоксичность и гепатотоксичность являются его основными неблагоприятными последствиями для здоровья, основной мишенью являются ферменты с тиамином в качестве кофактора $[10,11,12]$. Поскольку эти ферменты являются частью дыхательной цепи, любое нарушение их активности приводит к нехватке энергии, респираторному стрессу и потере функциональности миокарда, также токсин снижает активность глутатионпероксидазы и глутатионредуктазы, тем самым увеличивая окислительный стресс.

Целью наших исследований было выявить морфологические изменения в органах лабораторных животных при острой интоксикации монилиформином.

Материалы и методы. Экспериментальные исследования проводили на 10 белых крысах массой 150-180 г, разделенных по принципу аналогов на 2 группы. Группы животных формировали по принципу аналогов с учетом живой массы, возраста и пола. В течение всего 
опыта крысы находились в одинаковых условиях содержания и кормления. Животным опытной группы однократно внутрижелудочно вводили монилиформин («Sigma-Aldrich»), растворенный в дистиллированной воде в дозе 39,7 мг/кг живой массы (ЛД50). Контрольным животным в аналогичном объеме вводили дистиллированную воду. В период эксперимента за подопытными животными вели постоянное наблюдение по общепринятой схеме.

Для проведения патоморфологических и гистологических исследований у павших животных были взяты кусочки органов и тканей с последующей окраской их гемотоксилин эозином.

Результаты. Монилиформин - токсичный и стабильный метаболит, поражающий сердечно-сосудистую и иммунную систему. Острое воздействие монилиформина характеризовалось поражением сердца, печени, селезенки, головного мозга. При патологоанатомическом вскрытие наблюдали недостаточное кровоснабжение миокарда, увеличение селезенки, кровоизлияния в печени. Головной мозг отёчный, плотной консистенции с многочисленными кровоизлияниями, сосуды кровенаполнены.

При гистологическом исследовании регистрировали периваскулярный и перицеллюлярный отек головного мозга (рисунок 1), расширение сосудов, увеличение и деформацию нейронов, сателлитоз, нейронофагию.

Морфологические изменения сердца характеризовались набуханием кардиомиоцитов, расширением и полнокровием сосудов (рисунок 2). Расширение и полнокровие сосудов, а также кровоизлияния в красную пульпу наблюдали при анализе селезенки.

Гепатоциты печени увеличены, ядра некоторых гепатоцитов со слабо очерченными контурами (рисунок 3).

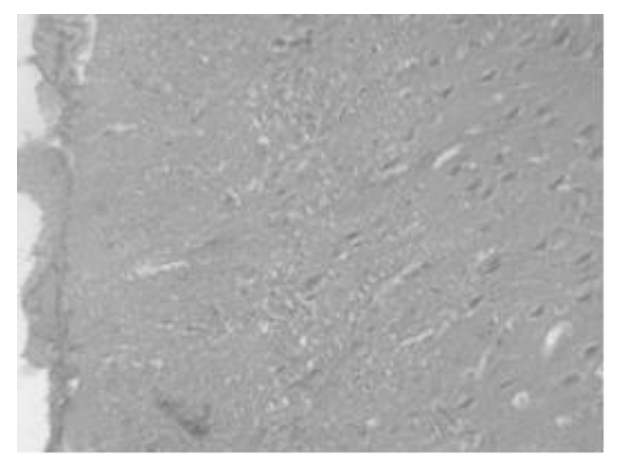

Рис. 1. Отек головного мозга белой крысы, однократное введение монилиформина

39,7 мг/кг живой массы, окраска гематоксилином и эозином водным, объектив х20.

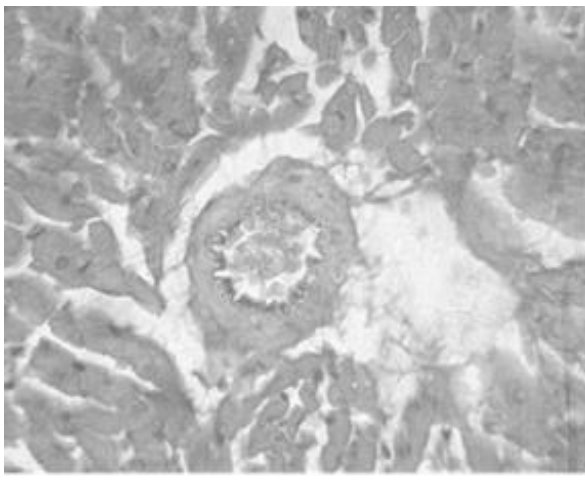

Рис. 2. Артериолоспазм сердца белой крысы, однократное введение монилиформина

39,7 мг/кг живой массы, окраска гематоксилином и эозином водным, объектив х20.

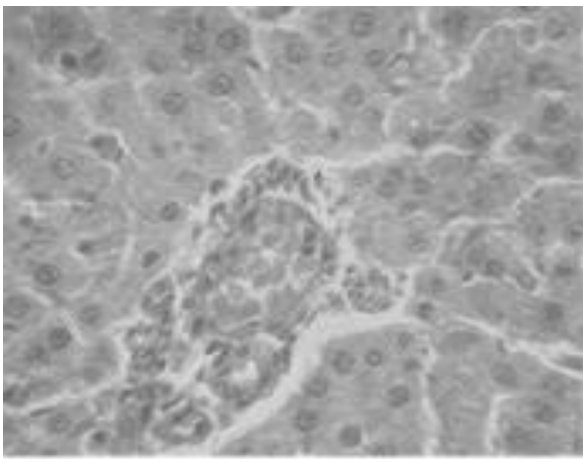

Рис. 3. Зернистая дистрофия печени белой крысы, однократное введение монилиформина 39,7 мг/кг живой массы, окраска гематоксилином и эозином водным, объектив х20. 
Заключение. Воздействие монилиформина сопровождается изменениями внутренних органов, которые морфологически характеризуются признаками паретического венозного полнокровия, отеком головного мозга, дистрофией нейронов и гепатоцитов печени, кровоизлияниями в красную пульпу селезенки.

Литература. 1. Гагкаева, Т.Ю. Фузариоз зерновых культур / Т.Ю. Гагкаева, О.П. Гаврилова, М.М. Левитин, К.В. Новожилов // Защита и карантин растений. - 2011. - №5. - С. 2-3. 2. Еремеев, И.М. Биологические методы борьбы с микотоксинами / И.М. Еремеев, Е.Н. Иванов, Л.Е. Матросова Л.Е., Э.И. Семенов, М.Я. Тремасов, А.А. Иванов // Ветеринарный врач. - 2014. - № 1. - С. 7-10. 3. Тремасов, М.Я. Микотоксины - реальная угроза продовольственной безопасности / М.Я. Тремасов, А.В. Иванов, Е.Ю. Тарасова // Вестник ветеринарии. - 2013. № 2 (65). - С. 78-80. 4. Танасева, С.А. Эффективность адсорбентов при сочетанном микотоксикозе цыплят-бройлеров / С.А. Танасева, Е.Ю. Тарасова, Л.Е. Матросова [и др.] // Международный вестник ветеринарии. - 2020. - № 4. - С. 50-56. 5. Шамилова, Т.А. О лечении экспериментального афлатоксикоза белых крыс / Т.А. Шамилова, Л.Е. Матросова, А.М. Тремасова // Ученые записки Казанской государственной академии ветеринарной медицины им. Н.Э. Баумана. - 2010. - Т. 203. - С. 287-291. 6. Бурдов, Л.Г. О результатах анализа кормов на содержание микотоксинов / Л.Г. Бурдов, Л.Е. Матросова // Ветеринарный врач. - 2011. - № 2. - С. 7-9. 7. Гогина, Н.Н. Микотоксин монилиформин в кормах: лабораторные методы обнаружения, обзор полученных результатов / Н.Н. Гогина, Л..М. Круглова, Ю..С. Кожаринова // Птицеводство. - 2019. - №6. - С.65-68. 8. Тарасова, Е.Ю. Изыскание средств для лечения животных при Т-2 микотоксикозе / Е.Ю. Тарасова // Автореферат диссертации на соискание ученой степени кандидата биологических наук / Федеральный центр токсикологической и радиационной безопасности животных (Всероссийский научноисследовательский ветеринарный институт). - Казань, 2010. - 23 c. 9. Tarasova, E. Yu. Protective effect of adsorbent complex on morphofunctional state of liver during chicken polymycotoxicosis / E.Yu. Tarasova, L.E. Matrosova, S.A. Tanaseva, N.N. Mishina, R.M. Potekhina, O.K. Ermolaeva, S.Yu. Smolentsev, A.M. Tremasova, I.R. Kadikov, V.I. Egorov, R.M. Aslanov, E.I. Semenov // Systematic Reviews in Pharmacy. - 2020. - T. 11. - № 11. - P. 264-268. 10. Fremy, J.M. A review on combined effects of moniliformin and co-occurring Fusarium toxins in farm animals / J.M. Fremy, I. Alassane-Kpembi, I.P. Oswald, B. Cottrill, H.P. Van Egmond // World Mycotoxin Journal. - 2019. - № 12(3). - P. 281-291. 11. Lumsangkul, C. Developmental toxicity of mycotoxin fumonisin B1 in animal embryogenesis: An overview / C. Lumsangkul, H.I. Chiang, N.W. Lo, Y.K. Fan, J.-C. Ju // Toxins. - 2019. - № 11(2). - P.114. 12. Pena, G.A. Fusarium species and monilliformin occurrence in sorghum grains used as ingredient for animal feed in Argentina / G.A. Pena, L.R Cavaglieri, S.N. Chulze // Journal of the Science of Food and Agriculture. - 2019. - № 99(1). - P. 47-54.

TOXIC EFFECT OF MYCOTOXIN MONILIFORMIN

Ermolaeva O.K., Ph.D., Tanaseva S.A., Ph.D., Tarasova E.Yu., Ph.D., Sadykova A.Sh., postgraduate student

(FGBNU "FCTRB-VNIVI", Kazan)

Summary. Moniliformin is a mycotoxin produced by several species of fungi of the Fusarium genus that infects crops in various climatic conditions. The presence of this mycotoxin in food and feed is a major risk factor for animal and human health. According to research, it is very toxic to rats, with a cut-off LD50 of $39.7 \mathrm{mg} / \mathrm{kg}$ body weight. It was concluded that the action of moniliformin leads to changes in all internal organs, causing cardiotoxicosis and damage to the heart muscle in animals. Key words: mycotoxins, moniliformin, histostructure 


\title{
РАЦИОНАЛЬНОЕ ИСПОЛЬЗОВАНИЕ ПОБОЧНЫХ ПРОДУКТОВ ЖИВОТНОГО УБОЯ
}

\author{
Ерохина Ю.М., обучающаяся 20ТБО-7 \\ Научный руководитель - к.с-х.н. Ярлыков Н.Г. \\ (ФГБОУ ВО Ярославская ГСХА, Ярославль, Россия)
}

\begin{abstract}
Аннотация: Побочные продукты животного убоя являются источником ценного животного белка, дефицит которого в рационе населения России увеличивается с каждым годом. Но в настоящее время существуют многочисленные свалки и захоронения отходов животного происхождения, что наносят вред окружающей среде, являясь источником повышенной опасности для человека. Расходы на утилизацию, неиспользование резервов приводят к повышению стоимости мясных продуктов. Основная часть побочного сырья образуется в процессе забоя животных на специализированных предприятиях.
\end{abstract}

Ключевые слова: продукты животного убоя, использование, субпродукт.

Статья посвящена теме рационального использования продуктов животного убоя.

Методика. В процессе исследования были проанализированы различные Интернетисточники и литература с целью изучения вопроса о рациональном использовании побочных продуктов убоя.

\section{Результаты исследований.}

Понятие субпродукта.

Субпродукт - это внутренние органы убойных животных, а также части их туш: хвост, голова, вымя, ноги; побочные продукты животного убоя.

Субпродукты подразделяются на 2 категории.

К первой категории относят печень, сердце, мозги, вымя, диафрагма, почки, язык.

У субпродуктов первой категории более высокая пищевая ценность и вкусовые качества, а некоторые являются деликатесным. Продукты данной категории широко используются в кулинарии, а также для производства ливерных колбас, паштетов.

Ко второй категории относят желудок, голова, ноги, легкие, гортань, селезенка, трахея, путовый сустав, свиной хвост.

Субпродукты второй категории содержат мало полноценных белков, имеют низкую пищевую ценность. В таких продуктах, как уши, губы, ножки, содержится много коллагена (около 13 - 19\% мякоти), который при варке дает клейкое вещество, поэтому их называют клейдающими. Это свойство позволяет широко использовать при производстве студней, зельцев и др. [1]

Использование продуктов животного убоя.

Применение органов пищеварения.

К органам пищеварения, являющимися побочными продуктами животного убоя, относят язык, глотку, гортань, пикало, желудок, кишечник, печень и поджелудочную железу.

- Язык - мясной деликатес с высоким содержанием питательных веществ. Используется в кулинарии, а также для изготовления фаршированных колбас, консервов и копчёностей. В продажу обычно поступает очищенный и в охлаждённом или замороженном виде. [2] Также для изготовления колбас используют язык вместе с глоткой и гортанью.

- $\quad$ Пикало или пикальное мясо - это анатомический пищевод, он не содержит жира. Пикальное мясо является идеальной пищей для любых пород собак. Содержит белки и жиры, множество витаминов, аминокислот, макро- и микроэлементов. Оно легко усваивается, является полезным субпродуктом. [2] А также анатомический пищевод, освобожденный от наружного мышечного слоя и кишечник используется как фаршевая оболочка колбас.

- Желудок используется как фаршевая оболочка и как сырье для фарша некоторых видов вареных колбас и зельцев; слизистая оболочка желудка идёт на выработку ферментного сырья для сыроварения. [2] 
- $\quad$ Печень - ценный продукт убоя животных, применяют в кулинарии, используют для получения лекарственных препаратов.

- $\quad$ Поджелудочная железа используется для получения инсулина и панкреатина.

Применение органов дыхания.

К органам дыхания, являющимися субпродуктами, относят гортань, трахею, лёгкие.

- $\quad$ Гортань и трахею используют в колбасном производстве.

- Лёгкие добавляют в фарш при изготовлении колбас, используют в кулинарии, применяют при производстве лекарственных препаратов.

\section{Применение органов мочеполовой системы.}

К органам мочеполовой системы, являющимися субпродуктами, относят почки, мочевой пузырь, яичники, плаценту, семенники.

- Почки используют в кулинарии. Считаются деликатесом, а по полезным свойствам приравнены к мясу.

- Мочевой пузырь используется как фаршевая оболочка колбас.

- $\quad$ Яичники - половые органы самок, вырабатывают гормон эстроген и прогестерон (гормон желтого тела). Препарат, изготавливаемый из продукта, вызывает трансформацию слизистой оболочки матки из фазы пролиферации в секреторную фазу, что необходимо для нормальной имплантации оплодотворенного яйца, а после оплодотворения способствует ее переходу в состояние, необходимое для развития оплодотворенной яйцеклетки.

- $\quad$ Плацента активно применяется в производстве натуральной косметики.

\section{Применение органов сердечно-сосудистой системы.}

К органам сердечно-сосудистой системы, являющимися субпродуктами, относят сердце, кровь.

- $\quad$ Сердце состоит из плотной мышечной ткани; она пригодна для вторых блюд, паштетов, ливерных колбас и консервов.

- Кровь - ценный белковый продукт, используется в различных сферах деятельности: пищевая, фармацевтическая, кормовая, техническая.

\section{Заключение}

Результаты исследования показали, что более глубокая переработка продуктов животного убоя обеспечивает комплексное и рациональное использование субпродуктов, что позволяет свести до минимума объемы неиспользуемых остатков в мясной промышленности и способствует повышению экологизации данной отрасли АПК. При этом одними из наиболее перспективных направлений использования полученных продуктов являются пищевая и кормовая промышленности.

Литература. 1. Понятие субпродукт. [Электронный ресурс] https://vmomentte.ru/subprodukty-vidy-polza-i-vred-subproduktov.html 2. Применение органов пищеварения. [Электронный ресурс] https://ru.wikipedia.org/wiki/\%D0\%AF\%D0\%B7\%D1\%8B\%D0\%BA_(\%D1\%81\%D1\%83\%D0\% B1\%D0\%BF\%D1\%80\%D0\%BE\%D0\%B4\%D1\%83\%D0\%BA\%D1\%82http://gafgav.ru/product/ $\% \mathrm{D} 0 \% \mathrm{BF} \% \mathrm{D} 0 \% \mathrm{~B} 8 \% \mathrm{D} 0 \% \mathrm{BA} \% \mathrm{D} 0 \% \mathrm{~B} 0 \% \mathrm{D} 0 \% \mathrm{BB} \% \mathrm{D} 1 \% 8 \mathrm{C} \% \mathrm{D} 0 \% \mathrm{BD} \% \mathrm{D} 0 \% \mathrm{BE} \% \mathrm{D} 0 \% \mathrm{~B} 5-$ $\% \mathrm{D} 0 \% \mathrm{BC} \% \mathrm{D} 1 \% 8 \mathrm{~F} \% \mathrm{D} 1 \% 81 \% \mathrm{D} 0 \% \mathrm{BE}-$ \%D0\%BF\%D0\%B8\%D1\%89\%D0\%B5\%D0\%B2\%D0\%BE\%D0\%B4/http://www.xn---7sbbhn4brhhfdm.xn--p1ai/nomenklatura-i-ispolzovanie-kishok.html

\section{RATIONAL USE OF ANIMAL SLAUGHTER BY-PRODUCTS}

Erohina J.M., student 20 TBO-7

Scientific adviser - Candidate of Agricultural Sciences Yarlykov N.G

(FSBEI HE Yaroslavl SAA, Yaroslavl, Russia)

This article is devoted to the topic of rational use of animal slaughter products.

Annotation: Slaughter by-products are a source of valuable animal protein, the deficit of which in the diet of the Russian population is increasing every year. But now there are numerous landfills and burials of animal waste, which harm the environment, being a source of increased danger to humans. 
Disposal costs, non-use of reserves lead to an increase in the cost of meat products. The main part of by-products is formed in the process of slaughtering animals at specialized enterprises.

Keywords: slaughter products, use, offal.

УДК 619:636.12

\section{ВЛИЯНИЕ БИОЛОГИЧЕСКИ АКТИВНЫХ ВЕЩЕСТВ НА ОРГАНИЗМ ЖЕРЕБЫХ КОБЫЛ В ПОСЛЕДНИЙ ТРИМЕСТР}

Ерыженская Н.Ф., с. н. с., к. б. н.

(ФГБНУ «Курский ФАНЦ», Россия)

Аннотация. Тема рождения полноценного приплода актуальна всегда. Поэтому мы предлагаем метаболический состав на основе янтарной кислоты с вводными компонентами, апробированный на жеребых кобылах в конных заводах Российской Федерации.

Ключевые слова: биологически активные вещества, метаболический состав, жеребые кобылы

Беременность - как любой физиологический процесс, может в организме самки обусловливать ряд явлений, граничащих с патологическим процессом.Формирование плода во многом зависит от состояния материнского организма и любое изменение параметров организма матери оказывает также изменения состороны самого плода[1].Исследование протекания жеребости у лошадей является важной темой, так как изучение процессов, наблюдаемых во время жеребости, позволяет выстраивать более обоснованные схемы кормления, направленные на восполнения затрат, пошедших на формирование организма матери,а также возможность получения наиболее ценного и плодовитого потомства $[1,2]$.Организация кормления жеребых кобыл сводится к поддержанию их в хорошей упитанности. Не допускается излишнее ожирение жеребых кобыл. Недокорм жеребых кобыл увеличивает продолжительность беременности и нередко приводит к рождению слабых жеребят и плохой молочности кобыл. Одно их главных условий развития коневодства, улучшения качества и снижения себестоимости продукции - полноценное кормление. Организм животного состоит из различных органических, минеральных веществ и воды. Восполнить израсходованные в процессе жизнедеятельности вещества он может только за счет корма, который является также источником энергии для работы органов и систем организма и поддержания заданной температуры тела. С кормами поступают важные регуляторы биохимических процессов, идущих в организме, - витамины, ферменты и др.Уровень и качество кормления определяют скорость развития организма. Так, неполноценное кормление молодняка нарушает рост костной и мышечной тканей, функционирование органов и систем организма; при этом возникают неблагоприятные изменения конституции животного. Кроме того, несбалансированное кормление ведет к резкому увеличению затрат корма на единицу продукции.В зависимости от направления хозяйственного использования, возраста, физиологического состояния (рост, беременность, лактация и др.) потребности животных в питательных веществах могут меняться. Неодинаковы они и у животных разного возраста и пола. Так, в растущем организме процессы синтеза преобладают над процессами распада, поэтому он нуждается в большем количестве протеина на килограмм живой массы, чем взрослые животные.Лошадь отличается от других животных тем, что основной ее продукцией является мышечная работа. Это определяет особенности ее пищеварения и обмена веществ. По сравнению с животными других видов лошади наиболее требовательны к качеству корма. Они хуже, чем жвачные, переваривают клетчатку, поэтому для них нужно выделять сено, заготовленное в фазе бутонизации бобовых или выметывания метелки у злаковых трав. Лучшими кормами считают хорошее луговое, степное, клеверное или люцерновое сено, вико-овсяную смесь, из зерновых - овес, кукурузу 
и ячмень, полезны пшеничные отруби и морковь.Хорошее сено скармливают без подготовки. Солому, предпочтительно овсяную, лучше запарить или сдобрить мелассой, отрубями, комбикормом. Отруби дают в увлажненном виде или в смеси с другими концентратами. Зерно желательно плющить или дробить: после такой обработки оно лучше усваивается организмом лошади. Это особенно важно при кормлении жеребят и старых лошадей.Наряду с традиционными кормами, такими, как сено и овес, в рационы лошадей включают комбикорма, сахарную свеклу, патоку, травяные гранулы, брикеты, сенаж, силос, минеральные и витаминные смеси, белковые и другие добавки.Из концентрированных кормов лошадям помимо овса скармливают кукурузу, ячмень, рожь, отруби пшеничные, жмых. В юговосточных районах страны для кормления лошадей используют молотые зерна проса, сорго, могара.Отличным диетическим и вкусовым кормом, усиливающим моторику желудочнокишечного тракта и послабляющее действующим на пищеварение, является патока. Взрослой рабочей лошади в день дают до 1,5 кг патоки, разведенной в 4 - 5 л воды, сдабривая ею грубые корма.Из сочных кормов для лошадей диетическим кормом считается морковь, норма скармливания которой может достигать $6-8$ кг в день. Для лошадей, работающих медленным аллюром, а также для жеребых и подсосных кобыл хорошими сочными кормами служат свекла, картофель и силос кукурузы, убранной в стадии молочно-восковой спелости. Дачу этих кормов при длительном моционе доводят до $2-4$ кг на 100 кг живой массы.Предложенный метаболический состав представляют следующие компоненты: янтарная кислота, меласса, йодинол, сульфаты железа, цинка, меди, кобальта, вытяжка крапивы и натрия хлорид.Янтарная кислота мощно стимулирует выработку энергии в клетках,включается в метаболические процессы и обеспечивает жизненно важные функции, нормализует работу нервной системы как противодействующее стрессам средство [4]. Меласса пополнит депо углеводов, при этом активирует сокращение матки после родов и отделение последа, улучшит вкус и повысит жирность молока. Йодинол обладает широким спектром антимикробного действия, компенсирует недостаток йода, принимает активное участие в обменных процессах[5].Минералы входят в состав гормонов, ферментов, витаминов, определяют их активность и влияние на интенсивность процессов обмена веществ в организме. Поэтому они не случайно были введены в метаболический состав.Имея уникальный природный состав, крапива восполнит депо минералов, витаминов, дубильных, биологически и физиологически активных веществ, оказав выраженное действие на основной обмен [6]. Хранение состава в течение длительного времени при комнатной температуре обеспечит хлорид натрия.

Цель исследования- влияние биологически активных веществ на организм жеребых кобыл в последний триместр.

Наши исследования были проведены совместно с Прилепским конным заводом Тульской области в 2020 году на жеребых кобылах Русской и Орловской породы на последнем триместре. Лабораторные исследования были проведены в лаборатории «Ветеринарная Медицина»ФГБНУ Курский ФАНЦ. По принципу аналогов были отобраныдве группы кобыл по 15 голов, опытная и контрольная на одиннадцатом месяце жеребости.Все кобылы были клинически здоровыми. Содержание было индивидуальное в денниках. Кормление производилось согласно сбалансированному рациону, для жеребых кобыл. Было проведено исследование на жеребых кобылах на одиннадцатом месяце жеребости. Кобылам опытной группы утреннюю порцию овса орошали 0,5 л метаболического состава 30 дней подряд до выжеребки. Вторая группа служила контролем. Кровь брали из яремной вены с учетом асептики и антисептики.В крови определяли содержание общего белка, резервную щёлочность, уровень глюкозы, кальция, фосфора, железа, меди, кобальта, цинка, йода. Биохимические исследования проводили на анализаторе Biochem FC 200.Статистическую обработку экспериментальных данных осуществляли с использованием t-критерия Стьюдента.

Контроль за физиологическим состоянием жеребых кобыл опытной и контрольной групп осуществляли путём клинических наблюдений. Оценку коррекции метаболических 
процессов анализировали по степени изменений изучаемых показателей крови: концентрации общего белка, резервной щёлочности, глюкозы, кальция, фосфора, железа, меди, кобальта, цинка и йода,пробы которых отбирались в первый и 15 день опыта. У жеребых кобыл, получавших метаболический составсодержание общего белка, резервной щёлочности, глюкозы, кальция, фосфора, железа, меди, кобальта, цинка, йода была значительно выше, чем у животных контрольной группы. Соответственноэто оказало положительное влияние на метаболические процессы материнского организма, физиологическое состояние и развитие плода. Приплодот кобыл опытной группы был хорошо сформирован,находился в хорошем физиологическом состоянии, наблюдалась устойчивость к легочным и желудочно- кишечным заболеваниям.

Вывод.Биохимические показатели крови, физиологическое состояние жеребых кобыл и рождение жизнеспособного приплода позволяют сделать соответствующее заключение: метаболический состав оказал существенное влияние на коррекцию метаболических процессов в организме жеребых кобыл,возможность получения наиболее ценного и плодовитого потомства

Метаболический состав прост в применении, в доступности компонентов и способа изготовления, что позволяет предложить его в качестве средства для коррекции метаболических процессов жеребых кобыл в последний триместр в конных заводах Российской Федерации.

Литература. 1.Щеголь, И.А., Балыкина, А.Б.Гематологический статус у кобыл в период жеребости // Молодежная наука - развитию агропромышленного комплекса:материалы Bсерос. (национальной) науч.-практ. конф. студентов, аспирантов и молодых ученых.-СПб, 2020. -С. 506-509. 2. Григорьева, Н.Н. Морфофизиологические показатели крови лошадей якутской породы в холодный период года / Н.Н. Григорьева. Л.П. Корякина, Н.В. Винокуров, А.Н. Бурцев // Иппология. - 2020. - №2. - С.24-30. 3.Ливанова, М.А.Все о лошади.Породы и выбор. Уход и лечение / Ливанова М.А., Ливанова Т.К.- М.: АСТ-ПРЕСС, 2018. -384 с. 4.Коваленко, А.Л.Янтарная кислота: Фармакологическая активность и лекарственные формы / Коваленко А.Л., Леонов Л.В. // Фармацея. -2000.- № 5-6. -С. 40-42. 5. Аухатова, С.Н. Влияние йода на метаболические процессы в организме// Успехи современного естествознания. -2006. -№ 1. -С. 32-33. 6. Константинов, Ю. Крапива. Уникальное природное средство. -М.: Центрполиграф,2016. -120 с.

\section{INFLUENCE OF BIOLOGICALLY ACTIVE SUBSTANCES ON THE ORGANISM OF} MALES IN THE LAST TRIMESTER

EryzhenskayaN.F.,Candidate of Biological Sciences, Senior research fellow (Kursk Federal Agrarian Scientific Center, Russia)

Summary.The topic of the birth of a full-fledged offspring is always relevant. Therefore, we propose a metabolic composition based on succinic acid with introductory components, tested on pregnant mares in stud farms of the Russian Federation.

Key words: biologically active substances, metabolic composition, pregnant mares

УДК 619:612.015.3:636.12

\section{КОРРЕКЦИЯ МЕТАБОЛИЧЕСКИХ ПРОЦЕССОВ РЫСИСТЫХ ЛОШАДЕЙ БИОЛОГИЧЕСКИ АКТИВНЫМИ ВЕЩЕСТВАМИ}

Ерыженская Н. Ф., с. н. с, к. б. н.

(ФГБНУ «Курский ФАНЦ», Россия)

Аннотация. Восстановление формы спортивной лошади актуальна всегда. Решить эту проблему с помощью дорогостоящих препаратов удается не всегда. Мы предлагаем 
метаболический состав на основе янтарной кислоты с вводными компонентами, апробированный в конных заводах Российской Федерации и Курском ипподроме.

Ключевые слова: спортивные лошади, янтарная кислота, биологически активные вещества

Интенсивный ипподромный тренинг ставит перед специалистами актуальную задачу: как восстановить спортивную форму лошади после её участия в розыгрыше традиционных призов. Влияние породных особенностей на результат высокого мастерства в различных классических видах конного спорта должно корректироваться биологически активными веществами с целью восстановления организма спортивной лошади в сложный физиологический период. Восстановление спортивной работоспособности лошади и нормального функционирования ее организма после тренировочных и соревновательных нагрузок - неотъемлемая составная часть правильно организованной системы спортивной тренировки, не менее важная, чем рациональный режим нагрузок. Восстановительные средства должны использоваться в полном соответствии с задачами и этапом подготовки, характером выполненной и предстоящей нагрузки [1].Педагогические средства обеспечивают повышение уровня тренированности с помощью направленного воздействия на процессы восстановления соответствующего режима тренировки.К педагогическим средствам относятся рациональное сочетание нагрузки и отдыха на всех этапах подготовки, переключение на другие виды деятельности, введение в тренировочное занятие упражнений для мышечного расслабления (преодоление препятствий «клавиш» высотой до 50 см на свободном поводу, репризы рыси и галопа на свободном поводу, репризы шага, рыси и галопа в воде, шаговые проводки в лесу и поле), изменение условий проведения занятий. Эти средства являются основными, естественными и обязательными для спортивных лошадей различной квалификации на всех этапах подготовки. Только при этом условии могут оказать желаемый эффект любые вспомогательные средства.Психологические средства направлены на снятие нервно-психологического напряжения лошади, что, в свою очередь, способствует быстрейшему восстановлению двигательной сферы и физиологических функций организма. К психологическим средствам относятся: индивидуальный подход тренера и спортсмена к лошади с учетом ее особенностей и состояния, организация разнообразного отдыха (шаговые проводки в лесу, поле, плавание, выгул в леваде совместно с другими лошадьми), применение отвлекающих факторов (музыкальное сопровождение занятия, оформление тренировочной площадки яркими предметами различной формы и подвижности), создание хорошего морального климата в отношениях «животное-человек», учет совместимости при подборе спортивной пары, размещение лошадей при транспортировке и на выезде с учетом индивидуальных особенностей животных, словесное одобрение и подкрепление лакомством желаемого поведения, выполнения команды и др.Для восстановления работоспособности также применяется широкий комплекс физических средств восстановления. Физические средства повышают защитные силы организма и устойчивость к действию различных неблагоприятных факторов среды, снимают усталость, ускоряют восстановление. Физические средства подразделяют на средства преимущественно общего воздействия (водные процедуры, ультрафиолетовое излучение) и локального воздействия (электропроцедуры, тепловые процедуры, массаж).Естественные природные факторы, в частности ультрафиолетовые лучи,способствуют нормализации функций организма лошади после физических нагрузок, снятию усталости, повышению работоспособности. Ультрафиолетовые лучи повышают иммунитет, регулируют обмен веществ, стимулируют функции центральной нервной системы. Для проведения восстановительных мероприятий для спортивных лошадей можно использоватьсолярий как источник ультрафиолетового излучения.Для быстрейшего снятия локального утомления мышц и сухожильно-связочного аппарата, особенно при их перенапряжении, используются различные видытепловых процедур: прогревание лампой «соллюкс», «биоптрон», парафиновые, грязевые и озокеритовые аппликации на сухожильносвязочный аппарат, тепловлажные укутывания (солевые попоны).Для восстановления работоспособности лошади применятсямассаж, который является высокоэффективным и естественным стимулятором восстановительных процессов, который может применяться для 
лошадей в соревновательный период с учетом правил Ветеринарного Регламента Международной Федерации конного спорта (FEI).Большая роль в обеспечении полноценного восстановления спортивной работоспособности принадлежитфармакологическим средствам, механизм действия которых связан как с повышением защитно-приспособительных свойств организма, ферментной и иммунологической активности, устойчивости к различным неблагоприятным факторам среды и стрессовым ситуациям, так и с быстрейшим снятием общего и локального утомления[2].Для ускорения восстановления, особенно при многодневных турнирах, ударных циклах тренировки и других интенсивных нагрузках для экстренного восполнения пластических и энергетических ресурсов организма лошади применяются также специальные легкоусвояемыеподкормки, сбалансированные, содержащие смесь незаменимых аминокислот с добавлением углеводов, минеральных солей, микроэлементов и витаминов[3].Этазадача, частично решаемая за счет применения биологически активных веществ, способных включаться в метаболические процессы организма и обеспечиватьжизненно важные функции в сложный период ипподромного тренинга.Метаболический состав представляют следующие компоненты: янтарная кислота, меласса, йодинол, сульфаты железа, цинка, меди, кобальта, вытяжка крапивы и натрия хлорид.Превращение янтарной кислоты в организме связано с «производством» энергии, необходимой для обеспечения жизнедеятельности.Мощность системы энергопродукции, замыкающейся на янтарной кислоте и ее использующей, в сотни раз превосходит все другие системы энергообразования организма. Именно это и обеспечивает широкий диапазон неспецифического лечебного действия янтарной кислоты и ее солей[4]. Меласса пополнит депо углеводов, улучшит вкус.Йодинол компенсирует недостаток йода,активно участвует в обменных процессах и обладает широким спектром антимикробного действия. Минералы входят в состав гормонов, ферментов, витаминов, определяют их активность и оказывают влияние на интенсивность процессов обмена веществ в организме[5].Ряд уникальных природных свойств крапивы оказывает выраженное действие на основной обмен и восполнит дефицит минералов, витаминов, дубильных, биологически и физиологически активных веществ[6]. Хлорид натрия обеспечит источник минералов и хранение состава в течении длительного времени при комнатной температуре.

Целью исследований являлось изучение влияния метаболического состава на метаболические процессы рысистых лошадей в тренинге.

Исследования проводили на Курском ипподроме в период бегового сезона 2020 г. По принципу аналогов были сформированы опытная и контрольная группы Русской и Орловской рысистой породы по двенадцать голов возраста 2...5 лет с резвостью класса 2.10и резвее. Все животные находились водинаковых условиях: способ содержания индивидуальный, кормление по зоотехническим нормам и тренинговой нагрузке. Лошади подвергались ипподромному тренингу и принимали участие в розыгрыше традиционных призов, согласно календарному плану испытаний, утвержденному АО «Россипподромы».Период между стартами составлял 14 дней. Лошадям опытной группы утреннюю порцию овса орошали 0,5 л метаболического состава 14 дней подряд. Вторая группа служилаконтролем.В крови определяли содержание общего белка, резервную щёлочность, уровень глюкозы, кальция, фосфора, железа, меди, кобальта, цинка, йода. Биохимическиеисследования проводили на анализаторе Biochem FC 200.Статистическую обработку экспериментальных данных осуществляли сиспользованием t-критерия Стьюдента.

Контроль за физиологическим состоянием лошадей опытной и контрольной групп осуществляли путём клинических наблюдений. Оценку коррекции метаболических процессов, физиологического состояния и повышения резистентности организма к интенсивному тренингу осуществляли по степени изменений изучаемых показателей крови, которую отбирали из яремной вены лошадей в состоянии покоя в первый и одиннадцатый день опыта.Проведённые исследования показали: концентрация общего белка, резервной щёлочности, глюкозы, кальция, фосфора, железа, меди, кобальта, цинка и йода в крови лошадей, получавших метаболический состав была значительно выше, чем у животных 
контрольной группы. Соответственно повышение резистентности отразилось на физиологическом состоянии, выносливости и резвости лошадей опытной группы. Необходимо отметить, лошади получавшие метаболический состав быстрее приходили в спортивную форму, что подтверждаетактуальность наших исследований.

Вывод.На основании биохимических показателей крови следует сделать заключение: метаболический состав оказал существенное влияние на коррекцию метаболических процессов рысистых лошадей в период физиологического восстановления, интенсивного тренинга и ипподромных испытаний. Метаболический состав прост в применении, в доступности компонентов и способа изготовления, что позволяет предложить его в качестве средства для коррекции метаболических процессов рысистых лошадей в период розыгрыша традиционных призов на ипподромах Российской Федерации.

Литература 1.Пашкова, Е.В., Коноплёв, В.АОсобенности буденновской породы лошадей и их влияние на спортивный потенциал /Актуальные проблемы ветеринарии и интенсивного животноводства: сб.материалов национальной науч.-практ. конф. с междунар. участием посвященной памяти д-ра биолог. наук, проф. Е.П. Ващекина.- СПб, 2021. - С. 231-236. 2. Stoilov, A.Y., Ovchinnikov, Y.D. Theoretical and methodological approaches to the consideration of rehabilitation measures in equestrian sport // Theoretical \& Applied Science. - 2019. - Vol. 10 (78).- P. 19-24. DOI: https://dx.doi.org/10.15863/TAS.2019.10.78.3. 3.Кормлениелошадей. URL: http: // www.eguestrian.ru (дата обращения 08 апреля 2021). 4.Коваленко, А.Л., Леонов, Л.В. Янтарная кислота: Фармакологическая активность и лекарственные формы // Фармацея.2000. -№ 5-6. -С. 40-42. 5. Аухатова, С.Н. Влияние йода на метаболические процессы в организме // Успехи современного естествознания. -2006. -№ 1. -С. 32-33. 6.Константинов Ю. Крапива. Уникальное природное средство. -М.: Центрполиграф, 2016. - 120 с.

\section{CORRECTION OF METABOLIC PROCESSES IN LYING HORSE BY BIOLOGICALLY}

\section{ACTIVE SUBSTANCES}

Eryzhenskaya N.F., Candidate of Biological Sciences, Senior research fellow

(Kursk Federal Agrarian Scientific Center, Russia)

Summary. Restoring the shape of a sports horse is always relevant. It is not always possible to solve this problem with the help of expensive drugs. We offer a metabolic composition based on succinic acid with introductory components, tested in stud farms of the Russian Federation and the Kursk hippodrome.

Key words: sports horses, succinic acid, biologically active substances

УДК 619:618:612.015.39:636.2

\section{ПРИМЕНЕНИЕ БИОЛОГИЧЕСКИ АКТИВНЫХ ВЕЩЕСТВ В ПЕРИНАТАЛЬНЫЙ ПЕРИОД ВЫСОКОУДОЙНЫХ КОРОВ}

Ерыженская Н. Ф., с. н. с, к. б. н.

(ФГБНУ «Курский ФАНЦ», Россия)

Аннотация: Проблема повышения продуктивности коров и сохранения ихздоровья остается острой. Поэтому актуальным является предложение метаболического состава в авторской разработке на основе янтарной кислоты с вводными компонентами, апробированного на высокопродуктивных коровах в перинатальный период на молочных комплексах Российской Федерации.

Ключевые слова: высокоудойные коровы, перинатальный период,биологически активные вещества

Актуальными проблемами современной ветеринарии является поиск эффективных средств для профилактики и лечения нарушения метаболических процессов материнского организма в периоды стельности, родов и последующей лактации,в то время как у них все 
чаще возникают нарушения обмена веществ, снижение иммунного статуса и естественной резистентности, в результате этого у животных ухудшается физиологическое состояние, снижается эффективность воспроизводства и сокращается срок их продуктивного долголетия. Высокая продуктивность молочных коров неразрывно связана с интенсивным течением обменных процессов. Нарушение обмена веществ наблюдается у всех животных, а во время вынашивания плода это приводит к глубокому патофизиологическому состоянию. Резкое снижение резистентности организма продуктивных коров ведёт к потере молочной продуктивности, воспроизводительной функции и рождению ослабленного приплода, подверженного заболеваниям различного рода[1,2].В современных условиях промышленного производства молока продолжительность продуктивного использования коровы в стаде напрямую влияет на прибыльность молочного производства, снижает затраты на ремонт и увеличивает количество лактаций высокопродуктивных животных, позволяет лучше организовать и провести селекционную работу со стадом, повысить эффективность ведения отрасли скотоводства $[3,4]$. Продуктивное долголетие коров в молочном скотоводстве рассматривается как один из важных хозяйственно-полезных признаков, по которому проводится селекционная работа. Успешность совершенствования продуктивных качеств молочного скота зависит от комплекса факторов, в том числе от используемой технологии производства молока $[4,5]$. Наращивание объемов производства молока в стране невозможно без обеспечения воспроизводства стада крупного рогатого скота. В технологии производства молока воспроизводству стада отводится первостепенное значение. Поэтому одним из главных факторов, сдерживающих увеличение производства молока в промышленных условиях России, является сокращение поголовья скота во всех сельскохозяйственных предприятиях страны. [2,6]. В данный периодприменение метаболического состава позволит корректировать обмен веществ материнского организма до нормы.Метаболический состав представляют следующие компоненты: янтарная кислота, меласса, йодинол, сульфаты железа, цинка, меди, кобальта, вытяжка крапивы и натрия хлорид.Янтарная кислота включается в метаболические процессы и обеспечивает жизненно важные функции, нормализует работу нервной системы, используется организмом при разного рода патофизиологических состояниях, мощно стимулируя выработку энергии в клетках [7]. Меласса пополнит депо углеводов, улучшит вкус, повысит жирность молока, при этом активирует сокращение матки после родов и отделение последа. Йодинол компенсирует недостаток йода и обладает широким спектром антимикробного действия, принимает активное участие в обменных процессах [8].Минералы,витамины, дубильные, биологически и физиологически активные вещества входят в состав гормонов, ферментов, витаминов, определяют их активность и оказывают влияние на интенсивность процессов обмена веществ в организме, а их дефицит пополнит уникальный природный состав крапивы,оказывая выраженное действие на основной обмен [9]. Хлорид натрия как источник минералов и консервант хранения состава при комнатной температуре.

Целью исследований являлось изучение влияния метаболического состава на обменные процессы, молочную продуктивность и репродуктивную функцию коров в перинатальный период.Изучение динамики и эффективность влияния биологически активных веществ, в частности, метаболического состава на метаболические процессы,молочную продуктивность и репродуктивную функцию высокоудойных коров в перинатальный период проводили в условиях молочного комплекса учхоза «Знаменское» Курской СХА в 2020 году с января по март месяц в период массового отёла. Для опыта отобрали две группы коров (контрольная и опытная) черно-пёстрой породы, возраста 4-7 лет по 25 голов после родов с явными симптомами нарушения обмена веществ. Все животные находились в одинаковых условиях кормления и содержания. Коровам опытной группы выпаивали метаболический состав по 0,5 л на голову сразу после родов с водопроводной водой в течение 30 дней подряд в утреннее кормление один раз в сутки, учитывая, что энергодефицитособенно опасен в первые недели после отелов. Коровам контрольного варианта отводилась сравнительная роль. $\mathrm{У}$ коров опытной и контрольной групп в первые часы и через 15 дней после родов отбирали 
кровь на биохимический анализ из ярёмной вены. Биохимические исследования крови проводили на биохимическом анализаторе StatFax 1904. Статистическую обработку экспериментальных данных проводили с использованием критерия достоверности Стьюдента.

От коров каждой группы исследовалась кровь на общий белок, резервную щелочность, кетоновые тела, кальций, фосфор, глюкозу, йод, железо, медь, цинк, кобальт, при этом учитывали физиологическое состояние животных после отёла, продуктивные качества и количество послеродовых осложнений. Необходимо отметить хорошее физиологическое состояние, в котором находились животные опытной группы после отёла, имели хороший аппетит, при этом удои были значительно выше, чем у коров контрольной группы и составили в среднем о до одиннадцати литров молока. В группе контроля этот показатель продуктивности находился в пределах до пяти литров молока.

Угнетённое состояние, повышенная температура тела, потеря аппетита у коров с послеродовыми осложнениями контрольной группы резко повлияло на продуктивные качества растелившихся коров.

Биохимический анализ крови свидетельствует о положительной динамики влияния метаболического состава на обменные процессы в организме высокоудойных коров.

Вывод. Анализ проведенных исследований позволил сделать заключение: применение метаболического состава обеспечит коррекцию метаболических процессов организма высокоудойных коров, повысит резистентность и молочную продуктивность, при этом значительно снизит послеродовую патологию коров.Новизна состава представлена в авторской разработке, способствующей частично решить актуальную проблему метаболизма в системе мер обеспечения здоровья высокопродуктивных коров в промышленном животноводстве, что позволит длительно получать максимум генетически обусловленной молочной продуктивности, воспроизводить в соответствующие сроки крепкое жизнеспособное потомство.

Литература. 1.Сафронов, С.Л., Давыдова, О.А.Эффективность разной продолжительности использования коров в условиях промышленного производства молока /Научное обеспечение развития АПК в условиях импортозамещения: Сб. научных трудов по материалам междунар. науч.-практ.конф.- СПб, 2020.- С. 208-213. 2.Сафронов, С.Л., Склярская, Т.В. Сравнительная характеристика воспроизводительных качеств коров разного возраста в ОАО «Ермолинское» / Научное обеспечение развития АПК в условиях импортозамещения:Сб. научных трудов по материалам междунар. науч.-практ. конф. - СПб, 2020. -С. 213-216. 3. Пристач, Н.В., Пристач, Л.Н.Современные проблемы нормированного питания высокопродуктивного молочного скота // Вопросы нормативно-правового регулирования в ветеринарии. - 2018. - №4. - С. 186191. 4. Виноградова, Н.Д. Продуктивное долголетие коров как фактор повышения эффективности производства молока // Научное обеспечение развития АПК в условиях реформирования: сб. науч. трудов материаловмеждунар. науч.-практ. конф. профес.-препод. состава. - СПб.: СПбГАУ, 2014. - С. 144-146. 5.Сафронов, С.Л. Научно-практическое обоснование увеличения производства продукции скота черно-пестрой породы: дис. ... д-ра с.-Х. наук: 06.02.10. - М., 2019. -304 с.

6.Давыдова, О.А. Методологический подход к оценке производственного потенциала молочного скотоводства // Вестник Южно-Уральского профессионального института. - 2015. -№1 (16). - С. 149-155. 7. Коваленко, А.Л., Леонов, Л.В. Янтарная кислота: Фармакологическая активность и лекарственные формы // Фармацея. -2000.-№ 5-6. -С. 4042. 8. Аухатова, С.Н. Влияние йода на метаболические процессы в организме // Успехи современного естествознания. -2006. -№ 1. -С. 32-33. 9. Константинов Ю. Крапива. Уникальное природное средство. -М.: Центрполиграф, 2016. - 120 с.

THE APPLICATION OF BIOLOGICALLY ACTIVE SUBSTANCES DURING THE PERINATAL PERIOD OF HIGH-PRODUCING COWS

Eryzhenskaya N.F., Candidate of Biological Sciences, Senior research fellow

(Kursk Federal Agrarian Scientific Center, Russia) 
Summary.The problem of increasing the productivity of cows and maintaining their health remains acute. Therefore, it is relevant to offer a metabolic composition in the author's development based on succinic acid with introductory components, tested on highly productive cows in the perinatal period at dairy complexes of the Russian Federation.

Key words:high-yielding cows, perinatal period, biologically active substances

УДК 619:616.98:579.852. 13

\title{
ПРИМЕНЕНИЕ ПРЕПАРАТА «ЭНТЕРОФУРИЛ» ПРИ ЛЕЧЕНИИ КЛОСТРИДИОЗА У ЖИВОТНЫХ
}

Ефимов В.Я., Красков Д.А.

Научный руководитель: ассистент Понамарев В.С. (ФГБОУ ВО СПБГУВМ, Россия)

\begin{abstract}
Аннотация: Ежедневно в ветеринарные клиники обращаются хозяева животных, с похожими друг на друга симптомами, которые показывают наличие бактериальной инфекции внутри животного. Несмотря на попытки ветеринарных врачей оказать воздействие на владельцев, чтобы предостеречь их и оградить питомцев от возникновения нежелательной бактериальной флоры, некоторые животные всё же заражаются. Но фармакология не стоит на месте и разрабатывает всё больше препаратов для борьбы с заболеваниями такого рода. Одним из таких является препарат «Энтерофурил».
\end{abstract}

Ключевые слова: Клостридиоз у животных, Энтерофурил, терапия, клиническая диагностика.

Введение: Большинство хозяев продолжает пренебрегать необходимыми правилами защиты своего питомца, вопреки советам ветеринарных специалистов. Одним из итогов таких нарушений становится заражение питомца бактериальными инфекциями, а именно клостридиозом. Причиной появление бактерий в желудочно-кишечном тракте животного может стать невнимательность владельца, когда животное подбирает и ест еду с улицы, халатное отношение к содержанию животного, когда животное может заразиться, находясь в антисанитарных условиях.Также одной из причин может стать перенос бактерий одним животным к другому, как правило, не все владельцы сразу обращаются в клиники, и до этого момента здоровые животные могут заразиться, находясь рядом со своим больным товарищем.[1,2]

Владельцам в первую очередь следует обратить внимание на состояние и поведение своего питомца. Если будут заметны симптомы воздействия на организм клостридий(жидкий стул, рвота, повышенная температура тела, вялость, пониженный или отсутствующий аппетит), следует незамедлительно обратиться к ветеринарному врачу. Если не принять меры, данные симптомы могут перейти из острой фазы в хроническую и стать причиной гастрита или энтерита. [3]

После обращения в клинику, ветеринарный врач соберёт анамнез и возьмёт анализы (анализ кала, мазок прямой кишки для ПЦР)[4], для подтверждения наличия именно бактериальной инфекции. После получения положительного ответа приступит к лечению, с применением противомикробных препаратов, например Энтерофурил.

Энтерофурил- это порошок желтого цвета или порошок желтого цвета с включениями в виде небольших кусочков спрессованной массы, или спрессованным порошком желтого цвета, который рассыпается при легком нажатии, содержится в капсулах. Содержит дейсвующее вещество нифуроксазид - 100мг; вспомогательные вещества - сахароза 36мг, крахмал кукурузный - 41.12 мг, целлюлоза микрокристаллическая - 5.1 мг, магния стеарат 3.78 мг. 
Материалы и методы исследования:Согласно журналу клиники, о пациентах, было установлено, что количество обращений владельцев к врачу с симптомами бактериальной инфекции, насчитывает 25 животных с июля по декабрь 2020 года, в их числе 17 кошек и 8 собак.

При обследовании и сборе анамнеза, стало ясно, что у животных может наблюдаться вирусное или бактериальное заболевание [5]. Для того, чтобы поставить точный диагноз, было принято решение взять анализ кала и мазок прямой кишки для ПЦР диагностики, для получения более точной картины о болезни животных. После сбора данных, все анализы отправлялись в лабораторию, где с помощью обнаружения присутствия частей клостридий (при ПЦР диагностике) или их роста, после посева на питательной среде (анализ кала),подтверждали наличие выявления наличия клостридиоза у животного.

После того, как приходил положительный ответ, животному прописывался препарат «Энтерофурил», в форме выпуска в виде капсул. До прихода ответов из лаборатории, лечение осуществлялось симптоматически. Кроме этого препарата, некоторым животным, по причине их обезвоживания, применялся раствор натрия хлорида и Рингера-Локка. Курс лечения препаратом «Энтерофурил» составлял $2-3$ недели, в зависимости от состояния животного, согласно принципам гуманного отношения к животным[6].

Результаты исследований: После курса в $2-3$ недели, состояние животного возвращалось к норме, все симптомы, вызванные развитиемклостридий, прошли, и после осмотра указывалось, как удовлетворительное. Препарат продолжали давать ещё несколько дней, после чего повторно отправляли анализы кала и мазок прямой кишки (для ПЦР диагностики) в лабораторию, откуда приходил отрицательный ответ.

Заключение: Препарат «Энтерофурил» показал высокую эффективность в борьбе с опасной бактериальной флорой вида clostridiumperfingens. Не стоит забывать провнимательность владельцев, которые своевременно обратили внимание на состояние своего питомца, и грамотные действия ветеринарного специалиста. Итогом применения препарата «Энтерофурил» стало полное выздоровление всех 25 животных (17 кошек и 8 собак), владельцы которых обратились за помощью.

Литература: 1. Барышников П.И. Лабораторная диагностика бактериальных болезней животных. // П.И. Барышников. М.: Лань, 2019. 712 с. 2. Сидорчук А.А. Ветеринарная санитария: Учебное пособие. // А.А. Сидорчук. М.: Лань, 2011. 368 с. 3. Рэмси Я. Инфекционные болезни собак и кошек. // Я. Рэмси, Б. Теннат. М.: Аквариум, 2019. 304 с. 4. Понамарев, В. С. Полимеразная цепная реакция с электрофоретической детекцией продуктов амплификации / В. С. Понамарев, С. А. Макавчик // Молодежный научный форум: естественные и медицинские науки. - 2016. - № 10(38). - С. 148-152. 5. Peculiarities of the manifestation of bronchial asthma in cats in metropolis environment / L. Sabirzianova, P. Anipchenko, A. Yashin [et al.] // Journal of Animal Science. - 2019. - Vol. 97. - No S3. - P. 214215. - DOI 10.1093/jas/skz258.439. 6. Анализ нормативных документов, регламентирующих требования к проведению доклинических исследований ветеринарных препаратов / С. В. Герасимов, В. С. Понамарев, Н. Л. Андреева [и др.] // Вопросы нормативно-правового регулирования в ветеринарии. - 2020. - № 3. - C. 27-29. - DOI 10.17238/issn20726023.2020.3.27.

\section{APPLICATION OF THE PREPARATION "ENTEROFURIL" IN THE TREATMENT OF CLOSTRIDIOSIS IN ANIMALS}

Efimov V.Y., Kraskov D.A., Scientific adviser: assistant V.S. Ponamarev (FSBEI HE St.Peterburg SUVM, Russia)

Annotation: Every day, the owners of animals come to veterinary clinics with similar symptoms, which indicate the presence of a bacterial infection inside the animal. Despite attempts by veterinarians to influence owners to warn them and protect pets from the development of unwanted bacterial flora, some animals still become infected. But pharmacology does not stand still and is developing more and more drugs to combat diseases of this kind. One of these is the drug "Enterofuril".

Key words:Clostridiosis in animals, Enterofuril, therapy, clinical diagnosis. 


\title{
ЭФФЕКТИВНОСТЬ ПОВИЦИДА ПРИ ЛЕЧЕНИИ КОРОВ С ПОДОДЕРМАТИТАМ
}

\author{
Журба В.А., доц., к.в.н., Ковалев И.А., асс.магистр вет. наук
}

(УО ВГАВМ, Беларусь)

\begin{abstract}
Аннотация. Разработка и внедрение в ветеринарную практику экологически чистых и эффективных препаратов для лечения продуктивных животных с болезнями кожи и ее производных есть и остается первостепенной задачей ветеринарной фармации. В особенности востребованына рынке препараты, по которым отсутствуют сроки ожидания по продукции.
\end{abstract}

Ключевые слова: коровы, лечение, хирургические болезни, Повицид.

На сегодняшний день для лечения крупного рогатого скота с поражениями кожи предлагается ряд препаратов. Многие из них в своем составе содержат антибиотики, что вследствие лечения приводит к ограничению использования продукции (молока) и увеличивает период ожидания, то есть период от последнего введения препарата до того момента, когда его остаточные количества не обнаруживаются в молоке.В тоже время если применяется постоянно один и тот же препарат то со временем может развиваться привыкание к применяемым лекарственным средствам, поэтому постоянно необходимо проводить ротацию используемых препаратов и их композиций. Особый интерес имеет необходимость применения таких современных препаратов у животных с хирургической патологией[1;2].

Применение лекарственных средств таким животным должно быть эффективным как для профилактики, так и для лечения животных с хирургическими болезнями. Одновременно с этим, необходимым условием является положительное влияние на скорость и характер заживления пораженных тканей и выздоровления животных, что влечет за собой восстановление продуктивности до болезни[1;2].

Цель определить путем проведения производственных испытаний эффективность препарата «Повицид» при лечении крупного рогатого скота сс гнойными пододерматитами.

Материалы и методы.Производственные испытания препарата «Повицид» проводили на базе клинике кафедры общей, частной и оперативной хирургии УО «Витебская ордена «Знак Почета» государственная академия ветеринарной медицины» и на одном из хозяйств Витебского района Витебской области на дойном поголовье крупного рогатого скота. Для проведения опыта было отобрано 14 животных с гнойнымипододерматитами. Коровы были сформированы в 2 группы (по 7 животных в каждой), по принципу условных клинических аналогов (одинакового веса, породы, возраста, продуктивности).

На первом этапе для объективного суждения об эффективности применяемого лечения проводили наблюдение за местным и общим статусом исследуемых коров. С этой целью у животных из каждой группы ежедневно определяли общую местную температуру тела, пульс, дыхание ируминацию, дополнительноместно определяли болезненность тканей, наличие гиперемии, размеры и сроки резорбции воспалительных отеков, их консистенцию, характер экссудата, время образования и характер развития грануляции.

Одновременно до начала опыта (фон, контроль), а также на $3,8,13$ и 18-е сутки после начала лечения осуществляли морфологическое исследование крови, полученной из яремной вены утром перед кормлением, соблюдая все правила асептики и антисептики.

Крупно рогатый скот фиксировали в стоячем положении в станке, поднимали пораженную конечность с помощью лебедки. Подготовку операционного поля проводили по общепринятой методике с применением современных антисептических препаратов. В последующем проводили механическую расчистку копытец у животных всех групп, проводили туалет раны (удаление экссудата, механическое очищение раны- путем воронкообразной выборки копытного рога, обработку $3 \%$ раствором перекиси водорода и раствором перманганата калия 1:10000), а также механическую антисептику.

В дальнейшем животные опытной группы были подвергнуты лечению с применением препарата«Повицид», применяли его1 раз в сутки путем наружного нанесения с помощью 
шпателя на пораженные участки с последующим наложением бинтовой повязки, замену повязки с Повицидом проводили через 2-е суток, до полного выздоровления животных.

В контрольной группе животным применяли традиционное лечение с использованием, после проведения ортопедической и первичной хирургической обработки, ихтиоловой $10 \%$ мази, замену повязки проводили так же через 2-е суток, до полного выздоровления животных.

Результаты исследований. В результате исследований установлено, что у больных животных всех групп отмечалась хромата опорного типа. Чаще всего поражения диагностировались на тазовых конечностях, при этом больные животные отвадили конечность незначительно в сторону и назад, или же выносили далеко вперед с переносом тяжести в центральную часть мякиша. При двухстороннем поражении латеральных пальцев животные часто переступали с конечности на конечность или отводили их в сторону, что б уменьшить тяжесть на латеральных пальцах.

В опытной группе, где применяли препарат «Повицид» общее состояние всех коров было удовлетворительным, температура тела, частота пульса и дыхания находилась в верхней границе нормы. В области поражения наблюдалиськлинические изменения: в первый день отмечалась отечность в области раны. Ткани в зоне отека горячие, болезненные. На 7 день у животных данной группы отмечалась болезненность при пальпации, незначительное повышение местной температуры, с незначительным количеством экссудата. На 15 день болезненность тканей в зоне раны были незначительны. Поверхность раны сухая, местная температура окружающих тканей не повышена. Коровы стали опираться на конечность. Выздоровление наступало в среднем на 21 - 22 день.

В контрольной группе, где применялась схема лечения с 10\% ихтиоловой мазью, было установлено, что общее состояние всех коров было удовлетворительным. В области поражения наблюдались клинические изменения: в первый день отмечалась болезненность в области поражения. Ткани в области патологического процесса горячие, болезненные. На 7 день у животных данной группы из раны выделялся гнойный экссудат, отмечалась болезненность с повышенной местной температуры. На 13 день поверхность влажная, в центре - светло-серого, а по периферии - коричневого цвета. Воспалительная припухлость и болезненность незначительны. На 19 день повышения местной температуры в области копытного рога не отмечалось. Выздоровление животных наступало в среднем на 26 - 27 день с начала лечения.

Заключение. Основываясь на полученных результатах проведенных клинических испытаний, можно сделать вывод, что ветеринарный препарат «Повицид» оказывает выраженный терапевтический эффект на процессы регенерации тканей у крупного рогатого скота. Препарат подавляет проявление воспалительной реакции, уменьшает продолжительность течения процесса, способствует формированию клеточного иммунитета и исключает повторное возникновение болезни, что в свою очередь сокращает сроки выздоровления животных в среднем на 5 дня.

Литература Веремей, Э. И.Лечебно-профилактические мероприятия для крупного рогатого скота при хирургической патологии на молочных комплексах Витебской области : рекомендации / Э. И. Веремей, В. М. Руколь, В. А. Журба ; Витебская государственная академия ветеринарной медицины. - Витебск : ВГАВМ, 2011. - 27 с. 2. Ковалёв, И. А. Комплексное лечение крупного рогатого скота с гнойными пододерматитами / И. А. Ковалёв, В. А. Журба // Молодые ученые - науке и практике АПК :[Электронный ресурс] материалы Международной научно-практической конференции молодых ученых, Витебск, 5-6 июня 2018 г. / УО ВГАВМ ;редкол : Н. И. Гавриченко (гл. ред.) [и др.]. - Витебск : ВГАВМ, 2018. C. 17-18. - Режим доступа : http://www.vsavm.by. свободный. - Загл. с экрана. - Яз.рус. 


\section{EFFECTIVENESS OF POVICIDE IN THE TREATMENT OF COWS WITH PODODERMATITIS}

Zhurba V. A., Associate Professor, PhD, Kovalev I. A., Acc. Master of vet. Sciences' (UO VGAVM, Belarus)

Summary. The development and introduction into veterinary practice of environmentally friendly and effective drugs for the treatment of productive animals with skin diseases and its derivatives is and remains the primary task of veterinary pharmacy. Especially in demand on the market are drugs for which there are no waiting periods for products.

Keywords: cows, treatment, surgical diseases, Povicide.

УДК 579.842.14.044:615.33

\section{АНТИБИОТИКОРЕЗИСТЕНТНОСТЬ ШТАММОВ SALMONELLA, ИЗОЛИРОВАННЫХ ИЗ РАЗЛИЧНЫХ ИСТОЧНИКОВ}

Забровская А.В., доктор ветеринарных наук, доцент кафедры, ФБОУ ВО СПбГУВМ, Россия Егорова С.А., доктор медицинских наук, старший научный сотрудник, ФБУН НИИЭМ имени Пастера, Россия

Аннотация В работе представлены результаты исследования чувствительности к антимикробным препаратам 424 штаммов Salmonella, изолированных от сельскохозяйственных животных и из продуктов питания животного происхождения в $2004-$ 2019 гг. Установлено, что 73,1\% штаммов являются антибиотикорезистентными, из них 40,1\% - полирезистентные. Устойчивость штаммов Salmonella наиболее распространенных сероваров S. Infantis, S. Typhimurium, S. Enteritidis имеет специфические различия.

Ключевые слова: Salmonella, чувствительность, резистентность

Была изучена чувствительность к антимикробным препаратам (АМП) у 424 штаммов Salmonella, выделенных в 2004 - 2019 гг. на территории СЗФО РФ от сельскохозяйственных животных (крупный рогатый скот, свиньи, птица) и из продукции, полученной от животных данных видов.

Чувствительность к АМП определяли диско-диффузионным методом, согласно клиническим рекомендациям «Определение чувствительности микроорганизмов к антимикробным препаратам» [1]. Использовали среду Мюллера-Хинтон и диски (Oxoid), содержащие АМП восьми фармакологических групп: аминопенициллины, расширенного спектра, карбапенемы, хинолоны, аминогликозиды, нитрофураны, тетрациклины, амфениколы, сульфаниламиды и триметоприм/сульфаметоксазол.

К препаратам всех исследованных групп АМП были чувствительны 26,9\% штаммов. Доля штаммов, устойчивых к АМП, принадлежащих к $1-7$ группам, составила 73,1\%, в то время как среди штаммов Salmonella, выделенных из аналогичных источников в 1983 - 1993 гг., устойчивых к препаратам 1 - 3 групп было всего 8,1\%. [2]. К препаратам, принадлежащим к одной и двум группам АМП было устойчиво $31,1 \%$, а доля полирезистентных (устойчивых к трем и более группам АМП) составила 40,1\%, причем 1,7\% обладали экстремальной резистентностью (чувствительные к одной или двум группам АМП).

Полирезистентные штаммы принадлежали к 22 сероварам, подавляющее большинство из которых составляли S.Typhimurium $(42,4 \%$ от общего количества полирезистентных) и S.Infantis (34,7 \%). Выделение экстремально резистентных штаммов отмечали с 2014 года.

Отдельно была проанализирована резистентность к АМП штаммов наиболее распространенных у животных и актуальных для людей серологических вариантов Salmonella:

S. Infantis, S. Typhimurium, S. Enteritidis. 
Устойчивость к 1 - 5 группам АМП выявлена у 97,1 \% штаммов серовара S.Infantis, причем доля полирезистентных насчитывала 85,5\%. Процент устойчивых штаммов этого серовара, выделенных в 1983 - 1993 гг., составлял 8,8\% [2], таким образом, за три десятилетия доля резистентных штаммов увеличилась в несколько раз, что отражает общемировую тенденцию [3, 4]. Эпидемиологический «успех» распространения резистентных клонов штаммов S.Infantis ряд исследователей объясняет наличием адаптационных механизмов к обитанию в условиях промышленного животноводства [5].

Из трех анализируемых сероваров S.Typhimurium являлся единственным, штаммы которого обладали экстремальной резистентностью к АМП (2,2\% от общего количества штаммов данного серовара). Чувствительными были 11,2 \% штаммов, процент устойчивых к одной и двум группам АМП составил 7,9\%. Доли полирезистентных штаммов у S.Typhimurium и S.Infantis не имеют статистически достоверных различий: $80,9 \%$ и 85,5\% соответственно. Согласно отчетам EFSA (European Food Safety Authority) и ECDC (European Centre of Disease Prevention and Control), в странах ЕС процент полирезистентных штаммов у данных сероваров в 2018 году составлял 50,0\% - 90,0\%, что согласуется с нашими результатами [6].

Штаммы S.Enteritidis отличались наиболее значительной долей чувствительных к АМП (32,4\%), устойчивыми были 67,6\% штаммов, причем значительная часть $(59,2 \%)-$ только к одной или двум группам АМП. Доля полирезистентных штаммов составила всего 8,5\%. Среди штаммов S.Enteritidis, выделенных в 1983 - 1993 гг., устойчивыми были 37,7\%, что было значительно выше, чем у штаммов сероваров S.Typhimurium и S.Infantis, изолированных в тот же период $(8,8 \%)[2]$. Таким образом, за прошедшие десятилетия отмечается тенденция к снижению процента устойчивых штаммов S.Enteritidis, в отличие от S.Infantis S.Typhimurium. Среди полирезистентных штаммов самый распространенный профиль устойчивости включал пять препаратов: хлорамфеникол, ампициллин, тетрациклин, стрептомицин и сульфаниламид (профиль ACSSuT). Штаммы, обладающие этим профилем, принадлежали к сероварам S.Typhimurium (93,7\%), S.Agona и S.Dublin. Штаммы с профилем ACSSuT широко распространены во многих странах как правило встречаются у штаммов S.Typhimurium $[4,7]$. В изученной коллекции штаммов, Salmonella с профилем ACSSuT были выделены от больных и павших свиней (Ленинградская область) и из продукции свиноводства (Ленинградская область, Белоруссия, Бразилия, Канада).

Второй по распространению профиль множественной резистентности включал три препарата: тетрациклин, налидиксовую кислоту и нитрофурантоин. Им обладали только штаммы S.Infantis, выделенные в 2006 - 2013 гг. от птицы или из продукции птицеводства, как отечественного производства, так и поступившей из-за рубежа (Германия, Литва, Португалия, Франция, Бразилия).

При изучении олигонуклеотидных последовательностей QRDR-региона гена gyrA устойчивых к фторхинолонам штаммов сероваров S.Enteritidis и S.Infantis были обнаружены единичные замены, обусловливающие резистентность к хинолонам. У двух штаммов S.Enteritidis замена серина на фенилаланин отмечена в 83 кодоне, у одного штамма замена аспарагиновой кислоты на глицин в 87 кодоне. У трех штаммов S.Infantis замена была одинакова - аспарагиновой кислоты на тирозин в 87 кодоне. Замены в тех же локусах отмечены у штаммов Salmonella тех же сероваров, выделенных от людей $[6,8,9]$.

Были выявлены 6 штаммов, устойчивых к цефалоспоринам 3-4 поколения, что составило 1,4\% от общего количества. У штаммов S.Haifa и S.Derby продукция $\beta$-лактамаз расширенного спектра (БЛРС) была выявлена методом двойных дисков: синергизм цефалоспоринов с клавулановой кислотой. Методом ПЦР с использованием специфических праймеров у этих штаммов были выявлены гены blaCTX-М, кодирующие синтез БЛРС генетического семейства CTX-M. У 2 штаммов S.Kentucky, выделенных продукции птицеводства (США) и 2 штамма S.Dublin, изолированных из внутренних органов крупного рогатого скота (Тосненский район Ленинградской области) фенотипически была выявлена 
продукция AmpC-цефалоспориназ (синергизм цефалоспоринов и клоксациллина) и в ПЦР обнаружены гены blaCMY-2, кодирующие продукцию AmpC-цефалоспориназы CMY-2.

Штаммы Salmonella, продуцирующие БЛРС и AmpC-цефалоспориназы, обнаружены во многих странах. Многими авторами отмечено, что принадлежность к БЛРС генетическим семействам и их распространение на разных континентах имеет географические особенности $[3,5]$.

Следовательно, изучение профилей резистентности микроорганизмов и генетических детерминант, обуславливающих механизмы устойчивости к АМП, может дать дополнительную информацию при изучении путей распространения штаммов микроорганизмов, вызывающих инфекционные болезни животных и человека.

Литература: 1. Определение чувствительности микроорганизмов к антимикробным препаратам. Клинические рекомендации. Режим доступа: http://www.antibiotic.ru/minzdrav/files/docs/clrec- dsma2018.pdf 2. Забровская А.В. Биологические свойства сальмонелл, выделенных от животных и из объектов внешней среды в Северо-Западных областях России: дисс. ... канд. вет. наук: 16.00.03/Забровская Анна Владленовна. - СПб, 1996. - 176 С. 3. EFSA (European Food Safety Authority) and ECDC (European Centre of Disease Prevention and Control), 2020. The European Union summary report on antimicrobial resistance in zoonotic and indicator bacteria from humans, animals and food in 2017/2018. //EFSA Journal. - 2020. - Vol.18. - №3. - P.6007 DOI: 10.2903/j.efsa.2020.6006 Режим доступа: https://efsa.onlinelibrary.wiley.com/doi/epdf/10.2903/j.efsa.2020.6007 4. Franco, A. Emergence of clonal lineage of multidrug-resistant ESBL-producing Salmonella Infantis transmitted from broilers and broiler meat to humans in Italy between 2011 and 2014/ A.Franco, P.Leekitcharoenphon, P.Alba, G.Cordaro, M.Iurescia et al.//PloS ONE. - 2015. - 10. - e0144802 DOI:10.1371/jourmal.pone.0144802. 5. EFSA and ECDC (European Centre of Disease Prevention and Control), 2018. The European Union summary report on trends and sources of zoonoses, zoonotic agents and food-borne outbreaks in 2017 // EFSA Journal. - 2018. - Vol.16. - №12. P.5500 DOI: 10.2903/j.efsa.2018.5500. Режим доступа: https://efsa.onlinelibrary.wiley.com/doi/epdf/10.2903/j.efsa.2018.5500 6. EFSA (European Food Safety Authority) and ECDC (European Centre for Disease Prevention and Control), 2015. EU Summary Report on antimicrobial resistance in zoonotic and indicator bacteria from humans, animals and food in 2013//EFSA Journal. - 2015. - Vol.3. - №2. - P.4036 doi:10.2903/j.efsa.2015.4036. 7. Nakaya, H. Life-threatening infantile diarrhea from fluoroquinolone-resistant Salmonella enterica Typhimurium with mutations in both gyrA and parC / H. Nakaya, A. Yasuhara, K. Yoshimura, Y. Oshihoi, H. Izumiya, H. Watanabe // Emerg Infect Dis. - 2003. - Vol. 9(2). - P. 255-257. 8. Козырева, В.К. Независимое приобретение резистентности к хинолонам у клональнородственных нозокомиальных штаммов Salmonella Typhimurium вследствие гипермутабельности/ В.К.Козырева, М.В.Эйдельштейн, Д.В.Тапальский, И.С.Азизов, Р.С.Козлов// Клиническая антимикробная химиотерапия. - 2012. - т.14. - №2. - С.153-161. 9. Cavaco, L.M. qnrD, a novel gene conferring transferable quinolone resistance in Salmonella enterica serovar Kentucky and Bovis morbificans strains of human origin / L.M.Cavaco, H.Hasman, S.Xia, F.M. Aarestrup//Antimicrobial Agents and Chemotherapy.- 2009. - Vol.53. - P.603-608.

\section{ANTIMICROBIAL RESISTANCE OF SALMONELLA STRAINS, ISOLATED FROM} DIFFERENT SOURSES

Zabrovskaia A.V., PhD, associate professor, FSBEI HE St.Peterburg SUVM, Russia Egorova S.A., $\mathrm{PhD}$, senior researcher, Saint-Petersburg Pasteur Institute, Russia

Summary This article presents the results of a study of antimicrobial susceptibility of 424 Salmonella strains isolated from farm animals and animal products. It was found that $73,1 \%$ of the studied strains were resistant to $1-7$ groups of antimicrobials, and 40,1\% were multidrug resistant (MDR). The antimicrobial resistance of Salmonella strains of the most common serovars S. Infantis, S. Typhimurium, and S. Enteritidis has specific differences.

Key words: Salmonella, susceptibility, resistance 


\title{
ФИЗИОЛОГИЧЕСКИЕ ИЗМЕНЕНИЯ В КРОВИ КОРОВ НА ФОНЕ КАТОЗАЛА
}

\author{
Завалишина С.Ю., д.б.н., доцент
}

ФГБОУ ВО Российский государственный социальный университет, Россия

\begin{abstract}
Аннотация.В результате применения шести курсов катозала по 20,0 мл ежесуточно на головуу лактирующих коров черно-пестрой породыудалось достичь биологически выгодных изменений показателей крови, отражающих белковый и углеводный обмен. Полученные результаты являются проявлениями активации на фоне катозалаанаболических процессов в метаболизме коров. Наступающие под действием катозалаизменения гематологических показателях белкового и углеводного обмена у коров весьма благоприятныдля
\end{abstract} интенсификации процесса лактации.

Ключевые слова: лактация, кровь, корова, катозал, физиология.

В условиях современности становится все более необходимой дальнейшая интенсификация животноводства за счет поиска резервов по увеличению его продуктивности [1].Одним из таких резервов по повышению общей жизнеспособности и продуктивности лактирующих коров является применение у них веществ, обладающих свойством биостимулятора. Это связано с их способностью интенсифицировать основные биологические процессы в организме животных. Известна связь между составом крови продуктивных животныхс их общим физиологическим статусом и хозяйственно важными показателями [2]. Для поиска наиболее оптимальных в этом плане препаратов и схем их применения необходимо вести дальнейшие исследования с уточнением характера их влияния на общие гематологические параметры [3]. Одним из перспективных биостимуляторов представляется катозал, способный усиливать различные биологические процессы у многих продуктивных животных.

Цель: выяснить особенности влияния катозалана основные показатели крови у актарующихкоров черно-пестрой породы.

Материалыиметодыисследований.Работа проведена на 48 здоровых коровах чернопестрой породы, благополучно лактирующих в течение месяца после оптимально протекавших второй стельности и отела. Все животные обладали сравнимым общим функциональным статусом и уровнем молочной продуктивности. Коровыслучайным образом были разделены на контрольную и опытную группы по 24 головы в каждой группе.

Животные, составившие опытную группу, прошли 6 курсов внутримышечных инъекций катозала (фирма производитель «BayerHealthcare LLC», США) ежесуточно по 20,0 мл в утренние время. Каждый курс инъекций продолжался по 7 суток. Между этими курсами инъекций выдерживались интервалы без применения препарата по 7 суток. Животные обоих групп обследовались в исходе и на седьмые сутки после последнего введения катозала в шестом курсе его использования у коров опытной группы.

Морфологические параметры крови оценивали по общепринятым в биологии методикам: в крови подсчитывали количества эритроцитов, тромбоцитов и лейкоцитов в стандартной камере Горяева. Уровень гемоглобина у животных оценивали, применяя метод Сали. С помощью биохимического анализатора «Expressplus»,Siemens (Германия) в их крови определяли концентрации общего белка, мочевины и глюкозы. Статистическая обработка полученных в ходе работы результатов велась программным пакетом "StatisticsforWindows v. 6.0", "MicrosoftExcel".

Результатыисследований. У опытных коров на фоне катозала найдено достоверное увеличение на 29,8\% количества в крови эритроцитов до уровня $129,7 \pm 2,0 г /$ л. Достигнутое значение превышало уровень контрольной группы на 25,3\%.

Исходный уровень гемоглобина был сравним у коров обоих групп. За время исследования на фоне катозала он у опытных животных возрос на 29,8\%, оставаясь в контроле 
без существенных изменений. В результате к концу наблюдения в опытной группе количество гемоглобина превышало контрольный уровень на 25,3\%.

Изначально в крови обоих групп были выяснены сходные уровни лейкоцитов. В конце наблюдения уопытных животных этотпоказательповысился на43,5\%. При этом в группе контроля существенных изменений числа лейкоцитов в крови отметить не удалось. В результате уровень данного параметра у коров опытной группы в конце исследования превышал уровень в контроле на $39,1 \%$.

На фоне применения катозала исходно нормальное количество тромбоцитов в крови животныхпонижалось на $16,3 \%$, тогда как в контрольной группе оно оставалось без изменений. В конце исследования в опытной группе данный параметр уступал значениям контроля на 19,8\%, что весьма положительно сказывалось на протекании у них процессов микроциркуляции.

Содержание белка в кровиобследованных коровобоихгруппизначально было сравнимо и находилось на уровне общепринятых нормативных значений.За время выполнения исследования количество общего белка претерпело динамику, более выраженную у опытных животных. За ходе наблюдениявопытнойгруппе отмечено достоверное повышение общегобелка(на30,3\%по сравнениюсисходом), что говорило об усилении на фоне катозала анаболических процессов. В конце исследования уровень общего белка у опытных коров превышал аналогичный показатель у контрольных животных на 24,5\%.

Плазменный уровень мочевины у коров за время наблюдения сохранялся впределах физиологическойнормы.К концу исследования в контрольной группе ее концентрация в плазме возросла всего на $1,6 \%$, а в опытной группе ее количество уменьшилось на10,9\%поотношению к исходу.За период выполнения наблюдения этот показатель в опытнойгруппеживотных оказался меньше контрольного на 13,1\%,указывая на интенсификацию усвоения азота из рациона у коров, получавшихкатозал.

Определение уровня глюкозы показало сравнимость ее исходной концентрации в крови в обоихгруппахнаблюдения и сохранение еев течение всего исследования на уровне физиологической нормы. При этом в опытной группе в конце исследования ее уровеньпревышал таковой в контроле на 11,6\%.

Заключение. Применение в течение шести недельных курсов катозала удалось достичь биологически весьма выгодных изменений в крови у лактирующих коров чернопестрой породы. Эти изменения являются проявлениямиразвивающихся позитивных сдвигов в метаболизме белков и углеводов у коров при введении им катозала, способствующих активации протекания у них лактации и анаболических процессов.

Литература.1.Кутафина, Н.В. Динамика физиологических показателей телят в раннем онтогенезе / Н.В.Кутафина, И.Н. Медведев // Зоотехния. -2015. - №3.- С.25-27. 2. Максимов, В.И. Оценка тромбоцитарных функций у телят и поросят в раннем онтогенезе / В.И.Максимов, И.Н. Медведев // Ветеринария. - 2008.- №11. - С.50-54. 3. Медведев, И.Н. Способность основных форменных элементов крови к агрегации у телят в фазу молочного питания /И.Н.Медведев, Т.И. Глаголева//Зоотехния. - 2015.- №7. - С.23-24.

\section{PHYSIOLOGICAL CHANGES IN BLOOD COWS AGAINST THE BACKGROUND OF}

\section{KATOZAL}

ZavalishinaS.Yu., D.S., associate professor

FSBEI HE Russian State Social University, Russia

Summary. As a result of the use of six courses of Katozal $20.0 \mathrm{ml}$ daily on the head in lactating black-motley breed cows managed to achieve biologically advantageous changes in blood indicators reflecting protein and carbohydrate exchange. The results obtained are manifestations of activation against the background of the Katozalof anabolic processes in the metabolism of cows. Coming under the action of knotose changes in the hematological indicators of protein and carbohydrate exchange in cows are very favorable to intensify the lactation process.

Keywords: lactation, blood, cow, Katozal, physiology. 


\title{
СРАВНИТЕЛЬНАЯ ХАРАКТЕРИСТИКА ОТЕЧЕСТВЕННЫХ И ЗАРУБЕЖНЫХ РАЗРАБОТОК ЛЕКАРСТВЕННЫХ СРЕДСТВ В ЖИВОТНОВОДСТВЕ
}

\author{
Земляная В.В., студент \\ (ФГБОУ ВО «СПбГУВМ)
}

\begin{abstract}
Аннотация: Как мы знаем, создание новых лекарственных средств занимает достаточно большое количество времени, в основном от 5 до 10 лет. Именно поэтому организовали этапы по разработке препаратов, чтобы точно сопоставить их эффективность, безопасность и значимость в животноводческой сфере. Одним из основныхфакторов разработки лекарственных препаратов является врачебная сфера: необходимо постоянно исследовать новые и совершенствовать уже имеющиеся фармацевтические препараты.
\end{abstract}

Ключевые слова: доклинические исследования, лекарственные средства, животноводство.

Одним из основныхпричин отставания является признак того, что за рубежом не зарегистрирован ни один отечественный препарат, действительно удовлетворяющий нуждам ветеринарии, который был бы разработан и доведён до рынка отечественными специалистами в области доклинических исследований и ранней разработки. Но также, наша страна не представлена в подходящих международных организациях. Проблемы терминологии и классификации также играют важную роль, ведь приразработке новых лекарственных средствв доклинических исследованиях в основном изучают непосредственно действующее вещество и его метаболит. Необходимость изучения метаболитов подтверждается тем, что в немногих случаях они оказывают фармакологические или токсические действия на организм животного, а не исходное соединение, которое поступило в организм. Ещё одним важным признаком являются животные модели, которые используют в доклинических исследованиях в целях безопасности, к ним относятся токсикологические исследования[1] и исследования фармакологической безопасности[2], за рубежом законодательным требованием является изучение безопасности препаратов на двух видах животных, в тех или иных доклинических исследованиях безопасности используются 4-6 видов, потому чтолюбой вид животного подходит или не подходит для изучения тех или иных факторов безопасности.

В нашей стране среди главных условий, обеспечивающих качество, безопасность и эффективность лекарственных средств, представлено пятью этапами. Первый - это правильная фармацевтическая разработка,в данном этапе обосновывается необходимость создания препарата для определённых групп животных, доказывают его состав, выбор лекарственной формы и технологии его изготовления и обеспечение стабильности. Второй этап-использование качественных компонентов для разработки, прежде всего фармацевтических формул.Третий этаппредставлен соблюдением всех требований к производству и обеспечению контроля качества готового продукта. Методы контроля стараются выбирать с расчётомтого, чтобы обеспечить определение качества в течение полного срока годности препарата. Четвёртый этап представлен доклиническими исследованиями, то есть изучение фармакологических и токсикологических свойств, а также исследование фармакокинетических свойств лекарственного средства. После этого обосновывают дозировку, схему применения и сроки использования в животноводстве.Все доклинические исследованиядолжны быть научно обоснованы. И пятый этап является заключительным, в нём доказывают эффективность лекарственного средства в рамках проведения клинических исследований.

За рубежомпредставлены следующие этапы разработки лекарственных средств. Первый - выявление областей стимулирования, то есть непосредственно установление экономических ориентиров и финансирование, сюда входят: разделение концепций получения прибыли и объёма продаж; создание необходимых инструментов стимулирования; заключение определённых сроков разработки лекарственных средств, путём определения его жизненного цикла; установление точности стимулирующих инструментов. Также сюда входят 
доклинические исследования и клинические испытания, которые занимают период с момента цели создания препарата и до начала первого этапа испытаний[3].Второй этап представлен определением приоритетности лекарственных препаратов. Третий этап является нахождением источников финансирования лекарственных средств. Данные источники поступают как из национальных бюджетов, так и средств мировых объединённых фондов. И заключительный этап представлен сочетанием новых стимулов и рационального применения лекарственных средств. Благодаря этой фазе создаются обдуманные и рациональные схемы применения препаратов для обеспечения эффективности и безопасности применения лекарственных средств в животноводстве.

Проанализировав данное сравнение разработки лекарственных средств в нашей стране и за рубежом, стоит сказать, что общее понятие по цикличности разработки препаратов схожи. Также имеются общие цели и факторы в создании препаратов, благодаря чему возможно появление общих перспектив в совместной разработке усовершенствованных лекарственных средств.

Литература: 1. Понамарев, В. С. Исследование острой токсичности гепатопротектора "ГЕПАТОН" на грызунах / В. С. Понамарев, Н. Л. Андреева, М. С. Голодяева // Международный вестник ветеринарии. - 2019. - № 4. - С. 81-85., 2. Кострова, А. В. Некоторые аспекты проверки безопасности гепатопротектора на растительной основе / А. В. Кострова, В. С. Понамарев // XXII Всероссийская научно-практическая конференция Нижневартовского государственного университета : Материалы конференции, Нижневартовск, 06-07 апреля 2020 года / Научный редактор: Д.А. Погонышев. - Нижневартовск: Нижневартовский государственный университет, 2020. - С. 25-28., 3.Анализ нормативных документов, регламентирующих требования к проведению доклинических исследований ветеринарных препаратов / С. В. Герасимов, В. С. Понамарев, Н. Л. Андреева [и др.] // Вопросы нормативноправового регулирования в ветеринарии. - 2020. - № 3. - С. 27-29. - DOI 10.17238/issn20726023.2020.3.27., 4. Понамарев, В. С. Влияние препарата "Гепатон " на реакции перекисного окисления липидов / В. С. Понамарев, О. С. Попова // Международный вестник ветеринарии. - 2020. - № 2. - C. 112-115. - DOI 10.17238/issn2072-2419.2020.2.112.

\title{
COMPARATIVE CHARACTERISTICS OF DOMESTIC AND FOREIGN MEDICINAL
} DEVELOPMENTS IN LIVESTOCK

Zemlyanaya V.V., student (FSBEI HE "SPbGUVM)

Summary: As we know, the creation of new drugs takes a fairly long amount of time, mainly from 5 to 10 years. That is why we organized the stages for the development of drugs in order to accurately compare their effectiveness, safety and significance in the livestock sector. One of the main factors in drug development is the medical field: it is necessary to constantly research new and improve existing pharmaceuticals.

Key words: preclinical studies, medicines, animal husbandry.

УДК: 615.24:619

\section{ПЕРСПЕКТИВА ИСПОЛЬЗОВАНИЯ НОВЫХ МИНЕРАЛЬНЫХ СОРБЕНТОВ В ВЕТЕРИНАРИИ}

Зенков К. Ф., доц., к.в.н. (ФГБОУ ВО СПбГУВМ, Россия)

\begin{abstract}
Аннотация. Перспектива использования активного диоксида кремния и микронизированной рисовой шелухи в качестве энтеросорбента в системе выращивания сельскохозяйственных животных.
\end{abstract}

Ключевые слова: Сельскохозяйственные животные, сорбенты, интоксикация. 
Современное животноводство и получение продукции высокого качества зависит не только от генетического потенциала животных, но и от воздействия факторов внешней среды, которые могут быть достаточно разнообразными, начиная с условий микроклимата помещений заканчивая составом потребляемой воды и если условия микроклимата - это показатели которые человек изначально сам проектирует и закладывает в производственный цикл, то наличие отравляющих веществ в окружающей среде иногда является факторами, которые невозможно исключить, поэтому приходиться искать методы и способы уменьшения их влияния на организм животного, а соответственно и на организм человека через продукцию животноводства [1].

Использование энтеросорбентов - это один из методов, который является физиологичным и эффективным, а если для создания таких препаратов используется дешевое и доступное сырье, то такой метод становиться еще и недорогим[2]. Примером таких сорбентов могут быть активный диоксид кремния (АДК) и микронизированная рисовая шелуха (МРШ), которые производят из отходов рисоперерабатывающей промышленности, представляющие собой оболочки зерна, которые просто складируются и никак не перерабатываются. АДК - сорбент получаемый методом кислотно-щелочного гидролиза и термообработки рисовой шелухи, а МРШ - это порошок, полученный путем измельчения рисовой шелухи на специальных роторно-вихревых мельницах[3]. Особенность рисовой шелухи - это дисперсный кремнезем, заключенный в матрицу полисахаридов и лигнина, который выполняет основную сорбционную функцию[4]. Достоверно установлено, что сорбенты, произведенные из рисовой шелухи, эффективно извлекают ионы тяжелых металлов из растворов. На основе литературных источников известно, что сорбенты, произведенные из рисовой шелухи, эффективно сорбируют нефтепродукты из воды различного происхождения. Более подробное изучение состава АДК и МРШ показывает, что данные сорбенты являются нетоксичными, инертными в отношении химических реакций, не вызывают травматизм выводятся из организма в неизмененном виде. При этом данные сорбенты обладают приемлемыми органолептическими свойствами. Данные факторы показывают возможность применения АДК и МРШ в качестве многофункциональных энтеросорбентов для лечения острых и хронических болезней желудочно-кишечного тракта сопровождающихся токсикозами, нарушениями пищеварения, иммунного статуса, метаболизма липидов, желчных кислот, других видов обмена, вывода тяжёлых металлов и ряд других эндотоксинов из организма при алиментарном скармливании. В зарубежных странах активный диоксид кремния исследован, как носитель различных биологически активных веществ, а именно витаминов, бактерицидов, вирулицидов, микоцидов и других и успешно используется, как наполнитель в медицинских и ветеринарных препаратах.

Таким образом, на основании краткого обзора литературных источников, можно утверждать о целесообразности включения микронизированной рисовой шелухи и активного диоксида кремния в рационы для сельскохозяйственных животных с целью повышения естественной резистентности организма, снижения метаболической нагрузки на организм и повышения качества продукции животноводства.

Литература. 1. Зенков, К. Ф. Результаты копрологических исследований телят при использовании нового энтеросорбента, полученного из растительного сырья / К. Ф. Зенков // Современное состояние и перспективы развития ветеринарной и зоотехнической науки : Материалы Всероссийской научно-практической конференции с международным участием, Чебоксары, 29 октября 2020 года. - Чебоксары: Чувашский государственный аграрный университет, 2020. - С. 272-276., 2. Понамарев, В. С. Влияние препарата "Гепатон" в сочетании с фитосорбционным комплексом на уровень эндогенной интоксикации / В. С. Понамарев, О. С. Попова // Вопросы нормативно-правового регулирования в ветеринарии. 2020. - № 3. - C. 124-125. - DOI 10.17238/issn2072-6023.2020.3.124., 3. Состояние воспроизводительной способности у коров при дозированном кормлении микронизированным тыквенным жмыхом в транзитный период / И. В. Иванова, А. Ф. Кузнецов, П. А. Полистовская, К. Ф. Зенков // Материалы национальной научной 
конференции профессорско-преподавательского состава, научных сотрудников и аспирантов СПбГАВМ, Санкт-Петербург, 21-25 января 2019 года. - Санкт-Петербург: СанктПетербургская государственная академия ветеринарной медицины, 2019. - С. 19-20., 4. Эффективность применения микронизированной рисовой шелухи на организм телят / А. Ф. Кузнецов, А. Е. Белопольский, К. А. Рожков [и др.] // Международный вестник ветеринарии. -2018 . - № 1. - C. 28-33.

THE PROSPECT OF USING NEW MINERAL SORBENTS IN VETERINARY MEDICINE

Zenkov K. F., associate professor, $\mathrm{PhD}$

(FSBEI HE St.Peterburg SUVM, Russia)

Summary. The prospect of using active silicon dioxide and micronized rice husk as an enterosorbent in the system of growing farm animals.

Key words: Farm animals, sorbents, intoxication.

УДК: 661.682:616-001.4-003.9;636.92

\section{ИЗУЧЕНИЕ РАНОЗАЖИВЛЯЮЩИХ СВОЙСТВ МОДИФИЦИРОВАННОГО АМОРФНОГО ДИОКСИДА КРЕМНИЯ НА РАНЕВЫХ ПОВЕРХНОСТНЫХ ПОРАЖЕНИЯХ КОЖИ КРОЛИКОВ}

Зенков К. Ф., доц., к.в.н. (ФГБОУ ВО СПбГУВМ, Россия)

Аннотация. Представлены результаты изучения ранозаживляющих свойств АДК, МАДК и Монклавит мази.

Ключевые слова: кролики, сорбенты, мазь, раны.

Исследования ранозаживляющих свойств модифицированного аморфного диоксида кремния (АДК) на раневых поверхностных поражениях кожи, проводились на кроликах. АДКэто сорбент получаемый методом кислотно-щелочного гидролиза и термообработки рисовой шелухи[1]. В качестве модели для изучения подобных исследований были использованы серые кролики массой не менее 1,5 кг. Исследование проводилось согласно принципам биоэтики [2].

В своих исследованиях использовали препараты АДК и МАДК, который представляет собой активный диоксид кремния, модифицированный витагмалом, обладающим бактерицидным действием. У кроликов на участке кожи размером $3 \times 3$ см в области бедра в день постановки опыта тщательно выстригли волосяной покров (до полного оголения), затем с помощью крупной наждачной бумаги сделали повреждения кожи до появления сукровицы[3,4]. На поврежденную кожу наносили препарат АДК (в виде присыпки). У второго кролика так же выстригали волосяной покров, проводили травматизацию кожи и наносили МАДК (в виде присыпки). В качестве контроля использовали мазь Монклавит, которую наносили так же, как и испытуемые препараты, на травмированную кожу кроликов. Кроликов помещали в отдельные клетки и ежедневно вели наблюдение за заживлением травм. Учитывали диаметр ран и толщину при захвате складки кожи до нанесения раны и после заживления раны[5] .

Динамика заживления ран представлена далее:

АДК: 1 день: 3 см-отек; 2 день: 2.7 см-отек; 3 день: 2.1 см-сухая; 4 день: 1.8 см-сухая; 5 день: 1.5 см-сухая; 6 день: 1.3 см-сухая; 7 день: 0.6 см-сухая.

МАДК: 1 день: 3 см-отек; 2 день: 2.7 см-отек; 3 день: 2.3 см-сухая; 4 день: 2,0 см-сухая; 5 день: 1.8 см-сухая; 6 день: 1.2 см-сухая; 7 день: 0.7 см-сухая.

Мазь Монклавит: 1 день: 3 см-отек; 2 день: 2.8 см-отек; 3 день: 2.5 см-сухая; 4 день: 2,2 см-сухая; 5 день: 2,0см-сухая; 6 день: 1.6см-сухая; 7 день: 0.7см-сухая. 
Толщина кожной складки после выстригания шерстного покрова, до нанесения испытуемых препаратов составляла в среднем 1,75 мм. После нанесения испытуемых препаратов образовывалась жесткая корочка её размеры представлены выше, а через неделю после ее рассасывания толщина кожной складки так же достигала первоначальной величины. Из представленных данных видно, что при использовании мази Монклавит отек сохраняется на одни сутки больше, чем при использовании исследуемых препаратов (АДК и МАДК). Причем на седьмые сутки наблюдения уже диаметр корочки при использовании АДК составлял - 0,6 см, а МАДК- 0,7 см; тогда как при использовании Монклавит мази - 0,7 см. Через неделю толщина кожной складки восстановилась до первоначальной во всех группах. Монклавит мазь, достаточно долго задерживается на поверхности раны, а АДК и МАДК образуют достаточно плотную корочку, которая препятствует повторному обсеменению раны. Полученные результаты показывают, что изучаемые сорбенты способствуют некоторому ускорению заживления ран и могут быть рекомендованы для лечения загрязненных и гнойных ран.

Литература. 1. Эффективность применения микронизированной рисовой шелухи на организм телят / А. Ф. Кузнецов, А. Е. Белопольский, К. А. Рожков [и др.] // Международный вестник ветеринарии. - 2018. - № 1. - С. 28-33. 2. Анализ нормативных документов, регламентирующих требования к проведению доклинических исследований ветеринарных препаратов / С. В. Герасимов, В. С. Понамарев, Н. Л. Андреева [и др.] // Вопросы нормативноправового регулирования в ветеринарии. - 2020. - № 3. - С. 27-29. - DOI 10.17238/issn20726023.2020.3.27., 3. Кострова, А. В. Некоторые аспекты проверки безопасности гепатопротектора на растительной основе / А. В. Кострова, В. С. Понамарев // XXII Всероссийская научно-практическая конференция Нижневартовского государственного университета : Материалы конференции, Нижневартовск, 06-07 апреля 2020 года / Научный редактор: Д.А. Погонышев. - Нижневартовск: Нижневартовский государственный университет, 2020. - С. 25-28., 4. Кострова, А. В. Изучение аллергизирующих свойств препарата «Гепатон» / А. В. Кострова, В. С. Понамарев // Инновационные тенденции развития российской науки : Материалы ХIII Международной научно-практической конференции молодых ученых, Красноярск, 08-09 апреля 2020 года. - Красноярск: Красноярский государственный аграрный университет, 2020. - С. 75-76., 5. Зенков, К. Ф. Зоогигиеническая оценка применения микронизированной рисовой лузги, модифицированной препаратом "Монклавит-1" / К. Ф. Зенков // Актуальные проблемы ветеринарной медицины : сборник научных трудов / Санкт-Петербургская государственная академия ветеринарной медицины. Санкт-Петербург : Санкт-Петербургская государственная академия ветеринарной медицины, 2013. - C. 23-26.

\title{
STUDY OF WOUND HEALING PROPERTIES OF MODIFIED AMORPHOUS SILICON DIOXIDE ON WOUND SURFACE LESIONS OF RABBIT SKIN
}

\author{
Zenkov K. F., associate professor, $\mathrm{PhD}$ \\ (FSBEI HE St.Peterburg SUVM, Russia)
}

Summary. The results of studying the wound-healing properties of ADC, ADC and Monclavit ointment are presented.

Key words: Rabbits, sorbents, ointment, wounds.

УДК 618.56-085:636.2

\section{ЭФФЕКТИВНОСТЬ ПРИМЕНЕНИЯ НЕКОТОРЫХ КОНСЕРВАТИВНЫХ МЕТОДОВ ЛЕЧЕНИЯ ДЛЯ ВЫВЕДЕНИЯ ПОСЛЕДА У КОРОВ}

Зенков К.Ф., К.в.н., доц., Иванова К. студент (ФГБОУ ВО СПбГУВМ, Россия)

\begin{abstract}
Аннотация: Задержание последа у коров является распространенной и часто встречающейся послеродовой гинекологической проблемойв условиях интенсивного хозяйственного использования животных. Послед считается задержавшимся, если он не выводится в течение
\end{abstract}


6-8 часов после завершения второй стадии родов - рождения плода. Целью работы было выявить эффективность применения комбинации таких лекарственных препаратов какраствор кальция борглюконата 20\% и окситоцина(10 MЕ/мл).

Ключевые слова: задержание последа, окситоцин, кальция боглюконат

Задержание последа у коров является распространенной и часто встречающейся послеродовой гинекологической проблемойв условиях интенсивного хозяйственного использования животных. Послед считается задержавшимся, если он не выводится в течение 6-8 часов после завершения второй стадии родов - рождения плода.

Целью работы было выявить эффективность применения комбинации таких лекарственных препаратов какраствор кальция борглюконата $20 \%$ и окситоцина $(10 \mathrm{ME} / \mathrm{Mл})$. Также определить эффективность применения только раствора кальция борглюконата 20\%, без последующего введения препарата окситоцина(10MЕ/мл). И оценить возможность выведения последа без применения каких-либо лекарственных препаратов.

Было сформировано 3 группы коров голштинской чёрно-пестрой породы 2-3 лактации. В каждой группе по 10 головс признаками задержания последа.

Первой группе коров по прошествии 8 часовпосле завершения второй стадии родов былиназначены внутривенные инъекции подогретого до $35^{\circ}$ Сраствора кальция борглюконата $20 \%$ в дозе 0,5 мл/кг массы тела животного, при этом разовая доза не должна превышать 250-300 мл для одного животного. Далее, после инъекции раствора кальция борглюконата $20 \%$, была назначена внутримышечная инъекция препарата окситоцина в дозе 50 ME на корову, что соответствует 5 мл на корову.

Второй группе коров по прошествии 8 часов после завершения второй стадии родов были назначены внутривенные инъекции подогретого до $35^{\circ} \mathrm{C}$ раствора кальция борглюконата $20 \%$ в дозе 0,5 мл/кг массы тела животного, при этом разовая доза также не должна превышать 250-300 мл для одного животного. Инъекции окситоцинаэтой группе животных не назначались.

Третьей группе животныхпо прошествии 8 часов после завершения второй стадии родов инъекции раствора кальция борглюконата $20 \%$ и окситоцина не назначались.

В ходе работы было выяснено, что в первой группе животных, по прошествии 12-24 часов после завершения второй стадии родов и введения указанных выше препаратов, выведение последа произошло у 6 из 10 коров. Во второй группе по прошествии 12-24 часов после завершения второй стадии родов и введения только раствора кальция борглюконата $20 \%$, выведение последа произошло у 4 из 10 коров. В третьей группе по прошествии 12-24 часов после завершения второй стадии родов и без введения каких-либо лекарственных препаратов, выведение последа произошло у 1 коровы из 10.

Таким образом в первой группе животных отхождение последа произошло у $60 \%$ коров из исследуемых. Во второй - у 40\%. В третье - у 10\% коров. В результате чего можно сделать вывод, что наиболее эффективным консервативным методом лечения задержания последа является метод, который применялся на первой группе животных, а именно введение препарата окситоцина(10 МЕ/мл) сразу после введения раствора кальция борглюконата 20\%. Менее эффективным является метод, применяемый на второй группе животных, а именно введение только раствора кальция борглюконата 20\%. Третий метод, по результатам проведенного исследования, следует считать неэффективным.

Литература:1. Внутренние болезни животных : учеб. для вузов / Г. Г. Щербаков, А. В. Яшин, А. П. Курдеко [и др.] . - Санкт-Петербург : Лань, 2020. - 716 с. 2. Клиническая диагностика внутренних болезней животных : учеб. для вузов / С. П. Ковалев, А. П. Курдеко, Е. Л. Братушкина [и др.] . - Санкт-Петербург : Лань, 2019. - 540 с. 3. Погодаева, П. С. Некоторые аспекты локального иммунного ответа в тканях молочной железы / П. С. Погодаева, Л. Ю. Карпенко, В. С. Понамарёв // Международный вестник ветеринарии. - 2020. - № 4. - С. 129133. 4. Щипакин, М. В. Учебно-методическое пособие по анатомии животных. Т. 1. Спланхнология / М. В. Щипакин, А. В. Прусаков, Д. С. Былинская. - Санкт-Петербург: 2012. 5. 
Evaluationofprogesteronemeasurementforthediagnosispregnancyandembryonicmortalityindairycow s / G. Nikitin, K. Plemyashov, A. Nikitina [etal.] // ReproductioninDomesticAnimals. 2019. - T. 54. № S3. P.136.

\title{
EFFICIENCY OF THE APPLICATION OF CERTAIN CONSERVATIVE TREATMENT METHODS FOR REMOVING AFTER COWS
}

\author{
Zenkov K.F., Ph.D., associate professor, Ivanova K. student (FSBEI HE St.Peterburg SUVM,
} Russia)

Summary: Retention of the placenta in cows is a widespread and frequent postpartum gynecological problem under conditions of intensive economic use of animals. The afterbirth is considered delayed if it is not excreted within 6-8 hours after the completion of the second stage of labor - the birth of the fetus. The aim of the work was to reveal the effectiveness of using a combination of such drugs as a solution of calcium borgluconate $20 \%$ and oxytocin (10 IU / ml).

Key words: retention of placenta, oxytocin, calcium bogluconate

УДК 636.03

\section{ЭФФЕКТИВНОСТЬ КОРМОВОЙ ДОБАВКИ НА ОСНОВАНИИ СОЛЕЙ ГУМИНОВЫХ КИСЛОТ ПРИ ПРИМЕНЕНИИ ТЕЛЯТАМ}

Иванникова Р.Ф.

ФГБОУ ВО МГАВМиБ-МВА имени К.И. Скрябина, Россия

\begin{abstract}
Аннотация. Гуматы являются доступным сырьем, которое можно использовать всельском хозяйстве и животноводстве в форме гуматного напитка или сухогокорма в качестве источника минеральных и органических веществ длястимуляции роста.Нами была изучена эффективность применения кормовой добавки на основании солей гуминовых кислот при выращивании телят. В результате проведенных исследований было установлено, что кормовая добавка, применяемая перорально с рождения в течение 21 дня, оказывает положительное влияние на рост и развитие телят.
\end{abstract}

Ключевые слова: соли гуминовых кислот, телята, масса, среднесуточный прирост.

Продуктивность сельскохозяйственных животных зависит отполноценности кормления. Для сбалансированности рациона необходимособлюдать оптимальные соотношения различных компонентов корма, чтодостигается добавлением различных кормовых добавок [1].К одним их таких добавок относится кормовая добавка на основе гуминовых веществ. Гумусовые (или гуминовые) вещества являются уникальными природнымисоединениями в цепи органических остатков. Гуматы представляют собойсоли гуминовой кислоты, в которых катион / анионообменные блокигуминовой кислоты представляют собой $\mathrm{Ca}^{2+}, \mathrm{Na}^{+}, \mathrm{Al}^{3+}$ и $\mathrm{Fe}^{2+}$. В составгуматов входят гумус, гуминовая кислота, фульвокислота, гульминоваякислота и микроэлементы $[2,3]$.

Цель исследования: изучение эффективности применения кормовой добавки на основании солей гуминовых кислот при выращивании телят.

Материалы и методы. В условиях ЗАО «Племрепродуктор Васильевское» Московской области было проведено исследование по оценке эффективности применения кормовой добавки на новорожденных телятах в различных дозах.Кормовая добавка представляет собой водный раствор солей гуминовых кислот, обогащённый кальцием, фосфором и микроэлементами в хелатной форме.Было сформировано 4 группы телят по 10 голов в каждой. Кормовую добавку вводили в различных дозах перорально вместе с водой в течение 21 дня: 1 группа (опытная) -в дозе 10 мл на голову;2 группа (опытная) -20 мл на голову;3 группа (опытная) -30 мл на голову;4 группа (контрольная) - интактная, кормовая добавка не применялась.В исследуемые группы включали новорожденных телят чернопестрой породы обоего пола, с начальной массой от 35,8 до 44,5 кг. 
Телята содержались в индивидуальных клетках.Кормление: первые 5 дней молозиво, затем молоко цельное, стартовый комбикорм, сено. Потребление воды не огранивали.

В период исследований проводили ежедневно контроль общего состояния животных, аппетита и потребления воды, поведения, температуры тела, частоты пульса и дыхания. Взвешивание животных проводили до начала эксперимента, на 5, 10, 15 и 21 дни исследования. Эффективность применения кормовой добавки оценивали по приросту живой массы, заболеваемости и сохранности телят.

Результаты исследований.В результате проведенных исследований установлено, что кормовая добавка хорошо переносится в различных дозах - от 10 до 30 мл на голову. Масса новорождённых телят в разных группах достоверно не отличалась. Живая масса телят при рождении отличалась, но была недостоверна и колебалась по группам от 35,8 кг до 44,5 кг. Наиболее высокий среднесуточный прирост отмечен у телят 1-й опытной группы, получавших кормовую добавку в дозе 10 мл на голову, и составил 0,582 $\pm 0,261$ кг. Скорость роста телят за период исследования составила: в 1 опытной группе $-12,3$ кг; во 2 опытной группе - 10,8 кг; в 3 опытной группе - 10 кг; в контрольной группе - 10,4 кг.

Общее состояние телят опытных групп не отличалось от животных контрольной группы - изменения физиологических функций не отмечено, аппетит и жажда сохранены, животные были активны. Изменения температуры тела, частоты пульса и дыхательных движений за пределы референсных значений за период наблюдения отмечено не было. Показатели температуры тела, пульса и числа дыханий в минуту сохранялись в пределах нормативных показателей.

Нами были проанализированы данные о сохранности и заболевемостителят в исследуемых группах. У 3-х телят из контрольной группы на 4 день наблюдения при клиническом обследовании отмечено снижение активности и аппетита, метеоризм и выделение жидких каловых масс. Заболевшим телятам проводили лечение, принятое в хозяйстве, что привело к улучшению общего состояния на 4-5-е сутки, каловые массы приобретали более плотную консистенцию.В опытных группах у телят также были зарегистрированы признаки простой диспепсии - в 1-й группе у одного теленка, во 2-й и 3-й опытных группах - у 2-х телят. Клиническое выздоровление наступало на 3-4 сутки. Сохранность телят во всех группах составила $100 \%$.

Заключение. В результате проведенных исследований по изучению эффективности применения кормовой добавки на основании солей гуминовых кислот в различных дозах системных изменений не отмечали во всех опытных группах: у целевых объектов показатели температуры, пульса и числа дыханий сохранялись в пределах физиологической нормы во все контрольные точки наблюдения и составили $38,0-39,2{ }^{\circ} \mathrm{C}, 145-86$ в минуту, $45-25$ в минуту соответственно.

Таким образом, кормовая добавка на основании солей гуминовых кислот, применяемая телятам с рождения в течение 21 дня перорально в дозировке 10 мл на голову, 20 мл на голову и 30 мл на голову, не оказывает отрицательного влияния на состояние телят.

Наиболее высокие показатели среднесуточного прироста (0,582 кг) регистрировали у телят 1-ой опытной группы, получавших кормовую добавку в дозе 10 мл на голову.

Заболеваемость также ниже была в этой же группе - за период наблюдения заболел 1 теленок, во 2-й и 3-й группах - по 2 теленка, в контрольной - 3 теленка. Выздоровление телят сокращалось в опытных группах по отношению к контрольной группе на 1-2 дня. Сохранность во всех группах составила $100 \%$.

Литература. 1. Лепина И.Н. Применение гуматов ветеринарии. /И.Н. Лепина, Р.Ф. Иванникова // Актуальные проблемы ветеринарной медицины, зоотехнии и биологии: Сборник научных трудов международной учебно-методической и научно-практической конференции, посвященной 100-летию со дня основания ФГБОУ ВО МГАВМиБ - МВА имени К.И. Скрябина. - Москва. - 2019. - С.467-472. 2. Самотин, А.М. Применение гуминовых препаратов в животноводстве и ветеринарии / А.М. Самотин, В.И. Беляев, В.Н. 
Богословский // М.: Изд-во РПК «Грин», 2006. - 85с. 3. Горовая, А.И. Гуминовые вещества / А.И. Горовая, Д.С. Орлов, О.В. Шербенко // Киев, Наукова Думка, 1995. - 304с.

\section{EFFECTIVENESS OF A FEED ADDITIVE BASED ON HUMIC ACID SALTS WHEN APPLIED TO CALVES}

Ivannikova R.F.

Federal State Budgetary Educational Institution of Higher Education «Moscow State Academy of Veterinary Medicine and Biotechnology - MVA named after K.I. Skryabin», Russia

Summary.Humates are an affordable raw material that can be used in agriculture and animal husbandry in the form of a humate drink or dry feed as a source of mineral and organic substances to stimulate growth. We have studied the effectiveness of the use of feed additives based on humic acid salts in the cultivation of calves. As a result of our research, it was found that a feed supplement used orally from birth for 21 days has a positive effect on the growth and development of calves.

Key words:humic acid salts, calves, weight, average daily weight gain.

УДК 619.616

\section{ТОКСИКО-ЭКОЛОГИЧЕСКАЯ ОЦЕНКА БЕЗОПАСНОСТИ И КАЧЕСТВА ПРОМЫСЛОВОЙ РЫБЫ НИЖНЕГО ДОНА}

Илларионова Н.Ф., доц., к.э.н.

(ФГБОУ ВО ДонГАУ, Россия)

Аннотация. В среднем за период 2015-2019 гг. в донных отложениях Нижнего Дона фиксируется четко выраженная тенденция к увеличению нефтяного загрязнения, а содержание цезия-137 и стронция-90 соответствует низкому уровню радиоактивногоь загрязнения. В воде концентрации большинства контролируемых металлов в течение последних пяти лет сохраняются на уровне, который не превышает ПДК для рыбохозяйственных водоемов. В течение преднерестового периода 2015-2019 гг., в органах и тканях всех исследованных образцов промысловых рыб, концентрации определяемых токсикантов и радионуклидов были значительно ниже, допустимого по СанПиН, уровня содержания в живой рыбе.

Ключевые слова. Нижний Дон, уровень накопления токсических веществ в рыбе.

Исследование водных биологических ресурсов в условиях антропогенного воздействия является актуальным и необходимым, поскольку рыбы способны аккумулировать тяжелые металлы даже в тех случаях, когда содержание их в воде не превышает установленных предельно допустимых токсических веществ норм. Под действием токсических веществ в организме рыб могут происходить патологические изменения на на молекулярном, организменном и популяционном уровнях [1-3]. Цель работы заключается в выявлении загрязнения водной среды и донных отложений нефтепродуктами, хлорорганическими пестицидами и тяжелыми металлами на участке реки Дон от станицы Романовской до гирла Мокрая Каланча в весенний и летне-осенний периоды и оценка уровня их накопления в мышцах, печени и гонадах окуня и леща.

Дон - главная река Ростовской области, она снабжает аквакультурвми дончан и соседние регионы, «поит» большую половину населения донского региона, орошает поля и выполняет транспортную функцию, ее длина составляет 1870 км. Плошадь бассейна реки Дон равна 422 тыс. кв. км, среднее многолетнее значение водных ресурсов Дона - 25,5 куб. км/год, водные ресурсы в 2019 г. составили 17 куб. км/год, отклонение от среднего многолетнего значения равно $-33,3$ \%. Это свидетельствует о том, что в бассейне реки Дон продолжилась фаза низкой водности, начавшаяся еще в 2007 г., причем в 2019 г. произошло резкое падение стока до значений ниже нормы на 33,3 \% после 3,9 \% ниже нормы в 2018 г. [4]. Нерационально организованное судоходство - главные причины экологической катастрофы реки, русло 
которой разрушают сильные волны, создаваемые тяжелыми грузами и крупными пассажирскими судами, разрушают русло реки. Это приводит к еще большему заиливанию дна и обмелению, и мальки погибают в районе прохода судов. При мытье судов происходит загрязнение реки маслом и керосином в воду сливают канализацию и сбрасывают мусор. Большую роль в загрязнении донских вод оказывают отходы Ростовской АЭС. Качество воды реки Дон в последние 3-7 лет колеблется от «слабо загрязненной» до «грязной».

Мониторинг, проведенный ФГБНУ «АзНИИРХ», выявил, что в течение последних пяти лет в донных отложениях прослеживается четко выраженная тенденция к увеличению нефтяного загрязнения, в водах Нижнего Дона - нефтяное загрязнение остается на одном уровне. В 2019 году в воде Нижнего Дона концентрации нефтепродуктов (далее - НП) варьировали от 0,02-0,11 мг/л. Повышенный уровень нефтяного загрязнения зафиксирован в весенний период в 0,5 км ниже устья реки Аксай в 2,2 раза выше ПДК нефтепродуктов, равного 0,05 мг/л, летом - до 1,7 ПДК у Мокрой Каланчи. Аномально высокое содержание НП, равное 15,7 г/кг сухой массы обнаружено в весенний период в донных осадках в 0,5 км ниже устья реки Темерник. Для гидробионтов пороговый уровень содержания нефтепродуктов в донных отложениях составляет 1,0 г/кг, при его превышении возможны нарушения питания, поведения, физиолого-биохимических функций [5]. Наблюдения в течение последних двух лет выявили, что содержание хлорорганических пестицидов (далее ХОП) в воде стабилизировалось на уровне 0,5-0,6 нанограмм/литр, что ниже уровня предыдущих трех лет и ниже ПДК, равной 10,0нг/ л. При этом, в 2019 году в донных отложениях фиксируется минимальная, за последние пять лет наблюдений, концентрация ХОП, равная 0,2 мкг/кг сухой масс. Концентрации железа, цинка, хрома, никеля и кадмия в донской воде в течение всего периода наблюдений были ниже нормативов, а мышьяка, свинца и ртути - не превышали предела определения. В весенний период в 2019 году в воде реки Дон обнаружено превышение ПДК меди (в 2,5 раза) и марганца (в 1,3-1,6 раза) в районе выпуска канализации г. Ростова-на-Дону. В летний период превышение марганца в 1,6 раза обнаружено в устье притока Аксай. В донных осадках, в среднем за пять лет наблюдений, прослеживается тенденция к снижению содержания железа, цинка, хрома, свинца и никеля в 1,2-2,0 раза. Содержание цезия-137 и стронция-90 в донных отложениях Нижнего Дона в 2016-2019 гг. соответствует низкому уровню радиоактивного загрязнения.

В 2019 году для оценки уровня накопления нефтяных углеводородов, хлорорганических пестицидов, тяжелых металлов и мышьяка в водных биоресурсах Нижнего Дона анализировались мышцы, печень и гонады окуня и леща, и, отдельно мышцы - для оценки уровня накопления радионуклидов (цезия-137 и стронция-90). Безопасность уровней накопления токсических веществ в органах и тканях рыб оценивалась по санитарноэпидемиологическим правилам и нормативам «Гигиенические требования безопасности и пищевой ценности пищевых продуктов. СанПиН 2.3.2.1078-01», утвержденным Главным государственным санитарным врачом Российской Федерации 06.11.2001. Правила действуют с 1 июля 2002 года. Допустимые уровни В промысловых рыбах в реке Дон в 2018 году, как и в период 2014-2017- гг., концентрация определяемых токсичных элементов нормативу СанПиН 2.3.2.1078-01. Правила действуют с 1-го июля 2002 года. Например, допустимые уровни накопления токсикантов в органах и тканях рыб составляют на сырую массу: свинец и мышьяк - 1,0 мг/кг, кадмий 0,2 мг/кг в мышцах, 0,7 мг/кг - в печени, 1,0 мг/кг - в гонадах и т.д. Уровень накопления в мышцах цезия-137 - 130,0 Бк/кг, стронция-90 - 100,0 Бк/кг. В обследованных видах рыб в течение преднерестового периода 2015-2019 гг. концентрации определяемых токсикантов не превышали допустимый уровень. Концентрации цезия-137 стронция-90 в мышечной ткани всех исследованных образцов промысловых рыб были значительно ниже допустимого уровня содержания этих изотопов в живой рыбе, что не представляет радиационной опасности для потребителей.

В настоящее время экологическая проблема сохранения водных ресурсов является наиболее актуальной. В связи с этим, в донском регионе действует комиссия по чрезвычайным 
ситуациям, под руководством председателя Правительства области, которая уделяет пристальное снимание развитию водохозяйственного комплекса.

Литература: 1. Попова О.С. Влияние фитосорбционных комплексов на организм пресноводных рыб / О.С. Попова, Л.А. Агафонова // Международный вестник ветеринарии. 2021 г.- №. - С. 117-121. 2. Барышев В.А. Использование сорбентов в рыбоводстве / В.А. Барышев, О.С. Попова // Международный вестник ветеринарии. - 2020 г. - № 2. - С. 122-126. 3. Илларионова Н.Ф. Проблема безопасного применения пестицидов / Н.Ф. Илларионова, Л.Б. Грабская // Материалы всероссийской научно-практической конференции «Актуальные проблемы экологии в сельскохозяйственных ландшафтах и урбанизированных территориях» 30 ноября 2017 года. - пос. Персиановский, Донской ГАУ, 2017. - С. 143-145. 4. О состоянии и об охране окружающей среды Российской Федерации в 2019 году. Государственный доклад. - М.: Минприроды России; МГУ имени М.В.Ломоносова, 2020. - 1000 с. 5. Экологический вестник Дона «О состоянии окружающей среды и природных ресурсов Ростовской области в 2019 году / Под общей редакцией М.В. Фишкина. - Ростов-на-Дону: Министерство природных ресурсов и экологии Ростовской области, 2020. - 374 с.

\section{TOXIC-ECOLOGICAL ASSESSMENT OF THE SAFETY AND QUALITY OF COMMERCIAL FISH OF THE LOWER DON}

Illarionova N.F., associate professor, Ph.D. (FSBEI HE DonGAU, Russia)

Annotation. On average for the period 2015-2019 in the bottom sediments of the Lower Don, a clearly expressed tendency towards an increase in oil pollution is recorded, and the content of cesium137 and strontium-90 corresponds to a low level of radioactive contamination. Over the past five years, the concentrations of most of the controlled metals in water have remained at a level that does not exceed the MPC for fishery reservoirs. During the pre-spawning period of 2015-2019, in the organs and tissues of all studied samples of commercial fish, the concentrations of the detected toxicants and radionuclides were significantly lower than the level allowed in the Sanitary rules and regulations in live fish.

Keywords. Lower Don, the level of accumulation of toxic substances in fish.

УДК:637.3.

DOI:10.52419/3006-2021-2-110-112

Аннотация:в работе представлены результаты исследования состава микрофлоры мягкого сыра, динамикаих изменения в процессе хранения, а так же установлены оптимальные сроки хранения готового продукта.

Ключевые слова: микрофлора, термокислотная коагуляция, белки, сыворотка, жизнеспособная клетка.

Введение.Безопасность пищевой продукции - это гарантия здоровья человека. Каждый из нас ежедневно употребляет пищевые продукты животного происхождения и должен быть уверен в том, что данные продукты не представляют собой опасности для здоровья.Потребители все больше и больше осознает опасности, связанные с патогенными микроорганизмами и химическими веществами, содержащимися в потребляемых пищевых продуктах. Внедрение новых технологий, включая генную инженерию в современных условиях вызывает все больше и больше обеспокоенности по поводу безопасности пищевой продукции. По этому в Республике Узбекистан принято ряд доументов, в частностипостановление Кабинета Министров Республики Узбекистан№ 474 «Об утверждении общего технического регламента о безопасности молока и молочной продукции» от 7 июля 2017 года, УказПрезидента Республики Узбекистан № УП-5303 «О 
мерах по дальнейшему обеспечению продовольственной безопасности страны» от 16 января 2018 года, Сан ПиНРУз № 0283-10 «Гигиенические требования к безопасности пищевой продукции» от 29 декабря 2010 года направленные на обеспечение пищевой безопасности всех граждан. [1].

Среди различных опасности, связанные с пищевыми продуктами можно отнести безопасностьпищевых продуктов по микробиологическим показателям, что является весьма важным.

Целью настоящих исследований являлось, на примере - мягкого сыра, определение состава микрофлоры готового продукта и изучение динамики их изменения в процессе хранения, в последствии которого устанавливались оптимальные сроки хранения продукта. Исследуемые продукты были получены по новой технологии с термокислотной коагуляцией белков термообработанного молока при 75 - $85{ }^{\circ} \mathrm{C}$. Для определения влияния принятых технологических режимов на состав микрофлоры исследованию подвергались опытные и контрольные варианты обезжиренных и массовой долей жира (м.д.ж.) в сухом веществе 20 \% мягких сыров. Контрольные варианты мягких сыров были получены по такой же технологии, что и опытные, но с коагуляцией белков молока при температуре пастеризации.

Результаты исследований:Учитывая, что коагуляция белков молока при производстве исследуемых сыров происходит при температурах выше $65^{\circ} \mathrm{C}$, можно предположить, что уровень обсеменения готовых продуктов будет соответствовать уровню обсеменения пастеризованного молока и сыворотки. Эта остаточная микрофлора может развиваться в процессе хранения исследуемых сыров. Однако рост этой остаточной микрофлоры в сырах зависит от ряда факторов: уровня активной кислотности, температуры хранения и осмотического давления[2].

Исследованиями ряда ученых установлено, что качество адыгейского сыра при повышенных температурах $\left(16-18{ }^{0} \mathrm{C}\right)$ хранения значительно ухудшается и срок его хранения сокращается до 12 ч. Ими рекомендуется температура хранения 0-8 ${ }^{0} \mathrm{C}$, при котором сроки хранения сыра удлиняются до 7 суток[3].

С учетом этого, микробиологические исследования мягких сыров проводили в процессе их хранения 6-8 ${ }^{0} \mathrm{C}$.

Поскольку, активная кислотность исследуемых сыров составляет 5,9-6,1, то при температурах хранения 6-8 ${ }^{0} \mathrm{C}$ в сырах, видимо, будет развиваться в основном психротрофныемикроорганизмы, а остальные не получат значительного развития. Кроме того, предусмотренная технологией посолка сыра, снижая активность воды, в свою очередь также может тормозить рост микроорганизмов.

В процессе тепловой обработки и коагуляции белков молока большая часть микрофлоры погибает, однако в готовом продукте, исследованной после окончания технологического процесса, были обнаружены мезофильные аэробные и факультативно анаэробные микроорганизмы (МАФАМ), психротрофные и молочнокислые бактерии. Бактерии группы кишечных палочек, дрожки и плесневые грибы не были обнаружены в 1 г продуктов. Результаты исследований опытных и контрольных вариантов обезжиренных и с м. д.ж. в сухом веществе $20 \%$ мягких сыров в процессе холодильного хранения при 6-8 ${ }^{0} \mathrm{C}$. В процессе холодильного хранения при 6-8 ${ }^{0} \mathrm{C}$ в течение 12 суток количество МАФАМ существенно не изменилось. В первые двое суток хранения их количество оставалось на уровне исходного обсеменения, а незначительное увеличение количества МАФАМ отмечалось до 5 суток хранения (в 1,8-3 раза). В последующие сутки хранения отмечалось тенденция к снижению МАФАМ а через 12 суток хранения их количество снизилось по сравнению с исходным в 1,5-4 раза. Судя по количеству МАФАМ в течение хранения, можно сказать, что качество исследованных сыров практически не изменилось и их можно употреблять втечение 12 суток. Испорченными и непригодными в пищу считают продукты, содержащие более 10 микроорганизмов в 1 г.

Аналогичные результаты получены и по психротрофныммикроорганизмам. Несмотря на то, что в процессе хранения их количество увеличилось в 6,5-21 раза, это не привело к 
заметным органолептическим изменениям в сырах. В широком смысле к психротрофнымотносят бактерии рода Pseudomonas, дрожжи, плесневые грибы, микрококки, спорообразующие палочки молочнокислые палочки и другие микроорганизмы, способные размножаться при температуре ниже $7{ }^{0} \mathrm{C}$. По заключению исследователей влияние психортрофов на изменение вкуса продукта определяется не только их количеством, но в большей степени типом и вдом микроорганизмов. Бактерии рода Pseudomonas вызывают порчу продукта, когда их количество достигает 5,2-200 млн клеток в 1 г, дрожжи 2,5-14 млн, coli-form 2,7 -150 млн[4].

Всвежевыработанных сырах дрожжи и плесневые грибы не были обнаружены, дажепри посеве 0,1 г, такжеих количество не превышало более 10 клеток в 1 г. На протяжении хранения при 6-8 ${ }^{0} \mathrm{C}$ в исследуемых сырах не отмечалось роста этих микроорганизмов.

Молочнокислые микроорганизмы, входившие в состав кислой молочной сыворотки, после выдержки смеси молока и сыворотки при температурах коагуляции в основном погибали, а динамика изменения оставшихся жизнеспособных клеток в процессе хранения не изменялось и соответствовало требованиям ветеринарно -санитарных норм.Однако нао отметить, что количество молочнокислых бактерий в опытном обезжиренномсыре намного больше по сравнению с другими вариантами сыров на протяжении всего рассматриваемого диапазона независимо продолжительности их хранения. Более высокое количество молочнокислых микроорганизмов в опытном сыре объясняетсяприменением более низкой температуры коагуляции $\left(75^{0} \mathrm{C}\right)$ белков молока и внесением повышенных доз кислой молочной сыворотки. В процессе хранения сыров при $6-8^{0} \mathrm{C}$ происходит постепенное снижение количества молочнокислыхмикроорганизмов.

Выводы. Таким образом, в готовом продукте, исследованной после окончания технологического процесса, были обнаружены мезофильные аэробные и факультативно анаэробные микроорганизмы (МАФАМ), психротрофные и молочнокислые бактерии. Несмотря на то, что их количество в процессе хранения подвергались значительным изменениям, оно не достигло величин приводящих к заметным органолептическим изменениям в сырах. Необходимо отметить, что дрожжей и плесневых грибов не были обнаружены в свежевыработанных сырах при посеве 0,1 г, также их количество не превышало более 10 клеток в 1 ги на протяжении хранения при 6-8 ${ }^{\circ} \mathrm{C}$ в исследуемых сырах не отмечалось роста этих микроорганизмов. Анализ проведенных микробиологических исследований свидетельствует о том, что при температуре хранения 6-8 ${ }^{0} \mathrm{C}$, соблюдении технологических режимов и санитарно - гигиенических условий производства сыровпри их высоком качестве сроки хранения в условияхУзбекистана составляет до 10 -12 суток.

Литература: 1. Технический регламент Таможенного союза «О безопасности молока и молочной продукции»(ТР ТС 033/2013) от 9 октября 2013 года N 67. 2. ДонченкоЛ.В., НадыктаВ.Д. Безопасность пищевой продукции. В 2 ч. Часть 1 учебник для Академического бакалавриата. 3-е изд., исправленное и дополненное. М. Издательство «Юрайт» 2019.264 с. 3. Постановление Кабинета Министров Республики Узбекистан№ 474 «Об утверждении общего технического регламента о безопасности молока и молочной продукции» от 7 июля 2017 года. 4. СанПиН РУз № 0283-10 «Гигиенические требования к безопасности пищевой продукции» от 29 декабря 2010 года.

\section{STUDY OF SOFT CHEESE MICROFLORA}

IshniyazovaSh.A. - Candidate of Chemical Sciences, Associate Professor,

Butaeva I.M. - Head of International Relations Department,

(Samarkand Institute of Veterinary Medicine, Uzbekistan)

Summary: The paper presents the results of studying the composition of the microflora of soft cheese, the dynamics of their change during storage, as well as the optimal shelf life of the finished product.

Key words: microflora, thermoacid coagulation, proteins, serum, viable cell. 


\title{
УДК 57.573:636.5/.6:637.5 \\ АНАЛИЗ МЯСНЫХ КАЧЕСТВ БРОЙЛЕРОВ ПРИ МАТЕМАТИЧЕСКОМ МОДЕЛИРОВАНИИ ОПЫТА
}

Капитонова Е.А., доц., к.с-х.н. (УО ВГАВМ, Республика Беларусь)

\begin{abstract}
Аннотация. Разработка новых адсорбентов микотоксинов является актуальной проблемой имеющей высокую практическую значимость. Применение адсорбентов микотоксинов нового поколения в бройлерном птицеводстве, позволяет повысить выход тушки и качество мяса цыплят-бройлеров. В лабораторных условиях нами была выявлена сравнительная эффективность адсорбентов «МеКаСорб» и «Беласорб». Полученные результаты позволили осуществить апробацию адсорбентов в производственных условиях.
\end{abstract}

Ключевые слова: цыплята-бройлеры, мясные качества, сортность, физико-токсикобиологическая оценка.

Бесперебойное обеспечение населения высококачественным белком обеспечивает продовольственную безопасность страны. Однако необходимо учитывать тот факт, что речь должна идти не только о количественных, но и о качественных показателях продукции [1, 2, 3]. В настоящее время, стимуляция продуктивных показателей сельскохозяйственной птицы, является необходимым фактором раскрытия генетического потенциала кросса. Применение в птицеводстве гранулированных комбикормов должно обеспечивать необходимое количество питательных веществ в одной грануле корма. Однако составные элементы комбикорма зачастую получены в различных погодных условиях и, прежде, чем попасть на комбикормовый завод, могли храниться с разным уровнем санитарной защиты. В связи с этим, на комбикормовых заводах и кормоцехах предприятий, с профилактической целью, вводятся адсорбенты микотоксинов, которые снижают негативные последствия полевых и амбарных грибов $[4,5,6,7]$. Установлено, что микотоксикозы приводят к дисбактериозам, снижению продуктивности, а в хронических случаях и к летальным исходам $[8,9,10]$.

Нами были разработаны, опробированы в лабораторных условиях и запатентованы эффективные и безопасные кормовые добавки на основе трепела (месторождение «Стальное», Могилевской области, Беларусь) «МеКаСорб» и «Беласорб».

Нашу научно-исследовательскую работу мы проводили в условиях клиники кафедры паразитологии и инвазионных болезней, а также ветеринарно-санитарной экспертизы им. академика Х.С. Горегляда УО «Витебская ордена «Знак Почета» государственная академия ветеринарной медицины» по теме: «Эффективность использования адсорбентов нового поколения при производстве мяса цыплят-бройлеров».

С целью изучения сравнительного влияния применения различных адсорбентов для повышения качества мяса цыплят-бройлеров, методом математического моделирования опыта нами был поставлен комплекс органолептических и лабораторных исследований на 40 тушках цыплят-бройлеров, убитых в конце технологического периода выращивания (41 день). Подопытным цыплятам-бройлерам кросса «Росс-308» методом математического моделирования опыта вводили в рацион 0,5\%-1,5\% «МеКаСорб» + 1,5\%-2,5\% «Беласорб». Для биометрической обработки данных от каждой подопытной группы нами изучалось по 10 голов / тушек.

При исследовании биологической ценности мяса руководствовались ГОСТ 18292-2012 «Птица сельскохозяйственная для убоя. Технические условия», ГОСТ 31470-2012 «Мясо птицы, субпродукты и полуфабрикаты из мяса птицы. Методы органолептических и физикохимических исследований», СТБ 1945-2010 «Мясо птицы. Общие технические условия» и ГОСТ 31962-2013 «Мясо кур (тушки кур, цыплят, цыплят-бройлеров и их части). Технические условия».

При анализе мясных качеств установлено, что наивысшими они были в группах с допустимым порогом применения 1,5-2,5 \% «Беласорб» при минимальном пороге 0,5 \% «МеКаСорб». Увеличение ввода «МеКаСорб» до 1,5 \% не способствует увеличению выхода 
потрошеной тушки. Убойный выход и в подопытных группах колебался в допустимых пределах - 68,3-72,7\%.

При анатомической разделке тушек от подопытных бройлеров было установлено, что выход грудки варьировал в пределах 39,5-41,2 \% в 4-й группе 0,5 \% «МеКаСорб» + 2,5\% «Беласорб». Максимальная массовая доля выхода бедра так же была получена от бройлеров выращенных в 4-й группе (13,3\%).

Увеличение массовой доли крыла в 1-й (1,5\% «МеКаСорб» + 2,5 \% «Беласорб») и 2-й группах $(0,5 \%$ «МеКаСорб» $+1,5 \%$ «Беласорб») в целом не способствуют увеличению мясной продуктивности цыплят-бройлеров.

При оценке выхода съедобных и несъедобных частей отметим, что максимальный выход съедобных частей отмечался в 3 -й $(81,8$ \%) и 4-й $(81,5 \%)$ группах, различия в которых были не достоверны. При этом показатели вышеназванных групп достоверно отличались от достижений 1-й и 2-й групп на 2,3-6,6 п.п. и 1,9-6,3 п.п. соответственно. Минимальные значения были получены от бройлеров выращиваемых во 2-й группе.

Максимальная массовая доля выхода съедобных субпродуктов была отмечена в 3-й группе $-4,38$ \% и в 1-й группе - 4,35 \% от живой массы птицы. Показатели 4-й группы были незначительно меньше - 4,22 \%. При этом в весовом эквивалента, наибольший выход был отмечен в 3-й группе - 112,8 г и в 4-1 группе - 111,5 г, а в 1-й группе этот показатель достиг - 107,1 г. Наименьший выход субпродуктов был отмечен во 2-й группе - 99,1 г (3,76 \%).

При анализе физико-токсико-биологических показателей мяса от подопытных бройлеров отметим, что во всех подопытных группах они были практически на одинаковом уровне. Реакция на аммиак и соли аммония была отрицательной, реакция на пероксидазу положительной, а при формольной реакции бульон был прозрачным без хлопьев и сгустков. Токсичности и патологическая форма простейших, с изменением движения или формы жгутиков - не выявлена.

Все тушки были классифицированы как относящиеся к I сорту. Тушек II сорта или не стандартных отмечено не было.

Органолептическая оценка подопытных групп особых отличий н имела. Внешний вид поверхности тушек имел корочку подсыхания и был беловато-серого цвета. Запах был специфическим и соответствовал свежему мясу птицы. Подкожный и внутренний жир был серовато-белого цвета, что является генетической особенностью и свойственно для цыплятбройлеров кросса «Росс-308». Мышцы имели плотную, упругую консистенцию, были слегка влажными. На разрезе бедренные мышцы имели светло-розовый цвет, а грудные - сероватобелый. Серозная оболочка была без слизи, влажная, тусклая.

При дегустационной оценке вареного мяса отметим, что в подопытных группах отличий также не наблюдалось. Мясо имело приятный и сильно выраженный запах (аромат). Обладало очень приятным выраженным мясным вкусом присущим мясу курицы. Было нежным, сочным, мягким. При пережевывании мышечные пучки легко разламывались и крошились, ощущалось обилие мясного сока.

При дегустационной оценке жареного мяса нами было установлено, что в подопытных группах отличий также не наблюдалось. Мясо имело приятный и сильно выраженный аромат и вкус присущий мясу курицы. Оно было нежным, сочным, мягким. При пережевывании мышечные пучки легко разламывались и крошились, ощущалось обилие мясного сока.

На основании проведенных исследований, постановки опыта методом математического моделирования, можно сделать вывод о том, что применение «Беласорб» в дозах 1,5-2,5 \% способствует увеличению мясных показателей цыплят-бройлеров кросса «Росс-308». Введение «МеКаСорб» в дозах 0,5-1,5 \% оказывает слабое стимулирующее воздействие на продуктивность птицы. При сравнительном анализе полученных мясных показателей от бройлеров при введении 0,5 \% «МеКаСорб» $+2,5$ \% «Беласорб» (4 группа) и $1,5 \%$ «МеКаСорб» + 1,5\% «Беласорб» (3 группа) различия были недостоверны. При сравнительном применение дозы 0,5 \% «МеКаСорб» + 1,5 \% «Беласорб» (2 группа) и 0,5\% «МеКаСорб» + 2,5 \% «Беласорб» (4 группа) различия были достоверны в пользу 
использования комбинации 4-й группы. Максимальное применение повышенных доз адсорбентов в модели 1,5 \% «МеКаСорб» + 2,5 \% «Беласорб» (1 группа), что соответствует 4 кг/т комбикорма, снижает питательность зерновой и зерно-бобовой группы рациона и не способствует повышению продуктивных показателей птицы.

Исследуемые образцы мяса от подопытных цыплят-бройлеров кросса «Росс-308» соответствуют требованиям ГОСТ 18292-2012, ГОСТ 31470-2012, СТБ 1945-2010 и ГОСТ 31962-2013.

Литература. 1. Сборник производственных ситуаций по гигиене животных: учебнометодическое пособие / Медведский В. А. [и др.]. - Витебск : УО ВГАВМ,2011. - 40 с. 2. Технология производства продукции животноводства. Курс лекций: в 2 ч. Ч. 2. Технология производства продукции скотоводства, свиноводства и птицеводства: учебно-методическое пособие / М.А. Гласкович [и др.]. - Горки: БГСХА, 2017. - 240 с. 3. Усовершенствование системы лечебно-профилактических и диагностических мероприятий в бройлерном птицеводстве / А. А. Гласкович, А. Р. Аль-Акаби, Е. А. Капитонова [и др.]. - I Международная научно-практическая конференция «Ветеринарная медицина на пути инновационного развития». - Гродно : ГрГАУ, 2016. - С. 134-143. 4. Гласкович, М. А. Анализ повышения эффективности использования кормовой базы на птицефабриках Республики Беларусь / М. А. Гласкович, Е. А. Капитонова // Ученые записки УО ВГАВМ : научно-практический журнал. Витебск : УО ВГАВМ, 2011. - Т. 47, вып. 1. - С. 333-335. 5. Капитонова, Е.А. Профилактика действия микотоксинов в растительных кормах / Е.А. Капитонова, А.А. Гласкович, С.В. Абраскова // Материалы Международной научно-практической конференции «Земледелие, растениеводство, селекция: настоящее и будущее». - Жодино : РУП «НПЦ НАН Беларуси по земледелию», 2012. - С. 302-305. 6. Использование трепела и добавок на его основе в кормлении молодняка крупного рогатого скота / Радчиков В.Ф. [и др.]. РУП «НПЦ НАН Беларуси по животноводству». Жодино, 2013. - С. 12. 7. Санитарно-гигиеническое значение бактерий и плесневых грибов в изменении качества кормов : учебно-методическое пособие / Абраскова С.В. [и др.]. - Витебск : ВГАВМ, 2012. - 32 с.: ил. 8. Капитонова, Е.А. Профилактика дисбактериозов / Е.А. Капитонова // Материалы VII Международной научнопрактической конференции «Экология и инновации». - Витебск : ВГАВМ, 2008. - С. 100-101. 9. Капитонова, Е.А. Профилактика заболеваний птиц путем введения в рацион цыплятбройлеров биологически активных веществ / Е.А. Капитонова // труды Всероссийского НИИ экспериментальной ветеринарии им. Я.Р. Коваленко, 2009. - Т. 75. - С. 329-33. 10. Красочко, П.А. Роль микрофлоры в возникновении заболеваний у животных и птиц / П.А. Красочко, B.М. Голушко, Е.А. Капитонова // «Проблемы интенсификации производства продуктов животноводства» Тезисы докладов Международной научно-практической конференции. Жодино : РУП «НПЦ НАН Беларуси по животноводству», 2008. - С. 292-294.

\section{ANALYSIS OF MEAT QUALITIES OF BROILERS IN MATHEMATICAL MODELING OF EXPERIENCE}

Kapitonova E.A., associate professor, Ph.D. (UO VSAVM, Belarus)

Summary. Annotation. The development of new mycotoxin adsorbents is an urgent problem of high practical significance. The use of mycotoxin adsorbents of a new generation in broiler poultry farming, allows to increase the yield of carcasses and the quality of meat of broiler chickens. In the laboratory, we have identified the comparative effectiveness of the adsorbents "MeKaSorb" and "Belasorb". The results obtained made it possible to test the adsorbents in production conditions.

Key words: broiler chickens, meat quality, grade, physical-toxic-biological assessment. 


\section{АНАЛИЗ АКТИВНОСТИ АМИНОТРАНСФЕРАЗ СЫВОРОТКИ КРОВИ КАРПА ПРИ ВОЗДЕЙСТВИИ ТЯЖЕЛЫХ МЕТАЛЛОВ}

Карпенко Л.Ю., д.б.н., профессор, Полистовская П.А., ассистент, (ФГБОУ ВО СПбГУВМ, Россия)

Аннотация. Тяжелые металлы являются довольно значимыми химическими загрязнителями. Опасность данных токсикантов заключается в их высокой биологической активности, способности к накоплению в тканях различных организмов и отсутствии биодеградации[1]. В статье рассматривается влияние ацетата кадмия и ацетата цинка на активность трансаминаз сыворотки крови карпа. В результате исследования было отмечено достоверное повышение уровня АлАТ и АсАТ сыворотки крови рыб при воздействии ацетата кадмия и достоверное повышение АсАТ при воздействии ацетата цинка.

Ключевые слова: токсикоз рыб, кадмий, цинк, тяжелые металлы, карп, трансаминазы.

Исследование кратковременного воздействия столь высоких концентраций токсикантов является актуальным в контексте локальных экологических катастроф, как, например, непреднамеренные сбросы в водоемы циркуляционных вод ТЭС и АЭС.

Целью исследования являлось изучение активности аминотрансфераз (АлАТ и АсАТ) сыворотки крови карпа при воздействии кадмия и цинка.

Схема опыта включала в себя использование 3 групп по 10 рыб (карп обыкновенный (лат. Cyprinus carpio)): контрольную группу - содержащуюся в воде без токсического агента, и двух подопытных групп: - содержащуюся в растворе ацетата кадмия $\left(\mathrm{Cb}\left(\mathrm{CH}_{3} \mathrm{COO}\right)_{2)} \mathrm{c}\right.$ концентрацией кадмия 0,5 мг/л; и - содержащуюся в растворе ацетата цинка $\left(\mathrm{Zn}\left(\mathrm{CH}_{3} \mathrm{COO}\right)_{2} \mathrm{c}\right.$ концентрацией цинка 1 мг/л (что соответствует превышению ПДК этих металлов в 100 раз). Экспозиция рыб в токсическом растворе составила 4 часа.

При анализе полученных данных нами было отмечено, что при воздействии кадмия, наблюдается достоверное повышение аланинаминотрансферазы $(\mathrm{p} \leq 0,05)$ на 88,82 \% $(38,34 \pm 0,19 \mathrm{ME} / л)$ и аспартатаминотрансферазы $(\mathrm{p} \leq 0,05)$ на $71,53 \% \quad(388,82 \pm 14,57 \mathrm{ME} / л)$

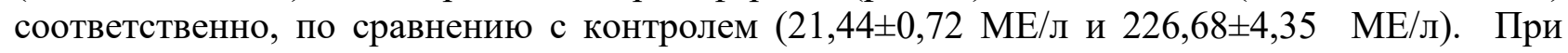
воздействии ацетата цинка наблюдается тенденция к повышению аланинаминотрансферазы на $0,47 \%(21,54 \pm 0,73 \mathrm{ME} / л)$ и достоверное повышение $(\mathrm{p} \leq 0,05)$ аспартатаминотрансферазы на $6,8 \%(242,1 \pm 4,09 \mathrm{ME} / л)$ по сравнению с контролем.

Исследование показало достоверное повышение уровня трансаминаз сыворотки крови рыб при воздействии ацетата кадмия и достоверное повышение аспартатаминотрансферазы при воздействии ацетата цинка. При отравлении тяжелыми металлами изменяется функционирование печени, наблюдается повреждение ее клеток, что сопровождается выходом цитоплазматических ферментов в кровоток [2]. Следует отметить, что, хотя оба исследуемых металла относятся к первому классу опасности, предельно-допустимая концентрация кадмия для рыбохозяйственных водоемов на порядок выше ПДК цинка, именно поэтому и эффект данных металлов на ферментную систему организма рыб также отличается. Кроме того, цинк является кофактором многих ферментов организма.

Согласно полученным нами результатам, а также по материалам других исследователей $[3,4]$ можно сделать вывод о возможности исследования трансаминаз сыворотки крови карпа, также, как для птиц и животных $[5,6]$, в качестве биомаркеров уровня токсического воздействия тяжелых металлов на организм рыб.

Литература: 1. Гребцов, М.Р. Экологотоксикологическое состояние Волховской губы ладожского озера/ М.Р. Гребцов // Вопросы нормативно-правового регулирования в ветеринарии. - 2014. № 3 - С. 229-235. 2. Динамика активности аминотрансфераз и щелочной фосфатазы в крови сеголеток карпа при хроническом воздействии ионов кадмия и марганца/ Б.С. Мусаев, И.К. Курбанова, Д.Н. Магомедгаджиева и др.// Известия Самарского научного центра РАН. - 2010. №1-5. - С. 1321-1324. 3. Влияние ацетата кадмия на динамику биохимических показателей сыворотки крови сеголеток карпа (Cyprinus carpio L.), Габибов 
М.М., Мусаев Б.С., Мурадова Г.Р., Рабаданова А.И., Абдулаева С.О., Вестник Дагестанского государственного университета. Серия 1: Естественные науки. 2008. № 6. С. 88-92. 4. Полистовская, П.А. Уровень активности трансаминаз сыворотки крови карпа при воздействии различных концентраций кадмия / П.А. Полистовская, К.П. Кинаревская, А.И. Енукашвили// Эффективные и безопасные лекарственные средства в ветеринарии, Материалы V-го Международного конгресса ветеринарных фармакологов и токсикологов. - СПб. -изд. ФГБОУ ВО «СПбГАВМ». - 2019.- С.157-159. 5. Бахта А.А., Динамика показателей, характеризующих состояние печени, у коз зааненской породы в зависимости от месяца сукозности/ А.А. Бахта, А.А. Погодаева, А.А. Погодаев, П.Д. Бохан// Знания молодых для развития ветеринарной медицины и АПК страны. 2015. С. 38-39. 6. Лечение кошек с дисфункцией печени препаратом "Хофитол" / В. А. Трушкин, И. В. Никишина, А. А. Воинова [и др.] // Эффективные и безопасные лекарственные средства в ветеринарии: Материалы IVго Международного конгресса ветеринарных фармакологов и токсикологов, - СанктПетербург: СПбГАВМ, 2016. - С. 197-198.

\section{ANALYSIS OF THE ACTIVITY OF CARP SERUM AMINOTRANSFERASES UNDER THE INFLUENCE OF HEAVY METALS}

Karpenko L. Yu., Doctor of Biological Sciences, Professor, Polistovskaya P. A., assistant (FSBEI HE St.Peterburg SUVM, Russia)

Summary. Heavy metals are quite significant chemical pollutants. The danger of these toxicants lies in their high biological activity, the ability to accumulate in the tissues of various organisms and the absence of biodegradation[1]. The article discusses the effect of cadmium acetate and zinc acetate on the activity of transaminases in carp blood serum. The study revealed a significant increase in the level of alanineaminotransferase and aspartateaminotransferase in fish serum when exposed to cadmium acetate and a significant increase in aspartate aminotransferase when exposed to zinc acetate.

Keywords: fish toxicosis, cadmium, zinc, heavy metals, corp, transaminases.

\section{УДК 57.044}

\section{ВЛИЯНИЕ ХИМИЧЕСКИХ ПЕСТИЦИДОВ НА ЗДОРОВЬЕ ЧЕЛОВЕКА В СФЕРЕ БИОЛОГИЧЕСКОЙ БЕЗОПАСНОСТИ}

Катанова Е.С., Панфилов А.Э., Нитяга И.М. доцент МГУПП, Россия

Аннотация: материалы данной работы направлены на проблемы с использованием пестицидов в промышленности сегодня. Это показывает актуальность научной статьи.

Ключевые слова: пестициды, здоровье, биологическая и пищевая безопасность

Пестициды - это вещества или смеси веществ, которые в основном используются в сельском хозяйстве или в программах охраны здоровья населения для защиты растений от вредителей, сорняков или болезней, а у людей от трансмиссивных болезней, таких как малярия, лихорадка денге. Типичными примерами являются инсектициды, фунгициды, гербициды, родентициды и регуляторы роста растений. Эти продукты также используются для других целей, таких как улучшение и обслуживание общественных городских зеленых зон и спортивных площадок. Кроме того, существуют и другие менее известные способы применения этих химических веществ, например, в шампунях для домашних животных, строительных материалах и днищах лодок для устранения или предотвращения присутствия нежелательных видов животных и растений.

Настоящий обзор направлен на то, чтобы подчеркнуть настоятельную необходимость разработки новой концепции в сельском хозяйстве, предусматривающей резкое сокращение использования химических пестицидов. Учитывая тот факт, что воздействие на здоровье широко обсуждается в текущей литературе, в настоящем документе основное внимание 
уделяется основным хроническим последствиям для здоровья и недавним выводам относительно воздействия на здоровье, которые были связаны с воздействием общих классов химических пестицидов, т. е. хлорорганических, фосфорорганических, карбаматных, пиретроидных, триазинов и неоникотиноидов. Больше внимания уделяется широко используемому гербициду "глифосат", который является фосфорорганическим пестицидом, очень тесно связанным с современным сельским хозяйством. Важные последствия для здоровья, о которых говорится ниже, свидетельствуют о настоятельной необходимости внедрения альтернативных решений.

Наиболее широко известным хлорорганическим пестицидом является дихлордифенилтрихлорэтан, т. е. инсектицид ДДТ, бесконтрольное применение которого вызвало множество экологических и медицинских проблем. Дильдрин, эндосульфан, гептахлор, дикофол и метоксихлор-это некоторые другие хлорорганические соединения, используемые в качестве пестицидов.

Есть несколько стран, которые все еще используют ДДТ или планируют вновь ввести его в целях общественного здравоохранения. Кроме того, ДДТ также используется в качестве раствора в некоторых растворителях. Это вездесущее химическое вещество, и считается, что каждый живой организм на Земле имеет бремя тела ДДТ, главным образом хранящееся в жире. Имеются также данные о том, что ДДТ и его метаболит $p$, pдихлордифенилдихлорэтилен (ДДЭ) могут обладать эндокринно-нарушающим потенциалом и канцерогенным действие. Внутриутробное воздействие как ДДТ, так и ДДЭ было связано с последствиями для развития нервной системы у детей. Более того, недавнее исследование связывало ДДЭ с печеночной липидной дисфункцией у крыс.

Общий класс хлорорганических пестицидов связан с такими последствиями для здоровья, как эндокринные нарушения, влияние на эмбриональное развитие, липидный обмен, гематологические и печеночные изменения. Их канцерогенный потенциал ставится под сомнение, но опасения по поводу возможного канцерогенного действия не следует недооценивать.

Фосфорорганические соединения, которые рекламировались как более экологичная альтернатива хлорорганическим соединениям, включают большое разнообразие пестицидов, наиболее распространенным из которых является глифосат. Этот класс также включает другие известные пестициды, такие как малатион, паратион и диметоат; некоторые из них известны своим разрушающим эндокринную систему потенциалом. Этот класс пестицидов связаны с воздействием на функцию ферментов холинэстеразы, снижение секреции инсулина, нарушение нормального клеточного метаболизма белков, углеводов и жиров, а также с генотоксические эффекты и влиянием на функции митохондрий, вызывая клеточный окислительный стресс и проблемы с нервной и эндокринной системы.

Популяционные исследования выявили возможную связь между воздействием фосфорорганических пестицидов и серьезными последствиями для здоровья, включая сердечно-сосудистые заболевания, негативное воздействие на мужскую репродуктивную систему и нервную систему, слабоумие, а также возможный повышенный риск развития неходжкинской лимфомы. Кроме того, пренатальное воздействие фосфорорганических соединений коррелирует с уменьшением продолжительности беременности и неврологическими проблемами, возникающими у детей.

Что касается глифосата, безопасность которого является предметом непрекращающихся научных споров, то он является наиболее широко используемым гербицидом в современном сельском хозяйстве, особенно после введения толерантных к глифосату генетически модифицированных культур, таких как некоторые виды сои и кукурузы. Его широкое использование при выращивании генетически модифицированных соевых бобов вызвало опасения по поводу возможных синергических эстрогенных эффектов из-за одновременного воздействия глифосата и фитоэстрогена “генистеина", который является распространенным изофлавоном, присутствующим в соевых бобах и соевых продуктах. 
Глифосат может проявлять разрушающую эндокринную систему активность, воздействовать на эритроциты человека invitro и способствовать канцерогенности кожи мыши. Кроме того, считается, что он вызывает крайние нарушения в шикиматном пути, который является путем, обнаруженным в растениях и бактериях, а также в кишечных бактериях человека. Это нарушение может повлиять на снабжение человеческого организма незаменимыми аминокислотами. Коммерческие препараты глифосата считаются более токсичными чем само активное вещество. Глифосат основе гербициды, такие как известный “Раундап”, может вызвать повреждения ДНК и действуют как эндокринные разрушители в человеческих клеточных линиях и у крыс тестикулярных клеток, привести к повреждению выращенные человеческие кожные клетки, и стимулировать гибель клеток в тестикулярных клетках экспериментальных животных. Имеются также свидетельства их возможной способности влиять на цитоскелет и внутриклеточный транспорт.

Недавнее исследование изучало возможную связь между глифосатом, генетически модифицированными культурами и ухудшением здоровья в США. Корреляционный анализ вызвал обеспокоенность по поводу возможной связи между использованием глифосата и различными последствиями для здоровья и заболеваниями, такими как гипертония, диабет, инсульты, аутизм, почечная недостаточность, болезни Паркинсона и Альцгеймера, а также рак. Кроме того, существуют опасения по поводу возможной способности глифосата вызывать непереносимость глютена, проблему со здоровьем, связанную с недостатком основных микроэлементов, репродуктивные проблемы и повышенный риск развития неходжкинской лимфомы.

Карбаматные пестициды, такие как альдикарб, карбофуран и зирам, являются еще одним классом химических пестицидов, которые были связаны с эндокринно-нарушающей активностью, возможными репродуктивными нарушениями и влиянием на клеточные метаболические механизмы и функцию митохондрий. Кроме того, invitroисследования invitro показали способность карбаматных пестицидов вызывать цитотоксические и генотоксические эффекты в клетках яичников хомяков и индуцировать апоптоз и некроз в иммунных клетках человека, естественных киллерных клетках, а также апоптоз в Т-лимфоцитах.

Кроме того, было подтверждено, что карбарил, который относится к категории карбаматных пестицидов, может выступать в качестве лиганда для печеночного рецептора арилуглеводорода, фактора транскрипции, участвующего в механизме токсичности диоксинов. Имеются также данные о способности пестицидов карбамата вызывать нейробехавиоральные эффекты, повышенный риск развития деменции.

Литература 1. World Health Organization. Public Health Impact of Pesticides Used in Agriculture. England: World Health Organization; (1990) 2. Alewu B, Nosiri C. Pesticides and human health. In: Stoytcheva M, editor. Pesticides in the Modern World - Effects of Pesticides Exposure. InTech; (2011). p. 231-50. Available from: http://www.intechopen.com/books/pesticides-in-the-modernworld-effects-of-pesticides-exposure/pesticide-and-human-health 3. NSW EPA. What Are Pesticides How Do They Work? (2013). Available from: http://www.epa.nsw.gov.au/pesticides/pestwhatrhow.htm 4. Hoffman RS, Capel PD, Larson SJ. Comparison of pesticides in eight U.S. urban streams. Environ Toxicol Chem (2000) 19:224958.10.1002/etc.5620190915

\section{INFLUENCE OF CHEMICAL PESTICIDES ON HUMAN HEALTH IN THE SPHERE OF BIOLOGICAL SAFETY}

Katanova E.S., Panfilov A.E., Nityaga I.M. assistant professor MGUPP, Russia

Summary: The materials of this work are aimed at the problems with the use of pesticides in industry today. This shows the relevance of the scientific article.

Key words: pesticides, health, biological and food safety 


\title{
ОСОБЕННОСТИ НАКОПЛЕНИЯ ТЯЖЕЛЫХ МЕТАЛЛОВ В МЫШЦАХ КРУПНОГО РОГАТОГО СКОТА
}

\author{
Качер Н.И., доц., к.Х.н. \\ (ФГБОУ ВО Ивановская ГСХА, Россия)
}

\begin{abstract}
Аннотация. В условиях ухудшения экологической обстановки в мире в целом, и в России в частности, качество и безопасность продуктов питания в последнее время вызывает как некоторую озабоченность, так и научный интерес.
\end{abstract}

Ключевые слова: тяжелые металлы, крупный рогатый скот, мышцы

В настоящее время все большее значение приобретает проблема, связанная с загрязнением пищевых продуктов токсичными элементами, в том числе и тяжёлыми металлами.

Развитие промышленного производства, увеличение количества автотранспорта, повышение степени благоустройства жилья, урбанизация территорий, использование минеральных удобрений все эти факторы можно рассматривать как источники антропогенного загрязнения окружающей природной среды. В атмосферу идет выброс различных токсичных веществ, в том числе и соединений мышьяка, свинца, кадмия, ртути, хрома, меди, фтора. Попадая в атмосферу, воду, данные соединения загрязняют и почву, а также произрастающую на ней растительность. Таким образом, мы можем наблюдать своеобразный процесс миграции тяжелых металлов из неорганической среды в органическую.

Поступая в организм животных с кормами и водой, данные элементы со временем аккумулируются в органах и тканях, а также могут выводится из организма с продуктами обмена и молоком.

Тенденция развития продовольственного рынка показывает, что в России, как и в других странах мира, возрастает спрос на продукцию животного происхождения и, в первую очередь, на молоко и мясо[1].

Мышцы (мясо) и молоко являются необходимыми продуктами питания для человека. Входят в потребительскую корзину, обязательно используются в питании людей, находящихся в лечебных и социальных учреждениях.

Поэтому исследования содержания тяжелых металлов в мышцах крупного рогатого скота (КРС), в субпродуктах, молоке считаем актуальными и необходимыми как для заинтересованных лиц, так и для обычных потребителей.

Содержание свинца, кадмия, мышьяка, ртути, цинка, марганца, никеля и железа определяли методом атомно-абсорбционной спектрофотометрии на спектрофотометре «Сатурн», пробоподготовку проводили методом «сухой» минерализации.

Отбор проб осуществляли, согласно общепринятой методики [2], сразу после убоя КРС непосредственно на площадках убоя трех сельскохозяйственных предприятий Фурмановского района Ивановской области. Для повышения верификации результатов исследований, продукцию отбирали в разные периоды года - зимой и летом.

Ртуть и мышьяк в исследуемых образцах обнаружены не были.

Содержание остальных исследуемых элементов находилось на уровне ниже установленных нормативов, однако, учитывая возможность биоаккумуляции тяжелых металлов, само их наличие, вызывает некоторую озабоченность и научный интерес.

Рассматривая характер изменения содержания ТМ в пробах мяса КРС, отобранных в различные периоды года, можно говорить о более высокой загрязненности этими токсикантами «летних» проб. Так, концентрации кадмия, свинца и марганца в 3,1, 2,2 и 2 раза соответственно, выше, чем концентрация этих элементов в «зимних» образцах мяса. В то же время содержание тяжелых металлов, относящихся к микроэлементам, а именно железа, меди и цинка незначительно выше в пробах, исследуемых зимой. 
Факт более высокой загрязнённости «летних» проб мяса свинцом и кадмием, можно объяснить меньшей упитанностью животных, следовательно, преобладанием в мышцах соединительной и хрящевой тканей, которые могут накапливать тяжелые металлы при условии несбалансированного кормления [3].

Литература. 1. Зернина С.Г. Сравнительная характеристка продуктивных качеств коров разного происхождления / Зернина С.Г., Склярская Т.В., Сафронов С.Л.// Материалы национальной научной конференции профессорскопреподавательского состава, научных сотрудников и аспирантов СПбГАВМ.- СПб, Издательство ФГБОУ ВО СПбГАВМ, 2020 г. C. 40-42. 2. Методические указания по отбору проб пищевой продукции животного и растительного происхождения, кормов, кормовых добавок с целью лабораторного контроля их качества безопасности. - Утв. Россельхознадзором 21.05.2009. - Москва, 2009. - 31 с. 3. Гуркина Л.В. Экологический мониторинг на страже здоровья человека /Гуркина Л.В., Иванов В.И., КачерН.И. // Аграрная наука в условиях модернизации и инновационного развития АПК России. Сборник материалов Всероссийской научно-методической конференции с международным участием, посвященной 100-летию академика Д.К. Беляева. 2017. - С. 9-12.

FEATURES OF THE ACCUMULATION OF HEAVY METALS IN THE MUSCLES OF CATTLE

Kacher N. I., Associate Professor, Candidate of Chemical Sciences

(Ivanovo State Agricultural Academy, Russia)

Summary. In the context of the deterioration of the environmental situation in the world as a whole, and in Russia in particular, the quality and safety of food has recently caused both some concern and scientific interest.

Key words: heavy metals, cattle, muscles

УДК 615.322:616.34-008.314.4:636.2-053.2

\section{ЛЕЧЕБНО-ПРОФИЛАКТИЧЕСКОЕ ПРИМЕНЕНИЕ НАСТОЯ ЗВЕРОБОЯ ПРОДЫРЯВЛЕННОГО ПРИ ДИАРЕЕ МОЛОДНЯКА КРУПНОГО РОГАТОГО СКОТА}

Киселенко П.С. доцент., кандидат ветеринарных наук (ФГБОУ ВО СПбГУВМ, Россия)

Аннотация. Испытана комплексная схема лечения диареи телят с включением в неё средств симптоматической терапии и перорального введения настоя травы зверобоя продырявленного за 20 - 30 минут до кормления. Применение данной схемы лечения позволяет добиться 100\% терапевтической эффективности при средней продолжительности курса в 4 дня. Ключевые слова. Диарея, лечение диареи, телята, настой травы зверобоя продырявленного,

Болезни молодняка первых дней жизни имеют повсеместное распространение в хозяйствах независимо от форм их собственности и сопровождаются значительным процентом отхода среди заболевших, что наносит ощутимый экономический ущерб.

В фармакотерапии заболеваний желудочно-кишечного тракта молодняка сельскохозяй- ственных животных наряду с химиотерапевтическими средствами всё чаще используются ле- карственные средства растительного происхождения [2,3].

Заслуживает внимания применение при расстройствах желудочно-кишечного тракта препаратов растительного происхождения. [1].

Такие средства могут готовиться непосредственно в условиях животноводческих ферм при сравнительно низкой затрате материальных средств, они не оказывают побочного влияния на организм при длительном применении. Такого рода препараты имеют несомненное пре- имущество перед дорогостоящими химиотерапевтическими средствами, так как организм жи- вотных по своей сути более близок к миру растений. Вместе с тем, 
совместное применение при расстройствах пищеварения молодняка препаратов растительного происхождения и про- тивомикробных средств усиливает действие последних и предупреждает развитие лекарствен- ных болезней.

Среди препаратов растительного происхождения засуживает внимания настой зверобоя продырявленного, пероральное применение которого обладает противовоспалительными и противомикробными свойствами, обладает вяжущим эффектом, ускоряет работу пищевари- тельных желёз.

Материал и методы исследований. Материалом для исследований служили телята черно-пестрой породы в возрасте от 4 до 15 дней, у которых наблюдались признаки расстройства акта дефекации в виде поноса. Всего в опытах было использовано 5 телят подобранных по принципу аналогов.

Всем заболевшим животным с лечебно-профилактической целью за 20-30 минут до кормления 3-4 раза в день выпаивали настой травы зверобоя (1: 10) в количестве 250-500 мл на приём. Настой готовили непосредственно перед его применением.

Результаты собственных исследований и их обсуждение. Заболевание протекало в легкой форме. Основным симптомом заболевания являлась учащённая дефекация и разжижение каловых масс. Отмечалось незначительное угнетение общего состояния, уменьшение аппетита. При аускультации живота прослушиваются звуки урчания или переливания жидкости. Имело место незначительное беспокойство телят на почве учащённой перистальтики кишечной трубки. Во время приступов беспокойства больные обнюхивали живот, били задними конечностями по животу. Происходило незначительное учащение частоты пульса и дыхания. Общая температура тела находилась в пределах физиологических показателей.

Заболевших животных изолировали от остального поголовья телят и помещали в отдель- ные теплые и сухие клетки.

После возникновения первых признаков заболевания пропускали выпойку очередной порции молозива с заменой его на тёплый настой травы зверобоя. В последующие кормления количество молозива постепенно снижали, что зависело от общего состояния заболевших. За 20-30 минут до кормления внутрь назначали подтитрованный активный антибиотик левомицетин из расчёта 20 мг/кг живой массы тела. С целью поддержания энергетических возможностей организма и снятия интоксикации внутривенно инъецировали 5\% раствор глюкозы из расчёта 1,0 мл/кг.

Терапевтическую эффективность комплексной схемы лечения диареи с включением в неё перорального введения настоя травы зверобоя продырявленного устанавливали, определяли с учётом количества выздоровевших телят от подвергшихся лечению, а также средней продолжительности лечения в днях. .

В процессе лечения среди заболевших телят отмечалось заметное улучшение общего со- стояния, восстанавливался сосательный рефлекс, нормализовался аппетит, каловые массы приобретали нормальную консистенцию, уменьшалось общее количество актов дефекации за сутки. Животные становились более активными. Температура тела, частота пульса и дыхания по мере выздоровления возвращались к нормальным значениям. Из пяти животных больных диареей клиническое выздоровление констатировалось у всех животных (терапевтическая эффективность - 100\%). Средняя продолжительность курса лечения составила 4 дня.

Заключение. Полученные нами результаты собственных исследований дают основание рекомендовать к практическому применению апробируемую схему лечения диареи молодняка крупного рогатого скота с включением в неё средств симптоматической терапии и выпойки настоя травы зверобоя продырявленного.

Литература. 1. Андреева Н.Л. Ветеринарная фармация /Н.Л. Андреева, Г.А. Ноздрин, А.М. Лунегов и др. //Учебное пособие. - СПб. - Изд-во «Лань». - 2020.- 452 с. 2. Киселенко П.С. Показатели крови телят при диарее //Материалы национальной международной научнопрактической конференции «Биотехнологические решения задач аграрной науки» 24 мая 2017 г.- Изд-во БелГАУ.- 2017- с. 19-21. 3. Ковалёв С.П. Фитотерапия в лечении диареи телят /С.П. 
Ковалёв, П.С. Киселенко // Вопросы нормативно-правового регулирования в ветеринарии. 2016.- № 4. - c. 97-101

THERAPEUTIC AND PREVENTIVE USE OF THE INFUSION OF ST. JOHN'S WORT, WHICH WAS PIERCED BY DIAR- RHOEA OF YOUNG CATTLE.

Kiselenko P.S. Associate Professor, Ph.D. (FSBOU VO STGUVM, Russia)

Annotation. A comprehensive treatment regimen for calves diarrhea has been tested, in- cluding symptomatic therapy and oral insistence of St. John's wort grass 20 to 30 minutes before feeding.

Keywords. Diarrhea, treatment of diarrhea, calves, infusion of St. John's wort grass.

УДК: 615.9: 615.099.092

\title{
СОВРЕМЕННЫЕ ГЕПАТОТОКСИКАНТЫ
}

Кострова А.С., студент

Научный руководитель- ассистент кафедры фармакологии и токсикологии Понамарёв В.С.

(ФГБОУ ВО «СПбГУВМ»)

\begin{abstract}
Аннотация: За последние годы в ветеринарии приобрела особую актуальность проблема роста патологий гепатобилиарной системы, которые негативно влияют на физиологический статус организма животного, что и обуславливает дальнейший поиск эффективных средств с гепатопротекторной активностью. Для проверки фармацевтической активности новых лекарственных средств постоянно совершенствуются методы моделирования различных видов гепатопатий.
\end{abstract}

Ключевые слова: печень, гепатотоксиканты, токсикология.

За последние годы в ветеринарии приобрела особую актуальность проблема роста патологий гепатобилиарной системы, которые негативно влияют на физиологический статус организма животного, что и обуславливает дальнейший поиск эффективных средств с гепатопротекторной активностью[1]. Для проверки фармацевтической активности новых лекарственных средств постоянно совершенствуются методы моделирования различных видов гепатопатий[2].

Токсическое поражение печени - это универсальная биомодель, связанная с гепатотоксическим действием различных химических веществ (гепатотоксикантов), вызывающих морфологические изменения ткани органа и связанные с ними функциональные нарушения. Высокая чувствительность печени к химическим веществам обусловлена её ведущей ролью в их метаболизме[3]. При биотрансформации токсикантов возможно образование высокореактивных промежуточных продуктов и инициация свободнорадикального окисления, вследствие чего может возникать поражение печени.

Известен широкий круг веществ, обладающих гепатотоксичностью. К их числу относятся природные соединения, продуцируемые растениями, грибами, микроорганизмами, минералы, продукты химической и фармацевтической промышленности, отходы этих видов производственной деятельности.

Высокая чувствительность печени к химическим соединениям определяется несколькими обстоятельствами. Во-первых, вещества, проникающие в организм через желудочно-кишечный тракт, прежде всего, поступают именно в печень; таким образом, это первый орган, стоящий на пути ксенобиотика, резорбировавшегося во внутренние среды организма. Во-вторых, печень - основной орган, ответственный за метаболизм чужеродных веществ. Поскольку это нередко сопряжено с образованием высоко реакционно-способных промежуточных продуктов и инициацией свободно-радикальных процессов.

Из наиболее применяемых препаратов к гепатотоксикантам относят:

1) Химиотерапевтические средства (изониазид, сульфаниламиды и пр.)

2) НПВС (фенацетин) [4] 
3) Хлорорганические вещества (дихлорэтан, тетрахлорэтан)[4]

4) Спирты (этанол, этиленгликоль)

5) Соли металлов (меди, железа, никеля, олова и т.д.)

Литература: 1. Понамарев, В. С. Влияние препарата "Гепатон " на реакции перекисного окисления липидов / В. С. Понамарев, О. С. Попова // Международный вестник ветеринарии. - 2020. - № 2. - C. 112-115. - DOI 10.17238/issn2072-2419.2020.2.112., 2. Кострова, А. В. Некоторые аспекты проверки безопасности гепатопротектора на растительной основе / А. В. Кострова, В. С. Понамарев // XXII Всероссийская научно-практическая конференция Нижневартовского государственного университета : Материалы конференции, Нижневартовск, 06-07 апреля 2020 года / Научный редактор: Д.А. Погонышев. Нижневартовск: Нижневартовский государственный университет, 2020. - С. 25-28., 3. Понамарев, В. С. Изучение эмбриотоксического и тератогенного действия препарата «Гепатон» / В. С. Понамарев // Инновационные тенденции развития российской науки : Материалы XIII Международной научно-практической конференции молодых ученых, Красноярск, 08-09 апреля 2020 года. - Красноярск: Красноярский государственный аграрный университет, 2020. - С. 85-86., 4. Понамарев, В. С. Влияние дихлорэтана и фенацетина на уровень белка в крови лабораторных животных при экспериментальном токсическом поражении печени / В. С. Понамарев, К. Ф. Зенков // Знания молодых для развития ветеринарной медицины и АПК страны : Материалы международной научной конференции студентов, аспирантов и молодых ученых, Санкт-Петербург, 19-20 ноября 2020 года. - СанктПетербург: Санкт-Петербургский государственный университет ветеринарной медицины, 2020. - C. 272-273.

\section{MODERN HEPATOTOXICANTS}

Kostrova A.S., student

Scientific adviser - assistant of the Department of Pharmacology and Toxicology Ponamarev V.S. (FSBEI HE "SPbGUVM")

Summary: In recent years, in veterinary medicine, the problem of the growth of pathologies of the hepatobiliary system, which negatively affects the physiological status of the animal's body, has acquired particular relevance, which determines the further search for effective agents with hepatoprotective activity. To test the pharmaceutical activity of new drugs, methods of modeling various types of hepatopathies are constantly being improved.

Key words: liver, hepatotoxicants, toxicology.

УДК 619:616.9

\section{ПРИМЕНЕНИЕ ПРЕПАРАТА «ВИТАФЕЛ-С» ПРИ ЛЕЧЕНИЕ ИНФЕКЦИОННЫХ ЗАБОЛЕВАНИЙ КОШЕК \\ Красков Д.А., Ефимов В.Я.}

Научный руководитель- ассистент кафедры фармакологии и токсикологии Понамарёв В.С. (ФГБОУ ВО «СПбГУВМ»)

Аннотация: Кошки в России заболевают инфекционными болезнями несмотря на стремительное развитие ветеринарии в данной области. Чтобы избежать этого надо выполнять ряд профилактических мероприятий (ежегодная вакцинация и плановый осмотр у ветеринара). Если животное всё же заболело, то нужно немедленно обратиться в ветеринарную клинику, в которой поставят предварительный диагноз и начнут незамедлительное лечение, в состав которого обязательно должна входить гипериммунизированная сыворотка, удачным выбором данного лекарственного средства является сыворотка «Витафел-С». 
Ключевые слова: Инфекционные заболевания кошек, Витафел-С, терапия, клиническая диагностика.

Введение: Несмотря на стремительное развитие ветеринарной медицины по направлению: лечения инфекционных заболеваний мелких домашних животных, к сожалению всё также множество кошек различных пород и возрастов подвергаются заражению инфекционными заболеваниями характерными для них (калицивироз, панлейкопения, инфекционный ринотрахеит)[1,2]. Данная проблема происходит из-за множества факторов: большое количество бездомных кошек, которые являются потенциальными переносчиками инфекционных заболеваний; пренебрежение ежегодными вакцинациями кошек их владельцами и т.д. [3].

При замечание владельцем первых симптомов (общее угнетенное состояние, повышенная температура тела, потеря аппетита, истощение и т.д)[4], необходимо сразу обратиться в ветеринарную клинику, в которой при сборе анамнеза и широком комплексном обследование врач-ветеринар должен правильно определить этиологию данного состояния животного, назначить дополнительные исследования (общий анализ крови, ПЦР)[5,6] , и сразу же приступить к лечению, главным компонентом которого является введение специфических гипериммунных сывороток (например Витафел-С).

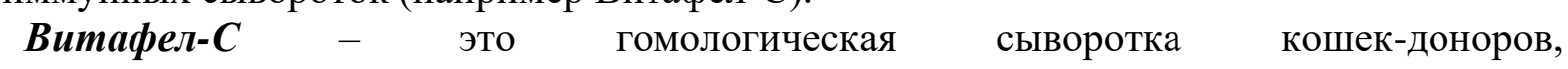
гипериммунизированных антигенами возбудителей панлейкопении, инфекционного ринотрахеита, калицивироза и хламидиоза. По внешнему виду представляет собой прозрачную жидкость от бесцветного до коричневато-красного цвета.

Материалы и методы иследования: По данным клиники, в которой проводились исследования, с июля по ноябрь 2020 года было зарегистрировано 20 кошек различных пород, пола и возраста с инфекционными заболеваниями ( по 5 случаев - панлейкопении и калицивироза и 10 случаев- инфекционного ринотрахеита) [7] с симптомами- характерными для данных заболеваний, и как выяснилось при сборе анамнеза- привиты они не были.

При комплексном обследование данных животных были поставлен первичные диагнозы- заболевание вирусного характера, чтобы окончательно убедиться в этом были взяты мазки из носовых отверстий и ротовой полости для ПЦР диагностики (в дальнейшем все ПЦР пробы были положительные).

Не дожидаясь результатов ПЦР диагностики, было назначено лечение, в зависимости от вида инфекционного заболевания комплексы лечебных мероприятий отличаются друг от друга, например цефазолин и витамин С при инфекционном ринотрахеите; синулокс и циклоферон при кальцивирозе; синулокс, регидрон и т.д., при панлейкопении. Неизменным остается только введение гипериммунной сыворотки «Витафел-С», данные курсы лечения составляли по 10 дней.

Результаты исследований: После 10 дней лечения были назначены повторные приёмы, на нём показатели температуры были в пределах референсных значений, симптомы которые были выявлены при первичном осмотре (общее угнетенное состояние, потеря аппетита, истощение и т.д.) - исчезли, общее состояние удовлетворительно.

Заключение: Препарат «Витафел-С» показал свою высокую эффективность в лечение инфекционных заболеваний кошек, в частности терапевтический и фармакологический эффект, подтверждение этому является 20 благополучных случаев выздоровления кошек от видовых вирусных заболеваний. Также стоит учесть и своевременное обращение владельцев к ветеринарному врачу, а также правильно поставленный им диагноз и незамедлительное лечение.

Литература: 1. Бессарабов Б.Ф., Воронин А.А., Воронин Е.С. Инфекционные болезни животных. // под ред. А. А. Сидорчука. М.: КолосС, 2007. 671 с. 2. Зелютков Ю.Г. Инфекционные болезни кошек. // Ю.Г. Зелютков. Витебск: 2003. 60 с. 3. Красков Д.А. Диагностика калицивироза у кошек// Д.А. Красков, В.А. Коноплёв// Материалы 75-й юбилейной международной научной конференции молодых учёных и студентов СПБГУВМ. - 2021. - С. 103-104. 4. Частота встречаемости вирусного иммунодефицита и вирусной 
лейкемии кошек / Б. С. Семенов, В. А. Гусева, К. Ф. Зенков, Т. Ш. Кузнецова // Актуальные проблемы ветеринарной медицины : сборник научных трудов / Редакционная коллегия: Конопатов Ю.В., Белова Л.М., Крячко О.В., Кузьмин В.А., Щербаков Г.Г., Орехов Д.А., Иванов В.С., Нечаев А.Ю., Кляузе В.М.. - Санкт-Петербург : Санкт-Петербургская государственная академия ветеринарной медицины, 2017. - С. 56-57. 5. Понамарев, В. С. Влияние препарата с гепатопротекторной активностью "Гепатон" на показатели периферической крови лабораторных животных / В. С. Понамарев // Международный вестник ветеринарии. - 2020. - № 2. - C. 116-121. - DOI 10.17238/issn2072-2419.2020.2.116. 6. Понамарев, В. С. Полимеразная цепная реакция с электрофоретической детекцией продуктов амплификации / В. С. Понамарев, С. А. Макавчик // Молодежный научный форум: естественные и медицинские науки. - 2016. - № 10(38). - С. 148-152. 7. Peculiarities of the manifestation of bronchial asthma in cats in metropolis environment / L. Sabirzianova, P. Anipchenko, A. Yashin [et al.] // Journal of Animal Science. - 2019. - Vol. 97. - No S3. - P. 214215. - DOI 10.1093/jas/skz258.439.

\section{APPLICATION OF THE PREPARATION "VITAFEL-S" IN TREATMENT OF INFECTIOUS DISEASES OF CATS}

Kraskov D.A., Efimov V.Y.

Scientific adviser - assistant of the Department of Pharmacology and Toxicology Ponamarev V.S. (FSBEI HE "SPbGUVM")

Summary: Cats in Russia fall ill with infectious diseases despite the rapid development of veterinary medicine in this area. To avoid this, it is necessary to carry out a number of preventive measures (annual vaccination and a routine examination by a veterinarian). If the animal is still sick, then you need to immediately contact the veterinary clinic, which will make a preliminary diagnosis and begin immediate treatment, which must include hyperimmunized serum, a good choice of this drug is the Vitafel-S serum.

Key words: Infectious diseases of cats, Vitafel-S, therapy, clinical diagnostics.

\section{УДК: 616.33-008.3-085:636.2-053.2 \\ ОПЫТ ПРИМЕНЕНИЯ РАЗНЫХ СХЕМ ЛЕЧЕНИЯ ДИСПЕПСИИ ТЕЛЯТ В УСЛОВИЯХ ХОЗЯЙСТВА}

Крюкова В.В. - асс., к.вет.н., Лаплаинен О.Т. - студент.

(ФГБОУ СПбГУВМ, Россия)

Аннотация. Сегодня поиск и внедрение новых схем лечения, преследующих высокую терапевтическую эффективность при минимальной токсической нагрузке остается актуальным вопросом для каждого животноводческого хозяйства[1]. В статье приводится клинический опыт по сравнению на практике двух терапевтических методов лечения диспепсии телят в условиях хозяйства. Один из методов является широко применяемой схемой лечения согласно внутрихозяйственного протокола, состоящей из парентеральной регидратационной терапии кристаллоидными растворами в комплексе с патогенетической терапией антибиотиками широкого спектра действия и нестероидными противовоспалительными препаратами. Другая схема является альтернативой внутрихозяйственному протоколу и представляет собой усиленную энтеральную регидратационную терапию кристаллоидными растворами в комплексе с патогенетической терапией препаратами йода и дезинфекцией парами йода. Последняя схема показала свою достаточную терапевтическую эффективность при минимальной токсической нагрузке в сравнении со схемой лечения согласно внутрихозяйственного протокола.

Ключевые слова: телята, диспепсия, регидратация, дренч-технология, острая токсичность

Введение.В связи с интенсивным ростом числа хозяйствующих животноводческих субъектов с большим поголовьем, а также острой проблемой постнатальных болезней телят и их раннего падежа, вопрос повышения эффективности ветеринарных мероприятий особо 
актуален[2]. При этом речь идёт о современном этапе обслуживания животноводства в промышленном секторе, где ведущими этиологическими факторами заболеваемости стада незаразными болезнями выступают ошибки и недоработки зоогигиенических и зоотехнических норм содержания скота. Цель исследования - апробация и сравнительный анализ лечения телят раннего постнатального периода с осложненными диспепсиями согласно внутрихозяйственного протокола и альтернативной схемы.

Материалы и методы. Клиническое исследование и сравнительный анализ двух схем лечения был проведен в осенне-летний период 2020 года на площадке по выращиваю молодняка крупного рогатого скота МТФ «Пустомержа» АО «ПЗ Агро-Балт» Кингисепского района Ленинградской области. Район и хозяйствующий субъект признаныэпизоотически благополучными. Лечению подвергались 158 телята в возрасте 1 неделя-2 месяца с клинической картиной осложненной диспепсии различной степени тяжести. Данный возраст является наиболее уязвимымк желудочно-кишечным заболеваниям, так как на него приходится период по коррекции рациона по возрасту и массе животных[3].За последние годы статистика предприятия показала, что в данных возрастных группах, в периоды «корректировки» рационов у молодняка чаще проявляются острые неинфекционные расстройства пищеварения с тяжелыми вторичными последствиями, и высокой летальностью. В хозяйстве ранний падеж молодняка объясняют нарушением технологии выпойки телят и гигиены их содержания, а также интоксикацией при использовании антибиотиков широкого спектра действия согласно внутрихозяйственного протокола лечения. В рамках исследования больные животные были изолированы и рандомно распределены в 2 подопытные группы по 79 телят в каждой: подопытная группа № 1 и подопытная группа N2. В качестве контроля использовали здоровых телят из основногостада.Животные обеих подопытных групп содержались в одинаковых зоогигиенических условиях с основным стадом и проходили общиепрофилактические мероприятия:с введением поливалентных сывороток Армавирскойбиофабрики двукратно в день в объеме 20 мл/гол, а также витаминизацию парэнтеральными препаратами Седимин ${ }^{\mathrm{TM}}$, Тривит $^{\mathrm{TM}}$, Е-селен $^{\mathrm{TM}}$, Катозал $^{\mathrm{TM}}$ или Лауритин ${ }^{\mathrm{TM}}$ согласно инструкции.Подопытную группу N1 лечили по протоколированной комплексной внутрихозяйственной схеме: парэнтеральное введение кристаллоидных растворов внутривенно/ подкожно в объеме 200-400 мл/гол.;инъекции $10 \%$ раствора Кетопрофенатм в дозе 0,03 мл/кг вводили для снятия спазмированности желудочно-кишечного тракта и купирования воспаления; патогене тическая терапия включала препараты выбора из пролонгированных антибиотиков широкого спектра действия - AzithronitM ${ }^{\mathrm{TM}}$, Ветбицин-5тм или Окситетрациклин 200LA ${ }^{\mathrm{TM}}$ согласно инструкции.Комплекс терапии в подопытной группе $\mathrm{N} 2$ заключался в организации ежедневной двухкратной групповой интенсивной энтеральной регидратационной терапии водным питательным раствором на основе соли, сахара и соды в обьеме 400-600 мл/гол с дачей йод-крахмальной микстуры в комплексе с дезинфекцией телятников йод-содержащими парами. В том числе при критически тяжелом состоянии телят и афагии применяли «дренч-технологию», но не более 5 суток подряд из-за риска значимых травм пищевода.

Результаты и обсуждения. За период эксперимента с ежедневным мониторингом проводимых схем лечения по группам животных было отмечено, что смертность телят от диспепсии и обезвоживания в подопытной группе $\mathrm{N} 2$ с альтернативной схемой лечения снизилась на 40,2\% в сравнении с подопытной группой № 1, в которой применяли лечение согласно внутрихозяйственного протокола терапии диспепсии телят. Несмотря на то, что признаки клинического улучшения состояния здоровья телят в подопытной группе № 1 наблюдались уже на 3-6 день, здесь летальных исходов было значительно больше чем положительных случаев нормализации общего состояния здоровья. При этом выжило и выздоровело около $10 \%$ заболевших телят, с общей оценкой клинического состояния как острое. Еще у 10-ти \% телят этой группы при нормализации общего состояния здоровья смертность наступала позднее окончания эксперимента, что по результатам проведенной аутопсии связывают с признаками острой токсичности после проведенной химиотерапев 
тической терапии. В подопытной группе N2 положительная динамка терапии наступала на 514 день, при этом выздоравливало в среднем 40\% заболевших в острой форме. Согласно проведенного анализа альтернативная методика не имела клинического и патоморфологического токсического эффекта на больной организм, исходя из результатов стационарного наблюдения и аутопсии павших телят обеих групп.Активное или пассивное выпаивание больных телят с помощью «дренч-технологии» зарекомендовали себя как эффективный и более экономный способ по сравнению с практикой парентеральных инфузий кристаллоидных растворов, поскольку осмотическая концентрация электролитов в смесях для выпойки и пороговый объем жидкости не ограничены строго из-за способа введения, эти параметры лабильны.

Заключение. Основываясь на представленных результатах исследования и сравнительной характеристике двух схем терапии телят по диагнозу осложненная диспепсия, целесообразно заключить, что апробированная в рамках работы интенсивная энтеральная регидратационная методика и её приемы (выпаивание, «дренч-технология», газация помещений) - эффективная и легко адаптируемая, безопасная для организма и ресурсосберегающая альтернатива регламентированной схеме лечения, обладающая перспективой применения.

Литература: 1.Куляков, Г.В. Сравнительная характеристика схем лечения телят, больных диспепсией с использованием фитотерапии/Г.В. Куляков, А.В. Яшин,П.С. Кисленко/Иппология и ветеринария.2020. №2.- С. 147-150. 2.Щербаков, Г.Г. Изменение показателей крови при диарее телят/ Г.Г. Щербаков, А.В. Яшин, С.П. Ковалев, П.С. Кисленко - Перспективы и актуальные проблемы развития высокопродуктивного мясного скотоводства: материалы международ. научн.-практ.конф.:Витебск, 2017.-С.186-188. 3.Иванова, И.В.Рост и развитие телят-молочников при включении в рацион кормовых микронизированных дрожжей / И.В. Иванова, А.Ф. Кузнецов, К.Ф. Зенков [и др.] // Вопро сы нормативно-правового регулирования в ветеринарии. - 2017. - № 3. - С.151-153.

\section{EXPERIENCE OF THE USE OF DIFFERENT TREATMENT REGIMENS OF CALVES WITH DYSPEPSIA IN FARM CONDITIONS}

Kryukova V. V.-associate, PhD, Laplainen O. T.-student. (FSEI SPbGUVM, Russia)

Summary: Nowadays, the search and implementation of a new treatment regimens, initiating high therapeutic effectiveness with minimal toxic load remains an essential problem for every livestock farm. The article presents clinical experience in comparison at practice of two therapeutic treatment methods of calves ' dyspepsia in farm conditions. One of the methods is a widely used treatment regimen according to the on-farm protocol, consisting of parenteral rehydration therapy with crystalloid solutions in combination with pathogenetic therapy with broad-spectrum antibiotics and non-steroidal anti-inflammatory drugs. Another scheme is an alternative to the on-farm protocol and is an enhanced enteral rehydration therapy with crystalloid solutions in combination with pathogenetic therapy with iodine farmacological forms and disinfection with iodine vapor. The latter scheme showed its sufficient therapeutic effectiveness with minimal toxic load in comparison with the treatment scheme according to the intra-economic protocol.

Key words: calves, dyspepsia, rehydration, drainage technology, acute toxicity 


\section{ПЕРСПЕКТИВЫ ИСПОЛЬЗОВАНИЯ КРЕМНИЙСОДЕРЖАЩИХ СОЕДИНЕНИЙ В ТЕХНОЛОГИИ СОЗРЕВАНИЯ ООЦИТОВ ЖИВОТНЫХ IN VITRO}

${ }^{1}$ Кузьмина Т.И., проф., д.б.н.,зав.лаб., ${ }^{2}$ Татарская Д.Н., аспир., ${ }^{3}$ Кравцов В.Ю.,проф., д.б.н.,зав.каф.

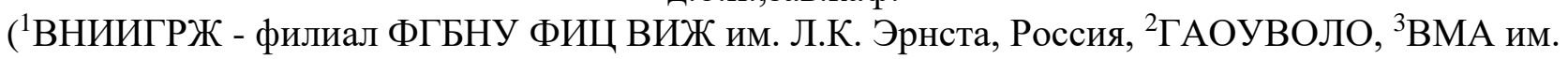
С.М.Кирова,Россия)

Аннотация. Получение эмбрионов животных invitro - важный инструмент для решения проблем мужского и женского бесплодия у животных. Моделирование систем экстракорпорального дозревания ооцитов с использованием в составе культуральных сред кремний содержащих соединений выявили особенности реализации их эффектов на соматические и половые клетки овариальных фолликулов в зависимости от структуры. Наночастицы высокодисперсного кремнезема (нВДК)оказывают положительный эффект на фертильность женских гамет BosTaurus и SusScrofaDomesticus.Гелевый субстрат (диметилглицеролат кремния - ДМГК) не вызывает повышения уровня дробящихся клеток, при этом не обладает цито- и генотоксичностью при его тестировании на соматических и половых клетках антральных фолликулов.

Ключевые слова: кремнийсодержащие соединения, созревание ооцитов животных, in vitro.

Совершенствование и внедрение инновационных клеточных репродуктивных технологий, основанных на использовании донорских ооцитов, в практику ветеринарии и животноводства - актуальная задача эмбриотехнологов, криобиологов, репродуктологов. Важнейшим фактором, детерминирующим получение нормального потомства из invitro созревших и оплодотворенных женских гамет является создание условий, соответствующих процессам завершения формирования яйцеклетки invivo. Используемые в настоящее время среды для культивирования позволяют получать при экстракорпоральном оплодотворении до $40 \%$ эмбрионов BosTaurus и SusScrofaDomesticus на завершающих стадиях доимплантационного развития. Необходимы новые подходы в структурирование состава культуральных сред. Перспективным представляется введение в их состав производных кремния. Высокодисперсный кремнезем обладает различными свойствами в зависимости от размера частиц, рабочей концентрации и объекта исследования [1]. Кремнезем - оксид кремния $\left(\mathrm{SiO}_{2}\right)$, широко распространенное в природе соединение этого неметалла. Для получения наноразмерного пирогенного кремнезема проводится высокотемпературный гидролиз тетрахлорида кремния в водородно-кислородном пламени при $1000-1400^{\circ} \mathrm{C}$ [2]. Нами использован аэросил А 300 (или ВДК А 300) - пирогенный кремнезем с размером частиц от 5 до 20 нм, с удельной поверхностью $300 \pm 30 \mathrm{~m}^{2} / \Gamma$ (ГОСТ 14922-77).Имеющаяся информацию о применении диметилглицеролата кремния в биомедицинских исследованиях, несмотря на положительные клинические эффекты, не представляет в достаточной мере данных о механизмах реализации их эффектов на клеточном уровне [3].В наших исследованиях проведены комплексные исследования по оценке цито- и гено-токсичности наночастиц высокодисперсного кремнезема и диметилглицеролата кремния с использованием технологии экстракорпорального созревания ооцитов коров и SusScrofaDomesticus. В экспериментах использовались биотехнологические (получение эмбрионов invitro), цитофлуориметрические, цитологические методы. В соответствии с предложениями производителей концентрации воздействующих веществ, составили, соответственно: 0,2\% диметилглицеролат кремния (Институт органического синтеза УрО РАН) и $0,001 \%$ наночастицы высокодисперсного кремнезема (Институт химии поверхности им. А.А. Чуйко НАН Украины).

Ранее нами показано положительное воздействие наночастиц высокодисперсного кремнезема на формирование зигот и развитие доимплантационных эмбрионов BosTaurus[4], что согласуется с данными другой группы ученых о положительном влиянии данного 
соединения в той же концентрации $(0,001 \%)$ на формирование зигот и дробление эмбрионов SusScrofaDomesticus[5]. Tакже показано положительное действие наночастицвысокодисперсного кремнезема в концентрации 0,001\% на сохранность и функциональное состояние девитрифицированных ооцитов, клеток кумулюсаи гранулезыBosTaurus, функциональную активность митохондрий в женских гаметах коров в динамике культивирования [6,7].

В настоящем исследовании наночастицы высокодисперсного кремнезема в концентрации $0,001 \%$ и диметилглицеролат кремния в концентрации $0,2 \%, 0,02 \%$ оказали цитопротекторный эффект, что показано в серии экспериментов по оценке частоты встречаемости «голых ядер» в образцах клеток гранулезыSusScrofaDomesticus, подвергшихся воздействию выше обозначенных кремниевых соединений. Показатель «частота встречаемости голых ядер» - один изспособов оценки потенций к дальнейшему культивированию соматическихклеток овариальных фолликулов.Для экспериментов клетки гранулезыSusScrofaDomesticusполучали аспирацией взвеси фолликулярной жидкости с клетками гранулезы из антральных фолликулов (d=3-6 мм). Взвесь центрифугировали при $250 \mathrm{~g} / 10$ мин. Затем супернатант удаляли, клетки дважды промывали в PBS («Sigma»). Культивировали клетки гранулезы $\left(1.1-1,6 \times 10^{6}\right.$ кл/мл среды) 3 часа при $37^{\circ} \mathrm{C}$ в $\mathrm{PBS}$ с $5 \%$ сыворотки крупного рогатого скота - контроль («Sigma-Aldrich», США), а также с 0,001\% наночастиц высокодисперсного кремнезема (опыт 1) или с 0,2\% диметилглицеролата кремния (опыт 2), 0,02\%диметилглицеролата кремния (опыт 3). Из экспериментальных и контрольной группклетокгранулёзы получали цитологические препараты методом жидкостной цитологии, путём роторного центрифугирования в фосфатном буфере и переносе отмытых клеток на предметное стекло. Цитоцентрифугаты окрашивали азур2-эозином по Май-Грюнвальд. В каждой пробе «под иммерсией»были подсчитаны по 500 клеток, в которых определяли частоты встречаемости «голоядерных клеток» и апоптотических телец. Всего повторностей в каждой группе - 4. В мазках, приготовленных из интактных клеток, обнаружен наибольший процент клеток гранулезы свиней с «голыми ядрами» (более 58\%) и апоптотическими тельцами $(13 \%)$, в то же время в образцах с добавлением наночастиц высокодисперсного кремнезема уровень «голоядерных» клеток составил 8,0土1,91\%, с

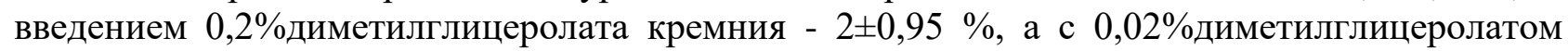

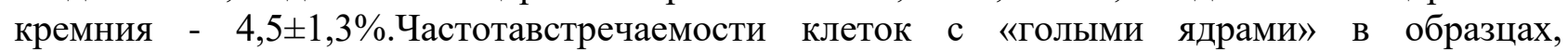
обработанных кремний содержащими соединениями, оказалось значительно ниже $(\mathrm{P}<0,001)$,чем в контроле, а апоптотическиетельца в клетках гранулезы, проинкубированных с нВДК и ДМГК не были обнаружены. Диметилглицеролат кремния оказал болеевыраженный цитопротекторный эффект, чем наночастицы высокодисперсного кремнезема в исследуемых концентрациях.Представленные данные в совокупности с результатами исследований, полученными ранее, позволяют сделать заключение о том, что протестированные производные кремния не только не индуцируют апоптоз, но и способствуют сохранности структурных компонентов соматических клеток овариальных фолликулов (ядер клеток гранулезы).

Работа выполнена при финансовой поддержке Министерства науки и высшего образования Российской Федерации (№ ГЗ 0445-2021-0005)

Литература. 1. Manavitehrani, I. Mesoporous Silica Nanoparticles: Synthesis, Modification and Applications / I. Manavitehrani, A. Schindeler, M. Parviz // Nanomed. Nanotechnol. - 2018. - V.3. - № 2. - Р. 000136. 2. Чуйко, А.А. (ред.). Медицинская химия и клиническое применение диоксида кремния / А.А. Чуйко // Киев: Наукова думка, 2003. - 417 с. 3. Хонина Т.Г. Исследование закономерностей, механизма образования и структуры биологически активных полиолатов кремния и гидрогелей на их основе / Т.Г.Хонина, О.Н. Чупахин, И.Н. Тосова, Е.В. Шадрина, М.В. Иваненко, Е.Ю. Ларченко// Сборник аннотационных отчетов по проектам регионального конкурса РФФИ «Урал». Екатеринбург. 2012. С. 135-138. 4. Чистякова, И.В. Воздействие кремнийсодержащих соединений на развитие доимплантационных эмбрионов Bos taurus / И.В. Чистякова, Т.И. Кузьмина, Т.И. Станиславович, Т.Г. Хонина // Вопросы 
нормативно-правового регулирования в ветеринарии. - 2018. - № 3. - С. 105-108. 5. Зюзюн А.Б. Застосування наноматеріалу в ембріогенетичній системі in vitro отримання ембріонів свиней / А.Б. Зюзюн, О.В. Щербак, О.С. Осипчук, С.І. Ковтун, В.В. Дзіцюк // Фактори експериментальної еволюції організмів. - 2015. - Т. 17. - С. 164-168. 6. Кузьмина, Т.И.Влияние наночастиц высокодисперсного кренезема на апоптоз в нативных и девитрифицированных клетках гранулезы овариальных фолликулов Bos Taurus / Т.И. Кузьмина, И.В. Чистякова //Актуальные вопросы ветеринарной биологии. - 2019. - Т.3. - № 43. - С. 8-12. 7. Кузьмина Т.И. Функциональная активность митохондрий и статус хроматина нативных и девитрифицированных ооцитов Bos taurus под воздействием наночастиц выскодисперсного кремнезема / Т.И.Кузьмина, И.В.Чистякова, Д.Н.Татарская //Сельскохозяйственная биология - 2020. - т. 55 - № 4. - C. 784-793.doi: 10.15389/agrobiology.2020.4.784rus

\section{PROSPECTS FOR THE USING OF SILICON-CONTAINING COMPOUNDS IN THE} TECHNOLOGY OF IN VITRO MATURATION OF ANIMAL OOCYTES

${ }^{1}$ Kuzmina T.I., prof., Dr.Sc. Biol., ${ }^{2}$ Tatarskaya D.N., Ph.D. student, ${ }^{3}$ Kravtsov V. YU.prof., Dr.Sc. Biol.

$\left({ }^{1}\right.$ VNIIGRZH- branch of the L.K. Ernst Federal Research Center for Animal Husbandry, Russia, ${ }^{2}$ Pushkin LSU, ${ }^{3}$ Military medical academy of S.M.Kirov,Russia)

In vitro production of animal embryos is an important tool for solving male and female infertility problems in animals. Modeling of extracorporeal maturation systems of oocytes using siliconcontaining compounds in the composition of culture media revealed the peculiarities of the realization of their effects on somatic and germ cells of ovarian follicles, depending on the structure. Highly dispersed silica nanoparticles (nHDS) positive effects on the fertility of female gametes in Bos Taurus and Sus Scrofa Domesticus. The gel substrate of silica (silicon dimethylglycerolate DMGC) does not cause an increase in the level of embryos cleavage, while it does not have cytoand genotoxicity when tested on somatic and germ cells of antral follicles.Key words: siliconcontaining compounds, in vitro maturation, animal oocytes.

УДК: 615:33.619:636.2

\section{ПРИМЕНЕНИЕ БИОЛОГИЧЕСКОГО ЛЕКАРСТВЕННОГО СРЕДСТВА НА ОСНОВЕ СЕКРЕТОМА МЕЗЕНХИМНЫХ СТВОЛОВЫХ КЛЕТОК КАК АЛЬТЕРНАТИВНЫЙ ПОДХОД К ПРОВЕДЕНИЮ АНТИБИОТИКОТЕРАПИИ В ПРОМЫШЛЕННОМ ЖИВОТНОВОДСТВЕ}

Лаврик А.А., ${ }^{1}$ ген. директор, Али С.Г., ${ }^{1}$ зам. генерального директора, Москалев В.Б., ${ }^{1}$ начальник отдела регистрации лекарственных средств, Надеждин С.В. ${ }^{1,2}$ зав. лабораторией, Эльдаров Х. Д., ${ }^{3}$ ген. директор, $\left({ }^{1} \mathrm{OOО} «\right.$ НОВИСТЕМ», ${ }^{2}$ НИУ «БелГУ» г. Белгород, Россия, ${ }^{3} \mathrm{OOO}$ «Беркат» д. Астапковичи, Смоленская обл.)

Аннотация. Чрезмерное и бесконтрольное использование антибиотиков в медицине, ветеринарии и животноводстве привело к распространению устойчивых к ним микроорганизмов, что в свою очередь стало причиной глобализации проблемы антибиотикорезистентности в XXI веке. В связи с этим поиск и внедрение лекарственных средств, которые могли бы стать альтернативой антибиотикам, на сегодняшний день является одной из важнейших задач человечества. В данной работе представлены результаты исследования эффективности инновационного биологического лекарственного препарата на основе секретома мезенхимных стволовых клеток при лечении бронхопневмоний у телят. Этот препарат прошел успешные лабораторные и производственные испытания, в результате которых разработана схема лечения инфекционной бронхопневмонии, полностью исключающая применение антибиотиков. 
Ключевые слова: антибиотикорезистентность, секретом мезенхимных стволовых клеток, инфекционные заболевания, бронхопневмония

Антибиотикорезистентность является одной из угроз мирового масштаба для здоровья человека, животных, растений, продовольственной безопасности и окружающей среды. Следствием развития устойчивости микроорганизмов к антибиотикам стала их массовая неэффективность, усложнение лечения инфекционных заболеваний, рост экономических затрат и смертности. Интересно, что путь от открытия до внедрения нового антибиотика занимает от 5 до 10 лет и обходится в несколько миллионов долларов, а полная адаптация к новым антибиотикам наблюдается в течение 5 лет, частичная - в течение года и менее. В связи с ростом темпов и развитием новых механизмов антибиотикорезистентности ВОЗ настаивает на изменении порядка назначения и использования антибиотиков [1]. Для сельскохозяйственного сектора Правительством РФ и специалистами ВОЗ разработаны новые стратегии борьбы с антибиотикорезистентностью, рекомендовано использование терапевтических схем, не включающих антибиотики, и увеличение профилактических мер для сокращения потребности в них [1-4].

На сегодняшний день во всем мире проводится активный поиск средств, которые могли бы быть предложены в качестве альтернативы антибиотикам [5-7]. При этом сформировалось 2 основные стратегии - терапия, оказывающая угнетающее влияние на микроорганизмы (например, фаговые препараты), и терапия, воздействующая на организм хозяина за счет регенеративных и иммуномодулирующих эффектов. В рамках последней известны средства растительного и животного происхождения. Особого внимания заслуживают препараты, разработанные на основе секретома (метаболитов) мезенхимных стволовых клеток животных. За счет содержания широкого спектра веществ цитокинового ряда, факторов роста, интерлейкинов, хемокинов, регуляторных пептидов и ферментов они оказались весьма эффективны для профилактики и лечения инфекционных заболеваний сельскохозяйственных животных $[8,9]$.

В данном исследовании изучена эффективность применения биологического лекарственного препарата, разработанного на основе секретома мезенхимных стволовых клеток крупного рогатого скота, для лечения инфекционных заболеваний с эпидемическим потенциалом (бронхопневмоний) у телят. В качестве контроля применяли стандартную схему лечения (5 мг «Байтрил», 4 сут.; n=10); животным группы 1 вводили препарат на основе секретома мезенхимных стволовых клеток («БовиСтэм»®) в дополнение к сокращенной стандартной схеме лечения (5 мг «Байтрил» 2 сут., 5 мл «БовиСтэм» ${ }^{\circledR}$ на 1 и 3 сут.; n=10); животным группы 2 вводили только препарат на основе секретома мезенхимных стволовых клеток («БовиСтэм»®) (5 мл на 1 и 3 сут.; n=10). Результаты клинических наблюдений показали, что экспериментальные схемы лечения, в которых применяли препарат на основе секретома мезенхимальных стволовых клеток, показали терапевтическую эффективность на 20-30 \% выше по сравнению с традиционной схемой. Так, длительность лечения бронхопневмоний снижалась с 17, $1 \pm 1,6$ суток в контроле до 10,3 $\pm 1,0$ и 11,3 $\pm 0,8$ суток в 1 и 2 группах соответственно ( $\mathrm{p} \leq 0,01)$, а выживаемость животных составила $70 \%$ в контроле против $100 \%$ в обеих опытных группах.

Клинические наблюдения подтверждались данными лабораторных исследований. До начала лечения содержание иммуноглобулинов в крови было на нижнем пределе нормы или ниже нормы и составляло в среднем $24,4 \pm 1,3$ мг/мл. То же характерно для фагоцитарного

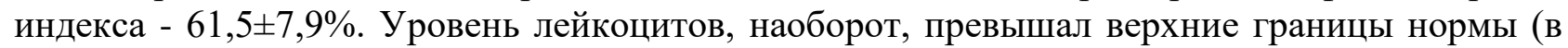
среднем, $\left.13,0 \pm 0,5 \times 10^{9} / л\right)$, что в совокупности свидетельствует о наличии воспалительного процесса и снижении защитных реакций организма.

На 10 - 12 сутки после начала лечения показатели контрольной группы остались на прежнем уровне, в то время как в опытных группах наблюдалось увеличение содержания

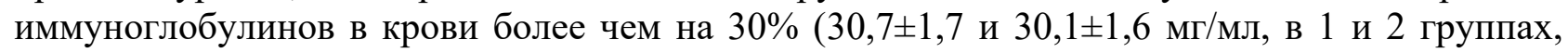

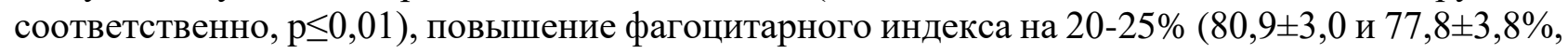


соответственно, $\mathrm{p} \leq 0,01)$ и снижение уровня лейкоцитов на $13 \%\left(11,4 \pm 0,5\right.$ и $11,6 \pm 0,7 \times 10^{9} /$ л, соответственно, $\mathrm{p} \leq 0,01)$.

Таким образом, полученные данные свидетельствуют о способности секретомного препарата стимулировать защитные механизмы организма и подтверждают более высокую эффективность лечения с его применением по сравнению с традиционными методами (на 20 - 30\%), длительность лечения в опытных группах при этом сокращалась в 1,5 - 1,7 раза. Показана эффективность как комплексного применения секретомного препарата, так и использования его в качестве монотерапии, т.е. в терапевтической схеме, полностью исключающей применение антибиотиков, что имеет исключительное значение для промышленного животноводства.

Литература 1. Alós J.I. Antibiotic resistance: A global crisis // Enferm Infecc Microbiol Clin. 2015. - №33(10). - P. 692-699. doi: 10.1016/j.eimc.2014.10.004. 2. Walger P. Rational use of antibiotics // Internist (Berl). - 2016. - №57(6). - P. 551-568. doi: 10.1007/s00108-016-0071-5. 3. Распоряжение Правительства РФ от 30.03.2019 N 604-р (ред. от 04.02.2021). 4. Федеральный закон от 03.08.2018 N 280-Ф3 «Об органической продукции и о внесении изменений в отдельные законодательные акты Российской Федерации». 5. Zumla A. Host-directed therapies network consortium. Host-directed therapies for infectious diseases: current status, recent progress, and future prospects / A. Zumla, M. Rao, R.S. Wallis, S.H. Kaufmann, R. Rustomjee, P. Mwaba, C. Vilaplana, D. Yeboah-Manu, J. Chakaya, G. Ippolito, E. Azhar, M. Hoelscher, M. Maeurer // Lancet Infect Dis. - 2016. - №16(4). - e47-63. doi: 10.1016/S1473-3099(16)00078-5. 6. Wang, X. Phage combination therapies for bacterial wilt disease in tomato / X. Wang, Z. Wei, K. Yang, J. Wang, A. Jousset, Y. Xu, Q. Shen, V.P. Friman // Nat Biotechnol. - 2019. - №37. - P. 1513-1520. doi: 10.1038/s41587-019-0328-3. 7. Новикова М.В. Перспективы применения бетулина в бройлерном птицеводстве / М. В. Новикова, И. А. Лебедева, Л. И. Дроздова, А. В. Бюлер // Ветеринария сегодня. - 2020. - №4(35). - С. 277-282. doi:10.29326/2304-196X-2020-4-35-277282. 8. Лаврик А.А. Препарат БовиСтэм в профилактике послеродовых осложнений коров и иммунодефицитов телят / А.А. Лаврик, В.Б. Москалев, С.Г. Али, А.В. Заремба, Х.Д. Эльдаров // Ветеринария и кормление. - 2020 - №2 - С. 29-32. doi CrossRef:10.30917/ATT-VK-18149588-2020-2-7. 9. Лаврик А.А. Сравнительная эффективность лечения послеродовых осложнений и восстановления репродуктивной функции коров / А.А. Лаврик, В.Б. Москалев, С.Г. Али, А.В. Заремба, Х.Д. Эльдаров // Ветеринария и кормление. -2020 - №3 - С. С.25-27. doi CrossRef:10.30917/ATT-VK-1814-9588-2020-3-7.

\section{APPLICATION OF A BIOLOGICAL MEDICAL PRODUCT BASED ON THE SECRETOME OF MESENCHYMAL STEM CELLS AS AN ALTERNATIVE APPROACH TO ANTIBIOTIC THERAPY IN INDUSTRIAL ANIMAL HUSBANDRY}

Lavrik A.A., ${ }^{1}$ gen. director, Aly S.G., ${ }^{1}$ deputy gen. director, Moscalev V.B., ${ }^{1}$ head of the Department of Registration of medical products, Nadezhdin S.V., ${ }^{2}$ head of the laboratory, Aldarov H.D., ${ }^{3}$ gen. director $\left({ }^{1}\right.$ LLC «NoviStem», ${ }^{2}$ NRU «BSU» Russia, Belgorod, ${ }^{3}$ LLC "Berkat" Russia, Smolensk region, Astapkovichi village)

Annotation. The excessive and uncontrolled use of antibiotics in medicine, veterinary medicine and animal husbandry has led to the spread of resistant microorganisms, which in turn was the cause of the globalization of the problem of antibiotic resistance in the twenty-first century. Consequently, the search and introduction of medicines that could become an alternative to antibiotics, today is one of the most important tasks. This work presents the results of the research of the effectiveness of an innovative biological product based on the secretome of mesenchymal stem cells in the treatment of bronchopneumonia in calves. This product has passed successful laboratory and production tests, as a result of which has been developed a treatment regimen for infectious bronchopneumonia, completely excluding the use of antibiotics.

The key words: antibiotic resistance, secretome of mesenchymal stem cells, infectious diseases, bronchopneumonia

УДК 619:615.37. 636.087.7 


\title{
ИЗУЧЕНИЕ МЕСТНО-РАЗДРАЖАЮЩЕГО И АЛЛЕРГИЗИРУЮЩЕГО ДЕЙСТВИЙ НАНОМАТЕРИАЛА НОВОГО ПОКОЛЕНИЯ
}

\author{
Ларина Ю.В., к.б.н. \\ (ФГБОУ ВО Казанская ГАВМ, Россия)
}

\begin{abstract}
Аннотация. Изучены местно-раздражающие и аллергизирующие свойства новой кормовой добавки. В результате исследований было обнаружено, что испытуемая добавка не оказывает отрицательного влияния на организм животных.
\end{abstract}

Ключевые слова: кормовая добавка, наночастицы, аллергизирующие свойства, местнораздражающие, крысы, кролики.

Агроминералы в настоящее время применяют для изготовления кормовых добавок изза содержания в них широко спектра биологически доступных, легкоусвояемых макро- и микроэлементов, при активации которых усиливается эффективность их действия на организм животных [1].

Исследования в данной области направлены на изучение механизмов и эффектов действия, распределение компонентов в органы и ткани [2].

Ранее было изучено действие новой кормовой добавки на белых крысах, где было показано, что препарат малотоксичный, не оказывает отрицательного действия на метаболизм и не способствует изменению гематологических и биохимических показателей в худшую сторону [3]. Однако, несмотря на это, внедрение в ветеринарную практику вновь созданных препаратов и кормовых добавок возможно лишь после проведения доклинических исследований, позволяющих подтвердить безопасность их применения $[4,5]$.

Целью исследования стало изучение местно-раздражающего и аллергизирующего действий новой кормовой добавки для животных.

Материал и методы исследований. Доклинические исследования наноматериала с содержанием активных наночастиц размером 50-180 нм, который предполагаем использовать при создании кормовой добавки. Фармакологические исследования проведены в соответствии с качественно-лабораторными практическими стандартами [6]. Изучение местнораздражающего действия проводили на 14 белых крысах массой 180-210 гр. Крысам на выстриженный участок кожи наносили с помощью ватно-марлевого тампона кормовую добавку. Противоположная сторона служила контролем, на которую аналогичным образом делали аппликацию дистиллированной водой. Спустя 4 часа удаляли ватно-марлевые тампоны и регистрировали реакцию кожи.

Исследования раздражающих свойств определяли методом «глазной пробы» на 4 кроликах. В конъюнктивальный мешок левого глаза закапывали препарат в количестве 50 мл, в правый глаз, который и служил контролем - аналогичное количество дистиллированной воды. Учет реакции вели через 15, 30, 60 минут и три часа, а в последующем один раз в день в течение 14 дней. Реакцию оценивали по состоянию оболочки глаза, наличию гиперемии и инъецированию сосудов конъюнктивы, слезоточивости, наличию выделений.

Результаты исследований. Экспериментально установлено, что однократная аппликация с помощью ватно-марлевого тампона на выстриженный участок кожи не привело к каким-либо кожно-реактивным нарушениям со стороны исследуемых тканей, как в течение первых трех часов, так и последующие 14 суток. При визуальном осмотре, пальпации за время наблюдений каких-либо функциональных и структурных нарушений со стороны кожи животных не отмечено.

При оценке раздражающих свойств глаза было установлено, что в течение 20 минут после введения испытуемого препарата отмечалось легкое покраснение слизистой оболочки, которая приходила в норму через 45-60 минут. В последующие сроки также не было выявлено отклонений структурно-функционального состояния глаза. 
Заключение. Таким образом, исследованиями на лабораторных животных установлено, что новая кормовая добавка не обладает местно-раздражающим и аллергизирующим действиями.

Литература. 1. Сафиуллина, Г.Я. Морфологический и биохимический состав крови животных при введении в рацион нативного и наноструктурного агроминерала / Г.Я. Сафиуллина, К.Г. Валеулов, Д.В. Ежков, Р.Н. Файзрахманов, А.М. Ежкова // Вестник Технологического университета. - 2017. - Т.20. - № 21. - С. 126-129. 2. Кузнецов, А.Ф. Зоогигиеническая и ветеринарно-санитарная оценка кормовой добавки, получаемой при переработке отходов рыбного и зернового производства / А.Ф. Кузнецов, К.А. Рожков, И.В. Лунегова, В.В. Богомолов, Е.М. Белоруссская, И.С. Яковлев // Международный вестник ветеринарии. - 2018. - №1. - С. 48-53. 3. Яппаров, И.А. Живая масса и состав крови молодняка норок в зависимости от формы и дозы применения кормовой добавки «Селевер» / И.А. Яппаров, Ю.В. Ларина, В.О. Ежков, А.Х. Яппаров и др. // Ветеринарный врач. - 2019. - №6. - С. 73-77. 4. Медетханов, Ф.А. Изучение местно-раздражающего действия и пирогенных свойств Нормотрофина / Ф.А. Медетханов // Ученые записки казанской государственной академии ветеринарной медицины имени Н.Э. Баумана. - 2016. - Т. 225. - №1. - С 46-49. 5. Анализ нормативных документов, регламентирующих требования к проведению доклинических исследований ветеринарных препаратов / С. В. Герасимов, В. С. Понамарев, Н. Л. Андреева [и др.] // Вопросы нормативно-правового регулирования в ветеринарии. - 2020. - № 3. - C. 27-29. - DOI 10.17238/issn2072-6023.2020.3.27. 6. Доклинические исследования лекарственных средств: Методические рекомендации / Под. Ред. Стефанова. - Киев, 2002. 566c.

\title{
STUDY OF LOCAL IRRITATING AND ALLERGIZING EFFECTS OF NANOMATERIAL OF A NEW GENERATION
}

\author{
Larina Yu.V., Ph.D.
}

(Kazan State Academy of Veterinary Medicine named after N.E. Bauman, Russia)

Summary. The local irritating and allergenic properties of the new feed additive have been studied. As a result of the research, it was found that the tested additive does not have a negative effect on the body of animals.

Key words: feed additive, nanoparticles, allergenic properties, local irritants, rats, rabbits.

УДК: 619:616-09

\section{ПРИМЕНЕНИЕ ГОРМОНАЛЬНЫХ ТЕСТОВ ДЛЯ ОЦЕНКИ ЭФФЕКТИВНОСТИ ИСПОЛЬЗОВАНИЯ БИОЛОГИЧЕСКИ АКТИВНЫХ ВЕЩЕСТВ}

Лебедева М.Б., доц., к.в.н., Кичеева Т.Г., доц., к.в.н., Пелех К.А., асс.

(ФГБОУ ВО Ивановская ГСХА имени Д.К. Беляева, Россия)

\begin{abstract}
Аннотация. В практике ветеринарной медицины до настоящего времени недостаточно освещены вопросы обоснования гормональных тестов для различных целей: для диагностики заболеваний, диагностики метаболических нарушений с целью их коррекции, обоснование использования различных фармакологических препаратов по их эффективности и другое $[2,4]$.
\end{abstract}

Ключевые слова: L- тироксин, инсулин, витамин- A.

Мы проводили исследования о параметрах изменения гормонального профиля валухов романовской породы при использовании экзогенного инсулина, L-тироксина, витамина A. Результаты исследования свидетельствуют о неоднозначных изменениях уровня гормонов при использовании указанных препаратов. Так, при использовании инсулина, колебания

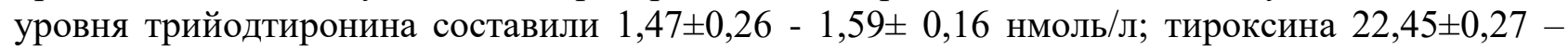
$28,2 \pm 0,3$ нмоль/л; иммунореактивного инсулина $30,6 \pm 4,7-47,3 \pm 4,6$ пмоль/л; кортизола

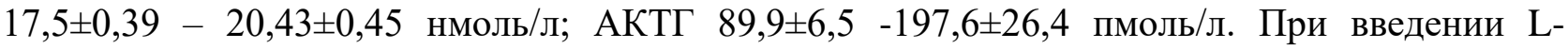


тироксина эти параметры составили по трийодтиронину $1,37 \pm 0,18-1,57 \pm 0,16$ нмоль/л;по тироксину $15,55 \pm 1,58-26,16 \pm 1,5$ нмоль/л; иммунореактивному инсулину $27,88 \pm 2,0-44,7 \pm$

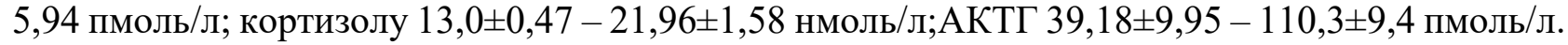
При введении витамина А - по трийодтиронину 1,62 $\pm 0,24-2,52 \pm 0,4$ нмоль/л; тироксину

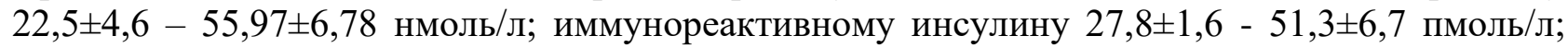

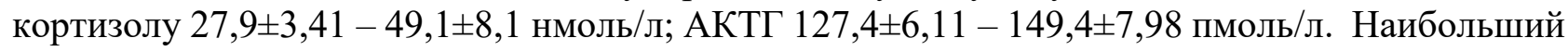
размах колебаний по трийодтиронину отмечали при использовании витамина А. Наименьший диапазон колебаний по Т 3 отмечали при введении инсулина, т.е. разница между максимумом и минимумом показателей составила 0,12 нмоль/л. Колебания уровня тироксина в период введения препаратов отмечали у валухов на фоне использования витамина А. Диапазон колебаний составил при этом 33,47 нмоль/л, а наименьший размах колебаний $\mathrm{T}_{4}$ отмечен при использовании инсулина 5,75 нмоль/л. Если использовать определенный термин «показатель гормональных изменений», то введение инсулина отмечается состоянием умеренного гипотиреоза за счет $\mathrm{T}_{3}$ и $\mathrm{T}_{4}$;при введении L-тироксина развивается гипотиреоз средней тяжести, а введение витамина А в первые дни - синдром низкого уровня $\mathrm{T}_{3}$, на 15, 30 дни умеренным гипертиреозом. Диапазоном колебаний иммунореактивного инсулина при введении экзогенного инсулина составил 16,7 пмоль/л, от экзогенного тироксина $-16,82$ пмоль/л и витамина $\mathrm{A}-23,5$ пмоль/л.

Следовательно, наименьший диапазон колебаний иммунореактивного инсулина отмечен на фоне экзогенного инсулина, наибольший - на фоне введения витамина А. Введение инсулина у животных опытной группы в первые две недели приводит к состоянию умеренной гипоинсулинемии, а при введении тироксина - к гипоинсулинемии на всем протяжении его использования. Введение витамина А вызывает состояние гипоинсулинемии в первые дни с последующей гиперинсулинемией. Уровень кортизола характеризовался наименьшим диапазоном колебаний в период использования экзогенного инсулина $-2,93$ пмоль/л, а наибольший при введении витамина А - 21,2 пмоль/л. Изменения кортизола характеризуется при введении экзогенного инсулина, как состояние умеренной гипокортизолемии. Диапазон колебаний уровня гормона гипофиза - АКТГ при введении экзогенного инсулина составил 107,7 пмоль/л; при введении тироксина - 71,2 пмоль/л; а при введении витамина А - 22,0 пмоль/л.

Следовательно, наименьший диапазон колебаний АКТГ отмечен на фоне тироксина, наименьший от экзогенного инсулина.

Таким образом, по выявленному уровню гормонов на фоне введения экзогенных гормональных препаратов и витамина А, можно полагать о том, что под влиянием экзогенных биологически активных веществ происходит взаимодействие гормонов на системном уровне, которое не заканчивается моментом прекращения введения гормонов, а продолжается в виде эффекта их «последействия».

Литература. 1. Ветеринарная токсикология / Г.М. Хмельницкий, В.Н. Локтионов , Д.Д. Полоз - Москва: Агропромиздат, 1987.-319с. 2.Иванов В.И., Лебедева М.Б. и др. Диагностика поражений животных токсическими веществами антропогенной природы: рекомендации / В.И. Иванов, М.Б. Лебедева - Иваново-1997, - 16 с. 3.Кулинский В.И. Основные принципы исследования эффектов гормонов и циклических нуклеотидов//Успехи современной биологии, I980, Вып.3 (6) - с.382-393. 4. Кулинский В.И. В сборнике "Механизм действия гормонов" Ташкент, 1976, - 56c. 5. Лебедева М.Б. Клинический статус коров и жизнеспособность телят при воздействии токсических веществ // Аграрная наука в условиях модернизации и инновационного развития АПК России: сборник материалов Всероссийской научно-методической конференции с международным участием, посвященной 85-летию ИГСХА им. Д.К. Беляева, 2015. С. 64-67. 6. Радченков В.П., Матвеев В.А.,Бутров Е.В., Буркова Е.И. Эндокринная регуляция роста и продуктивности с/х животных. М. В. О. Агропромиздат, 1991, - 60с. 


\title{
APPLICATION OF HORMONAL TESTS TO ASSESS THE EFFICIENCY OF THE USE OF BIOLOGICALLY ACTIVE SUBSTANCES
}

Lebedeva M.B., Associate Professor, Ph.D., Kicheeva T.G., Associate Professor, Ph.D., Pelekh K.A., Ass.

(FSBEI HE Ivanovskaya State Agricultural Academy named after D.K.Belyaev, Russia)

Summary. In the practice of veterinary medicine, the issues of substantiation of hormonal tests for various purposes have not been sufficiently illuminated to date: for the diagnosis of diseases, the diagnosis of metabolic disorders in order to correct them, the rationale for the use of various pharmacological drugs for their effectiveness, and more $[2,4]$.

Key words: L-thyroxine, insulin, vitamin - A.

\section{УДК 543.544.45}

\section{ПРОБОПОДГОТОВКА С ПРИМЕНЕНИЕМ ТФЭ ПРИ ОПРЕДЕЛЕНИИ ФОСФОРОРГАНИЧЕСКИХ ПЕСТИЦИДОВ В ЗЕРНЕ МЕТОДОМ ГХ-МС}

Лихачева А.Ю.м.н.с., Фицев И.М. к.х.н., в.н.с., Мухарлямова А.З.н.с., Рахметова

Э.Р.н.с.,Мухамметшина А.Г.м.н.с.

(ФГБНУ «ФЦТРБ-ВНИВИ», Россия)

\begin{abstract}
Аннотация.Фосфорорганические пестициды широко применяются в сельском хозяйстве против вредителей различных культур, в связи с чем существует потребность в быстром и недорогостоящем анализе продуктов питания на данный вид поллютантов. Предложен способ определения фосфорорганических пестицидов в матрице зерновых культур с применением твердофазной экстракции.Он характеризуетсянизким пределом обнаружения, малым временем анализа и стоимостью. Для определения фосфорорганических пестицидов применяли газовую хроматографию с масс-спектрометрическим детектором.
\end{abstract}

Ключевые слова: газовая хроматография, масс-спектрометрия, фосфорорганические пестициды, твердофазная экстракция.

Способность хлорорганических пестицидов сохранять свою устойчивость в окружающей среде после применения стала большой экологической проблемой. В отличие от множества поллютантов, пестициды вводят в окружающую среду преднамеренно, ведь они играют роль агентов, способствующих гибели сорняков и насекомых-вредителей. Таким образом, в большей мере начали применять антихолинэстеразные фосфорорганические препараты. ФОП (фосфорорганические пестициды)являются органическими эфирами кислот фосфора, открытые в конце 1930-х годов. Как эффективные инсектициды широкого спектра действия они часто используются в сельском хозяйстве. Однако большинство фосфорорганических пестицидов имеют высокий коэффициент распределения в системе масло - вода, соответственно, они лишь незначительно растворимы в воде [1]. Эти липофильные соединения склонны к отложению и накоплению в жировых тканях и представляют собой потенциальный риск для здоровья человека [2]. К тому же они оказались гораздо более токсичными, чем хлорорганические пестициды. ФОП проявляют канцерогенные, мутагенные, нейротоксические, генотоксические, тератогенные и иммунотоксические свойства у млекопитающих[3].

Основные пути попадания в организм фосфорорганических пестицидов - это вдыхание, всасывание через кожу и прием внутрь [4]. Для подобных загрязнителей предпочтительной матрицей являются продукты питания, содержащие растительные жиры, в частности некоторые зерновые культуры. Подобная матрица обеспечивает устойчивость ФОП в течение долгого времени.

Поскольку это низкополярныелипофильные соединения, полностью изолировать их от матрицы зерна непросто. Этап очистки весьма важен впоследующем определении для 
обеспечения чувствительности и селективности аналитического сигнала. Газовая хроматография в сочетании с масс-спектрометрией (ГХ-МС) является привычным методом обнаружения ФОП. На стадии пробоподготовки жидкость-жидкостная экстракция может занимать много времени и требовать большое количество растворителя на экстракцию. В таком случае целесообразно применять метод твердофазной экстракции.

В качестве анализируемых матриц были выбраны следующие объекты: рапс, овес и соя, т.к. они содержат большее количество жиров в сравнении с другими зерновыми культурами, такими как, пшеница, овес, ячмень и др.

10 г гомогенизированного зерна помещали в коническую колбу на 125 мл и добавляли 20 мл гексана. Встряхивали смесь в течение 10 мин при 150 об/мин, затем центрифугировали 5 мин при 4000 об/мин. Отбирали 5 мл супернатантаи помещали его в полипропиленовые центрифужные пробирки, в которые предварительно добавляли сорбенты (200 мг $\mathrm{MgSO}_{4}, 100$ мг $\mathrm{C}_{18}$ и 50 мг PSA). Встряхивали смесь в течение 2 мин и центрифугировали 5 мин при 4000 об/мин. Отбирали 2 мл супернатанта и упаривали в токе азота. Осадок перерастворяли в 500 мклгексана и проводили газохроматографический анализ.

Таблица - Время удерживания, основной, подтверждающие ионы масс-спектра ЭИ и пределы обнаружения ФОП

\begin{tabular}{|c|c|c|c|c|}
\hline $\begin{array}{l}\text { Определяемый } \\
\text { компонент, } \\
\text { (Мол. масса, } \\
\text { г/моль) }\end{array}$ & $\begin{array}{l}\text { Время } \\
\text { удерживания, } \\
\text { мин }\end{array}$ & $\begin{array}{l}\text { Основной и } \\
\text { подтверждающие ионы, } \\
\text { m/z и их относительная } \\
\text { интенсивность, }(\%)\end{array}$ & $\begin{array}{l}\text { Предел } \\
\text { обнаружения, } \\
\text { мг/кг }\end{array}$ & $\begin{array}{l}\text { Максимально } \\
\text { допустимый } \\
\text { уровень, } \\
\text { мг/кг }\end{array}$ \\
\hline $\begin{array}{l}\text { Диметоат } \\
(229.2)\end{array}$ & 13.63 & $\begin{array}{l}87(100), 93(54), 125(45), \\
47(16)\end{array}$ & $1.1 \cdot 10^{-3}$ & 0.05 \\
\hline $\begin{array}{l}\text { Фозалон } \\
(367.8)\end{array}$ & 14.80 и 25.55 & $\begin{array}{l}182(100), 121(36), 184 \\
(34), \\
97(22)\end{array}$ & $5.3 \cdot 10^{-3}$ & 0.2 \\
\hline $\begin{array}{l}\text { Метил- } \\
\text { паратион } \\
(263.2) \\
\end{array}$ & 16.37 & $\begin{array}{l}125(100), 109(98), 263 \\
(75), \\
79(19)\end{array}$ & $3.6 \cdot 10^{-3}$ & 0.1 \\
\hline $\begin{array}{l}\text { Хлорпирифос } \\
\text { (350.6) }\end{array}$ & 17.94 & $\begin{array}{l}197(100), 199(97), 314 \\
(87), 97(80), 316(65)\end{array}$ & $2.2 \cdot 10^{-3}$ & 0.05 \\
\hline $\begin{array}{l}\text { Бромофос } \\
(365.0)\end{array}$ & 18.39 & $\begin{array}{l}331(100), 329(75), 125 \\
(31), 333(29)\end{array}$ & $2.4 \cdot 10^{-3}$ & 0.05 \\
\hline
\end{tabular}

Анализ стандартных образцов пестицидов проводился в условиях полного ионного тока(TIC) на газовом хроматографе «Trace 1300 GC» с масс-спектрометрическим детектором «DSQ II» (ThermoFisherScientific, США) при электронной ионизации (ЭИ, 70 эВ) в диапазоне масс $\mathrm{m} / \mathrm{z}=50-400$,длительность анализа - 40 мин. Применяликварцевую капиллярную колонку «TraceGold TG-5 MS» $(30 \mathrm{м} \times 0.25$ мм $\times 0.25$ мкм, ThermoFisherScientific, CША). Условия проведения хроматографического разделения:

температура ионного источника, ${ }^{\circ} \mathrm{C}$

температура испарителя (инжектора), ${ }^{\circ} \mathrm{C}$.

280

начальная температура термостата колонок, ${ }^{\circ} \mathrm{C}$.

60

скорость нагрева термостата колонок, ${ }^{\circ} \mathrm{C} / \mathrm{Mин}$

10

коэффициент деления потока.

газ-носитель

гелий

напряжение на электронном умножителе, В

1440

скорость потока газа-носителя, мл/мин •*

0.8

объем пробы, мкл .

\section{1}

Для построения градуировочных зависимостей и анализа исследуемых образцов идентификацию фосфорорганических пестицидов проводили в режиме регистрации 
селективных ионов (SIM/SIR-режим) по наиболее интенсивным и характеристичным ионам масс-спектра ЭИ, которые представлены в таблице.

Полнота извлечения ФОП находится в интервале 89-93\%. Разработанный способ ГХМС определения ФОП с применением твердофазной экстракции позволяет достичь необходимых пределов обнаружения, не превышающих МДУ по каждому из представленных пестицидов.

Литература. 1. Rezaee, M. Determination of organic compounds in water using dispersive liquidliquid microextraction / M. Rezaee, Y. Assadi, M-R. M. Hosseini, E. Aghaee, F. Ahmadi, S. Berijani // Journal of Chromatography A. - 2006. -№ 1116. - P. 1-9. 2. Pope, C. N. Organophosphorus pesticides: do they all have the same mechanism of toxicity? / C. N. Pope // Journal of Toxicology and Environmental Health, Part B: Critical Reviews. - 1999. -№ 2. - P. 161-181. 3. Sousa, S. Method development for the determination of synthetic musks and organophosphorus pesticides in human adipose tissue / S. Sousa, D. Pestana, G. Faria, F. Vasconcelos, C. Delerue-Matos, C. Calhau, V. F. Domingues // Journal of Pharmaceutical and Biomedical Analysis. - 2020. - available online. doi:https://doi.org/10.1016/j.jpba.2020.113598. 4.Rosenstock, L. Chronic central nervous system effects of acute organophosphate pesticide intoxication / L. Rosenstock, M. Keifer, W. E. Daniell, R. McConnell, K. Claypoole // The Lancet. - 1991. № 338. - P. 223-227.

\section{SAMPLE PREPARATION USING SPE IN THE DETERMINATION OF ORGANOPHOSPHORUS PESTICIDES IN CORN BY GC-MS}

Likhacheva A. Y.,junior researcher, Fitsev I. M., leading researcher, Ph. D.,MukharlyamovaA. Z., researcher, RakhmetovaE. R., researcher,MukhammetshinaA. G., juniorresearcher

(FGBNU "FTsTRB-VNIVI", Russia)

Summary.Organophosphate pesticides are widely used in agriculture against pests of various crops, and therefore there is a need for a quick and inexpensive analysis of food products for this type of pollutants. A method for determining organophosphorus pesticides in the matrix of grain crops using solid-phase extraction is proposed. It is characterized by a low detection limit, low analysis time, and low cost. Gas chromatography with a mass spectrometric detector was used to determine organophosphorus pesticides.

Key words:gas chromatography, mass spectrometry, organophosphate pesticides, solid phase extraction.

УДК 636.085

\section{ПРОДУКТИВНОСТЬ И МЯСНЫЕ КАЧЕСТВА ЦЫПЛЯТ КРОССА «СМЕНА 9» ПРИ ВЫГУЛЬНОМ ВЫРАЩИВАНИИ}

Лукашенко В. С., д. с.-Х. Н., г.н.с., Комаров А. А., соискатель (ФНЦ «ВНИТИП» РАН, Россия)

Аннотация. В статье представлены результаты исследований по изучению продуктивности и мясных качеств цыплят нового отечественного кросса «Смена 9», при выгульном выращивании, в сравнении с клеточным и напольным выращиванием птицы.

Ключевые слова: мясные цыплята, живая масса, сохранность, конверсия корма, мясные качества тушек.

В современном отечественном птицеводстве наиболее широкое распространение получили интенсивные способы выращивания цыплят-бройлеров - в клетках и на подстилке $[1,2]$. Но, при интенсивных способах выращивания, у птицы часто возникает состояние стресса, которое отрицательно сказывается на продуктивности и показателях качества мяса цыплят-бройлеров [3].

В последнее время, особенно за рубежом, наряду с традиционными способами выращивания птицы, всё больший интерес вызывает технология выгульного содержания 
птицы. При такой технологии ряд авторов отмечают более высокое качество мяса у цыплят, по сравнению с интенсивной технологией их выращивания $[4,5]$.

В нашей стране проведенных научных исследований, направленных на разработку технологии выращивания мясных цыплят с использованием выгульных площадках, достаточно мало.

В связи с этим была поставлена задача - изучить продуктивность и мясные качества цыплят нового отечественного кросса «Смена 9» при выгульной технологии выращивания в сравнении с клеточным и напольным способами выращивания.

Для этого в условиях фермерского хозяйства Московской области был проведен опыт на цыплятах кросса «Смена 9». В опыте было сформировано 3 группы птицы по 35 голов в каждой. В группе 1 цыплят выращивали в клеточной батарее, в группе 2 - на полу на подстилке из опилок, а в группе 3 - при выгульном способе содержания птицы. Цыплят во всех группах выращивали до 8-недельного возраста.

В ходе проведенного опыта в конце выращивания была изучена продуктивность цыплят-бройлеров. По данным зоотехнических показателей было установлено, что наиболее высокая живая масса 1 головы в конце выращивания была в группе 3, где она составила 3892 г, против 3844 г в группе 1 и 3831 г в группе 2, что было выше на 1,2 и 1,6 \% соответственно.Жизнеспособность цыплят в группе 3, при выгульном способе содержания птицы, была на 3,4 \% выше, чем в группе 2 при клеточном, и на 3,1 \% выше, по сравнению с группой 2, при напольном способе выращивания. Конверсия корма в группах 2 и 3 были ниже на 1,83 и 1,0\% соответственно, по сравнению с группой 1.

С целью определения убойного выхода и сортности тушек цыплят-бройлеров, в 8недельном возрасте был произведен убой поголовья. Было установлено, что убойный выход в опытных группах 2 и 3 был на 0,2 и $0,5 \%$ выше, по сравнению с группой 1 . В связи с этим выход тушек первого сорта был самым высоким в группе 3 при выгульном выращивании птицы и составил 82,4 \% или на 3,6 и 3,0 \% выше, чем в группах 1 и 2 соответственно.

Для определения мясных качеств, была проведена анатомическая разделка тушек цыплят. По результатам разделки было установлено, что лучшими мясными качествами обладали тушки, где при выращивании цыплят применялась технология напольного содержания с использованием выгульных площадок. Так, общий выход мышц в тушках цыплят в опытной группе 3 составил $65,0 \%$, что было на 3,0 \% выше, чем в тушках цыплят в группе 1, которых выращивали в клетках, и на 0,9\% выше, чем в группе 2 у цыплят, выращенных на полу без выгула. Следует отметить, что в тушках цыплят при выгульном выращивании было меньше внутреннего абдоминального жира и кожи с подкожным жиром. В опытной группе 3 количество абдоминального жира составило 1,2 \%, против 1,6 \% в группе 1, и 1,4 \% в группе 2, а кожи с подкожным жиром - 12,0 \%, против 13,1 \% при клеточном содержании в группе 1 , и 12,2 \% при напольном выращивании в группе 2.

Для оценки крепости костяка у птицы, при различных способах выращивания, определяли содержание золы, фосфора и кальция в большеберцовых костях. Результаты исследования показали, что наиболее высокое содержание кальция в большеберцовых костях цыплят было в группе 3 и составило 18,26 \%, что было на 0,43 и 2,14 \% выше по сравнению с группами 2 и 1 соответственно. Содержание фосфора в костях в группе 3 также было выше на 0,76 и $0,92 \%$ соответственно, по сравнению с группами 2 и 1 . Это свидетельствует о том, что в отличие от традиционных напольной и клеточной технологий содержания, использование выгульного способа выращивании цыплят, благоприятно сказывается на развитии костной системы у птицы.

На основании вышеизложенных результатов проведенного исследования можно сделать заключение о том, что выгульная технология выращивания мясных цыплят до 8недельного возраста, благоприятно сказалась на жизнеспособности птицы, а также позволяет повысить живую массу на 1,2 - 1,6 \%, убойный выход на $0,2-0,5 \%$, и сортность тушек на 3,0 - 3,6 \%, по сравнению с интенсивными способами выращивания птицы в клетках и на 
подстилке, при этом выгульный способ выращивании цыплят способствует повышению уровня содержания кальция и фосфора в большеберцовых костях птицы.

Литература. 1. Астраханцев, А.А. Продуктивность цыплят-бройлеров при различных технологических вариантах выращивания /А.А. Астраханцев // Птицеводство. - 2019. - № 1.

- С. 26-30. 2. Буяров, В.С. Эффективность современных технологий производства мяса бройлеров / Буяров В.С. // Биология в сельском хозяйстве. - 2020. - № 1 (26). - С. 15-21. 3. Гудыменко, В.И. Мясная продуктивность цыплят-бройлеров при выращивании по разной технологии / В.И. Гудыменко, А.Е. Ноздрин // Известия Оренбургского ГАУ. - 2014. - № 6 (50). - C. 136-139. 4. Chen, X. Effects of outdoor access on growth performance, carcass composition, and meat characteristics of broiler chickens/ X. Chen, W. Jiang, H. Z. Tan, G. F. Xu, X. B. Zhang, S. Wei, X. Q. Wang // Poultry Science - 2013. - Vol. 92. - P. 435-443. 5. Sihua, Jin. Influence of free-range days on growth performance, carcass traits, meat quality, lymphoid organ indices, and blood biochemistry of Wannan Yellow chickens/ SihuaJin, Lei Yang,He Zang, Yuan Xu,Xianzen Chen, Xingyong Chen, Ping Liu, ZhaoyuGeng //Poultry Science. - 2019. - Vol. 98. P. 6602-6610.

\section{THEPRODUCTIVEPERFORMANCEANDMEATYIELDS IN FREE RANGE HOUSED BROILERS OF SMENA-9 CROSS \\ Lukashenko V.S., KomarovA.A. \\ (Federal Scientific Center "All-Russian Research and Technological Institute of Poultry" of RussianAcademy of Sciences)}

Summary.The productive performance and meat yields in free range housed broiler of new Russian cross Smena-9 was studied as compared to standard cage and floor housing.

Key words: broilers, live bodyweight, mortality, feed conversion ratio, meat yields.

УДК636.5.033:636.085.8:636.087

\section{БЕЗОПАСНОСТЬ МЯСА БРОЙЛЕРОВ ПРИ ИСПОЛЬЗОВАНИИ КОРМОВЫХ ДОБАВОК, ПОЛУЧЕННЫХ ИЗ ОТХОДОВ ПТИЦЕПЕРЕРАБОТКИ}

Лукашенко В.С., д. с.-х. н., г.н.с., Салеева И.П. д. с.-х. н., г.н.с., Волик В.Г. д.б.н., г.н.с., Исмаилова Д.Ю. к.б.н., в.н.с., Овсейчик Е.А. к. с.-х. н., с.н.с., Журавчук Е.В. к. с.-х. н., н.с. (ФНЦ «ВНИТИП» РАН, Россия)

Аннотация. В данной статье представлены результаты исследований по изучению продуктивностии безопасности мяса цыплят-бройлеров, в рационе которых использовались новые кормовые добавки, полученные из отходов птицепереработки в сравнении с цыплятами, в рационе которых источником животного белка была рыбная мука.

Ключевые слова: цыплята-бройлеры, кормовые добавки, живая масса, безопасность мяса.

Одним из основных источников белка в кормовых рационах сельскохозяйственной птицы является рыбная мука. Однако, в связи с сокращением рыбных запасов в мировом океане, промышленное производство рыбной муки значительно сократилось, поэтому все актуальнеевстаетвопрос о её замене в кормовых рационах для птицы на новые источники полноценного белка.

Одним из таких источников получения кормового белка является использование отходов, возникающих при убое и переработке птицы. Так, при переработке птицы возникает до $27 \%$ продуктов убоя и потрошения, которые, при соответствующей технологической обработке, могут служитьполноценным источником кормового белка животного происхождения, способным восполнить рыбную муку в кормовых рационах для птицы, в том числе, и для цыплят-бройлеров[1, 2].

В отечественной мясоперерабатывающей отрасли значительное количество белоксодержащих ресурсов в виде отходов производства остается невостребованным, трудно 
поддается утилизации и в связи с этим приводит к загрязнению окружающей среды. Среди них особый интерес представляют вторичные продукты убоя животных и птицы [3].

Специалистами ВНИИПП была разработана технология получения кормовых добавок из вторичных продуктов птицепереработки(пера, кишечника, крови) и получены легкоусвояемые гидролизованные и ферментированные кормовые белковые добавки для использования в рационах цыплят-бройлеров [4].

При разработке новых кормовыхдобавок была проведенаоценка некоторых показателей безопасности пера, кишечника и крови, возникающих при убое и переработке птицы.

Результаты исследований показали, что массовая доля влаги в пере составляла не выше $55 \%$, массовая доля протеина - 46,1 \%, массовая доля золы - 1,5\%, массовая доля жира - 1,01 \% при минимальном (ниже ПДК) содержании свинца, кадмия, мышьяка и ртути. Бактерии группы кишечной палочки, сальмонеллы, анаэробы и протеи в 50 г не были обнаружены.

Результаты исследований кишечника показали, что массовая доля влаги в нем составляла не выше 71,6 \%, массовая доля протеина - 13,2 \%, массовая доля золы $-2,1 \%$, массовая доля жира - 13,2 \%, содержание кальция составляло 22.034,0 мг/кг, фосфора - 1433,2 мг/кг, при минимальном содержании свинца, кадмия, мышьяка и ртути, фактические результаты были в разы ниже нормируемых значений. Хлорорганические пестициды, антибиотики и радионуклиды не были обнаружены.Бактерии кишечной палочки, сальмонеллы, анаэробы и протеи в 25 г также не были обнаружены.

Результаты исследований крови птицы показали, что массовая доля влаги в ней составляла не выше 81,5\%, массовая доля протеина - 16,8 \%, массовая доля золы $-1,12 \%$, массовая доля жира - 1,02 \%. При минимальном содержании свинца, кадмия, мышьяка и ртути, фактические результаты этих были в разы ниже нормируемых значений. Хлорорганические пестициды, антибиотики и радионуклиды не были обнаружены. Бактерии группы кишечной палочки, сальмонеллы, анаэробы и протеи в 25 г не были обнаружены.

С целью определения влияния использования в комбикормах легкоусвояемых кормовых добавок из продуктов убоя и переработки птицы на продуктивностьибезопасность мяса птицы, было проведено исследование на птице кросса «Смена-9». Для этого в условиях вивария СГЦ «Загорское ЭПХ» - филиала ФНЦ «ВНИТИП» РАН было сформировано три группы цыплят по 35 голов в каждой. Птицу выращивали при одинаковых условиях содержания с суточного до 38-дневного возраста на подстилке из опилок с плотностью посадки 18 гол/м².

Контрольная группа 1 получала полнорационный комбикорм, в котором источником животного белка была рыбная мука. Опытная группа 2 получала рацион с ферментированной кормовой добавкой из пера, кишечника и крови. Опытная группа 3 получала рацион с гидролизованной кормовой добавкой из пера, кишечника и крови.

В результате проведенных исследований было установлено, что по показателям продуктивности в 38-суточном возрасте лучшей была опытная группа 2, в которой цыплята получали ферментированную кормовую добавку вместо рыбной муки. Так, средняя живая масса цыплят, в этой группе опережала данный показатель контрольной группы на 9,4 \% $(\mathrm{p} \leq 0,001)$.Использование в опытной группе 3 рациона с гидролизованной кормовой добавкой, бройлеры по средней живой массе на $5,5 \%(p \leq 0,05)$ был выше, по сравнению с контрольной группой 1.

Проведенная дегустационная оценка мяса птицы по 5-балльной шкале показала, что наиболее высокие вкусовые и ароматические достоинства бульона были получены в опытной группе 2- 4,87 баллов. Вкусовые качества мяса в опытной группе 2, также были более высокие, чем в контрольной группе 1. Грудные мышцы в опытной группе 2 были оценены в 4,77 балла, бедренные - в 4,82 балла, а в контрольной группе грудные мышцы получили оценки $-4,56$ балла, а бедренные $-4,66$ баллов.

Проведенная оценка безопасности мяса цыплят-бройлеров показала, что содержание в мясе свинца во всех исследуемых трех группах составило менее 0,1 мг/кг, при нормируемом 
значении 0,5 мг/кг. Содержание кадмия во всех трех группах составило менее 0,01 мг/кг, при нормируемом значении 0,05 мг/кг. Содержание мышьяка во всех трех группах составило менее 0,05 мг/кг, при нормируемом значении 0,1 мг/кг. Содержание ртути во всех трех группах составило менее 0,002 мг/кг, при нормируемом значении 0,03 мг/кг.

Исследование мяса бройлеров на содержание пестицидов показало, что уровень гексахлорциклогексана во всех трех группах был менее 0,04 мг/кг, при нормируемом значении 0,1 мг/кг. Содержание ДДТ и его метаболитов во всех трех группах составило менее 0,04 мг/кг, при нормируемом значении 0,1 мг/кг.

Содержание антибиотика левомицетина во всех трех группах составило менее 0,00008 мг/кг, при нормируемом значении 0,0003 мг/кг. Содержание цезия-137 в контрольной группе 1 составило менее 3,7 Бк/кг, в опытной группе 2 менее 2,5 Бк/кг и в опытной группе 3 менее 3,1 Бк/кг, при нормируемом значении 200 Бк/кг.

Таким образом, в результате проведенных исследований было установлено, что использование кормовых добавок, полученных их отходов убоя и переработки птицы (перо, кишечник и кровь) в питании цыплят-бройлеров, положительно сказалось на результатах продуктивности цыплят-бройлеров. При этом по таким показателям безопасности мяса, как токсичные элементы, пестициды, антибиотики и радионуклиды, не было обнаружено превышение нормативов, приведенных ТР ТС 021/2011 «О безопасности пищевой продукции».

Исследование выполнено при финансовой поддержке Российского научного фонда (проект № 17-16-01028-П)

Литература. 1. Полянских, С.В. Комплексный подход в переработке птицы /С.В. Полянских // Мясная индустрия. 2010. № 7. С. 53-55. 2.Волик, В.Г. Эффективное использование побочного сырья переработки птицы и яиц на кормовые цели: новые направления / В.Г. Волик, В.В. Гущин // Птица и птицепродукты. - 2020. - № 2. - С. 60-62. 3.Гладий, М.В. Безотходное производство на предприятиях по выращиванию цыплят-бройлеров / М.В. Гладий, И.И. Муржа, В.Г. Кебко, Ю.П. Полупан, Л.А. Дедова//Актуальные проблемы интенсивного развития животноводства. - 2017. - № 20-2. - С. 91-97.4. Волик В.Г. Повышение эффективности использования вторичного сырья, получаемого при переработке птицы / В.Г. Волик, Д.Ю. Исмаилова, С.В. Зиновьев, О.Н. Ерохина. // Птица и птицепродукты. - 2017. - № 2. - C. 40-43.

\section{MEAT BIOSAFETY IN BROILERS FED NEW PROTEIN ADDITIVES BASED ON THE WASTES OF POULTRY PROCESSING}

Lukashenko V.S., Saleeva I.P., Volik V.G., IsmailvaD.Yu., Ovseychik E.A., Zhuravchuk E.V. (Federal Scientific Center "All-Russian Research and Technological Institute of Poultry" of Russian Academy of Sciences)

Summary. The productive performance and biosafety in broilers fed diets supplemented with new animal protein additives based on the wastes of the slaughter and primary processing of poultry was studied in compare to broilers fed diet with fishmeal as the source of animal protein.

Key words: broiler chicks, protein feed additives, live bodyweight, biosafety of meat.

УДК 637.112

\section{ОСНОВНЫЕ АСПЕКТЫ ПРИ ОРГАНИЗАЦИИ ДОЕНИЯ КОРОВ}

Лукин О.А., к.в.н.

(Учебный центр переподготовки и переквалификации, Могилев, Республика Беларусь)

Аннотация.В настоящей научной статье рассмотрены главные аспекты проведения организации доения коров. Определен главный фактор при организации и проведения акта доения. Проанализирована и дана оценка двум основным способам доения (ручной и машинный). 
Ключевые слова: доение, оператор машинного доения, ручной способ доения, машинный способ доения, организация, молоко, молочная продукция, гигиена.

Актуальность и значимость организации доения коровзаключается в том, что на сегодняшний день современное развитие молочного животноводстваклассифицируется его интенсификацией, которая развивается на основе роста и развития уровня молочной продукции и молочного производства, а также материального и технического совершенствования и повышения финансовой и экономической эффективностей.

Главным фактором при организации и проведении доения коров является соблюдение основных санитарно-гигиенических требований при получении молочной продукции, а также ееобработке, переработки, транспортировке и хранении.

Технология организации и проведения доения коров должна не только облегчать и усовершенствовать труд оператора машинного доения, но и увеличивать коэффициент производительности труда. Также способствовать наиболее эффективной отдачи и реализации молоковыделительного рефлекса у дойных животных. машинное.

В современных условиях существует два главных способа доения - ручное и

Ручное доение. На сегодняшний день очень трудоемкий и затратный процесс (с точки зрения организации в современных экономических условиях), при производстве молока и молочной продукции на его долю приходится около 80 \% затрат человеческого (ручного) труда $[1,2]$. Один оператор машинного доения (дояр) может обслужить лишь 40 - 50 дойных животныхкоров при доении в стойлах и при наличии молокопровода (при машинном доении 100-200 дойных животных) (Рисунок 1).

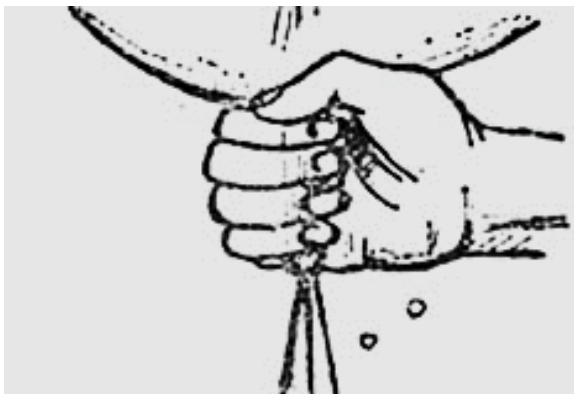

A

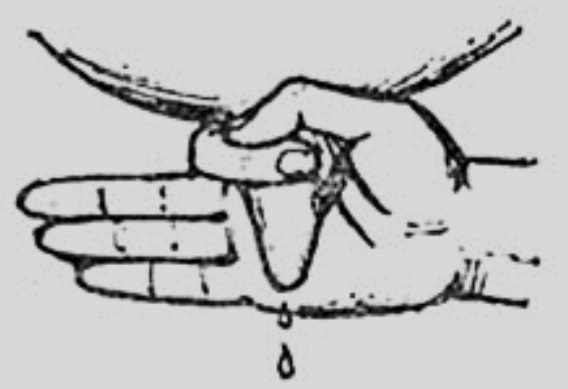

Б

Рисунок 1 - Ручное доение коров (А - “щипком”, Б - кулаком)

Машинное доение. Имеет огромнейшее преимущество перед ручным по двум основным признакам:

1.Машинное доение облегчает труд операторов машинного доения (дояров).

2.Машинное доение повышает коэффициент производительности труда операторов машинного доения (дояров) (Рисунок 2).

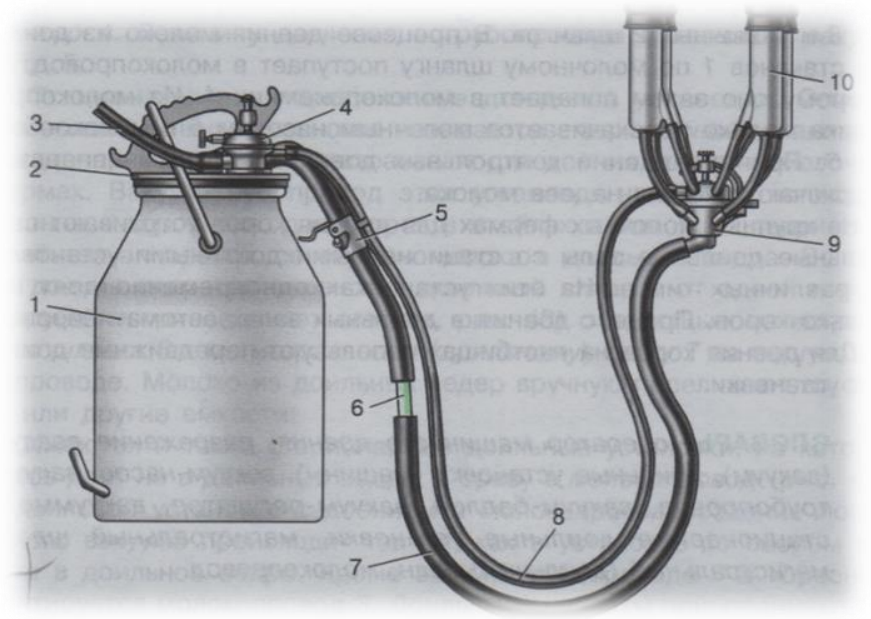

Рисунок 2 - Трехтактный доильный аппарат "Волга" (со сбором молока в доильное ведро):

1 - доильное ведро; 2 - крышка ведра; 3 - магистральный шланг постоянного вакуума; 4 - пульсатор; 5 зажим молочного шланга; 6 - смотровое стекло; 7 - молочный шланг; 8 - шланг переменного вакуума; 9 - коллектор; 10 доильный стакан 
Главным отличием ручного доения от машинного заключается в том, что машинное доение основано на отсасывании, а не на выжимании молока из соска вымени, тем самым создаются благоприятные условия для дойных животных (эффект естественного акта сосания новорожденных телят) $[4,5]$.

В заключении настоящей научной статьи хотелось бы подчеркнуть, что главным фактором в организации и проведении доения является соблюдение установленного распорядка дня, так как у дойных животных очень быстро вырабатывается основной рефлекс на временной фактор. Неправильная эксплуатация распорядка дня вызывает прежде всего снижение фактических удоев и ряд патологических факторов, связанных с работой нервной деятельности.

Литература.1.Ведищев С.М. Механизация доения коров: учебное пособие для студентов высших учебных заведений / С.М. Ведищев. - Тамбов, 2013. - 160с. 2.Кузнецов А.Ф. Гигиена животных: Учебник /Под ред. А.Ф. Кузнецова. - СПб.: Издательство “Квадро”, 2015. - 448 с. 3.Кузнецов А.Ф. и др. Зоогигиена и ветеринарная санитария: учебник /А.Ф.Кузнецов, В.Г. Тюрин, В.Г.Семенов, Г.С. Никитин; научный ред. А.Ф.Кузнецов. - СПБ.: ООО "Квадро", 2017. - 384 с. 4.Куликова Н.И. Основы разведения сельскохозяйственных животных и частная зоотехния: учеб. пособие/ Н.И. Куликова, О.Н. Еременко. - Краснодар: КубГАУ, 2017. - 247c. 5.Трухачев В.И., Капустин И.В. и др. Технологическое и техническое обеспечение процессов машинного доения коров, обработки и переработки молока: учебное пособие / В.И. Трухачев, И.В. Каустин, В.И. Будков, Д.И. Грицай. - Ставрополь: АГРУС, 2012. $-300 \mathrm{c}$.

\section{THE BASIC MAIN ASPECTS OF THE ORGANIZATION OF MILKING COWS}

$$
\text { Lukin O.A. c.v.n. }
$$

(Training Center for retraining and retraining, Mogilev, RB)

Summary. In this scientific article, the main aspects of the organization of milking cows are considered. The main factor in the organization and conduct of the milking act is determined. Two main methods of milking (manual and machine) are analyzed and evaluated.

Keywords: milking, machine milking operator, manual milking method, machine-milking method, organization, milk, dairy products, hygiene.

УДК: 504.054:615

\section{ПРОБЛЕМА ФАРМАЦЕВТИЧЕСКОГО ЗАГРЯЗНЕНИЯ ОКРУЖАЮЩЕЙ СРЕДЫ}

Лунегов А.М. заведующий кафедрой фармакологии и токсикологии, доцент, к.в.н. (ФГБОУ ВО СПбГУВМ, Россия)

Аннотация. В связи с увеличивающимся фармацевтическим загрязнением окружающей среды, многие лекарственные вещества негативно влияют на животных и гидробионтов, что сказывается на снижении их популяции. Проблема загрязнения лекарственными препаратами состоит из-за отсутствия процедуры централизованной утилизации лекарственных отходов от населения и животноводческих хозяйств. Для того чтобы кардинально решить проблему фармацевтического загрязнения окружающей среды лекарственными отходами, в первую очередь должны быть направлены усилия на уровне государственной политики в области рационального обращения лекарственных средств. Также особое значение приобретают вопросы совершенствования способов утилизации лекарственных препаратов и фармацевтических субстанций.

Ключевые слова: фармацевтическое загрязнение, лекарственные препараты

В местах, где живут люди, есть риск фармацевтического загрязнения окружающей среды лекарственными средствами. Более 200 различных фармацевтических агентов, в том числе антибиотиков, нестероидных противовоспалительных препаратов, анальгетиков, 
эстрогенов, и препаратов из других терапевтических групп были обнаружены в водной и наземной средах по всему миру.

Фармацевтические отходы могут быть стойкими химическими соединениями, которые даже в низких концентрациях, могут нарушить нормальную работоспособность организма, проявляющуюся функциональными или органическими повреждениями физиологических систем. Наличие антибиотиков в окружающей среде может способствовать развитию устойчивости к антибиотикам у микроорганизмов, в том числе в в водной среде.

На сегодняшний день во всем мире идет интенсивное развитие фармацевтической промышленности, что увеличивает риск производства большого количества фальсифицированной, недоброкачественной и появления просроченной продукции. Вместе с известнымитоксикантами, такими как тяжелые металлы и пестициды, лекарственные препараты также непрерывно поступают в окружающую среду загрязняя ее.

Быстрое развитие фармацевтической промышленности увеличило рост отходов лекарственных препаратов и в 1979 году Всемирная организация здравоохранения отнесла фармацевтические отходы к классу опасных отходов. К сожалению, в научной литературе очень мало данных о влиянии лекарственных средств на организмы, в том числе гидробионты, после того как они попадают в окружающую среду различными путями.

Так в Швеции, в результате воздействия гормональных препаратов у самцов рыб было замечено нарушение в развитии половых желез и вместо сперматозоидов в них начали формироваться незрелые яйцеклетки.

В странах Южной Азии в начале 2000 годов резко сократилась популяция стервятников из-за использования анальгетического средства диклофенак. Его применяли при травмах различной этиологии у крупных животных, в частности крупного рогатого скота, а также для снятия болезненности при лечении опухолей. Погибших на пастбищах животных, поедали стервятники, которые накапливали токсические дозы диклофенака. В результате такой миграции анальгетика по пищевой цепи привело к снижению популяции стервятников более $90 \%[1,2]$.

Создание и применение лекарственных средств играют важную роль в обеспечении здоровья как людей, так и животных. В связи с этим необходимо соблюдать требования по снижению воздействия лекарственных веществ на окружающую среду.

На сегодняшний день в нашей стране население утилизирует лекарственные средства с истекшим сроком годности совместно с общебытовыми отходами из-за отсутствия процедуры централизованной утилизации лекарственных отходов от населения и животноводческих хозяйств.

Для того чтобы кардинально решить проблему фармацевтического загрязнения окружающей среды лекарственными отходами, в первую очередь должны быть направлены усилия на уровне государственной политики в области рационального обращения лекарственных средств.Также особое значение приобретают вопросы совершенствования способов утилизации лекарственных препаратов и фармацевтических субстанций.

Литература.1. Боксал, А. Основные экологические характеристики лекарственных препаратов и их метаболитов / А. Боксал, Б.Н. Аубакирова, Р.Р. Бейсенова, М.Р. Хантурин // Вестник КарГУ. - 2015. 2.http://positime.ru/upryamstvo-cheloveka-skazyvaetsya-na-dikojprirode/30704.

THE PROBLEM OF PHARMACEUTICAL POLLUTION OF THE ENVIRONMENT

Lunegov A.M. Head of the Department of Pharmacology and Toxicology, Associate Professor, Ph.D. (FSBEI HE SPbGUVM, Russia)

Summary.Due to the increasing pharmaceutical pollution of the environment, many medicinal substances negatively affect animals and aquatic organisms, which affects the decline in their population. The problem of drug pollution is due to the lack of a procedure for the centralized disposal of medicinal waste from the population and livestock farms. Elimination or minimization of environmental pollution with medicinal wastes requires actions both at the level of state policy in the 
field of rational use of medicinal products, and improving technology for the utilization and treatment of wastewater.

Key words: pharmaceutical pollution, medicinal products

УДК: 616-036.14-001.4:619

\section{ЛЕЧЕНИЕ ЗАСТАРЕЛЫХ ГНОЙНЫХ РАН}

Лунегов А.М.зав. кафедрой фармакологии и токсикологии, доц., к.в.н., Барышев В.А., доц., К.В.Н.

(ФГБОУ ВО СПбГУВМ, Россия)

Аннотация. В ветеринарии постоянно ведется поиск новых антисептических и ранозаживляющих лекарственных средств предназначенных для лечения ран различной этиологии. Заживление ран представляет собой это сложный, многостадийный процесс, при терапии которых предпочтительно использовать комбинированные лекарственные средства. Нами проведен эксперимент по заживлению застарелых гнойных ран у собак, где лучшую эффективность показала новая мазь, состоящую из компонентов, обладающих антимикробной активностью, противовоспалительным и регенерирующим действием, анестезирующим свойством и глубоко проникающей способностью мазевой основой, в сравнении с 5\% диоксидиновой мазью и левомеколем.

Ключевые слова:Мазь, раны, собаки, ранозаживляющие средства.

Для терапии раневых патологий используют различные лекарственные средства, обеспечивающие антимикробное, очищающее и регенерирующее действие. Из лекарственных форм на первом этапе лечения чаще всего используют растворы антисептиков, а затем мази, линименты или эмульсии [1][2].

В связи с тем, что поражения кожи у животных встречаются достаточно часто, нами был проведен эксперимент по лечению застарелых гнойных ран у собак в ветеринарной клинике «НикаВет» (Санкт-Петербург). Исследования были проведены в течение всего 2018 года. Нами была испытана новая мазь, в состав которой входили компоненты, обладающие антимикробной активностью, противовоспалительным и регенерирующим действием, анестезирующим свойством и глубоко проникающей способностью мазевой основой. Сравнивали течение раневого процесса у собак при гнойных поражениях кожи.

Были подобраны собаки с застарелыми гнойными ранами, которых разделили на три группы, по 20 животных в каждой. В качестве аналога для лечения использовали 5\% диоксидиновую мазь, в контрольной группе на раневую поверхность наносили мазь левомеколь.

Проведенный эксперимент показал, что при назначении животным 5\% диоксидиновой мази стадия эксудации наблюдались в среднем по группе почти 2-е суток. Совместное применение новой мази сократила первую фазу заживления раны в два раза В контрольной группе собак (мазь левомеколь) этот показатель растягивался до 2,3 суток. В аналогичной последовательности происходил переход первой фазы раневого процесса в стадию пролиферации (появление грануляций). Быстрее всего этот процесс происходил при назначении новой мази диметол - 5,4 суток и соответственно, при использовании диоксидиновой мази 7,2 суток, и мази левомеколь - 8,7 суток. Полное заживление ран при применении новой мази произошло на 14 день. Заживление раневой поверхности при применении диоксидиновой и мази левомеколь наступила на 16 и 17 сутки соответственно. В процессе терапии гнойных ран осложнения при использовании мази левомеколь составило $10 \%$, при лечении диоксидиновой мазью 5\%, чего не наблюдалось при использовании новой мази. 
Таким образом, новая мазь оказалась значительно эффективнее двух официальных мазей диоксидиновой и левомеколь, ускоряя заживление застарелых гнойных ран соответственно на 2-3 дня.

Литература. 1. Фисенков, Н.Н. Сравнительная оценка диоксидиновых мазей / Н.Н. Фисенков // Международный вестник ветеринарии №3 2013 С. 35-37. 2. Ветеринарная фармация. учебник: / Н.Л. Андреева, Г.А. Ноздрин, А.М. Лунегов [и др.]// СПб.: Лань, 2020 г. - 452 с.

\title{
TREATMENT OF CHRONIC PURULENT WOUNDS
}

Lunegov A.M. head Department of Pharmacology and Toxicology, Associate Professor, Ph.D., Baryshev V.A., Associate Professor, Ph.D.

(FSBEI HE SPbGUVM, Russia)

Summary. In veterinary medicine, there is a constant search for new antiseptic and wound-healing medicines intended for the treatment of wounds of various etiologies. According to the latest scientific literature, the use of combination drugs is preferable for the treatment of wounds. We conducted an experiment on the healing of chronic purulent wounds in dogs, where the best efficiency was shown by a new ointment consisting of components with antimicrobial activity, antiinflammatory and regenerating effect, anesthetic properties and deep penetrating ability of an ointment base, in comparison with $5 \%$ dioxidine ointment and levomecol.

Keywords: Ointment, wounds, dogs, wound healing agents.

УДК: 636.034

\section{СПОСОБ ПОВЫШЕНИЯ ЕСТЕСТВЕННОЙ РЕЗИСТЕНТНОСТИ ОРГАНИЗМА СУХОСТОЙНЫХ КОРОВ}

Лунегова И.В., доц., к.вет.н

(ФГБОУ ВО СПХФУ Минздрава России, Россия)

\begin{abstract}
Аннотация. В статье изложены исследования по применению кормовой смеси «Энерджи» для профилактики нарушения обмена веществ, повышения резистентности организма животных, а также увеличения количества и качества получаемой продукции в сухостйный период у коров. В результате эксперимента нами установлено положительное влияние смеси на воспроизводительную функцию и молочную продуктивность, которая оценивалась в первый месяц после отёла. Так скорость отделения последа до 10 часов в подопытной составила $85 \%$, против контроля $76 \%$. Сервис период в подопытной группе составил 93 дней, против контроля 109 дней. Включение кормовой смеси «Энерджи» в рацион сухостойных положительно сказалось на массе тела телят при рождении и составило 37,1 кг, против контроля 36,6 кг, а также на росте и развитии телят в первые два месяца жизни. Сохранность молодняка за весь период эксперимента в двух группах составила $100 \%$. На фоне применения «Энерджи» увеличилась среднесуточная продуктивность коров и составила в первый месяц лактации в первой подопытной группе 29,2 кг, в контрольной группе 27,6 кг.
\end{abstract}

Ключевые слова: Комромовая смесь, сухостойныке коровы, естественная резистентность.

Для получения высоких удоев, коров необходимо обеспечить энергетически плотными, энергетически насыщенными рационами, удовлетворяющие физиологические потребности животного в основных и биологически активных веществах. Основными источниками энергии в рационах являются концентрированные (зернозлаковые и зернобобовые культуры, отходы маслоэкстракционной промышленности, свеклосахарного производства). Являясь основными источниками энергии, концентрированные корма, при длительном скармливании приводят к развитию метаболического ацидоза рубца, за счет большого образования летучих жирных кислот и как следствие снижения рН рубца до 5,5 5,2. Нивелировать негативное воздействие концентратов, возможно только за счет снижения их доли в рационе, но, к сожалению, в погоне за высокими удоями, сделать этого практически 
невозможно. В последние годы все чаще перед животноводами встает вопрос, за счет каких кормов или добавок, можно нивелировать негативное воздействие концентратов на микрофлору рубца, тем самым продлить продуктивное долголетие коровы $[2,3,4]$.

Фундаментом будущей высокой продуктивности является вторая половина сухостойного периода (3 недели до предполагаемого отёла). В этот период доля концентрированных кормов составляет до 4 - 4,5 кг на голову в сутки. Организм сухостойных коров в данный период испытывает колоссальные нагрузки и требует дополнительное количество энергии [5].

Перед нами была поставлена задача по разработке кормовой смеси с широким спектром биологического действия для профилактики нарушения обмена веществ, повышения резистентности организма животных, а также увеличения количества и качество получаемой продукции.

Совместно с ООО «ПТК «ПитерБио» (г. Санкт-Петербург) разрабатывается и запускается в производство кормовая смесь «Энерджи» (Патент RU 2493725). В качестве основного действующего вещества нами была взята янтарная кислота, для усиления её действия добавлена лимонная. В качестве дополнительного источника энергии и глюкозы в организме коров, были включены полисахариды, которые принимают непосредственное участие в промежуточном обмене в качестве глюкопластического материала, в синтезе энергии в цикле Кребса, увеличивают концентрацию глюкозы в крови. Для развития полезной микрофлоры и дополнительного источника витаминов группы В, в состав кормового комплекса введены дрожжи (Saccharomyces cerevisiae). Для усиления гепатопротекторной активности в состав кормовой смеси включен метионин.

Для оценки эффективности применения «Энерджи» в рационах сухостойных коров, нами в промышленных условиях Республики Башкортостан были сформированы две группы сухостойных коров, за 3 недели до отёла, черно-пестрой породы, по 10 голов в каждой. Условия содержания и кормления были одинаковы для всех групп.

Коровам первой подопытной группы дополнительно включали кормовую смесь «Энерджи» в количестве 250 мг/кг массы тела. Кормовую смесь «Энерджи» задавали в смеси с концентратами. Вторая подопытная группа служила контролем и получала стандартный рацион, принятый в хозяйстве.

В результате эксперимента нами установлено положительное влияние смеси на воспроизводительную функцию и молочную продуктивность, которая оценивалась в первый месяц после отёла.

Так скорость отделения последа до 10 часов в подопытной составила 85\%, против контроля 76\%. Сервис период в подопытной группе составил 93 дней, против контроля 109 дней.

Включение кормовой смеси «Энерджи» в рацион сухостойных положительно сказалось на массе тела телят при рождении и составило 37,1 кг, против контроля 36,6 кг, а также на росте и развитии телят в первые два месяца жизни. Наши данные согласуются с рядом других исследователей (Евглевский, 2013, 2018), которые изучали влияние янтарной кислоты и её солей на организм глубокостельных коров. Сохранность молодняка за весь период эксперимента в двух группах составила 100\%. На фоне применения «Энерджи» увеличилась среднесуточная продуктивность коров и составила в первый месяц лактации в первой подопытной группе 29,2 кг, в контрольной группе 27,6 кг.

Литература. 1. Евглевский, А.А. Биологическая роль и метаболическая активность янтарной кислоты/ А.А. Евглевский, Г.Ф. Рыжкова, Е.П. Евглевская, Н.В. Ванина, И.И. Михайлова, А.В. Денисова, Н.Ф. Ерыженская //Вестник Курской государственной сельскохозяйственной академии. 2013. №9. - С.67-69. 2. Евглевский, А.А. Метаболический кетоацидоз высокопродуктивных лактирующих коров: причины, последствия и перспективные подходы решения/ А.А. Евглевский, О.М. Швец, Е.П. Евглевская, Н.Ф. Ерыженская, Т.А. Сулейманова, Н.В. Гапеев, Ю.А. Переверзева// Вестник Курской государственной сельскохозяйственной академии. 2018. №2. - С.27-30. 3. Лунегова, И.В. Улучшение воспроизводительных качеств и нормализация обменных процессов в организме новотельных коров /И.В. 
Лунегова//Материалы II Международного ветеринарного конгресса VETinstanbul Group-2015. Санкт-Петербург. СПбГАВМ.2015. - С.276. 4. Лунегова, И.В. Перспективы использования кормовой смеси на основе янтарной кислоты/ И.В. Лунегова, А.Ф. Кузнецов// Вопросы нормативно-правового регулирования в ветеринарии. 2015. №2. - С.415-418. 5. Лунегова, И.В Оптимизация рубцового пищеварения коров/И.В. Лунегова, А.А. Святковский//Эффективное животноводство.2015. № 11 (120). - С.38-39.

\section{METHOD FOR INCREASING THE NATURAL RESISTANCE OF THE ORGANISM OF DRY COWS}

Lunegova I.V., Associate Professor, Ph.D.

(FSBEI HE SPCPU, Russia)

Summary. The article describes the research on the use of the feed mixture "Energy" for the prevention of metabolic disorders, increasing the resistance of the organism of animals, as well as increasing the quantity and quality of the products obtained during the dry period in cows. As a result of the experiment, we established a positive effect of the mixture on reproductive function and milk productivity, which was assessed in the first month after calving. So the rate of separation of the placenta up to 10 hours in the experimental was $85 \%$, versus $76 \%$ in the control. The service period in the test group was 93 days, versus 109 days in the control group. The inclusion of the feed mixture "Energy" in the diet of dry beetles had a positive effect on the body weight of calves at birth and amounted to $37.1 \mathrm{~kg}$, versus the control $36.6 \mathrm{~kg}$, as well as on the growth and development of calves in the first two months of life. The safety of young animals for the entire period of the experiment in two groups was $100 \%$. On the background of the use of "Energy", the average daily productivity of cows increased and in the first month of lactation in the first experimental group was $29.2 \mathrm{~kg}$, in the control group - $27.6 \mathrm{~kg}$.

Key words: Lumpy mixture, dry cows, natural resistance.

\section{СРАВНИТЕЛЬНЫЙ АНАЛИЗ ГИДРОХИМИЧЕСКИХ ПОКАЗАТЕЛЕЙ ВОД ФИНСКОГО ЗАЛИВА В РАЙОНЕ ГОРОДА САНКТ-ПЕТЕРБУРГ}

Луцко Т.П., доц., к.Х.н., Полянских А.Г., студ., Кузьмина Е.С., студ., Волобуев И.Д., студ. (ФГБОУ ВО СПбГУВМ, Россия)

Аннотация. Сейчас Финский заливактивно используются для бытовых нужд населения Санкт-Петербурга. Поэтому был сделан гидрохимический анализ вод Финского залива в различных районах города и определены концентрации нитратов, нитритов, ионов меди, железа, кремния, аммония, а также карбонатная жесткость и водородный показатель. В результате исследования установлено, что все изученные показатели, кроме ионов железа, не превышают ПДК.

Ключевые слова: гидрохимические показатели, природная вода, Финский залив

Финский залив играет большую роль в бытовой, культурной и рекреационной сферах в жизни населения Санкт-Петербурга. Это место отдыха жителей города, добычи водных биологических ресурсов. Это водная артерия для сообщения Санкт-Петербурга с другими городами и странами. Поэтому вопрос о безопасности использования природных вод в рекреационных и бытовых целях стоит достаточно остро.

Цель данной работы заключалась в определении гидрохимических показателей вод Финского залива в разных районах Санкт-Петербурга. Для анализа отбирали пробы природной воды в марте 2021 года: в Приморском районе - в парке 300-летия СанктПетербурга, в Василеостровском районе - недалеко от станции метро «Приморская», в Кировском районе - на Жемчужном пляже. В каждом из вышеперечисленных районов отбирали по две пробы воды в разных точках прибрежной зоны Финского залива.В образцах 
воды исследовались следующие гидрохимические показатели: водородный показатель, содержание нитратов, нитритов, ионов меди, железа, кремния, аммония, а также карбонатная жесткость. Водородный показатель измеряли иономером И-510, концентрацию катионов и анионов определяли с помощью JBL-тестов.

В результате проведенных исследований было установлено, что водородный показатель всех проб находился в пределах 7,02-7,29. Содержание нитритов во всех пробах составило 0,1 мг/л. Содержание нитратов в Приморском и Василеостровском районах - 4 мг/л, а в Кировском районе - 7 мг/л. Ионов меди в пробах не обнаружено. Содержание ионов железа во всех пробах составило 1,5 мг/л. Содержание кремния в Кировском районе - 3 мг/л, а в Приморском и Василеостровском - 0,8 мг/л. Содержание ионов аммония было незначительно и составило 0,025 мг/л. Карбонатная жесткость равна 1 \%Ж. Следовательно, воды Финского залива можно отнести к группе мягких вод.

Сравнив результаты анализов воды с требованиями ГН 2.1.5.1315-03 «Предельно допустимые концентрации (ПДК) химических веществ в воде водных объектов хозяйственнопитьевого и культурно-бытового водопользования»[1], мы выяснили, что все гидрохимические показатели не превышают ПДК, кроме ионов железа: при ПДК ионов железа 0,3 мг/л их концентрация в исследуемых пробах составила 1,5 мг/л. Это может быть связано с нахождением в воде рядом с местом отбора проб остатков металлических конструкций. Ионы железо относится к умеренно опасному классу веществ. Этот показатель ставит под сомнение безопасность использования изученных вод в хозяйственно-питьевых и культурно-бытовых целях [2].

Литература. 1. ГН 2.1.5.1315-03 «Предельно допустимые концентрации (ПДК) химических веществ в воде водных объектов хозяйственно-питьевого и культурно-бытового водопользования» [Электронный ресурс]. - Режим доступа: URL.: https://docs.cntd.ru/document/901862249 (дата обращения 13.04.2021).

2. Красков Д.А., Луцко Т.П. Сравнение гидрохимического состава вод Финского залива в районе города Ломоносов в весенне-летний и осенне-зимний период [Текст] / Д.А. Красков, Т.П. Луцко // Неделя науки СПбПУ: материалы научн. конф. с междунар. участием, 18-23 сентября 2019 г. Институт био- мед. систем и биотехн. В 2 ч. / ПОЛИТЕХ-ПРЕСС. - СанктПетербург, 2019. - Ч. 1. - С. 35-37.

\section{COMPARATIVE ANALYSIS OF THE HYDROCHEMICAL INDICATORS OF THE WATERS OF THE FINSKIY BAY IN THE AREA OF ST. PETERSBURG}

Lutsko T.P., associate professor, Ph.D., Polyanskikh A.G., student, Kuzmina E.S., student, Volobuev I.D., student

(FSBEI HE St.Peterburg SUVM, Russia)

Summary.Now the Finskiy bay is actively used for the everyday needs of the population of St. Petersburg. Therefore, in various districts of the city, a hydrochemical analysis of the waters of the Finskiy bay was carried out and the concentrations of nitrates, nitrites, ions of copper, iron, silicon, ammonium, as well as carbonate hardness and $\mathrm{pH}$ were determined. As a result of the study, it was found that all studied parameters, except for iron ions, do not exceed the MPC.

Key words:hydrochemical indicators, natural water, Finskiy bay

УДК: 549.623.59:544.723.2:504.45

DOI:10.52419/3006-2021-2-151-151

\section{ОСОБЕННОСТИ КОНЦЕНТРИРОВАНИЯ НЕКОТОРЫХ ТЯЖЕЛЫХ МЕТАЛЛОВ СОРБЕНТАМИ НА ОСНОВЕ ВЕРМИКУЛИТА ИЗ ОБЪЕКТОВ ГИДРОСФЕРЫ}

Луцко Т.П. доц., к.х.н., зав.каф., Осипова А.В. доц., к.х.н., Скворцов Д.А.

(ФГБОУ ВО СПбГУВМ, Россия)

Аннотация. Проблема качества воды занимает определяющее место в системе охраны природы и здоровья населения. Вследствие антропогенной деятельности одними из наиболее 
распространенных загрязнителей природных вод являются тяжелые металлы. Природный минерал вермикулит зарекомендовал себя как эффективный поглотитель микроколичеств тяжелых металлов.

Ключевые слова: вермикулит, тяжелые металлы, гидросфера.

В системе охраны природы и здоровья населения проблема качества воды занимает определяющее место.Главным образом, это обусловлено многочисленными фактами интенсивного загрязнения природных водоемов и источников водозабора производственными стоками, содержащими опасные для здоровья людей соединения. Решением Европейской экономической комиссии ООН в группу наиболее опасных, а, следовательно, приоритетных для наблюдения, контроля и регулирования, тяжелых металлов, относят: ртуть, свинец, кадмий, хром, марганец, никель, кобальт, ванадий, медь, железо, цинк, сурьму, а также типичные металлоиды мышьяк и селен. Большинство этих металлов входят в состав простетических групп ферментов и некоторых белков. Потребность организмов в таких элементах очень мала, а поступление из внешней среды избыточных количеств приводит к разного рода токсическим эффектам. Особенно опасными оказываются ксенобиотики: ртуть, кадмий, свинец [1].

В настоящее время глобальные биогеохимические циклы тяжелых металлов значительно искажены антропогенной деятельностью. Многие тяжелые металлы добываются в количествах, сопоставимых с участвующими в природных круговоротах, или даже превосходящие их. Использование извлеченных из земных недр металлов, как правило, ведет к рассеиванию в окружающей среде за счет истирания, коррозии, улетучивания. Прогрессивное накопление в биосфере создает фатальную угрозу для живых организмов. В ходе эволюции были выработаны механизмы предотвращения токсического эффекта тяжелых металлов, однако в современных условиях они уже не могут достаточно надежно защищать живые организмы.

Одним из наиболее распространенных загрязнителей природных вод является железо, поэтому фактор присутствия ионов железа в воде играет решающую роль при оценке ее качества. Согласно нормативам СанПиН, предельная концентрация (ПДК) железа (общ.) составляет $0,30 \mathrm{мг/л.}$

В природных водах чаще отмечается присутствие Fe(III). В подземных водах и резервуарах при отсутствии карбонатов и сульфидов часто происходит накопление $\mathrm{Fe}$ (II) до концентраций порядка 1 мг/л и более. Тем не менее, даже при соблюдении содержания железа в воде в границах установленных характеристик $\mathrm{pH}$, соли $\mathrm{Fe}(\mathrm{II})$ окисляются до соединений $\mathrm{Fe}$ (III).

И органические загрязнители, и тяжелые металлы не извлекаются до значений ПДК из сточной воды традиционными методами очистки. Поэтому на последней стадии процесса пробоподготовки воды проводится ее адсорбционная доочистка, с помощью которой происходит удаление разнообразных загрязнений до минимальных остаточных значений. Весьма перспективно, и что немаловажно, экологично, применение природных минеральных сорбентов, например, силикатов, которые в своем составе содержат материалы с регулярной структурой (опоки, вермикулиты, гидрослюды). Такие вещества термохимически переводят в активную форму с большей пористой структурой. Для увеличения сорбционной емкости слоистых сорбентов можно использовать минеральные кислоты. Такое модифицирование трансформирует структуру и изменяет пористую поверхность.

Природный минерал вермикулит зарекомендовал себя как эффективный поглотитель микроколичеств тяжелых металлов; он нашел широкое применение в сорбции органических веществ, а также весьма результативен в очистке нефтепродуктов. Вермикулит - продукт вторичного изменения темных слюд (биотита и флогопита), который принадлежит к группе гидрослюдных минералов и имеет слоистую структуру с молекулярной межслоевой водой. В химический состав минерала входят также магний, железо, алюминий, кремний. При нагревании до $900-1000{ }^{\circ} \mathrm{C}$ вермикулит вспучивается с увеличением удельной поверхности. $\mathrm{C}$ позиции экологичности важны такие свойства вспученного вермикулита, как химическая 
инертность, термостойкость, прочность, безвредность, высокая адсорбционная емкость, способность к ионному обмену. Именно благодаря этим свойствам вермикулит служит неорганической матрицей для создания сорбента [2].

Была изучена сорбция железа (III), меди (II) с помощью сорбента вермикулит(Ковдорское месторождение, Карелия). Процесс сорбции осуществлялся как в статическом, так и динамическом режимах. Установлено, что степень извлечения вермикулитом находится в интервале 73,6 \% (железо) - 48,8 \% (медь).

В результате проделанной работы установлено, что вермикулит может быть использован в качестве эффективного и экологичного сорбента таких металлов, как, например, железо, медь.

Литература. 1. Исидоров, В.А. Экологическая химия. - СПб.:Химиздат, 2001. - 304 с. 2. Луцко, Т.П. Биохимическая оценка некоторых показателей сорбции тяжелых металлов минералом вермикулит / Т.П. Луцко, А.В. Осипова // Вопросы нормативно-правового регулирования в ветеринарии, 2019. - №4. - С. $136-137$.

\section{FEATURES OF CONCENTRATION OF SOME HEAVY METALS BY SORBENTS} BASED ON VERMICULITE IN HYDROSPHERE OBJECTS

Lutsko T.P. associate professor, Ph. D., Head of the Department, Osipova A.V. ass.,Ph. D., Skvortsov D.A.

(FSBEI HE St.Peterburg SUVM, Russia)

Summary. The problem of water quality occupies a crucial place in the system of nature protection and public health. Due to anthropogenic activities, heavy metals are one of the most common pollutants of natural waters. The natural mineral vermiculite has proven to be an effective absorber of trace amounts of heavy metals.

Key words: vermiculite, heavy metals, hydrosphere.

\section{ТОКСИКО-ЭКОЛОГИЧЕСКИЙ АНАЛИЗ ВОДЫ В ФИНСКОМ ЗАЛИВЕ}

Красков Д.А., Луцко Т.П. (ФГБОУ ВО СПБГУВМ, Россия)

Аннотация: Финский залив играет важную роль во многих аспектах деятельности людей, проживающих в Санкт-Петербурге и Ленинградской области, исходя из этого нужно контролировать химический состав вод Финского залива, чтобы избежать нежелательных осложнений со стороны здоровья животных.

Ключевые слова:Финский залив, катионы, анионы, интоксикация, гигиенические нормы.

Введение: Финский залив играет важную роль в хозяйственной, культурной и бытовой деятельность людей, проживающих в Санкт-Петербурге и Ленинградской области. Именно поэтому следует, проверять химический состав вод залива, чтобы избежать каких-либо нежелательных последствий, например, отравление и интоксикация рыб, пресмыкающихся, земноводных и млекопитающих [1,2]. Например, животные могут отравиться нитратами и нитритами при случайном поедании азотных удобрений, а также при употреблении ими воды из природных водоемов, в которые удобрения с грунтовыми водами попадают при избыточном их внесении в почву. Вследствие этого у животных начинается гипоксия (из-за перехода нормального гемоглобина в метгемоглобин), воспаление слизистых оболочек ЖКТ, нарушение осмотического давления. Отравление катионами аммония у рыб проявляется поражением ЦНС (судороги, нарушения координации), дыхательной системы, и также через 3-5 дней после отравления возникает некроз жабр.

Материалы и методы исследования: Воду из Финского залива в районе города Ломоносов отбирали 3 месяца: октябрь, ноябрь и декабрь 2020 года. Показатели катионов 
аммония, железа, меди, а также показатели анионов нитратов, нитритов, силикатов и фосфатов исследовались с помощью тестов: JBL, VladOx и НИЛПА. Для определения водородного показателя использовали иономер И-510. Концентрацию кислорода определяли с помощью кислородомера «АНИОН 4141».

Результаты исследований:Врезультате исследований природной воды в осеннезимний период было выявлено, что концентрация нитритов, нитратов за 3 месяца не изменялась и составила: 0,$0 ; 5,0 ; 1,5$ мг/л соответственно, и не превышала предельно допустимые нормы. Концентрация кислорода увеличилась с 2 мг/л в октябре до 4,0 мг/л в ноябре и декабре.Это увеличение произошло из-за снижения температуры воды, так как чем меньше температура воды, тем больше растворимость в ней газов. Содержание силикатов в воде увеличилось с октября по декабрь с 1,2 до 3,0 мг/л. Концентрация фосфатов с октября по декабрь уменьшилась с 0,05 до 0,02 мг/л. Концентрация катионов аммония и катионов меди в течение трёх месяцев не изменялась и составила соответственно 0,05 и 0,1 мг/л. Концентрация катионов железа увеличилась с октября по декабрь с 0,02 мг/л до 0,25 мг/л. Значение водородного показателя рН было в пределах нормы и составило 6,4 -6,8.

Заключение: Таким образом, в результате исследований природной воды в районе города Ломоносов было установлено, что содержаниеисследуемых катионов меди, железа, аммония, а также показатели анионов - нитратов, нитритов, силикатов и фосфатов не превышали предельно допустимых концентраций, предусмотренных гигиеническими нормами ГН 2.1.5.1315-03 для водных объектов хозяйственно-питьевого и культурнобытового водопользования, а значит эту воду можно использовать для питья и хозяйственных работ.

Литература: 1. Каурова 3.Г., «Нормирование загрязнения окружающей среды в Российской Федерации на современном этап»// Вопросы нормативно-правового регулирования в ветеринарии.- 2015.-N1.- С. 15-18. 2. Луцко Т.П., Харитонова Э.В, «Экологические аспекты при изучении химии»// Актуальные проблемы ветеринарной медицины: сб. науч. тр./ СПБГАВМ.-СПБ., 2011.- N142.- С. 49-52.

\section{TOXIC-ECOLOGICAL ANALYSIS OF WATER IN THE GULF OF FINNISH}

Kraskov D.A., Lutsko T.P.

(FSBEI HE St.Peterburg SUVM, Russia)

Summary: The Gulf of Finland plays an important role in many aspects of the activities of people living in St. Petersburg and the Leningrad region, based on this, it is necessary to control the chemical composition of the waters of the Gulf of Finland in order to avoid unwanted complications from animal health.

Key words: Gulf of Finland, cations, anions, intoxication, hygiene standards.

УДК 619:614.31:637.5

\section{ТОКСИКО-БИОЛОГИЧЕСКАЯ ОЦЕНКА КОРМОВОЙ ДОБАВКИ НА ОСНОВЕ ВТОРИЧНОГО СЫРЬЯ ПЕРЕРАБОТКИ ВИНОГРАДА}

Майорова Т.Л., доц., к.в.н. (ФГБОУ ВО ДагГАУ, Россия)

Аннотация. В статье приведены данные по изучению токсико-биологической безопасности кормовой добавки. Результаты исследований показали отсутствие негативного действия водных экстрактов на живые клетки Paramecium caudatum, отрицательную кожную реакцию у кроликов, подтверждающую отсутствие дермато-токсичности кормовой добавки.

Ключевые слова: кормовая добавка, известняк-ракушечник, виноградные выжимки.

Одним из надежных резервов пополнения источников кормопроизводства является использование вторичного сырья переработки винограда[1]. Ежегодно в стране производится 
тысячи тонн вторичного сырья переработки винограда, в том числе виноградные выжимки. За последние годы в результате улучшения использования винограда как сырья для производства сока, вина и продуктов его переработки увеличился выход кормовой муки в 1,5 раза [2].

Примеры эффективного использования вторичного сырья переработки винограда имеются и в других странах. В Европе (страны Балканского полуострова) для замены подсолнечного шрота и обрезков сахарной свеклы используют виноградную выжимку с содержанием сухих веществ 65\%. Это эффективное вяжущее средство при включении его в состав гранулированного корма для бройлеров снижает дробление гранул на 30-50\%, увеличивает поедаемость их птицей, способствует суточным привесам[3]. Во Франции отходы винодельческой промышленности сохраняют силосованием и консервированием минеральными или органическими кислотами[4]. В Италии на корм жвачных животных используют обрезанные побеги виноградной лозы. В США (Калифорния) выжимки после экстрагирования высушивают и после отделения семян направляют на птицефабрики, где используют в качестве добавки при приготовлении корма[5].

В Республике Дагестан ежегодно накапливаются тонны фруктовых, овощных и виноградных выжимок. Они характеризуются определенной питательной ценностью и наличием биологически активных веществ[6]. В виноградных выжимках содержатся 11,6\% сырого протеина, 13,4\% сырого жира, 20\% сырой клетчатки, 6\% золы. 49\% БЭВ- 1 кг выжимок приравнивается к 0,3 к. е. и 29 г переваримого протеина. Помимо того, в виноградных выжимках содержатся 2-3\% флаваноидных веществ[7].

О положительном действии скармливания отходов переработки винограда птице, мелкому и крупному рогатому скоту известно из практики и отдельных источников литературы (Mamos L. 1978; Pirija O. et al 1978; Romagosa V. J. 1979: Cottyn B. et al., 1979; Стоянов В. 1982; Магомедов И. М., 1982) [8]. Проведены также исследования по изучению переваримости виноградных выжимок и поедаемости их разными видами животных (Reyne G , CaramBois X , 1977; Dumont R, Tiesserand J. 1978; Lazor M. et al., 1982. Аболиньш Я, 1978). При этом отмечают, что большое содержание фенольных соединений в отходах снижает их усвоение (Famujawa O., Ough C., 1982) [9].

Цель нашей работы заключалась в проведении токсико-биологической оценки кормовой добавки на основе виноградных выжимок и минерала «известняк ракушечник»

Материалы и методы. Объект исследований - кормовая добавка для птицы, содержащая муку из виноградных выжимок и минеральную добавку «известняк-ракушечник» [10]. Токсико-биологическое исследование кормовой добавки проводили на материальнотехнической базе Прикаспийского зонального НИВИ и в лаборатории микробиологии ДагГАУ.

В реакциях на простейших организмах в качестве модельного объекта при испытании кормовой добавки, как фактора риска для животных и птицы, использовали простейших животных Paramecium caudatum (тип Protozoa, класс Ciliata). Токсикобиологическое исследование проводили на кроликах в ветеринарной клинике ДагГАУ. Испытуемые компоненты были проверены на токсичность методом аппликации на кожу кролика (ГОСТ 13496.7-71). Острую токсичность кормовой добавки на животных изучали по методике, утвержденной ГУВ МСХ СССР 28.12.79 г.

Результаты исследования. Кормовая добавка для сельскохозяйственной птицы, содержащая муку из виноградных выжимок(3\%) и минерал «известняк-ракушечник»(1\%).

В качестве модельного объекта при испытании кормовой добавки, как фактора риска для животных и птиц, использовали простейших животных Paramecium caudatum (тип Protozoa, класс Ciliata).

Критерием для определения чувствительности одноклеточных служило время от начала воздействия испытуемого экстракта до гибели инфузорий (прекращение движения и распад) (П.Капуццинели,1982).Результаты исследований показали отсутствие какого-либо негативного действия водных экстрактов, из кормовой добавки, на живые клетки. При этом, не было зафиксировано прекращения движения или изменения характерных особенностей 
перемещения парамеций (нарушение метахромного ритма и спиральной траектории, реакция избегания на высокие концентрации в среде различных химических веществ, отсутствовали признаки начала распада клетки. Биоиндикация подтвердила отсутствие общей токсичности у кормовой добавки, обусловленной наличием водорастворимых, ядовитых элементов.

Высокую чувствительность кожи кроликов к некоторым токсическим веществам использовали для испытания кормовой добавки, поэтому испытуемая кормовая добавка была проверена на токсичность методом аппликации на кожу кролика (ГОСТ 13496. 7- 71). Следовательно, отрицательная кожная реакция у кроликов, при взаимодействие с природными минералами, подтверждает отсутствие дермато-токсичности у испытуемых препаратов (Ю.А. Ершов, 1989, А.М.Шариф, А.Ф. Кузнецов, Н.В. Мухина, 1991, Р.М. Хоменко, А.Ф.Кузнецов, 2003).

Из результатов опытов по определению безвредности и эффективности природных минералов на лабораторных животных следует, что природные минералы месторождений Дагестана не обладают токсическими свойствами, не оказывают отрицательного влияния на организм животных и птицы.

Выводы. Результаты исследований природных минералов показали: отсутствие негативного действия водных экстрактов на живые клетки Paramecium caudatum. Отрицательная кожная реакция у кроликов подтверждает отсутствие дермато-токсичности; исследованные природные минералы являлись экологически чистыми по отношению к радиоактивности.

Литература.1.Бареева Н.Н., Донченко Л.В. Виноградные выжимки - перспективный промышленный источник пектиновых веществ. Политематический сетевой электронный научный журнал Кубанского государственного аграрного университета. 2006. № 20. - С. 6-16; 2.Понамарев, В. С. Влияние препарата "Гепатон" в сочетании с фитосорбционным комплексом на уровень эндогенной интоксикации / В. С. Понамарев, О. С. Попова // Вопросы нормативно-правового регулирования в ветеринарии. - 2020. - № 3. - С. 124-125. - DOI 10.17238/issn2072-6023.2020.3.124.;3.Бодякова А.В., Христюк В.Т., Черненко Е.И. О путях совершенствования технологии комплексной переработки вторичных ресурсов виноделия //Индустрия напитков, 2012, № 3. -С.14-15;4.Долгов Е.П., Кузьминова Е.В., Тяпкина Е. В. Определение острой токсичности кормовой добавки из вторичных растительных ресурсов // Сборник научных трудов СКНИИЖ. 2018. №1. URL: https://cyberleninka.ru/article/n/opredelenie-ostroy-toksichnosti-kormovoy-dobavki-iz-vtorichnyhrastitelnyh-resursov (дата обращения: 12.03.2021); 5.Есжанова Г.Т., Рахимжанова Д.Т., Утешова К.А., Серікқанқызы Г. Оценка биологической и фармакологической активности CALLIGONUM LEUCOCLADUM BUNGE Материалы V-го Международного конгресса ветеринарных фармакологов и токсикологов «Эффективные и безопасные лекарственные средства в ветеринарии». - СПб., 2019. - С.65;6.Жолобова И. С., Хусид С.Б., Семененко М.П., Лопатина Ю.А. Получение функциональной кормовой добавки на основе бентонитовых глин и каротинсодержащего сырья // Научный журнал КубГАУ. 2014. №96. URL: https://cyberleninka.ru/article/n/poluchenie-funktsionalnoy-kormovoy-dobavki-na-osnove-

bentonitovyh-glin-i-karotinsoderzhaschego-syrya-1 (дата обращения: 12.03.2021);7.Касьянов Г.И., Тагирова П.Р.Эффективность использования вторичных ресурсов переработки винограда/ Современные достижения в исследовании натуральных пищевых добавок: Сборник материалов международной научно-технической Интернет - конференции, 17-18 октября 2014 г.- Краснодар: Изд. КубГТУ, 2014.- С.9.;8.Тагирова П.Р., Касьянов Д.Г. Переработка виноградных выжимок и виноградных семян с использованием жидкого диоксида углерода //Известия вузов. Пищевая технология, 2010, № 2-3. С. 60-62;9.Хусид С. Б., Донсков Я. П. Получение функциональной кормовой добавки на основе рисовой мучки и бентонита // Научный журнал КубГАУ. 2014. №101. URL: https://cyberleninka.ru/article/n/poluchenie-funktsionalnoy-kormovoy-dobavki-na-osnove-risovoymuchki-i-bentonita (дата обращения: 12.03.2021).10. Майорова Т.Л., Джамбулатов 3.М., Мусиев Д.Г. Способ применения кормовой добавки «известняк ракушечник» для 
профилактики микотоксикозов у сельскохозяйственной птицы. Патент №2732154. Заяв.10.06.2019 Опубл.11.09.2020.

TOXIC -BIOLOGICAL EVALUATION OF FORAGE ADDITIVES BASED ON SECONDARY RAW MATERIALS OF GRAPE PROCESSING

Mayorova T.L., associate professor, Ph.D.

(FSBEI HE DagGAU, Russia)

Summary. The article provides data on the study of the toxic and biological safety of the feed additive. The research results showed the absence of a negative effect of aqueous extracts on living cells of Paramecium caudatum, a negative skin reaction in rabbits confirming the absence of dermatotoxicity of the feed additive.

Key words: feed additive, shell limestone, grape pomace.

УДК 619:614.31:637.5

\section{ТОКСИКО-БИОЛОГИЧЕСКАЯ ОЦЕНКА КОРМОВОЙ ДОБАВКИ ИЗ ВИНОГРАДНЫХ ВЫЖИМОК}

Майорова Т.Л., доц., к.в.н.

(ФГБОУ ВО ДагГАУ, Россия)

Аннотация. В статье приведены данные по изучению токсико-биологической безопасности кормовой добавки. Кормовая добавка нетоксична, не оказывает отрицательного влияния на организм животных, а также улучшает показателей неспецифической резистентности у молодняка крупного рогатого скота.

Ключевые слова: гамма-глобулин, сыворотка крови, неспецифическая резистентность, крупный рогатый скот.

Для стабильного обеспечения населения республики продуктами животноводства при разработке аграрной политики необходимо предусмотреть три известных положения: структура кормового поля должна соответствовать потребностям отрасли, поголовье скота кормовым ресурсам, а рационы кормления - потребностям животных по всем жизненно необходимым питательным веществам, особенно незаменимым. Ряд лет в нашей республике нет существенных сдвигов в увеличении продуктивности скота, наоборот с каждым годом идет перманентное ее снижение. Одна из причин-игнорирование значения минеральных добавок и недостаточное их использование в рационах животных. В кормлении крупного рогатого скота отмечается дефицит микро- и макроэлементов. Хронический недостаток их в рационах вызывает глубокие нарушения обмена веществ[1,2], что ведет не только к снижению продуктивности животных и качества получаемой продукции, по и рождению слабого молодняка, подверженного костным и другим заболеваниям. В связи с этим кормовые добавки должны быть постоянными компонентами рационов в соответствии с установленными нормативами и с учетом наличия указанных элементов в местных кормах[3,4]. В кормах выращенных на территории Дагестана отмечается дефицит йода, магния и селена. Имеются многочисленные сведения о влиянии скармливания виноградных выжимок на темпы роста животных[5,6].

Цель нашей работы заключалась в том, чтобы исследовании токсико-биологической безопасности кормовой добавки и выяснить ее влияет на показатели неспецифического иммунитета молодняка крупно рогатого скота.

Материалы и методы. Кормовая добавка для сельскохозяйственных животных, содержала муку из виноградных выжимок и минерал «известняк-ракушечник»[7]. Токсикобиологическое исследование кормовой добавки проводили на материально-технической базе Прикаспийского зонального НИВИ, ветеринарной клинике и в лаборатории кафедры эпизоотологии ДагГАУ. 
Для проведения опыта были взяты беспородные белые мыши и телята 5-месячного возраста средней живой массой 100 кг. Животные в опытных группах получали дополнительно к основному рациону $5 \%$ исследуемой кормовой добавки. Острую токсичность кормовой добавки определяли на беспородных белых мышах, живой массой 2025 г. В сыворотке крови определяли активность лизоцима по Маркову К. М. (1974). бетализина-по Бухарину О. В, Фролову Б. А., Луда А. П. (1972), бактерицидность-по Смирновой О. В., Кузьминой Г. А. (1966, пропердин-по методике Погребняк А.Л. (1975), коплементарную активность по Вагнеру Г. Ф. (1963), количество общего белка определяли рефрактометрически, а белковые фракции-электрофорезом на бумаге.

Результаты исследования. Результаты биологического тестирования исследуемой кормовой добавки проводили на белых мышах. Острую токсичность кормовой добавки определяли на беспородных белых мышах, живой массой 20-25 г. Мыши были разделены на группы. Контрольная группа животных получала основной рацион. Животные опытной группы находились на диете с кормовой добавкой. Навеску кормовой добавки (5\%) добавляли к основной массе корма.

Все мешанки животные съедали в течение дня полностью, не проявляя при этом никаких видимых симптомов отравления, и, своим поведением, внешне не отличались от контрольных животных. За подопытными животными наблюдали в течение десяти дней. Падежа мышей не отмечали. Их убивали непосредственно перед исследованием, помещая в эксикатор, где находился тампон с эфиром, и проводили морфологический контроль патологических изменений. При патологоанатомическом вскрытии патологических изменений не обнаружилось.

Фактически вводимые дозы с учетом приготовленной взвеси препаратов, превосходили естественную емкость желудков у лабораторных животных, или представляли такое количество, которое в естественных условиях не может попасть в организм мышей. Не удавалось установить и максимально переносимую дозу продукта для мышей, что позволяет сделать вывод о том, что испытуемая кормовая добавка нетоксична. Тем более, что рекомендуемые дозы для сельскохозяйственных животных и птиц, по международному научно-исследовательскому и производственному опыту соответствуют 3 - 5\% к рациону.

Биологическое тестирование исследуемой кормовой добавки проводили на телятах 5 месячного возраста. Опыт провели на молочно-товарной ферме, 20 телят 5-месячного возраста средней живой массой 100 кг разделили на две группы по принципу аналогов. Телятам опытной группы ежедневно в течение месяца скармливали дополнительно к основному рациону кормовую добавку, а животные контрольной группы оставались на обычном рационе

До начала опыта и спустя 10-20-30 дней у телят обеих групп брали кровь для определения гематологических показателей и активности фагоцитоза. В сыворотке крови определяли активность лизоцима, бета-лизина, бактерицидность, пропердин, коплементарную активность, количество общего белка и белковые фракции.

Анализ полученных данных показывает, что скармливание кормовой добавки в небольших дозах положительно влияет на организм телят. У подопытных животных установлено повышение количества гемоглобина и эритроцитов, улучшение показателей неспецифической резистентности.

На 10-й день эксперимента бактерицидность крови у подопытных телят превышала контроль на 48,8\% (p<0,05). Имелась тенденция к повышению активности бета-лизина, фагоцитоза, уровня пропердина.

На 20-й день количество пропердина и активность комплемента превзошли контрольный уровень соответственно 17,8\% и $30 \%(\mathrm{p}<0,05)$.

В конце эксперимента подопытные телята не имели достоверных различий с контрольными по активности лизоцима, бета-лизина, комплемента, фагоцитоза, однако, уровень пропердина и бактерицидность у них превышал контроль соответственно на $57 \%$ и $26 \%(\mathrm{p}<0,05)$. 
Анализ белковой картины сыворотки крови показывает, что скармливание кормовой добавки сопровождается повышением общего количества белка и уровня гамма-глобулинов на 30-й день эксперимента эти показатели у подопытных животных были соответственно на $5,1 \%$ и $17,6 \%(\mathrm{p}<0,05)$ выше контрольных

Таким образом включение в рацион телят кормовой добавки в небольших дозах повышает бактерицидкость, количество протромбина, уровень общего белка, гаммаглобулинов в сыворотке крови, а также улучшает гематологические показатели у молодняка крупного рогатого скота.

Выводы. Полученные нами результаты исследований на острую токсичность, дают основание исключить степень риска острого отравления животных. Из результатов опытов по определению безвредности и эффективности кормовой добавки на лабораторных животных следует, что кормовая добавка не обладает токсическими свойствами, не оказывают отрицательного влияния на организм животных . Анализ полученных данных показывает, что скармливание кормовой добавки в небольших дозах положительно влияет на организм телят. Включение в рацион телят кормовой добавки в небольших дозах повышает бактерицидкость, количество протромбина, уровень общего белка, гамма- глобулинов в сыворотке крови, а также улучшает показателей неспецифической резистентности у молодняка крупного рогатого скота.

Литература. 1. Бареева Н.Н., Донченко Л.В. Виноградные выжимки - перспективный промышленный источник пектиновых веществ. Политематический сетевой электронный научный журнал Кубанского государственного аграрного университета. 2006. № 20. - С. 616.;2. Кузнецов, А.Ф. Влияние монклавита-1 на естественную резистентность организма цыплят-бройлеров / А.Ф. Кузнецов, В.М. Канаева // Актуальные проблемы ветеринарной фармакологии, токсикологии и фармации:мат. III съезда фармакологов и токсикологов России. - СПб., 2011. - С. 269 -271;3. Тагирова П.Р. Технологические приемы переработки винограда // Политематический сетевой электронный научный журнал КубГАУ.-2014.-№ 100 (06). -С. 140-153;4. Шкурихина К.И., Кузнецов А.Ф., Майорова Т.Л. "Применение известняка в птицеводстве". Дагестанский ЦНТИ, Махачкала, 2004; 5. Понамарев, В. С. Влияние препарата "Гепатон" в сочетании с фитосорбционным комплексом на уровень эндогенной интоксикации / В. С. Понамарев, О. С. Попова // Вопросы нормативно-правового регулирования в ветеринарии. - 2020. - № 3. - С. 124-125. - DOI 10.17238/issn20726023.2020.3.124.;6. Касьянов Г.И., Тагирова П.Р.Эффективность использования вторичных ресурсов переработки винограда/ Современные достижения в исследовании натуральных пищевых добавок: Сборник материалов международной научно-технической Интернет конференции, 17-18 октября 2014 г.- Краснодар: Изд. КубГТУ, 2014. С.9.;7. Майорова Т.Л., Джамбулатов 3.М., Мусиев Д.Г. Способ применения кормовой добавки «известняк ракушечник» для профилактики микотоксикозов у сельскохозяйственной птицы. Патент №2732154. Заяв.10.06.2019 Опубл.11.09.2020.

\section{TOXIC -BIOLOGICAL EVALUATION OF FODDER ADDITIVE FROM GRAPE PRESS}

Mayorova T.L., associate professor, Ph.D.

(FSBEI HE DagGAU, Russia)

Summary. The article provides data on the study of the toxic and biological safety of the feed additive. The feed additive is non-toxic, does not have a negative effect on the body of animals, and also improves the indices of nonspecific resistance in young cattle.

Key words: gamma globulin, blood serum, nonspecific resistance, cattle. 


\section{АНТИБИОТИКОРЕЗИСТЕНТНОСТЬ И БИОЛОГИЧЕСКИЕ СВОЙСТВА МИКРООРГАНИЗМОВ РANTOEA AGGLOMERANS, ИЗОЛИРОВАННЫХ ОТ СЕЛЬСКОХОЗЯЙСТВЕННЫХ ЖИВОТНЫХ С РЕСПИРАТОРНОЙ ПАТОЛОГИЕЙ \\ Макавчик С.А. доц., к.в.н. ', Сухинин А.А., д.б.н., проф. ' , Смирнова Л.И, доц., к.в.н., Кротова А.Л. ${ }^{2}$, Кузьмин В.А. ${ }^{1}$

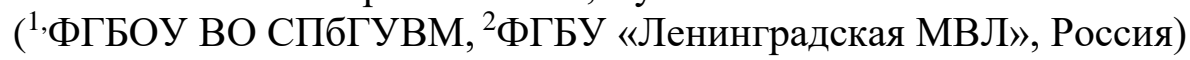

Ключевые слова: Pantoea agglomerans, биологические свойства, патологии респираторного тракта, сельскохозяйственные животные, микробиологические методы, антибиотикорезистентность.

Аннотация. Инфекции животных, вызванные резистентными микроорганизмами, отличаются более тяжелым течением, рецидивами, хронизацией или латенцией (бактерионосительством) инфекционного процесса, что увеличивает продолжительность лечения. Изучены биологические свойства изолятов Pantoea agglomerans, выделенных из клинического материала от сельскохозяйственных животных с хроническими респираторными патологиями и их антибиотикорезистентность.

Введение. В последнее время отмечается устойчивость микроорганизмов к антимикробным препаратам, что создает угрозу для проведения эффективной профилактики и лечения постоянно возрастающего числа инфекций животных. Необходимо рациональное использование антимикробных препаратов (АМП) с учетом спектра их активности и профиля антибиотикорезистентности основных возбудителей $[3,4,5,6,7]$.

Одними из основных факторов, определяющих эффективность антибиотикотерапии выбор АМП с учетом выделенного возбудителя и интерпретация антибиотикограмм. Выбор антибиотика согласно рекомендациям ВОЗ, где АМП поделены на несколько групп. В первую группу вошли антибиотики, которые обладают активностью в отношении широкого спектра распространенных чувствительных к ним бактериальных патогенов и с которыми связана меньшая вероятность формирования резистентности к ним по сравнению с антибиотиками групп наблюдения и резерва [7].

Лабораторный мониторинг резистентности к АМП необходим для: оценки и определения основных причин резистентности; выявления новых механизмов антибиотикорезистентности; сбора данных, необходимых для анализа риска здоровья животных; обоснование рекомендаций по сохранению здоровья животных и человека; сбора информации для оценки назначаемых противомикробных препаратов и выработки рекомендаций по их безопасному использованию; оценки и определения результативности действий, предпринятых для сдерживания резистентности к АМП.

В процессе распространения антибиотикорезистентности играет роль общая совокупность в окружающей среде патогенных, комменсальных и свободно живущих бактерий, бактериофагов и мобильных генетических элементов, которые являются резервуаром резистентности, так называемой «резистомой». Патогенные бактерии могут получать гены устойчивости от комменсальных и свободноживущих.

Род Pantoea входит в семейство Enterobacteriacae. Род Pantoea состоит из двух видов: P. agglomerans (ранее Enterobacter agglomerans, Erwinia herbicola, Erwinia milletiae ) и P. dispersa. Представители P. agglomerans широко распространены в природе как коменсалы, эпифиты, а иногда патогенны, существование которых ассоциировано со многими растениями и теплокровными животными. Бактерии рода Pantoea выделяются с поверхности растений, из почвы и воды, а также из отделяемого ран, абсцессов, крови и дыхательных путей животных $[1,2,3]$.

Важную роль в развитии инфекционного процесса, как у животных, так и у растений, выполняют липополисахариды, которые являются основными компонентами внешней среды 
грамотрицательных бактерий, образованные липидом А и полисахаридным компонентом, каждый из которых определяет биологическую активность. Основу биологических свойств возбудителей оппортунистических инфекций составляют факторы патогенности (адгезины, инвазины, ферменты, токсины и др.), которые сформировались у них для проникновения в клетки и ткани представителей почвенной, водной флоры и фауны, а также способны воздействовать на соответствующие химические мишени в организме теплокровных животных и человека [1,2,3].

Цель исследования: определение биологических свойств и антибиотикорезистентности микроорганизмов Pantoea agglomerans, выделенных при ринитах, бронхитах, бронхопневмониях сельскохозяйственных животных (крупного рогатого скота и лошадей).

Материалы и методы. Первичные посевы смывов из трахеи и мазков из носовой полости от лошадей, коров и телят делали на МПБ и МПА с 1 \% глюкозы и лошадиной сыворотки, инкубировали при $37^{\circ} \mathrm{C}$ в течение 24 часов. Затем производили посев бульонной культуры на питательные среды: колумбийский агар с кровью барана, шоколадный агар, среду Эндо, Гисса, также инкубировали $37^{\circ} \mathrm{C}$ в течение 24 часов.

Подтверждали идентификацию выделенных культур и изучали биохимические свойства с применением тест-систем: Enterotest 24 N («Erba Lachema», Чешская Республика), а также api 20 E («BIOMERIEUX», Франция).

Определяли чувствительность к антибиотикам и диско-диффузионным методом с использованием агара Мюллера-Хинтона согласно рекомендациям Европейского комитета по определению чувствительности к антибиотикам (EUCAST).

Патогенные свойства изучали путём постановки биопробы на белых мышах.

Результаты. Провели исследование 149 проб клинических образцов от сельскохозяйственных животных с респираторными патологиями, изоляты Pantoea agglomerans составили менее 5\% от общего числа выделенных микроорганизмов.

Все микроорганизмы были вирулентны, отличались по культурально-биохимическим свойствам, а также по чувствительности к разным группам антибактериальных препаратов.

Большинство Pantoae agglomerans образовывали желтый нерастворимый в воде пигмент, $\mathrm{H}_{2} \mathrm{~S}$ не образовывали, не синтезировали лизиндекарбоксилазу. Катаболизировали глюкозу и другие сахара с образованием кислоты. Pantoea agglomerans образовывали мукоидные колонии (напоминали капельку воды) (М-форма), при температуре 20-25ㄷ формировалось большее количество полисахаридов, чем при температуре культивирования $37^{\circ} \mathrm{C}$.

В результате изучения патогенных свойств было установлено, что P. agglomerans являлся одним из основных возбудителей инфекции при хроническом течении ринитов, бронхитов и пневмоний. Поэтому наряду с изучением биологических свойств P. agglomerans нами были проведены исследования по определению антибиотикочувствительности данного микроорганизма.

На основании результатов исследований бактерии устойчивы: аминогликозидам (гентамицин), фторхинолонам (ципрофлоксацин, энрофлоксацин), тетрациклинам (доксициклин) и макролидам (эритромицин).

Изоляты P. agglomerans, выделенные из клинического материала от сельскохозяйственных животных, были чувствительны к бензилпенициллину, клиндамицину, цефолексину, цефтриаксону и цефотаксиму. Для лечения важно не использовать препараты из группы резерва, если доступны другие препараты из более низкой категории/класса для лечения инфицированных животных.

Заключение. На ряду с лабораторной диагностикой актуальным для борьбы с инфекциями животных является подбор антибактериальных препаратов и анализ антибиотикограмм, изучение механизмов резистентности к АМП - основа рациональной фармакотериапии животных и выпуска безопасной продукции животноводства. 
Литература. 1.Кисленко, В.Н. Экология патогенных микроорганизмов: Учеб. пособие/ Кисленко В.Н.// Новосибирский государственный аграрный унивеситет.- Новосибирск, 2009.с.294. 2.Надеин, К.А. Фармакологическая коррекция диффузного воспаления соединительной ткани у крупного рогатого скота: автореферат дис. доктора биологических наук: 06.02.03 / Надеин Константин Александрович - 2016 - 39 с. 3.Потатуркина-Нестерова, Н.И. Молекулярно-генетический метод исследования возбудителей рода Enterobacter: учеб.-метод. пособие / Н.И. Потатуркина-Нестерова [и др.]. - Тольятти : Изд-во ТГУ, 2012. - 32 с. : обл. 4. План мероприятий на 2019-2024 годы по реализации Стратегии предупреждения распространения антимикробной резистентности в Российской Федерации на период до 2030 года. Утвержден распоряжением П равительства Российской Федерации от 30 марта 2019 г. № 604-p. https://www.garant.ru/products/ipo/prime/doc/71677266 5. Макавчик, С.А. Механизмы резистентности к антимикробным препаратам у микроорганизмов, выделенных от крупного рогатого скота Макавчик С.А., Кротова А.Л., Баргман Ж.Е., Сухинин А.А., Приходько Е.И. Вопросы нормативно-правового регулирования в ветеринарии.- 2020.- № 4.- С. 41-46. 6.Сухинин, А.А., Этиологическая структура респираторных болезней крупного рогатого скота в Северо-Западном регионе / А.А.Сухинин, С.А. Макавчик, С.В.Герасимов, О.В.Прасолова // Ветеринария - 2015. - № 12. - С. 21-24. 7. The selection and use of essential medicines: report of the WHO Expert Committee on Selection and Use of Essential Medicines, 2019 (including the 21st WHO Model List of Essential Medicines and the 7th WHO Model List of Essential Medicines for Children). Geneva: World Health Organization; 2019. Licence: CC BY-NC-SA 3.0 IGO: https://apps.who.int/iris/bitstream/handle/10665/330668/9789241210300-eng.pdf?ua=1).

\title{
ANTIBIOTIC RESISTANCE AND BIOLOGICAL PROPERTIES OF MICROORGANISMS PANTOEA AGGLOMERANS, ISOLATED FROM
} AGRICULTURAL ANIMALS WITH RESPIRATORY DISEASES

${ }^{1}$ Makavchik S.A., associate professor, Ph.D., ${ }^{1}$ Suchinin A.A., professor, Ph.D.,

${ }^{1}$ Smirnova L.I., associate professor, Ph.D., ${ }^{2}$ Кротова A.Л., ${ }^{1}$ Kuzmin V.A., professor, Ph.D.

$\left({ }^{1}\right.$ FSBEI HE St.Peterburg SUVM ${ }^{2}$ FGBU LIVL, Russia)

Key words: Pantoea agglomerans, biological properties, respiratory tract pathologies, farm animals, microbiological methods, antibiotic resistance.

Summary. Infections of animals caused by resistant strains of microorganisms are characterized by a more severe course, the duration of treatment is often increased and leads to recurrence, chronicity or latency of the infectious process. The biological properties of Pantoea agglomerans isolates isolated from clinical material from farm animals with chronic respiratory pathologies and their antibiotic resistance were studied.

УДК: 556+574 (470)

\section{ВЛИЯНИЕАНТРОПОГЕННОЙ НАГРУЗКИ НА ВОДНЫЕ ОБЪЕКТЫ НЕКОТОРЫХ РЕГИОНОВ ПОВОЛЖЬЯ}

Макаева В.И. м.н.с., Альмитова Л.И. м.н.с., Потехина Р.М. к.б.н., в.н.с., Макаева А.Р. к.б.н, с.н.с (ФГБНУ «ФЦТРБ-ВНИВИ», Россия)

\begin{abstract}
Аннотация. В работе представлены результаты исследований проб воды водных объектов Республик Татарстан, Чувашия, Марий Эл. В исследованных образцах воды наблюдается превышение ПДК по содержанию железа, ионов аммония, сульфатов, фосфатов. Поэтому необходимыэффективная очистка сточных вод, сбрасываемых в водные объекты, и регулярный мониторингкачества воды.
\end{abstract}

Ключевые слова: качество воды, водные объекты, антропогенное воздействие, загрязняющие вещества 
Одной из самых острых проблем современности является сохранение окружающей среды, здоровья людей, животных. Из-за влияния антропогенных факторов наблюдаетсяухудшение экологической ситуации экосистем. Химическое влияние насреду обитания приобретает глобальный характер. Антропогенное воздействие на окружающую среду - прямое и косвенное или неосознанное воздействие деятельности человека, оказывающее влияние на природную среду, безусловно, должно подлежать всевозможному ограничению и нормированию [1].

Пресные поверхностные (реки, озера, болота) и грунтовые воды в наибольшей степени подвержены техногенному воздействию, что является причиной загрязнения водоемов химикатами, уменьшения рыбных запасов, изменения водной фауны и флоры [2]. Попадая в водоемы, токсические вещества нарушают биологическое самоочищение и вызывают гибель организмов [3].

Ухудшение состояния воднойсреды влияет не только на экологическую и экономическую ситуацию, а также наносит урон рыбному хозяйству в виде гибели половозрелых рыб, рыбной молоди, личинок, ухудшения качества рыбы, сокращения мест нагула, нереста, обитания рыб и др., что может сказаться нарыбохозяйственном значении водоема [4]. Поэтому важное значение приобретает оценка качества воды водных объектов.

В связи с вышеизложеннымцельюнастоящих исследований является оценка состояния некоторых водных объектов Республик Татарстан, Чувашия, Марий Эл, расположенных в черте населенных пунктов и промышленных предприятий и подвергающихся антропогенному воздействию.

Материалы и методы: Для исследования качества воды в течение 2020 года были взяты пробы из р. Волга, Меша, Вятка, Свияга, Илеть, Кубня, Карла, Урюм, Каипка иоз. Ср. Кабан. Исследования выполнялись в отделении токсикологии ФГБНУ «ФЦТРБ-ВНИВИ» ионометрическими, фотоколориметрическими, титриметрическими методами по соответствующим ГОСТ и ПНД Ф. Оценку качества воды осуществляли по содержанию ионов аммония, нитритов, нитратов, сульфатов, хлоридов, фторидов, фосфатов, ионов железа, величине жесткости, водородного показателя (pH).

Физико-химические показатели оценивались по нормативам для водных объектов рыбохозяйственного значения, согласно приказу Росрыболовства от 18 января 2010 г.«Об утверждении нормативов качества воды водных объектов рыбохозяйственного значения...»иСанПиН «Гигиенические требования к охране поверхностных вод»[5,6].

Результаты исследований. Было исследовано 32 пробы воды, по которым проведено 320 анализов. По результатам исследований в $56 \%$ пробах содержание ионов аммония превышает нормы $\left(0,5\right.$ мг/дм $\left.{ }^{3}\right)$ в 1,5-13,6 раза. Наибольшее количество ионов аммония обнаружено в воде p. Меша, отобранных вблизи населенных пунктов, в пробах изКуйбышевского водохранилища -вблизи промышленных предприятий. Превышение содержания ионов аммония указывает на загрязнение водоемов, что может вызвать ухудшение кислородного режима и замор рыб. Кроме того, аммиак в избытке ядовит для животных и подавляет развитие большинства водорослей. Выявлено, что азотистые соединения действуют на центральную нервную и дыхательную системы, вызывают токсические изменения в крови, приводя к метгемоглобинемии[7].

В пробах из оз. Ср. Кабан, р. Илеть, р. Карла обнаружено превышение ПДК (100 мг/дм³ $)$ содержания сульфатов в 1,2-10,2 раза, что свидетельствует об интенсивном распаде органических веществ, поступающих в водоемы со сточными водами. В результате у рыб может снизиться устойчивость как к неблагоприятным условиям среды, так и к возбудителям различных заболеваний [7].

Одним из важных санитарно-токсикологических показателей является содержание фосфатов в воде. Они, попадая в реку со сточными водами, служат удобрением для синезеленых водорослей, способствуют активному их размножению, которыев последствии отмирают и разлагаются. Бактерии активно участвуют в этих процессах, поглощая большоеколичество кислорода, создавая его дефицит. В результате у воды появляется 
неприятный цвет и запах, в реках погибает рыба. Для эвтрофных вод фосфаты нормируются в пределах 0,2 мг/дм³ ${ }^{3}$ По результатам исследований в 8 пробах ихпревышениесоставило 1,59,8 раз.

В 94\% проб содержание ионов железа превышает допустимую норму0,1 мг/дм ${ }^{3}$ и составляет от 0,19 (оз. Ср. Кабан) до 17,96 мг/дм³ (вблизи промышленного предприятия). Избыточное содержание железа негативно сказывается на органолептических свойствах воды, при этом меняется цвет, прозрачность, вода приобретает запах сероводорода, и в сочетании с гуминовыми соединениями - болотный привкус; можетвызвать снижение содержания растворенного кислорода, затрудняет дыхание рыб, приводит к накоплению его в органах и тканях.

Пробы воды из р. Меша и р. Вятка по исследованным показателям не превышают установленных норм.

Заключение. В30 исследованных образцах воды наблюдается превышение ПДК следующихэкотоксикантов: железа, ионов аммония, сульфатов, фосфатов.

Так как источников загрязнения водных объектов загрязняющими агентами множество - сточные воды от животноводческих и промышленных предприятий, дождевые и талые воды с прилегающих территорий, сельскохозяйственных угодий и др., состояние водоема для их обитателей остается неблагоприятным.

Загрязнения водных объектовподобного рода наносят значительный вред гидросфере, вызывая дефицит чистой пресной воды, гибель водных обитателей (растений, рыб), заболачивание местностей, приводит к эвтрофикации водоемов. Поэтому так важно проводить эффективную очистку сточных вод, поступающих в водные объекты, повышать эффективность мониторинга состояния окружающей среды.

Литература. 1. Ситаров, В. А. Социальная экология / В. В. Ситаров, В. В. Пустовойтов. - М.: Издательский центр «Академия», 2000. - 280 с.2. Тремасов, М.Я. О проблемах и перспективах ветеринарной токсикологии / М.Я. Тремасов, К.Х. Папуниди, В.И. Степанов // Материалы международной научно-практической конференции «Биотехнология: токсикологическая, радиационная и биологическая безопасность». - Казань, 2010. - С. 153 157.3. Макаева, А.Р. Экологические ирыбохозяйственные последствия загрязнения водных объектов / А.Р. Макаева, Р.М. Асланов, В.И. Макаева, Г.Ф. Ахметзянова // Материлы Всероссийской научно-практической конференции молодых ученых и специалистов: Инновационные решения актуальных проблем в АПК. -Екатеринбург, 2013. - С. 309312.4Матылицкая, Е.Ю. Контроль качества водной среды при выращивании осетровых в установке с замкнутым циклом водооборота / Е.Ю. Матылицкая, Л.К. Говоркова // Материалы XIV Международной молодежной научной конференции: Тинчуринские чтения. -Казань, 2019. - C.371-376.5. Об утверждении нормативов качества воды водных объектов рыбохозяйственного значения, в том числе нормативов предельно допустимых концентраций вредных веществ в водах водных объектов рыбохозяйственного значения, утвержденный приказом Федерального агентства по рыболовству от 18 января 2010 г. № 20.6. СанПиН 2.1.5.980-00 «Водоотведение населенных мест, санитарная охрана водных объектов. Гигиенические требования к охране поверхностных вод», утвержденный Главным государственным санитарным врачом РФ 22.06.2000.7. Тремасов, М.Я. Сезонный мониторинг водных объектов Республики Татарстан / М.Я. Тремасов, Р.М. Асланов, Э.К. Папуниди, А.Р. Макаева, В.А. Конюхова, В.И. Макаева// Ветеринарный врач. - 2014. - №3. - С. 3-8.

\section{INFLUENCE OF ANTHROPOGENIC LOAD ON WATER BODIES IN SOME}

\section{REGIONS OF THE VOLGA REGION}

Makaeva V.I. - junior researcher,Almitova L.I. - junior researcher, Potekhina R.M. leading researcher, candidate of biological sciences,Makaeva A.R. - senior researcher, candidate of biological sciences

(FSBSI “FCTRBS-RRVI”, Russia)

Summary.This paper presents the results of studies of water samples of water bodies from the Republics of Tatarstan, Chuvashia, and Mari El. There is an excess of the MPC for the content 
of iron, ammonium ions, sulfates, and phosphates in the studied water samples. Therefore, effective treatment of wastewater discharged into water bodies and regular monitoring of water quality are necessary.

Key words: water quality, water bodies, anthropogenic influence, pollutants

УДК619:618.19-002619:618.19-002

\section{ЭФФЕКТИВНОСТЬ ПРИМЕНЕНИЕ ПРОТИВОМАСТИТНЫХ ПРЕПАРАТОВ В СОСТАВ, КОТОРЫХ ВХОДИТ ПРЕДНИЗОЛОН}

Макаров А.В ${ }^{1}$. к.б.н, Бригида А.В. ${ }^{2}$ к.в.н,Ханипова В.А. ${ }^{1}$ к.б.н., Землянский Р.Д. ${ }^{1}$

$\left({ }^{1}\right.$ ФГБОУ ВО Красноярский государственный аграрный университет; ${ }^{2}$ ИИБЖ — филиал ФГБНУ ФНЦ ВИЖ им. Л.К. Эрнста, Россия)

Аннотация:Маститы у коров, во всем миреявляются однимиз наиболее распространённых заболеваний. Данное заболеваниенаносит животноводческим хозяйствамзначительные экономическийущерб, которые сводятся не только к недополученниюпроизводимой продукции, но и к значительным затратам, связанными с лечением больных животных. На рынке лекарственных препаратов,предназначенных для лечения мастита, большинство из них в составе имеют не только антимикробныевещества, но и вещества гормонального характера, в частности преднизолон.

Ключевые слова: мастит, преднизолон, антимикробные вещества.

Маститы у коров являются одни из самых распространённых заболеваний во всем мире. По причине данного заболевания, животноводческие хозяйства, занимающиеся разведением крупного рогатого скота молочного направления продуктивности, ежегодно претерпевают значительные экономические потери, связанные с недополученнием продукции и затратами на лечение больного животного. Мастит является следствием интрамаммарного инфицирования возбудителями различных семейств микроорганизмов, реже грибами и микоплазмами. Также воспаление в вымени могут быть вызванытравматизмом или химическимповреждением. При этом,последние вышеуказанные причины, вызывающие возникновение мастита,являются менее распространенными.Как показывает практика, при лечении мастита, наибольшую эффективность демонстрируют препараты для интрацистернального введения.

Производители лекарственных средств, ежегоднопредоставляют на рынок множество различных препаратов в составе которых входят действующие вещества являющиеся антимикробными. Препараты против маститов являются не исключением. На сегодняшний день, большинство препаратов, предлагаемых на рынке содержат не только антимикробные вещества, но и вещества гормонального характера,в частности преднизолон.

В связи с вышесказанным, нами была поставлена цель - изучить эффективность применения препаратов против мастита, в состав которых входит преднизолон.

Материалом исследования служили коровы черно-пестрой породы у которых наблюдали в одной или более долях мастит клинической формы. Для диагностики мастита, применяли комплексный клинический метод оценки: осмотр, пальпацию вымени, оценивание состояния молока, а также постановку пробы отстаивания. В качестве лекарственных средств для лечения мастита использовали препараты в состав которых входит преднизолон «Гамарет» (Биовета, Чехия.), «Мастиет-Форте» (МСД ЭнималХэлс (MSDAnimalHealth), Нидерланды), «Мастиет-Голд» (МСД ЭнималХэлс (MSDAnimalHealth), Нидерланды), «Мультибай» (NorbrookLaboratoriesLimited, Великобритания).

Для изучения эффективности лечения нами были сформированы четыре группы коров.В группе I, входили животные $(\mathrm{n}=40)$, у которых общее число пораженных долей 
вымени составило 86 шт. Лечение животных в группе проводили препаратом «Гамарет» в состав которого входят преднизолон в количестве 10 мг, пенициллин и стрептомицин, а также новобиоцин. В группе II входили животные $(\mathrm{n}=31)$, у которых общее число пораженных долей вымени составило 72 шт. Лечение животных в группе проводили препаратом «Мастиет Форте» в состав которого входят преднизолон в количестве 10 мГ, неомецин,бацитрацин и тетрациклин. В группе III (n= 50), общее число пораженных долей вымени у всех животных составило 95 шт. Лечение животных в группе проводили препаратом «МастиетГолд» в состав которого входят преднизолон в количестве 20 мг и цефопирин. В группе IV (n= 42), у всех животных группы, общее число пораженных долей вымени составило 55 штук соответственно. Лечение животных в группе проводили препаратом «Мультибай» в состав которого входят преднизолон в количестве 10 мг, пенициллин и стрептомицин.

Результаты исследований.

При сравнении схем лечения коров от маститов мы отметили, что в группеI, после проведенного процедуры лечения у животных зафиксирована клиническая форма мастита в трех долях вымени, что составило 95\% эффективности лечения, тогда как рецидивы заболеваниябыли отмечены у 84,21 \% голов после лечения данным препаратом.

В группе ІІэффект был отмечен значительно лучше, и данная группа характеризовалась как наиболее успешная, при том, что из 72 пораженных долей выздоровление наблюдали во всех долях. После окончания лечения через некоторое время наблюдали рецидив заболеваний у 76,67 \% коров. В группе III отсутствие эффективности лечения отмечено в 6 долях вымени, a рецидив наблюдался у 77,78\%, соответственно.При лечении животных группы IVпрепаратом «Мультибай» рецидивы отмечены у 94,44\% тогда как эффект от лечения отсутствовалв 5 долях вымени животных.

На основании вышеизложенного, мы можем предположить, что наличие рецидивов,происходит на фоне угнетения высвобождения медиаторов воспаления в патологическом очаге. При этом стоит отметить, что, у животных наблюдается иммунодепрессивный эффект, который обусловлен инволюцией лимфоидной ткани, угнетением пролиферации лимфоцитов, подавлением миграции В-клеток и взаимодействие их с Т-лимфицитами, что в свою очередь, приводитк снижению образования антител у животного.

На фоне этого можно отметить, что наиболее выраженный противовоспалительный эффект препаратов, который проходит по мере его отмены, т.е. давая кратковременный эффект, проявляется в виде иммунодепрессивного эффекта. Кроме того, отмечается эффект запуска долей вымени животных на фоне примененияк ним препаратов, содержащих преднизолон, при повторном применении его после рецидивов.

Подводя итог, мы можем сделать вывод, что при внезапной отмене препаратов содержащих преднизолон возможно развитие обострения заболевания у животных.

\section{EFFICIENCY OF THE APPLICATION OF ANTI-MASTITIC PREPARATIONS IN THE COMPOSITION WHICH INCLUDES PREDISOLONE}

MakarovA.V1 ${ }^{1}$ Ph.D., BrigidaA.V. ${ }^{2}$ Ph.D.,KhanipovaV.A. ${ }^{1}$ Ph.D., Zemlyansky R.D. ${ }^{1}$

$\left({ }^{1}\right.$ FSBEI HE Krasnoyarsk State Agrarian University; ${ }^{2}$ IIBZh - branch of FGBNU FSC VIZh named after L.K. Ernst, Russia)

Summary: Mastitis in cows is one of the most common diseases in the world and in any dairy farming that causes significant economic losses, which are reduced to a shortage of products and the cost of treating a sick animal. On the market for drugs for the treatment of mastitis, the majority of the composition, which includes, in addition to antimicrobial components, and hormonal drugs, in particular prednisone.

Key words: mastitis, prednisone, antimicrobial substances 


\title{
ОЦЕНКА АНТИБАКТЕРИАЛЬНЫХ СВОЙСТВ НАСТОЙКИ ЧИСТОТЕЛА И ЙОДОПИРОНА
}

\author{
Миллер Т.В., вед. науч. сотр., к.б.н., Дикунина С.С., науч. сотр., \\ Котельникова Е.П., мл. науч. сотр. \\ (ФГБНУ ДальЗНИВИ, Россия)
}

\begin{abstract}
Аннотация. Одним из перспективных и динамично развивающихся направлений современной медицины и фармации является разработка новых эффективных средств растительного или природного происхождения для лечения и профилактики острых и хронических заболеваний, вызванных различными микроорганизмами. Выраженную антибактериальную активность проявила настойка чистотела по всем четырем грамотрицательным микроорганизмам. Рекомендуется наружное применение настойки чистотела при лечении и профилактике кожных заболеваний, в патогенезе которых принимают участие грамотрицательные микроорганизмы Enterobacter cloacae, Proteus mirabilis, Proteus vulgaris и Pseudomonas aeruginosa.
\end{abstract}

Ключевые слова: настойка чистотела, препарат Йодопирон, антибактериальные свойства

Болезни кожных покровов, слизистых оболочек, возникающие при лечении антибиотиками, заставляют пользоваться последними с большой осторожностью. Кроме того, необходимо иметь в виду, что не всякий организм переносит действие антибиотиков и сульфаниламидных препаратов [1].

В этом плане интерес представляют препараты, действующие вещества которых могут служить в качестве альтернативы антибиотикам. Трава чистотела - известное природное средство, помогающее при различных заболеваниях кожи. Лекарственные формы чистотела для наружного применения оказывают антибактериальное действие, так как в своем составе содержит изохинолиновые алкалоиды, которые оказывают противовоспалительные действия и фитонциды (природные антибиотики).

Давно известно, что фитонциды является природными антибиотиками, однако их действие на отдельные группы бактерий недостаточно изучены. Поэтому, изучить антибактериальные свойства чистотела на отдельные виды патогенной микрофлоры, с целью дальнейшего применения как натурального, природного антибиотика на сегодняшний день является актуальным.

Цель исследований: изучить антибактериальные свойства настойки чистотела и препарата Йодопирона на полевых штаммах патогенной микрофлоры (Enterobacter cloacae, Proteus mirabilis, Proteus vulgaris, Pseudomonas aeruginosa).

В качестве альтернативы антибиотикам исследованиям подверглись противовоспалительные препараты для наружного применения: препарат Йодопирон и приготовленная 70\% настойка чистотела.

Чистотел это фитопрепарат с противовоспалительным действием, обеспечивающий широкий спектр фармакологической активности. Сангвиритрин действует бактерицидно на грамположительные и грамотрицательные бактерии. Действующим веществом препарата Йодопирон является йод, который обладает выраженными противомикробными свойствами. Заявленные противовоспалительные препараты рекомендуется применять наружно или местно при инфекционно-воспалительных поражениях кожи.

Исследованию на антимикробную активность подверглись настойка чистотела и препарат Йодопирон, на четырех культурах грамотрицательных микроорганизмов изолированных от больных телят хозяйств Амурской области.

Для оценки антибактериальных свойств настойки чистотела и препарата Йодопирона к Enterobacter cloacae, Proteus mirabilis, Proteus vulgaris, Pseudomonas aeruginosa использовали диско-диффузный метод [2]. Обработанные противовоспалительными растворами диски 
помещали на питательные среды с засеянными бактериальными суспензиями, после аппликации дисков чашки Петри помешали в термостат кверху дном и инкубировали в течение суток при температуре $35^{0} \mathrm{C}$. Диаметр зон задержки роста измеряли с точностью до 1 мм, штангенциркулем.

Антимикробная активность настойки чистотела по отношению к грамотрицательным микроорганизмам показала задержку роста по всем четырем культурам. Более выраженная задержка роста отмечалась у Proteus vulgaris $(15,7 \pm 0,4 \mathrm{Mm})$. В отношении других культур также

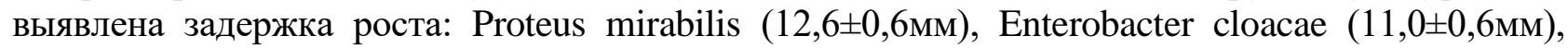
Pseudomonas aeruginosa $(9,7 \pm 0,4 \mathrm{Mm})$. Оценка зон задержки роста микроорганизмов на препарат

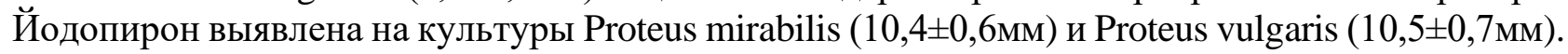

Серия экспериментов наглядно показала возможность наружного применения настойки чистотела в качестве лечения кожных заболеваний, в патогенезе которых принимают участие грамотрицательные микроорганизмы Enterobacter cloacae, Proteus mirabilis, Proteus vulgaris и Pseudomonas aeruginosa. Терапевтические дозы настойки чистотела действуют бактериостатически на Enterobacter, Proteus и Pseudomonas aeruginosa, за счет подавления бактериальных ферментов.

Литература. 1. Лунегов А.М. Фармакологическая характеристика антисептического препарата фураргент // Международный вестник ветеринарии. - 2008. - № 1. - С. 33 -38.

2. Определение чувствительности микроорганизмов к антибактериальным препаратам / Методические указания. МУК 4.2.1890-04 // Клиническая микробиология и антимикробная химиотерапия, 2004. - Том 6.- №4. C. 306-359.

\title{
ANALYSIS OF ANTIBACTERIAL PROPERTIES CHELIDONIUM AND YODOPYRON TINCTURES
}

Miller T.V., leading researcher, candidate of biological sciences, Dikunina S.S., researcher, Kotelnikova E.P., junior researcher (FGBNU DalZNIVI, Russia)

Summary. One of the promising and dynamically developing areas of modern medicine and pharmacy is the development of new effective means of herbal or natural origin for the treatment and prevention of acute and chronic diseases caused by various microorganisms. A pronounced antibacterial activity was shown by celandine tincture for all four gram-negative microorganisms. Recommended external use of celandine tincture in the treatment and prevention of skin diseases, in the pathogenesis of which are involved gram-negative microorganisms Enterobacter cloacae, Proteus mirabilis, Proteus vulgaris and Pseudomonas aeruginosa.

Key words: chelidoniae tincture, Yodopiron preparation, antibacterial properties

\section{ВЛИЯНИЕ ЭНРОФЛОКСАЦИНА НА ДИНАМИКУ БЕЛОЙ КРОВИ ПТИЦ PАННЕГО ВОЗРАСТА}

${ }^{1}$ Моисеева А.А., науч. сотр., ${ }^{1,2}$ Присный А.А., д.б.н., гл. науч. сотр. ${ }^{1}$ Скворцов В.Н., д.в.н., руководитель филиала

( ${ }^{1}$ Белгородский филиал ФГБНУ ФНЦ ВИЭВ РАН, Россия

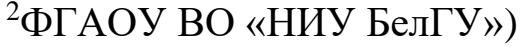

\begin{abstract}
Аннотация. Оценка гематологического профиля птиц служит своеобразным инструментом для мониторинга воздействия на организм различных лекарственных препаратов и выявления их незнакомых эффектов. Используя данные показателей крови, нашей задачей было расширить имеющуюся информацию о влиянии фторхинолонов на организм разных видов птиц, ввиду недостаточной полноты имеющейся информации, особенно касаемо животных раннего возраста.
\end{abstract}

Ключевые слова: птица, фторхинолоны, лейкоцитарная формула. 
Фторхинолоны $(\Phi X)$ - группа химиотерапевтических антибактериальных средств, обладающих высокоэффективным действием против грамположительных и грамотрицательных микроорганизмов [1]. Особую популярность этот класс антимикробных препаратов имеет в птицеводческой отрасли для терапии бактериальных инфекций [2]. Механизм уничтожения патогенов зависит от концентрации препарата, при этом оптимальный эффект возникает в результате введения высоких доз в течение непродолжительного временного периода. Подобное дозозависимое явление связано с относительно длительным постантибиотическим эффектом, что также представляет собой важное преимущество этой группы, относительно других противомикробных средств [3].

Несмотря на спорность мнений, касаемо применения антибактериальных препаратов в птицеводческой отрасли, к сожалению, на данный момент не имеется иных аналогичных по эффективности профилактических и терапевтических методов, направленных на предотвращение заболеваний бактериальной этиологии. Для борьбы с такими болезнями среди птицепоголовья используют энрофлоксацин, представляющий собой антимикробное средство широкого спектра действия, созданное исключительно для ветеринарного использования, преимущественно в птицеводческой отрасли $[4,5]$.

Несмотря на хорошо изученные противомикробные свойства энрофлоксацина, а также обусловленную этим популярность применения препарата в ветеринарии, некоторые аспекты его воздействия на организм разного вида птиц особенно в раннем возрасте, исследованы не полностью, в связи с чем наша работа посвящена изучению этого вопроса.

Было осуществлено две серии опытов, где с учетом принципа аналогов сформировали следующие группы. Первая серия: цыплята суточного возраста кросса «Хайсекс Браун», разделены на контрольную (I), получавшую питьевую воду и опытную группу (II), которой выпаивали с водой энрофлоксацин на протяжении 10 суток в дозе 200 мг/л. Вторая серия: схема выпаивания аналогичная, задействованы утята суточного возраста породы «Башкирская», где группа III - контроль, IV - опыт.

Отбор крови методом внутрисердечной пункции осуществляли на 1, 3, 5, 7 и 9 сутки после отмены энрофлоксацина.

Изучение показателей белой крови включало в себя подсчет количества лейкоцитов с использованием камеры Горяева, а так же учет эозинофилов, базофилов, псевдоэозинофилов, моноцитов и лимфоцитов в мазках крови окрашенных по Романовскому-Гимзе.

В некоторых случаях применения фторхинолоновых препаратов у млекопитающих выявляют гематологические реакции, например, такие как эритроцитоз или лейкопения. Тем не менее, результаты, зафиксированные в нашем исследовании, отражают отсутствие серьезного токсического воздействия энрофлоксацина на организм птиц, что подтверждает лишь однократное повышение содержания лейкоцитарных клеток на $16 \%$ в сравнении с контролем, проявившееся только в крови опытных цыплят на третьи сутки после отмены препарата.

Обнаружено повышение абсолютного количества базофилов в крови птиц II группы, произошедшее на третьи, пятые, седьмые и девятые сутки (выше на 45 \%, 30 \%, 67 \% и 52 \% соответственно). Единовременное снижение этого показателя только на третьи сутки после отмены препарата (ниже на 38 \%) выявлено в группе IV. Зарегистрирован рост относительного содержания базофильных клеток в крови цыплят, произошедший, вероятно, в связи с некоторой аллергической реакцией, проявившейся в организме, что также подтверждается достоверной эозинофилией в опытной группе на пятые (22 \%), седьмые и девятые сутки (более $50 \%$ ). Также, проявление эозинофилии может быть ответной реакцией организма на отдельные компоненты препарата, как на чужеродные антигенные вещества. Подобная реакция, вероятно, произошла у утят опытной группы, что выявлено в неоднозначном волнообразном сдвиге относительного содержания эозинофилов в крови.

Кратковременные изменения зафиксированы в динамике псевдоэозинофилов в крови птиц группы IV, по сравнению с аналогичной II группой, где сдвиг зарегистрирован в сторону достоверного снижения на девятые сутки (21\%) после отмены энрофлоксацина. Повышение 
псевдоэозинофильных клеток в крови утят произошло на третьи и седьмые сутки, что составило $20 \%$ и более чем 50 \%. Весьма неоднозначным было и содержание лимфоцитов в крови птиц, что проявилось в разных сдвигах показателя - у цыплят зарегистрировано достоверное увеличение на третьи сутки (на $22 \%$ ), а затем снижение на седьмые сутки. Динамика, обнаруженная в группе IV, была более волнообразной. Количество лимфоцитарных клеток в крови утят опытной группы было достоверно ниже на третьи сутки относительно контрольных значений на $20 \%$, затем на пятые сутки зафиксирован рост данных более чем на $50 \%$, однако же, к седьмым суткам исследования было выявлено повторное падение значений на 41 \%. Вероятно, подобное колебание показателя может быть связано со способностью фторхинолонов оказывать влияние на продукцию интерлейкина-2, который, в свою очередь, способен воздействовать на пролиферацию этого вида агранулоцитов в организме.

Кратковременными были изменения содержания моноцитов в крови птиц всех опытных групп. Так, на первые сутки после отмены препарата в группе II зафиксировано снижение данных на $63 \%$, а затем на седьмые сутки увеличение на 38 \%. Сдвиг количества моноцитов в крови утят был единовременным и зарегистрирован только на первые сутки, где спад показателя составил 45 \% в сравнении с контрольными значениями.

Известны некоторые случаи выявления отдельных нежелательных эффектов в гематологических исследованиях у млекопитающих после применения фторхинолонов, что в целом, не является распространенным и часто регистрируемым. В результате изучения подобного вопроса на цыплятах и утятах, выявлено, что серьезных сдвигов в содержании лейкоцитарных клеток в крови энрофлоксацин не вызвал, зафиксированное единоразовое изменение, вероятно, связано в большей степени с индивидуальными особенностями развития птиц в раннем возрасте.

Литература. 1. Скворцов, В.Н. Антимикробная активность и лечебная эффективность норфлоксацина при экспериментальном колибактериозе цыплят / В.Н. Скворцов, В.В. Маханёв, Д.В. Юрин // Ветеринарная патология. - 2012. - № 3 (41). -С. 68-72. 2. Andersson, M. I. Development of the quinolones / M. I. Andersson, A. P. MacGowan // Journal of Antimicrobial Chemotherapy. - 2003. - Vol. 51(1). - PP. 1-11. 3. Goudah, A. Dispositin kinetics of levofloxacin in sheep after intravenous and intramuscular administration / A. Goudah, S. Hasabelnaby // Veterinary Medicine International. - 2010. - 727231. 4. Haag, G. Quantification of residual enrofloxacin and ciprofloxacin in feathers of broiler chickens by high-perfomance liquid chromatography fluorescence after oral administration of the drugs / G. Haag, G. Marin, J. Errecalde // Journal of Advanced Pharmaceutical Technology. - 2016. - Vol. 7(1). - PP. 2-5. 5. Reyes-Herrera, I. The relationship between and muscle samples to monitor for residues of the antibiotic enrofloxacin in chickens / I. Reyes-Herrera, M. J. Schneider, P. J. Blore, D. J. Donoghue // Poultry Science. 2011. - Vol. 90(2). - PP. 481-485.

\section{EFFECT OF ENROFLOXACIN ON WHITE BLOOD CELL DYNAMICS IN YOUNG POULTRY}

${ }^{1}$ Moiseeva A.A., researcher, ${ }^{1,2}$ Prisnyi A.A., Doctor of Biological Sciences, principal researcher,

${ }^{1}$ Skvortsov V.N., Doctor of Veterinary Sciences, Head of Branch

( ${ }^{1}$ Belgorod Branch of FGBNU FNTs VIEV RAN, ${ }^{2}$ FGAOU VO NIU BelGU, Russia)

Summary. Analysis of hematological profile of poultry may serve as a tool for monitoring the impact of various medicinal drugs on the organism and for detection of their unknown effects. We studied the obtained blood parameters while bearing in mind our goal to extend knowledge of the impact of fluoroquinolones on the organism of different kinds of poultry in view of certain lack of such knowledge especially for poultry of young ages.

Keywords: poultry, fluoroquinolones, leukogram. 


\title{
АКТУАЛЬНОСТЬ ПОВЫШЕНИЯ УРОВНЯ ДОКАЗАТЕЛЬНОСТИ КЛИНИЧЕСКИХ ИССЛЕДОВАНИЙ В ВЕТЕРИНАРИИ
}

\author{
Назарова А.В., аспирант, Кузнецова Т.Ш., к.б.н., доцент, Семенов Б.С., д.в.н., профессор, \\ Виденин В.Н., д.в.н., профессор, Нечаев А.Ю., д.в.н., доцент \\ (ФГБОУ ВО СПбГУВМ, Россия)
}

\begin{abstract}
Аннотация. Как в гуманной, так и в ветеринарной медицине разрабатывается и используется большое количество лекарственных средств. Однако методология клинических исследований в ветеринарии недостаточно разработана и уровень достоверности доказательств не соответствует современным требованиям доказательной медицины. На примере проведённых нами исследований применения Бовгиалуронидазы азоксимера у мелких домашних животных с урологическими болезнями мы предлагаем использовать подход, который будет способствовать повешению уровня доказательности ветеринарной медицины.

Ключевые слова: доказательная медицина, статистическая обработка, Бовгиалуронидаза азоксимер
\end{abstract}

Актуальность. В настоящее время как в гуменной, так и в ветеринарной медицине разрабатывается и используется в лечебном процессе большое количество лекарственных средств. Внедрение новых лекарственных средств в клиническую практику требует проведения доклинических и клинических исследований предлагаемого препарата. Однако, если в гуманной медицине методология проведения клинических исследований хорошо разработана $[1,2,3,4]$, то в ветеринарной медицине нормативные документы, определяющие порядок проведения исследований, ограничены Приказом «Об утверждении правил проведения доклинического исследования лекарственного средства для ветеринарного применения, клинического исследования лекарственного препарата для ветеринарного применения, исследования биоэквивалентности лекарственного препарата для ветеринарного применения» [5]. В данном Приказе указана необходимость статистической обработки результатов исследования и описания использовавшихся для статистического анализа процедур, однако определены только обязательные данные описательной статистики, без указания методов медицинской статистики, которые должны быть использованы при обработке результатов исследования [5, 6, 7]. Отсутствие требований к использованию статистических критериев делает затруднительным оценку достоверности научных доказательств в проведённых исследованиях [8]. Также в ветеринарной медицине нет разработанных требований к дизайну проводимых исследований, что также не позволяет включить полученные данные в единую систему оценки уровней достоверности доказательств и убедительности рекомендаций [8].

Целью нашего исследования было оценить с точки зрения доказательной медицины результаты проведённых нами клинических исследований применения препаратов Бовгиалуронидазы азоксимера (БА) у мелких домашних животных с урологическими болезнями.

Материалы и методы. Нами было проведено три исследования БА: 1) Пилотное исследования влияния БА на частоту возникновения осложнений после хирургического вмешательства на уретре и мочевом пузыре у кошек (50 кошек, 21 и 29 животных в подопытной и контрольной группах соответственно) [9]. 2) Клиническое исследование препарата БА для профилактики осложнений после проведения реконструктивных операций на уретре и мочевом пузыре у кошек (оценено по критериям включения в исследование 80 кошек, включены в исследование 53 кошки, которым были проведены операции на мочевом пузыре и/или уретре, 24 и 29 животных в подопытной и контрольной группе соответственно) [10]. 3) Клиническое исследование применения БА для повышения эффективности лечения собак с урологическими болезнями (46 собак, 26 и 20 животных в подопытной и контрольной группах соответственно) [11]. Животные подопытных групп дополнительно к общепринятой 
терапии получали БА в форме ректальных суппозиториев. Животным контрольных групп в качестве плацебо ректально вводили суппозитории из масла какао.

Дизайн проведённых клинических исследований: рандомизированное слепое плацебоконтролируемое исследование в параллельных группах. Метод рандомизации: ограниченная блоковая рандомизация по территориальному признаку.

Статистический анализ выполнялся в программе BioStat Pro, AnalystSoft Inc., версия 7.3. Доверительные интервалы мы рассчитывали с помощью онлайн-калькуляторов Jeff Sauro (http://www.measuringusability.com/wald.htm) и сайта «Медицинская статистика» (https://medstatistic.ru/calculators/).

Результаты исследования и обсуждение. Уровень достоверности доказательств (УДД) показывает, насколько мы можем быть уверены в том, что исследуемый препарат действительно оказывает значимый эффект. Достоверность доказательств складывается из трёх частей: качественной (quality) и количественной (quantity) характеристик доказательств и их согласованности (consistency).

При оценке качественных характеристик исследования мы рассматриваем методы проведения исследований, их соответствие методологических основам доказательной медицины. Выбранный нами дизайн проведения клинических исследований рандомизированные исследования - на сегодня является «золотым стандартом» клинических исследований в гуманной медицине, так как доказано, что их результаты обладают наибольшей достоверностью [8, 12].

Объём доказательств (количественная характеристика проведённых исследований) складывается из полученной величины эффекта, количества исследований и суммарного размера выборки, на основе которой мы делаем свои выводы. В проведённых нами трёх исследованиях величина эффекта составила: 1) В пилотном исследовании частота осложнений снизилась на $45,7 \%(55,2-9,5 \%=45,7 \%), 2)$ В клиническом исследовании применения БА у кошек у животных подопытной группы осложнения возникали реже на $50,1 \%(61,9 \%-11,8 \%=50,1 \%) .3)$ В клиническом исследовании применения БА у собак срок выздоровления животных подопытной группы сократился на 52,4 \% (рассчитано по медиане срока выздоровления в собак подопытной и контрольной групп $(42-20) / 42=0,542)$ по сравнению с собаками контрольной группы.

Суммарный размер выборки составил 176 животных, из них 130 кошек (Felis domestica (Felis catus)) и 46 собак (Canis lupus familiaris) разных пород, пола и возраста.

Мы не можем в полной мере оценить согласованность доказательств, так как исследования БА при лечении животных с урологическими болезнями были проведены впервые и на данный момент нет данных других исследователей по этой теме. Поэтому мы сравнили результаты пилотного и клинического исследований. В пилотном исследовании у 9,5\% (2 из 21) животных подопытной группы и 55,2 \% (16 из 29) животных контрольной группы наблюдались послеоперационные осложнения. В клиническом исследовании эти цифры составили 11,8 \% (2 из 17) и 61,9 \% (13 из 21) у животных подопытной и контрольной групп соответственно, что позволяет нам говорить о согласованности доказательств в наших исследованиях. Однако для более достоверной оценки согласованности и воспроизводимости [13] требуется проведение дополнительных исследований.

Выводы. Проведённые нами исследования применения БА у мелких домашних животных с урологическими болезнями имеют удовлетворительный уровень достоверности доказательств. Использование в клинических исследованиях в ветеринарии методологии проведения исследований, принятой в гуманной медицине, способствует повышению уровня достоверности доказательств и убедительности рекомендаций в ветеринарной медицине.

Литература. 1. ГОСТ Р P52379-2005 Надлежащая клиническая практика. Good Clinical Practice (GCP). М. : Стандартинформ, 2006. - 33 с. 2. Правила надлежащей клинической практики Евразийского экономического союза, утвержденные Решением Совета Евразийской экономической комиссии от 3 ноября 2016 г. № 79 URL: https://docs.eaeunion.org/docs/ruru/01411924/cncd_21112016_79 (дата обращения: 11.08.2020). 3. Руководство по принципам 
применения биостатистики в клинических исследованиях. Документ опубликован 30 января 2020 г. URL: https://docs.eaeunion.org/pd/ru-ru/0104473/pd_30012020 (дата обращения: 11.08.2020). 4. Статистические принципы клинических исследований (ICH E9). Перевод: PharmAdvisor, версия перевода от 31.03.2019. URL: http://pharmadvisor.ru/document/tr3536/ (дата обращения: 11.08.2020). 5. Анализ нормативных документов, регламентирующих требования к проведению доклинических исследований ветеринарных препаратов / С. В. Герасимов, В. С. Понамарев, Н. Л. Андреева [и др.] // Вопросы нормативно-правового регулирования в ветеринарии. - 2020. - № 3. - С. 27-29. - DOI 10.17238/issn20726023.2020.3.27. 6. Токарева, О.А. Изучение острой токсичности препарата Тилдокс / О.А. Токарева, С.В. Енгашев, Е.С. Енгашева, А.Н. Токарев // Вопросы нормативно-правового регулирования в ветеринарии. - 2020. - № 3. - С. 118-120. 7. Карпенко, Л.Ю. Корреляционный анализ показателей функции щитовидной железы у клинически здоровых собак / Л.Ю. Карпенко, О.Н. Ершова, А.А. Бахта, А.И. Козицина // Вопросы нормативноправового регулирования в ветеринарии. — 2020. — № 4. - С. 145-147. 8. Андреева, Н.С. Система оценки достоверности научных доказательств и убедительности рекомендаций: сравнительная характеристика и перспективы унификации / Н.С. Андреева, О.Ю. Реброва, Н.А. Зорин, М.В. Авксентьева, В.В. Омельяновский // Медицинские технологии. — 2012. № 4. - С. 10-24. 9. Стекольников, А.А. Результаты пилотного исследования влияния бовгиалуронидазы азоксимера на частоту возникновения осложнений после хирургического вмешательства на уретре и мочевом пузыре у кошек / А.А. Стекольников, А.В. Назарова, Б.С. Семёнов, Т.Ш. Кузнецова // Международный вестник ветеринарии. — 2019. — № 4. — С. $158-$ 165. 10. Назарова, А.В. Применение статистических методов при оценке результатов клинического исследования препарата Бовгиалуронидазы азоксимера у кошек с урологическими болезнями / А.В. Назарова, Б.С. Семенов, Т.Ш. Кузнецова // Вестник Ульяновской государственной сельскохозяйственной академии. - 2020. - С. 212-218. 11. Назарова, А.В. Применение Бовгиалуронидазы азоксимера для повышения эффективности лечения собак с урологическими болезнями / А.В. Назарова, Б.С. Семенов, Т.Ш. Кузнецова // Вестник Алтайского государственного аграрного университета. - 2021. - № 1 (186). С. 69-75. 12. Середа, А.П. Рекомендации по оформлению дизайна исследования / А.П. Середа, М.А. Андрианова // Травматология и ортопедия России. — 2019. — № 25(3). - С. 165-184. 13. Krafczyk, M.S. Learning from reproducing computational results: introducing three principles and the Reproduction Package / M.S. Krafczyk, A. Shi, A. Bhaskar, D. Marinov and V. Stodden // Philosophical Transactions of The Royal Society A Mathematical Physical and Engineering Sciences. — 2021. - 379(2197). — 28 p. DOI:10.1098/rsta.2020.0069

\section{THE RELEVANCE OF INCREASING THE EVIDENCE-BASED LEVEL OF CLINICAL TRIALS IN VETERINARY MEDICINE}

Nazariva A.V., post-graduate student, Kuznetsova T.Sh., PhD, docent, Semenov B.S., Doctor of Veterinary Sciences, Professor, Videnin V.N., Doctor of Veterinary Sciences, Professor, Nechaev A.U., Doctor of Veterinary Sciences, docent (FSBEI HE St.Peterburg SUVM, Russia)

Summary. Both in humane and veterinary medicine, a large number of medicines are developed and used. However, the methodology of clinical trials in veterinary medicine is not sufficiently developed and the level of reliability of evidence does not meet the modern requirements of evidence-based medicine. Using the example of our studies on the use of Bovgialuronidaza azoksimer in companion animals with urological diseases, we propose to use an approach that will help to increase the evidence level in veterinary medicine.

Key words: Evidence Based Medicine, statistical processing, Bovgialuronidaza azoksimer 


\title{
ФАРМАКОЛОГИЧЕСКИЕ АСПЕКТЫ ПРИМЕНЕНИЯ КОМБИНИРОВАННЫХ СУЛЬФАНИЛАМИДОВ
}

Никитина С.В., доцент, к.б.н. (ФГБОУ ВО «Оренбургский ГАУ», Россия)

\begin{abstract}
Аннотация. В статье представлены результаты фармакокинетики сульфамонометоксина в крови оренбургских коз. Результаты исследования показывают, что с увеличением дозы сульфаниламида отмечается снижение скорости всасывания препарата и максимальная концентрация его в крови отмечается позднее.
\end{abstract}

Ключевые слова: химиотерапевтические препараты, сульфаниламиды, триметоприм, оренбургские козы.

Актуальность. Поиск эффективных химиотерапевтических препаратов способствовал увеличению ассортимента антибиотиков на фармацевтическом рынке и активное введение их в ветеринарную практику. Однако, серьезным препятствием применения антибиотиков является рост резистентности микроорганизмов, нарушение жизнедеятельности симбионтной микрофлоры организма [1,2]. В группу синтетических химиотерапевтических препаратов входят сульфаниламиды, это первые синтезированные антибактериальные средства применяемые в ветеринарии и медицине [3]. В настоящее время их использование несколько сократилось, в тоже время широкое распространение получили комбинированные сульфаниламидные препараты, в состав которых входят сульфаниламиды и триметоприм. Трисульфон комбинированный препарат с широким спектром антибактериального действия. В состав трисульфона входят сульфамонометоксин эффективный в отношении грамположительных и грамотрицательных микроорганизмов и триметоприм усиливающий антибактериальное действие [4]. В связи с этим, при использовании в клинической практике данные препараты необходимо знать фармакокинетику определяющую фармакологическую и терапевтическую активность.

Исходя из этого, мы поставили цель - изучить скорость всасывания сульфамонометоксина при однократном введении в разных дозах и время максимальной концентрации в крови оренбургских коз.

Материалы и методика. Экспериментальные исследования проводились в условиях племенного репродуктора СПК «Донской» Оренбургской области по разведению коз оренбургской породы. Козы находились в одинаковых технологических условиях с общим кормовым рационом. В ходе эксперимента были укомплектованы четыре опытные группы $(n=10)$ интактных козоматок. I-й опытной группе трисульфон задавали по сульфамонометоксину в дозе - 0,025 г/кг, II-й - 0,05 г/кг, III-й - 0,075 г/кг, IV - 0,1 г/кг. массы тела. В опытных группах после введения препарата, через 30 минут, 1, 2, 3, 5, 8, 12, 24, 48, 72, 96, 120 часов брали кровь из яремной вены для определения концентраций исследуемого вещества. Определение свободной формы сульфамонометоксина в крови проводили по методу В. Н. Пребстинг и Н. И. Гаврилова в модификации А. М. Тимофеевой. Исследование проводили на фотоэлектрическом колориметре ФЭК-56 ПМ. Для обработки данных использовался метод математической статистики, достоверность различий сравниваемых выборок проводили с использованием критерия Стьюдента.

Результаты исследования. По данным ряда исследователей сульфаниламиды быстро всасываются в кровь из желудочно-кишечного тракта, создавая длительное время высокие концентрации [5]. Так, сульфамонометоксин в дозе 0,025 г/кг. быстро всасывается из желудочно-кишечного тракта в кровяное русло и через 30 минут его концентрация в пробах крови составила - 8,0 $\pm 1,72$ мкг/мл. В дальнейшем содержание сульфамонометоксина в крови

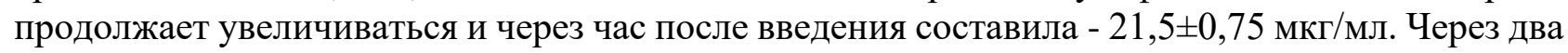

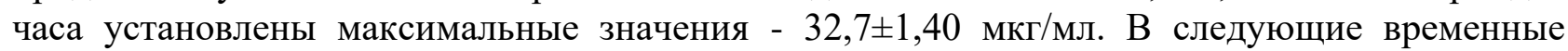
интервалы наблюдается снижение концентрации сулфамонометоксина, и спустя 48 часов 
определялись следовые концентрации, через 72 и 96 часов препарат в пробах крови не обнаруживается.

При изучении фармакокинетики сульфамонометоксина в кровяном русле второй опытной группы, через 30 минут концентрация вещества в пробах увеличилась в 2,1 раза. В последующее время содержание препарата в циркулирующей крови продолжает постепенно увеличиваться и достигает максимальных значений через три часа - 56,05 $\pm 0,75$ мкг/мл., через

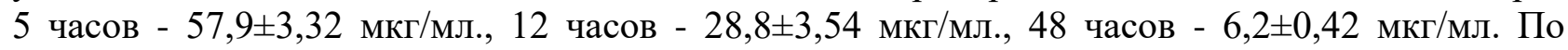
прошествию 72 часов в пробах крови опытных животных регистрируются следовые значения исследуемого вещества. Минимальной терапевтической концентрацией сульфаниламидных препаратов в периферической крови, органах и тканях животных считается концентрация 40,0 мкг/мл. В связи с этим доза 0,05 г/кг. создала не продолжительную терапевтическую концентрацию.

В пробах крови третьей опытной группы (доза 0,075 г/кг.) через 30 минут

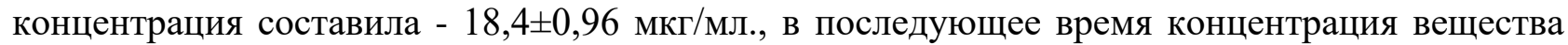
постепенно нарастает. Максимальные показатели в пробах крови регистрируются через пять

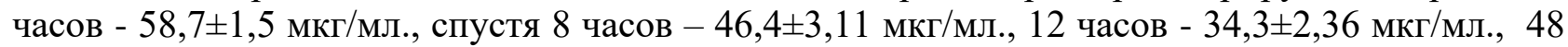

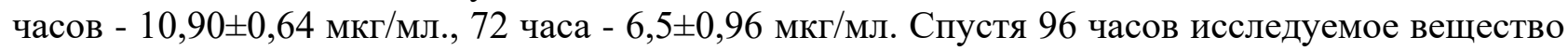
в пробах крови уже не обнаруживается.

В пробах крови IV опытной группы при дозе 0,1 г/кг. через 30 минут концентрация составила - 14,4 $\pm 0,96$ мкг/мл. Максимальные значения отмечены спустя 8 часов и составили - 78,3 $\pm 1,5$ мкг/мл. После 12 часов хода эксперимента наблюдается снижение сульфамонометоксина в пробах крови на $24 \%$. Через 72 часа в пробах крови препарат

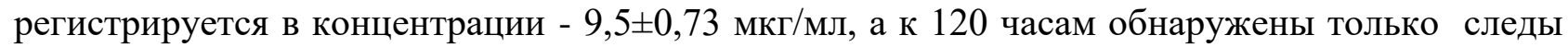
исследуемого вещества.

Анализ полученных данных выявил ряд характерных закономерностей. Входящий в состав трисульфона сульфамонометоксин быстро всасывается из желудочно-кишечного тракта, однако максимальная концентрация вещества создается в разное время в зависимости от дозы препарата [6]. При дозе 0,025 г/кг максимальная концентрация вещества в пробах крови регистрируется через 2 часа, при дозе 0,05 г/кг. к трем часам, в дозе 0,075 г/кг. наибольшая концентрация вещества в крови наблюдается спустя пять часов. В количестве 0,1 г/кг. максимальные значения нарастают к восьми часам. В малых дозах трисульфон быстро выводится из организма не достигая в крови терапевтических концентраций.

Выводы. 1. Сульфамонометоксин быстро всасывается в кровь из желудочнокишечного тракта, благодаря способности сульфаниламидов растворяться в кислой и щелочной среде желудочно-кишечного тракта.

2. При повышении дозы замедляется всасывание препарата, увеличивается время нарастания максимальной концентрации, что, возможно, связано с угнетающим воздействием больших доз препарата на моторную функцию желудочно-кишечного тракта.

3. Длительность пребывания различных доз сульфамонометоксина в кровяном русле различно и составляет: при дозе 0,025 г/кг. - 48 часов, при дозе $-0,05$ г/кг - 72 часа, при дозе 0,075 - 96 часов и при дозе 0,1 г/кг - 120 часов.

Литература. 1. Токарева, О.А. Клиническое испытание переносимости нового химиотерапевтического препарата на свиньях / О.А. Токарева, О.С. Попова, В.А. Барышев, А.Н. Токарев // Международный вестник ветеринарии. - 2018. - № 4. - С.53-58. 2. Шугалей И.В. Перспективы поиска новых антимикробных препаратов в ряду n- оксидов / И.В. Шугалей, Д.О. Виноходов, А.О. Олехнович // Международный вестник ветеринарии. - 2021. - №1. - С.128-135.3. Определение чувствительности микробных клеток к сульфаниламидным препаратам методом электрооптического анализа / О.И. Гулий, В.Д. Бунин, О.С. Ларионова, Е.Г. Потемкина, О.В. Игнатов // Антибиотики и химиотерапия. - 2015. - 60 - № 3-4. - С.14-19. 4. Емельянова, Н.Б. Острая пероральная и подострая токсичность препарата Трисульфон сульфон суспензия / Н.Б. Емельянова, В.А. Абрамов, Е.Н. Глазьев, А.В. Балышев. Международный вестник ветеринарии. - 2013. - № 2. - С.34-37. 5. Ортман, Р.А. Скорость 
всасывания и динамика концентрации сульфамонометоксина в крови овец / Р.А. Ортман // Новые фармакологические средства в ветеринарии. Санкт Петербург. - 2001. - С. 64-65. 6. Пантелеев, А.П. Динамика концентрации сульфамонометоксина в крови поросят в зависимости от его дозировки / А.П. Пантелеев // Известия Оренбургского государственного аграрного университета. - 2009. - С.164-165.

\section{PHARMACOLOGICAL ASPECTS OF THE USE OF COMBINED SULFONAMIDES}

Nikitina S. V.

Candidate of Biological Sciences (Orenburg State Agrarian University, Russia)

Summary. The article presents the results of the pharmacokinetics of sulfamonometoxin in the blood of Orenburg goats. The results of the study show that with an increase in the dose of sulfonamide, there is a decrease in the rate of absorption of the drug and its maximum concentration in the blood is noted later.

Key words: chemotherapeutic drugs, sulfonamides, trimethoprim, Orenburg goats

УДК 616.12-008.331.1:615.22:619

\section{КЛИНИЧЕСКИЙ СЛУЧАЙ ИСПОЛЬЗОВАНИЯ ПРЕПАРАТА АКТИЛИЗЕ У КОТА ПОРОДЫ МЕЙН-КУН ПРИ АРТЕРИАЛЬНОЙ ТРОМБОЭМБОЛИИ}

Николаева В.А., студент

Научный руководитель: ассистент, Понамарев В.С. (ФГБОУ ВО СПбГУВМ, Россия)

Аннотация. Как правило, при артериальной тромбоэболии (АТЭ) у кошек используется в качестве тромболитической терапии препарат Стрептокиназа. Актилизе реже применяется изза стоимости и недоказанной эффективности по выживанию в сравнении с консервативной терапией. В данном клиническом случае произошел довольно быстрый лизис тромба при рецидиве АТЭ по сравнению с применением стрептокиназы при первичном обращении с той же проблемой.

Ключевые слова: Актилизе, альтеплаза, артериальная тромбоэмболия.

Гипертрофическая кардиомиопатия (ГКМП) - это болезнь сердца, которая характеризуется утолщением стенок сердца [1] и является наиболее распространенной формой кардиомиопатии у кошек. У мейн-кунов и регдоллов ГКМП наследуется как аутосомно-доминантный признак с переменной пенетрантностью, т.е. все кошки, имеющие генетическую предрасположенность, в конечном итоге проявляют наличие данной патологии. Однако степень тяжести заболевания у животных различается из-за неоднородной генетики популяций.[2]

ГКМП у кошек довольно часто приводит к артериальной тромбоэмболии ( около $12 \%$ кошек с кардиомиопатией). Считается, что самцы наиболее подвержены АТЭ. При ГКМП развивается обычно гипертрофия левого желудочка, что при компенсации этого порока приводит к дилатации левого предсердия и в тяжелых случаях к застою в малом круге кровообращения, что ведет к недостаточности кровообращения[3] и хронической гипоксии тканей. В кровь поступают продукты ишемического повреждения тканей, в результате этого активируется свертывающаяся система, стаз крови, повышается артериальное давление. Все эти причины приводят к образованию тромба. Обычно тромб локализуется в полости или ушке левого предсердия, в последствии он попадает в аорту и приводит к частичной или полной закупорки сосуда. Это вызывает у животного резкую боль и парез или паралич конечности или конечностей [4], они в свою очередь выглядят бледными, пульс в пораженном участке отсутствует, падает местная температура.

В начале июня в клинику экстренно обратились владельцы кота породы мейн-кун 7 лет с жалобой на резкое ухудшение состояние животного. У кота была одышка и парез задних конечностей. В анамнезе у животного уже имелись ГКМП и застой в малом круге 
кровообращения. При клиническом осмотре видимые слизистые оболочки бледно-розовые, периферические лимфатические узлы не увеличены, парез левой задней конечности. Она холодная, подушечки пальцев бледные, пульс на бедренной артерии отсутствует. Правая тазовая конечность теплее, пульс нитевидный. При аускультации легких дыхание тяжелое с влажными хрипами. Ректальная температура $35,2^{\circ}$ C, артериальное давление 235/86.

По рентгеновскому снимку выявлен кардиогенный отек легких.

Применялась следующая терапия: оксигенотерапия, внутривенно фуросемид (в расчете 4 мг/кг), преднизолон (2 мг/кг) [5] , стрептокиназа болюсно (21 $230 \mathrm{ME}$ на кг), далее в дозировке $10154 \mathrm{ME/кг} \mathrm{на} \mathrm{инфузии} \mathrm{с} \mathrm{постоянной} \mathrm{скоростью} \mathrm{(ИПС),} \mathrm{в} \mathrm{качестве}$ обезболивающего средства акупан в стандартной дозировке внутримышечно каждые 8 часов.

Полное восстановление пациента произошло на одиннадцатый день лечения. Появилась поверхностная и глубокая чувствительность. Животное свободно наступало на задние конечности. Состояние было стабильное. Однако в процессе лечения произошло повышение почечных и печеночных показателей (3 стадия хронической болезни почек), наблюдалась анемия. Назначено симптоматическое лечение амбулаторно: Телмисартан (1мг/кг), Альмагель (0,2 мл/кг) перорально, Эпокрин (1000MЕ) по 0.2мл, 1раз в 3 дня подкожно, а также препараты для поддержания деятельности сердца по предыдущим назначениям.

Через 4 месяца произошел рецидив. У кота имелись те же клинические признаки АТЭ, что и при предыдущем остром состоянии. Однако в этот раз была повреждена только правая тазовая конечность. Был назначен курс лечения аналогичный предыдущему. Через 3 дня была проведена корректировка назначений, и препарат Стрептокиназа был сменен на «Актилизе» в дозировке 0,25-1 мг/мл в час. В этот же день функции правой тазовой конечности восстановлены, но животное осторожно наступало на пораженную конечность, при этом наблюдались вокализация и агрессия, чувствительность пораженной конечности восстановлена, но наблюдалась ее слабость. На четвертый день лечения по анализу крови наблюдалась почечная недостаточность 4 стадии, далее проводилась терапия, направленная на снижение почечных показателей.

В данном клиническом случае наблюдался наиболее быстрый лизис тромба при применении «Актилизе» по сравнению со стрептокиназой (разница в 10 дней). Чаще при АТЭ применяется стрептокиназа, так как имеется большое количество исследований по ее применению у кошек, а также довольно низкая стоимость препарата (примерно в 2 раза дешевле альтеплазы).

Стрептокиназа является фибринолитическим средством. Активное вещество стрептокиназа (стрептококковый белок с антигенными свойствами, поэтому возможна ее нейтрализация в организме соответствующими, антителами). Соединяясь с плазминогеном, она образует комплекс, активирующий его переход в крови или в кровяном сгустке в плазмин - протеолитический фермент, растворяющий волокна фибрина в кровяных сгустках и тромбах, вызывающий деградацию фибриногена и V и VII факторов свертывания. После растворения тромба восстанавливается проходимость кровеносных сосудов. При внутривенном введении снижает артериальное давление и общее периферическое сопротивление сосудов с последующим уменьшением минутного объема крови. У больных с хронической сердечной недостаточностью улучшает функцию левого желудочка.

Максимальный эффект наблюдается через 45 мин после начала введения. После окончания инфузии фибринолитический эффект наблюдается в течение нескольких часов. Активирует тканевой (действие; направлено на растворение тромба - тромболиз) и системный фибринолиз (расщепление фибриногена крови), из-за этого может развиться кровотечение вследствие гипофибриногенемии.

Метаболизируется путем гидролиза. Комплекс стрептокиназа-профибринолизин частично инактивируется-антистрептококковыми антителами. Образующийся фибринолизин инактивируется- альфа2-антиплазмином и альфа2-микроглобулином и выводится в небольшом количестве почками. При заболеваниях печени клиренс замедлен. 
Применяется при различных тромбозах. Противопоказана при заболеваниях, сопровождающихся кровотечениями или способными их вызвать. С осторожностью применяется при почечной и печеночной недостаточности, перенесенной стрептококковой инфекции. К побочным действиям относятся различные кровотечения и при многократном введении - повышение активности "печеночных" трансаминаз и ЩФ, ГГТ и КФК; гипербилирубинемия, снижение активности холинэнстеразы, массивное повреждение мышц.

Рекомендованные дозы $90000 \mathrm{ME}$ на кошку в течение 30 мин, затем $4500 \mathrm{ME}$ на кошку в час до 24 ч .

Препарат «Актилизе» содержит в качестве активного компонента альтеплазу (рекомбинантный человеческий тканевый активатор плазминогена, гликопротеин, который непосредственно активизирует превращение плазминогена в плазмин). После внутривенной инфузии альтеплаза остается относительно неактивной в системе циркуляции. Она активируется, связываясь с фибрином, что вызывает превращение плазминогена в плазмин и ведет к растворению сгустка фибрина. Значительного и длительного уменьшения уровня циркулирующего фибриногена, как правило, не отмечается, в отличие от стрептокиназы.

Актилизе быстро выводится из кровотока и метаболизируется главным образом в печени. Период полувыведения из плазмы составляет 4-5 минут.

Применяют при тромболитической терапии. $\mathrm{He}$ применяют при гиперчувствительности к альтепазе и гентамицину (следовые количества в процессе производства), а также при повышенном риске кровотечений. К побочным эффектам относят кровоизлияние в любой части или полости тела .

Дозировка при АТЭ 0,25-1 мг/кг в час внутривенно.

Достоинством Актилизе является более быстрый лизис тромба и меньший риск кровотечений. Однако не доказана эффективность по сравнению с консервативной терапией, зарегестрированы летальные случаи, обусловленные гиперкалиемией и шоком .

Можно сделать вывод, что применение альтеплазы в ветеринарии при АТЭ у кошек дает довольно быстрый результат разрушения тромба по сравнению со стрептокиназой. Однако еще недостаточно информации о применении данного препарата у кошачьих и из-за высокой себестоимости не каждый владелец может позволить применение Актилизе у своего питомца.

Литература. 1. Влияние препарата с гепатопротекторной активностью «Гепатон» на суммационно-подпороговый показатель и сердечно-сосудистую деятельность / В. С. Понамарев, Е. С. Королева, А. В. Кострова, К. Д. Русакова // Перспективы развития отрасли и предприятий АПК: отечественный и международный опыт : Сборник материалов Международной научно-практической конференции, Омск, 30 марта 2020 года. - Омск: Омский государственный аграрный университет имени П.А. Столыпина, 2020. - С. 213-217. 2. Peculiarities of the manifestation of bronchial asthma in cats in metropolis environment / L. Sabirzianova, P. Anipchenko, A. Yashin [et al.] // Journal of Animal Science. - 2019. - Vol. 97. No S3. - P. 214-215. - DOI 10.1093/jas/skz258.439. 3. Понамарев, В. С. Влияние препарата с гепатопротекторной активностью "Гепатон" на показатели периферической крови лабораторных животных / В. С. Понамарев // Международный вестник ветеринарии. - 2020. № 2. - C. 116-121. - DOI 10.17238/issn2072-2419.2020.2.116. 4. Лекарственные средства, с преимущественным действием на центральную нервную систему : учебно-методическое пособие по ветеринарной фармакологии для студентов факультета ветеринарной медицины / А. М. Лунегов, Н. Л. Андреева, В. А. Барышев [и др.]. - Санкт-Петербург : СанктПетербургский государственный университет ветеринарной медицины, 2020. - 55 с. 5. Иванова, К. Изучение схем стимуляции коров в охоту в зависимости от комбинации разных гормональных препаратов / К. Иванова, К. Ф. Зенков // Знания молодых для развития ветеринарной медицины и АПК страны : Материалы международной научной конференции студентов, аспирантов и молодых ученых, Санкт-Петербург, 19-20 ноября 2020 года. - СанктПетербург: Санкт-Петербургский государственный университет ветеринарной медицины, 2020. - C. 159-160. 


\section{A CLINICAL CASE OF THE USE OF THE DRUG ACTILIZE IN A MAINE COON CAT WITH ARTERIAL THROMBOEMBOLISM}

Nikolaeva V. A., student

Scientific adviser -Ponomarev V. S., assistant

((FSBEI HE Spbgavm, Russia)

Summary. The drug Aktilize is rarely used in veterinary practice, since there is little information about its use in animals, and the cost of this drug is high. However, its use in the literature and in this clinical case gave good results in a short period of time in comparison with streptokinase.

Key words: Actilize, alteplase, Arterial Thromboembolism.

УДК 619:618.7

\section{КОРРЕКЦИЯ РЕПРОДУКТИВНОЙ ФУНКЦИИ КОРОВ ПРИ ЭНДОМЕТРИТАХ И ГИПОФУНКЦИЯХ ЯИЧНИКОВ}

Нуруллин Р.Ш., студент, Терентьева Н.Ю., доц., к.в.н., Иванова С.Н., ст. преп., к.в.н. (ФГБОУ ВО УлГАУ им. П.А. Столыпина, Россия)

Аннотация. Работа посвящена коррекции репродуктивной функции коров при эндометрите и гипофункции яичников. Установлено, что при лечении коров с острым гнойно-катаральным эндометритом наибольшая эффективность была получена в опытной группе. Выздоровление наступило у 75\% животных, количество дней бесплодия по группе составило 24,6 1 1,45 дня, плодотворно осеменено 46,6 \% голов.

Ключевые слова: эндометрит, репродуктивность, гипофункция яичников, лечение.

В настоящее время ведущей отраслью животноводства является молочное скотоводство, основной целью которого является удовлетворение потребности людей в продуктах питания. Одним из этиологических факторов сдерживания темпов увеличения производства молока являются акушерско-гинекологические заболевания, наносящие большой экономический ущерб отрасли $[1,2]$.

Наука и практика предложили множество методов лечения коров. Однако все они направлены на устранение клинических признаков воспаления, и только после этого ветеринарные врачи занимаются восстановлением функции яичников, что приводит к увеличению дней бесплодия и периода от отела до успешного оплодотворения. Фермы теряют значительное количество телят и ежегодное производство молока от бесплодных коров. Большое количество молодых коров забивают до того, как окупятся деньги на их выращивание. Содержание и кормление бесплодных коров, их лечение и многократное осеменение значительно увеличивают производственные затраты $[3,4,5]$.

В животноводстве, с целью лечения и профилактики акушерско-гинекологических заболеваний, и коррекции иммуно-биохимических процессов, используют: микроэлементы, антиоксиданты, витамины, тканевые препараты и т.д. Однако, несмотря на достигнутые результаты ученых, проблема высокой заболеваемости коров в родовой и послеродовой периоды остаётся до конца не решенной $[4,5]$.

Задачей наших исследований являлось определение наиболее экономически и терапевтически эффективного метода лечения коров при послеродовом эндометрите и дисфункции яичников, путем сравнительной оценки в ООО «Мегаферма «Октябрьский» Чердаклинского района Ульяновской области.

В течение анализируемого периода острый гнойно-катаральный эндометрит регистрировался в среднем у 47,2\% коров. При этом отмечена сезонность заболевания. Самые высокие уровни наблюдались в весенние месяцы: март, апрель и осенние месяцы: октябрь и ноябрь. 
В контрольных группах для лечения животных применялись препараты, применяемые на ферме. В первой контрольной группе применяли комплекс витаминного препарата элеовит и внутриматочную суспензию эндометромага, массаж матки; во второй контрольной группе гормональный препарат сурфагон в сочетании с внутриматочной суспензией, риометрин и массаж матки. В третьей опытной группе был предложен способ лечения коров, заключающийся во введении в аорту 100 мл $1 \%$ раствора новокаина в сочетании с гомеопатическими препаратами мастометрина и овариовита по 5 мл.

При анализе исследований было установлено, что при лечении коров с острым гнойнокатаральным эндометритом наибольшая эффективность была достигнута в третьей опытной группе. Выздоровление наступило у $75 \%$ животных, а количество дней бесплодия в группе составило 24,6 \pm 1,45 дня, плодотворно осеменилось 46,6\% голов.

Наихудшая эффективность лечения наблюдалась в первой контрольной группе. Выздоровление наступило у 40\% коров, количество дней бесплодия 74,5 \pm 3,85 дня и плодотворное осеменение наблюдалось у $10 \%$ коров.

Во второй контрольной группе выздоровление наступило у 40\% коров, количество дней бесплодия в группе составило $61,0 \pm 3,25$ дня, оплодотворены 20,0 \% животных.

Таким образом, при использовании предложенного метода лечения в опытной группе увеличивается количество выздоровевших животных, продолжительность дней от отела до оплодотворения. Кроме того, схема лечения в опытной группе не содержит антибиотик и потому молоко и мясо можно использовать без ограничений.

Литература. 1.Васильева, С.В. Влияние питательной ценности рационов на показатели метаболизма у лактирующих коров / С.В. Васильева // Материалы национальной научной конференции профессорско-преподавательского состава, научных сотрудников и аспирантов СПбГУВМ. - 2021. - С. 20-22. 2.Комплексный метод лечения острого гнойно-катарального эндометрита коров / Д.В. Капралов, Т.В. Миллер, В.А. Коноплёв, С.П. Ковалёв // Международный вестник ветеринарии. - 2018. - № 2. - С. 117-121. 3.Олонцев, В.А. Оценка показателей репродуктивных качеств голштинизированного холмогорского скота / В.А. Олонцев, О.Г. Шараськина // Материалы 75-й юбилейной международной научной конференции молодых ученых и студентов СПбГУВМ, посвященной, объявленному в 2021 году президентом РФ Путиным В.В., году науки и технологий. - 2021. - С. 167-168. 4.Терентьева, Н.Ю. Некоторые аспекты применения фитопунктуры для профилактики и лечения послеродовой патологии / Н.Ю. Терентьева, С.Н. Иванова // Материалы Международной научно-практической конференции, посвященной 65-летию Ульяновской ГСХА: Актуальные вопросы аграрной науки и образования. - 2008. - С. 125-127. 5.Терентьева, Н.Ю. Некоторые функциональные нарушения яичников коров и методы коррекции репродуктивной функции / Н.Ю. Терентьева, В.А. Ермолаев, С.Н. Иванова //: Материалы IX Международной научно-практической конференции, посвященной 75-летию Ульяновского государственного аграрного университета имени П.А. Столыпина: Аграрная наука и образование на современном этапе развития: опыт, проблемы и пути их решения. - 2018. - С. 148-152.

\section{CORRECTION OF REPRODUCTIVE FUNCTION OF COWS FOR ENDOMETRITIS AND OVARIAN HYPOFUNCTIONS}

Nurullin R.Sh., student, Terentyeva N.Yu., associate professor, Ph.D., Ivanova S. N., senior lecturer, Ph.D.

(FSBEI HE UlGAU, Russia)

Summary. The work is devoted to the correction of the reproductive function of cows with endometritis and ovarian hypofunction. It was found that in the treatment of cows with acute purulent-catarrhal endometritis, the greatest effectiveness was obtained in the experimental group. Recovery occurred in $75 \%$ of the animals, the number of days of infertility in the group was $24.6 \pm 1.45$ days, $46.6 \%$ of the heads were fruitfully inseminated.

Key words: endometritis, reproduction, ovarian hypofunction, treatment 


\section{ИСПОЛЬЗОВАНИЕ ПРЕПАРАТА «РЕПАРИН-ХЕЛПЕР ${ }^{\circledR}$ В ЛЕЧЕНИИ СКАЛЬПИРОВАННОЙ РАНЫ}

Пайтерова В.В., к.б.н, вет. врач ${ }^{1}$, Кузнецова Н.В., к.в.н, асс. ${ }^{2}$, Кузнецов Ю.Е. д.в.н., доц. ${ }^{2}$ ( ${ }^{1}$ клиника «Фауна», Россия, ${ }^{2}$ ФББОУ ВО СПбГУВМ, Россия).

Аннотация. В статье приводится описание клинического случая собаки с диагнозом скальпированная рана левой грудной конечности с применением препарата «РепаринХелпер ${ }^{\circledR} \gg$.

Ключевые слова: клинический случай, собака, грудная конечность, скальпированная рана, «Репарин-Хелпер ${ }^{\circledR} »$.

Скальпированные раны с обширным отслоением или полным отрывом кожного лоскута являются результатом прямого воздействия травмирующего агента на кожу. Соответствующая хирургическая тактика при первичной хирургической обработке раны, основанная на определении жизнеспособности тканей, позволяет прогнозировать приживление травмированных тканей, сократить сроки лечения и снизить количество осложнений [1]. К основным принципам лечения скальпированных ран относят хирургическую обработку с последующим дренированием для эвакуации раневого содержимого, антибактериальную и дезинтоксикационную терапию. В случае тяжелых обширных повреждений мягких тканей благоприятный исход возможен только при раннем радикальном оперативном вмешательстве. Соблюдение этих принципов направлено на укорочение фазы воспаления и способствует раннему переходу к регенеративным процессам [2]. Стимуляция регенераторных процессов в самых различных органах и тканях является важным звеном ветеринарных мероприятий, причем не только лечебных, но и профилактических. С профилактической и лечебной целями инфекционных ран было предложено множество препаратов, различающихся по механизму действия на раневой процесс. Большинство специалистов, принимая во внимание разнообразие раневой инфекции, предлагает применять антибиотики широкого спектра действия или комбинации антибиотиков после тщательно проведенной хирургической обработки ран [3].

Цитокины - биологически активные вещества пептидной природы, регулирующие широкий спектр процессов, протекающих в организме. [4]. Цитокины играют ключевую роль в регуляции процессов заживления, поскольку регулируют все последовательные этапы развития воспаления, процесс межклеточного взаимодействия, а также иммунный ответ. [5].

Материалы и методы. В ветеринарную клинику «Фауна» филиал г. Можайска Московской области поступила собака в возрасте 3 лет с диагнозом скальпированная рана левой грудной конечности размером $14 \times 9$ см с кожно-мышечным лоскутом. Дно раны представлено мышцами, диффузно кровоточащими. Аускультация легких выявило нормопноэ, ЧДД 20 дых. дв./мин., везикулярное дыхание смешанного типа. Аускультация сердца - ЧСС 81 уд/мин.

С целью осуществления осмотра раны собаки и оказания ей помощи была проведена внутривенная седация пропофолом. После осмотра было принято решение провести лечение раны закрытым методом. Метод заключается в закрытии раны глухими швами, удалив при этом сгустки крови, фибрина, инородные предметы, и наложение местной повязки до снятия швов.

Перед проведением хирургической операции тщательную обработали рану $0,05 \%$-ным водным раствором хлоргексидина, для инфильтрационной анестезии использовали раствор бупивакаина (форма выпуска 5 мг/мл). Послеоперационную обработку кожно-мышечных швов обработали спреем «Репарин-Хелпер ${ }^{\circledR} »$. С целью профилактики развития раневой инфекции введены антибактериальные препараты мелоксивет $2 \%$ в дозе 0,6 мл и амоксициллин в дозе 5,6 мл. 


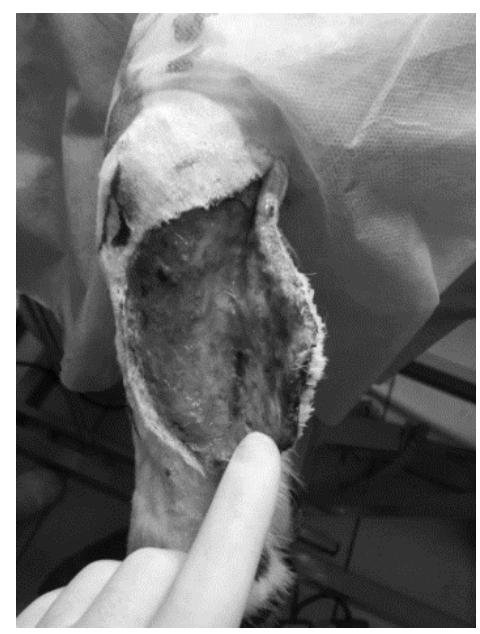

Рис. 1. Скальпированная рана левой грудной конечности

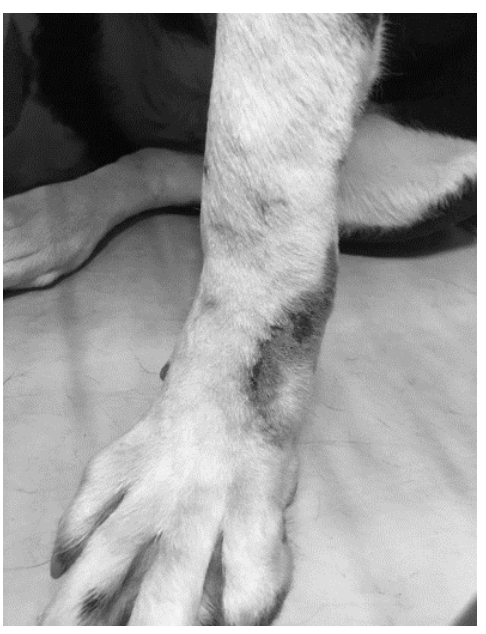

Рис. 2 Послеоперационный рубец после снятия швов

После операции была назначена обработка раны с применением раствора хлоргексидина 2 раза в день и спрея «Репарин-Хелпер ${ }^{\circledR} \gg$. Лекарственный препарат применяли согласно инструкции, нанося препарат на шов один раза в день в количестве от 3 до 6 капель (что равнялось 1 - 3-кратному нажатию на распылительную головку) на протяжении 10 дней. Так как рана достаточно обширная, то дополнительно была назначена курсовая 7-дневная антибактериальная терапия с применением синулокса таблетки 500 мг внутрь по 1,5 таблетки 2 раза в день и нестероидная противовоспалительная - онсиор таблетки 40 мг внутрь по 1,5 таблетки 1 раз в день 5 дней. Начиная с 3-го по 5-ый день было зарегистрировано формирование фазы дегидратации, а с 7-го по 9-й день - фазы эпителизации и рубцевания. Осложнялось заживление раны тем, что это была собака гигантской породы, постоянно срывала любой защитный воротник, бинтовые повязки и лизала рану.

На 12-е сутки у собаки были сняты швы с послеоперационной раны, полная эпителизация раны наступила к 15 суткам после травматизации. (Рис. 2)

Таким образом, при исследовании препарата «Репарин-Хелпер®» на процесс заживления скальпированной раны, было установлено его ранозаживляющее и противовоспалительное действие. Картина послеоперационной раны левой грудной конечности отличалась сухостью раневой поверхности, а выздоровление наступает на 15 суткам.

Литература. 1. Опыт местного лечения обширной травматической раны с помощью пектинов и раствором с наночастицами серебра (клиническое наблюдение) / Е.Б. Лазарева, М.В. Шахламов, Е.Д. Меньшикова, И.Н. Пономарев // Журнал им. Н. В. Склифосовского Неотложная медицинская помощь. - 2014. - № 1. - С. 47-50. 2. Суворов, О.Н. Комплексная терапия воспалительных процессов в области пясти и плюсны у собак / О.Н. Суворов, А.А. Стекольников, А.В. Бокарев // Новые фармакологические средства в ветеринарии: материалы XIX Международной научно-практической конференции (01 января - 31 декабря 2007 г., Санкт-Петербург). - Санкт-Петербург, 2007. - С. 41-42. 3. Батраков, А.Я. О некоторых аспектах применения антисептиков, антибиотиков и средств иммунокоррекции при хирургических инфекциях у животных / А.Я. Батраков, В.Н. Виденин, Б.С. Семенов, А.Ю. Нечаев // Эффективные и безопасные лекарственные средства в ветеринарии: материалы $\mathrm{V}$-го Международного конгресса ветеринарных фармакологов и токсикологов (22-24 мая 2019 г., Санкт-Петербург). - Санкт-Петербург, 2019. - С. 34-37. 4. Телетаева, Г.М. Цитокины и противоопухолевый иммунитет / Г.М. Телетаева // Практическая онкология. - 2007. - Т. 8. № 4 (32). - С. 211-21. 5. Носенко, М.А. Провоспалительные цитокины и заживление кожных ран у мышей / М.А. Носенко, С.Г. Амбарян, М.С. Друцкая // Молекулярная биология. - 2019. - Т. 53. - № 5.- С. 741-754. 


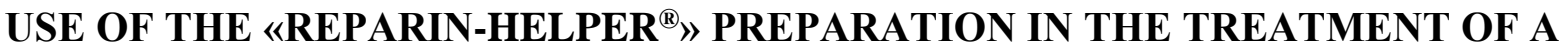 SCALPED WOUND
}

Payterova V.V., Ph.D., vet. doctor (clinic "Fauna", Russia).

Kuznetsova N.V., Ph.D., ass., Kuznetsov Yu.E. Doctor of Medical Sciences, ass. (FSBEI HE St.Peterburg SUVM, Russia).

Summary. The article describes a clinical case of a dog diagnosed with a scalped wound of the left thoracic limb using the "Reparin-Helper ${ }^{\circledR}$ " drug.

Key words: clinical case, dog, chest limb, scalped wound, "Reparin-Helper ${ }^{\circledR}$.

\section{УДК 615:628}

\section{ТОКСИКОЛОГИЧЕСКАЯ ОЦЕНКА ВЕТЕРИНАРНОГО ПРЕПАРАТА «МАРБОБЕЛ АКТИВ» В ОСТРОМ ОПЫТЕ}

Петров В. В., доц., к.в.н, Романова Е. В., асс., магистр в. н. (УО ВГАВМ, Республика Беларусь)

\begin{abstract}
Аннотация. Разработка ветеринарных препаратов и кормовых добавок для животных является приоритетным направлением современной ветеринарной фармации в мировой практике. Все вновь разработанные ветеринарные препараты и кормовые добавки должны быть исследованы не только на предмет соответствия нормативно-технической документации, но и определена безопасность препарата для животных в токсикологическом плане. Определение токсикологической характеристики ветеринарного препарата и кормовой добавки (острая токсичность) является неотъемлемой частью их разработки и рекомендации в последующем в клинической практике [1].
\end{abstract}

Ключевые слова: марбофлоксацин, белые мыши, LD50 .

Изучение острой оральной и парентеральной (при подкожном введении) токсичности ветеринарного препарата «Марбобел Актив» проводили в виварии УО «Витебская ордена «Знак Почета» государственная академия ветеринарной медицины». Опыты проводили в соответствии с методическим рекомендациями [1].

В 1 мл ветеринарного препарата содержится 0,16 г марбофлоксацина. Марбофлоксацин, входящий в состав препарата, относится к группе фторхинолонов. Механизм действия марбофлоксацина основан на угнетении ДНК-гиразы и топоизомеразы IV, что приводит к нарушению синтеза белка микробной клеткой и ее гибели. Обладает широким спектром бактерицидного действия в отношении грамположительных (Staphylococcus spp., Listeria spp. и др.) и грамотрицательных микроорганизмов (Escherichia coli, Pasteurella spp., Actinobacillus pleuropneumoniae), а так же микоплазм (Mycoplasma spp.), хламидий (Chlamydia spp.) и риккетсий (Ricketsia spp.). Не активен против облигатных анаэробов [2]. Марбофлоксацин хорошо всасывается из места инъекции. Биодоступность близка к 100\%. Он слабо связывается с белками плазмы крови (менее $10 \%$ у свиней и $30 \%$ у КРС), значительно распределяется во многие ткани (печень, почки, кожу, легкие, стенку матки) и достигает в них более высоких концентраций, чем в плазме. При однократном внутримышечном введении марбофлоксацина в дозе 10 мг/кг массы животного крупному рогатому скоту максимальная концентрация в плазме крови достигается примерно через 1,28 часа и составляет около 7,915 мкг/мл; $\mathrm{t}_{1 / 2}$ составляет 17,5 часов; терапевтическая концентрация поддерживается на протяжении 48 часов. При однократном внутримышечном введении марбофлоксацина в дозе 8 мг/кг массы животного свиньям максимальная концентрация в плазме крови достигается примерно через 0,93-1,0 часа и составляет 5,55-6,29 мкг/мл; $\mathrm{t}_{1 / 2}$ составляет 11,92-15,14 часа; терапевтическая концентрация поддерживается на протяжении 48 часов. Выделяется марбофлоксацин преимущественно в неизменном виде с мочой и калом $[2,3]$. 
Марбобел Актив применяют крупному рогатому скоту и свиньям при патологии органов дыхания, пищеварительной и мочеполовой системы, инфекциях кожи и мягких тканей, вызываемых микроорганизмами, чувствительными к марбофлоксацину.

Определение острой оральной и парентеральной (при подкожном введении) токсичности ветеринарного препарата «Марбобел Актив» проводили на белых, беспородных не линейных мышах, обоего пола, массой 19 - 21 г. Для опытов были сформированы: девять опытных групп и одна контрольная по шесть животных в каждой. Перед исследованием мышей выдержали на 12-часовом голодном режиме.

Мышам первой-пятой опытных групп препарат вводили внутрижелудочно в дозах 25000,0 мг/кг, 20000, мг/кг, 15000,0 мг/кг, 10000 мг/кг, 5000, мг/кг соответственно (по препарату). Мышам шестой-девятой опытных групп препарат вводили в дозах 15000,0 мг/кг, 10000,0 мг/кг, 5000,0 мг/кг, 2500,0 мг/кг соответственно (по препарату).

Мышам контрольной группы препарат не вводили. Срок наблюдения за мышами составил 14 суток.

Результаты исследований отображены в таблице 1.

Таблица 1 - Влияние ветеринарного препарата «Марбобел Актив» на подопытных мышей, при однократном оральном и парентеральном (подкожном) введении (n-6 исходные данные для расчета $\mathrm{LD}_{50}$ )

\begin{tabular}{|l|l|l|l|}
\hline № группы/путь введения & $\begin{array}{l}\text { Доза препарата, } \\
\text { мг/кг }\end{array}$ & $\begin{array}{l}\text { Количество } \\
\text { живых мышей }\end{array}$ & $\begin{array}{l}\text { Количество } \\
\text { павших мышей/\% }\end{array}$ \\
\hline 1 (внутрь) & 25000,0 & 0 & $6 / 100 \%$ \\
\hline 2 (внутрь) & 20000,0 & 1 & $5 / 83,3 \%$ \\
\hline $3($ внутрь) & 15000,0 & 3 & $3 / 50 \%$ \\
\hline $4($ внутрь) & 10000,0 & 4 & $2 / 33,3 \%$ \\
\hline $5($ внутрь) & 5000,0 & 6 & $0 / 0 \%$ \\
\hline 6 (подкожно) & 15000,0 & 0 & $6 / 100 \%$ \\
\hline 7 (подкожно) & 10000,0 & 1 & $5 / 83,3 \%$ \\
\hline 8 (подкожно) & 5000,0 & 4 & $2 / 33,3 \%$ \\
\hline 9 (подкожно) & 2500,0 & 6 & $0 / 0 \%$ \\
\hline Контроль & -- & 6 & $0 / 0 \%$ \\
\hline
\end{tabular}

В первой опытной группе в течение первых трех часов наблюдения после введения препарата пали все мыши (100\% падежа). Падеж мышей наблюдали в разные временные сроки ограниченные указанным периодом времени. Во второй опытной группе пало пять мышей в течение первых четырех часов наблюдения (падеж 83,3\%). Оставшаяся в живых мышь выздоравливала в течение 24-48 часов. По истечению указанного времени мышь охотно принимала корм и воду, реагировала на внешние раздражители.

Клинические признаки интоксикации характеризовались возбуждением, клоникотоническими судорогами, цианозом, атаксией, диспноэ, адинамией, комой и наступал смертельный исход.

В третьей опытной группе пало три мыши в течение первых четырех-восьми часов после введения препарата (падеж 50\%). Клинические признаки интоксикации характеризовались возбуждением, фибрилляциями мышц туловища, судорогами конечностей, цианозом, атаксией, диспноэ, адинамией, комой и наступал смертельный исход. Оставшиеся в живых мыши выздоравливали в течение 24 часов от момента введения препарата. По истечению указанного времени мыши охотно принимали корм и воду, естественно реагировали на внешние раздражители.

В четвертой опытной группе пало две мыши в течение первых двух суток наблюдения (падеж 33,3\%). Оставшиеся в живых мыши выздоравливали в течение 16 часов от момента введения препарата. По истечению указанного времени мыши охотно принимали корм и воду, естественно реагировали на внешние раздражители. 
В пятой опытной группе падежа мышей не отмечено. Мыши охотно принимали корм и воду, хорошо реагировали на внешние раздражители.

При вскрытии трупов павших мышей наблюдали застойные явления в органах брюшной полости. Отек легких, цианоз слизистых и кожи. В полости желудка обнаруживали остаточное количество препарата желтоватого цвета, слабого специфического запаха; гиперемия слизистой.

В шестой опытной группе в течение первого часа наблюдения после введения препарата пали все мыши (100\% падежа). В седьмой опытной группе пало пять мышей в течение первого часа наблюдения (падеж 83,3\%). Оставшаяся в живых мышь выздоравливала в течение 24-30 часов. По истечению указанного времени мышь охотно принимала корм и воду, реагировала на внешние раздражители.

Клинические признаки интоксикации характеризовались возбуждением, тоническими судорогами, цианозом, атаксией, диспноэ, адинамией, комой и наступал смертельный исход.

При вскрытии трупов павших мышей наблюдали застойные явления в органах брюшной полости. Отек легких, цианоз слизистых и кожи. На месте введения препарата обнаруживали серозный отек и часть не всосавшегося препарата желтого цвета.

В восьмой опытной группе две мыши в течение трех часов наблюдения после подкожного введения препарата (падеж 33,3\%). Клинические признаки интоксикации характеризовались фибрилляциями мышц всего тела, цианозом, атаксией, диспноэ, адинамией, комой и наступал смертельный исход.

Оставшиеся в живых мыши выздоравливали в течение первых восьми часов наблюдения. По истечению указанного времени мыши охотно принимали корм и воду, реагировали на внешние раздражители.

В девятой опытной группе за время наблюдения падежа мышей не отмечено. Мыши охотно принимали корм и воду, хорошо реагировали на внешние раздражители.

В контрольной группе падежа мышей не отмечено. Мыши контрольной группы охотно принимали корм и воду, хорошо реагировали на внешние раздражители.

Расчет среднесмертельной дозы (LD50) проводили по методу Першина. LD50 препарата при однократном пероральном введении в желудок белым лабораторным мышам составила 14170,0 мг/кг. При однократном подкожном введении LD 50 препарата составила 7086,25 мг/кг.

Таким образом, ветеринарный препарат «Марбобел Актив» при однократном пероральном и парентеральном (подкожном) введении белым лабораторным мышам обладает выраженным токсическим действием. $\mathrm{LD}_{50}$ ветеринарного препарата «Марбобел Актив» при пероральном введении для белых лабораторных мышей составляет 14170,0 мг/кг, при однократном подкожном введении - 7086,25 мг/кг. Ветеринарный препарат «Марбобел Актив» по классификации ГОСТ 12.1.007-76 относится к IV классу опасности - вещества малоопасные (DL50 свыше 5000 мг/кг).

Литература. 1. Руководство по экспериментальному (доклиническому) изучению новых фармакологических веществ» / Р. У. Хабриев [и др.]; под ред. Р. У. Хабриева. - М. :ЗАО ИИА «Медицина», 2005. - 892 с. 2. Фармакология / В. Д. Соколов [и др.]; под ред. В. Д. Соколова СПб. : Издательство «Лань», 2013. - 576 с. 3. Пламб Дональд К. Фармакологические препараты в ветеринарной медицине/ Пер. с англ. / В двух томах. Том 1. (А-Н) - М.: Издательство Аквариум, 2019. - 1040 с.

\section{TOXICOLOGICAL ASSESSMENT OF THE VETERINARY PREPARATION "MARBOBEL ACTIVE IN ACUTE EXPERIENCE}

Petrov V.V., Assoc., Ph.D., Romanova E.V., Ass., Master of Science n.

(UO VGAVM, Republic of Belarus)

Annotation. The development of veterinary drugs and feed additives for animals is a priority area of modern veterinary pharmacy in world practice. All newly developed veterinary drugs and feed additives should be examined not only for compliance with regulatory and technical documentation, but also to determine the safety of the drug for animals in toxicological terms. Determination of the 
toxicological characteristics of a veterinary drug and feed additive (acute toxicity) is an integral part of their development and subsequent recommendations in clinical practice [1].

Key words: marbofloxacin, white mice, LD50.

\section{УДК615:628}

\section{ЭФФЕКТИВНОСТЬ ВЕТЕРИНАРНОГО ПРЕПАРАТА «ОКСИФЛУ ЗО» ПРИ БРОНХОПНЕВМОНИИ У ТЕЛЯТ}

Петров В.В., доц., к.в.н., Романова Е.В. асс., магистр в.н. (УО ВГАВМ, Республика Беларусь)

Аннотация. Особенности этиопатогенеза и распространения болезней в условиях промышленного животноводства обуславливает широкое применение не только антимикробных средств [1], но и средств симптоматической и патогенетической терапии, котрыеиспользуютдля борьбы с условно-патогенной и патогенной микрофлорой, а также устраняют воспаление, повышенную температуру тела, боль. Чаще всего, из этих средств используются антибиотики и нестероидные противовоспалительные препараты (НПВС), как более эффективные и позволяющие значительно снизить заболеваемость, тяжесть течения и летальность $[3,4,5,6,7]$. Ветеринарныепрепараты содержащие в своем составе антибиотики и НПВС в настоящее время широко востребованы клинической практикой.

Ключевые слова:телята, бронхопневмония, эффективность.

Целью исследований являлось определениелечебной эффективности ветеринарного препарата «Оксифлу 30» при бронхопневмонии у телят.Препарат в 1 мл в качестве действующих веществ содержит окситетрациклин (в форме дигидрата) - 300 мг, флуниксин (в форме меглумина) - 20 мг. Окситетрациклин, входящий в состав препарата, обладает выраженной противомикробной активностью в отношении большинства грамотрицательных и грамположительных микроорганизмов, в том числе: Escherichiacoli, Salmonellaspp., Proteusspp., Campylobacterspp., Pseudomonasaeruginosa, Bordetellaspp., Pasteurellaspp., Haemophilusspp., Actinobacillusspp., Brucellaspp., Staphylococcusspp., Streptococcusspp., Listeriamonocytogenes, Corynebacteriumspp., Erysipelothrixinsidiosa, Dermatophiluscongolensis,Fusobacteriumnecrophorum, Clostridiumspp., a также Anaplasmaspp., Mycoplasmaspp., Rickettsiaspp., Chlamydiaspp., $\quad$ Treponemaspp. (включаяSerpulinahyodysenteriae).

Флуниксинамеглумин обладает противовоспалительным свойством в очагах, вызванных эндотоксинами бактерий, и выраженным жаропонижающим эффектом. Флуниксинингибируетциклооксигеназы (ЦОГ1 и ЦОГ2), угнетает синтез простагландинов Е2 - медиаторов воспаления, что обуславливает его анальгезирующее, противовоспалительное, жаропонижающее и антитоксическое действие.

Окситетрациклин быстро всасывается из места инъекции и достигает максимальных концентраций в органах и тканях через 30-50 минут после введения, обеспечивая терапевтическую концентрацию продолжительностью до 120 часов. Окситетрациклин выводится из организма преимущественно почками и с желчью, у лактирующих животных частично с молоком.

Флуниксин быстро всасывается из места инъекции и проникает в большую часть органов и тканей, достигая максимальной концентрации в крови через 5 - 45 минут, кумулируется в очаге воспаления, обеспечивая терапевтический эффект продолжительностью до 24 часов. Выводится из организма преимушественно с фекалиями и в меньшей степени почками [7, 10,11,13].

Определение лечебной эффективности ветеринарного препарата «Оксифлу 30» при бронхопневмонии у телят проводили в условиях хозяйствГородокского района на фоне принятых в хозяйствах технологии ведения животноводства, условий кормления и 
содержания, а также схем ветеринарных мероприятий при незаразных болезнях молодняка.С целью определения лечебной эффективности испытуемого препарата были сформированы две группы телят, больных острой бронхопневмонией в возрасте два-три месяца: опытная девятнадцать голов и контрольная - девять животных. Формирование групп проходило постепенно, по мере заболевания телят и с учетом принципа условных аналогов. Во время проведения опыта, все животные находились приблизительно в одинаковых условиях кормления и содержания. Животным опытной группы применяли ветеринарный препарат «Оксифлу 30» в дозе $1 \mathrm{~cm}^{3}$ на 10 кг массы тела внутримышечно, двукратно с интервалом 5 дней.

В контрольной группе телятам внутримышечно применяли ветеринарный препарат «Роксилонг 300» в дозе 0,75 мл на 10 кг массы тела, двукратно с интервалом трое суток.

Животных обеих групп на время болезни выделяли в отдельные секцию в этом же помещении, поили теплой водой и отварами лекарственных трав. В качестве отхаркивающего применяли натрия гидрокарбонат два раза в день по 1 г 10 кг массы курсом 4-5 дней подряд. Внутримышечно вводили ветеринарный препарат «Тривит» в дозе 2 мл однократно. При выраженной одышке применяли $0,1 \%$ раствор атропина сульфата. При необходимости назначали детоксикационную терапию (аверон, унитокс, антитокс) и внутривенно вводили раствор «Трисоль».

Было установлено, что бронхопневмонией заболевают массово телята 1-3 месячного возраста. На период проведения исследований основными причинами заболевания были неудовлетворительные параметры микроклимата в телятнике (повышенная влажность - более 80-85 \%, повышенная скорость движения воздуха - 0,6 м/с и повышенное содержание вредных газов (содержание аммиака выше $10 \mathrm{m \Gamma} / \mathrm{M}^{3}$ ), содержанием в помещении разновозрастных групп телят, неудовлетворительным санитарным состоянием. Поение производится холодной водой. Так же отмечены способствующие факторы в возникновении бронхопневмонии телят, как-то погрешности в кормлении и формирование групп телят с низкой естественной резистентностью, переболевшим ранее желудочно-кишечными болезнями, рахитом и др. Возбудителей специфических пневмоний по данным лабораторных исследований не выявлялось. При определении чувствительности к антибактериальным препаратам выделенной от больных телят микрофлоры (май 2020) установлена ее высокая чувствительность к ДВ препарата окситетрациклину.

Основными клиническими признаками острой бронхопневмонии у телят являлись: угнетение, субфебрильная лихорадка у 15 больных животных (53,57 \%), уменьшение аппетита, жажда у телят с гипертермией, учащением дыхания и смешанной одышкой. Отмечали кашель, который вначале заболевания был сухим, одиночным и болезненным, а ко 2-3 дню становился более продолжительным, частым и не редко выявлялись кашлевые приступы с выделением слизисто-гнойного экссудата. При аускультации легких прослушивалось жесткое везикулярное дыхание и патологическое бронхиальное, у части животных перкуссией обнаруживали незначительные по размеру очаги притупления. Хрипы (мелко- и крупно-пузырчатые) чаще выявлялись у телят начиная со 2-3 дня развития болезни и постепенно они усиливались, становились влажными.За животными после применения препаратов вели ежедневное клиническое наблюдение, учитывали степень проявления признаков бронхопневмонии, сроки выздоровления, наличие осложнений и летального исхода.

В результате проведенных исследований установили, что в опытных и контрольных группах у большинства животных с второго-третьего дня после начала лечения наблюдалась положительная динамика клинических признаков болезни, свидетельствующая о выздоровлении. В результате проведенных лечебных мероприятий полное исчезновение клинических признаков заболевания происходило в среднем в течение 5-7 дней.

В опытной группе средняя длительность болезни составила $6,0 \pm 1,1$ дня. Переход заболевания в подострую форму с последующим продолжением лечения отмечен у двух 
животных (10,52 \%). Падежа телят, рецидивов болезни и негативного влияния препаратов за период опыта не отмечали.

В контрольной группе полное исчезновение клинических признаков бронхопневмонии происходило в среднем в течение 6-8 дней. Средняя длительность болезни составила 7,0 $\pm 1,2$ дня. Переход бронхопневмонии в подострую форму отмечен с последующим продолжением лечения у двух телят (22,2 \%). Пал один теленок (11,1\%). Рецидивов болезни и негативного влияния препаратов за период опыта и дальнейшего наблюдения в течение месяца не отмечали.

В результате проведенных исследований и полученным при этом данным можно сделать вывод что: ветеринарный препарат«Оксифлу 30», целесообразно использовать в комплексном лечении телят при бронхопневмонии в качестве антимикробного, противовоспалительного, анальгезирующего и жаропонижающегопрепарата, так как получен высокий $(89,48$ \%) терапевтический эффект. Присутствие в препарате флуниксина повышает эффективность лечения, что подтверждают проведенные исследования.

Литература.1.Яшин, А.В. Незаразная патология крупного рогатого скота в хозяйствах с промышленной технологией / А.М. Яшин [и др.]. - СПб.: Лань, 2019. - 220 с. 2.Выращивание и болезни молодняка : практическое пособие / Под.общ. ред. А.И. Ятусевича [и др.] - Витебск : ВГАВМ, 2012. - 816 с. 4.Данилевская, Н.В. Справочник ветеринарного терапевта / под ред. А.В. Коробова, Г.Г. Щербакова / серия «Мир медицины». - СПб., 2000. - С. 65-82. 5. Ковалев В.Ф. Антибиотики, сульфаниламиды и нитрофураны в ветеринарии: справочник / В.Ф. Ковалев [и др.] - М.: Агропромиздат, 1988.- 223 с. 6.Пламб Дональд К. Фармакологические препараты в ветеринарной медицине/ Пер. с англ. / В двух томах. Том 2. (О-Я) - М.: Издательство Аквариум, 2019. - 1040 с. 7. Гилберт, Д. Антимикробная терапия по ДжэюСэнфорду // Под ред. Д. Гилберта, Г. Чемберса, Дж. Эллиоупоса и [др.]. - М.: Гранат, 2019. - 784 с.8. Дьякова В.В. Диагностика и лечение бронхопневмонии телят, вызванной mycoplasmabovis // В.В. Дьякова, Н.Ю. Терентьева, В.А. Ермолаев, С.Н Иванова, П.М. Ляшенко // Ученые записки Казанской государственной академии ветеринарной медицины им. Н.Э. Баумана. - 2020.- Т. 242. -№ 2. -С. 54-60.

\section{EFFICIENCY OF THE VETERINARY PREPARATION "OXIFLU" IN BRONCHOPNEUMONIA IN CALFS}

Petrov V.V., Assoc., Ph.D., Romanova E.V. Ass., Master of Science

(UO VGAVM, Republic of Belarus)

Annotation. The peculiarities of the etiopathogenesis and spread of diseases in industrial animal husbandry determine the widespread use of not only antimicrobial agents [1], but also symptomatic and pathogenetic therapy, which are used to combat opportunistic and pathogenic microflora, and also eliminate inflammation, increased body temperature, and pain. Most often, of these funds, antibiotics and non-steroidal anti-inflammatory drugs (NSAIDs) are used, as they are more effective and can significantly reduce the incidence, severity and mortality [3,4,5,6,7]. Veterinary drugs containing antibiotics and NSAIDs are currently in wide demand in clinical practice.

Key words: calves, bronchopneumonia, efficiency.

УДК 619:616.155.194:663.4

\section{ЭФФЕКТИВНОСТЬ ПРИМЕНЕНИЯ ВЕТОФЕНА 5 \% ДЛЯ ЛЕЧЕНИЯ СОБАК ПРИ ЗАБОЛЕВАНИЯХ С БОЛЕВЫМ СИНДРОМОМ И ВОСПАЛЕНИЕМ}

Петров В.В., доц., к.в.н., Мацинович М.С., асс., Романова Е. В., асс. маг-р. в.н. (УО ВГАВМ, Республика Беларусь)

Аннотация. В практике оказания ветеринарной помощи собакам имеется необходимость широкого применения нестероидных противовоспалительных препаратов. Однако многие из них имеют осложнения и прямые противопоказания к применению данному виду животных. 
Был испытан ветеринарный препарат «Ветофен 5\%» на основе карпрофена. Данный препарат показал высокую эффективность, а побочных эффектов на организм собак не было выявлено. Ключевые слова: карпрофен, ветофен 5 \%, собаки, болевой синдром, воспаление.

Применение нестероидных противовоспалительных препаратов (НПВП) в качестве средств патогенетической и симптоматической терапии при воспалительных заболеваниях, болезнях с болевым синдромом, колике для купирования постоперационных болей и др. позволяет значительно повысить терапевтическую эффективность схем лечения собак $[1,2]$. Кроме того, их применяют с этической точки зрения, для облегчения боли у животных и уменьшения их страданий [3]. Применяя препараты этой фармакологической группы, следует обращать внимание на риск возникновения побочных эффектов, связанных с нарушением функций желудочно-кишечного тракта, работы печени, почек и сердечно-сосудистой системы [4]. Одним из наиболее безопасных для собак средств из группы НПВП по литературным данным является карпрофен, который рекомендуют им вводить перорально или подкожно [5, 6]. Поэтому разработка препаратов для разных методов введения на основе карпрофена является актуальным, и они будут востребованы практикой при оказании лечебной помощи собакам.

Целью исследований являлось определение эффективности ветеринарного препарата «Ветофен 5 \%» для лечения собак при заболеваниях с болевым синдромом и воспалением.

Материалы и методы исследований. Исследования проводили в условиях клиники кафедры акушерства, гинекологии и биотехнологии разведения животных им. Я.Г. Губаревича и кафедры внутренних незаразных болезней животных УО ВГАВМ.

Ветеринарный препарат «Ветофен 5 \%» представляет собой раствор для подкожного или внутривенного введения. В 1,0 мл препарата содержится 50 мг карпрофена и вспомогательные вещества. Карпрофен, входящий в состав препарата относится к производным пропионовой кислоты. Ингибирует фермент циклоксигеназу в цикле арахидоновой кислоты, преимущественно влияя на циклоксигеназу-II, которая вырабатывается в ответ на воспаление. В результате этого блокируется синтез простагландинов. В терапевтических дозах карпрофен значительно слабее действует на циклоксигеназу-I, и благодаря этому не оказывает существенного влияния на синтез протективных (выполняющих защитную функцию) простагландинов. Карпрофен не препятствует нормальным физиологическим процессам в тканях, особенно в желудочнокишечном тракте, почках и тромбоцитах. Кроме того, препарат обладает антибрадикининовой активностью, подавляя восприятие боли на уровне ЦНС [6, 7].

Препарат предназначен для лечения собак и кошек с воспалительными процессами при острых и хронических заболеваниях опорно-двигательного аппарата (артрозы, артриты, отеки, тендовагиниты), болевом синдроме различной этиологии (грыжи межпозвоночных дисков, невриты, травмы и пр.); а также в качестве обезболивающего средства до хирургического вмешательства и в послеоперационной реабилитации.

Собакам применяют внутривенно или подкожно, на первое введение в дозе 1 мл препарата на 12,5 кг массы животного; на последующие - через 24 часа в дозе 1 мл на 25 кг массы животного. Продолжительность применения препарата зависит от состояния пациента.

Были подобраны две группы собак в возрасте от десяти месяцев до десяти лет. В первую (опытную) группу были отобраны десять животных: две собаки породы алабай, по одной собаке породы английский и французский бульдог с диагнозом артроз, одна собака породы лабрадор с диагнозом дисплазия тазобедренного сустава в стадии обострения, одна собака породы лабрадор и одна породы шарпей после оперативного лечения многочисленных кусаных ран; одна собака «дворняжка» в послеоперационный период (одна после удаления матки (пиометра), две суки без породы больные фиброзно-кистозной мастопатией с явлением гнойного мастита. Во вторую (контрольную) группу были отобраны шесть животных: по одной собаке пород английский и французский бульдог с диагнозом артроз, одна собака породы лабрадор с диагнозом дисплазия тазобедренного сустава в стадии обострения, одна собака без породы в послеоперационный период по поводу овариэктомии, одна собака 
«дворняжка» с диагнозом раневая инфекция и одна собака без породы больные фибрознокистозной мастопатией с явлением гнойного мастита. Формирование групп животных проводили постепенно, по мере поступления животных в клиники и в виварии академии. Диагноз устанавливали путем сбора анамнестических данных, анализа клинических признаков, лабораторных и инструментальных методов исследований. У собак всех групп отмечались следующие характерные клинические признаки того или иного заболевания.

В зависимости от диагноза назначалось комплексное лечение, включавшее средства этиотропной терапии, патогенетической, а при необходимости симптоматической и заместительной. Собакам первой опытной группы в качестве противовоспалительного, обезболивающего и жаропонижающего средства изучаемый ветеринарный препарат «Ветофен 5\%» вводили собакам опытной группы в дозе: на первое введении 1 мл на 12,5 кг массы животного, с кратностью в 24 часа в дозе 1 мл на 25 кг массы животного, подкожно или внутривенно. Собакам контрольных групп применяли ветеринарный препарат «Флексопрофен 2,5\%» («ВИК- здоровье животных»), содержащий в качестве ДВ кетопрофен, который вводили в дозе (1 мл на 12,5 кг) внутримышечно, подкожно или внутривенно, один раз в сутки. Кратность введения и путь определялись диагнозом и тяжестью патологического процесса.

Результаты исследований. У собак с многочисленными инфицированными кусаными ранами, регистрировали гнойное истечение из раневых полостей, отек травмированных участков кожи и подкожной клетчатки, болезненность при пальпации, температура тела была в пределах 39,8 и $40^{\circ} \mathrm{C}$. Животные были угнетены, не охотно принимали корм и воду, реагировали на внешние раздражители. Ветофен 5 \% им вводили внутривенно, двукратно, с интервалом в 24 часа. После первого введения температура снизилась в течение 25 минут до 38,7 и $38,9{ }^{0} \mathrm{C}$ от момента введения препарата. После второго введения в течение 35 минут снижение температуры было так же заметно на 0,4 и $0,3{ }^{0} \mathrm{C}$. В последующем температура у животных не поднималась выше $38,5^{\circ} \mathrm{C}$.

Суке опытной группы после овариогистерэктомии с гнойным истечением из операционной раны, расхождением постоперационных кожаных швов, отеком перираневого поля и его болезненности при пальпации, с температурой тела была в пределах $39,5-39,9{ }^{0} \mathrm{C}$ испытуемый препарат вводили подкожно, 3-х кратно, с интервалом в 24 часа. Жаропонижающий эффект наступал в течение 20-30 минут после введения ветофена 5 \%-го и после третьей инъекции температура находилась в пределах $38,4-38,6{ }^{0} \mathrm{C}$.

После введения препарата данным животным отмечали обезболивающий эффект, проявлявшийся в успокоении животного и уменьшении угнетения, а также снижалась болезненность при пальпации перираневого поля, несколько уменьшалась и местная температура.

У собак при артрозе ветеринарный препарат «Ветофен 5\%» вводили четырехкратно, а при дисплазии тазобедренного сустава - трехкратно с интервалом в 24 часа, подкожно. Через 30-40 минут после введения препарата отмечали уменьшение болезненности суставов при пальпации и хромоты, увеличение двигательной активности и снижение угнетения. Данный эффект сохранялся не менее 8 - 10 часов.

При фиброзно-кистозной мастопатии с явлением мастита сукам опытной группы ветеринарный препарат «Ветофен 5 \%» назначали курсом на 5 дней подряд, 1-е введение внутривенно, а последующие подкожно, один раз в сутки. Температура тела после первого (внутривенного) введения исследуемого препарата снижалась до физиологической нормы через 22-25 минут, а с 4-х суток лечения оставалась в ее пределах. Уменьшалась болезненность молочной железы и выделения из нее. Средняя продолжительность мастита у животных составила 5-7 дней. Фиброкистозные образования за это время несколько уменьшились в размере из-за снижения степени отечности молочной железы. У животных контрольной группы отмечались, которым применяли известный препарат из группы НППВ «Флексопрофен 2,5 \%» отмечалась сходная динамика клинических признаков. Видимых негативных явлений при применении собакам ветеринарного препарата «Ветофен 5\%» 
установлено не было. У отдельных собак при подкожном введении регистрировали беспокойство. Болезненность на месте подкожного введения препарата была кратковременной.

Заключение. Ветеринарный препарат «Ветофен 5\%», в комплексной терапии при инфекционно-воспалительных заболеваниях собак и патологиях с болевым синдромом обладает выраженным жаропонижающим, анальгезирующим и противовоспалительным эффектом, не уступающим известным препаратам аналогичного действия.

Литература. 1. Щербаков, Г.Г. Справочник ветеринарного терапевта / Г.Г. Щербаков [и др.]; под ред. проф. Г.Г. Щербакова. - СПб.: Лань, 2009. - 656 с. 2. Тили, П.Л. Болезни кошек и собак /П.Л. Тили, Ф. Смит. - М.: ГЭОТАР-Медиа, 2010. - 625 с. 3. Профессиональная этика и деонтология ветеринарной медицины / А.А. Стекольников, Ф.И. Василевич, Э.И. Веремей, А.И. Ятусевич. - СПб.: Лань, 2015. - 448 с. 4. Карамян, А.С. Клиническая оценка влияния лекарственных форм карпрофена / А.С. Карамян, А.Ю. Савочкина // Международный научноисследовательский журнал. - 2017. - № 12 (66) 76 - 79. 5. Кемельман, Е.Л. Оценка частоты возникновения гастроэнтерологических осложнений при назначении собакам карпрофена в комбинации с омепразолом /Е.Л. Кемельман, К.С. Варенов, А.А. Архипова // Российский ветеринарный журнал. Мелкие домашние и дикие животные. - 2015. - № 1. - С. 16 - 19. 6. Пламб Дональд, К. Фармакологические препараты в ветеринарной медицине / Пер. с англ. / В двух томах. Том 1. (А-Н) - М.: Издательство Аквариум, 2019. - 1040 с. 7. Соколов, В. Д. Фармакология : учебник / В. Д. Соколов. - 4-е изд., испр. и доп. - Санкт-Петербург : Лань, 2013. - $576 \mathrm{c}$.

\title{
THE EFFECTIVENESS OF VETOFEN 5\% FOR THE TREATMENT OF DOGS WITH DISEASES WITH PAIN AND INFLAMMATION
}

Petrov V.V. associative Ph.D., Matsinovich M.S. assist., Romanova E.V. assist., Master of Vet.medicine

(Vitebsk State Academy of Veterinary Medicine, Vitebsk, Republic of Belarus)

Summary. In the practice of providing veterinary care to dogs, there is a need for widespread use of non-steroidal anti-inflammatory drugs. However, many of them have complications and direct contraindications to the use of this type of animal. The veterinary drug Vetofen 5\% based on carprofen was tested. This drug has shown high efficiency, and no side effects on the dog's body have been identified.

Key words: carprofen, vetafen 5\%, dogs, pain syndrome, inflammation.

УДК615.277.3:616.441-006.66:636.7

\section{ИСПОЛЬЗОВАНИЕ ЗАМЕСТИТЕЛЬНОЙ ТЕРАПИИ И ПРОТИВООПУХОЛЕВЫХ ПРЕПАРАТОВ ПРИ АДЕНОКАРЦИНОМЕ ЩИТОВИДНОЙ ЖЕЛЕЗЫ У СОБАКИ}

Петрова Е.К., студент

Научный руководитель - СабирзяноваЛ. И., к.в.н., асс. (ФГБОУ ВО СПбГУВМ, Россия)

\begin{abstract}
Аннотация.На данный момент онкологические заболевания у животных встречаются достаточно часто, и необходимо понимать, какие лекарственные средства нужно использовать при том или ином новообразовании [1].Рак щитовидной железы (РЩЖ) - злокачественная опухоль, развивающаяся из железистого эпителия щитовидной железы.При лечении аденокарциномы щитовидной железынеобходимо использовать заместительную терапию и противоопухолевые препараты. Данные лекарственные средства способствуют поддержанию уровня гормонов этого органа эндокринной системы и могут предотвратить дальнейшее развитие метастазов.
\end{abstract}


Ключевые слова: аденокарцинома щитовидной железы, поддерживающая терапия, противоопухолевые препараты

Аденокарцинома щитовидной железы является злокачественным новообразованием. В случае отсутствия метастазов проводится удаление поражённого органа - тиреоидэктомия. При наличии метастазов проводится комбинированная терапия[2].

В ветеринарной клинике Кировского района города Санкт-Петербурга в 2021 году в марте месяце был проанализирован клинический случайаденокарциномыдевятилетнего кобеля породы бигль по кличке «Юкки», 15 кг.На осмотре обнаружили у животного новообразование щитовидной железы и рекомендовали пациенту проведение ультразвуковой диагностики органа, также был сдан анализ на определение гормона Т4. Уровень тироксина составлял 46,47 нмоль/л, что входит в пределы референтных значений.По результатам ультразвукового исследования было выявлено два неоднородных образования на обеих долях щитовидной железы. Животное направили для консультации к онкологу. После последних анализов и УЗИ, жалоб на состояние у собаки не было.Была взята кровь для исследованияионизированного кальция, уровень которого составил 1,31 ммоль/л, что входит в диапазон референтных значений, также была проведена компьютерная томография.По результатам КТ обнаружено, что доли правой и левой щитовидной железы увеличены. Правая доля имеет округлый кистеобразный очаг, левая - множественные гиподенсные очаги. Признаки метастазирования в лёгких и иных органах и тканях выявлены не были.Рекомендовано проведение двусторонней тиреоидэктомии.После проведения операции, на протяжении всего пребывания собаки в клинике контролировался уровень ионизированного кальция. Показатели не превышали референтных значений, и колебались в диапазоне от 1,26 до 1,38 ммоль/л.

После операции назначена заместительная терапия с использованием препарата «Эутирокс». Животному рекомендовалось давать по одной таблетке (150 мкг) 2 раза в день за 30 минут до кормления, длительно.Препарат «Эутирокс» выпускается немецкой компанией Merck.Активным веществом данного препарата является левотироксин натрия, синтетический изомер тироксина. В почках и печени левотироксин превращается в трийодтиронин, переходит в клетки организма и влияет на развитие и рост тканей, а также на обмен веществ [3].Левотироксин сильно напоминает естественный гормон, вырабатываемый щитовидной железой. Таким образом, с помощью «Эутирокса» можно восполнить потребность организма в гормоне Т4. Помимо этого, данный препарат подавляет ТТГ и применяется при лечении больных с онкологическими заболеваниями щитовидной железы. Снижение уровня тиреотропного гормона очень важно в послеоперационном лечении рака щитовидной железы с целью снижения риска рецидива.

Через две недели был назначенпротивоопухолевый препарат«Палладия» 50 мг 2 раза в неделюна длительный срок.При этом владелец был предупреждён о том, что эффективность лекарственного средства «Палладия» при карциноме щитовидной железы окончательно не определена. Однако в ходе некоторых исследований данный препарат демонстрировал активность при лечении сарком и карцином. В отличии от «Эутирокса» препарат «Палладия» является исключительно ветеринарным. Он используется для лечения онкологических заболеваний у собак и представляет собой фосфат тоцераниба. В статьях, опубликованных в журнале «VeterinaryandComparativeOncology» в 2012 году, говорится о том, что при лечении собаки породы ши-тцу с саркомой щитовидной железы и метастазами в лёгких тоцеранибом,привело к частичному регрессу первичной опухоли и полному регрессу лёгочных метастазов[4].«Палладия» ингибирует тирозинкиназы (ферменты, способствующие разрастанию опухолей),таким образом, оказывая противоопухолевое действие. Препаратбылодобрен FDA (U.S. Food and drug administration) в 2009 году.В том же году было проведено исследование Американским онкологическим обществом. Целью исследования было определить процент больных, у которых наблюдается объективный ответ (частота объективного ответа) после лечения опухолей тучных клеток у собак фосфатом тоцераниба. Вторичными целями являлось определение скорости биологического ответа, безопасности и 
качества жизни животных. В ходе исследования было выяснено, что «Палладия» обладает биологической активностью в отношении тучных клеток у собак и может применяться для непрерывного лечения [5].Согласно статье, выпущенной по итогам конференции «Veterinaryoncologyroundtable», проходившей в 2017 году, ветеринары онкологи на данный момент используют более низкую дозу препарата до 2,75 мг/кг, а не 3,25 мг/кг, как указано на этикетке. Снижение дозы было связано с возникновением у пациентов побочных эффектов, а эффективность более низких доз подтверждена результатами фармакологических исследований.Врачи убеждены, что хотя побочные эффекты и возможны, эти проблемы можно решить,уменьшив дозу препарата [6].

Через месяц после проведённой операции пациентом была сдана кровь на определение гормона Т4 в крови по назначению врача. Уровень тироксина составил 28,6 нмоль/л, что входит в диапазон референтных значений.

После выполненной тиреоидэктомии«Юкки» получал заместительную терапию в форме препарата «Эутирокс» и противоопухолевый препарат «Палладия». Уровень гормона T4 за весь период лечения не выходил за пределы референтных значений. До проведённой тиреоидэктомии он составлял 46,47 нмоль/л, после проведения операции уровень гормона снизился в 1,6 раза, но так и остался в диапазоне референтных значений. Во многом этому способствовала заместительная терапия. На данный момент эффективность препарата «Палладия» при карциноме щитовидной железы окончательно не определена. Его использование при похожих клинических случаях в будущем поможет сделать вывод о действии фосфата тоцераниба при данном онкологическом заболевании.

Литература.1.Гусева В.А., Семёнов Б.С. Тромбоцитарнаяаутоплазма как альтернатива гормональной терапии в дерматологии мелких домашних животных // Естественные науки и медицина: теория и практика: Сб. ст. по матер. хххі-хххіімеждунар. науч.-практ. конф. № 23(19). - Новосибирск: Сибак, 2021. - с. 21-24.2. Вахрушева Т. И. Онкология: учебное пособие. Красноярск: КрасГАУ, 2018. С130-132.3.Описание лекарственного препарата Эутирокс (Euthyrox) [Электронный pecypc] // Справочник Видаль "Лекарственные препараты в России" URL: https://www.vidal.ru/drugs/euthyrox_32016 (дата обращения: 06.04.21)4. Cheryl London, TamraMathie, Nicole Stingle, Craig Clifford, Siobhan Haney, et all. Preliminary evidence for biologic activity of toceranib phosphate (Palladia $\left.{ }^{\circledR}\right)$ in solid tumors //Vet Comp Oncol. 2012 Sep; 10(3).pp.194-205.5.CherylA. London,PhyllisB. Malpas, StaceyL. Wood-Follis, etall. Multi-center, Placebo-controlled, Double-blind, Randomized Study of Oral Toceranib Phosphate (SU11654), a Receptor Tyrosine Kinase Inhibitor, for the Treatment of Dogs with Recurrent (Either Local or Distant) Mast Cell Tumor Following Surgical Excision// Clinical Cancer Res. 2009 Jun 1;15(11). P.3856.6. Oncology roundtable 2 [Электронныйресурс] // Zoetis united states URL: https://www.zoetisus.com/products/dogs/palladia/faq.aspx(датаобращения: 06.04.21).

\section{USAGE OF REPLACEMENT AND ANTINEOPLASTIC THERAPYFOR THYROID} CARCINOMA IN DOGS

Petrova E.K.

Scientific adviser - Sabirzyanova L. I., Ph.D., Ass.

(FSBEI HE St.Peterburg SUVM, Russia)

Summary.A lot of animals suffer from oncological diseases now a days, thus it is very important to understand what kind of medicine we should use to overcome them. Thyroid cancer is a malignant tumor which develops from the glandular epithelium of the thyroid gland.In order to treat thyroid carcinoma replacement and antineoplastic therapy is to be used. Such drugs help to maintain the level of thyroid hormones and can prevent development of metastases.

Key words:thyroid carcinoma,replacement therapy,antineoplastic drugs 


\title{
ВЛИЯНИЕ СТАФИЛОКОККОВОЙ ВАКЦИНЫ НА АНТИГЕНПРЕЗЕНТИРУЮЩИЕ КЛЕТКИ МОЛОЧНОЙ ЖЕЛЕЗЫ
}

асп. Погодаева П.С., проф., д.б.н., Карпенко Л.Ю.

(ФГБОУ ВО СПбГУВМ, Россия)

\begin{abstract}
Аннотация. Локальная антигенная стимуляция молочной железы с помощью стафилококковой вакцины была предложена в качестве альтернативного метода лечения и профилактики мастита достаточно давно. Однако механизмы формирования локального иммунитета молочной железы до настоящего времени не были подробно изучены. В своей работе мы на примере воздействия стафилококковой вакцины происследовали изменения количественных показателей антигенпрезентирующих клеток макрофагальной природы в молочной железе на различных этапах лактации.Согласно полученным результатам, показатели макрофагальных клеток у иммунизированных животных выше в 1,7- 2,2 раза на всех сроках исследования.
\end{abstract}

Ключевые слова: мыши, молочная железа, стафилококковая вакцина, антигенпрезентирующие клетки, локальная антигенная стимуляция, лактация

Лечение маститов является одной из актуальнейших задач в молочном скотоводстве[1]. Локальная антигенная стимуляция молочной железы с помощью стафилококковой вакцины была предложена в качестве альтернативного метода лечения и профилактики мастита достаточно давно. Данный метод доказал свою эффективность и преимущество над методами антибиотикотерапии. Вакцина формирует напряженный и достаточно длительный иммунитет к основным возбудителям маститов - бактериям вида стафилококков, при этом не оказывая негативного влияния на молочную продукцию, в отличии от антибиотиков.

Согласно нашей рабочей гипотезе, первичным звеном локального иммунитета, воспринимающим действие вакцины, могут являться антигенпрезентируюцие клетки макрофагальной природы[2,3]. Поэтому, в своей работе мы на примере воздействия стафилококковой вакцины проследовали изменения количественных показателей клеток макрофагальной природы в молочной железе на различных этапах лактации[4]. Для проведения исследования были заявлены следующие цели: обнаружить тканевые макрофаги в молочной железе лактирующих мышей, подсчитать количество макрофагов у мышей опытной и контрольной группы на разных этапах лактации, сравнить показатели иммунизированных и не иммунизированных особей и оценить изменения в количестве макрофагов на разных этапах лактации.

Опыт был проведён согласно принципам биоэтики[5].Мышей опытной группы за 5 дней до родов обработали фабричной стафилококковой вакциной (производство АО «Биомед» им. И.И.Мечникова, Россия),введенной подкожно в область молочных желез. Для контрольной группы использовался стерильный изотонический раствор натрия хлорида, по аналогичной схеме.Отбор патологоанатомического материала проводился в начале первой, второй и третьей недель лактации, для наблюдения динамики изменений.Гисто-срезы окрашивали гематоксилин-эозином.Подсчет клеток проводился методом световой микроскопии в ста полях зрения, в ходе чего были получены следующие результаты:

\begin{tabular}{|l|l|l|l|}
\hline Среднее количество клеток макрофагального ряда в ста полях зрения \\
\hline & 1 неделя лактации & 2 неделя лактации & 3 неделя лактации \\
\hline Опытная группа & $69,6 \pm 2,07^{*}$ & $78,2 \pm 2,38^{*}$ & $50,8 \pm 2,38^{*}$ \\
\hline Контрольная группа & $38,3 \pm 2,51^{*}$ & $47,3 \pm 1,52^{*}$ & $23,3 \pm 1,52^{*}$ \\
\hline
\end{tabular}

$* \mathrm{P}<0,05$

Согласно полученным результатам, наибольшее количество макрофагальных клеток приходится на период второй недели лактации, как у опытной, так и у контрольной группы. В свою очередь, на третьей неделе наблюдается значительное снижение числа 
антигенпрезентирующих клеток, что можно связать с завершением лактации. Кроме того, полученные данные свидетельствуют о повышении иммунной активности макрофагальных клеток молочной железы у животных, подвергнутых иммунизации стафилококковой вакциной, что подтверждается более высокими числовыми значениями в опытной группе - в 1,7-2,2 раза на всех сроках исследования.

Литература: 1. Барышев, В. А. Сравнительная оценка лечебной эффективности препаратов "Мастисан A" и "Мастифит" при субклиническом мастите коров / В. А. Барышев // Международный вестник ветеринарии. - 2016. - № 2. - С. 34-37., 2. Погодаева, П. С. Влияние различных термостабильных антигенов на формирование локального иммунитета молочной железы / П. С. Погодаева, Л. Ю. Карпенко, В. С. Понамарев // Международный вестник ветеринарии. - 2021. - № 1. - C. 247-251. - DOI 10.17238/issn2072-2419.2021.1.247., 3. Погодаева, П. С. Особенности формирования локального иммунного ответа молочной железы / П. С. Погодаева, В. С. Понамарев // Знания молодых для развития ветеринарной медицины и АПК страны : Материалы международной научной конференции студентов, аспирантов и молодых ученых, Санкт-Петербург, 19-20 ноября 2020 года. - Санкт-Петербург: СанктПетербургский государственный университет ветеринарной медицины, 2020. - С. 285-286., 4. Погодаева, П. С. Некоторые аспекты локального иммунного ответа в тканях молочной железы / П. С. Погодаева, Л. Ю. Карпенко, В. С. Понамарев // Международный вестник ветеринарии. - 2020. - № 4. - С. 129-133. - DOI 10.17238/issn2072-2419.2020.4.129, 5. Анализ нормативных документов, регламентирующих требования к проведению доклинических исследований ветеринарных препаратов / С. В. Герасимов, В. С. Понамарев, Н. Л. Андреева [и др.] // Вопросы нормативно-правового регулирования в ветеринарии. - 2020. - № 3. - С. 27-29. DOI 10.17238/issn2072-6023.2020.3.27.

\title{
INFLUENCE OF STAPHYLOCOCCAL VACCINE ON ANTIGEN-PRESENTING BREAST CELLS
}

asp. Pogodaeva P.S., prof., Doctor of Biological Sciences, Karpenko L.Yu. (FSBEI HE St.Peterburg SUVM, Russia)

SummaryLocal antigenic stimulation of the mammary gland using staphylococcal vaccine has been proposed as an alternative method of treatment and prevention of mastitis for a long time. However, the mechanisms of formation of local immunity of the mammary gland have not yet been studied in detail. In our work, using the example of the effect of staphylococcal vaccine, we studied changes in the quantitative indicators of antigen-presenting cells of macrophage nature in the mammary gland at various stages of lactation. According to the results obtained, the indices of macrophage cells in immunized animals are 1.7-2.2 times higher at all periods of the study.

Key words: mice, mammary gland, staphylococcal vaccine, antigen-presenting cells, local antigenic stimulation, lactation

УДК 616-097:611.69.018.1

\section{СРАВНИТЕЛЬНОЕ ВЛИЯНИЕ РАЗЛИЧНЫХ ТЕРМОСТАБИЛЬНЫХ АНТИГЕНОВ НА АНТИГЕНПРЕЗЕНТИРУЮЩИЕ КЛЕТКИ МОЛОЧНОЙ ЖЕЛЕЗЫ} асп. Погодаева П.С., проф., д.б.н., Карпенко Л.Ю. (ФГБОУ ВО СПбГУВМ, Россия)

\begin{abstract}
Аннотация.Проблема широкого распространения маститов бактериальной этиологии в современных животноводческих комплексах все еще является актуальной. Известно, что основными возбудителями мастита являются бактерии группы стафилококков, стрептококков и кишечная палочка.В своем исследовании мы изучаем механизмы воздействия различных термостабильных антигенов, соответствующих основным возбудителям мастита на клеточные факторы локального иммунитета молочной железы. В результате проделанного опыта было установлено достоверное повышение количества антигенпрезентирующих клеток
\end{abstract}


у иммунизированных мышей во всех опытных группах, что позволило сделать вывод о наличии стимулирующего влияния вакцин на факторы клеточного иммунитета молочной железы.

Ключевые слова:мыши, молочная железа, термостабильные антигены, антигенпрезентирующие клетки, локальная антигенная стимуляция

Известно, что основными возбудителями мастита являются бактерии групп стафилококков, стрептококков и кишечная палочка[1]. Учитывая всё более нарастающую антибиотикорезистентность данных возбудителей, применяемые ранее методы лечения с использованием антибиотиков стремительно теряют свою эффективность. В связи с этим становится актуальной разработка альтернативных методов лечения и профилактики бактериальных маститов[2]. Одним из перспективных для изучения и усовершенствования является метод локальной антигенной стимуляции[3].

Большое количество лимфоидной ткани и иммунокомпетентных клеток в молочной железе способствует реализации локального иммунного ответа и делает её благоприятной мишенью для проведения локальной антигенной стимуляции. Однако механизм формирования локального иммунного ответа молочной железы на данный момент остается малоизученным[4].

Целью нашей работы было осуществить локальную антигенную стимуляцию молочной железы на опытной модели лакирующих мышей, отобрать патологоанатомический материал молочных желез у исследуемы особей, подсчитать количество клеток макрофагальной природы в полученных гистологических препаратах и ссравнить показатели полученные в результате обработки мышей различными термостабильными антигенами и показатели не иммунизированных особей.

Опыт проводился согласно принципам биоэтики[5]. Мышей составляющих опытные группы за 5 дней до родов обработали фабричными вакцинами: стафилококковой вакциной (производство АО «Биомед» им. И.И.Мечникова, Россия), вакциной СТАРТВАК (STARTVAK) (производство Laboratorios Hipra, Spain) и вакцинойПРЕВЕНАР 13 (производствоНПО ПетроваксФарм, Россия) введенными подкожно в область молочных желез. Для контрольной группы использовался стерильный изотонический раствор натрия хлорида, по аналогичной схеме. Отбор патологоанатомического материала проводился на второй неделе лактации.Гисто-срезы окрашивали гематоксилин-эозином.

В некоторых полях зрения были обнаружены искомые клетки макрофагальной природы.Подсчет клеток проводился методом световой микроскопии в ста полях зрения. При этом среднее количество макрофагов в ста полях зрения у группы иммунизированной стафилококковой вакциной равняется 70,1 $\pm 0,69$ (P<0,05), у группы иммунизированной

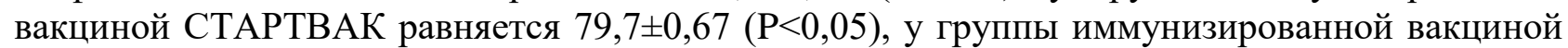

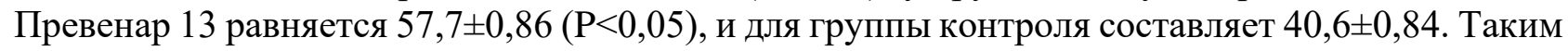
образом, можно сделать вывод, все показатели опытных групп достоверно превышают показатели контрольной группы: стафилококковая вакцина на 75\%, вакцина СТАРТВАК на 97,5\% и Превенар 13 на 42,5\%, что позволяет сделать вывод о иммунной активности макрофагальных клеток молочной железы и наличии стимулирующего влияния использованных вакцин.

Литература: 1. Барышев, В. А. Влияние Мастифита на биохимические показатели молока лактирующих коров / В. А. Барышев // Международный вестник ветеринарии. - 2017. - № 1. - С. 18-21., 2. Погодаева, П. С. Влияние различных термостабильных антигенов на формирование локального иммунитета молочной железы / П. С. Погодаева, Л. Ю. Карпенко, В. С. Понамарев // Международный вестник ветеринарии. - 2021. - № 1. - С. 247-251. - DOI 10.17238/issn2072-2419.2021.1.247., 3. Погодаева, П. С. Особенности формирования локального иммунного ответа молочной железы / П. С. Погодаева, В. С. Понамарев // Знания молодых для развития ветеринарной медицины и АПК страны : Материалы международной научной конференции студентов, аспирантов и молодых ученых, Санкт-Петербург, 19-20 ноября 2020 года. - Санкт-Петербург: Санкт-Петербургский государственный университет 
ветеринарной медицины, 2020. - С. 285-286., 4. Погодаева, П. С. Некоторые аспекты локального иммунного ответа в тканях молочной железы / П. С. Погодаева, Л. Ю. Карпенко, В. С. Понамарев // Международный вестник ветеринарии. - 2020. - № 4. - С. 129-133. - DOI 10.17238/issn2072-2419.2020.4.129, 5. Анализ нормативных документов, регламентирующих требования к проведению доклинических исследований ветеринарных препаратов / С. В. Герасимов, В. С. Понамарев, Н. Л. Андреева [и др.] // Вопросы нормативно-правового регулирования в ветеринарии. - 2020. - № 3. - C. 27-29. - DOI 10.17238/issn20726023.2020.3.27.

\section{COMPARATIVE EFFECT OF DIFFERENT THERMOSTABLE ANTIGENS ON ANTIGEN-PRESENTING CELLS OF MAMMARY GLAND}

asp. Pogodaeva P.S., prof., Doctor of Biological Sciences, Karpenko L.Yu. (FSBEI HE St.Peterburg SUVM, Russia)

Summary. The problem of widespread mastitis of bacterial etiology in modern livestock complexes is still relevant. It is known that the main causative agents of mastitis are bacteria of the group of staphylococci, streptococci and E. coli. In our work, we study the mechanisms of action of various thermostable antigens corresponding to the main causative agents of mastitis on the cellular factors of local immunity of the mammary gland. As a result of the experiment, a significant increase in the number of antigen-presenting cells was found in immunized mice in all experimental groups, which made it possible to conclude that there is a stimulating effect of vaccines on factors of cellular immunity of the mammary gland.

Key words: mice, mammary gland, thermostable antigens, antigen-presenting cells, local antigenic stimulation

УДК 619:618.14-002:636.2

\section{РАСПРОСТРАНЕНИЕ И ЛЕЧЕНИЕ СУБКЛИНИЧЕСКОГО ЭНДОМЕТРИТА У КОРОВ В ООО «СИБИРСКАЯ НИВА» \\ Попов Ю.Г. ${ }^{1}$, проф., д. в. н., А.В. Ляхова ${ }^{2}$, вет. спец., к. в. н. \\ $\left({ }^{1}\right.$ ФГБОУ ВО «Новосибирский ГАУ», Россия) \\ ( ${ }^{2} \mathrm{OOO}$ «Сибирская Нива» Новосибирской области, Россия)}

Аннотация.Исследования, проведенные в ООО «Сибирская Нива» Новосибирской области, выявили высокий процент $(28,1 \%)$ распространения субклинического эндометрита у коров. С целью устранения патологии в период охоты внутриматочно применили хинасепт-гель («Росветфарм») в дозе 100 мл. Однократное внутриматочное введение хинасепт-геля обеспечило повышение оплодотворяемости коров на 50,0 \%, снижение индекса осеменения до 1,5 и сокращение сервис-периода на 24,5 дня.

Ключевые слова:эндометрит субклинический, распространение, лечение, хинасепт-гель.

Многочисленные источники современной литературы свидетельствуют о том, что оплодотворяемость коров после отела при осеменении в первую охоту не превышает 15,022,0\% [1-3]. Среди причин, сдерживающихрост этого показателя, важное значение имеет субклинический (скрытый) эндометрит.

В зимне-весенний период 2020 года на молочном комплексе ООО «Сибирская Нива» мы провели обследование на субклинический (скрытый) эндометрит в первую после отела охоту 52-х клинически здоровых коров и 12-ти животных после 1-2-х безрезультатных осеменений с использованием физико-химической (по Ю.Н. Попову) и биологической (по А.Н. Флегматову) проб. Диагноз на субклинический (скрытый) эндометрит считали установленным, если получали положительные реакции с течковой слизью по обеим пробам.

Эндометрит в скрытой форме был диагностирован по обеим положительным пробам у $18(28,1 \%)$ исследованных животных. В том числе из 52 клинически здоровых коров, исследованных в первую после отела охоту, выявлено 15 больных (28,8 \%), а среди коров, 
безрезультатно осемененных 1-2 раза после отела, процент обнаружения скрытой формы эндометрита был выше на 4,5 \%.

Результаты сопоставления времени от отела до проявления первой охоты и частоты проявления у коров скрытого эндометрита представлены нами в таблице.

Таблица

Сопоставление времени от отела до первой охоты с частотой проявления

у коров заболевания скрытым эндометритом

\begin{tabular}{|l|l|l|l|}
\hline $\begin{array}{l}\text { Интервал от отела до } \\
\text { первой охоты, дней }\end{array}$ & $\begin{array}{l}\text { Исследовано коров, } \\
\text { голов }\end{array}$ & $\begin{array}{l}\text { Выявлено больных субклиническим } \\
\text { эндометритом }\end{array}$ \\
\cline { 2 - 4 } & 24 & 9 & $\%$ \\
\hline $31-60$ & 22 & 6 & 37,5 \\
\hline $61-90$ & 18 & 3 & 27,3 \\
\hline Более 91 & 22 & 16,7 \\
\hline
\end{tabular}

Из данных, приведенных в таблице, видно, что частота проявления субклинического эндометрита у коров снижается с увеличением времени от отела до первой охоты. Самая высокая заболеваемость коров скрытой формой эндометрита приходится на первые два месяца после отела.

Из 64 коров, исследованных на субклинический (скрытый) эндометрит, у 50 была спонтанная охота, а у 14 животных - индуцированная. Сопоставление частоты обнаружения эндометрита у коров со спонтанной и индуцированной охотой показало, что у вторых заболевание регистрировали в 3 раза чаще (24,4 и 73,6 \% соответственно).

С целью устранения скрытого эндометрита и повышения оплодотворяемости коров применили Хинасепт-гель (разработчик и изготовитель ЗАО «Росветфарм», п. Краснообск Новосибирской области). Коровам, течковая слизь у которых дала положительную реакцию на скрытый эндометрит, вместо осеменения внутриматочно вводили Хинасепт-гель в дозе 100 мл при помощи шприца с катетером. Перед введением в матку препарат подогревали до температуры тела. В следующую охоту животных осеменяли. По истечении 1,5-2 месяцев после осеменения учитывали его результаты путем ректального исследования на стельность и УЗИ-диагностики.

Полученные результаты свидетельствуют о том, что однократное внутриматочное введение Хинасепт-геля обеспечивало повышение оплодотворяемости коров на 50,0 \%, снижение индекса осеменения до 1,5 и сокращение сервис-периода на 24,5 дня.

Литература. 1.ДорощукС.В.Современные проблемы и методы контроля воспроизводства в молочном скотоводстве /С.В. Дорощук, И.Ш. Шашиев // Вопросы нормативно-правового регулирования в ветеринарии. 2014. № 3. 2. Кухтина О.Н. Оплодотворяемость коров при первом и последующих осеменениях // Животноводство и ветеринарная медицина. 2015. № 3. 3. ДороховаЯ.Д. Влияние препарата «Маримикс 5:0» на минеральный обмен и воспроизводительную функцию высокопродуктивных коров / Я.Д. Дорохова, К.В. Племяшов // Международный вестник ветеринарии. 2016. № 4.

\section{DISTRIBUTION AND TREATMENT OF SUBCLINICAL ENDOMETRITIS IN COWSIN SIBIRSKAYA NIVA LLC}

Popov Yu.G., professor, doctor of veterinary sciences

Federal State Budgetary Educational Institution of Higher Education

"Novosibirsk State Agrarian University", Russia

Lyakhova A.V., veterinary specialist, candidate of veterinary sciences

SibirskayaNiva LLC, Novosibirsk region, Russia

Summary. Studies carried out in SibirskayaNiva LLC, Novosibirsk region, revealed a high percentage $(28.1 \%)$ of the distribution of subclinical endometritis in cows. In order to eliminate the pathology during the estrous period, Hinasept-gel ("Rosvetfarm") was used intrauterinely at a dose of $100 \mathrm{ml}$. A single intrauterine injection of Hinasept-gel provided an increase in cows' fertility by $50.0 \%$, a decrease in the insemination index to 1.5 and a reduction in the service period by 24.5 days. Key words: subclinical endometritis, distribution, treatment, Hinasept-gel. 


\title{
ОБЕСПЕЧЕНИЕ БЕЗОПАСНОСТИ И КАЧЕСТВА ПРОДУКЦИИ В СЕЛЬСКОМ ХОЗЯЙСТВЕ В РОССИЙСКОЙ ФЕДЕРАЦИИ
}

\author{
Попова О.С. к.вет.н., доц.каф. фармакологии и токсикологии \\ (ФГБОУ ВО СПбГУВМ, Россия)
}

\begin{abstract}
Аннотация. Продовольственная безопасность является одним из главных направлений обеспечения национальной безопасности страны в долгосрочном периоде. Все больше статей, препаратов и методов предлагает нам фармацевтическая индустрия, но необходимо менять подход к ведению хозяйства в целом. И, самое главное в ведении хозяйства, это не лечение, а профилактика. Причем не только эффективная, но и материально доступная.
\end{abstract}

Ключевые слова: безопасность, качество, сельское хозяйство, цифровизация

На Россию приходится более 5 \% мирового производства мяса птицы. Но, несмотря на ежегодную положительную динамику внутри РФ, ее доля в мире начинает снижаться из-за более быстрых темпов роста производства у стран - лидеров отрасли.Производство мяса бройлеров в мире в 2017 году составляло 94,5 млн т, а в 2020 году может превысить 100 млн T.

Мировым лидером по производству мяса остаются США, второе место у Китая, который начинает наращивать производство значительными темпами, третье место у Бразилии. Россия занимает четвертое место (если не считать ЕС как единое государство) с показателем более 4,7 млн т в год [4]. Положение могут менять вспышкивысококонтагиозных заболеваний, но в целом картина распределения зависит от возможностей ветеринарных врачей и ученых.

Согласно Указу Президента РФ от 21 января 2020 г. № 20 “Об утверждении Доктрины продовольственной безопасности Российской Федерации” [3] , продовольственная безопасность является одним из главных направлений обеспечения национальной безопасности страны в долгосрочном периоде, фактором сохранения ее государственности и суверенитета, важнейшей составляющей социально-экономической политики, а также необходимым условием реализации стратегического национального приоритета - повышение качества жизни российских граждан путем гарантирования высоких стандартов жизнеобеспечения.

Чтобы быть конкурентно способными, необходимо менять подходы:

1. Забота о благополучии животных: содержание, кормление. Факторы стресса и плохое благополучие животных могут повысить восприимчивость сельскохозяйственных животных к болезням, создавая микробный риск для потребителей.

2. Снижение затрат на лечение. Это будет возможно, если правильно проводить диагностику животных. Необходимо не только лечить то что «видно врачу при осмотре», но и рассматривать преморбидное состояние. Искать маркеры, которые запускают интоксикацию, которая и является спусковым механизмом в открытой форме заболевания.

3. Корректное устранение патологического состояния. Кроме правильной постановки диагноза, нужно и правильное лечение, корректировка течения патологического процесса. При этом, на данное время у ветеринарных врачей огромное количество препаратов, которые можно использовать в арсенале, это и химиотерапевтические средства, и эрготропики, и различного происхождения стимуляторы.

4. Но, самое главное в ведении хозяйства, это не лечение, а профилактика. Причем не только эффективная, но и материально доступная.

За последние 10лет, на середину 2021г.,по данным Научной электронной библиотекиеLIBRARY, при поиске ключевых слов: «безопасность продукции» написано порядка 490 тыс. статей по безопасности, из них почти 40 тыс., по данным Sciencedirect, за тот же временной промежуток при запросе «productsafety» всплывает около 400 тыс, а при запросе «productsafety, veterinarymedicine, medicinalproduct» около 3,5 тыс. результатов, с 
предложением конкретных препаратов и их модификаций. Все это говорит о том, что проблема актуальна и по сути решить ее с помощью «чудо-добавки» не удастся.

Исходя из вышеизложенного, нам предоставляется возможным решение данного вопроса с помощью создания линейки препаратов[1]., обладающих основой, матрицей[2], куда в зависимости от требований и показаниям можно наслаивать (добавлять) компоненты, с возможностью он -лайн конструктора. Это упростит работу ветеринарных фельдшеров и владельцев частных подворий. Так, нами разработана линейка фитосорбционных добавок, в основе которого универсальный сбалансированный комплекс, приемлемый для всех животных, в т.ч. для жвачных. В качестве дополнения используются растительные компоненты, проверенные как invitro, так и invivo, при этом есть возможность подбора (по патогенезу, клиническим показаниям, биохимическим тестам) нужного фармакологического действия, возможность выбора с заданным действием экстракты растений.

Использование фитосорбционных комплексов в ветеринарии в рамках перехода к высокопродуктивному и экологически чистому агрохозяйству и цифровизации производственных технологий, позволяет подбирать ветеринарному врачу нужный рецепт, исходя из диагноза и проведенных исследований. Это даёт возможности экологически чисто, безопасно и прогнозируемо использовать для всех видов животных.

И соблюдая подход: оценивая предморбидное состояние, правильно ставя диагноз, который возможно еще не как и не проявившим себя симптоматически, с помощью он лайнконструктора, создать фитосорбционный комплекс, с проверенными компонентами, и матрицей, для профилактики или лечения заболеваний.

Таким образом, все вышеизложенное, позволит получать качественную и безопасную продукцию, при низких затратах на лечение животных.

Литература. 1. Попова, О. С. Применение БАВ в сельском хозяйстве/ О. С. Попова, В. А. Барышев // Инновационные тенденции развития российской науки : Материалы ХІІІ Международной научно-практической конференции молодых ученых, Красноярск, 08-09 апреля 2020 года. - Красноярск: Красноярский государственный аграрный университет, 2020. - С. 87-89. 2.Барышев, В. А. Повышение эффективности современных сорбентов / В. А. Барышев, О. С. Попова, А. В. Свиридова // Международный вестник ветеринарии. - 2017. № 2. - C. 13-16. 3. https://www.garant.ru/products/ipo/prime/doc/73338425/ (дата обращения 20.04.2021г). 4. https://specagro.ru/news/202103/pticevodstvo-v-rossii-trendy-problemyperspektivy (дата обращения 20.04.2021г)

\title{
ENSURING THE SAFETY AND QUALITY OF PRODUCTS IN AGRICULTURE IN THE RUSSIAN FEDERATION.
}

Popova O.S. Phdof Veterinary Sciences, Associate Professor pharmacology and toxicology (FSBEI HE St.Peterburg SUVM, Russia)

Summary. Food security is one of the main directions of ensuring the national security of the country in the long term. More and more articles, preparations and methods are offered to us by the pharmaceutical industry, but it is necessary to change the approach to housekeeping as a whole. And, the most important thing in housekeeping is not treatment, but prevention. Moreover, it is not only effective, but also materially accessible.

Key words: safety, quality, poultry farming, digitalization

УДК 543.862/.862.34

\section{ОБЗОР НА СПЕКТРОФОТОМЕТРИЧЕСКИЙ МЕТОД ИССЛЕДОВАНИЯ АДСОРБЦИОННЫХ СВОЙСТВ СОРБЕНТОВ}

\author{
Радкевич А.В.- студ. 5 курса, ФВМ
}

Научный руководитель к.вет.н., доц. Попова О.С.

Аннотация: Спектрофотометрический анализ используется для изучения оптической плотности растворов. С помощью вычислений с этим показателем можно находить, в первую 
очередь, количественное содержание определённых компонентов раствора. Так, при различных длинах волн определяют количество белков, красителя, спиртов.

Ключевые слова: сорбенты, Спектрофотометрический анализ, адсорбционные свойства

Спектрофотометрический анализ используется для изучения оптической плотности растворов[2]. С помощью вычислений с этим показателем можно находить, в первую очередь, количественное содержание определённых компонентов раствора. Так, при различных длинах волн определяют количество белков, красителя, спиртов. Принцип метода заключается в сравнении оптических плотностей “нулевого" буфера или растворителя с раствором вещества-аналита. В основе использования спектрофотометрического метода лежит объединённый закон Бугера-Ламберта-Бера, через который можно пересчитать концентрацию исследуемого аналита в растворе. СФ достаточно проста в применении, не требует редких и дорогостоящих реактивов. Измерения проводят на спектрофотометре, длину волны устанавливают исходя из информации в общей или частной фармакопейной статье, либо из справочной литературы [4,1].

При исследовании фармакологической активности сорбентов выбор аналитического метода зависит от исследуемого вещества, моделирующего токсин, при этом необходимо понимать, какие трансформации могут происходить с ним как при воздействии с физиологическими средами, так и при контакте с сорбентами разных видов. Возможные и предпочтительные варианты анализа, как правило, представлены в государственной фармакопее [3]. Так, для высоких концентраций мочевины может использоваться титрометрия, а для определения концентраций желатина необходимо добавление буретова реактива.

При разработке новых активных фармацевтических субстанций необходим тщательный контроль и многократное исследование их на разных стадиях изготовления и по разным параметрам. На кафедре фармакологии и токсикологии СПбГУВМ ведётся разработка и улучшение технологии и рецептуры энтеросорбента на основе перлита, вермикулита и лигнины, а также рассматриваются варианты его усовершенствования различными фитодобавками, например, “Сангровит”. Особенность энтеросорбентов как лекарственных препаратов в том, что они проходят через желудочно-кишечный тракт с минимальными конформациями и выходят практически в неизменном виде. Именно поэтому важно выбирать вещества, имеющие большую сорбционную поверхность и обладающие низкой степенью взаимодействия как с другими веществами, так и с тканями организма. Входящий в состав исследуемого сорбента перлит химически инертен и не изменяет $\mathrm{pH}$ воды, а также является адсорбентом для различных красителей, масел и других веществ. Вермикулит также химически инертен, обладает высокой поглощающей способностью относительно воды и является асептическим материалом. Лигнин добавляется как источник неперевариваемой клетчатки.

Очевидно, что помимо разработки фармтехнологии, изучения свойств отдельных компонентов и их безопасности для здоровья животных, необходимо также исследовать эффективность итогового препарата относительно различных вероятно возможных токсинов, в том числе для понимания области применения лекарственного средства и изучения механизма его действия, фармакодинамики и фармакокинетики. Для исследования адсорбционной способности сорбента относительно молекул среднего размера используют раствор витамина В12 (цианокобаламина). Молекулярная масса этого кофермента составляет 1355 г/моль, то есть он занимает промежуточное положение между низкомолекулярными веществами, такими как мочевина, и веществами с высокой молекулярной массой, как белки.Цианокобаламин обладает высокой биологической активностью и сложной структурой, имеет в своём составе атом кобальта и циангруппу, при этом он не образуется тканями животного организма.Исследование оптической плотности растворов цианокобаламина проводят при длине волны 360 нм.

Таким образом, спектрофотометрический анализ образцов растворов цианокобаламина различной концентрации до и после добавления сорбента и биологически активных добавок 
позволяет определить адсорбционную способность сорбента в отношении молекул среднего размера, что позволяет сделать вывод об области применения разрабатываемого препарата и дальнейших перспектив его улучшения.

Литература. 1.Конорев, М. Р. Клиническая фармакология энтеросорбентов нового поколения / М. Р. Конорев // Вестник фармации. - 2013. - № 4(62). - С. 79-85. 2. Маркелов Д.А., Ницак O.В., Геращенко И.И. Сравнительное изучение адсорбционной способности медицинских сорбентов. Химико-фармацевтический журнал. Том 42, №7, 2008.3.ОФС.1.2.3.0021.15. 3. Определение адсорбционной активности энтеросорбентов/ГФ РФ ХIV.-т.1.-С.1096-1099.4. 4. Барышев В.А. Повышение эффективности современных сорбентов / В. А. Барышев, О. С. Попова, А. В. Свиридова // Международный вестник ветеринарии. - 2017. - № 2. - С. 13-16.

\section{A REVIEW ON THE SPECTROPHOTOMETRIC METHOD OF STUDYING THE ADSORPTION PROPERTIES OF SORBENTS}

A.V. Radkevich - 5th year student, FVM

Scientific adviser Ph.D., Assoc. Popova O.S.

Summary: Spectrophotometric analysis is used to study the optical density of solutions. With the help of calculations with this indicator, it is possible to find, first of all, the quantitative content of certain components of the solution. So, at different wavelengths, the amount of proteins, dyes, alcohols is determined.

Key words: sorbents, spectrophotometric analysis, adsorption properties.

УДК 615.275 .4

ПРИМЕНЕНИЕ ИММУНОСТИМУЛЯТОРОВ В ВЕТЕРИНАРНОЙ МЕДИЦИНЕ

Рафекова Э.В., Ломбоева С.С. доц. канд.фарм.наук

(ФГБОУ ВО «Иркутский ГАУ им. А.А. Ежевского», Россия)

Аннотация. На данный момент на рынке ветеринарной фармации достаточно большое количество препаратов, относящихся к группе иммуностимуляторов с разными механизмами действия. В данной статье проведена работа по обзору лекарственных препаратов данной группы, внесенных в государственный реестр и выявлению самых популярных препаратов в ветеринарной практике города Иркутска.

Ключевые слова: иммунитет, иммуномодуляторы, иммуностимуляторы

Иммуностимуляторы относятся к иммунотропным лекарственным препаратам, лечебный эффект которых связан с восстановлением и усилением функций клеток иммунитета. Иммунитет в организме животных и человека выполняет важную роль по сохранению постоянства внутренней среды организма путем своевременного распознавания и ликвидации эндогенных и экзогенных антигенов. Данные функции осуществляются с помощью врожденного и приобретенного иммунитета. В связи с существующей эпидемиологической ситуацией в мире, на рынке фармакологических средств как гуманитарной, так и ветеринарной медицины, возрос спрос на препараты с иммуномодулирующей способностью [1].

Так как многие лекарственные средства обладают различной степенью иммуностимулирующих свойств, то, как таковой, общепринятой классификации иммуномодуляторов нет. Иммуномодуляторы принято классифицировать в основном по происхождению: микробные и вирусные, костномозговые и тимические, цитокины и нуклеиновые кислоты, а также химические и растительные.

До сих пор для данной группы препаратов не разработаны четкие инструкции: показания и противопоказания, в каких условиях их применение необходимо, а при каких категорически запрещено, нет определенного плана назначения того или иного препарата, практически нет исследований в области совместимости с другими препаратами. Поэтому 
закономерно наблюдать, что препараты, стимулирующие иммунитет, имеют достаточно спорную репутацию среди практикующих врачей, использование препаратов данной группы рассматривается многими врачами со скептицизмом [2].

Применение иммуностимуляторов, согласно рекомендациям производителей, в комплексной терапии с другими препаратами позволяет повысить эффективность и сократить продолжительность лечения, значительно уменьшить использование антибиотиков, глюкокортикостероидов, увеличить срок ремиссии.

Механизмы действия препаратов данной группы различны у разных препаратов - одни нацелены на усиление устойчивости организма за счет активации макрофагов, фагоцитоза, цитокинов и стимуляции продукции интерферонов и клеток тимуса, другие же нацелены на подавление синтеза белков возбудителей, но в основном у препаратов комбинированный механизм действия [4].

Цель данной работы: провести обзор доступных ресурсов, включающих сведения по применению иммуностимулирующих средств в ветеринарной медицине, изучить Государственный реестр лекарственных средств для ветеринарного применения на сайте Федеральной службы по ветеринарному и фитосанитарному надзору и выявить наиболее популярные и широко используемые, проанализировать применение этих средств в ветеринарных клиниках Иркутской области.

Государственный реестр лекарственных средств для ветеринарного применения размещен на сайте Федеральной службы по ветеринарному и фитосанитарному надзору и включен в поисковую информационную систему «Гален» [5]. В данный реестр включены только разрешенные к применению в ветеринарной медицине в настоящее время лекарственные препараты. Нами была проведена тщательная работа по поиску иммуностимуляторов, включенных в реестр, и анализ сведений о них. Данные исследования представлены ниже.

\section{Препараты естественного происхождения}

Гамапрен. В состав входят фосфорилированныеполиизопреноиды шелковицы. Подавляет синтез вирусных белков, стимулирует продукцию интерферонов и других цитокинов, повышает естественную резистентность организма животных.

Лигфол. Содержит гуминовые вещества, действующие иммунотропно за счет неспецифического повышения бактерицидной, лизоцимной активности сыворотки крови, стимулирования функции органов тимико-лимфатической системы и фагоцитоза.

Нуклеинат натрия. Натриевая соль нуклеиновой кислоты дрожжевых клеток. Иммуномодуляция обусловлена входящими в состав пуриновыми (ингибиция) и пиримидиновыми (стимуляция) нуклеотидами, индукцией интерферонов и интерлейкина-1.

Полиферрин-А, содержащий лактоферрин, усиливает фагоцитарную и цитолитическую функции, синтез интерлейкина-18 и интерферонов, ускоряет созревание Тклеток и активирует нейтрофилы, нарушает репликацию вирусов, оказывает противовоспалительный эффект.

Риботан. Комплекс низкомолекулярных полипептидов тимуса и фрагменты дрожжевой РНК. Механизм заключается в стимуляции Т-, и В-клеток, активации макрофагов, усилении синтеза интерферона и других цитокинов, имеет адъювантные свойства.

Сальмозан. Содержит полисахаридные компоненты О-соматического антиген сальмонелл, активирует макрофаги, В-клетки, стволовые клетки, индуктирует интерфероны, стимулирует естественную резистентность.

Форвет. Полисахаридный комплекс класса гексоз из Solanumtuberosum. Цитопротектор, стимулирует образование Т- и В-клеток, активирует макрофаги, усиливает синтез интерферонов и ряда цитокинов, обладает адъювантными свойствами $[2,4,6]$.

Фоспренил. Активные вещества - фосфорилированныеполипренолы хвои - участвуют в активации макрофагов, повышении продукции ИЛ-1, индукции ранней выработки ИЛ-12, ИФН $\gamma$, ФНО-а, ИЛ-4, ИЛ-6; имеют адъювантные свойства и противовирусный эффект [6,7].

\section{Синтетические препараты}


Анандин. Производное акридонуксусной кислоты глюкоаминопропилкарбакридон. Стимулирует синтез ИФН $\alpha$, индукцию синтеза и секреции ряда Th-1 цитокинов.

Гала-вет (5-амино-2,3-дигидро-1,4-фталазиндион натрия). Обратимо снижает избыточную активность моноцитов/макрофагов, активирует микробицидную систему нейтрофилов и фагоцитоз.

Гликопин - глюкозаминилмурамилдипептид - аналог фрагмента пептидогликана клеточной стенки бактерий является модулятором врожденного иммунитета. Стимулирует эффекторные функции фагоцитов и продукцию провоспалительных цитокинов, индуцирующих пролиферацию, активацию и дифференцировку Т- и В-лимфоцитов, активирует все звенья иммунной системы с усилением противоинфекционного и противоопухолевого иммунитета.

Иммунофан. В составе есть синтетический пептид, модифицированный фрагмент гормона тимуса - тимопоэтина. Регулирует продукцию тимулина, ИЛ-2, ФНО, иммуноглобулинов, обладает адъювантными свойствами.

Карданон. Действующее вещество - натриевая соль 10-метилен карбоксилат-9акридона. Стимулирует выработку интерферона, оказывая выраженное противовирусное действие на РНК- и ДНК-геномные вирусы, включая вирус чумы собак; индуцирует синтез и секрецию ФНО, повышает функциональную активность Т- и В- лимфоцитов $[1,4,6]$.

Максидин $\quad 0,4 \quad(0,15)$. Раствор бис(пиридин-2,6-дикарбоксилата). Индуктор интерферонов, блокирует трансляцию вирусных белков и стимулирует естественную резистентность животных, повышает активность макрофагов, Т и В-лимфоцитов[1,6,7].

\section{Препараты на основе рекомбинантных белков}

Ронколейкин. Препарат на основе рекомбинантного интерлейкина-2 из клеток дрожжей S.cerevisiae. Усиливает пролиферацию Т-лимфоцитов и синтез ИЛ-2, активацию Ти В-клеток, ЦТЛ, ЕК, МФ, повышает синтез ИФН.

Кинорон. В состав входит лиофилизированная смесь лейкоцитарного интерферона и цитокинов. Стимулирует иммунокомпетентные клетки, повышает неспецифическую резистентность, усиливает действие вакцин, применяется для профилактики и лечения чумы плотоядных, вирусного энтерита и инфекционного гепатита собак $[1,2,6]$.

\section{Комплексные препараты}

Гамавит. Раствор, содержащий нуклеинат натрия, денатурированный экстракт плаценты, витамины, аминокислоты, минералы. Обладает активностью поликлонального иммуностимулятора, регулируя миграцию Т-лимфоцитов и процессы кооперации Т- и Влимфоцитов, усиливает фагоцитарную активность макрофагов и продукцию факторов неспецифической защиты, стимулирует лейкопоэз $[1,6,7]$.

Азоксивет. Содержит в качестве действующего вещества азоксимера бромид, маннитол, повидон, бетакаротен. Стимулирует выработку интерферона и факторов естественной защиты, снижает интоксикацию $[2,6]$.

Опрос, проведенный в ветеринарных клиниках г. Иркутска, Ангарска и Братска, показал достаточно разнообразные результаты: большинство опрошенных ветеринарных врачей не используют в своей практике иммуностимулирующие средства из-за низкой доказательной базы, заменяя их на витаминные и минеральные добавки, а также улучшенный рацион питания и моцион. Среди оставшейся части врачей, которые используют иммуностимуляторы, оказалось, что наиболее популярными и широко используемыми являются следующие:иммунофан, ронколейкин, риботан, гамавит. Многие врачи называли так же витаминные и минеральные препараты, ошибочно относя их к иммуномодуляторам. Все эти препараты имеются в Государственном реестре лекарственных средств для ветеринарного применения и, соответственно, разрешены к применению в ветеринарной медицине.

Литература.1. Белозерцев Ю.А. Основы доказательной фармакологии. - Чита, 2012. - 120 с.2. Воробьев, А. А. Принципы классификации и стратегия применения иммуномодуляторов в 
медицине / А. А. Воробьев // ЖМЭИ - 2002. - № 4. - С. 93-98. 3. Субботин В.М. Ветеринарная фармакология / В.М Субботин, И.Д. Александров - М.: КолосС,2004.-720 с.4. Государственный реестр лекарственных средств для ветеринарного применения [Электронный ресурс] - режим доступа:. https://galen.vetrf.ru/\#/registry/pharm/registry?page=1 (Дата обращения: 22.03.2021).5. Санин, А. В.Применение иммуномодуляторов при вирусных заболеваниях мелких домашних животных / А. В. Санин // Российский журнал ветеринарной медицины - 2005. - № 1. - С. 38-42. 6.Леонард, Р. А. Влияние гамавита, фоспренила и максидина на ряд биохимических показателей крови собак, больных пироплазмозом / Р. А. Леонард // Ветеринарная клиника. - 2006. — № 3. - С. 2-5.

\section{THE USE IMMUNOSTIMULATOR DRUGS IN VETERINARY MEDICINE}

Rafekova E.V., Lomboeva S.S associateprofessor, Ph.D

(FSBEI HE «Irkutsk State University named after A. A. Yezhevsky», Russia)

Summary: Now, on the market of veterinary pharmacies, there are quite a lot of medications related to the group of immunostimulants with a different mechanism of action. This study conducted a review of medicinal products of this group, which is also introduced in the state register, as well as studying the most popular medications in veterinary practices in Irkutsk

Key words: immunity, immune system, immunomodulator, immunostimulator

\section{МЕЗЕНХИМАЛЬНЫЕ СТВОЛОВЫЕ КЛЕТКИ В ВЕТЕРИНАРНОЙ ОРТОПЕДИИ}

Руколь В.М., доктор ветеринарных наук, профессор Андреева Е.Г., студент

(УО «Витебская ордена «Знак Почета» государственная академия ветеринарной медицины», г Витебск, Республика Беларусь)

Аннотация. Применение мезенхимальных стволовых клеток жировой ткани (МСК ЖТ) в лечении животных с подотрохлеитом определяется противовоспалительными свойствами данных клеток, их способностью увеличивать ангиогенез и стимулировать внутренние прогениторные клетки к регенерации функций ткани. Эти свойства позволяют сократить время заживления тканей у коров, значит целесообразно использовать схему лечения с применением мезенхимальных стволовых клеток.

Ключевые слова: мезенхимальные стволовые клетки, челночный блок, крупный рогатый скот, копытца.

Введение. Лечение крупного рогатого скота с болезнями копытец начинается с санации и терапии, направленной на заживление гнойно-некротического очага поражения, повышения резистентности организма (вакцинация, витаминно-минеральные комплексы). Однако, при недостаточной эффективности первоначального этапа лечения развиваются системные осложнения, требующие применения антибиотиков. Как известно, широкое применение антибактериальных препаратов сопровождается распространением резистентных к антибиотикам патогенных микроорганизмов, что остается одной из самых непростых и актуальных проблем ветеринарной медицины. Использование мезенхимальных стволовых клеток жировой ткани (МСК ЖТ) в настоящее время рассматривается в качестве перспективного подхода к лечению ряда хирургических заболеваний дистальной части конечностей крупного рогатого скота $[1,2,3,4,5]$.

В данной работе МСК ЖТ крупного рогатого скота были применены для лечения коров с подотрохлеитом. В результате данного исследования было установлено, что применение мезенхимальных стволовых клеток может быть одним из альтернативных способов лечения животных с болезнями конечностей в животноводстве. В свою очередь применение антибиотиков вызывает известные негативные последствия, связанные, прежде всего, с появлением устойчивых штаммов патогенных микроорганизмов, инфицирующих как животных, так и человека. 
Терапевтический потенциал мезенхимальных стволовых клеток жировой ткани в лечении животных с болезнями копытец определяется противовоспалительными свойствами данных клеток, их способностью увеличивать ангиогенез и стимулировать внутренние прогениторные клетки к регенерации функций ткани.

Целью данной работы было оценить терапевтическую эффективность использования мезенхимальных стволовых клеток жировой ткани для лечения крупного рогатого скота с подотрохлеитом.

Материалы и методы. Жировую ткань получали на мясокомбинате от убойных бычков в возрасте 16-18 месяцев не позднее 30 минут после убоя. Материалом для отбора была подкожная жировая клетчатка в области основания хвоста, далее ткань помещали в 70\% этанол на 30 секунд, затем депонировали в фосфатно-солевой буфер с добавлением $100 \mathrm{ME} / \mathrm{Mл}$ пенициллина, 100 мкг/мл стрептомицина и 2,5 мкг/мл амфотерицина В и транспортировали в лабораторию для культивирования клеток.

Культивирование клеток проводили в течение 30-35 суток со сменой ростовой питательной среды и пассированием как описано в методах. Изучение морфологии культивированных клеток из жировой ткани крупного рогатого скота показало, что адгезировавшие к культуральному пластику клетки имели как веретеновидную, так и округлую или неправильную форму. Размер данных клеток варьировал от 20 до 40 мкм, они делились и начинали образовывать колонии.

Трансплантат мезенхимальных стволовых клеток для инъекций представлял собой суспензию в физиологическом растворе. Клетки в суспензии были округлой формы, при посеве в ростовой среде в процессе формирования монослоя через 48 ч приобретали веретеновидную (фибробластноподобную), округлую или неправильную морфологию.

Срок годности препарата с момента выдачи составлял не более 12 ч при температуре от $+4{ }^{\circ} \mathrm{C}$ до $+10^{\circ} \mathrm{C}$ и не более 4 ч при температуре от $+10{ }^{\circ} \mathrm{C}$ до $+37{ }^{\circ} \mathrm{C}$.

По принципу условных аналогов были сформированы опытная и контрольная группы коров (по 10 голов) с клиническими признаками подотрохлеита.

Для приготовления клеточного трансплантата использовали криоконсервированные МСК ЖТ крупного рогатого скота. Всем животным предварительно проводили анатомофункциональную ортопедическую расчистку копытец и обрезку чрезмерно отросшего копытцевого рога.

Животные содержались в одинаковых условиях кормления и ухода, в чистом помещении с сухим полом и мягкой подстилкой. Первоначальный отбор коров для участия в клинических испытаниях проводился по явно выраженным клиническим признакам: хромота разной степени, отведение конечности в сторону, повышенная местная температура, наличие патологического очага и др.

Всем животным была проведена анатомо-функциональная ортопедическая расчистка копытец, полное удаление омертвевших тканей и разросшихся патологических грануляций. После хирургической обработки расчистки рану обрабатывали 3\% раствором перекиси водорода, осушали стерильной марлевой салфеткой, присыпали сложным порошком (калия перманганат $-50 \%$, борная кислота $-13 \%$, сульфаформ - $13 \%$, стрептоцид $-12 \%$, тилозин 12\%). Через 7-10 дней дальнейшее лечение пораженного участка проводили ветеринарным препаратом «Аламицином».

Животным опытной группы вводили клеточный трансплантат мезенхимальных стволовых клеток в область патологического очага в дозе $5 \times 10^{7}$ клеток в 4 мл физиологического раствора..

Введение мезенхимальных стволовых клеток производили однократно с применением проводниковой анестезии не позднее 2 часов после получения клеточного трансплантата. После введения суспензии мезенхимальных клеток на обработанное копытце накладывалась асептическая повязка, которая обеспечивала защиту раны и пересаженной культуры клеток от инфицирования. Эффективность лечения оценивали в динамике по клинической картине общего состояния и регенеративного процесса. Клинически оцениваемыми признаками были 
степень хромоты, наличие болезненности, площадь раневого дефекта, состояние окружающих тканей (отек, гиперемия), характер выделяемого экссудата, степень развития грануляционной ткани, сроки эпителизации ран.

Результаты исследования. У отобранных для клинических испытаний животных наблюдался подотрохлеит с выраженной воспалительной реакцией окружающих тканей, которые были болезненными с наличием небольших очагов некроза. У всех больных животных до лечения наблюдали угнетение общего состояния, понижение пищевой возбудимости, реакции на окружающую обстановку. Температура тела находилась в пределах верхней границы нормы, характерной для данного вида животных. Частоты дыхания и пульса были увеличены. Наблюдалась выраженная хромота опорного типа.

У коров опытной группы с применением клеточной терапии уже на $4 \pm 0,38$ сутки отмечалось улучшение общего состояния. После снятия повязки и осмотра раны было установлено уменьшение отечности ткани и снижение болезненности, но животные неуверенно опирались на больную конечность. Местные изменения характеризовались наличием грануляционной ткани. К $11 \pm 1,16$ суткам размеры раневого дефекта значительно уменьшились, вся рана заполнилась грануляционной тканью, а по краям раны наблюдали рост эпидермального ободка. Отечность и гиперемия ткани в области раны отсутствовали. Животные уверенно опирались на пораженную конечность и при движении наблюдалась еле заметная хромота. Защитная повязка далее не накладывалась. На $16 \pm 1,47$ сутки в группе коров с применением МСК ЖТ при визуальном осмотре вся поверхность раны была заполнена здоровой грануляционной тканью розового цвета. Наблюдался активный рост эпидермального ободка, на месте язвы образовалась рубцовая ткань. При ходьбе животные уверенно наступали на пораженную конечность, хромота отсутствовала. Полное клиническое выздоровление наступило в среднем на $23 \pm 1,18$ сутки с начала применения препарата из стволовых клеток.

У коров контрольной группы, после снятия антисептической повязки через $6 \pm 1,74$ суток с начала лечения, общее состояние было удовлетворительным, однако при движении отмечалась хромота и животные с осторожностью опирались на больную конечность, сохранялась болезненность и отечность. Поверхность раны немного подсохла, участок раны был покрыт коричневой корочкой. Дальнейшее лечение пораженного участка проводили Аламицином в виде аэрозоля. К $11 \pm 1,91$ суткам большая часть раны покрылась струпом. Местные изменения характеризовались уменьшением отечности тканей, снижением болезненности, отмечалось образование нормальной грануляционной ткани. На $22 \pm 1,43$ сутки раневая поверхность была заполнена мелкозернистой грануляционной тканью. Выздоровление животных данной группы наступило на 28t1,56 сутки после введения мезенхимальных стволовых клеток.

Заключение. В результате исследования нами установлено, что подкожная клетчатка из области основания хвоста крупного рогатого скота, полученная от животных после убоя является хорошим источником биомассы МСК. В результате проведённых клинических испытаний было показано, что применение клеточного трансплантата мезенхимальных стволовых клеток, полученных из жировой ткани крупного рогатого скота, позволяет сократить время заживления гнойно-некротических поражений копытец у коров в среднем на 5 суток по сравнению с аналогичной схемой лечения без использования МСК ЖТ.

Результаты проведенного исследования показали возможность успешного использования комплексной схемы терапии с использованием МСК ЖТ и целесообразность её дальнейшего развития. Мезенхимальные стволовые клетки жировой ткани могут быть успешно использованы в качестве альтернативы антибиотикам для заживления поражений копытец крупного рогатого скота.

Литература. 1. Костюк, Н. И. Использование мезенхимальных стволовых клеток жировой ткани для лечения крупного рогатого скота с гнойно-некротическими болезнями / Н. И. Костюк [и др.] // Экология и животный мир. - 2020. -№ 1. - С. 70- 78. 2. Руколь, В. М. Профилактика и лечение коров при болезнях конечностей / В. М. Руколь, А. А. Стекольников 
// Ветеринария. - 2011. - №11. - С. 50-53. 3. Руколь, В. М. Мероприятия при хирургической патологии крупного рогатого скота на молочных комплексах Гомельской области : рекомендации / В. М. Руколь, В. А. Журба, Э. И. Веремей ; Витебская государственная академия ветеринарной медицины. - Витебск : ВГАВМ, 2011. - 28 с. 4. Руколь, В. М. Профилактика и лечение коров при болезнях конечностей / В. М. Руколь, А. А. Стекольников // Ветеринария. - Москва, 2011. - № 11. - С. 50-53. 5. Руколь, В. М. Технологические основы ветеринарного обслуживания молочного крупного рогатого скота с хирургическими болезнями в Республике Беларусь : дис. ... докт. вет. наук : 06.02 .04 : защищена 22.02 .13 / Руколь Василий Михайлович. - Санкт-Петербург, 2013. - 461 с.

\section{MESENCHYMAL STEM CELLS IN VETERINARY ORTHOPEDICS}

\section{Rukol V. M., Doctor of Veterinary Sciences, Professor}

Andreeva E. G., student

( Vitebsk Order" Badge of Honor " State Academy of Veterinary Medicine, Vitebsk, Republic of Belarus)

Annotation. The use of adipose tissue mesenchymal stem cells (VT MSCs) in the treatment of animals with subtrochleitis is determined by the anti-inflammatory properties of these cells, their ability to increase angiogenesis and stimulate internal progenitor cells to regenerate tissue functions. These properties can reduce the time of tissue healing in cows, so it is advisable to use a treatment regimen using mesenchymal stem cells.

Key words: mesenchymal stem cells, shuttle block, cattle, hooves.

УДК 615.357:617.723-002:636.7

\section{КЛИНИЧЕСКИЙ СЛУЧАЙ ЯЗВЫ РОГОВИЦЫ, ОСЛОЖНЕННОЙ ПЕРЕДНИМ ГНОЙНЫМ ЭКЗОГЕННЫМ УВЕИТОМ У ФРАНЦУЗСКОГО БУЛЬДОГА, ВОЗНИКШЕЙ НА ФОНЕ ДЛИТЕЛЬНОЙ СИСТЕМНОЙ ТЕРАПИИ ГЛЮКОРТИКОСТЕРОИДНЫМИ ПРЕПАРАТАМИ}

Сароян С.В. к.в.н., асс. ФГБОУ ВО МГАВМиБ - МВА им. К.И. Скрябина, Крюкова В.В. к.в.н., асс. ФГБОУ ВО СПБГУВМ

Аннотация.В некоторых случаях длительное, иногда пожизненное, применение СПВС необходимо. У таких животных существует повышенный риск осложнений, включая возникновение стероидных язв роговицы. В статье описан клинический случай язвы роговицы на фоне системного применения СПВС у собаки породы французский бульдог.Выбранная схема лечения включала комплексную терапию с применением регенеративного препарата Репарин-Хелпер ${ }^{\circledR}$, по итогам которой произошло быстрое и качественное заживление роговицы с сохранением зрительных функций глазного яблока.

Ключевые слова:язва роговицы, сирингомиелия, французский бульдог, Репарин-Хелпер, регенерация

Введение. Существует большое количество хронических заболеваний как органов зрения, так и других органов и систем организма животного инфекционной и неинфекционной природы,при которых длительное, иногда пожизненное, применение СПВС необходимо [1].Как известно, СПВС обладают ингибирующим воздействием на местный и общий иммунитет, препятствуют процессам заживления, снижают коллагеноз[2]. Все эти факторы, при длительном местном или системном применении, могут привести к образованию эрозий или язв роговицы[3,4,]. Такие язвы тяжело поддаются лечению.

В данном клиническом случае французский бульдог получал глюкокортикостероидные препараты в связи с основным заболеванием - синдромом Киари и сирингомиелией. Киари-подобный порок развития связан с несоответствием размеров каудальной ямки черепа $\mathrm{c}$ eе содержимым, мозжечком и стволом мозга. Такая 
несовместимость приводит к нарушению оттока ликвора и гидроцефалии. В результате развивается сирингомиелия - хроническое прогрессирующее заболеваниенервной системы, при котором в спинном мозге образуются полости, и в них скапливается жидкость. При этом отмечается болевой синдром, слабость или атрофия грудных конечностей, атаксия тазовых конечностей, судорожные припадки, паралич черепно-мозговых нервов [5,2].Лечение таких животных, как правило, включает пожизненную поддерживающую терапию, одним из компонентов которой является системное применение СПВС.Это связано не только с побочными эффектами от применения СПВС, но и основного заболевания, при котором также могут происходить негативные последствия, обусловленные снижением местного и общего иммунитета и способности организма к репаративным и регенеративным процессам[6].

Цель статьи - продемонстрировать актуальную роль регенеративной медицины, на примере препарата Репарин-Хелпер ${ }^{\circledR}$, позволяющей отменять терапию СПВС на более короткие сроки (либо использовать минимальную дозировку) и стимулировать процессы заживления тканей роговицы у ослабленного организма животного.

Материал и методы. На базе «Центра неотложной ветеринарной офтальмологии и микрохирургии глаза»г. Москвана лечении находилась собака породы французский бульдог(кабель, нестерилизован, проходит ежегодную вакцинацию, содержание домашнее, кормление - сухой и влажный корм фабричного производства). При клиническом осмотре животного использовались следующие методы диагностики: общий офтальмический осмотр, щелевая биомикроскопия, тонометрия. В анамнезе у животного - киари-подобный порок и сирингомиелия. За год до возникновения язвы роговицы собаке была проведена черепноцервикальная декомпрессия и назначено дальнейшее консервативное лечение в виде применения СПВС (метилпреднизолон).

Собака поступила в клинику со следующими жалобами от владельцев: помутнение роговицы, покраснение конъюнктивы и слизистые выделения из правого глаза. При общем офтальмическом осмотре быливыявлены следующие изменения со стороны правого глаза отсутствие блефароспазма и фотофобии, умереннаягиперемия и отек конъюнктивы, скудное слизистое отделяемое из конъюнктивального мешка, движение глазного яблока неограничено, окулярные рефлексы сохранены. При биомикроскопии- незначительный отек роговицы, в центральной зоне роговицы язва округлой формы, диаметром 4 мм, глубиной до 1/3, перифокальный отек отсутствует, края язвы неровные, неоваскуляризация не выявлена. На интрамаргинальном крае нижнего века обнаружены патологические ресницы в количестве 4-ех штук. При исследовании передней камеры глаза обнаружен гипопион, миоз и незначительный отек радужной оболочки. Тонометрия проведена аппланационным методом (Tonovet) - 16 мм рт. ст. Исходя из проведенных исследований, был поставлен следующий диагноз - стромальная язва роговицы, дистрихиазис, передний экзогенный гнойный увеит. При этом, как следует из анамнестических данных, животное в течение года получает системную терапию СПВС с целью контроляосновного заболевания (сирингомиелия).Клиническая картина, характеризующаяся центральным расположением язвы роговицы, практически полным отсутствием «роговичного синдрома», а также наличием переднего увеита и стерильного гноя в передней камере глаза, позволила сделать вывод, что мы имеем дело с язвой роговицы, образовавшейся на фоне системной терапии СПВС, а дистрихиазис стал фактором, который усугубил течение патологического процесса.

После консультации с врачом, который осуществлял курацию пациента по поводу сирингомиелии, было приняторешение на месяц отменить применение СПВС, пока будет проводиться курслечения язвы роговицы. План лечения включал применение «цитокинового коктейля» для стимуляции регенеративного процесса роговицы, что способствовало быстрому и качественномуее заживлению при сохранении зрительных функций глазного яблока. Животному было проведено следующее лечение: после седации животного (пропофол, внутривенно, в дозе 10 мг/кг) выполнили коагуляцию патологических ресниц, дебридмент язвы роговицы с захватом здоровых тканей. Затем субконъюнктивально ввели $0,1 \%$ раствор атропина сульфата $(0,2$ мл), гентамицина сульфат $(0,5$ мл) и $0,5 \%$ раствор 
новокаина (0,6 мл). Для защиты роговицы от внешних факторов была сделана тарзорафия на срок30 дней. В качестве послеоперационной терапии мы использовали регенеративный препарат Репарин-Хелпер ${ }^{\circledR}$ в форме глазных капель и антибактериальный препарат из группы фторхинолонов, также в форме глазных капель. Кратность инстилляций обоих препаратов составила 4 раза в день, интервал между препаратами 15 минут, Репарин-Хелпер ${ }^{\circledR}$ последний. Длительность терапии составила 30 дней.ПрепаратРепарин-Хелпер ${ }^{\mathbb{R}}$ позволил отказаться от классическихкератопротекторов. Действующее вещество регенеративного препарата Репарин-Хелпер ${ }^{\circledR}$ - это стандартизированный комплекс цитокинов, которые продуцируются мезенхимальными клетками. Анализ сред,содержащих цитокины, проведённый Новериной Р. с соавт. в 2019 г. показал, что цитокины играют ключевую роль в восстановлении эпителия роговицы[7].Цитокиныотвечают за регуляцию фаз воспалительного процесса[8], привлекают иммунные и эндотелиальные клетки в очаг поражения, стимулируют васкуло- и ангиогенез, таким образом способствуяулучшению трофического обеспечения поврежденной области [9] и позволяют избежать осложнений, например, помутнений роговицы.

Результаты и их обсуждение. После снятия швов мы провели биомикроскопию роговицы, по результатам которой отметили полную регенерацию тканей в области язвы с образованием макулы и незначительное изменение кривизны роговицы, неоваскуляризация роговицы отсутствовала. Признаков увеита и повторного появления патологических ресниц также не было обнаружено.Таким образом, комплексная терапия, включающая применение регенеративного препарата Репарин-Хелпер ${ }^{\circledR}$,показала хорошие результаты лечения стероидной язвы роговицы и качественного восстановления эпителия глазной поверхности.

Далее были назначены препараты для рассасывания рубцовой ткани. Терапия сирингомиелии продолжена.

Выводы. Длительная системная терапия СПВС у животных может приводить к возникновению стероидных язв роговицы, которые имеют относительно бессимптомное течение, но при этом быстро прогрессируют и могут осложняться или усугубляться другими патологиями глазного яблока и вспомогательного аппарата. Поэтому тактика лечения такого рода пациентов должна в первую очередь осуществляться в слаженной работе офтальмолога и специалиста, осуществляющего лечение основного заболевания. Применение регенеративного препарата Репарин-Хелпер ${ }^{\circledR}$ в комплексе с хирургической обработкой язвы способствовало быстрому и качественному заживлению язвы роговицы с сохранением зрительных функций.

Список литературы. 1. Ниманд Х.Г. Болезни собак: практ. рук-во для вет. врачей/ Х.Г. Ниманд, П.Ф. Сутер 8 изд.перевод с нем - М.: "Аквариум", 1998. - 806 с. 2. Харкевич Д.А. Фармакология: учебник/Д.А. Харкевич 8-е изд., перераб., доп. и испр. - М.: ГЭОТАР-Медиа, 2005. - 736 с. 3. Егоров, Е.А. Заболевания роговой оболочки: клинические лекции по офтальмологии/ Е.А. Егоров, С.Н. Басинский.- М: 2007. -147 с. 4. Копенкин, Е.П. Болезни глаз мелких домашних животных: учебное пособие/ Е.П. Копенкин, Л.Ф.Сотникова- М.: Товарищество научных изданий КМК; Авторская академия, 2008. - 186 с. 5. Риис Рональд К. Офтальмология мелких домашних животных: рук. для вет.врачей/ Риис Рональд К. пер. с англ. - М.: ООО «Аквариум-Принт», 2006. - 280 с. 6. Кирк М. Современный курс ветеринарной медицины/ М. Кирк.- М: Аквариум-прин, -2014. - 1376 с.Д 7. Noverina, R. Growth factors profle in conditioned medium human adipose tissue-derived mesenchymal stem cells (CMhATMSCs)/ Noverina, R. et al.//Clin. Nutr. Exp.- 2019. № 24.-P. 34-44. 8. Isabel, Arranz-Valsero IL-6 as a corneal wound healing mediator in an in vitro scratch assay/ Isabel Arranz-Valsero, Laura SorianoRomaní, Laura García-Posadas et al.,// Exp Eye Res. -2014.- 125.P.183-92. 9. Apte, R.S. VEGF in Signaling and Disease/ R.S. Apte, D.S.Chen, N. Ferrara// Beyond Discovery and Development.2019.-176(6) P. 1248-1264

\section{CLINICAL CASE: TREATING STEROID-INDUCED CORNEAL ULCERS IN FRENCH BULLDOG WITH REGENERATIVE DRUG REPARIN-HELPER ${ }^{\circledR}$}

S.V. Saroyan - PhD, aasistent FSBEI HE MGAVMa B., V.V. Kryukova - PhD, assistant FSBEI HE St.Peterburg SUVM 
Summary.This article describes a regenerative medicine approach for treating corneal stromal ulcers developed as a side effect of prolonged glucocorticosteroid therapy. A detailed clinical picture of the corneal disease, complications, as well as factors contributing to the aggravation of the pathological process are described. The ulcer treatment plan included application of a topical cytokine-rich drop to the cornea to stimulate the regenerative process, resulting in the rapid and high-quality healing of the cornea while preserving the visual functions of the eyeball.

Key words: corneal ulcer, syringomyelia, french bulldog, regeneration, steroidal anti-inflammatory drugs

\title{
ДИНАМИКА БИОХИМИЧЕСКИХ ПОКАЗАТЕЛЕЙ КРОВИ НОВОТЕЛЬНЫХ КОРОВ НА ФОНЕ ПРИМЕНЕНИЯ ГЕПАТОПРОТЕКТОРА
}

Сахно Т.А., соискатель, Гринь В.А., к.в.н. ст. научн. сотрудник, Семененко М.П., доц., д.в.н., зав. отделом фармакологии

(ФГБНУ КНЦЗВ, Россия)

\begin{abstract}
Аннотация. Изучено влияние нового инъекционного гепатопротекторного препарата ливазен при профилактике гепатозов высокопродуктивных новотельных коров. Проведенная фармакопрофилактика показала высокую эффективность при коррекции заболеваний гепатобиллиарной системы и метаболической недостаточности.
\end{abstract}

Ключевые слова: печень, новотельные коровы, биохимические показатели

Современное развитие молочного животноводства направлено на увеличение производства молока при одновременном снижении затрат на содержание животных и сохранение их продуктивного здоровья. Особый интерес для молочно-товарных хозяйств представляют животные с генетически высоким потенциалом выработки молока. Однако современная экологическая обстановка, частые нарушения условий кормления и содержания, увеличение интенсивности воздействия химико-физических и биологических токсикантов, низкий адаптивный потенциал самих животных, в конечном итоге, приводят к метаболической переориентации и глубоким нарушениям всех видов обмена веществ в печени - органе, который прямо или косвенно участвует во множестве обменных реакций организма животного [1].

У коров в транзитный период (около 3-х недель до отела и 3-х после) в связи с подготовкой организма к отелу и лактации,начинаются выраженные физиологические изменения в метаболическом и эндокринном статусе. На последней неделе отела возрастает потребность в получении большего количества энергии и белка для выработки молока, но в результате гормональной перестройки у животных возникает энергодефицитное состояние. Нехватка пластических и энергетических веществ приводят к мобилизации жировой ткани организма и липолизу. Развивается жировой гепатоз[2, 3].Поэтому, для улучшения обменных процессов, гомеостаза, стимуляции регенеративных и репаративных процессов в печени и организма в целом, у новотельных коров целесообразно проводить профилактическую терапию препаратами, обладающими гепатопротекторным действием.

В связи с вышесказанным, целью исследования явилось изучение действия нового инъекционного гепатопротекторного препарата ливазен для профилактики нарушений гепатобилиарной системы новотельных коров.

Исследование проведено в условиях молочно-откормочного комплекса Краснодарского края на высокопродуктивных новотельных коровах 3-5 летнего возраста голштинской породы через 7-14 дней после отела с признаками нарушений работы гепатобилиарной системы. Для постановки диагноза были проведены комплексные клинические исследования, которые выявили у животных снижение продуктивности, аппетита, общее угнетение, расстройство работы ЖКТ и преджелудков, тусклый волосяной 
покров, желтушность на склере и слизистых оболочках глаз. При изучении биохимических показателей сыворотки крови у половины (50\%)обследованных коров установлено снижение уровня общего белка. В белковом обмене отмечено низкое содержание альбуминов относительно показателей нижней границы нормы. Нарушена коллоидная стойкость белков (в 100\%), увеличена тимоловая проба, обусловленная повышением уровня $\gamma$-глобулинов.

Показатели ферментной активности - АсАт и АлАт находились у верхних границ видовой нормы, щелочная фосфатаза повышена, в среднем, на 49,2\%. Уровень триглицеридов снижен на 2,64раза, концентрация общего билирубина, напротив, повышена в 2,5 раза относительно референсных значений.

Для проведения исследования по принципу парных аналогов было сформировано две группы животных(n=10): 1 группа-опытная, которой внутримышечно на протяжении 14 дней в одном шприце вводился раствор гепатопротектора и $0,9 \%$ стерильный раствор натрия хлоридав соотношении 2 мл ливазена и 10 мл NaCL; 2 группа - контрольная, 14 днейполучавшая только инъекции натрия хлорида в объеме 12 мл.

На протяжении всего исследовательского периода проводились наблюдения за физиологическим и клиническим состоянием животных. По окончанию эксперимента у животных осуществлялся забор крови для проведения биохимического анализа.

Результатами исследований установлено, что у животных опытной группы на фоне фармакопрофилактикипроизошло увеличение уровня общего белка на 14,7 \% при одновременном перераспределении белкового спектра сыворотки крови. Так, количество альбуминов повысилось на 19,4 \%, а уровень глобулиновых фракций снизился на 32,4%. В контрольной группе диспротеинемия сохранялась у 80 \% коров.

Концентрация общего билирубина в группе с применением ливазена снизилась на 53,5 $\%$, тогда как у контрольных аналогов его количество осталось на прежнем уровне. Произошло увеличение триглицеридов: в опытной группе - в 2,3 раза, в контрольной - на 24,7 \%.

АктивностьАсАт и АлАТ находилась в физиологических границах нормы в обеих группах, но в первой группе уровень аланинаминотрансферазы за период опыта снизился на $32,7 \%$, аспартатаминотрансферазы - на $40,8 \%$, тогда как во второй группе снижение показателей составило 14,3 и 21,7 \% соответственно. Концентрация ЩФ у опытных коров снизилась на 21,7 \%, у животных контрольной группы - на 18,8 \%.

Таким образом, проведенные исследования показали, что гепатопротекторный препарат ливазен восстанавливает гомеостаз печени, стимулирует репаративные регенерационные процессы, способствует более быстрому восстановлению организма животных после отела.

Литература.1. Годовалова, А.М. Тенденции развития молочного скотоводства как основа импортозамещения / А.М. Годовалова, Н.Н. Жикина// В кн.: Современные проблемы и тенденции развития АПК региона. - Пермь, 2015. - C. 177-181.2. Rossi F, Righi F, Romanelli $\mathrm{S}$, et al. (2008) Reproductive efficiency of dairy cows under negative energy balance conditions. AnnFacMedicVetDifarma 28, 173-180. 3. Мищенко, В.А. Проблема патологии печени у высокопродуктивных коров / В.А. Мищенко, А.В. Мищенко, О.Ю. Черных // Ветеринария Кубани. - 2014. - С. 11-12.

\section{DYNAMICS OF BIOCHEMICAL INDICATORS OF BLOOD IN FRESH COWS ON THE BACKGROUND OF HEPATOPROTECTOR APPLICATION}

Sakhno T.A., PhD student, Grin V.N., Ph.Din Veterinary Sciences, Senior Researcher,, Semenenko M.P., Associate Professor, Doctor of Veterinary Sciences, Head of the Department of Pharmacology

(FSBSI KRCAHVM, Russia)

Summary. The influence of a new injectable hepatoprotective drug livasen in the prevention of hepatosis in highly productive fresh cows has been studied. The performed pharmacoprophylaxis has shown high efficiency in the correction of diseases of the hepatobiliary system and metabolic insufficiency.

Key words: liver, fresh cows, biochemical parameters 


\title{
ПРИМЕНЕНИЕ СРЕДСТВ ДЛЯ НАРКОЗА В ВЕТЕРИНАРИИ
}

Скобелева И.С., Ломбоева С.С., доц., канд. фарм. наук (ФГБОУ ВО Иркутский ГАУ имени А.А.Ежевского,Россия)

\begin{abstract}
Аннотация: Средства для наркоза находят широкое применение в ветеринарии. Была проведена работа по изучению литературы, Государственного реестра лекарственных средств для ветеринарного применения и выявлению наиболее популярных и широко используемых в ветеринарной медицине средств для ингаляционного и неингаляционного наркозов.
\end{abstract}

Ключевые слова: средства для наркоза, межнейронная (синаптическая) передача возбуждения, анестезия, анальгезия.

Нервная система в той или иной степени «отвечает» на действие любого фармакологического вещества, но нейротропными называют те средства, которые непосредственно действуют на какие-либо отделы системы. Исходя из системной классификации, нейротропные вещества подразделяют на средства, регулирующие центральную и периферическую нервную систему. Основа действия нейротропных средств на нервную систему - способность видоизменять процессы межнейронной (синаптической) передачи возбуждения. В зависимости от направленности эффекта различают угнетающее или стимулирующие те или иные отделы нервной системы. В данной работе представлен материал по средствам, угнетающим центральную нервную систему - средствам для наркоза.

Важным разделом клинической ветеринарии, особенно хирургической практики, является обезболивание и обездвиживание животных. Для лекарственной анестезии используют препараты, вызывающие анальгезию, сон, расслабление мышц и снижение рефлексов. Лекарственные средства данной группы называют анестетиками, ихподразделяют на общие и местные. Общие вызывают утрату чувствительности всех видов, а также приводят к обратимой потере сознания. Местно анестезирующие средства устраняют болевую чувствительность только в зоне, ограниченной местом введения препарата [1].

Механизм действия наркозных препаратов заключается в блокаде межнейронной (синаптической) передачи возбуждения в центральной нервной системе.Несмотря на различия в биохимическом и физико-химическом механизме действия, все наркозные средства влияют на мембрану нейронов, изменяя ее проницаемость для ионов натрия и калия, нарушая процесс деполяризации. Это препятствует возникновению потенциала действия, в результате блокируется межнейронная передача возбуждения. Возможно, некоторые препараты действуют на пресинаптическом уровне, нарушая освобождение медиаторов, обусловливающих межнейронные контакты. В зависимости от химического строения и физико-химических свойств различные препараты имеют особенности влияния на нейроны, что отражается на их фармакодинамике. Чувствительность синапсов различных отделов центральной нервной системы к наркозным средствам неодинакова: наиболее чувствительны к действию химических агентов синапсы восходящей активирующей системы ретикулярной формации ствола мозга и коры головного мозга, наиболее устойчивы - жизненно важные центры продолговатого мозга [2, 3].

Цель работы - провести обзор доступной литературы, включающей сведения по применению средств для наркоза в ветеринарной медицине, изучить Государственный реестр лекарственных средств для ветеринарного применения на сайте Федеральной службы по ветеринарному и фитосанитарному надзору и выявить,какие средства для общей анестезии, взятые из справочной литературы, можно использовать в 2021 году, а также выяснить, какие из них являются наиболее популярными и широко применяемыми в ветеринарных клиниках Иркутска и Иркутской области.

Государственный реестр лекарственных средств для ветеринарного применения размещен на сайте Федеральной службы по ветеринарному и фитосанитарному надзору и включен в поисковую информационную систему «Гален». В данный реестр включены только 
разрешенные к применению в ветеринарной медицине в настоящее время лекарственные препараты[4].

Ингаляционные средства для наркоза, приведенные в справочной литературе - закись азота, галотан (фторотан), энфлюран, севофлюран, изофлюран, десфлюран, метоксифлюран, эфир диэтиловый, хлороформ, циклопропан $[1,2,3,5,6]$, отсутствуют в Государственном реестре лекарственных средств для ветеринарного применения. Первые семь препаратов характеризуются как современные, менее токсичные, более эффективные и управляемые, чем их предшественники [1].

Из неингаляционных средств для наркоза, приведенных в справочной литературе в настоящий реестр включены золетил 50 и золетил 100, ксилазин (ксилазин 2\%, ксиланит, зооксилазин, ксила), медетомидин (дексдомитор, седамидин, медитин, домитор), домоседан. Отсутствуют в реестре тиопентал натрия, кетамина гидрохлорид (кетанест, кетажект, калипсол, кеталар, кетажест, кетазет, кетолар, веталар), пропофол (ветофол, пропован, анестефол, проповет), дорбен, бутомидор, рометар.

Ниже приведена характеристика препаратов, внесенных в Государственный реестрлекарственных средств для ветеринарного применения и, соответственно разрешенных к применению в Российской Федерации.

Золетил 50 и 100(тилетамин + золазепам). Лекарственная форма - порошок для приготовления раствора для инъекций. Используется для общей анестезии собак и кошек, не предназначен для применения продуктивным животным.Во время пробуждения может наблюдаться рвота, гиперсаливация и бронхиальная гиперсекреция (безпремедикации атропином), непроизвольное подергивание мышц, гипертония, ригидность мышц.

Ксилазин, ксилазин 2\%, ксиланит, зооксилазин, ксила. Лекарственная форма - раствор для инъекций, используется в качестве седативного, анальгезирующего, анестезирующего и миорелаксирующего средства для животных, противопаказан самкам в последнюю треть беременности, кроме случаев родовспоможения, животным при механическом повреждении желудочно-кишечного тракта, с нарушением проводимости сердечной мышцы.

Медетомидин, дексдомитор, седамидин, медитин, домитор. Лекарственная форма раствор для инъекций, используется для получения седативного эффекта и анальгезии у собак и кошек, противопоказан при повышенной индивидуальной чувствительности к компонентам препарата, тяжелых системных заболеваниях, сердечной недостаточности, нарушениях функций печени или почек, беременности и лактации, возрасте собак моложе 4-х месяцев и кошек моложе 3-х месяцев; возможно снижение артериального давления, снижение частоты сердечных сокращений, дыхательных движений и гипотермия; у собак и, в особенности, у кошек возможна рвота в первые минуты после инъекции препарата.

Детомидина гидрохлорид, домоседан. Лекарственная форма - раствор для инъекций, применяется для получения седативного эффекта и анальгезии лошадей, противопоказан при повышенной индивидуальной чувствительности животного к компонентам препарата; возможно угнетение кровообращения или дыхания.

Опрос, проведенный в ветеринарных клиниках г. Иркутска иИркутского района, показал, что наиболее популярными и используемыми препаратами для наркоза являются «Золетил 50 и 100», «Ксила». Они включены в Государственный реестр лекарственных средств для ветеринарного применения и разрешены к применению в ветеринарной медицине.

Отдельно хочется отметить препарат «Пропофол», относящийся к неингаляционным средствам для наркоза. Благодаря высокой растворимости в жирах, пропофол быстро проникает в мозг, что обуславливает практически мгновенное начало действия. Время пикового эффекта составляет примерно 90 секунд. Он быстро метаболизируется в печени путём конъюгации с образованием водорастворимых неактивных метаболитов (глюкуронидов и сульфатов), выводимыми почками. Дает быстрый выход из анестезии, уже через 10 минут после вводной индукции пациент может передвигаться самостоятельно. Объясняется данный эффект спецификой элиминации и распределения препарата. Но пропофол не был включен в Государственный реестр лекарственных средств для 
ветеринарного применения, соответственно, его нельзя применять в ветеринарной практике. В разные годы препараты, содержащие пропофол, присутствовали в Государственном реестре, но срок их регистрации, к сожалению, закончился. Их включение в Государственный реестр крайне желательно, так как эти препараты имеют минимальные побочные эффекты и дают легкий выход из наркоза [6].

При анализе данныхвозникает закономерный вопрос - почему ингаляционные средства для наркоза не внесены в искомый реестр, хотя ингаляционный наркоз имеет существенные преимущества перед неингаляционным (быстрый вход и выход из наркоза, возможность управления наркозом)? На то, очевидно, есть несколько причин:

1. Для того,чтобы зарегистрировать препарат, производитель и дистрибьютор несут большие временные и финансовые затраты. Данный процесс является довольно продолжительным по времени, поскольку предусматривает выполнение целого ряда требований существующих нормативных документов.

2. Применение средств для ингаляционного наркоза требует наличия дорогостоящего специального аппарата и не все клиники могут себе это позволить.

3. Необходимо обслуживание аппарата для ингаляционного наркоза, наличие дополнительного персонала клиники в лице высококвалифицированного анестезиолога и ассистента хирурга, а это - дополнительные затраты.

В силу последних двух причин большая часть клиник, возможно, не заинтересована в приобретении ингаляционных средств для наркоза и спрос на эти препараты не так высок.

Таким образом, вероятно, все вышеперечисленные обстоятельства являются предпосылкой к отсутствию этих средств в Государственном реестре лекарственных средств для ветеринарного применения. Но, поскольку он постоянно пересматривается и дополняется,возможно, что в арсенале у ветеринарного врача появится больший выбор средств для наркоза.

Литература. 1. Бойко, Т.В. Клиническая фармакология лекарственных средств, применяемых для общей анестезии и седации животных: учебное пособие / Т.В. Бойко. - Омск: Омский ГАУ, 2018. - 116 с. - URL: https://e.lanbook.com/book/159617. 2. Фармакология: учебник /В.Д. Соколов, Н.Л. Андреева, Г.А. Ноздрин, С.Н. Преображенский; под редакцией В.Д. Соколова. - 3-е изд., испр. и доп. - Санкт-Петербург: Лань, 2010. - 560 с. - URL: https://e.lanbook.com/book/570. 3. Слободяник, В.И. Препараты различных фармакологических групп. Механизм действия: учебное пособие / В.И. Слободяник, В.А. Степанов, Н.В. Мельникова. - Санкт-Петербург: Лань, 2014. - 368 c. - URL: https://e.lanbook.com/book/49472. 4. Государственный реестр лекарственных средств для ветеринарного применения [Электронный ресурс] - режим доступа:https://galen.vetrf.ru/\#/registry/pharm/registry?page=1. 5.Лунегов А.М. Лекарственные средства, с преимущественным действием на центральную нервную систему / А.М. Лунегов, Н.Л. Андреева, В.А. Барышев, О.С. Попова, О.А. Токарева, К.Ф. Зенков, О.Н. Каурина, В.В. Крюкова, Н.В. Кузнецова, Л.И. Сабирзянова, В.С. Понамарев // Санкт-Петербург, 2020.6. Набиев, Ф.Г. Современные ветеринарные лекарственные препараты: справочник / Ф. Г. Набиев, Р. Н. Ахмадеев. - 2-е изд., перераб. - Санкт-Петербург: Лань, 2011. - 816 c.- URL: https://e.lanbook.com/book/1547

\section{THE USE OF DRUGS FOR ANESTHESIA IN VETERINARY MEDICINE}

Skobeleva I.S., Lomboeva S.S.associate professor, candidate of pharmaceutical sciences (FSBEI HE Irkutsk SAU named after A.A.Ezhevsky, Russia)

Summary: Drugs for anesthesia are widely used in veterinary medicine. Work has been done on the study of the literature of the State Register of Medicines for veterinary use, and to identify the most popular, and widely used in veterinary medicine drugs for inhalation and non-inhalation anesthesia. Keywords: Drugs for anesthesia, pain sensitivity, interneuronal (synaptic) transmission of excitation, anesthesia. 


\title{
ОЦЕНКА ТОКСИКОЛОГИЧЕСКОЙ БЕЗОПАСНОСТИ РЫБЫ, ПРИМЕНЯЕМОЙ ДЛЯ КОРМЛЕНИЯ ЖИВОТНЫХ В ЗООЛОГИЧЕСКИХ УЧРЕЖДЕНИЯХ \\ ${ }^{1}$ Степанова М.В., доц., к.б.н., ${ }^{2}$ Остапенко В.А., проф., д.б.н. (
}

\begin{abstract}
Аннотация. Проведено исследование уровня накопления тяжелых металлов и мышьяка в морской рыбе, применяемой для кормления диких и экзотических животных. Превышения ПДК не установлено. Установлено наличие корреляционной связи между содержанием химических элементов в рыбе и биосубстратах животных.
\end{abstract}

Ключевые слова: биосубстраты, морская рыба, тяжелые металлы, мышьяк, рационы.

За последнее время все больше поднимается вопрос по правильному сбалансированному кормлению животных, содержащихся в условиях зоопарков. Но до настоящего момента времени нет разработанных унифицированных и полностью сбалансированных по основным показателям рационов для диких и экзотических животных, поскольку в зоологических коллекциях по всему миру содержится огромное по видовому разнообразию количество животных. Рационы разрабатываются каждым учреждением индивидуально для каждого вида с учетом регионального компонента (доступность на территории кормов растительного и животного происхождения). В кормовые рационы животных зоологических учреждений входят не только компоненты, применяемые для сельскохозяйственных животных, но и многие продукты питания, употребляемые человеком [1].

Корма животного происхождения являются важными компонентами рационов животных зоопарка, причем не только питающихся рыбой и мясом, но и всеядных и некоторых растительноядных животных. Для животных, которые специализируются на поедании рыбы, она является незаменимым и единственным кормом. Многие виды диких и экзотических животных зоопарков должны получать рыбу в качестве дополнительного корма, которая должна соответствовать требованиям, в том числе по содержанию химических веществ $[1,2]$.

Целью исследования было изучить содержание некоторых тяжелых металлов и мышьяка в мороженой рыбе, используемой для кормления животных зоологических учреждений.

Исследования проводились с 2018 по 2020 годы на базе Ивановского, Московского и Ярославского зоопарков. Материалами для исследования служили ткани и органы рыб семейств корюшковые Osmeridae (мойва), сельдевые Clupeidae (салака), лососёвые Salmonidae (горбуша, кета), тресковые Gadidae (минтай, путассу), терпуговые Нехаgrammidae (терпуг). Токсикологические анализы выполнены на базе Ярославской государственной сельскохозяйственной академии и лаборатории ГБУ ЯО «Ярославская областная ветеринарная лаборатория» на атомно-абсорбционном спектрометре «Квант-2А». Отбор точечных проб рыбы осуществлялся в соответствии с ГОСТ 31339-2006 и МосMР 2.3.2.00603, пробоподготовка производилась методом сухой минерализации с добавлением азотной кислоты на электроплитке и в муфельной печи по ГОСТ 26929-94, определение $\mathrm{Zn}, \mathrm{Cu}, \mathrm{Fe}, \mathrm{Pb}$ и Сd произведено атомно-абсорбционным методом по ГОСТ 30178-96, As - по ГОСТ Р 517662001. Оценка качества рыбы производилась в соответствии с СанПиН 2.3.2.1078-01. Всего было отобрано 39 проб морской рыбы, выполнено 234 измерений ХЭ.

В результате проведенных исследований установлено, что по величине среднего содержания в рыбе, используемой зоологическими учреждениями для кормления диких и экзотических животных, исследуемые элементы образуют следующий убывающий ряд: $\mathrm{Fe}>$ $\mathrm{Zn}>\mathrm{Cu}>\mathrm{As}>\mathrm{Pb}>\mathrm{Cd}$. В сырой морской рыбе поллютанты содержались в следующем соотношении, \% от общего количества всех исследуемых элементов: $\mathrm{Zn}-18,5 ; \mathrm{Cu}-4,9 ; \mathrm{Fe}-$ 
73,$1 ; \mathrm{Pb}-0,8 ; \mathrm{Cd}-0,1$ и $\mathrm{As}-2,5$, что соответствует уровням накопления и соотношения макрои микроэлементов, и наибольшей чувствительности к накоплению $\mathrm{Fe}$.

При сопоставлении данных микроэлементного статуса морской рыбы с территорией отбора установлено достоверно более высокое содержание $\mathrm{Cu}, \mathrm{Fe}$ и $\mathrm{Cd}$ в кормовой рыбе мегаполиса, самые низкие концентрации ХЭ определены в компонентах рациона областного текстильного центра. В отношении $\mathrm{Zn}, \mathrm{Pb}$ и As достоверных отличий не выявлено.

Для проверки возможного взаимозависимого накопления ХЭ в рыбе был проведен попарный корреляционный анализ, в ходе которого выявлена достоверная слабая прямая связь между уровнем $\mathrm{Cd}-\mathrm{Fe}$ и $\mathrm{Pb}-\mathrm{Cd}(\mathrm{r}=0,59$ при $\mathrm{p}=0,00007$ и $\mathrm{r}=0,57$ при $\mathrm{p}=0,00013)$.

При изучении рационов питания, затребований на кормокухню диких и экзотических животных зоопарков было установлено у каких видов животных в рационах присутствовала рыба. В ходе непараметрического анализа содержания металлов и мышьяка в морской рыбе и элементного статуса биосубстратов (шерсти и перьев), указанных выше животных, установлено наличие достоверно слабой прямой корреляционной связи между содержанием $\mathrm{Pb}, \mathrm{Cd}$ и As в рыбе и биосубстратах животных (табл. 3). Статистически подтвержден антагонизм между поступлением и накоплением в организме птиц и млекопитающих следующих элементов: $\mathrm{Zn}-\mathrm{Pb}, \mathrm{Cu}-\mathrm{Pb}$ и $\mathrm{Zn}-\mathrm{Cd}$. Накоплению As в биосубстратах содействует поступление $\mathrm{Zn}$ и $\mathrm{Cd}, \mathrm{a} \mathrm{Cu}-\mathrm{Zn}$.

Литература. 1. Книга рационов. Основные нормы кормления животных Московского зоопарка / сост. Горваль В.Н. - М.: ГУК «Московский зоопарк», 2009. - 401 с. https://roev.ru/wp-content/uploads/2020/03/Kniga-ratsionov-Moskovskij-zoopark-1.pdf (дата обращения 13.04.2021) 2. Нажметдинова А.Ш. Вопросы контроля за химическими контаминантами в продовольственном сырье и продуктах питания // Медицина (Алматы). 2015. № 8 (158). C. 52-56 https://www.elibrary.ru/download/elibrary_36263465_62153146.pdf (дата обращения 13.04.2021)

\title{
ASSESSMENT OF TOXICOLOGICAL SAFETY OF FISH USED FOR FEEDING
} ANIMALS IN ZOOLOGICAL INSTITUTIONS

${ }^{1}$ Stepanova M.V., associate professor, Ph.D., ${ }^{2}$ Ostapenko V.A., prof., D.Sc.

$\left({ }^{1}\right.$ FSBEI HE YAGSKHA, ${ }^{2}$ FSBEI HE MVA named after K.I. Skryabin, Russia)

Summary. A study of the level of accumulation of heavy metals and arsenic in sea fish used for feeding wild and exotic animals was carried out. Exceeding the MPC has not been established. The presence of a correlation and between the relationship the content of chemical elements in fish and biosubstrates of animals has been established.

Key words: biosubstrates, sea fish, heavy metals, arsenic, rations.

УДК: 614.35

\section{НОРМАТИВНО-ПРАВОВОЕ РЕГУЛИРОВАНИЕ ЭКСПЕРТИЗЫ БЕЗОПАСНОСТИ И ЭФФЕКТИВНОСТИ ВЕТЕРИНАРНЫХ ПРЕПАРАТОВ}

Танирбергенов Т.Б., в.н.с., к.б.н. (ФГБУ ВГНКИ, Россия)

\begin{abstract}
Аннотация. Вопросы обеспечения безопасности и эффективности лекарственных препаратов для ветеринарного применения регулируются Федеральным законом от 12.04.2010 г. Ф3-61 «Об обращении лекарственных средств», государственными стандартами, актами Евразийской экономической комиссии, Техническими регламентами Таможенного союза и Евразийского экономического союза, иными нормативными документами. В то же время важным и до конца не решенным остаетсявопрос онормировании остатков фармацевтических субстанций в продукции животноводства.
\end{abstract}


Ключевые слова:ветеринарные препараты, нормативно-правовое регулирование, экспертиза безопасности и эффективности

Федеральный закон от 12.04.2010 г. Ф3-61 «Об обращении лекарственных средств» [1] регулирует вопросы обеспечения безопасности и эффективности лекарственных препаратов для ветеринарного применения в процессе их разработки и в ходе государственной регистрации.

Порядок проведения доклинических исследованийлекарственных препаратов определяется Приказом Минсельхоза России от 06.03.2018 г. № 101 «Об утверждении Правил проведения доклинического исследования лекарственного препарата для ветеринарного применения, клинического исследования лекарственного препарата для ветеринарного применения, исследования биоэквивалентности лекарственного препарата для ветеринарного применения»[2]. В соответствии с Правилами разработчикам необходимо представить результаты изучения: общетоксических свойств (включая изучение местно-раздражающего действия); специфической токсичности (иммунотоксичности, аллергенности, репродуктивной токсичности, эмбриотоксичности и тератогенности, мутагенности с прогнозом канцерогенности); переносимости лекарственного препарата здоровыми животными целевых видов при однократном и многократном введении в терапевтической (профилактической) и повышенной дозах; фармакокинетики действующего вещества (действующих веществ) и/или метаболитов в организме целевых животных; сроков выведения остаточных количеств действующего вещества (действующих веществ) и/или метаболитов из организма целевых продуктивных животных при введении в максимальной рекомендованной дозе.

Проведение клинических исследований и исследований биоэквивалентности лекарственных препаратов для ветеринарного применения определяется действующими законодательными и нормативными документами[1, 2].Согласно Статьи 12 Федерального закона «Об обращении лекарственных средств» целями клинических исследований являются: «установление переносимости лекарственных препаратов здоровыми животными;подбор оптимальных дозировок лекарственных препаратов и курса лечения на конкретной группе животных с определенным заболеванием;установление безопасности и эффективности лекарственного препарата, предназначенного для лечения определенных заболеваний животных, или эффективности лекарственного препарата для профилактики заболеваний здоровых животных;изучение возможностей расширения показаний к применению зарегистрированного лекарственного препарата и выявления ранее неизвестных побочных действий».

Качество проведения лабораторных исследований, в том числе в ходе исследованийбезопасности и эффективности лекарственных препаратов регулируется как государственными стандартами [3], так и межгосударственными соглашениями в рамках Евразийского экономического союза [4].

Вопросы безопасности продукции животноводства в плане нормирования содержания остаточных количеств фармацевтических субстанций отражены в Техническом регламенте Таможенного союза «О безопасности мяса и мясной продукции» (ТР ТС 034/2013)[5] и в Техническом регламенте Евразийского экономического союза «О безопасности рыбы и рыбной продукции» (ТР ЕАЭС 040/2016)[6].

В настоящее время в продуктах убоя продуктивных животных нормируются максимально допустимые уровни (МДУ) содержания 51 антимикробного средства (индивидуальных соединений и групп родственных соединений), 11 антипротозойных средств и 1 инсектицида [5]. В пищевой продукции аквакультуры животного происхождениянормируются МДУ 28 антимикробных средств (индивидуальных соединений и групп родственных соединений) и 9 антипротозойных средств[6].

Согласно оценке Ф.И.Василевича с соавторами [7] ветеринарное законодательство в Российской Федерации в целом находится в состоянии как структурной, так и внутрисистемной рассогласованности.Для разрешения данной ситуации ставится задача гармонизации и унификации законодательства. 
Применительно к нормативно-правовому регулированию безопасности продукции животноводства и аквакультуры это означает необходимость дальнейшего совершенствования нормативной базы, разработки и стандартизации аналитических методов, гармонизации требований в рамках Евразийского экономического союза.

К числу не до конца решенных проблем в этой области следует, в частности, отнести:

- необходимость расширения списка контролируемых фармацевтических субстанций;

- отсутствие в ряде случаев аттестованных методов анализа;

- отличающиесятребования к МДУ некоторых фармацевтических субстанций в Евразийском экономическом союзе и в Европейском союзе (например, по содержанию антибиотиков группы тетрациклиновразличия достигают десятикратной величины - не более 10 мг/кг и не более 100 мг/кг, соответственно);

- отсутствие утвержденных МДУ фармацевтических субстанций для продукции птицеводства(в настоящее время разрабатывается Технический регламент Евразийского экономического союза «О безопасности мяса птицы и продукции ее переработки»).

Литература.1. Федеральный закон от 12.04.2010 г. Ф3-61 «Об обращении лекарственных средств». 2. Приказ Минсельхоза России от 06.03.2018 г. № 101 «Об утверждении Правил проведения доклинического исследования лекарственного препарата для ветеринарного применения, клинического исследования лекарственного препарата для ветеринарного применения, исследования биоэквивалентности лекарственного препарата для ветеринарного применения». 3. ГОСТ 33044-2014 «Принципы надлежащей лабораторной практики». 4 «Правила надлежащей лабораторной практики Евразийского экономического союза (ЕАЭС) в сфере обращения лекарственных средств» (решение Совета Евразийской экономической комиссии от 03.11.2016 г. № 81).5. Технический регламент Таможенного союза «О безопасности мяса и мясной продукции» (ТР ТС 034/2013). 6. Технический регламент Евразийского экономического союза «О безопасности рыбы и рыбной продукции» (ТР ЕАЭС 040/2016). 7. Василевич Ф.И., Василевский Н.М., Шевкопляс В.Н. Гармонизация ветеринарного законодательства // Ученые записки КГАВМ им. Н.Э. Баумана. - 2013. - №2. URL: https://cyberleninka.ru/article/n/garmonizatsiya-veterinarnogo-zakonodatelstva (дата обращения: 18.03.2021).

\section{LEGISLATIVE REGULATIONS OF SAFETY AND EFFECTIVENESS EXPERTISE OF VETERINARY DRUGS}

Tanirbergenov T.B.,senior researcher, Ph.D

(FGBU VGNKI, Russia)

Summary. The issues of ensuring the safety and effectiveness of medicines for veterinary use are regulated by the Federal Law of 12.04.2010 FZ-61 "On the Circulation of Medicines", state standards, acts of the Eurasian Economic Commission, Technical Regulations of the Customs Union and the Eurasian Economic Union, and other regulatory documents. At the same time, the problem of rationing the residues of pharmaceutical substances in livestock products remains important and not fully resolved.

Key words:veterinary drugs, legislative regulations, expertise of safety and effectiveness

УДК: 636.15

\section{ВЛИЯНИЕ ЛЬНЯНОГО ЖМЫХА НА ПОКАЗАТЕЛИ НЕСПЕЦИФИЧЕСКОГО ИММУНИТЕТА У МОЛОДНЯКА ЛОШАДЕЙ}

Тарасова А.О., аспирант

(ФГБОУ ВО «Курганская государственная сельскохозяйственная академия имени Т.С.Мальцева», Курган, Россия)

Аннотация. Исследованиями установлено, что у молодняка лошадей, получавших в составе рациона льняной жмых, отмечалась более устойчивая неспецифическая резистентность, о чем 
свидетельствовали фагоцитарные реакции и лейкоцитарный профиль этих животных. Это выражается в общем укреплении организма, повышении его защитных возможностей в борьбе с различными возбудителями болезней.

Ключевые слова:льняной жмых, лошади, неспецифический иммунитет

«Кормление лошадей в тяжеловозных конных заводах организуют на основе норм и рекомендаций с учетом индивидуальных особенностей. Рационы должны быть достаточными по общей питательности п обеспечивать потребность лошадей в переваримом протеине, витаминах, макро- и микроминеральных веществах» [1].

Любой живой организм может функционировать только при слаженной работе всех систем, в том числе иммунной. Естественная устойчивость организма представлена общей иммунобиологической реактивностью, клеточным и тканевым иммунитетом, неспецифическими гуморальными факторами и ее определяют как естественную резистентность или реактивность организма. Исследованиями установлено значительное влияние факторов внешней среды, в том числе кормления на показатели функционирования биологических систем и неспецифической реактивности организма [2 - 8].

Целью научной работы являлось изучение неспецифического иммунитета у молодняка лошадей русской тяжеловозной породы, потреблявших различные дозировки льняного жмыха.

Научно-хозяйственный опыт провели в ООО «Логиново» Курганской области на молодняке лошадей русской тяжеловозной породы в возрасте 9 - 12 месяцев. Молодняк был распределен в три группы по принципу аналогов (с учетом возраста, происхождения, живой массы), по 9 голов в каждой группе, по 5 жеребчиков и 4 кобылки в каждой [9]. Контрольная группа молодняка получала основной рацион, 1 опытная - рацион с добавлением льняного жмыха в дозировке 300 г/гол, а 2 опытной - 500 г/гол в сутки. Льняной жмых давали в смеси с овсом. При проведении опыта иммунные показатели крови контролировали в начале опыта, в середине и в конце. Полученный в опытах цифровой материал подвергли биометрической обработке с использованием программы Microsoft Excel [10].

В начале опыта уровень естественной резистентности в группах практически не отличался и в среднем показатели составили: количество лейкоцитов 9,56 х $10^{9}$ /л, фагоцитарная активность - 58,67\%, фагоцитарное число и фагоцитарный индекс - 3,57 и 6,09 соответственно, фагоцитарная емкость - 58,32 тыс.мик.тел.

В наших исследованиях отмечено положительное влияние использования льняного жмыха в рационе лошадей. К середине опыта у лошадей всех групп отмечалось уменьшение числа лейкоцитов: в контроле на $1,37 \%$, в 1 опытной - на $1,75 \%$ и во 2 опытной - на $0,84 \%$. Однако, если в контроле одновременно с уменьшением лейкоцитов снижался и уровень клеточного иммунитета, то в опытных эта тенденция не наблюдалась. У лошадей контрольной группы к середине опыта уменьшились: фагоцитарная активность на 0,67\%, фагоцитарное число - на 3,05\%, фагоцитарный индекс - на 1,80\% и фагоцитарная емкость - на $3,36 \%$. В опытных группах данные показатели, наоборот увеличивались: в 1 опытной на 2,00; 5,62; 2,47 и $0,34 \%$, во 2 опытной - на 3,$00 ; 8,45 ; 3,45$ и 2,51\% соответственно. Непосредственно в середине опыта количество лейкоцитов в контрольной группе было меньше по сравнению с 1 опытной на $2,03 \%$ и на $0,86 \%$, чем во 2 опытной. Фагоцитарная активность в опытных группах была больше, чем в контроле на 2,34 и 3,00\%; фагоцитарное число - на 7,43 и 10,00\%, фагоцитарный индекс - на 3,49 и 4,66\%, фагоцитарная емкость - на 5,60 и 5,69\% соответственно.

Тенденции середины опыта по ряду показателей сохранялись и в конце исследований. Количество лейкоцитов увеличилось у лошадей всех групп: в контрольной на 2,25\%, в 1 опытной - на 1,26\% и во 2 опытной - на 2,65\%. В конце опыта данный показатель был минимален в контроле (9,55 х 109/л) и был меньше на 1,05 и 1,26\% по сравнению с опытными соответственно. У лошадей контрольной группы в конце опыта уменьшилась фагоцитарная активность и фагоцитарное число на 1,33 и 0,57\%, при увеличении фагоцитарного индекса на $1,66 \%$ и фагоцитарной емкости - на 4,12\%. В 1 и 2 опытных группах все показатели 
естественной резистентности увеличивались: фагоцитарная активность - на 0,66 и 2,00\%, фагоцитарное число - на 1,86 и 4,16\%, фагоцитарный индекс - на 0,32 и 0,79\%, фагоцитарная емкость - на 1,70 и 3,34\% соответственно. В конце опыта все показатели естественной резистентности были больше в опытных группах, животные которых потребляли в составе рациона льняной жмых: фагоцитарная активность - на 4,33 и 6,33\%, фагоцитарное число - на 10,06 и $15,23 \%$, фагоцитарный индекс - на 2,13 и 3,76\%, фагоцитарная емкость - на 3,15 и $4,90 \%$ соответственно.

Известно, что по данным лейкоцитарной формулы можно судить о ходе различных процессов в организме, физиологического и патологического характера. Лейкоцитарная формула молодняка лошадей в различные периоды опыта представлена в таблице 2.

В начале опыта у лошадей всех групп лейкоцитарный профиль практически не отличался, и в среднем по клеткам составил: нейтрофилы (палочко- и сегметноядерные) 3,55 и 52,67 соответственно, эозинофилы $-3,89 \%$, базофилы $-0,44 \%$, моноциты $-2,56 \%$ и лимфоциты - 36,89 \%. Разница между максимальным и минимальным показателям профиля в начале опыта была незначительной и составила по нейтрофилам (палочко- и сегметноядерным) 1,33 и $1,66 \%$ соответственно, эозинофилам - 1,00\%, базофилам и моноцитам $-0,34 \%$ и лимфоцитам $-2,33 \%$. Таким образом, лейкоцитарный профиль лошадей в начале опыта соответствовала физиологической норме.

К середине опыта значительных изменений в лейкограмме лошадей всех групп отмечено не было. В контрольной группе снизилось число сегментоядерных нейтрофилов на $2,00 \%$ и увеличились: палочкоядерные нейтрофилы - на $0,33 \%$, моноцитов - на $0,34 \%$ и лимфоцитов - на 1,34\%. В 1 и 2 опытных группах уменьшилось число палочкоядерных нейтрофилов на 0,33 и $0,66 \%$ и лимфоцитов - на 1,33 и 2,00\% соответственно; и увеличилось сегментоядерных нейтрофилов - на 0,67 и $1,33 \%$, эозинофилов - на $0,67 \%$ и моноцитов - на 0,33 и $0,66 \%$. Непосредственно в середине опыта у лошадей 1 и 2 опытных групп было больше сегментоядерных клеток на 4,33 и 4,66\% и меньше - на 4,67 и 5,67\% соответственно в сравнении с контролем.

К концу опыта у лошадей всех групп уменьшается число сегментоядерных нейтрофилов: в контроле - на $0,67 \%$, в 1 опытной - на 2,33 и во 2 опытной - на 2,00\% и увеличивается число лимфоцитов - на 1,66; 2,00 и 1,33\% соответственно. В конце опыта у лошадей опытных групп больше клеток, отвечающих за неспецифический иммунитет (сегментоядерных нейтрофилов - на 2,67 и 3,33\% и моноцитов - на 1,00 и 1,33\%) и меньше лимфоцитов - на 4,33 и 6,00\% в сравнении с контролем.

Таким образом, у молодняка лошадей опытных групп, получавших в составе рациона льняной жмых, отмечалась более устойчивая неспецифическая резистентность, о чем свидетельствовали фагоцитарные реакции и лейкоцитарный профиль этих животных. Это выражается в общем укреплении организма, повышении его защитных возможностей в борьбе с различными возбудителями болезней.

Литература.1. Рекомендации по технологии выращивания племенных лошадей советской и русской тяжеловозных пород в конных заводах СССР. - М.: Колос. - 1977. - 33 с. 2. Суханова С.Ф., Лещук Т.Л., Бисчоков Р.М. Математическое обоснование действия внешних факторов, влияющих на биологический объект // Вестник Курганской ГСХА. - 2019. - № 1 (29). - С. 46 - 50. 3. Суханова С.Ф., Лещук Т.Л., Корниенко И.Г., Бисчоков Р.М. Отбор факторов и показателей, обуславливающих действие биологической системы // Инновационные технологии в АПК: материалы Международной научно-практической конференции 21-23 ноября 2018 г /под общ.ред.В.А.Бабушкина. - Мичуринск: Изд-во Мичуринского ГАУ, 2018. - С. 137 - 140. 4. Суханова С.Ф., Бисчоков Р.М. Разработка версий моделей влияния внешних факторов на показатели биологических систем // Роль аграрной науки в устойчивом развитии сельских территорий: Сб. III Всероссийской (национальной) научной конференции (г.Новосибирск, 20 декабря 2018 г.)/Новосиб.гос.аграр.ун-т. - Новосибирск: ИЦ НГАУ «Золотой колос», 2018. - С.417 - 418.5. Суханова С.Ф., Азаубаева Г.С., Лещук Т.Л. Использование методов математического моделирования для обработки результатов 
биологических исследований // Актуальные проблемы развития профессионального образования: Материалы Всероссийской научно-практической конференции (31 октября 2017 г.). - Курган: Изд-во Курганской ГСХА, 2017. - С. 210 - 214. 6. Суханова С.Ф., Азаубаева Г.С., Лещук Т.Л. Степень влияния внешних факторов на показатели функционирования биологических систем // Вестник Курганской ГСХА. - 2017. - № 2 (22). - С. 65-69. 7. Азаубаева Г.С., Суханова С.Ф., Лещук Т.Л. Использование модели мониторинга факторов при определении эффективного функционирования биологических систем // Актуальные проблемы экологии и природопользования: Матер. Всероссийской научно-практической конф. (18 мая 2017 г). - Курган: Изд-во Курганской ГСХА, 2017. - C.16-24. 8. Sukhanova S.F., Bischokov R.M. Identifying Mobile Indicators that Reflect the Functioning of Biological Systems Depending on the Environmental Factors // Advances in engineering research (International scientific and practical conference "AgroSMART - Smart solutions for agriculture" (AgroSMART 2018). Vol.151, 2018. - p.p.95 - 100. 9. Суханова С.Ф., Азаубаева Г.С., Махалов А.Г. Планирование и организация эксперимента. - Курган: Изд-во Курганская ГСХА, 2015. - 210 с.10. Суханова С.Ф., Азаубаева Г.С., Лещук Т.Л., Кощаев А.Г. Биометрические методы в животноводстве. Краснодар: КубГАУ, 2017. - 162 с.

\section{EFFECT OF LINSEED ON NONSPECIFIC IMMUNITY IN YOUNG HORSES}

Tarasova A.O., graduate student

(FSBOU VO "Kurgan State Agricultural Academy named after T.S. Maltsev," Kurgan, Russia) Summary. Studies have found that young horses treated as part of the flaxseed diet showed more stable non-specific resistance, as evidenced by the phagocytic reactions and white blood cell profile of these animals. This is expressed in the general strengthening of the body, increasing its protective capabilities in the fight against various pathogens of diseases.

Key words:flaxseed, horses, nonspecific immunity

УДК: 619:615:579

\section{АДСОРБЦИЯ Т-2 ТОКСИНА IN VITRO}

Тарасова Е.Ю., к.б.н., Матросова Л.Е., д.б.н., Садыкова А.Ш., аспирант (ФГБНУ «Федеральный центр токсикологической, радиационной и биологической безопасности», Россия)

Аннотация. Были проведены эксперименты in vitro для оценки эффективности против Т-2 токсина двух новых биосорбентов (цеолита и цеолита обожженного при температуре $1000{ }^{\circ} \mathrm{C}$ с иммобилизованными на их поверхности бактериями $P$. mucilaginosus). В качестве препаратов сравнения выступали исходный цеолит до модификации и коммерческий адсорбент микотоксинов на основе гидратированного алюмосиликата кальция и натрия (Новазил Плюс). Показано, что самую высокую эффективность удаления Т-2 токсина показал биосорбент на основе обожженного цеолита, процент биосорбции составил 79,5 \%.

Ключевые слова: Т-2 токсин, цеолит, адсорбция, P. mucilaginosus

Микотоксины - это токсичные вторичные метаболиты грибов, которые представляют серьезную угрозу безопасности пищевых продуктов и кормов $[1,2]$. Трихотецены являются наиболее важной группой фузариотоксинов, а Т-2 токсин является одним из наиболее цитотоксических в исследованиях на животных, оказывает иммунодепрессивное действие и вызывает широкий спектр желудочно-кишечных, дерматологических и неврологических симптомов $[3,4,5]$. Этот микотоксин был ретроспективно связан с пищевым токсикозом человека, известным как алиментарная токсическая алейкия, который характеризуется тяжелой лейкопенией с истощением иммунных клеток и аплазией костного мозга. Присутствие Т-2 токсина в пищевых продуктах и кормах давно признано потенциальной опасностью для здоровья человека и животных $[6,7]$. 
Из-за неблагоприятного воздействия Т-2 токсина на здоровье человека и животных идет поиск безопасных, практичных, недорогих и эффективных стратегий обеззараживания $[8,9]$. В настоящее время наиболее широко используемой стратегией физической дезактивации является адсорбция Т-2 токсина различными материалами $[10,11,12,13]$. В связи с этим целью исследования была оценка эффективности против Т-2 токсина двух новых биосорбентов (цеолита и цеолита обожженного при температуре $1000{ }^{\circ} \mathrm{C}$ c иммобилизованными на их поверхности бактериями $P$. mucilaginosus) в сравнении с исходным цеолитом до модификации и коммерческим адсорбентом микотоксинов на основе гидратированного алюмосиликата кальция и натрия (Новазил Плюс) in vitro.

Материалы и методы. Адсорбцию Т-2 токсина (10 мкг/мл) исследовали при содержании сорбентов (10 мг/мл) и трех значениях $\mathrm{pH}(2,7$ и 8). Эксперименты проводили при $37{ }^{\circ} \mathrm{C}$. Для оценки эффективности адсорбентов в удалении Т-2 токсина из буферных растворов использовали метод, описанный ранее $[14,15]$. В опыте использованы: образец № 1 - на основе внеклеточных полисахаридов, синтезируемых штаммом 574 бактерии $P$. mucilaginosus и цеолита, образец № 2 - на основе внеклеточных полисахаридов, синтезируемых штаммом 574 бактерии P. mucilaginosus и обожженного цеолита, образец № 3 - некоммерческое связующее микотоксинов (цеолит), образец № 4 - коммерческое связующее микотоксинов Новазил Плюс.

Результаты исследований. Значительная эффективность адсорбции ( $\mathrm{pH} 2$ ) была достигнута при использовании образца № 2 - 41,2 мкг Т-2 токсина, против 36,8, 23,5 и 35,0 мкг соответственно у первого, третьего и четвертого образцов, что свидетельствует об улучшенной связывающей способности биосорбентов по сравнению с исходным цеолитом. Это увеличение, вероятно, связано с повышением пористости за счет иммобилизации на поверхности P. mucilaginosus и большим количеством вариаций типов сайтов связывания относительно материнского цеолита.

Уровень адсорбции Т-2 токсина при рН 7 составил 73,6, 82,4, 43,6, 72,8 \%. При этом адсорбция Т-2 токсина увеличивалась при повышении рН у первого, второго и четвертого образцов соответственно на 2,4, 4,0 2,8 \%. Этот эффект может быть связан с изменениями зарядов адсорбентов, вызванными рН буферных растворов.

Потери Т-2 токсина (десорбция) при изменении рН с 2,0 до 8,0 составили 1,2, 1,3, 1,5 и 2,8 мкг с наименьшими значениями у первых двух образцов. Таким образом, истинная сорбция была на уровне $35,5,40,0,22,0,32,2$ мкг. Самую высокую эффективность удаления Т-2 токсина показал второй образец, процент биосорбции составил 79,5 \%, что на 5,9, 38,3, 17,5 \% выше показателей первого, третьего и четвертого образцов.

Заключение. Полученные результаты показывают, что биосорбенты на основе цеолита демонстрируют конкурентную адсорбционную способность при удалении неполярного Т-2 токсина. Возможно, разработанные биосорбенты будут связывать широкий спектр различных загрязнителей окружающей среды, содержащихся в пищевых продуктах и кормах, что поможет свести к минимуму воздействие микотоксинов на организм животных и человека.

Литература. 1. Тремасов, М.Я. Микотоксины - реальная угроза продовольственной безопасности / М.Я. Тремасов, А.В. Иванов, Е.Ю. Тарасова // Вестник ветеринарии. - 2013. № 2 (65). - С. 78-80. 2. Тремасов, М.Я. Опыт применения пробиотика при микотоксикозах / М.Я. Тремасов, Л.Е. Матросова, Е.Ю. Тарасова // Вестник ветеринарии. - 2009. - № 3 (50). - С. 38-41. 3. Идиятов, И.И. Цитотоксическая активность Т-2 токсина к перевиваемым культурам клеток эпителия легкого эмбриона крупного рогатого скота / И.И. Идиятов, Л.Р. Валиуллин, В.В. Бирюля [и др.] // Гены и Клетки. - 2017. - Т. 12. - № 1. - С. 41-46. 4. Валиуллин, Л.Р. Изучение изменений биохимических показателей культур клеток при воздействии Т-2 токсина / Л.Р. Валиуллин, В.В. Бирюля, И.И. Идиятов [и др.] // Ученые записки Казанской государственной академии ветеринарной медицины им. Н.Э. Баумана. - 2018. - Т. 236. - № 4. - С. 39-43. 5. Идиятов, И.И. Сочетанное воздействие малых доз диоксина и Т-2 токсина на организм поросят и пути коррекции / И.И. Идиятов // автореферат дис. кандидата 
биологических наук / Федеральный центр токсикологической и радиационной безопасности животных. - Казань, 2013. 6. Тарасова, Е.Ю. Изыскание средств для лечения животных при Т2 микотоксикозе / Е.Ю. Тарасова // Автореферат диссертации на соискание ученой степени кандидата биологических наук / Федеральный центр токсикологической и радиационной безопасности животных (Всероссийский научно-исследовательский ветеринарный институт). - Казань, 2010. 7. Папуниди, Э.К. Ветеринарно-санитарная экспертиза мяса овец при остром и подостром Т-2 микотоксикозе на фоне применения лекарственных средств / Э.К. Папуниди, М.Я. Тремасов, Е.Ю. Тарасова // Ветеринарный врач. 2010. - № 2. - С. 21-23. 8. Понамарев, В.С. Влияние препарата "Гепатон" в сочетании с фитосорбционным комплексом на уровень эндогенной интоксикации / В.С. Понамарев, О.С. Попова // Вопросы нормативно-правового регулирования в ветеринарии. - 2020. - № 3. - С. 124-125. 9. Барышев, В.А. Повышение эффективности современных сорбентов / В.А. Барышев, О.С. Попова, А.В. Свиридова // Международный вестник ветеринарии. - 2017. - № 2. - С. 13-16. 10. Семенов, Э.И. Сравнительная оценка адсорбирующей активности дрожжей по отношению к микотоксинам / Э.И. Семенов, Л.Е. Матросова, Е.Ю. Тарасова [и др.] // Вестник Казанского технологического университета. - 2013. - Т. 16. - № 10. - С. 195-197. 11. Баскова, Е.Ю. Применение энтеросорбентов на основе нанотехнологий для борьбы с микотоксикозами животных / Е.Ю. Баскова // Ученые записки Казанской государственной академии ветеринарной медицины им. Н.Э. Баумана. - 2008. - Т. 192. - С. 234. 12. Matrosova, L.E. Enterosorbent efficiency mineral attenuation during pig mycotoxicosis / L.E. Matrosova, N.N. Mishina, S.A. Tanaseva [et al.] // International Journal of Mechanical and Production Engineering Research and Development. - 2020. - V. 10. - P. 1851. 13. Tarasova, E.Yu. Protective effect of adsorbent complex on morphofunctional state of liver during chicken polymycotoxicosis / E.Yu. Tarasova, L.E. Matrosova, S.A. Tanaseva [et al.] // Systematic Reviews in Pharmacy. - 2020. - V. 11. - № 11. - Р. 264-268. 14. Тарасова, Е.Ю. Изучение сорбционной активности потенциальных средств профилактики микотоксинов в отношении афлатоксинов / Е.Ю. Тарасова, Э.И. Семенов, Л.Е. Матросова [и др.] // Ветеринарный врач. - 2020. - № 2. - С. 51-58. 15. Тарасова, Е.Ю. Поиск эффективных адсорбентов Т-2 токсина / Е.Ю. Тарасова, Э.И. Семенов, А.Р. Валиев [и др.] // Вестник Марийского государственного университета. Серия: Сельскохозяйственные науки. Экономические науки. - 2019. - Т. 5. - № 3 (19). - С. 322-329.

\section{T-2 TOXIN ADSORPTION IN VITRO}

Tarasova E.Yu., Ph.D., Matrosova L.E., D.Sc., Sadykova A.Sh., postgraduate student (FGBNU "Federal Center for Toxicological, Radiation and Biological Safety", Russia)

Summary. In vitro experiments were carried out to evaluate the effectiveness against T-2 toxin of two new biosorbents (zeolite and zeolite fired at $1000^{\circ} \mathrm{C}$ with $\mathrm{P}$. mucilaginosus bacteria immobilized on their surface). In comparison with the original zeolite before modification and a commercial adsorbent of mycotoxins based on hydrated calcium aluminosilicate and sodium (Novazil Plus). It was shown that the highest efficiency of T-2 toxin removal was shown by a biosorbent based on fired zeolite, the percentage of biosorption was $79.5 \%$.

Key words: T-2 toxin, zeolite, adsorption, $P$. mucilaginosus 


\title{
ОСОБЕННОСТИ КОЛОСТРАЛЬНОГО ИММУНИТЕТА ТЕЛЯТ ПРИ СОЧЕТАННОЙ СТИМУЛЯЦИИ КОРОВ-МАТЕРЕЙ ИММУНОМОДУЛЯТОРОМ И СИНЭСТРОЛОМ 2\%
}

Терентьев Сергей Сергеевич - стар. прд., Великанов Валериан Иванович - д.б.н., проф., Кляпнев Андрей Владимирович - к.б.н., Горина Анна Владимировна - аспирант, Трунова Екатерина Андреевна - аспирант, Дунаевская Анастасия Алексеевна - аспирант; Чвала

Александр Викторович - к.б.н., доцент (ФГБОУ ВО Нижегородская ГСХА, Россия)

\begin{abstract}
Аннотация. целью нашего исследования явилось изучение влияния сочетанного введения коровам за 3-5 дней до отелаиммуномодулятора полиоксидоний и синтетического аналога эстрона Синэстрол $2 \%$ на колостральный иммунитет телят. Эксперимент показал, что телята полученные от таких коров имеют при рождении большее количество лейкоцитов, Тлимфоцитов и В-лимфоцитов. Синэстрол $2 \%$ вероятно проникает через плаценту и влияет на плод, что отражается в ускорении метаболизма новорожденного. В результате мы наблюдали ускоренное усвоение молозива из ЖКТ, что отразилось на резком приросте фракций $\beta$ - и $\gamma$ глобулинов через час после выпойки молозива. Кроме того резко выросло количество Тлимфоцитов и В-лимфоцитов.
\end{abstract}

Ключевые слова:Полиоксидоний, Синэстрол 2\%, колостральный иммунитет

У высокомолочных коров современного комплекса имеются метаболические нарушения, в том числе белковые и витаминные, что отрицательно влияет на внутриутробное развитие плода и качество молозива, получаемого от этих животных $[1,5]$. Телята в этом случае имеют дефект колострального иммунитета, что отрежется на становлении резистентности организма $[2,6]$. Многочисленные научные изыскания прошлого столетия определили пути развития нивелирования отрицательных эффектов интенсивного животноводства на организм молодняка, одним из которых является стимуляция организма коров матерей иммуномодулирующими и гормональными препаратами $[3,7]$.

Материал и методы исследований. Эксперимент был проведен на базе СПК «Нижегородец» расположенном в Дальнеконстантиновском районе Нижегородской области, в летний период (июнь-август) 2020 года. Объектом исследования послужили телята полученные от коров черно-пестрой породы. Предметом исследования стали гематологические, биохимические и иммунологические показатели проб кровиполученных от телят. Из отобранных коров было сформировано три группы n=20, контрольная, 1-ая и 2-ая опытная. Группы формировались из клинически здоровых животных по принципу параналогов. При отборе животных для эксперимента учитывались следующие параметры животных: количество стельностей (2-3), объем прошлой лактации, количество осеменений, физиологическое состояние (отбирались клинически здоровые животные). Коровам в зависимости от группы за 3-5 дней до отела вводили препараты: 1-ой группе полиоксидоний в дозе 6 мг; 2-ой группе полиоксидоний в дозе 6 мг и Синэстрол $2 \%$ в дозе 1 мл; контрольным животным 2мл физиологический раствора. Непосредственно после отела от коров отбиралась проба молозива для лабораторного исследования. Народившимся телятам в течении первого часа жизни выпаивали 2 литра молозива от коровы-матери при помощи дренчер-зонда. Пробы крови отбиралась в первые 30 минут жизни, затем через 1 час после выпойки молозива и спустя сутки от рожденияи в 30 день жизни.

Лабораторные исследования крови проводились на гематологическом анализаторе XТ 2000, Sysmex, Europe, GmbH. Содержание общих иммуноглобулинов молозива (Ig) определяли методом с натрия сульфитом описанном в справочнике «Методы ветеринарной клинической лабораторной диагностики» под редакцией профессора И.П. Кондрахина [4].Полученный цифровой материал подвергали статистической обработке с использованием 
общепринятых параметрических методов, степень достоверности определяли по t-критерию Стьюдента с применением пакета прикладных программ MicrosoftExcel (2007).

Результаты и обсуждения эксперимента. В отобранных пробах молозива первой

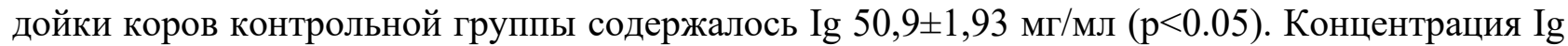
в молозиве коров 1-ой и 2-ой опытной групп составило 63,44 $\pm 1,43$ мг/мл и 65,02 $\pm 3,41$ мг/мл, что было больше по сравнению с контрольными пробами на 24,64\% и 27,74\% соответственно.

Хотя показатели концентрации иммуноглобулинов в молозиве первой дойки у коров 1-ой и 2-ой группы были близки, морфологические и биохимические показатели крови телят имели значительные отличия как между собой, так и от контроля. Уже при рождении в крови

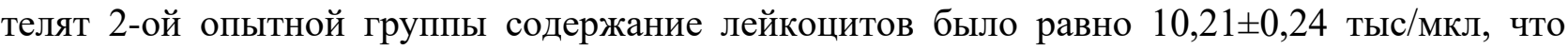
больше на 13,7\% по сравнению с 1-ой группой $(8,98 \pm 0,21$ тыс/мкл) и на 18,45 больше чем у контрольных животных $(8,62 \pm 0,22$ тыс/мкл). Спустя час от выпойки молозива происходил рост числа лейкоцитов у телят 2-ой группы до 11,54 \pm 0,23 тыс/мкл (на 13,03\%), а у 1-ой группы до 9,13 \pm 0,22 тыс/мкл. У контрольных-же телят мы наблюдали мы наблюдали уменьшение числа лейкоцитов до 7,92 $\pm 0,28$ тыс/мкл. В суточном возрасте мы зарегистрировали следующие значения концентрации лейкоцитов в крови телят контрольной, 1-ой и 2-ой групп: 8,38 $\pm 0,26$ тыс/мкл, 10,01 $\pm 0,28$ тыс/мкл и 13,33 $\pm 0,26$ тыс/мкл соответственно. В период от суточного возраста до 30 суток у телят контрольной 2-ой группы происходило плавное снижение числа лейкоцитов до значений в 7,51 $\pm 0,25$ тыс/мкл и 10,11 \pm 0,22тыс/мкл, а у телят 1-ой группы наблюдалось повышение до 10,82 $\pm 0,27$ тыс/мкл.

Анализ содержания лимфоцитов показал, что при рождении телята 2-ой группы имели абсолютное число Т-лимфоцитов в $1,78 \pm 0,15$ тыс./мкл, что больше по сравнению с контролем на $35,88 \%(1,31 \pm 0,16$ тыс./мкл) и на $32,84 \%$ больше в сравнении с 1 -ой группой $(1,34 \pm 0,14$ тыс./мкл). Через час после выпойки молозива их концентрация повысилась у телят контрольной, 1 -ой и 2-ой групп до 1,35 $\pm 0,13$ тыс./мкл, $1,85 \pm 0,17$ тыс./мкл (рост в 38,06\%) и $2,65 \pm 0,14$ тыс./мкл (рост в 48,88\%) соответственно. В суточном возрасте был зарегистрирован резкий рост показателя до значений в $2,29 \pm 0,12$ тыс./мкл, 2,32 $\pm 0,13$ тыс./мкл, 3,51 $\pm 0,12$ тыс./мкл соответственно. На 30 день жизни показатель достиг значений в 2,36 $\pm 0,15$ тыс./мкл, 2,45 $\pm 0,19$ тыс./мкл и 3,71 $\pm 0,19$ тыс./мклсоответственно.

Абсолютное число Б-лимфоцитов в крови телят подопытных групп при рождении не имело значимых различий между собой и составляло $0,74 \pm 0,05,0,71 \pm 0,03$ и 0,67 \pm 0,03 тыс./мкл соответственно. Однако уже через час после выпойки молозива концентрация Блимфоцитов в крови телят 2-ой группы выросла до 0,76 \pm 0,04тыс./мкл, у телят контрольной осталась на том же уровне, а у 1-ой группы наоборот снизилась до 0,68 $\pm 0,04$ тыс./мкл. В суточном возрасте количество Б-лимфоцитов у телят контрольной, 1-ой и 2-ой групп достигло $0,88 \pm 0,07$ тыс./мкл, 1,21 $\pm 0,09$ тыс./мкл и 1,28 $\pm 0,07$ тыс./мкл. В возрасте 30 суток значения исследуемого параметра крови приняли значения в $1,1 \pm 0,15$ тыс./мкл, $1,31 \pm 0,11$ тыс./мкл и $1,4 \pm 0,14$ тыс./мкл соответственно.

Важным фактором гомеостаза организма теленка являются сывороточные белки которые в виде альбуминов и глобулинов молозива которые поступают в организм теленка с первой порцией молозива. При рождении концентрация общих белков сыворотки крови (далее ОБС) у телят подопытных групп не имела значимых различий и принимала значения в $40,62 \pm 1,78$ г/л, 41,76 \pm 4,42 г/л и 40,43 \pm 0,77 г/л у телят контрольной, 1-ой и 2-ой групп соответственно. Однако через час после выпойки молозива их концентрация в крови телят 2ой группы поднялась до 44,89 $\pm 2,05$ г/л (выросла на 4,37 \%), а у телят контрольной и 1 -ой группы до 40,31 $\pm 2,22$ г/л и 42,5 $\pm 2,19$ г/л (осталась практически на том же уровне). В суточном возрасте показатель принял значения в 58,37 $\pm 2,35$ г/л, 70,65 $\pm 2,31$ г/л и 72,38 $\pm 2,38$ г/л у телят контрольной, 1-ой и 2- групп соответственно. В возрасте 30 суток значения

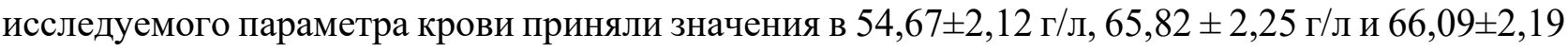
г/л соответственно, иными словами демонстрировал плавное снижение.

Резкий рост ОБС производил в первую очередь за счёт фракции $\gamma-$ глобулинов. При рождении их количество составляло $0,81 \pm 0,09$ г/л, $0,89 \pm 0,02 \Gamma / л$ и $0,93 \pm 0,02$ г/л у телят 
контрольной, 1-ой и 2-ой групп соответственно. Уже через час после выпойки молозива их концентрация увеличилась до 1,44 $\pm 0,1$ г/л (рост на 77,78\%), 2,36 $\pm 0,04$ г/л (рост в 1,65 раза) и 3,26 $\pm 0,03 г / л$ (рост в 2,51 раза) соответственно. В суточном возрасте наблюдался ещё больший уровень исследуемого показателя до значений в 15,02 $\pm 0,27$ г/л, 21,23 \pm 0,24 г/л и $25,92 \pm 0,29$ г/л соответственно. В течении от суточного возраста до 30 дня жизни содержание

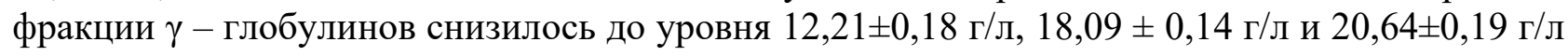
соответственно.

Фракция $\beta$ - глобулинов внесла свой в клад при росте ОБС. При рождении их количество составляло $3,46 \pm 0,05 \Gamma / л, 3,67 \pm 0,07$ г/л и 3,69 $\pm 0,02$ г/лу телят контрольной, 1 -ой и 2-ой групп соответственно. Уже через час после выпойки молозива их концентрация увеличилась до $3,72 \pm 0,18$ г/л (рост на 7,51 \%) у контрольной и 4,97 $\pm 0,03$ г/л (рост рост на $34,69 \%$ ) у телят 2-ой группы, а 1-ой группы животных показатель практически не изменился и составил, 3,55 $\pm 0,11$ г/л. В суточном возрасте уровень исследуемого показателя достиг значений в 7,23 $\pm 0,21 \Gamma /$ л, $8,37 \pm 0,23$ г/л и $9,09 \pm 0,18$ г/л соответственно. В течении от суточного возраста до 30 дня жизни содержание фракции $\beta$ - глобулинов снизилось до уровня $6,33 \pm 0,07 \Gamma /$ л, 6,31 $\pm 0,05$ г/л и 7,65 $\pm 0,09$ г/л соответственно.

Наглядным результатом вышеописанного стало снижение заболеваемости телят незаразными патологиями ЖКТ. Так заболеваемость в 1 -ой группе снизилась на 55,56\%, а во 2 -ой на 77,78\% по сравнению с контрольной группой. Как результат снижения заболеваемости у телят 1-ой и 2-ой групп увеличились суточные привесы за первый месяц жизни на 13,01 и $18,96 \%$ соответственно.

Заключение. Подводя итоги, можно сказать, что сочетанное введение иммуномодулятора полиоксидоний и синтетического аналога эстрона Синэстрола 2\% коровамза 3-5 дней до отела, приводит к увеличению в первой порции молозива иммуноглобулинов на $27,74 \%$ по сравнению с коровами контрольной группы.Телята, полученные от таких коров имеют при рождении большее количество лейкоцитов, Тлимфоцитов и В-лимфоцитов. Синэстрол $2 \%$ вероятно проникает через плаценту и влияет на плод, что отражается в ускорении метаболизма новорожденного. В результате мы наблюдали ускоренное усвоение молозива из ЖКТ, что отразилось на резком приросте фракций $\beta$ - и $\gamma$ глобулинов через час после выпойки молозива. Кроме того резко выросло количество Тлимфоцитов и В-лимфоцитов.

Таким образом, можно заключить, что использование комбинации препаратов за 3-5 дней до отела, способствует повышению содержания иммуноглобулинов в молозиве. На состояние телят влияет своевременная выпойка полученного от коров-матерей молозива, что оказывает усиливающее действие на защитные системы организма теленка и увеличивает скорость обменных процессов.

Литература.1. Баринов Н. Д. Влияние L-карнитина на энергетический обмен в клетке и иммунную систему телят в постнатальный период / Н.Д. Баринов // Аграрный научный журнал. - 2016. - № 12 - С. 3-8. 2. Винникова С.В. Лабораторная диагностика уровня напряженности колострального иммунитета у телят при диспепсии/ С.В. Винникова, Е.В. Касаткина // Вопросы нормативно-правового регулирования в ветеринарии. 2019. № 1. С. 236238. 3. Кляпнев, А.В. Физиолого-биохимические показатели крови новорожденных телят при использовании препарата «Синэстрол $2 \%$ в в антенатальный период// Ветеринарный врач. Казань 2017. - № 6. - С. 61-68. 4. Кондрахин, И.П., Курилов Н.В., Малахов А.Г. и др. Клиническая лабораторная диагностика в ветеринарии. /Справочное издание / И.П. Кондрахин, Н.В. Курилов, А.Г. Малахов и др. // - М.: Агропромиздат. - 1985. - 287 с. 5. Пономарев В.В. Влияние способов содержания на резистентность новорожденных телят/ В.В. Пономарев // Международный вестник ветеринарии. 2013. № 1. С. 51-54. 6. Харитонов Л.В./ Влияние введения глубокостельным коровам синтетического аналога эстрона на становление естественной резистентности у новорожденных телят/ Харитонов Л.В., Харитонова О.В., Великанов В.И., Кляпнев А.В., Горина А.В./ Проблемы биологии продуктивных животных, №1 2018 год, Стр. 29-37.7. Valerian I. Velikanov, Andrey V. Klyapnev, Leonid V. Kharitonov and 
Alexander S. Zenkin and Nataliya Yu. Kalyazina // The Level of Metabolic and Immunoligical Status of Newborn Calves Under the Action of Timogen on the Body of Down-calving Cows // BIOSCIENCES BIOTECHNOLOGY RESEARCH ASIA, June 2016. Vol. 13 (2), 1247-1252, http://dx.doi.org/10.13005/bbra/2159

FEATURES COLOSTRAL IMMUNITY CALVES IN COMBINED STIMULATION PREGNANT COWS IMMUNOMODULATORS AND SYNESTROL2\%

Terent'ev S.S. - senior lector, Velikanov V.I. - d.b.n., prof., Kljapnev A.V. - Ph.Dsenior lector,

Gorina A.V. - postgraduate student, Trunova E.A. -postgraduate student, Dunaevskaja A.A. postgraduate student.

(Federal State Budgetary Educational Institution Nizhny Novgorod State Agricultural Academy) Summary. The purpose of our experiment was to study the effect of the combined administration of an immunomodulator and a synthetic analogue of estrone to cows 3-5 days before calving on the colostral immunity of calves. The result of the work showed that the calves obtained from such cows have a greater number of leukocytes, T-lymphocytes and B-lymphocytes at birth. A synthetic analogue of estrone probably cross the placenta and affect the fetus, which is reflected in the acceleration of the metabolism of the newborn. As a result, there was an accelerated assimilation of colostrum from the gastrointestinal tract, which was reflected in a sharp increase in the fractions of $\beta$ - and $\gamma$-globulins one hour after drinking colostrum. In addition, the number of T-lymphocytes and B-lymphocytes has sharply increased.

Key words: Polyoxidonium, Sinestrol $2 \%$, colostral immunity

УДК: 636.4

\section{ФИЗИОЛОГИЧЕСКИЕ ОСОБЕННОСТИ ГЕМАТОЛОГИЧЕСКИХ ПОКАЗАТЕЛЕЙ ПОРОСЯТ МОЛОЧНОГО ПИТАНИЯ}

Ткачева Е.С., к.б.н. ${ }^{1}$, Медведев И.Н., д.б.н., профессор ${ }^{2}$

${ }^{1}$ ФГБОУ ВОВологодская государственная молочнохозяйственная академия имени Н. В. Верещагина, Россия

${ }^{2}$ ФГБОУ ВО Российский государственный социальный университет, Россия

Аннотация. На протяжении фазы молочного питания в крови растет уровень общего белка, количество альбуминов, содержание мочевины, указывая на активацию у них белкового метаболизма. Это сопровождается у них ростом в крови концентраций глюкозы, триглицеридов и холестерина.Наступающая интенсификация метаболизма является биологической основой процессов роста поросят в течение фазы молочного питания.

Ключевые слова: поросята, фаза молочного питания, кровь, физиология.

Сохранение оптимальногообщего физиологического статуса весьма значимо для роста и развития поросят в течение всего раннего онтогенеза[4]. При этом особое значение в ходе его протекания имеет фаза молочного питания [1,2]. Для более глубокого понимания процессов в их организме в течение фазы молочного питания необходимо продолжение сбора сведений об особенностях их гематологических показателей в этом возрасте. Уточнение этих параметров способно помочь оптимизировать условия их содержания и кормления с минимизацией затрат в ходе достижения ими параметров реализации [3].

Цель: оценить физиологические особенности основных параметров крови поросят на протяжении фазы молочного питания.

Материалы и методы. В данном исследовании была собрана группа из 36 голов шестисуточных поросят крупной белой породы без признаков патологии. Они наблюдались в течение всей фазы молочного питания. У этих животныхчетыре раза осуществлялось взятие крови: на 6 сутки, на 10 сутки, на 15 сутки и на 20 сутки жизни с оценкой в ней количеств 
общего белка, альбуминов, мочевины, триглицеридов, холестерина и глюкозы общеизвестными методами.Обработка полученных данных велась критерием Стьюдента.

Результаты исследования. В крови у шестисуточных поросят количество общего белка была невелико, достигая $69,7 \pm 0,35$ г/л. В течение наблюдения у животных его уровень в крови постепенно увеличивался на $11,5 \%(\mathrm{p}<0,05)$, достигая на момент завершения срока

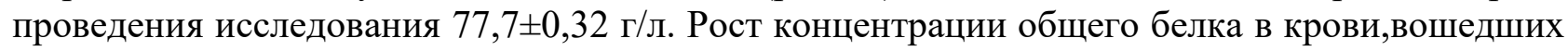
в исследование поросят, между 6 и 20 сутками жизни, видимо,обеспечивался активацией всасывания в их желудке и кишечнике аминокислот, являющихся продуктами расщепления, поступающих с кормом белков. В плазме взятых в работу поросят на шестые сутки онтогенеза количество альбуминов составило $33,5 \pm 0,28$ г/л, возрастая за время наблюдения на $11,3 \%(\mathrm{p}<0,05)$.

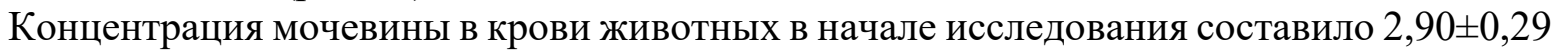
ммоль/л. В ходе последующего наблюдения её количество у поросят росло, достигая к концу

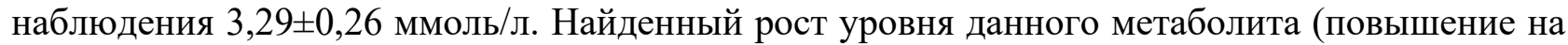
$13,4 \%$ ) можно считать несомненным маркером усиления у поросят в этом возрасте процессов белкового обмена.

На протяжении всей фазы молочного питания у поросят отмечена стабильность углеводного обмена. На это указывало стабильно нормальное количество глюкозы в их

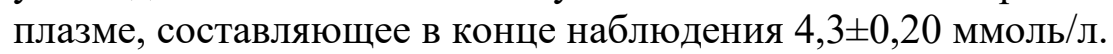

У включенных в группу наблюдения поросят отмечена биологически выгодная динамика показателей, характеризующих липидный обмен. Количество холестерина в их

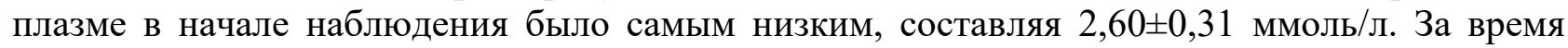
наблюдения его уровень в их крови постепенно увеличивался, достигая $2,97 \pm 0,47$ ммоль/л (повышение 14,2\%, p<0,05).

В крови поросят в шестисуточном возрасте уровень триглицеридов был минимальным $(0,28 \pm 0,07$ ммоль/л), повышаясь в дальнейшем на $25,0 \%$ и достигая на двадцатые сутки $0,35 \pm 0,06$ ммоль/л $(\mathrm{p}<0,05)$.

Заключение. Вторая фаза раннего онтогенеза является весьма важным этапом развития поросят. Вэтом возрасте показатели крови, характеризующие протекание белкового, жирового иуглеводного обмена, испытывают закономерную динамику, обеспечивающую у них интенсификацию анаболизма. Учитывая основные показатели разных видов обмена веществ можно точно определять текущий биологический статус поросенка и при необходимости эффективно проводить у него профилактические и оздоровительные мероприятия.

Литература. 1. Завалишина, С.Ю. Сосудистый гемостаз у телят в период молочнорастительного питания / С.Ю. Завалишина // Зоотехния. - 2012. - №2.- С.21. 2. Завалишина, С.Ю. Контроль сосудистой стенки над индуцированной агрегацией тромбоцитов у новорожденных телят в условиях дефицита железа / С.Ю. Завалишина, Т.И. Глаголева // Ветеринарная практика. - 2013.- №2.- C.40. 3. Skoryatina, I.A. Some aspects of treatment of patients having dyslipidemia on the background of hypertension / I.A. Skoryatina, S.Y. Zavalishina, O.N. Makurina, G.S. Mal, O.V. Gamolina // PrensaMedica Argentina. - 2017. - T.103, №3.- C.3. 4. Vorobyeva, N.V. Influence of physical exercise on the activity of brain processes / N.V. Vorobyeva, T.I. Glagoleva, G.S. Mal, S.Y. Zavalishina, I.I. Fayzullina // Research Journal of Pharmaceutical, Biological and Chemical Sciences.- 2018. T.9. № 6. - C.240-244.

\section{THE PHYSIOLOGICAL FEATURES OF THE HEMATOLOGICAL INDICATORS OF THE PIGLETS OF MILK NUTRITION}

Tkacheva E.S., Ph.D. ${ }^{1}$, Medvedev, I.N., D.S., professor ${ }^{2}$

${ }^{1}$ FSBEI HE Vologda State Dairy Academynamed after N.V. Vereshchagin, Russia

${ }^{2}$ FSBEI HE Russian State Social University, Russia

Summary. During the milk nutrition phase, the level of general protein, the number of albumin, urea content, indicating the activation of protein metabolism to activate them. This is accompanied by their height in the blood of glucose concentrations, triglycerides and cholesterol. The upcoming 
intensification of metabolism is the biological basis of growth processes of piglets during the milk phase.

Keywords: piglets, milk nutrition phase, blood, physiology.

УДК: 615.33.015.36:619

\title{
ОПРЕДЕЛЕНИЕ ПОЛУЛЕТАЛЬНОЙ ДОЗЫ КОМБИНИРОВАННОГО АНТИБИОТИКА НА ОСНОВЕ ДОКСИЦИКЛИНА ГИКЛАТА И ТИЛОЗИНА TAPTPATA
}

Токарева О.А., доц., к.вет.,н.; Токарев А.Н., доц., д.вет.н. (ФГБОУ ВО СПбГУВМ, Россия)

\begin{abstract}
Аннотация. Полулетальная доза (ЛД50) комбинированного антибиотика Тилдокс при введении крысам в желудок составляет $35 \pm 3,2$ г/кг массы тела, что соответствует 3500 мг/кг доксициклина гиклата и 3500 мг/кг тилозина тартрата.
\end{abstract}

Ключевые слова: доксициклин, тилозин, показатели острой токсичности.

На сегодняшний день актуальной является разработка, испытание и внедрение в ветеринарную практику новых антибактериальных препаратов. Это связано с широким применением антибиотиков в животноводстве и, как следствие, приобретением устойчивости микроорганизмов к используемым долгое время препаратам [1,2].

В то же время для регистрации лекарственных средств основным и важным требованием является оценка токсичности и опасности химических веществ и их смесей.

Научно-внедренческим центром «Агроветзащита» разработан химиотерапевтический препарат Тилдокс в виде порошка. Содержит в 1 г в качестве действующих веществ доксициклина гиклат - 100 мг, тилозина тартрат - 100 мг, а в качестве вспомогательных веществ - натрия бензоат, сахарозу.

Цель данной работы заключалась в определении полулетальной дозы (ЛД50) указанного препарата, а также показателей острой токсичности: ЛД16, ЛД 84

Данная работа была выполнена в ФГБОУ ВО «Санкт-Петербургский государственный университет ветеринарной медицины» на кафедре фармакологии и токсикологии. Весь объём доклинических испытаний проводили по действующим нормативным документам [3-6].

Изучение химиотерапевтического препарата Тилдокс проводили на лабораторных белых крысах породы Wistar путем введения его в желудок. На основании полученных данных рассчитаны параметры токсичности - ЛД16, ЛД 50 и ЛД 84.

Для эксперимента было отобрано 42 белых крысы женского и мужского пола поровну. Исходный вес был в пределах 220-230 г. В опыте принимали участие здоровые животные, предварительно прошедшие двухнедельный карантин, и были адаптированы к лабораторным условиям содержания. Для них была создана комфортная экспериментальная среда: температура в помещении вивария в пределах $23{ }^{\circ} \mathrm{C}$, а относительная влажность воздуха составила 50 \%, освещение искусственное. В рационе кормления использовали стандартную диету, предназначенную для грызунов с неограниченным потреблением воды.

Экспериментальных животных разделили на семь групп по 6 голов в каждой. Животные шести групп были подопытными - им вводили препарат в желудок при помощи булавовидной иглы в виде водной суспензии в следующих дозах: 10,$0 ; 20,0 ; 30,0 ; 40,0 ; 50,0$ и 60,0 г/кг массы тела (что соответствовало 1000; 2000; 3000; 4000; 5000 и 6000 мг/кг по доксициклина гиклату и 3500 мг/кг по тилозина тартрату). На основании расчетов, объём вводимой суспензии на одно животное составлял 3,$0 ; 5,0 ; 7,5 ; 8,5 ; 11,5$ и 12,5 мл соответственно. Контрольной седьмой группе вводили 12,5 мл дистиллированной воды. 
На протяжении двух недель за экспериментальными животными наблюдали, фиксировали происходящие изменения в их поведении, наблюдали за общим физиологическим состоянием и отмечали гибель.

ЛД50 определяли методом Кербера в модификации Прозоровского. Применяли следующую формулу: ЛД $50=Л_{100}-\Sigma \mathrm{Zd}: \mathrm{n}$, где $\mathrm{Z}-$ среднее арифметическое из числа животных, у которых отмечен учитываемый эффект под влиянием двух смежных доз; d интервал между двумя смежными дозами; $\mathrm{n}$ - количество животных в каждой испытуемой группе. ЛД 16 и ЛД 84 нам удалось установить при помощи графического метода анализа зависимости «доза-эффект» путём построения кривой летальных доз.

Стандартную ошибку ЛД 0 высчитывали по формуле Гаддама: $\mathrm{S}=$ $\sqrt{\mathrm{K} * \mathrm{~s} * \mathrm{~d}(\text { среднее }): n}$, где $\mathrm{K}=0,564 ; \mathrm{s}=\left(\right.$ ЛД$_{84}-$ ЛД$\left._{16}\right): 2$ [2,4].

Для того, чтобы оценить опасность смертельного отравления препаратом Тилдокс мы рассчитали более объективный критерий оценки - величину $\mathrm{S}$ - функция угла наклона прямой летальных доз к оси абсцисс по формулам: $S=\left(\right.$ ЛД $_{84}:$ ЛД $50+$ ЛД$_{50}:$ ЛД16) : 2. [3]

Bce животные подопытной группы, которым вводили препарат в дозе 10,0 г/кг, остались живыми. В подопытных группах животных, которым вводили Тилдокс в дозах в диапазоне от 20,0 до 60,0 г/кг, наблюдали гибель.

Полученные данные позволяют нам полагать, что картина острого отравления животных, прежде всего, зависела от дозы введенного препарата. Мы наблюдали угнетение, атаксию, и снижением подвижности. Животные погибли от остановки дыхания.

Наблюдая на протяжении опыта за животными контрольной группы их состояние было в пределах нормы, признаков интоксикации и гибели среди них не было.

В результате опыта, ЛД $0=60-150: 6=35$ г/кг, что соответствует 3500 мг/кг по доксициклина гиклату и 3500 мг/кг по тилозина тартрату.

Путём построения графика установили ЛД $16=19$ г/кг, а ЛД $84=41$ г/кг.

Стандартная ошибка ЛД $50(\mathrm{~S})=\sqrt{0,564 * 11 * 10: 6}=3,2$ г/кг. Функция угла наклона прямой летальных доз к оси абсцисс $(\mathrm{S})=(41: 35+35: 19): 2=1,5$.

На основании полученных данных, ЛД 0 препарата Тилдокс при введении крысам в желудок составляет $35 \pm 3,2$ г/кг массы тела, что соответствует 3500 мг/кг доксициклина гиклата и 3500 мг/кг тилозина тартрата.

Литература. 1. Baryshev, V.A. Use of a new phytosorption complex for diarrhea in animals / V.A. Baryshev, O.S. Popova, Y.E. Kuznetsov, N.V. Kuznetsova, M.S. Petrova, O.A. Tokareva // Research Journal of Pharmaceutical, Biological and Chemical Sciences - 2018. -Vol. 9, № 6. - P. 1800-1806. 2. Барышев, В.А. Аспекты решения проблемы антибиотикотерапии в ветеринарной практике / В.А. Барышев, О.С. Глушкова, А.М. Лунегов // Международный вестник ветеринарии. 2016. - № 1. - С. 23-27.3. Прозоровский В.Б. Статистическая обработка результатов фармакологических исследований / В.Б. Прозоровский // Психофармакология и биологическая наркология. - 2007. - Т. 7, вып. 3 - 4. - С. 2090-2120.4. Токарева, О.А. Изучение острой токсичности препарата Ципровет-пульмо / О.А. Токарева, С.В. Енгашев, А.Н. Токарев //Вопросы нормативно-правового регулирования в ветеринари. - 2015. - № 2. - С.418-420. 5. Хабриев Р.Ю. Руководство по экспериментальному (доклиническому) изучению новых фармакологических веществ / Р.Ю. Хабриев. - М., Медицина, 2005. - 829 с. 6. Оценка токсичности и опасности химических веществ и их смесей для здоровья человека: Руководство. - М.: Федеральный центр гигиены и эпидемиологии Роспотребнадзора, 2014. $639 \mathrm{c.}$

\section{DETERMINATION OF SEMI-LETHAL DOSE OF COMBINED ANTIBIOTICS BASED ON DOXYCYCLINE HYCLATE AND TYLOSINE TARTRATE}

Tokareva O.A., associate professor, Ph.D.; Tokarev A.N., D.V.M., associate professor (FSBEI HE St.Petersburg SUVM, Russia) 
Summary. The semi-lethal dose $\left(\mathrm{LD}_{50}\right)$ of the combined antibiotic Tildox when it was administered to rats in the stomach is $35 \pm 3.2 \mathrm{~g} / \mathrm{kg}$ of body weight, which corresponds to $3500 \mathrm{mg} / \mathrm{kg}$ of doxycycline hyclate and $3500 \mathrm{mg} / \mathrm{kg}$ of tylosin tartrate.

Key words: doxycycline, tylosin, indicators of acute toxicity.

УДК 615.33.015.4:577.161.11:598.261.7

\section{ВЛИЯНИЕ АЭРОЗОЛЕЙ ГЕНТАМИЦИНА И ЕГО СОЧЕТАНИЯ С ЙОДИДОМ КАЛИЯ НА СОДЕРЖАНИЕ ВИТАМИНА А В ОРГАНИЗМЕ ЦЫПЛЯТ}

Туварджиев А.В., асс., к.в.н.; Киселенко П.С., доц., к.в.н. (ФГБОУ ВО СПбГУВМ, Россия)

Аннотация. Изучено влияние аэрозолей антибиотика гентамицина и йодида калия на содержание витамина А в печени и сыворотке крови здоровых цыплят при их раздельном и сочетанном применении. Показано благоприятное действие сочетанного применения этих препаратов в одном аэрозоле на уровень ретинола в организме птицы.

Ключевые слова: аэрозоли, гентамицин, йодид калия, витамин А.

Большую роль в достижении высокой продуктивности птицы играет обеспечение её организма витаминами, в частности витамином А. Вместе с тем, широкое применение в птицеводстве антимикробных препаратов с целью лечения и профилактики бактериальных болезней птиц может вызывать расстройства в витаминном обмене [2,3],

Сфера взаимодействия антибиотиков и витаминов пересекается в ферментативных процессах, однако, этот процесс сложен и до конца не выяснен. Характер и глубина влияния антимикробных препаратов на уровень витаминов в организме зависят от дозы, химической структуры вещества, от физиологического состояния птицы $[1,2,3]$. Вместе с тем, литературные данные о влиянии аэрозолей антибиотиков на обмен витаминов единичны[ 4,5$]$.

Нами установлено, что при двукратном ингалировании гентамицина в дозах 250 и 500 мг/ достоверно $(\mathrm{p}<0,05)$ повышается уровень витамина А в сыворотке крови и печени 30 дневных цыплят. На 4 день с момента первого распыления препарата в дозе 250 мг/

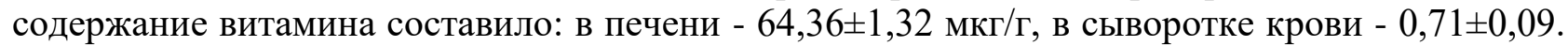

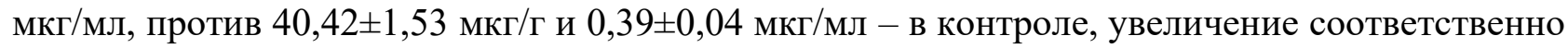
на 34 и 82\%; в дозе. 500 мг/ : в печени - 51,37 $\pm 2,63$ мкг/г, в сыворотке крови

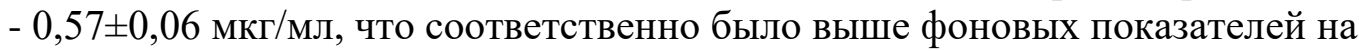

46 и 49\%. Восстановление ретинола до уровня фоновых показателей происходило к 15 дню.

Повышение дозы антибиотика до 1000 мг/ вызывало значительное снижение уровня витамина А как в печени, так и в сыворотке крови цыплят. При ингалировании гентамицина максимальное уменьшение содержания ретинола к уровню контроля (в печени - на $12 \%$, в сыворотке крови - на $30 \%$ ) наблюдалось к 8 дню опыта. Кроме того содержание витамина к 15 дню опыта оставалось достоверно ниже нормы ( $<<0,05)$.

Трёхкратное ингалирование йодида калия в дозе I50 мг/ здоровым цыплятам вызывало повышение уровня витамина А в их организме. Максимум увеличения наблюдался на 4 день от первой ингаляции препарата.

К этому моменту содержание витамина в печени подопытных цыплят составляло $49,12 \pm 3,32$ мкг/г, в сыворотке крови $0,68+0,09$ мкг/мл, против соответственно 40,42 $\pm 1,53$ мкг/г и $0,39 \pm 0,04$ мкг/мл - у контрольной птицы. Повышенное содержание витамина А в организме обработанных аэрозолями йодида калия цыплят наблюдалось на протяжении 8 дней;

Ингалирование йодида калия в сочетании с гентамицином в дозах соответственно 150 и $250 \mathrm{мг/}$ двукратно интактной птице способствовало поддержанию витамина А на более высоком уровне $(\mathrm{p}<0,05)$ в организме птицы. Так на 4 день после первой сочетанной 
ингаляции содержание витамина А в печени составляло 66,24 $\pm 3,84$ мкг/мл, в сыворотке крови 0,64 $\pm 0,06$ мкг/мл, что соответственно на $9,7 \%$ и $28 \%$ было больше, чем в группе с применением только антибиотика и на $35 \%$ и $13 \%$ больше, чем в группе с применением только йодида калия.

Таким образом, гентамицин при двукратном аэрозольном применении в дозах 250 и 500 мл/ и йодид калия при трехкратном применении в дозе 150 мл/ стимулируют образование ретинола в организме цыплят, причем максимальный эффект наблюдается при сочетанном применении препаратов.

Литература.1)Ковалев, С.П. Изучение степени дисперсности аэрозолей экстракта элеуторококка, фуродонина и диклосациллина при их раздельном и сочетанном применении. /С.П. Ковалев, П.С. Киселенко // Актуальные проблемы ветеринарной медицины. - Санкт Петербург. - 2017. - С.26 -28. 2) Андреева, Н.Л. Ветеринарная фармация: учебник /Н.Л. Андреева, Г.А. Ноздрин, А.М. Лунегов, [и др.] // Санкт-Петербург: “Лань”. 2020. - 452 с..3) Соколов, В.Д. Теория и практика группового применения лекарственных средств в птицеводстве. /В. Д. Соколов, Н. Л. Андреева// Vetpharma: Pharm Animals.- Санкт Петербург.2013.- №1.- С.84-86. 4) Туварджиев, А.В. Динамика концентрации ретинола в организме птицы под влиянием аэрозолей антибиотиков /А.В. Туварджиев, П.С. Киселенко// Материалы национальной науч. конф. проф.-препод. состава, науч. сотрудников и аспирантов СПбГУВМ : СПбГУВМ. - 2021.- С. 106-108. 5) Туварджиев, А. В. Аэрозольный метод профилактики и терапии колибактериоза птиц йодидом калия, его сочетания с ампициллином. /А. В. Туварджиев, С. П. Ковалев //Вопросы нормативно-правового регулирования в ветеринарии. 2020. - №1.- С.63 - 65.

\title{
INFLUENCE OF AEROSOLS OF GENTAMICIN AND ITS COMBINATION WITH POTASSIUM IODIDE ON THE CONTENT OF VITAMIN A IN THE BODY OF CHICKENS.
}

Tuvardzhiev A.V., Ass., Ph.D .; Kiselenko P.S., Assoc., Ph.D. (FSBEI HE St.Peterburg SUVM, Russia)

Summary. The effect of aerosols of the antibiotic gentamicin and potassium iodide on the content of vitamin A in the liver and blood serum of healthy chickens was studied in their separate and combined use. The beneficial effect of the combined use of these drugs in one aerosol on the level of retinol in the bird's body has been shown.

Key words: aerosols, gentamicin, potassium iodide, vitamin A.

УДК 638.157

\section{ПРИМЕНЕНИЕ МУРАВЬИНОЙ КИСЛОТЫ ПРИ ВАРРОАТОЗЕ ПЧЁЛ В ОРГАНИЧЕСКОМ ЖИВОТНОВОДСТВЕ}

Чучунов В.А., доц., к.б.н., Радзиевский Е.Б. доц., к.с.-Х.н.,Коноблей Т.В. доц., к.с.-х.н. (ФГБОУ ВО «Волгоградский ГАУ», Россия)

\begin{abstract}
Аннотация. Одной из главных проблем пчеловодства является эффективная борьба с клещом рода Varroa. При ведении пчеловодства в рамках органического производства, при котором возможность применения широкого спектра профилактических и лечебных препаратов становится невозможным, то использование органических кислот становиться достаточно перспективным. По результатамнаших исследований, рекомендовано при ведении органического пчеловодства, применять в качестве акарицидного препарата муравьиную кислоту.
\end{abstract}

Ключевые слова: органическое животноводство; пчела медоносная. 
Первые данные о том, что на поверхности тела пчелы медоносной обнаруживаются клещи, появились в литературных источниках в 1958 году. Когда по результатам обследования пчел, которые разводились на юге Китая, на их хитиновом покрове регистрировались паразиты. После чего, спустя 6 лет клещ рода Varroa стал наблюдаться и в нашей стране, в Приморском крае. За тем распространение паразита осуществилось на Азиатскую территорию и в Европейскую части континента, и в последствии охватило и весь мир. С 90-х годов двадцатого столетия каждая пасека, которая находится на территории Российской Федерации в той или иной мере поражена клещом рода Варроа. На сегодняшний день по ущербу наносимому пчеловодческой отрасли и вследствие своего глобального распространения, варроатоз несопоставим ни с какими другими заболеваниями пчёл. [5]

С принятием ГОСТ Р 57022-2016 и ГОСТ 33980-2016 для повышения конкурентоспособности меда и другой пчеловодческой продукции необходимо соответствовать требованиям ведения органического животноводства. Стандартом ГОСТ 33980-2016 допускается использование при производстве органической продукции использование муравьиной кислоты (Е 236) [6,7].

По ряду исследований установлено, что применяемые для лечения варроатоза химические средства, предусматривают обработку пчелосемей веществами химической природы, которые воздействуют на паразита, приводя к осыпанию клещей либо к его гибели $[3,4]$. Из классических химических веществ которые применяют в борьбе с паразитами наиболее эффективными средством считается проведение обработок семей парами муравьиной, щавелевой или же молочной кислот, а кроме того тимолом. [1] Исследованиями ряда авторов в этом направлении отмечается, что при условии даже тщательно проведённых лечебно-профилактических мероприятий полностью избавится от данного паразита не представляется возможным в следствии биологических особенностей клеща и перекрёстного заражения от других насекомых в время сборы пыльцы и нектара [2]. Поэтому все проводимые лечебно-оздоровительные мероприятия, позволяют только на некоторое время сократить уровень заклещованности пчелиных семей до так называемого условнобезопасного уровня.

Целью наших исследований явилосьоценить эффективности применения муравьиной кислоты в качестве противопаразитарного препарата, воздействующего на клеща варроа, и определить возможность ее использования при ведении органического пчеловодства.

Перед началом подготовки пчелиных семей к зимовке при сокращении гнезда были сформированы методом пар аналогов по 3 опытные и контрольные семьи на пасеке. В опытных группах двукратно с интервалом в две недели проводились противопаразитарные мероприятия с применением геля, содержащего 85\% муравьиной кислоты.Гель находился в пакетиках массой 30 гр. и из расчета 1 пакетик на семью раскладывался по верх рамок под холстик.

Перед проведением наших исследований и через неделю после повторного применения препарата, из семей отобранных по принципу пар - аналогов, из центра гнезда отбирались пробы состоящая из нескольких десятков живых пчел с целью определения степени заклещованности. После чего выборку заливали растворителем, а за тем после тщательного перемешивания и отстаивания отделяли от мертвых пчёл, мёртвых клещей, а за тем производили количественный подсчет тех и других, и находили процентное соотношение, определяя при этом, на сколько семи заклещованны. Схема проводимых нами исследовании представлена в табл. 1.

Таблица 1 - Схема опыта

\begin{tabular}{|l|l|l|}
\hline Группа & Препарат & Количество семей \\
\hline опытная & муравьиная кислота & 3 \\
\hline контрольная & - & 3 \\
\hline
\end{tabular}


Таблица 2 - Сравнительная оценка заклещованности семей $(\mathrm{n}=3)$

\begin{tabular}{|c|c|c|c|c|c|}
\hline \multicolumn{3}{|c|}{$\begin{array}{l}\text { До обработки препаратами (в опытных } \\
\text { группах) }\end{array}$} & \multicolumn{3}{|c|}{$\begin{array}{l}\text { После обработки препаратами (в опытных } \\
\text { группах) }\end{array}$} \\
\hline $\begin{array}{l}\text { Кол-во } \\
\text { пчел в } \\
\text { пробе }\end{array}$ & $\begin{array}{l}\text { Кол-во } \\
\text { осыпавшегося } \\
\text { клеща }\end{array}$ & $\begin{array}{l}\text { \% } \\
\text { заклещованнос } \\
\text { ти }\end{array}$ & $\begin{array}{l}\text { Кол-во пчел } \\
\text { в пробе }\end{array}$ & $\begin{array}{l}\text { Кол-во } \\
\text { осыпавшего } \\
\text { ся клеща }\end{array}$ & $\begin{array}{l}\text { \% } \\
\text { заклещованн } \\
\text { ости }\end{array}$ \\
\hline \multicolumn{6}{|c|}{ Опытная группа } \\
\hline $85,4 \pm 4,33$ & $18,8 \pm 2,05$ & 21,9 & $95,6 \pm 3,06$ & $3,6 \pm 0,4$ & 3,8 \\
\hline \multicolumn{6}{|c|}{ Контрольная группа } \\
\hline $91 \pm 1,24$ & $18,6 \pm 0,55$ & 20,4 & $93,6 \pm 0,94$ & $23,2 \pm 0,74$ & 24,2 \\
\hline
\end{tabular}

Обследуя пасеки после главного взятка, на поражение их клещом рода Варроа установили, что наивысшее количество клеща было в опытной группе $21,9 \%$ после двукратной обработки муравьиной кислотой в опытных семьях количество клеща снизилось до $3,8 \%$. В тоже время в контрольной группе отмечалась тенденция увеличения процента заклещованности с 20,4 \% до 24,2\%.

После лечения в конце августа пчелы закармливались в зиму 50\% сахарным сиропом. В ноябре месяце были удалены крайние рамки не занятые пчелами, и гнездо с обеих сторон было сжато диафрагмами. Зимовка пчел осуществлялась на улице при этом клуб пчел в семьях располагался на 6-8 дадановских рамках. Показатели зимовки пчел представлены в таблице 3.

Таблица 3 - Оценка зимовки пчел

\begin{tabular}{|l|l|l|l|}
\hline Группа & $\begin{array}{l}\text { Количество рамок с } \\
\text { пчелами пошедшими на } \\
\text { зимовку }\end{array}$ & $\begin{array}{l}\text { Количество рамок с } \\
\text { пчелами вышедшими с } \\
\text { зимовки }\end{array}$ & \% отхода \\
\hline опытная & $7,6 \pm 0,24$ & $7 \pm 0,32$ & 7,9 \\
\hline контрольная & $7,4 \pm 0,24$ & $5,75 \pm 0,19$ & 22,3 \\
\hline
\end{tabular}

Оценивая показатели зимовки отмечали, что в семьях где проводили обработку от клеща процент отхода пчел не превышал $8 \%$ в то время как в контрольной группе он составил $22,3 \%$.

В конце мая перед выездом на кочевку, мы так же оценили семьи участвующие в опыте по степени заклещованности. Данные проведенных исследований представлены в таблице 4.

Таблица 4 - Весенняя оценка пчелиных семей на заклещованность

\begin{tabular}{|l|l|l|}
\hline Кол-во пчел в пробе & Кол-во осыпавшегося клеща & \% заклещованности \\
\hline Опытная группа & $7 \pm 0,71$ & 7,2 \\
\hline $96,8 \pm 3,09$ & $23,2 \pm 0,74$ & 25,7 \\
\hline Контрольная группа &
\end{tabular}

По данным таблицы 3 видно, что в опытных группах, где осенью проводили противоварроатозные обработки, количества клеща было на уровне 7,2\% а в контрольных $25,7 \%$

В конце сезона после главного взятка, была проведена сравнительная оценка медовой продуктивности опытных и контрольных семей, подвергнутых в конце лета предыдущего года лечебным мероприятиям с семьями в которых противоварроатозные мероприятия не проводили. Данные о продуктивности семей представлены в таблице 5.

Таблице 5 - Оценка медовой продуктивности пчел

\begin{tabular}{|l|l|l|l|}
\hline Группа & $\begin{array}{l}\text { Количество соторамок с } \\
\text { медом, шт }\end{array}$ & $\begin{array}{l}\text { Получено } \\
\text { всего меда, кг }\end{array}$ & $\begin{array}{l}\text { В том числе } \\
\text { товарного меда, кг }\end{array}$ \\
\hline опытная & $11,4 \pm 0,6$ & $34,9 \pm 2,04$ & $23,58 \pm 1,091$ \\
\hline контрольная & $4,5 \pm 0,22$ & $13,7 \pm 0,72$ & $5,98 \pm 0,59$ \\
\hline
\end{tabular}

Изучив показатели медовой продуктивности семей отмечали, что разница по полученному валовому меду между контрольными и опытными семьями составляла 21,2 кг. 
Наибольшее количество товарного меда так же было получено в опытных группах, разница составила 17,6 кг.

Экономическая эффективность производства меда представлена в таблице 6.

Таблица 6 - Экономическая эффективность производства меда

\begin{tabular}{|l|l|l|}
\hline \multirow{2}{*}{ Показатели } & Группа & контрольная \\
\cline { 2 - 3 } & опытная & 350 \\
\hline Цена реализации за кг & 350 & 325,0 \\
\hline Полные издержки, руб. & 225,4 & 25 \\
\hline Прибыль на 1 кг, руб. & 124,6 & 5,98 \\
\hline Получено товарного меда с 1 семьи, кг & 23,58 & 149,5 \\
\hline Прибыль в расчете на 1 семью & 2938,07 & 7,69 \\
\hline Уровень рентабельности, \% & 55,28 & \\
\hline
\end{tabular}

Данные сравнительной экономической эффективности производства меда показывают, что в семьях, где проводились потивоварроатозные мероприятия, в расчете на одну семью было получено больше товарного меда притом, что полные издержки были значительно меньшими. Это нашло отражение в большей прибыли, которая была получена в расчете на одну семью. Оценивая уровень рентабельности так же отмечалось, что в семьях где проводили обработку он был наивысший и составил от 55,28 \%

Применение муравьиной кислоты позволило снизить \% заклещеванности до безопасного уровня. Установлена положительная динамика зимовки таких семей, а также их лучшее весеннее развитие. Рекомендуем в качестве противоварроатозного средства при органическом пчеловодстве использовать муравьиную кислоту в виде $85 \%$ геля т.к. это позволяет снизить заклещованность пчелиных семей до $3,8 \%$ и увеличить выход товарного меда.

Литература.1.Землянкина Ж.А., Эффективность ветеринарных препаратов в профилактике и лечении варроатоза пчел / Ж.А. Землянкина[и др.] // Пчеловодство. 2019. № 2. - С. 24-26. 3. Ивойлова М.М., Критерии резистентности медоносных пчел к Varroa destructor / M.M. Ивойлова, А.З. Брандорф, А.А. Семакина // Пчеловодство. 2017. № 7. - С. 20-23. 4. Сохликов А.Б., Борьба с варроатозом / А.Б.Сохликов, Г.И.Игнатьева // Пчеловодство. 2018. № 3. - С. 30 33. 5. Чучунов В.А. Борьба с клещом Варроа-Якобсони на пасеках Волгограской области / Чучунов В.А., Радзиевский Е. Б., Злепкин В. А., Коноблей Т. В// Известия Нижневолжского агроуниверситетского комплекса: наука и высшее профессиональное образование № 1 (57), 2020 С 213-219. 6. Чучунов В.А. Борьба с клещом Варроа-Якобсони на пасеках Волгограской области / Чучунов В.А., Радзиевский Е. Б., Злепкин В. А., Коноблей Т. В// Известия Нижневолжского агроуниверситетского комплекса: наука и высшее профессиональное образование № 1 (57), 2020 С 213-219. 7. Продукция органического производства. Правила производства, переработки, маркировки и реализации (с Поправкой) ГОСТ 33980-2016. 8. Продукция органического производства. Порядок проведения добровольной сертификации органического производства ГОСТ Р 57022-2016

\section{THE USE OF FORMIC ACID IN THE VARROATOSIS OF BEES IN ORGANIC ANIMAL HUSBANDRY}

Chuchunov V.A., associate professor, c.b.n., Radzievskiy E.B. associate professor, k.s.-h.n., Konobley T.V. associate professor, k.s.-h.n.

(FSBEI HE "Volgograd state agrarian university », Russia)

Annotation. One of the main problems of beekeeping is the effective control of the Varroa mite. When conducting beekeeping in the framework of organic production, in which the possibility of using a wide range of preventive and therapeutic drugs becomes impossible, the use of organic acids becomes quite promising. According to the results of our research, it is recommended to use formic acid as an acaricidal drug when conducting organic beekeeping.

Key words: organic animal husbandry; honey bee. 


\title{
ИНДИВИДУАЛЬНЫЕ ЗАДАНИЯ НА ОСМЫСЛЕНИЕ И СИСТЕМАТИЗАЦИЮ ПОЛУЧЕННЫХ ЗНАНИЙ ПО ВЕТЕРИНАРНОЙ ФАРМАКОЛОГИИ
}

Шаронина Н.В., доцент,к.б.н.

(ФГБОУ ВО Ульяновский ГАУ, Россия)

\begin{abstract}
Аннотация. Данная статья посвящена значимости индивидуальных заданий в курсе изучения ветеринарной фармакологии.Индивидуальные задания способствуют закреплению, углублению и обобщению знаний, полученных студентами за время обучения, и применение этих знаний к комплексному решению конкретных задач.
\end{abstract}

Ключевые слова: личность, задание, студент, дисциплина, фармакология.

Для подготовки ветеринарных врачей, важной и одной из наиболее «трудных» учебных дисциплин, требующей много времени и сил для освоения и актуализации огромного объема необходимой информации является Ветеринарная фармакология.

Фармакология - наука о действии лекарственных средств на живой организм. Изучает влияние лекарственных веществ на уровне рецепторов, отдельных клеток и организм в целом.Фармакология имеет две противоположности. С одной стороны, она очень консервативна. С другой стороны, она очень изменчива. Это связано с новыми препаратами, новыми направлениями, новыми методиками преподавания и развития предмета[1,2,3].

Для лучшего усвоения материала в качестве закрепляющего материала для студентов 3 курса были разработаны индивидуальные задания по изучаемым разделам.

Перед выполнение индивидуальных заданий, студенты должны прослушать лекции, практические занятия, ознакомиться с дополнительной информацией. Эта работа предполагает, что каждый студент получает специально для него разработанноезадание. Тематика индивидуального задания должна отвечать учебным задачам данного предмета и наряду с этим увязываться с практическими требованиями.

Важно, чтобы при этом педагог, следуя совету Г. Лихтенберга, учил студентов не тому, что думать, а тому, как они должны думать[4].

Такие формы обучения носят личностно-ориентированный характер. Обучающиеся могут выполнять задания повышенногоуровня (если была работа с дополнительной литературой)и задания базового уровня (материал, полученный на лекциях и практических занятиях)[5,6].

Пример:

Задание 1. Лекарственный препарат амоксациллин (у каждого студента свой лекарственный препарат)

1 Дайте определение данной лекарственной формы

2. К какой группе лекарственных средств относиться данный препарат

3.Опишите фармакодинамику данного лекарственного препарата

4. Перечислите противопоказания (если они есть)

5.Составьте рецепт с использованием справочной литературы

По завершению работы индивидуальные задания сдаются преподавателю для оценивания.Критерии оценивания заданий для закрепления полученных знаний и умений:

5 «отлично»- выполнены все 5 заданий без ошибок

4 «хорошо» - не выполнено 4 задание (Перечислите противопоказания), не соблюдена последовательность выписывания рецепта на лекарственные формы.

3 «удовлетворительно» - выполнено 3 задания, в ответах допущены неточности

2 «неудовлетворительно» - нет правильно выполненных заданий

Индивидуальные задания способствуют закреплению, углублению и обобщению знаний, полученных студентами за время обучения, и применение этих знаний к комплексному решению конкретных задач. Выполнение индивидуальных заданий позволяет 
путем решения конкретных задач приобщить студентов к практике, воспитать их в духе ответственности за выполненную работу, прививать им элементы научной работы.

Литература: 1. Андреева, Н. Л. Ветеринарная фармация /Н.Л. Андреева, Г.А. Ноздрин, А.М. Лунегов [и др.]. - СПб.: Лань, 2020. - 452 с. 2. Андреева, Н.Л. Учебнометодическое пособие к практическим занятиям по фармацевтической технологии для студентов ветеринарного факультета очной и заочной формы обучения / Н.Л. Андреева, В.Д. Соколов, А.М. Лунегов [и др.]. - Санкт-Петербург: Издательство СПбГАВМ, 2015. - 123 с. 3. Крикова А.В. Роль и место интерактивных методов при подготовке специалистов в области фармации/ А.В. Крикова, Т.А. Анащенкова, Н.А.Павлюченкова, Т.В. Николаева, В.М. Зайцева // Фармация и фармакология. - 2016. Т. 4 № 1 (14)- С. 91-99. 4. Балыхин Г. А. Федеральная целевая программа развития образования: новаторские решения на перспективу/ Г. А. Балыхин// Профессиональное образование. $-2006 . \quad$ № $4 . \quad$ С.14-15. 5.Антонова Е.И. Научно-исследовательский центр как база формирования компетенций магистров направления подготовки 06.04.01 Биология профиля образовательной программы «Биотехнология с основами нанотехнологий» / Е.И. Антонова, Н.А. Ленгесова, А.В. Соловьев, О.Е. Беззубенкова// Фундаментальные и прикладные исследования по приоритетным направлениям биоэкологии и биотехнологии: сборник материалов II Bсерос. науч. конф.с межд. участ. (Ульяновск, 30 апреля 2019 г.) / - Чебоксары: ИД «Среда», 2019.- С. 94-97. 6. Дежаткина С.В. Совершенствование методической работы преподавателя /С.В. Дежаткина //Всероссийская (национальная) научная конференция «Роль аграрной науки в устойчивом развитии сельских территорий». Новосибирский ГАУ. - 2017. - С. 511-514. 7. Дежаткина, С.В. Инновации в рамках изучения дисциплины «Радиобиология с основами радиационной гигиены» /С.В. Дежаткина //Национальная научно-методическая конференция профессорскопреподавательского состава: Инновационные технологии в высшем образовании. - 2018. - С. $39-44$.

\title{
INDIVIDUAL TASKS FOR UNDERSTANDING AND SYSTEMATIZATION OF THE ACQUIRED KNOWLEDGE IN VETERINARY PHARMACOLOGY
}

Sharonina N. V., Associate Professor, Candidate of Biological Sciences

(Ulyanovsk State University, Russia)

Annotation. This article is devoted to the importance of individual tasks in the course of studying veterinary pharmacology. Individual tasks contribute to the consolidation, deepening and generalization of the knowledge gained by students during their studies, and the application of this knowledge to the complex solution of specific tasks.

Key words: personality, task, student, discipline, pharmacology.

УДК 619:615

\section{ВЛИЯНИЕ «ВИТААмИН» НА АКТИВНОСТЬ ФЕРМЕНТОВ АСТ И АЛТ ЛАБОРАТОРНЫХ ЖИВОТНЫХ ПРИ ИЗУЧЕНИИ ХРОНИЧЕСКОЙ ТОКСИЧНОСТИ}

Шаронина Н.В., доцент,к.б.н. (ФГБОУ ВО Ульяновский ГАУ, Россия)

\begin{abstract}
Аннотация. Работа посвящена изучению влияния аминокислотного комплекса «ВитаАмин» на активность ферментов в крови белых мышей при изучении хронической токсичности. Установили, что аминокислотный комплекс «ВитаАмин» при длительном применении в диапазоне 0,02-0,04 мл на голову повышает активность активности ферментов АСТ и АЛТ в крови белых мышей в пределах нормы.
\end{abstract}

Ключевые слова: «ВитаАмин», доза, ферменты, АСТ, АЛТ, мыши. 
Одна из часто используемых инноваций в сфере кормления - кормовые добавки для животных. Кормовая добавка представляет собой специальную смесь, которую ежедневно добавляют в рацион поголовья в установленных нормах. Как правило, ее количество составляет 5-30\% от общей массы корма в сутки. Ее главная задача - сбалансировать рацион по питательным элементам, сделать его более полноценным и эффективным.

Один из самых важных вопросов, позволяющих углубиться в специфику системы питания сельскохозяйственных животных, оценить целесообразность применения кормовых добавок в рамках производства [1,2,3].

«ВитаАмин» - новый аминокислотный комплексный препарат, животного происхождения, предназначен для животных и птиц в качестве кормовой добавки, поэтому изучение данного комплекса является актуальным.

Цель работы - изучить влияние аминокислотного комплекса «ВитаАмин» на биохимические показатели АСТ и АЛТ в крови при изучении хронической токсичности на лабораторных мышах.

Материалы и методы исследований. Научно-исследовательская работа проводилась в виварии на кафедре хирургии, акушерства, фармакологии и терапии УлГАУ. Исследование крови проводили современным методом на биохимическом анализаторе «Stat Fax 1904 Plus» в межкафедральном центре факультета ветеринарной медицины и биотехнологии УлГАУ. Объектами исследования были белые мыши.

Результаты исследований и их обсуждение. Работа проводилась на белых мышах со средней живой массой 34,7 г. в каждой группе было по 10 животных. Всего было сформировано 4 группы мышей (3 опытных и 1 контрольная). Животные содержались в виварии в стандартных клетках при 12-часовом световом режиме и свободном доступе к пище и воде в соответствии со стандартами, утвержденными МЗ РФ.

Опытным животным «ВитаАмин» давали энтерально 1 раз в день, каждому животному на голодный желудок в течение 60 дней. Небольшие кусочки хлеба пропитывали в рассчитанной дозировки «ВитаАмин». Рацион животных соответствовал норме[4,5].

На всем протяжении опыта наблюдали за поведением животных, проводили контрольные взвешивания. В 4-й группе отмечали явления токсикоза, снижение веса. В конце эксперимента было проведено вскрытие животных, были отобраны пробы печени, проведен забор крови и изучены ее биохимические показатели.

Результаты исследований и обсуждения. АЛТ - это фермент аланинаминотрансфераза, который содержится в тканях всего организма и обеспечивает ускоренную переработку глюкозы. АСТ локализуется в цитозоле и митохондриях многих типов клеток. АСТ в наиболее высокой концентрации выявляется в скелетной мускулатуре, в меньшей - в печени и миокарде. Повышенный уровень АСТ чаще всего является показателем повреждения клеток печени или мускулатуры (скелетной или сердечной). Фермент может высвобождаться из клеток вследствие сублетального повреждения клеток (путем просачивания через клеточную мембрану) или вследствие их некроза [6,7].

Включение натуральной добавки в рацион в различных дозировках оказало влияние на активность ферментов АЛТ и АСТ в крови белых мышей, результаты представлены на рисунке 1.

Как следует из данных, представленных на рисунке 1, активность ферментов в 2-й и 3й группе имели определенные колебания. Однако все изменения показателей не выходили за пределы верхних и нижних границ нормы.

В результате проведённых исследований было обнаружено повышение активности ферментов у мышей при введении «ВитАмин» в дозе 0,08 мл на голову, локализованных преимущественно в печени (АсАТ, АлАТ).

По степени увеличения активности ферментов АСТ и АЛТ в сыворотке крови в сравнении с контролем (100\%) дозы «ВитАмин» составляют следующий ряд: 0,08 мл $(246,2 \%$ и $137,47 \%)>0,04$ мл $(140 \%$ и 118,5\%) > 0,02мл (105,9\%5 и 94,2\%) (Рис. 1$)$. 


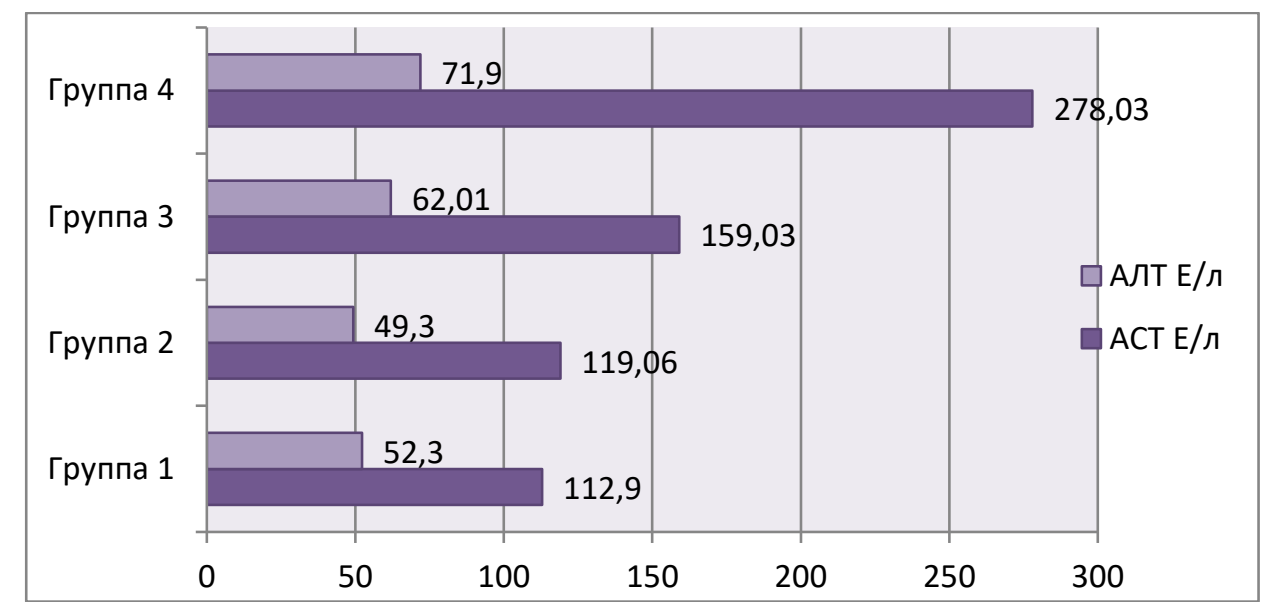

Рисунок 1 - Показатели АСТ и АЛТ в опытных и контрольной группах белых мышей при изучении хронической токсичности

Это может быть результатом повышения проницаемости клеточных мембран. Увеличение активности печеночных трансфераз, особенно значительное увеличение активности АСТ, указывает на развитие эндогенной интоксикации.

Заключение. Анализируя полученные данные, установили, что аминокислотный комплекс «ВитаАмин» при длительном применении в диапазоне 0,02-0,04 мл на голову повышает активность активности ферментов АСТ и АЛТ в крови белых мышей в пределах нормы.

Литература: 1. Молочная кислота как кормовая добавка Соколов В., Андреева Н., Евелева В., Касаткин А. Птицеводство. 1995. № 5. С. 17-18. 2. Дежаткина С.В. Обмен веществ и продуктивность животных при использовании комплексной подкормки / С.В. Дежаткина, Н.А. Любин, М.Е. Дежаткин // Вестник Ульяновской государственной сельскохозяйственной академии. 2018. № 1 (41). С.79-85 3. Дежаткина С.В. Влияние препарата "Aminobiol" на молочную продуктивность коров / С.В. Дежаткина, А.З. Мухитов, Н.В. Шаронина // Вестник Ульяновской государственной сельскохозяйственной академии. 2019. № 2 (46). С.179-183 4. Шаронина, Н.В. Коррекция минерального профиля у птиц введением в их рацион БУМВ подкормки / Н.В. Шаронина, А.3. Мухитов, С.В. Дежаткина, //Вестник Ульяновской государственной сельскохозяйственной академии. - 2018. - № 3 (43) - С. 202-206. 5. Зялалов Ш.Р. Влияние аминокислотного комплекса «ВитАамин» на гематологические показатели лабораторных животных при изучении хронической токсичности / Ш.Р. Зялалов, А.З. Мухитов// Материалы Х Международной научно-практической конференции. - 2020. - С. 283 286. 6. Дежаткина С.В. Применение соевой окары в питании кур / С.В. Дежаткина, Н.В.Силова, В.В. Ахметова // Материалы V Международной научно-практической конференции. - Ульяновск: УГСХА, -2013. -С. 34-37 7. Шаронина Н.В. Содержание минеральных элементов в тканях кур-несушек при включении в рацион соевой окары/ Н.В.Шаронина, А.З.Мухитов, С.В.Дежаткина// Вестник Ульяновской государственной сельскохозяйственной академии. -2017.- № 4 (40).- С. 169-173. 8. Свешникова Е.В. Влияние биологически активной добавки на морфо-биохимические показатели у свиней /Е.В. Свешникова, Н.А. Любин, С.В. Дежаткина //Вестник Ульяновской государственной сельскохозяйственной академии. - 2016. - № 3 (35). - С. 38-42.

THE EFFECT OF "VitaAmin" ON THE ACTIVITY OF AST AND ALT ENZYMES IN LABORATORY ANIMALS IN THE STUDY OF CHRONIC TOXICITY

Sharonina N. V., Associate Professor, Candidate of Biological Sciences (Ulyanovsk State University, Russia)

Annotation. The work is devoted to the study of the effect of the amino acid complex "VitaAmin" on the activity of enzymes in the blood of white mice in the study of chronic toxicity. It was found that the amino acid complex "VitaAmin" with prolonged use in the range of 0.02-0.04 ml 
per head increases the activity of the AST and ALT enzymes in the blood of white mice within the normal range.

Key words: vitaamine, dose, enzymes, AST, ALT, mice.

УДК 619:615

\title{
КЕЙС-ЗАДАЧИ КАК ОДИН ИЗ ИННОВАЦИОННЫХ МЕТОДОВ В ПРЕПОДАВАНИИ ВЕТЕРИНАРНОЙ ФАРМАКОЛОГИИ
}

Шаронина Н.В., доцент,к.б.н.

(ФГБОУ ВО Ульяновский ГАУ, Россия)

\begin{abstract}
Аннотация. Данная статья посвящена теоретическому обоснованию и внедрению в учебный процесс кейс-метода как одного из инновационного метода в преподавании ветеринарной фармакологию. Метод case-study или метод анализа конкретных ситуаций - метод активного проблемно-ситуационного анализа, основанный на обучении путем решения конкретных задач. Считаем, что внедрения данного метода будет способствовать мотивации студентов при изучении данной дисциплины.
\end{abstract}

Ключевые слова:кейс, метод, задача, компетенция, дисциплина, фармакология.

Одно из основных направлений современноговысшего образования является практикоориентированность, способностьобучающихся применять знания в решении практических задач, ориентироваться в нестандартных ситуациях, встречающиеся в текущей и будущей профессиональной деятельности.

Процесс изучения дисциплины Ветеринарная фармакологиянаправлен на формирование у студентов профессиональной компетенции:ПК-3 - Способен использовать и анализировать фармакологические и токсикологические характеристики лекарственного сырья, препаратов, биологически активных добавок и биологически активных веществ для лечебно-профилактической деятельности, осуществлять контроль качества и соблюдение правил производства, реализации кормов, кормовых добавок и ветеринарных препаратов

Средством достижения компетенций в области фармакологии служат лекции, практические занятия, аудиторная и внеаудиторная самостоятельная работа, участие студентов в научном кружке. Это достигается также включением в учебный процесс элективных курсов, направленных на углубление знаний по ключевым разделам профессиональной подготовки.

Исследования показывают,что стимулировать у студентов устойчивый и длительный интерес к учебе весьма сложно.Инновационные технологии, это принципиально новые способы, методы взаимодействия преподавателей и учащихся, обеспечивающие эффективное достижение результата педагогической деятельности. Так, для расширения знаний по фармакологии в учебный процесс на 3 курсе считаем целесообразным включения решение кейс-задач.

Метод case-study или метод анализа конкретных ситуаций (от английского case случай, ситуация) - метод активного проблемно-ситуационного анализа, основанный на обучении путем решения конкретных задач $[1,2,3]$.

При решении кейсов студентам предлагается обдумать определенную ситуацию, описывающую конкретную практическую проблему, основанную на комплексе знаний, умений и навыков у студентов, необходимых для разрешения проблемы, поэтому case-study считается одним из самых эффективных методов обучения навыкам решения типичных практических проблем.

Кейсы составляют, используя реальный опыт профессиональной деятельности, как основу учебно-познавательной деятельности студентов под руководством преподавателя. 
Поэтому метод кейсов включает одновременно и особый вид учебного материала, и особые способы использования этого материала в учебном процессе [4].

Метод анализа конкретных ситуаций способствует активизации учебнопознавательной активности студентов, побуждает их к практической работе в процессе овладения материалом, когда активен не только преподаватель, но и обучающиеся. Студенты становятся участниками решения проблемных ситуаций, взятых из профессиональной практики ветеринарного врача. От обучающихся требуется проведение глубокого анализа ситуации и принятие приемлемого и верного решения [5].

Одна из разновидностью кейс задач- ситуации, направленные на оценку решения. В этом варианте кроме описания ситуации (предоставляется в распоряжение вся существенная информация) приводились принятые решения ветеринарного врача, которые студенты должны были проанализировать и критически оценить[6].

На практическом занятии обучающиеся делятсяна группы по 2-3 человека. Цель каждой группы - это решение ситуационной задачи, определение алгоритма выхода из ситуации.

Пример проблемной ситуации. В аптеку поступил рецепт, выписанный ветеринарным врачом Ивановым И.Н.: Возьми: Эуфиллина 0,15; Кислоты аскорбиновой 0,1; Сахара 0,2. Смешай, чтобы получился порошок. Дай таких доз числом 10. Обозначь.

Задание: приготовить порошок; упаковать и правильно выписать рецепт.

В решении ситуационных задач этого типа была заложена ошибка, и целью был поиск этой ошибки, а затем разработка собственного решения. Предварительно студенты прослушали лекции по фармакологии и самостоятельно повторили полученный материал по теме несовместимости лекарственных средств.

Ход решения: 1. Определить совместимость данных веществ приступить к технологии:эуфиллин в большинстве своем не совместим с аскорбиновой кислотой, так как вступает с ней в реакцию нейтрализации, при этом смесь желтеет, а в данном случае отсыревает. Целесообразно заменить эуфиллин на эквивалентное количество теофиллина. 2. Упаковка и рецепт на рецептурном бланке.

В конце преподаватель должен подвести итог, при этом учесть, как правильность решения ситуационной задачи, так и сам процесс обсуждения, аргументированность решения проблемы.

Таким образом, использование кейс-методов как интерактивного метода обучения соответствует практико-ориентированному подходу к результатам обучения, где обучающийся предстает в роли ветеринарного врача, что способствует высокому уровню мотивации и формированию профессионального мышления. Будут достигнуты высокие результаты в изучении дисциплины, формировании компетенций и подготовке к будущей профессиональной деятельности.

Литература: 1. Андреева Н. Л. Ветеринарная фармация / Н.Л. Андреева, Г.А. Ноздрин, А.М. Лунегов [и др.]. - СПб.: Лань, 2020. - 452 с. 2. 2. Крикова А.В., Анащенкова Т.А., Павлюченкова Н.А., Николаева Т.В., Зайцева В.М. Роль и место интерактивных методов при подготовке специалистов в области фармации // Фармация и фармакология. 2016. Т. 4 № 1 (14). С. 91-99. 3.Солтис В.В., Беззубенкова О.Е. Системный подход к организации научноисследовательской и проектной деятельности студентов (на примере профессиональной подготовки биологов в педагогическом университете) // Поволжский педагогический поиск. 2018. №4(26). С. 19-27 4. Балыхин Г. А. Федеральная целевая программа развития образования: новаторские решения на перспективу/ Г. А. Балыхин// Профессиональное образование. -2006. № 4. С.14-15. 5.Дежаткина С.В. Совершенствование методической работы преподавателя /С.В. Дежаткина //Всероссийская (национальная) научная конференция «Роль аграрной науки в устойчивом развитии сельских территорий». Новосибирский ГАУ. 2017. - С. 511-514. 6. Дежаткина С.В. Инновации в рамках изучения дисциплины «Радиобиология с основами радиационной гигиены» /С.В. Дежаткина //Национальная научно- 
методическая конференция профессорско-преподавательского состава: Инновационные технологии в высшем образовании. - 2018. - С. 39-44.

\title{
CASE-TASKS AS ONE OF THE INNOVATIVE METHODS IN TEACHING VETERINARY PHARMACOLOGY
}

Sharonina N. V., Associate Professor, Candidate of Biological Sciences

(Ulyanovsk State University, Russia)

Annotation. This article is devoted to the theoretical justification and implementation of the case method in the educational process as one of the innovative methods in teaching veterinary pharmacology. The case-study method or the method of analyzing specific situations is a method of active problem-situation analysis based on learning by solving specific tasks. We believe that the introduction of this method will contribute to the motivation of students in the study of this discipline.

Keywords: case, method, task, competence, discipline, pharmacology.

УДК: 658.382

\author{
РОЛЬ ИНФОРМАЦИОННЫХ ТЕХНОЛОГИЙ В ПРЕПОДАВАНИИ КУРСА \\ «ЭКОЛОГИЯ» \\ ${ }^{1}$ Шевцов В.В., кандидат технических наук, \\ ${ }^{2}$ Глебов В.В., доцент, кандидат биологических наук \\ ( ${ }^{1}$ ФАОУ ВО РУДН, Россия) \\ ( ${ }^{2}$ ГБОУ ВО РГАУ - МСХА имени К.А. Тимирязева, Россия)
}

\begin{abstract}
Аннотация. В представленной работе приведены различные подходы в подготовке специалистов экологов. Дана информация о удачной интеграции в экологическую подготовку экологов современных информационных компьютерных технологий. Обсуждаются проблемные системные аспекты при подготовке специалистов в природоохранной деятельности в России.
\end{abstract}

Ключевые слова:методические подходы, информационные компьютерные технологииобучения, экология,студенты высшей школы

Введение. Научно-технический прогресс и экономическая активность человека на земле сопровождается образованием больших экологических проблем, которые значимо воздействуют на многие стороны жизни человека. Многие эти проблемы часто носят повсеместный характер и по своей сути являются долговременными. В этой связи усиливается роль экологического воспитания и образования[1].

Процессы тотальной информатизации общества во всем мире хорошо проявила себя в период вирусной пандемии, когда возникла острая необходимость применение информационных компьютерных технологий (ИКТ) при обучении специалистов различных специальностей включая и экологов. Поэтому меняются условия среды, которые требуют формирования новых условий труда и требования к умениям и навыкам в отношении использования компьютерных технологий - важной составляющей в профессиональной деятельности человека. В данной статье авторы предприняли попытку рассмотреть ИКТ в образовательном процессе РУДН.

По утвержденной программефедерального государственного Стандарта (ФГОС) существует следующая номенклатура профильных специальностей: 013100 - «Экология»; 320100 - «Природопользование»; 320200 «Биоэкология»; 320300 «Геоэкология»; 320500 «Мелиорация, рекультивация и охрана земель»; 320600 «Комплексное использование и охрана водных ресурсов»; 320700 «Охрана окружающей среды и рациональное использование природных ресурсов»; 320800 «Природоохранное обустройство территорий»; 330200 «Инженерная защита окружающей среды» [4].Перечисленные специальности высшей школы Российской Федерации практически охватывают все направления в экологии, которые 
отвечают современным вызовам в быстро меняющихся условиях глобального мира: усложнение технологических процессов, возрастание техногенной нагрузки на природную среду в ряде промышленных регионов Россиии антропогенное влияние на функциональные состояние человека [2].

Применение ИКТ в РУДН для студентов-экологов включаетподготовку умений составлять тексты реферативных, курсовых и дипломных работ на электронных носителях. Большая работа ведется в обучении студентов навыкам поиска информационных ресурсов в Интернете, обработке и анализе этой информации, при работе с различными информационносправочными системами и правовыми источниками в области природоохранной деятельности.Неоценимую помощь оказывают информационныекомпьютерные технологии в оценке знаний учащихся в области природоохранной деятельности, правовых знаний охраны окружающей среды, когда студенты проходяттестовые и контрольные задания. Навыки публичных выступлений студентов отрабатывается при подготовке презентаций. Также большую помощь оказывает ИКТ при статистической обработке экспериментальных данных $[3,4]$.

Для преподавателейв образовательном процессе подготовки студентов по экологическим специальностям конечноИКТдает возможность доступа к информационным ресурсам через Интернет и коммуникации с студентами через корпоративнуюэлектронную почту, дающая возможность конструктивного и быстрого общения со студентами. Для наглядности и лучшему закреплению знаний ИКТ дает возможность подготовки лекционных материалов и показа лабораторных работ. [4-6]

В настоящее время можно отметить, что в вузах есть хорошая обеспеченность учебниками по экологии и ИКТ, причем наибольшее распространение получили учебники в электронной форме [4,5].

Также успешной интеграцией в образовательный процесс высшей школы при подготовке экологов является ведение геоинформационных систем (ГИС), где имеется широкая представленность электронных базы данных по вопросам рационального природопользования.

Хорошим методическим подспорьем вприродоохранных дисциплин в подготовке смежных экологических специальностей является комплекс Z/Study, который успешно используется в Российском гидрометеорологическом университете. Данный программный комплексоценивает в автоматическом режиме уровень качества атмосферного воздуха урбанизированных территорий и городских промышленных зон [6].

Между тем важно отметить некоторые сложности, которые имеют системный характер. Например, в настоящее время, к сожалению, не существует планового распределения молодых специалистов, в частности экологов в народном хозяйстве России, которая была отлажена и хорошо себя зарекомендовала во времена СССР для выпускников Вузов.Эта практика способствовала развитию профессионализма у молодых специалистов и закрепление профессиональных кадров в отрасли.Также слабо развита среди выпускников и трудовая миграция. Анализ анкет выпускников РУДН показывает, что большая часть выпускников трудоустраиваются в пределах города проживания и не по специальности. И здесь важную роль может играть государство, которое может выступать заказчиком подготовки специалистов по бюджетным местам [3].

В подготовке и повышение качества обучения студентов безусловно большую роль играют вузы. Это может формироваться за счет дальнейшей цифровизации образования и расширения роли ИКТ в разных эколого-экономических направлениях подготовки специалистов [6].

Для студентов-экологов при обучении в вузах, как правило, не предусматривается параллельного получения «второй» специальности (как это делается для «учителей»). Если это ввести в практику высшей школы это могло бы расширить возможности трудоустройства молодых специалистов. Теоретически это можно осуществить на «коммерческой основе» по заочной форме, но практически сделать это сложно [5]. 
По сравнению с периодом существования СССР подготовка зарубежных студентов в России (в т.ч. и по экологии) значительно сократилась в настоящее время. Это касается большинства вузов Российской Федерации. В настоящее время на наш взгляд является перспективное направление работы с бывшими среднеазиатскими странами, входившими в состав СССР. Это направление достаточно легко реализуемо, используя методы дистанционного обучения на основе ИКТ [6].

\section{Выводы.}

1.Существующая система подготовки экологов в России не в полной мере отвечает требованиям рынка и запросам современного бизнеса.

2. Расширение применения информационных компьютерных технологийпри подготовке экологов требует углубления подготовки специалистов в отношении владения информационными технологиями.

3. Необходимо наладить утраченную практику закрепление выпускников вузов на предприятиях, которая поможет решать проблемы кадров и снижать социальное напряжение в обществе (проблема трудоустройства).

Литература 1. Глебов В.В., Аникина Е.В. TheexportofRussianhighereducation // В сборнике: Образование: молодежь, конкурентоспособность Сборник докладов Международной научнопрактической конференции, приуроченной к 80-летнему Оюбилею академика Российской академии образования, доктора философских наук, п0рофессора Г.Ф. Шафранова-Куцева. 2018. С. 165-168. 2. Глебов В.В., Лямина Д.С., Трушин В.А., Попова П.Ф. Динамика работы функциональных систем студентов экологов РУДН за последние 10 лет // В сборнике: Эколого-физиологические проблемы адаптации материалы XVIII Всероссийского симпозиума с международным участием. Российский университет дружбы народов. 2019. С. 66-67. 3. Глебов В.В., Соловьева Е.А. В сборнике: Образование: молодежь, конкурентоспособность Сборник докладов Международной научно-практической конференции, приуроченной к 80-летнему юбилею академика Российской академии образования, доктора философских наук, профессора Г.Ф. Шафранова-Куцева. 2018. С. 159162. 4. Гузеева Т. Н., Панин В. Ф. Создание электронного учебника «Экология для инженера» // Актуальные проблемы современной науки: Tp. V Междунар. конф. молодых ученых и студ. Естественные науки. Ч. 13. Экология. - Самара: Изд-во СамГТУ, 2004. - С. 56-57. 5. Даначева М.Н., Глебов В.В. VariousapproachestothecompetitivenessofuniversitiesinEurope // В сборнике: Образование: молодежь, конкурентоспособность Сборник докладов Международной научнопрактической конференции, приуроченной к 80-летнему юбилею академика Российской академии образования, доктора философских наук, профессора Г.Ф. Шафранова-Куцева. 2018. С. 153-155. 6. Ефимова Е.И. Котляров В.П. Опыт использования информационных технологий в экологическом образовании//Информатика. Образования. Экология и здоровье человека. Астрахань,25-30сентября 2000 г.: Тез.докладов V Междунар. конф. - Астрахань: Изд-во АГПУ, ИПЦ «Факел», 2000. - С. 78.

\section{THE ROLE OF INFORMATION TECHNOLOGIES IN TEACHING THE COURSE «ECOLOGY»}

${ }^{1}$ Shevtsov V. V., Candidate of Technical Sciences

${ }^{2}$ Glebov V. V., associate Professor, Candidate of Biological Sciences $\left({ }^{1}\right.$ FGAOU VO RUDN, Russia)

( ${ }^{2}$ FSBEI HE RGAU - MSHA named after K. A. Timiryazev, Russia)

Summary.The paper presents various approaches to the training of environmental specialists. Information is given about the successful integration of modern information computer technologies into the environmental training of ecologists. The article discusses the problematic systemic aspects of training specialists in environmental protection in Russia.

Keywords: methodological approaches, information computer technologies of teaching, ecology, higher school students 


\title{
ОЦЕНКА ВКУСОВЫХ КАЧЕСТВ МЯСА ПТИЦЫ
}

\author{
Шпаковская Ю.С. аспирант ${ }^{1}$, Лунегов А.М. зав. кафедрой фармакологии и токсикологии, \\ доц., к.в.н. ${ }^{1}$, Лунегова И.В., доц., к.вет.н ${ }^{2}$ \\ (
}

\begin{abstract}
Аннотация. В статье приведены результаты органолептического исследования мяса цыплят-бройлеров при скармливании кормовой добавки «Пуляр»к основному рациону. В результате проведенного исследования независимые эксперты дали максимальную оценку по вкусовым качествам. Все участники дегустации (более 50 человек) единогласно отметили, что жареное мясо пулярки очень сочное, ароматное. По вкусу намного превосходит мясо цыплятбройлеров. Ббыло отмечено высочайшие вкусовые качества отварной пулярки и бульона.
\end{abstract}

Ключевые слова: кормовая добавка, цыплята-бройлеры, органолептические исследования.

Нами было проведено исследование по оценке качества мяса и бульона, приготовленного из мяса цыплят-бройлеров, рацион которых состоял из комбикорма ПК-6 (первая подопытная группа - контроль) и из мяса цыплят-бройлеров, рацион которых состоял из комбикорма ПК-6, с добавлением 40\% кормовой добавки «Пуляр» (вторая подопытная группа).

При органолептическом исследовании выявлено: тушки достаточно хорошо обескровлены, чистые, без остатков пера и пуха. Поверхность тушки сухая, цвет беловатожелтый с розовым оттенком. Мышцы на разрезе слегка влажные, бледно-розового цвета. Абдоминальный жир бледно-желтого цвета. Консистенция упругая. При надавливании пальцем на тушку ямка быстро выравнивается. Запах разреза специфический, свойственный свежему мясу птицы. При варке мяса бульон ароматный, прозрачный. Жир на поверхности бульона присутствовал в виде больших капель. Посторонние запахи отсутствовали. Из представленных данных следует, что бульон из мяса цыплят-бролеров, получавших к основному рациону ПК-6 40\% кормовой добавки «Пуляр» по всем показателям (достоверно по внешнему виду, вкусу, наваристости, запаху и общей оценке) имеет более высокую оценку, чем бульон из мяса цыплят-бройлеров контрольной группы.

Для оценки вкусовых качеств мяса птицы, в рацион которой входила кормовая добавка «Пуляр», была проведена дегустационная экспертиза в трех ресторанах Санкт-Петербурга и группой независимых экспертов. В состав данных ресторанов входили: 1. Каскад. 2. Русская рюмочная №1. 3. Фиш-Хаус.

В результате откорма бройлерных цыплят с добавлением кормовой добавки «Пуляр» на 42-й день, птица весом 2,3-2,5 кг использовалась в дегустации. Такая птица принимает название пулярки. Пулярка - это употребляемое в Западной Европе и в русской дореволюционной кулинарии название специально откармливаемых мясных кур.

В результате проведенной экспертизы, рестораны Санкт-Петербурга и независимые эксперты дали максимальную оценку по органолептическим, в особенности вкусовым, показателям птицы. Все участники дегустации (более 50 человек) единогласно отметили, что жареное мясо пулярки очень сочное, ароматное. По вкусу намного превосходит не только мясо бройлеров, но и специально откормленных для ресторанов фермерских кур. Так же было отмечено высочайшие вкусовые качества отварной пулярки и бульона.

Общая дегустационная оценка показала, что качество бульона из мяса цыплятбройлеров, получавших кормовую добавку «Пуляр», была выше на 1-2 балла, чем из мяса контрольной группы. Вареное мясо отличалось сочностью, нежностью, имело приятный специфический вкус. Никаких посторонних запахов и привкуса не было обнаружено.

Таким образом, в результате проведенного эксперимента было доказано, что снижение количества энергии в кормовой добавке «Пуляр» в финишный период откорма на фоне увеличенного количества белка способствует более интенсивному отложению жира и 
улучшению вкусовых качеств мяса.

EVALUATION OF THE TASTE OF POULTRY MEAT

Shpakovskaya Yu.S. postgraduate ${ }^{1}$, Lunegov A.M., head Department of Pharmacology and Toxicology, Associate Professor, Ph.D. ${ }^{1}$, Lunegova I.V., Associate Professor, Ph.D. ${ }^{2}$ ( ${ }^{1}$ FSBEI HE SPbGUVM, ${ }^{2}$ FSBEI HE SPCPU, Russia)

Summary. The article presents the results of organoleptic research of meat of broiler chickens when feeding the feed additive "Pular" to the main diet. As a result of the study, independent experts gave the maximum assessment of taste. All the participants of the tasting (more than 50 people) unanimously noted that the fried poulard meat is very juicy and aromatic. It tastes much better than broiler chicken meat. The highest taste qualities of the boiled poulard and broth were noted.

Key words: feed additive, broiler chickens, organoleptic research.

\section{ВЕТЕРИНАРНОЕ ОБРАЗОВАНИЕ КАК КОМПОНЕНТА СОВРЕМЕННОЙ ВЫСШЕЙ ШКОЛЫ РОССИИ: КРАТКИЙ РЕТРОСПЕКТИВНЫЙ ЭКСКУРС ДОИНДУСТРИАЛЬНОГО РАЗВИТИЯ}

Шумилина М.А. ${ }^{1}$, к.э.н., доцент; Нефедова К.А. ${ }^{1}$, к.э.н., доцент; Чистяков М.С. ${ }^{1}$, научный сотрудник, Золкин А.Л. ${ }^{2}$, к.т.н.

( ${ }^{1}$ Владимирский филиал Российского университета кооперации, Россия)

( Поволжский государственный университет телекоммуникаций и информатики (ПГУТИ); Частное учреждение образовательная организация высшего образования "Медицинский университет "Реавиз" (Реавиз), Россия)

Аннотация. В статье приводится краткий исторический событийный ряд становления современного облика высшего ветеринарного образования России - в Россий империи и советской России. Рассматриваются некоторые институциональные меры формирования высшей школы ветеринарной медицины, послужившие основой последующего становления ветеринарии как научного направления.

Ключевые слова: ветеринарная медицина, ветеринарное образование, высшая школа.

Для понимания сущности проблемных аспектов и перспектив дальнейшего развития ветеринарного образования в современной России с учетом современных образовательных стандартов - обозначим частность в предметной области эволюции ветеринарии, а именно: исторические предпосылки становления ветеринарного образования, послужившие платформенной основой права субъектности данного направления в общей концепции высшего образования.

Дефиниция «ветеринария» имеет латинские корни от Veterinariusи означает ухаживающий за скотом, лечащий скот. Впервые оно упоминается в трактате «О сельском хозяйстве» Колумеллы (1 в. н.э.), римского писателя, посвятившего свои произведения агрономии [1].

Отсчётом в становлении ветеринарного образования в России является начало XIX века. Основой данного образования как фундамента подготовки ветеринара в качестве специалиста высококвалифицированной и разносторонне развитой личности становится самостоятельное научное направление. Необходимо отметить разносторонний спектр дисциплин, как специальных, так и естественнонаучных. Будущий специалист должен был владеть русским и иностранными языками.Катализатором озвученной исторической данности послужили нужды армии. 23 мая 1719 года Указ «о научении нижних чинов в медицине» послужил основой зарождения ветеринарного образования в России, за 47 лет до первой ветеринарной школы в Европе [2]. 
В 1808 году в Императорской медико-хирургической академии в Санкт-Петербурге открывается ветеринарное отделение. Эту дату можно считать официальной точкой отсчета развития ветеринарии как науки. В 1812 производится первый выпуск ветеринарных лекарей для военных нужд.

С 1924 года ВУЗ именовался Ленинградским ветеринарным институтом [3].

По университетскому уставу 1804 года при медицинских отделениях создавались кафедрыскотолечения. Реализация данной направленности проходила с большими затруднениями ввиду отсутствия собственного преподавательского пула, а также программ подготовки ветеринарных врачей.

Одной из таковых практических школ по подготовке ветеринарных лекарей стала кафедра скотолечения университета Казанской губернии, начавшая свою деятельность в 1822 году. 31 мая 1873 года высочайшим Повелением «Об учреждении в Казани высшего учебнопрактического заведения, имеющего целью образование ученых ветеринаров» был организован Институт, датой отсчёта деятельности которого является 22 августа 1874 года (по старому стилю) [4]. Высокое качество ветеринарного образования обеспечивалось теоретическими знаниями и практическими навыками профессорско-преподавательского состава института.

Однако, как и все высшее, ветеринарное образование было доступно узкому кругу населения Российской империи.

В советский период высшая школа подверглась реформированию на основе концепции формирования студенчества из рабоче-крестьянского сословия. Открываются рабочие факультеты, устанавливаются льготы для абитуриентов из рабочего класса.

Учитывая сложную политическую и экономическую обстановку, в 1920 году решением специального правительственного постановления организуется ускоренная подготовка ветеринарных врачей [5].

Основу подготовки специалистов в высшей школе составляло становление у нихкоммунистической идеологии посредством общественно-политических дисциплин (например, история ВКП(б) с основами марксизма-ленинизма, политэкономия, исторический материализм и пр.).

В 30-х годах XX века ветеринарная наука сталкивается с проблемой отсутствия соответствия ветеринарного специалиста-практика требованиям отраслевого планового сельского хозяйства. Признается необходимость ветеринарного врача с дифференцированной специализацией. В 1931 году Государственным ученым советом Народного комиссариата просвещения РСФСФ (ГУСом)утверждается специализации в ветеринарной подготовке, а именно: ветеринарный врач-профилактик-клиницист, ветеринарный врач-эпизоотолог, ветеринарный врач-профилактик санитарной службы. Предлагалось расширить специализацию по видам животных. При этом срок обучения в ветеринарных ВУЗах сократили до 4 лет [6]. Ранее (с 1926 года)высшее ветеринарное образование составляло 5 лет $[7,159]$.

В данной коллективной работе авторы напомнили читателям о некоторых исторических вехах до эпохи индустриализации, заложивших основу современного ветеринарного образования России. Безусловно, история ветеринарной медицины богата на события и интересна в многоликом хронологическом коллаже своего эволюционного становления. Возможно, данные тезисы краткого исторического экскурса послужат стимулом для продолжения повествовательного ознакомления «носителем» бесценных знаний широкого круга читающей аудитории истории становления и развития ветеринарии.

Литература. 1. История ветеринарной медицины [Электронный pecypc]. URL: http://www.sgau.ru/kisuuz/uploads/img/18-09-

15/1537003578/\%D0\%9A\%D1\%80\%D0\%B0\%D1\%82\%D0\%BA\%D0\%B8\%D0\%B9\%20\%D0\% BA\%D1\%83\%D1\%80\%D1\%81\%20\%D0\%BB\%D0\%B5\%D0\%BA\%D1\%86\%D0\%B8\%D0\%B9 $\% 20 \% \mathrm{D} 0 \% 98 \% \mathrm{D} 0 \% 92 \% \mathrm{D} 0 \% 9 \mathrm{C} . \mathrm{pdf}$ (02.04.2021). 2. Валерий Шарпило. Из истории отечественной ветеринарии: юбилейный даты в 2015 и 2016 годах [Электронный ресурс]. 
URL: $\quad$ http://zoosovet.spb-gov.ru/publikacii/istoriya/valerij-sharpilo-mihail-bolshakov-godyubileev-ippologiya-i-veterinari/ (05.04.2021). 3. История академии. Императорская медикохирургическая академия [Электронный ресурc]. URL: https://spbgavm.ru/akademija/istoriyaakademii/ (08.04.2021). 4. Гальмутдинова О.М., Хакимова А.С. Содружество ученых в становлении высшего ветеринарного образования в России в последней трети XIX века // Казанский педагогический журнал. - 2015. - № 6-2(113). - С. 420-423. 5. Известия ВЦИК. 1920. - 14 июл. 6. Вестник современной ветеринарии - 1930. - № 2. - С.57; 1930. - №5. - С. 145 . 7. Донченко А.С., Осташко Т.Н., Самоловова Т.Н. Очерки истории ветеринарии в Сибири 1917-1927 гг. - Новосибирск, 2006.

\section{VETERINARY EDUCATION AS A COMPONENT OF MODERN HIGHER SCHOOL IN RUSSIA: A BRIEF RETROSPECTIVE FLASHBACK OF PRE-INDUSTRIAL DEVELOPMENT}

Shumilina M.A., Candidate of Economic Sciences, Associate Professor; K.A. Nefedova, Ph.D., Associate Professor; Chistyakov M.S., Researcher

(Vladimir Branch of the Russian University of Cooperation, Russia)

Zolkin A.L., Ph.D. (Povolzhskiy State University of Telecommunications and Informatics (PGUTY); Private institution of higher education "Medical University" Reaviz

Summary.The article provides a brief historical event series of the formation of the modern appearance of higher veterinary education in Russia - in the Russian Empire and Soviet Russia. Some institutional measures for the formation of a higher school of veterinary medicine, which served as the basis for the subsequent development of veterinary medicine as a scientific direction, are considered.

Key words: veterinary medicine, veterinary education, higher school.

УДК: 615.35/.37.014.43:619

ИСПОЛЬЗОВАНИЕ ПРОБИОТИКА «БАКТОВИТ» В ВЫРАЩИВАНИИ ЦЫПЛЯТ БРОЙЛЕРОВ И КРОЛИКОВ В УСЛОВИЯХ ЖАРКОГО КЛИМАТА УЗБЕКИСТАНА

Юлдашев Д.К., к.с.х.н, заведующий отделом птицеводства НИИ животноводства и птицеводства Узбекистана. Хидиров К.И., директор центра селекции и генетики кролиководства НИИ животноводства и птицеводства Узбекистана

Аннотация. За годы независимости Узбекистана, начиная с 1992 годас каждым годом количество птиц в республике растет. Это в свою очередь привело к дефициту кормовых добавок, ветеринарных препаратов и вакцин. Намисовместно с сотрудниками НИИ микробиологии АН Узбекистана изучены свойства и действие на цыплят и кроликовновогопробиотика «Бактовит». Этот пробиотикв течении 2018-2020 годов прошел успешные лабораторные и производственные испытания и рекомендован для использованияпривыращиваниицыплят бройлеров и кроликов.

Ключевые слова: пробиотики, бройлеры, кролики, биологически активные вещества

За годы независимости Узбекистана, начиная с 1992 года поголовье птиц возросло с 26,1 млн голов к 2020 году до 90 млн голов. За это время производство яиц возросло с 2,7 млрд шт до 8,1 млрд шт в год, производство птичьего мясо с 44 тыс. т до 400 тыс т. Благодаря проведенной работе за последние 10 лет среднедушевое потребление птичьего мясо возросло с 0,2 кг до 8,2 кгв год. Но вместе с тем, с развитием птицеводческой отрасли возникли определенные трудности в обеспечении ветеринарными препаратами, кормами и оборудованием. По статическим данным за последние годы около $80 \%$ вакцин и лекарственных средств,БАДов, кормовых добавок завозится извне. Крупными поставщиками ветеринарныхпрепаратов и кормовых добавок стали Китай, Германия, Россия и Турция, поставляющие около 50 \% препаратов и оборудования. При этом импорт продукции с 2016 
года возрос в 4 раза. В связи с этим остро встало вопрос импортозамещениявышеперечисленных средств.

Научно-исследовательским институтом животноводства и птицеводства Узбекистана в период 2018-2020 года в рамках НИР проведено изучение адаптогенных и иммуностимулирующих свойств нового пробиотика «Бактовит», разработанного учеными института микробиологии АН Узбекистана.

За последние 30лет в практике промышленного птицеводства, в том числе в экологически неблагоприятных регионах мира, для профилактики и лечения дисбактериоза птиц, повышения общей и неспецифической резистентности организма, для борьбы с условно-патогенной микрофлорой животных и птиц, широко стали применятся различные иммуномодуляторы, к числу которых относятся и пробиотики [1-3].

Результаты научно-производственных опытов и многолетней практики применения пробиотиков показали положительные результаты применения препаратов для снижения патогенной и условно-патогенной микрофлоры, улучшения обменных процессов и продуктивности, снижения воздействий различных стресс факторов и падежа поголовья. [58].

Разработка и испытание нового пробиотика «Бактовит» осуществилось совместно институтом микробиологии АН в три этапа. На первом этапе (2018 год) были изучены литературные данные, разработана технология получения пробиотика и получены первыеопытные образцы препарата, изученыего биологические свойства. На втором этапе проведены лабораторные исследования пробиотиков. На третьем этапе проведены научнопроизводственные опыты на птице различных кроссов и кроликах.

Опыты проведены по общепринятым методикам на аналогичных группах (Овсян,1987), гематологические показатели определены -морфологические по методу Сале, биохимические и цитохимические по НСТ-тесту Г.И. Гордиенко, общего белка и иммуноглобулинов по общепринятым методам Гринкевича [4]. Полученные результаты обработаны по программе Statistika for Windows и по методу Стьюдента.

В период работы был получен пробиотик, состоящий из 8 видов бактерий из родов Lactobacillus, Bifidobacterium, Propionibacterium и Bacillus subtilis с активностью $10^{9}-10^{10}$ КОЕ/мл.

Проведены два научних опыта на цыплятах бройлерах и один опыт на кроликах. Опыты на цыплятах проведены в различные периоды года на птицеводчесом комплексе “Той тепа парранда" Урта Чирчикского района, Ташкентской области, на кроликах - на экспериментальной базе кролиководческого центра НИИ животноводства и птицеводства.Были сформированы 2 группы животных и птиц (контрольная и опытная). Контрольная группа содержалось на рационе, а опытная группа получала дополнительно пробиотик "Бактовит"

Проведенными исследованиями установлено положительное влияние пробиотика “Бактовит" на обменные процессы птиц и кроликов, среднесуточные привесы, сохранность игематологические показатели.

Результаты опытов по влиянию “Бактовита" на сохранность показали, что применение препарата увеличивает сохранность на 4,5 - 5,5\%. $13,6 \%$.

Кроме этого, применение “Бактовита” увеличивало среднесуточный привес на 11,1 -

Полученные результаты показали положительное влияния пробиотика в кормлении цыплят-бройлеров.

Изучение показателей крови показало что, в крови обих групп содержание лейкоцитов и эритроцитов были в пределах физиологической нормы. Однако, показатели эритроцитов в опытой группе в 10 дневном возрасте былы выше на 1,8\%, в 20 дневном возрасте на 17,7\%, по лейкоцитам на 12,6 и 14,4\% соответственно. Из биохимических показателей СЦК МП -8,97,9\%, НСТ -24,1-7,4, СЦК КБ -19,8-13,2\%, общего белка в крови опытных групп было выше 
на 12,8 \%, иммунные комплексы на 12,6\%. Эти изменения показали, что применение пробиотика «Бактовит» улучшаетадаптогенные и иммунные показатели цыплят.

Убойный выход забитых цыплят был выше у цыплят опытных групп на 45\%.

В опытах на кроликахпороды «Калифорния» пробиотик «Бактовит» применяли с водой. Показатели крови в 30-,45-, 65 дневном возрасте соответствовали физиологическим нормам. Сохранность кроликов в опытных группах была выше на 11,7\% по сравнению с сохранностью кроликов в контрольных группах.

На основании полученных результатов был сделано вывод:

Пробиотик «Бактовит» улучшает сохранность и привесы птицы и кроликов.

Литература: 1. Бондаренко В.М. Дисбиоз современные возможности профилактики и лечения. Пробиотическая микробиология: современное состояние и проблемы - М., 1995. - С. 5-10.24 2. Герасименко В.В. Обмен веществ и продуктивные качества гусей при использовании пробиотиков / Автореф. На соиск. уч степ. Докт. биол наук, Боровск, 2008. 44 с. 3. Джавадов Э.Д. Применение ферментативного пробиотика в кормлении цыплятбройлеров / соавт.: В.А. Манукян и др. // Птица и птицепродукты. 2013. № 5. С. 22-25. 4. Мамыкова О.И. Методические положения по количественному определению и качественному анализу циркулирующих иммунных комплексов в сыворотке крови животных при заболеваниях инвазионной этиологии. Всероссийский научно-исследовательский институт гельминтологии им. К.И. Скрябина, (одобрены секцией «Инвазионные болезни животных» отделения ветеринарной медицины Россельхозакадемии 19 мая 2011 г., протокол № 2). 5.Ноздрин Г.А. Пробиотики на основе Bacillussubtilis и их роль в поддержании здоровья животных разных видов / Г.А. Ноздрин, А.Б. Иванова, А.Г. Ноздрин / /Сиб. вестн. с.-х. науки. 2006. №7- С. 63-66 6. Ноздрин Г.А. Новые иммуномодуляторы и лечебно-профилактические средства / Г.А. Ноздрин, В.Н. Зеленков // Новые фармакологические средства в ветеринарии: тез. докл. к 4-й межгос. межвуз. науч.-практ. конф.- СПб., 1992.- С. 31-32. 7. Попова О. С. “Фармако-токсикологическая характеристика препарата Маримикс 5:0”.Автореферат на соискание степени кандидата ветеринарных наук. Санкт Петерург, 2013 г. 8. OuwehendA. C. Probiotics: anoverviewofbeneficialeffects / A.C. Ouwehend, S. Salminen, E. Isolauri // J. Microbiol. 2003. - Vol. 41. №2. - P. 63-72.

\section{USING PROBIOTIC "BAKTOVIT" IN GROWING BROILERS AND RABBITS IN THE HOT CLIMATE OF UZBEKISTAN.}

D.K. Yuldashev, Candidate of Agricultural Sciences, Head of the Department of the Research Institute of Livestock and Poultry in Uzbekistan.

Annotation.Over the years of Uzbekistan's independence, since 1992, the number of birds in the republic has been growing every year. This, in turn, has led to a shortage of feed additives, veterinary drugs and vaccines. Together with the Research Institute of Microbiology of the Academy of Sciences of Uzbekistan, we studied the properties and effects of the new probiotic "Baktovit" on chickens and rabbits. This probiotic has passed successful laboratory and production tests during 2018-2020 and is recommended for the use of health and immunodeficiency in raising broilers and rabbits.

Key words: probiotics, broilers, rabbits, biologically active substances

УДК 636.592

\section{ВЛИЯНИЕ ПРОБИОТИЧЕСКОГО ПРЕПАРАТА НА СОДЕРЖАНИЕ ЭРИТРОЦИТОВ В КРОВИ ИНДЮШАТ}

Яковлева М.С., аспирант Яковлева Н.С., аспирант

(ФГБОУ ВО НГАУ, Россия)

Аннотация. Одним из показателей физиологического состояния живых организмов, которое отражают гематологические показатели крови, является нормальная работа пищеварительной системы напрямую связанная с составом микробного биоценоза кишечника. Поэтому в 
настоящее время стремительно возрастает интерес к исследованию пробиотических препаратов.

Ключевые слова: ветом, индейки, пробиотики.

В связи с поиском альтернативных вариантов кормовым антибиотикам, в настоящее время увеличился научный интерес к пробиотическим препаратам. В результате многочисленных исследований в этой области, создается все больше новых пробиотических добавок как для медицины, так и для ветеринарии [1].

Пробиотики, являясь культурами микробов, симбионтных по отношению к нормальной микрофлоре желудочно-кишечного тракта, подавляют жизнедеятельность патогенных и условно-патогенных бактерий кишечника, повышают резистентность организма животного, улучшают усвоение питательных веществ корма, активизируют обменные процессы [2-7].

Целью нашей работы является изучение влияния пробиотического препарата ветом на содержание эритроцитов в крови индюшат.

Научно-производственный опыт проводили на подобранных по принципу пар аналогов клинически здоровых индюшатах в возрасте 1 мес., прошедших предварительное карантинирование периодом 2 нед., которое предполагало адаптацию животных. Было сформировано 5 опытных и контрольная группа по 10 птиц в каждой. Все птицы содержались в одинаковых условиях.

Опытный образец - микробиальный препарат ветом 1.2. Представляет собой белый, мелкодисперсный порошок, без запаха, растворимый в воде, с образованием осадка белого цвета. В 1 г содержит бакмассу живых спорообразующих бактерий B. subtilis штамм ВКПМ B-10641 (не менее $1 \times 10^{6}$ КОЕ), $B$. amyloliquefaciens штамм ВКПМ В-10642 и $B$. amyloliquefaciens штамм ВКПМ В-10643 (не менее $2 \times 10^{6}$ КОЕ), а также вспомогательные вещества (сахарная пудра, крахмал).

Испытуемый препарат задавали в дозе, выбранной согласно методическим указаниям, перорально ежедневно в одно и то же время утром с водой. Продолжительность назначения препарата составляла 30 суток. Индюшатам из 1-5-ой опытных групп препарат назначали в дозах 12,5; 25; 50; 75 и 100 мг/кг массы соответственно. Индюшатам контрольной группы препарат не назначали. Кровь для проведения исследований отбирали до начала опыта, на 15е; 30-е и 60-е сутки в вакуумные пробирки с ЕДТА.

Под действием изучаемого препарата изменялась концентрация эритроцитов в крови у индеек. До начала эксперимента концентрация эритроцитов крови у индеек контрольной и опытных групп не имела достоверных отличий. На 30-е сутки эксперимента у индеек 1-3-й и 5-ой опытных групп концентрация эритроцитов крови была ниже на 41,92 (P<0,01); 1,52; 11,11 $(\mathrm{P}<0,01)$ и $19,19 \%$ соответственно, чем у индеек из контроля, а у индеек 4-ой опытной группы была выше на $35,35 \%$ (P $<0,01)$, чем у индеек из контроля. На 60 -е сутки эксперимента у индеек 1-3-й и 5-ой опытных групп концентрация эритроцитов крови была выше 16,$60 ; 55,99$ $(\mathrm{P}<0,01) ; 22,01(\mathrm{P}<0,01)$ и 11,20\% соответственно, а у индеек 4-й опытной на 19,30\% ниже, чем у аналогов из контроля. За период эксперимента концентрация эритроцитов крови у индеек контрольной и 1-5-й опытной групп понизилась на 47,25; 38,49; 17,$72 ; 35,64 ; 57,43$ и $41,34 \%$, соответственно, по сравнению с исходными данными.

Таким образом, под действием изучаемого препарата ветом 1.2 в период применения повышение эритроцитов в крови по отношению к контролю происходит только при применении его в дозе 75 мг/кг, а в период последействия - при применении в минимальных (до 50 мг/кг массы) дозах.

Такие данные согласуются с представленными в литературе данными, когда в период применения пробиотических препаратов происходит повышение концентрации эритроцитов крови.

Вывод: Ветом 1.2 в дозах 12,5; 25; 50; 75 и 100 мг/кг не оказывает негативного влияния на физиологическое состояние опытных птиц, стабилизирует уровень эритроцитов в крови индеек опытных групп. 
Литература. 1. Кван О.В. Влияние пробиотических препаратов на гематологические показатели крови лабораторных животных / О.В. Кван, Ю.А. Константинова, Г. П. Алёхина и др. // Вестник Оренбургского государственного университета. - 2017. - № 6 (206). - С. 76-79. 2. Шевченко А.И. Естественная резистентность мясной птицы и ее фармакокоррекция пробиотиками и синбиотиками / А.И. Шевченко, С.А. Шевченко, Ю.Н. Федоров // Сельскохозяйственная биология. - 2013. - № 2. - С. 93-98. 3. Яковлева М.С. Влияние пробиотического препарата ветом 1 на содержание эритроцитов в крови индеек / М.С. Яковлева, Г.А. Ноздрин, А.А. Леляк и др. // Роль аграрной науки в устойчивом развитии сельских территорий. Сборник III Всероссийской (национальной) научной конференции. 2018. - С. 799-801. 4. Ноздрин Г.А. Физиологическое состояние и интенсивность роста телят в ранний постнатальный период жизни при применении ветом 1 / Г.А. Ноздрин, О.В. Лагода, Е.А. Вальтер // В сборнике: Теория и практика современной аграрной науки. сборник национальной (Всероссийской) научной конференции. - Новосибирский государственный аграрный университет. - 2018. - С. 429-430. 5. Кожевников С.В. Влияние пробиотических препаратов на продуктивность и морфологические показатели крови гусят-бройлеров / С.В. Кожевников, С.В. Шульгин // Кормление сельскохозяйственных животных и кормопроизводство. - 2011. - № 4. С. - 40-43. 6. Орлова Т.Н. Влияние пробиотического препарата "Пропионовый" на показатели крови цыплят-бройлеров / Т.Н. Орлова, В.Н. Хаустов // В сборнике: Научные исследования молодых ученых для АПК Сибири, Дальнего востока и Казахстана. Материалы VIII региональной научно-практической конференции с международным участием. - 2019. - С. 150-154. 7. Корниенко И.Г. Влияние пробиотического препарата на морфобиохимические показатели крови гусей / И.Г. Корниенко // В сборнике: Перспективы устойчивого развития АПК. Сборник материалов Международной научнопрактической конференции. - 2017. - С. 106-111.

THE EFFECT OF A PROBIOTIC PREPARATION ON THE ERYTHROCYTE CONTENT IN THE BLOOD OF TURKEYS.

Yakovleva M.S., st., Yakovleva N.S., st. (FSBEI HE NSAU, Russia)

Summary. One of the indicators of the physiological state of living organisms, which is reflected by the hematological parameters of the blood, is the normal functioning of the digestive system directly related to the composition of the microbial biocenosis of the intestine. Therefore, interest in the study of probiotic preparations is rapidly increasing.

Key words: vetome, turkey, probiotics.

УДК 57.573:636.5/.6:637.5

DOI:10.52419/3006-2021-2-253-256

\section{РЕЗУЛЬТАТЫ ОРГАНОЛЕПТИЧЕСКОЙ И ДЕГУСТАЦИОННОЙ ОЦЕНКИ МЯСА ПТИЦЫ ПРИ ВВЕДЕНИИ В РАЦИОН РЕГУЛЯТОРНОГО КОМПЛЕКСА «БАЙПАС»}

Янченко В.В., Капитонова Е.А., доц., к.с-х.н. (УО ВГАВМ, Республика Беларусь)

Аннотация. Стимуляция организма сельскохозяйственной птицы регуляторным комплексом «Байпас» позволила получить высококачественный продукт. Выведение из комбикорма синтетических аминокислот способствует повышению вкусовых качеств мяса цыплятбройлеров кросса «Росс-308».

Ключевые слова: мясо, органолептика, дегустация, варка, жарка, цыплята-бройлеры.

Промышленное птицеводство это наиболее рентабельная подотрасль животноводства, которая позволяет обеспечить максимальный выход готовой продукции при наименьших затратах труда и кормосредств. Короткий срок выращивания бройлеров обеспечивает 
продовольственную безопасность страны и ставит отрасль птицеводства в приоритетное финансирование госдотациями $[1,2]$.

Однако в условиях интенсивного ведения птицеводства встречаются такие всеобщие проблемы, как дисбактериозы сельскохозяйственной птицы. Болезни органов желудочнокишечного тракта выходят на первое место по снижению экономического эффекта птицеводческих предприятий. Профилактика дисбактериозов является актуальной проблемой, т.к. приводит к снижению продуктивности молодняка и недополучению валовой продукции $[3,4,5]$.

Изыскание резервов снижения потерь производства мяса птицы от дисбактериозов, побуждают многих исследователей изыскивать новые профилактические средства. Усовершенствование системы лечебно-профилактических и диагностических мероприятий в бройлерном птицеводстве способствовало созданию и применению такого эффективного и безопасного средства, как регуляторный комплекс «Байпас» $[6,7]$.

Наша научно-исследовательская работа проводилась в условиях клиники кафедры паразитологии и инвазионных болезней животных УО «Витебская ордена «Знак Почета» государственная академия ветеринарной медицины». Для опытной работы нами были использованы цыплята-бройлеры кросса «Росс-308», из которых были сформированы группы пар-аналогов в суточном возрасте по живой массе $(39,1 \pm 0,1)$.

«Байпас» призван стимулировать организм птицы добывать необходимые аминокислоты естественным образом из белка содержащегося в комбикорме. В процессе гидролиза белка концентрация свободных аминокислот в химусе не повышается одновременно, а возрастает пролонгировано. Синтезированные собственным организмом аминокислоты равномерно расходуются на синтез эндогенного белка., что повышает продуктивность сельскохозяйственных животных, в том числе и птиц.

Первая группа цыплят получала только основной рацион, который используется на птицефабрике с наличием синтетических аминокислот. Второй группе птиц скармливали комбикорм лишенный аминокислотной группы. Третьей группе молодняка заместили аминокислотную группу используемую на птицефабрике на регуляторный комплекс «Байпас» в норме 0,3 \% к комбикорму.

Ветеринарно-санитарную, товароведческую оценку мяса, категорию упитанности, органолептические и физико-химические показатели мяса от подопытных цыплят-бройлеров проводили согласно общепринятой методикой ВНИТИП [8] и ГОСТ 7269-2015 «Мясо. Методы отбора образцов и органолептические методы определения свежести», ГОСТ 31962 2013 «Мясо кур (тушки кур, цыплят, цыплят-бройлеров и их части). Технические условия», ГОСТ 31470-2012 «Мясо птицы, субпродукты и полуфабрикаты из мяса птицы. Методы органолептических и физико-химических исследований».

Метод определения свежести мяса и субпродуктов основан на органолептической оценке их качества с помощью органов чувств: зрения, обоняния, осязания. Внешний вид и цвет мышц определяли сразу после разреза мышечной ткани в глубоких слоях мяса или субпродуктов. При этом устанавливали наличие липкости путем ощупывания и увлажненности поверхности мяса или субпродуктов на разрезе путем приложения к разрезу фильтровальной бумаги. Консистенцию определяли на разрезе тушки и ее частей, а также субпродуктов. Легким надавливанием шпателя образовывали ямку и следили за ее выравниванием. Органолептически оценивали запах поверхностного слоя тушки и ее частей, а также субпродуктов. Затем чистым скальпелем делали разрез и сразу определяли запах в глубинных слоях. При этом особое внимание обращали на запах мышечной ткани, прилегающей к кости. Цвет, запах и консистенцию жира устанавливали сжиманием и растиранием кусочков жира между пальцами. Состояние сухожилий определяли в тушке в момент отбора образцов. Ощупыванием сухожилий устанавливали их упругость, плотность и состояние суставных поверхностей.

В результате определения свежести мяса и субпродуктов от подопытной птицы нами было установлено, что во всех подопытных группах внешний вид и цвет поверхности тушки 
были сухими, желтовато-серого цвета. Запах был специфическим, свойственный свежему мясу. Подкожный и внутренний жир были светло-серого цвета, что соответствует генетическим особенностям кросса «Росс-308». Мышцы на разрезе были слегка влажные, светло-розовые, плотной упругой консистенции. Серозная оболочка влажная и блестящая.

В опытной группе № 3 отмечено, относительно контроля, светло-желтое окрашивание конечностей птицы, подкожного жира, кожи и пр. Отмечено окрашивание от белого до цвета - «Банан», согласно колор-тестера Yolk Color Fan соответствует - № 1, что придает наиболее выгодные товарные качества тушкам, а в группе № 2 отмечен «Серо-желтый», бледный оттенок.

Дегустационная оценка мяса и бульона от подопытных цыплят-бройлеров проводилась в условиях лаборатории кафедры ветеринарно-санитарной экспертизы им. академика Х.С. Горегляда УО ВГАВМ. Для определения прозрачности и запаха бульона брали 20 г свежеприготовленного фарша (взвешивали до первого десятичного знака), помещали в коническую колбу вместимостью $100 \mathrm{~cm}^{3}$, заливали $60 \mathrm{~cm}^{3}$ дистиллированной воды, тщательно перемешивали, закрывали часовым стеклом и ставили в кипящую водяную баню.

Запах бульона определяли в процессе нагревания до $80-85^{\circ} \mathrm{C}$ в момент появления паров, выходящих из приоткрытой колбы во время варки. Для определения прозрачности 20 $\mathrm{cm}^{3}$ бульона наливали в мерный цилиндр вместимостью $25 \mathrm{~cm}^{3}$ и устанавливали степень его прозрачности визуально.

В результате проведения дегустационной оценки пробой варки полученных образцов мяса от подопытных цыплят-бройлеров кросса «Росс-308» было установлено, что образцы из 1-й и 3-й группы обладали выраженным ароматом и высокими вкусовыми свойствами. Наваристость бульона была достаточно крепкой, он был прозрачным, с долго не проходящим ощущением мясного вкуса, имелось наличие крупных пятен жира. Во 2-й группе бульон был соломенного цвета и выраженным ощущение вкуса мяса птицы, имелись незначительные пятна жира. В целом, 1-й контрольной группе был установлен средний балл - 8,2. Опытной группе № 3 - 8,4 балла, что было на 2,4 \% выше, чем в 1-й группе. Результаты 2-й опытной группы достигла - 7,0 балла, что было на 14,6 \% ниже контроля.

При оценке жаренного мяса было установлено, что все образцы имели приятный и сильно выраженный аромат, присущий мясу курицы. Мясо было нежным, а при пережевывании мышечные пучки легко разламывались и крошились. Образцы мяса оставались сочными и мягкими с достаточным выделением мясного сока. Оценка жаренного мяса полностью соответствовала достигнутым результатам варенных образцов.

Как видно из представленных результатов, наилучшими органолептическими показателями обладало кусковое мясо и бульон полученный от бройлеров из 3-й опытной группы. Также высокими вкусовыми качествами обладали образцы мяса, полученные от 1-й контрольной группы. Образцы мяса от 2-й опытной группы хоть и обладали хорошими вкусовыми свойствами, но в наименьшей степени.

При этом необходимо учитывать, что производить дегустационную оценку могут те специалисты, которые имеют низкий порог чувствительности вкусовых оттенков. Наибольшему же количеству потребителей это сделать гораздо сложнее, а с учетом добавления различных приправ и специй, практически невозможно. В связи с этим, на изготовителя полностью возлагается ответственность за сохранение высоких потребительских качеств предлагаемого к реализации выпускаемого продукта.

На основании проведенной органолептической и дегустационной оценки подопытных образцов мяса нами было установлено, что наибольшими вкусовыми качествами обладали образцы 3-й опытной и 1-й контрольной групп. Образцы мяса 2-й опытной группы в наименьшей степени обладали высокими вкусовыми качествами.

Литература. 1. Сборник производственных ситуаций по гигиене животных: учебнометодическое пособие / Медведский В. А. [и др.]. - Витебск : УО ВГАВМ,2011. - 40 с. 2. Технология производства продукции животноводства. Курс лекций: в 2 ч. Ч. 2. Технология производства продукции скотоводства, свиноводства и птицеводства: учебно-методическое 
пособие / М.А. Гласкович [и др.]. - Горки: БГСХА, 2017. - 240 с. 3. Капитонова, Е.А. Профилактика дисбактериозов / Е.А. Капитонова // Материалы VII Международной научнопрактической конференции «Экология и инновации». - Витебск : ВГАВМ, 2008. - С. 100-101. 4. Капитонова, Е.А. Профилактика заболеваний птиц путем введения в рацион цыплятбройлеров биологически активных веществ / Е.А. Капитонова // труды Всероссийского НИИ экспериментальной ветеринарии им. Я.Р. Коваленко, 2009. - Т. 75. - С. 329-33. 5. Красочко, П.А. Роль микрофлоры в возникновении заболеваний у животных и птиц / П.А. Красочко, B.М. Голушко, Е.А. Капитонова // «Проблемы интенсификации производства продуктов животноводства» Тезисы докладов Международной научно-практической конференции. Жодино : РУП «НПЦ НАН Беларуси по животноводству», 2008. - С. 292-294. 6. Усовершенствование системы лечебно-профилактических и диагностических мероприятий в бройлерном птицеводстве / А. А. Гласкович, А. Р. Аль-Акаби, Е. А. Капитонова [и др.]. - I Международная научно-практическая конференция «Ветеринарная медицина на пути инновационного развития». - Гродно : ГрГАУ, 2016. - С. 134-143. 7. Гласкович, М. А. Анализ повышения эффективности использования кормовой базы на птицефабриках Республики Беларусь / М. А. Гласкович, Е. А. Капитонова // Ученые записки УО ВГАВМ : научнопрактический журнал. - Витебск : УО ВГАВМ, 2011. - Т. 47, вып. 1. - С. 333-335. 8. Методика проведения исследований по технологии производства яиц и мяса птицы / В.С. Лукашенко [и др.]. - Сергиев Посад: ФГБНУ ВНИТИП, 2015. - 104 с.

RESULTS OF ORGANOLEPTIC AND TASTING EVALUATION OF POULTRY MEAT WHEN INTRODUCING THE REGULATORY COMPLEX "BYPASS" INTO THE DIET

Yanchenko V.V., Kapitonova E.A., associate professor, Ph.D. (UO VSAVM, Belarus)

Summary. Stimulation of the body of poultry by the regulatory complex "Bypass" allowed us to obtain a high-quality product. The removal of synthetic amino acids from the feed helps to improve the taste of the meat of broiler chickens of the «Ross-308» cross.

Keywords: meat, organoleptics, tasting, cooking, frying, broiler chickens. 


\section{ОГЛАВЛЕНИЕ}

Лунегов А.М., Андреева Н.Л. 100 лет кафедре фармакологии и токсикологии санктпетербургского государственного университета ветеринарной медицины (исторический очерк) ......

Агафонова Л.А. Выращивание гидропонного корма с заданными свойствами для функционального кормления КРС ................................................................................. Ажикина О.Ю. Оценка качества активности дезинфицирующего средства «Парасод» на предприятии по выращиванию индейки

Акчурин С.В., Акчурина И.В., Вершинина М.А. К вопросу совершенствования преподавания дисциплины «Ветеринарная фармакология» .....................................................13 Аманова Ж.Т., Баракбаев К.Б., Булатов Е.А., Абдураимов Е.О., Закарья К.Д. Совершенствование технологии изготовления ассоциированной вакцины против чумы мелких жвачныхживотных и оспы овец.

.15

Барышев В.А., Попова О.С. Влияние фитосорбционного комплекса на содержание тяжелых металлов в молоке .20

Бахта А.А., Махнин И.А. Перспективы и проблемы использования антимикробных пептидов в ветеринарной медицине

Белов А.А., Дерюгина А.В., Иващенко М.Н. Коррекция технологического стресса низкоинтенсивным лазерным излучением.

Белопольский А.Е. Влияние инкорпорированного облучения на организм продуктивных животных .

Бригида А.В., Скачкова О.А. Актуальность применения фсг для суперовуляции коровдоноров и пути повышения его эффективности...................................................................28

Бурсаков С.А. Бригида А.В. Растительные биоактивные соединения для стимуляции репродуктивного и молочного потенциала крупного рогатого скота ........................................30 Бурцева Т.В., Курочкина Н.Г. Формирование профессиональных компетенций у студентов

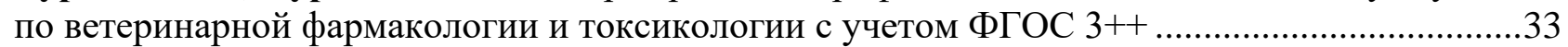
Бушарова Ю.Б. О перспективе применения этамзилата (дицинона) в качестве ангиопротектора при лечении инфекционного перитонита кошек .........................................36 Великодная Е.К. Особенности исследования острой оральной токсичности в соответствие с методом «вверх-и-вниз» (согласно ОЕСD/OCDE 425).

.38

Великодная Е.К. Особенности исследования субхронической кожной токсичности в соответствие с OECD/OCDE 413

Веретенникова В.С., Якоб Д.А., Жарикова Е.А., Бойко Т.В. Сочетанное действие фитокомпозиции и агонистов альфа2-адренорецепторов …..............................................41

Веселова Д.К., Моисеева К.А. Эффективность лечения хронического обструктивного бронхита лошадей с помощью ингаляционных препаратов .................................................44 Виноходов В.О. Фаттахов А.К. Ретроспективный анализ распространённости FCV у кошек в Санкт-Петербурге ....

Воробьева Н.В., Медведев И.Н. Функциональные параметры тромбоцитов у телят молочнорастительного питания черно-пестрой породы ....................................................................47 Гаврилова Н.А., Белова Л.М., Щербина Ю.А. Применение препарата «Азифлумин» при

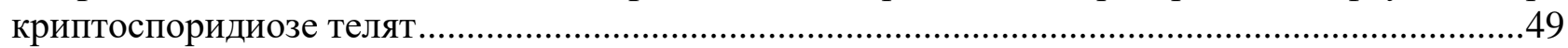
Герунов Т.В., Герунова Л.К., Тарасенко А.А., Чигринский Е.А. К вопросу об информативности инструкций по применению иммуномодуляторов ветеринарного

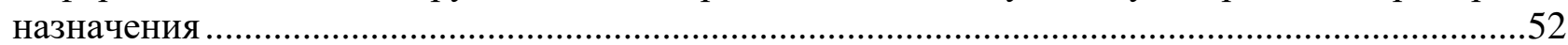

Герунова Л.К., Шилков А.А., Тарасенко А.А. Регидратационные средства: механизм

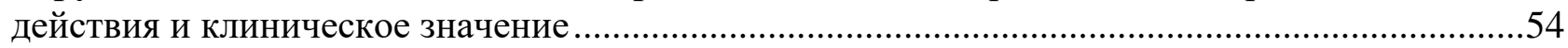
Гирфанов А.И., Бозова Г.Б., Шах А.Д. Ежова А.М. Токсикологическая безопасность наноструктурных веществ при парентеральном способе введения животным .......................57 
Глебов В.В., Соловьева Е.А. Практика ведения предмета «Экология» студентам высшей школы (на примере российского государственного аграрного университета имени К.А.

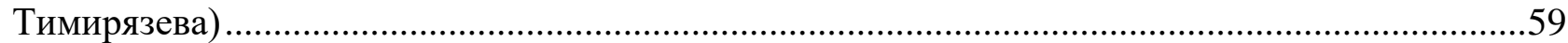

Глухова Э.Р., Кичеева Т.Г., Лебедева М.Б., Пануев М.С. Оценка эффективности лечения

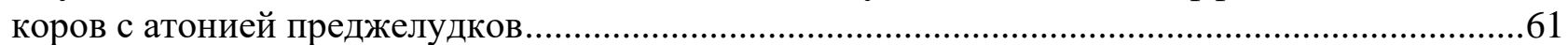

Горбунова А.С. Клинический случай лечения аллопеции Х химической кастрацией ............63 Готовский Д.Г., Петров В.В., Кондакова В.В., Романова Е.В. Изучение эффективности

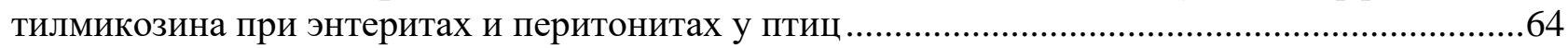
Гришин Е.А. Морфологические и биохимические показатели крови у гусей, потреблявших

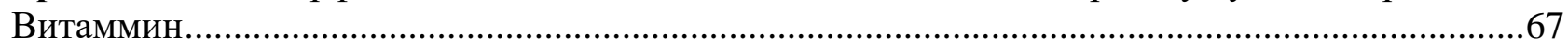

Гурина Е.Р., Барышев В.А., Каблуков А.Д. Митоксантрон как препарат выбора на основе клиническихслучаевпри лечении уротелиальной карциномы у собак ...................................69 Дроздова А.М. Опыт применения препарата «апоквел» в лечении атопического дерматита у

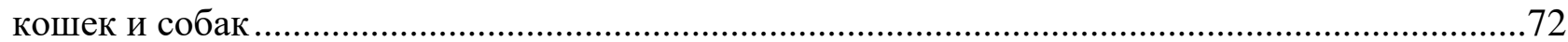

Еганян Е.С. Изучение эмбриотоксического и тератогенного действия кормовой добавки

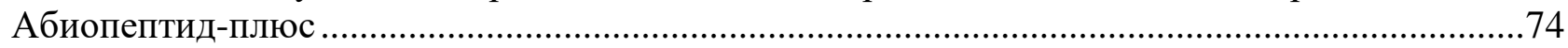

Елисютикова А.В., Баженова Е.Д., Милованов А.В., Лунева А.В. Использование бактерий рода Azotobacter в переработке отходов птицеводства............................................................ 77 Ермолаева О.К., Танасева С.А., Тарасова Е.Ю., Садыкова А.Ш. Токсическое действие

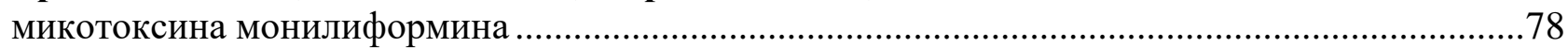

Ерохина Ю.М. Рациональное использование побочных продуктов животного убоя .............81 Ерыженская Н.Ф. ВЛияние биологически активных веществ на организм жеребых кобыл в

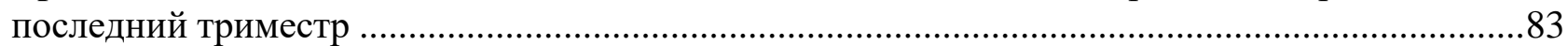

Ерыженская Н.Ф. Коррекция метаболических процессов рысистых лошадей биологически

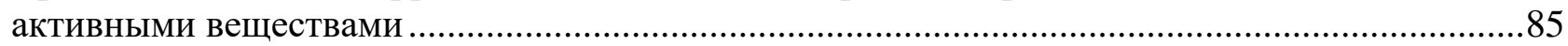
Ерыженская Н.Ф. Применение биологически активных веществ в перинатальный период

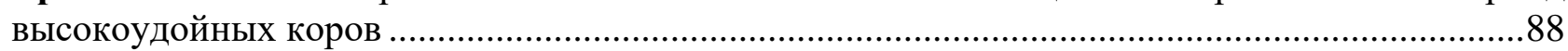
Ефимов В.Я., Красков Д.А. Применение препарата «Энтерофурил» при лечении

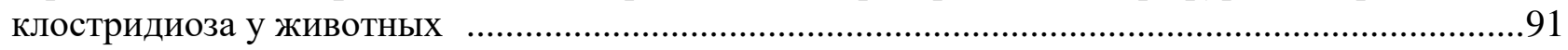
Журба В.А., Ковалев И.А. Эффективность Повицида при лечении коров с

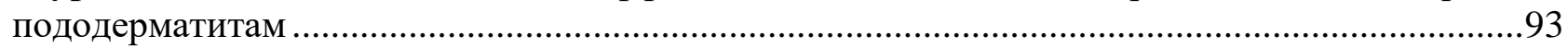

Забровская A.B., Егорова С.А. Антибиотикорезистентность штаммов Salmonella,

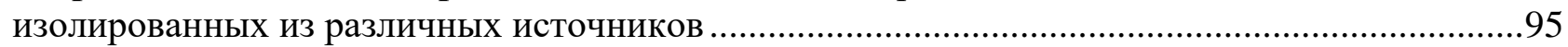

Завалишина С.Ю. Физиологические изменения в крови коров на фоне катозала .................98 Земляная В.В. Сравнительная характеристика отечественных и зарубежных разработок лекарственных средств в животноводстве ...................................................................... 100 Зенков К.Ф. Перспектива использования новых минеральных сорбентов в ветеринарии...101 Зенков К.Ф. Изучение ранозаживляющих свойств модифицированного аморфного диоксида кремния на раневых поверхностных поражениях кожи кроликов ..........................................103 Зенков К.Ф., Иванова К. Эффективность применения некоторых консервативных методов

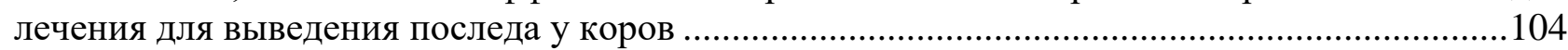
Иванникова Р.Ф. Эффективность кормовой добавки на основании солей гуминовых кислот

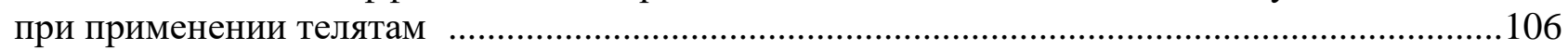
Илларионова Н.Ф. Токсико-экологическая оценка безопасности и качества промысловой

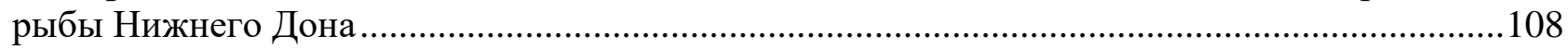
Ишниязова Ш.А., Бутаева И.М. Изучение микрофлоры мягкого сыра ............................110 Капитонова Е.А. Анализ мясных качеств бройлеров при математическом моделировании опыта

Карпенко Л.Ю., Полистовская П.А. Анализ активности аминотрансфераз сыворотки крови

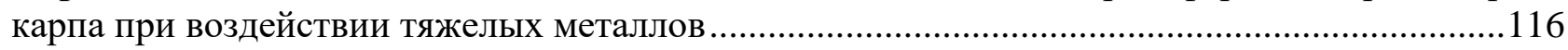
Катанова Е.С., Панфилов А.Э., Нитяга И.М. Влияние химических пестицидов на здоровье человека в сфере биологической безопасности 
Качер Н.И. Особенности накопления тяжелых металлов в мышцах крупного рогатого

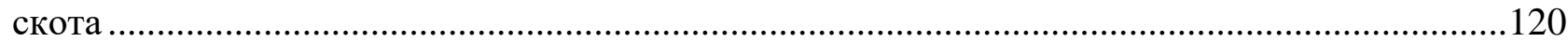

Киселенко П.С. Лечебно-профилактическое применение настоя зверобоя продырявленного

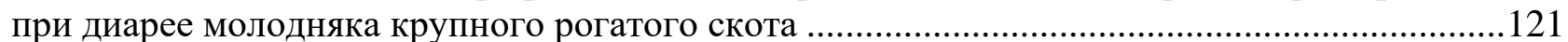

Кострова А.С. Современные гепатотоксиканты .................................................................123

Красков Д.А., Ефимов В.Я. Применение препарата «Витафел-С» при лечение инфекционных заболеваний кошек

Крюкова В.В., Лаплаинен О.Т. Опыт применения разных схем лечения диспепсии телят в

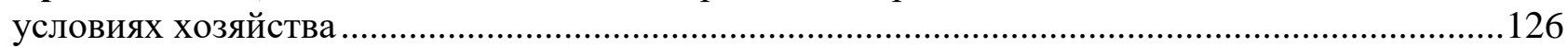

Кузьмина Т.И., Татарская Д.Н., Кравцов В.Ю. Перспективы использования кремнийсодержащих соединений в технологии созревания ооцитов животных in vitro.......129 Лаврик А.А., Али С.Г., Москалев В.Б., Надеждин С.В., Эльдаров Х.Д. Применение биологического лекарственного средства на основе секретома мезенхимных стволовых клеток как альтернативный подход к проведению антибиотикотерапии в промышленном животноводстве.

Ларина Ю.В. Изучение местно-раздражающего и аллергизирующего действий наноматериала нового поколения ..... 134

Лебедева М.Б., Кичеева Т.Г., Пелех К.А. Применение гормональных тестов для оценки эффективности использования биологически активных веществ .........................................135 Лихачева А.Ю., Фицев И.М., Мухарлямова А.З., Рахметова Э.Р., Мухамметшина А.Г. Пробоподготовка с применением ТФЭ при определении фосфорорганических пестицидов в зерне методом ГХ-МС.

Лукашенко В.С., Комаров А.А. Продуктивность и мясные качества цыплят кросса «Смена 9» при выгульном выращивании ..........................................................................139 Лукашенко В.С., Салеева И.П., Волик В.Г., Исмаилова Д.Ю., Овсейчик Е.А., Журавчук Е.В. Безопасность мяса бройлеров при использовании кормовых добавок,

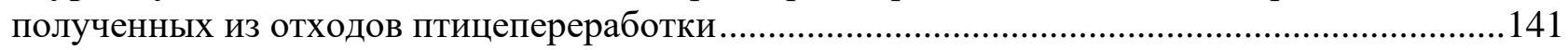

Лукин О.А. Основные аспекты при организации доения коров ..........................................143

Лунегов А.М. Проблема фармацевтического загрязнения окружающей среды ....................145

Лунегов А.М., Барышев В.А. Лечение застарелых гнойных ран.........................................147

Лунегова И.В. Способ повышения естественной резистентности организма сухостойных

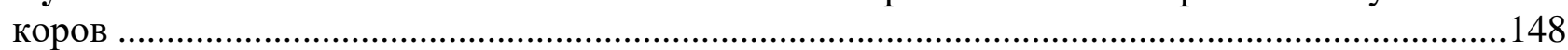

Луцко Т.П., Полянских А.Г., Кузьмина Е.С., Волобуев И.Д. Сравнительный анализ гидрохимических показателей вод Финского залива в районе города Санкт-Петербург.......150 Луцко Т.П., Осипова А.В., Скворцов Д.А. Особенности концентрирования некоторых тяжелых металлов сорбентами на основе вермикулита из объектов гидросферы .................151

Красков Д.А., Луцко Т.П. Токсико-экологический анализ воды в Финском заливе ..........153 Майорова Т.Л. Токсико-биологическая оценка кормовой добавки на основе вторичного

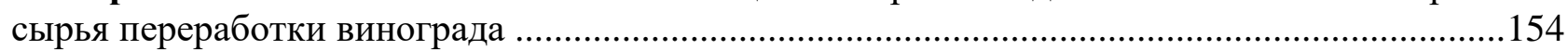
Майорова Т.Л. Токсико-биологическая оценка кормовой добавки из виноградных

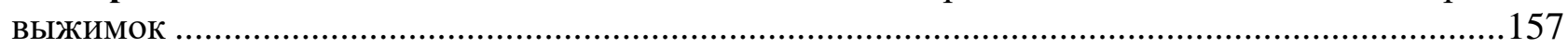
Макавчик С.А., Сухинин А.А., Смирнова Л.И, Кротова А.Л., Кузьмин В.А. Антибиотикорезистентность и биологические свойства микроорганизмов Pantoea agglomerans, изолированных от сельскохозяйственных животных с респираторной

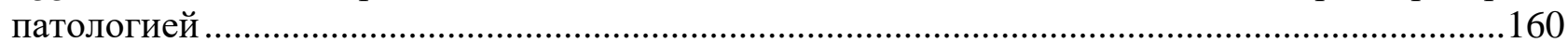

Макаева В.И., Альмитова Л.И., Потехина Р.М., Макаева А.Р. Влияние антропогенной нагрузки на водные объекты некоторых регионов Поволжья ….............................................162 Макаров А.В., Бригида А.В., Ханипова В.А., Землянский Р.Д. Эффективность применение противомаститных препаратов в состав, которых входит преднизолон.................................165 Миллер Т.В., Дикунина С.С., Котельникова Е.П. Оценка антибактериальных свойств настойки чистотела и йодопирона ..... 
Моисеева А.А., Присный А.А., Скворцов В.Н. Влияние энрофлоксацина на динамику белой

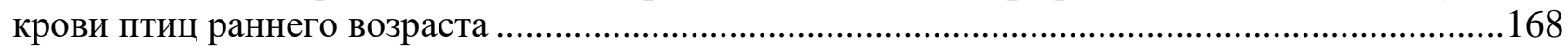

Назарова А.В., Кузнецова Т.Ш., Семенов Б.С., Виденин В.Н., Нечаев А.Ю. Актуальность повышения уровня доказательности клинических исследований в ветеринарии ..................171 Никитина С.B. Фармакологические аспекты применения комбинированных сульфаниламидов. 174

Николаева В.А. Клинический случай использования препарата актилизе у кота породы мейнкун при артериальной тромбоэмболии. 176 Нуруллин Р.Ш., Терентьева Н.Ю., Иванова С.Н. Коррекция репродуктивной функции коров при эндометритах и гипофункциях яичников..........................................................179 Пайтерова В.В., Кузнецова Н.В., Кузнецов Ю.Е. Использование препарата «РепаринХелпер ${ }^{\circledR} \gg$ в лечении скальпированной раны.................................................................181 Петров B.В., Романова Е.В. Токсикологическая оценка ветеринарного препарата «Марбобел

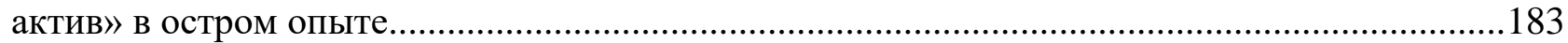
Петров B.B., Романова Е.В. Эффективность ветеринарного препарата «Оксифлу 30» при бронхопневмонии у телят . 186 Петров В.В., Мацинович М.С., Романова Е.В. Эффективность применения Ветофена 5 \% для лечения собак при заболеваниях с болевым синдромом и воспалением ...........................188 Петрова Е.К. Использование заместительной терапии и противоопухолевых препаратов при аденокарциноме щитовидной железы у собаки....................................................................191 Погодаева П.С., Карпенко Л.Ю. Влияние стафилококковой вакцины на антигенпрезентирующие клетки молочной железы.............................................................194 Погодаева П.С., Карпенко Л.Ю. Сравнительное влияние различных термостабильных антигенов на антигенпрезентирующие клетки молочной железы.......................................195 Попов Ю.Г., Ляхова А.В. Распространение и лечение субклинического эндометрита у коров в ООО «Сибирская Нива».

Попова О.С. Обеспечение безопасности и качества продукции в сельском хозяйстве в Российской Федерации 199 Радкевич А.В. Обзор на спектрофотометрический метод исследования адсорбционных

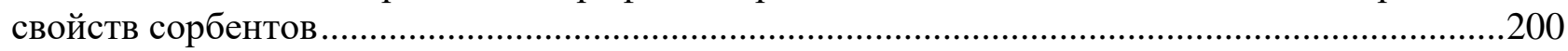
Рафекова Э.В., Ломбоева С.С. Применение иммуностимуляторов в ветеринарной

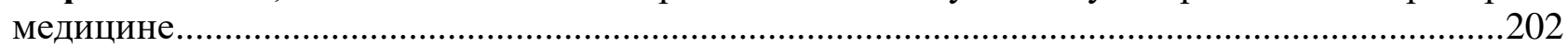
Руколь B.М., Андреева Е.Г. Мезенхимальные стволовые клетки в ветеринарной

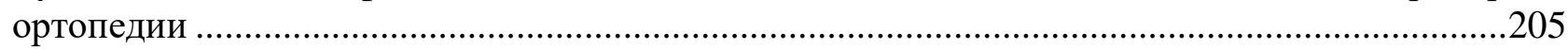

Сароян С.В., Крюкова В.В. Клинический случай язвы роговицы, осложненной передним гнойным экзогенным увеитом у французского бульдога, возникшей на фоне длительной системной терапии глюкортикостероидными препаратами ................................................208 Сахно Т.А., Гринь В.А., Семененко М.П. Динамика биохимических показателей крови новотельных коров на фоне применения гепатопротектора .................................................2211

Скобелева И.С., Ломбоева С.С. Применение средств для наркоза в ветеринарии ..............213 Степанова М.В., Остапенко В.А. Оценка токсикологической безопасности рыбы, применяемой для кормления животных в зоологических учреждениях ..............................216 Танирбергенов Т.Б. Нормативно-правовое регулирование экспертизы безопасности и эффективности ветеринарных препаратов ...................................................................2 217 Тарасова А.О. Влияние льняного жмыха на показатели неспецифического иммунитета у

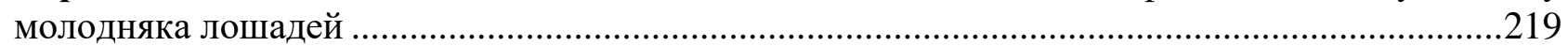

Тарасова Е.Ю., Матросова Л.Е., Садыкова А.Ш. Адсорбция Т-2 токсина in vitro ............222 Терентьев С.С., Великанов В.И., Кляпнев А.В., Горина А.В., Трунова Е.А., Дунаевская А.А., Чвала А.В. Особенности колострального иммунитета телят при сочетанной стимуляции коров-матерей иммуномодулятором и синэстролом $2 \% \ldots \ldots \ldots \ldots . . . .225$ Ткачева Е.С., Медведев И.Н. Физиологические особенности гематологических показателей

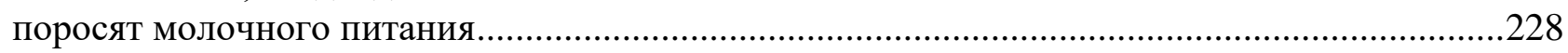


Токарева О.А., Токарев А.Н. Определение полулетальной дозы комбинированного антибиотика на основе доксициклина гиклата и тилозина тартрата ....................................2230 Туварджиев А.В., Киселенко П.С. Влияние аэрозолей гентамицина и его сочетания с йодидом калия на содержание витамина А в организме цыплят.........................................2232 Чучунов В.А., Радзиевский Е.Б., Коноблей Т.В. Применение муравьиной кислоты при варроатозе пчёл в органическом животноводстве

Шаронина Н.В. Индивидуальные задания на осмысление и систематизацию полученных знаний по ветеринарной фармакологии

Шаронина Н.В. Влияние «ВитаАмин» на активность ферментов АСТ и АЛТ лабораторных животных при изучении хронической токсичности.

Шаронина Н.В. Кейс-задачи как один из инновационных методов в преподавании ветеринарной фармакологии

Шевцов В.В., Глебов В.В. Роль информационных технологий в преподавании курса «Экология»

Шпаковская Ю.С. Лунегов А.М., Лунегова И.В. Оценка вкусовых качеств мяса птицы 246 Шумилина М.А., Нефедова К.А., Чистяков М.С., Золкин А.Л. Ветеринарное образование как компонента современной высшей школы россии: краткий ретроспективный экскурс доиндустриального развития.

Юлдашев Д.К., Хидиров К.И. Использование пробиотика «Бактовит» в выращивании цыплят бройлеров и кроликов в условиях жаркого климата Узбекистана 249

Яковлева М.С., Яковлева Н.С. Влияние пробиотического препарата на содержание эритроцитов в крови индюшат .

Янченко В.В., Капитонова Е.А Результаты органолептической и дегустационной оценки мяса птицы при введении в рацион регуляторного комплекса «Байпас». 253 


\section{МАТЕРИАЛЫ}

Международной научно-практической конференции «ТЕОРИЯ И ПРАКТИКА ВЕТЕРИНАРНОЙ ФАРМАЦИИ, ЭКОЛОГИИ И ТОКСИКОЛОГИИ В АПК»,

посвященной 100-летию кафедры фармакологии и токсикологии СПбГУВМ

\section{9-21 мая 2021 года}

Ответственный редактор:

Компьютерная верстка и подготовка макета:
Лунегов Александр Михайлович

Понамарев Владимир Сергеевич

Подписано в печать 11.05.2021 г.

Формат 60×84/16. Бумага офсетная. Печать цифровая.

Усл. печ. л. 15,2. Тираж 100 экз.

Заказ № 5461.

Отпечатано с оригинал-макета заказчика

в ООО «Издательство “ЛЕМА”»

199004, Россия, Санкт-Петербург, 1-я линия В.О., д.28

тел.: 323-30-50, тел./факс: 323-67-74

e-mail: izd_lema@mail.ru

http://lemaprint.ru 


\section{ОТ БОЛИ И ХАРА}

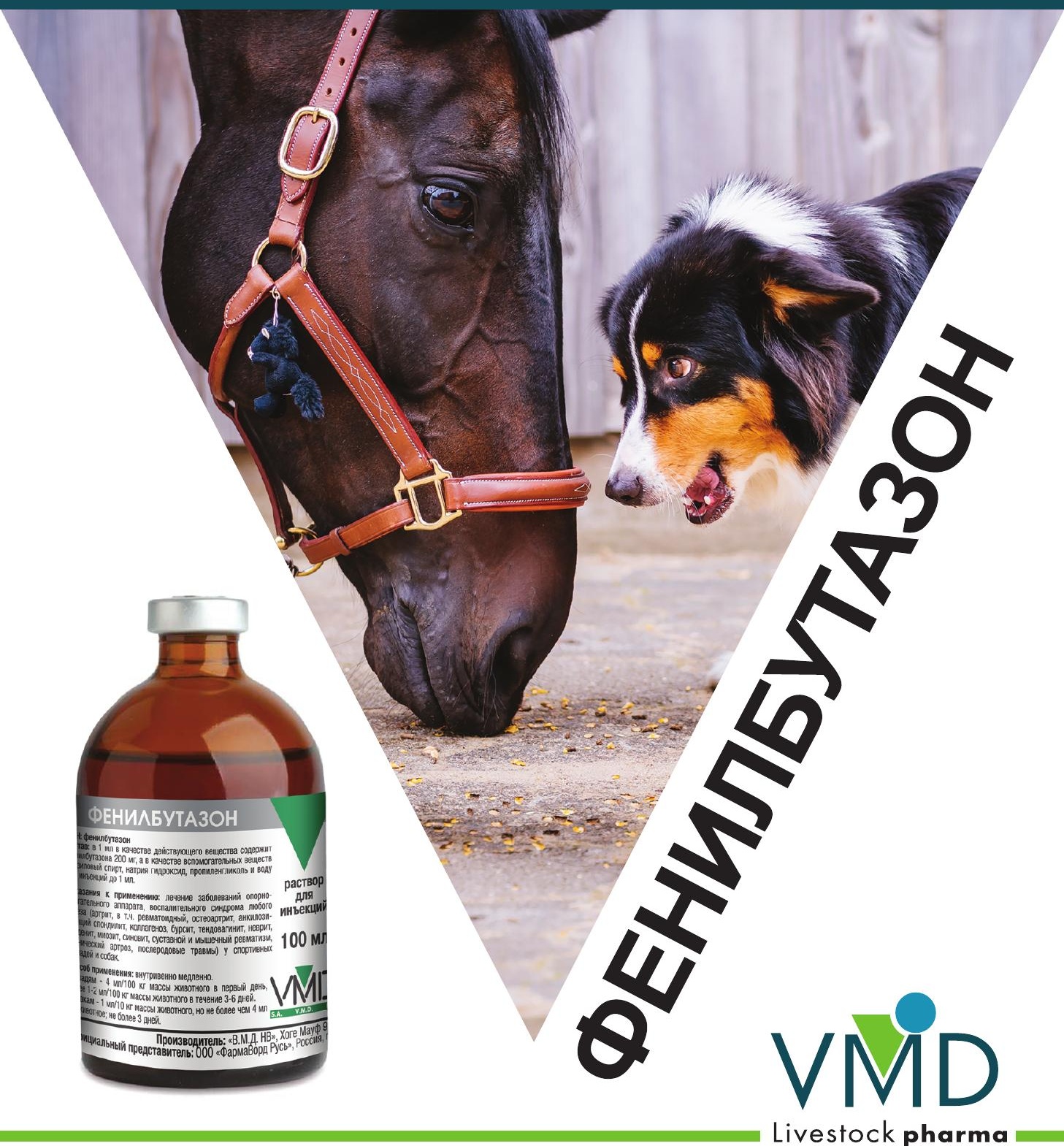

Нестероидное противовоспалительное, анальгезирующее, жаропонижающее средство для собак и лошадей

Официальный эксклюзивный дистрибьютор в странах ЕАЭС: ГК HEВА-ВЕТ, тел. (812) 596-39-62, e-mail: shop@vetapteka.ru

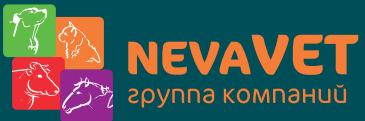




\section{Бонхарен
форте \\ @}

\section{гиалуронат натрия 10 мг/мл}

Бонхарен форте применяют лошадям, собакам и кошкам при заболеваниях опорно-двигательного аппарата внутривенно или подкожно (лошадям также интраартикулярно); при офтальмологических заболеваниях в конъюнктивальный мешок в виде капель.

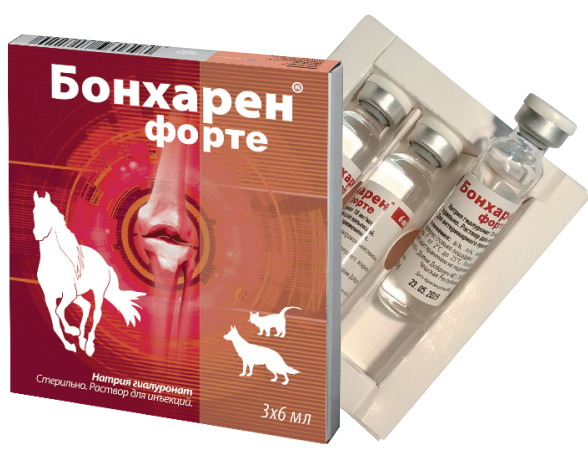

\section{Эффективное средство при:}

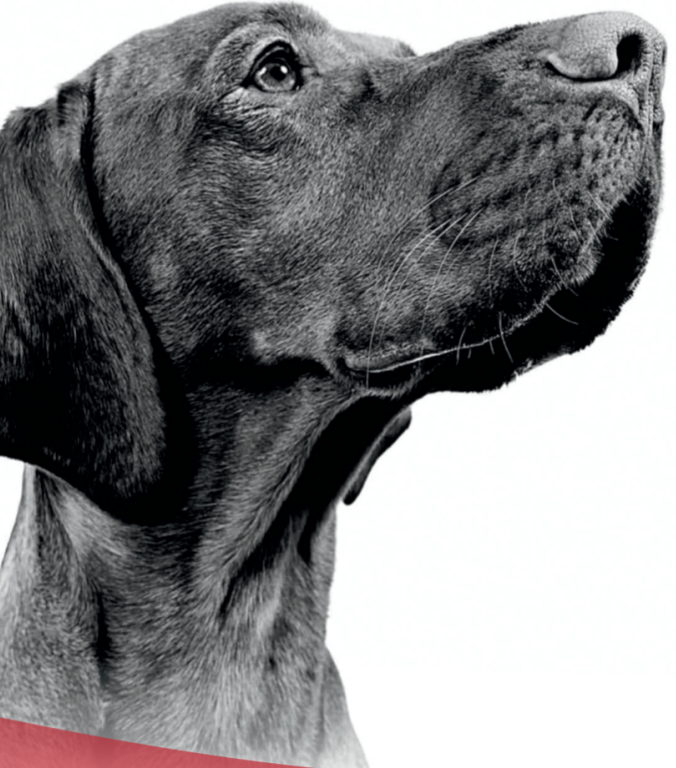

- артрозах и полиартритах

- артритах неинфекционного происхождения

- тендовагинитах

- бурситах

- остеохондрозах

- кератитах

- конъюнктивитах и кератоконъюнктивитах

- язвах и повреждениях роговицы

- ксерофтальмии
Перед применением ознакомиться с инструкцией Номер регистрационного свидетельства в РБ:66486-10-19 3ПХ-Ф
Производитель: "Contipro a.S.», Dolni Dobrouc 401, 56102 Dolni Dobrouc, Czech Republic СПРАШИВАЙТЕ В ВЕТЕРИНАРНЫХ АПТЕКАХ ВАШЕГО ГОРОДА 